\title{
O PROCESSO DECISÓRIO JUDICIAL À LUZ DOS TIPOS PSICOLÓGICOS DE CARL GUSTAV JUNG
}

(DISSERTAÇÃO DE MESTRADO)

ORIENTADORA: ProF ${ }^{\mathrm{A}}$ DR $^{\mathrm{A}}$ LÍDIA REIS DE ALMEIDA Prado CANDIDATO: ANTOIN ABOU KHALIL (№ USP: 492.351)

FACULDADE DE DIREITO DA UNIVERSIDADE DE SÃO PAULO DePartamento de Filosofia e TeOria Geral do Direito (DFD)

SÃo Paulo (SP)

2010 
Todas as opiniões que há sobre a natureza

Nunca fizeram crescer uma erva ou nascer uma flor.

Toda a sabedoria a respeito das cousas

Nunca foi cousa em que pudesse pegar, como nas cousas;

Se a ciência quer ser verdadeira,

Que ciência mais verdadeira que a das cousas sem ciência?

Fecho os olhos e a terra dura sobre que me deito

Tem uma realidade tão real que até as minhas costas a sentem,

Não preciso de raciocínio onde tenho espáduas.

$$
---\mathrm{X}---
$$

Assim como falham as palavras quando querem exprimir qualquer pensamento, Assim falham os pensamentos quando querem exprimir qualquer realidade.

Mas, como a realidade pensada não é a dita mas a pensada,

Assim a mesma dita realidade existe, não o ser pensada.

Assim tudo o que existe, simplesmente existe.

O resto é uma espécie de sono que temos,

Uma velhice que nos acompanha desde a infância da doença.

$$
\text { --- X --- }
$$

O espelho reflete certo; não erra porque não pensa.

Pensar é essencialmente errar.

Errar é essencialmente estar cego e surdo.

(Alberto Caeiro) $^{1}$

\footnotetext{
${ }^{1}$ PESSOA, Fernando. Obra e Poética em Prosa, vol. 1, in "Poemas Inconjuntos", Lello \& Irmão - Editores, Porto, 1986, pp. 798, 792 e 793.
} 


\section{RESUMO}

O presente trabalho tem por objeto a análise da influência do psiquismo do juiz no modo como preside o processo - estilo de colheita de dados e relacionamento com os demais sujeitos (partes e advogados, principalmente) - e produz suas decisões. Há, portanto, uma interface entre Direito e Psicologia, tomando-se como paradigma a teoria dos tipos psicológicos de Carl Gustav Jung e seguidores, com os acréscimos que lhe foram feitos por Isabel Briggs Myers e Katharine Cook Briggs. Para fins de contraste, a teoria de Jung é confrontada com a tipologia psicanalítica de Freud. No âmbito jurídico, especial atenção é dada à relação das funções pensamento e sentimento com o "senso de justiça", sugerindose que a teoria tridimensional do Direito, de Miguel Reale, seja a expressão jurídica do uso equilibrado das funções perceptivas e judicativas. Esta a primeira parte do trabalho.

Na segunda, são analisados tipologicamente seis magistrados do Tribunal de Justiça do Estado de São Paulo, tomando-se por base sua atuação profissional, conforme por eles expressa em entrevista. A entrevista foi feita a partir de um questionário padrão, de modo a estabelecer paralelos discursivos e daí colher semelhanças e diferenças, analisadas à luz do tipo psicológico aferido. Para aferição do tipo psicológico de cada entrevistado, além da análise do conteúdo de sua fala, foi aplicado um segundo questionário, de natureza específica.

A título de conclusão, verificou-se haver grande consistência no postulado de que existe correlação entre o tipo de personalidade do magistrado e o resultado de seu trabalho. Isso abre grandes perspectivas seja de estudo-aprendizado na área, seja de aperfeiçoamento profissional e pessoal destes agentes, cuja atividade é tão vital para o processo de produção de justiça no caso concreto. 


\section{"ABSTRACT"}

This paper is aimed at analyzing the influence of the judge's psyche as s/he presides over the process - the way s/he collects data and relates with the other parties (to the lawsuit and attorneys, mainly) - and makes his/her decisions. There is therefore an interface between Law and Psychology, since we have selected as a paradigm the theory of psychological types of Carl Gustav Jung and his followers, with the additions made by Isabel Briggs Myers and Katharine Cook Briggs. For contrasting purposes, Jung's theory is compared with Freud's psychoanalytical typology. From a legal perspective, special attention is given to the correlation between thought and feeling functions and the «sense of fairness», and it is suggested that Miguel Reale's three-dimensional theory of Law be the legal expression of the balanced use of perceptive and judicative functions. This is the first part of the paper.

In the second, six judges of the São Paulo State Court are typologically analyzed, based on their professional activities, as stated by them during an interview. The interview was based on a standard questionnaire so as to draw discursive parallels and be able to collect similarities and differences in the light of the psychological type assessed. To assess the psychological type of each interviewee, in addition to analyzing their speech content, a second questionnaire, of a specific nature, was applied.

In conclusion, the assumption that there is a correlation between a judge's type of personality and the result of his/her work has proven to be greatly consistent. This could bring great prospects, both in area studies and learning and the personal and professional improvement of these agents, whose activity is so vital to the actual process of administering justice. 


\section{AGRADECIMENTOS}

Como nenhum empreendimento é fruto do trabalho de um único indivíduo, cumpre agradecer a muitas pessoas, especialmente:

A Maria Luiza Sant'Anna do Amaral, nossa "Liza", pelo apoio técnico, sem o qual este trabalho não seria possível;

Aos magistrados "Isabella", "Mirtes", "Judith", "Émerson”, "Eustáquio" e "Evandro", que me acolheram com generosidade e afeto, franqueando-me o caminho de acesso aos bastidores de sua atuação profissional. Por dever de ofício, para o mundo hão de continuar anônimos, mas seus nomes seguirão comigo vida afora, gravados em meu coração;

Aos Professores Doutores Anna Mathilde Pacheco e Chaves, Laura Villares de Freitas e José Jorge de Morais Zacharias, pelo inestimável auxílio acadêmico, contribuindo com instrução, sugestões e críticas;

A meus sócios, Luiz Carlos Waisman Fleitlich e Roberto da Silva Rocha, em nome de quem prestigio todos os meus colegas de trabalho, sem os quais eu não teria tido o equilíbrio necessário para dedicar tempo à pesquisa;

A Aldacy, Naty e Otavio, pelas muitas horas de atenção e convívio que viram ser sacrificadas;

Por fim, à $\operatorname{Prof}^{\mathrm{a}} \operatorname{Dr}^{\mathrm{a}}$ Lídia Reis de Almeida Prado, pela paciente orientação, marcada pela sensibilidade que lhe é peculiar e pela precisão científica; não apenas me permitiu sonhar, mas também sonhou comigo; não apenas me apontou o caminho, mas o trilhou a meu lado; não apenas me falou da importância do equilíbrio das funções para uma vida plena de sentido, como foi, em seu trabalho de orientação, exemplo disso. Se algum mérito resultou dessa empreitada, forçoso dividi-lo com ela. 


\section{ÍNDICE}

INTRODUÇÃO $7 / 15$

\section{PARTE 1: A TEORIA DOS TIPOS}

Introdução à teoria dos tipos

$16 / 23$

\section{Capítulo 1: Os tipos humanos na Psicanálise de Freud}

1. Alguns conceitos de teoria psicanalítica ................................................................. 24/31

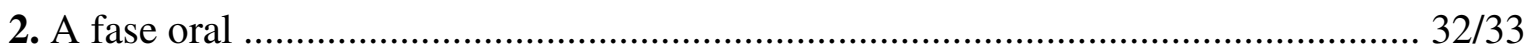

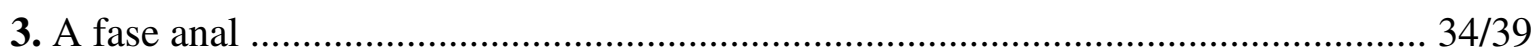

4. A fase fálica .................................................................................................. 40

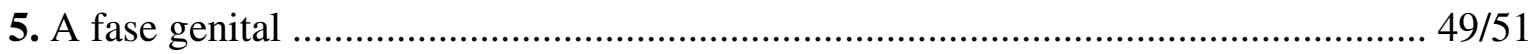

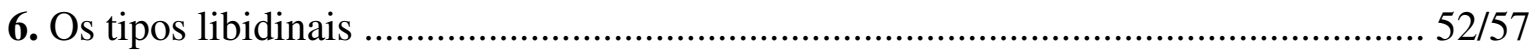

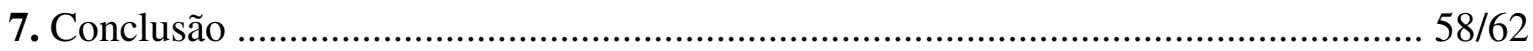

\section{Capítulo 2: A teoria dos tipos psicológicos de Carl Gustav Jung}

1. Conceitos fundamentais da teoria dos tipos psicológicos ......................................... 63/64

2. As duas atitudes (introversão-"I" e extroversão-"E") ................................................ 65/75

3. As quatro funções .......................................................................................... 76/80

3.1 A dicotomia das funções perceptivas (sensação-"S" e intuição-"N")

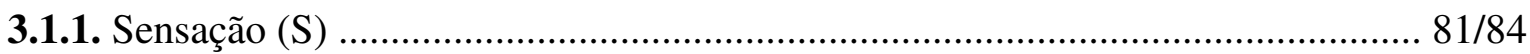

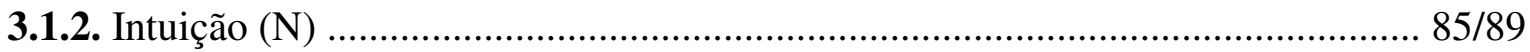

3.2. A dicotomia das funções judicativas (pensamento-"T" e sentimento-"F")

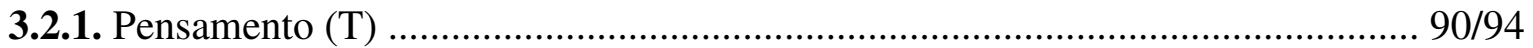

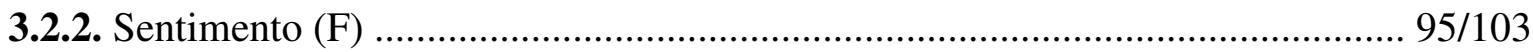

3.3. Sobre as funções auxiliares ........................................................................ 104/106

3.4. A importância da função inferior no processo de individuação ........................... 107/112

\section{Capítulo 3: A contribuição de Myers-Briggs}

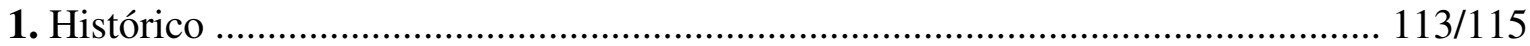

2. A dicotomia dos pares de funções quanto à sua natureza (tipos perceptivos-"P" e judicativos-"J") 


\section{Capítulo 4: Contribuições da tipologia junguiana ao Direito}

1. Relações de pensamento e sentimento com a noção de "justiça" ......................... 124/139

2. A dinâmica das funções e o ofício de bem julgar ............................................... 140/145

3. Uma possível síntese: a teoria tridimensional do Direito, de Miguel Reale ......... 146/149

\section{PARTE 2: UMA POSSÍVEL APLICAÇÃO DA TEORIA DOS TIPOS} (Análise do perfil tipológico de seis magistrados do Tribunal de Justiça do Estado de São Paulo)

1. Introdução $150 / 152$

2. Entrevista com Isabella $153 / 160$

2.1. Análise do perfil tipológico de Isabella $161 / 171$

3. Entrevista com Eustáquio $172 / 190$

3.1. Análise do perfil tipológico de Eustáquio $191 / 208$

4. Entrevista com Judith $209 / 221$

4.1. Análise do perfil tipológico de Judith $222 / 235$

5. Entrevista com Mirtes $236 / 253$

5.1. Análise do perfil tipológico de Mirtes $254 / 270$

6. Entrevista com Evandro $271 / 289$

6.1. Análise do perfil tipológico de Evandro $290 / 306$

7. Entrevista com Émerson $307 / 331$

7.1. Análise do perfil tipológico de Émerson $332 / 345$

Glossário $354 / 362$

1. Jurídico $355 / 359$

2. Psicológico $360 / 362$

Bibliografia $363 / 369$

1. Geral e interdisciplinar 363

2. Direito $364 / 365$

3. Psicologia $366 / 369$ 


\section{INTRODUÇÃO}

Via de regra as partes se digladiam apenas externamente, procurando falhas na armadura individual do adversário. Geralmente esta luta é de pouca valia. Bem mais valioso seria se a disputa fosse transferida para o campo psicológico, lugar donde se origina em primeira instância. Esta transferência logo mostraria que há atitudes psicológicas de diferentes espécies, cada qual com direito à existência, ainda que esta existência leve à formulação de teorias incompatíveis. (...) Verdadeira compreensão, a meu ver, só é possível quando for aceita a diversidade das premissas psicológicas.

Carl G. Jung ${ }^{2}$

Desde que me iniciei no exercício da advocacia, a maior parte de meus esforços profissionais são canalizados para a área contenciosa, de modo que o resultado de meu trabalho costuma passar pelo crivo das decisões judiciais.

Muito cedo percebi que a interferência de fatores psicológicos era determinante na maneira como cada magistrado conduzia o processo e o levava a termo. Nos bancos da faculdade de Direito somos ensinados a ver o trabalho do juiz sob a perspectiva exclusiva da aplicação da lei ao caso concreto, momento em que dela se extrai algum dos diversos sentidos possíveis.

O leigo em Direito não imagina a pluridiversidade de sentidos da norma legal; o profissional do Direito, porém, aprende a destrinchá-los, e para isso lhe são dadas inúmeras ferramentas. Sabe que a interpretação pode ser gramatical, histórica, dogmática, sistemática, teleológica, etc.. ${ }^{3}$ Não aprende, porém, que a diversidade das decisões judiciais não decorre apenas dos vários sentidos possíveis da lei. Até porque, antes de aplicá-la, cabe ao juiz perceber os fatos que se apresentam à sua frente, e a experiência demonstra que o modo como são estes são percebidos, ou não, muitas vezes tem mais peso para o deslinde do caso do que o sentido que se dá à lei.

\footnotetext{
${ }^{2}$ Tipos Psicológicos (CW VI), trad.: Lúcia Mathilde Endlich Orth, Editora Vozes, Petrópolis (RJ), 1991, p. $453, \S 922$.

${ }^{3}$ STRECK, Lenio Luiz. Hermenêutica Jurídica e(m) Crise, 4ª edição, RS, Livraria do Advogado Editora, 2003, pp. $108 / 110$.
} 
A vivência forense, portanto, obriga o profissional do Direito a notar a existência de fatores de grande relevância para o destino de um litígio. Não sendo fatores propriamente jurídicos, não dispõe de instrumentos adequados para compreendê-los. Seria preciso buscálos junto a outras disciplinas, sendo uma delas a Psicologia.

Richard Posner, jurista norte-americano e magistrado de segunda instância, em recente trabalho a respeito do que leva os juízes a decidir de uma forma ou de outra, reconhece que, quando os juízes não conseguem se apoiar em posições já claramente definidas pelo ordenamento jurídico, seja do ponto de vista legal, seja jurisprudencial, boa parte deles se deixa guiar pela análise das consequências de suas decisões. No entanto, diz o autor, mesmo que tenham orientação pragmática, fica uma questão: ao avaliar as consequências da decisão, que fatores levam o magistrado a dar pesos diferentes a umas e outras? Segundo Posner, esse sopesamento é resultado da interação de fatores pessoais e, nesse momento, a lógica desempenha um papel limitado, especialmente na fase de apelação, sendo poucos os estudos a respeito da influência de aspectos psicológicos na conduta do juiz. Diz, ainda, que as motivações e fatores de pressão que agem sobre os juízes, e o resultado disso em sua atuação profissional, são ignorados, como se os juízes fossem computadores, e não seres humanos intelectualmente limitados navegando em mares de incerteza. ${ }^{4}$

Estudos mais recentes vêm incorporando à discussão o problema dos limites do racionalismo e a relevante influência de aspectos inconscientes no trabalho do julgador, destacando-se, no Brasil, além dos trabalhos de Lídia R. A. Prado, os de Renato Nalini e David Zimerman.

Renato Nalini, antes de considerarmos o mérito de seu trabalho científico, traz uma qualidade preciosa: é magistrado de carreira. Tal circunstância confere-lhe a vantagem de dispor, de maneira direta, da "matéria-prima" de suas reflexões. Seu trabalho vem se focando nos aspectos subjetivos do magistrado: sua personalidade, caráter, motivação, e os reflexos disto em sua conduta perante as partes do processo, operadores do direito e sociedade, além, claro, do próprio processo decisório. Graças a isso, ganhou relevância o procedimento de recrutamento e seleção dos magistrados.

\footnotetext{
${ }^{4}$ How Judges Think, Harvard University Press, Cambridge, Massachussetts, 2008, pp. 369/377.
} 
David Zimerman é médico psiquiatra, com formação em Psicanálise. Tem trabalhos a respeito do reflexo de elementos psicopatológicos no comportamento dos juízes. Para isso, traça uma espécie de "tipologia", interessante, mas de aplicação restrita, pois não aborda aspectos do que se usa chamar "normalidade".

Lídia R. A. Prado, graças à sua dupla formação (Direito e Psicologia), aponta as importantes contribuições de conceitos da Psicologia Analítica (trabalha particularmente o do arquétipo da anima) para a compreensão do ato decisório judicial. A autora resgata a importância do sentimento no trabalho do juiz, ressaltando lições de juristas clássicos, porém pouco estudados entre nós, como Recaséns Siches, Joaquim Dualde e Jerome Frank. ${ }^{\mathbf{5}}$

No entanto, se por um momento simplesmente se ignorava a forma de atuação de mecanismos psicológicos no processo decisório, e, noutro momento, passou-se a tratar da importância destes, não se constata, até onde se tem ciência, o estudo dos padrões normais de atuação da personalidade dos magistrados na forma de perceber, sentir, pensar e, consequentemente, de se comportar em face dos agentes e elementos integrantes do processo judicial. Neste ponto é que se colhe preciosa contribuição dos estudos de Carl Gustav Jung a respeito dos tipos psicológicos, que ora me proponho a trazer para a cena jurídica.

Em vez de buscar saber se os juízes primeiro decidem, para depois buscar no ordenamento jurídico a fundamentação de suas decisões, ou, pelo contrário, deixam para decidir após analisar o que informa o ordenamento jurídico a respeito da questão apresentada hipóteses estas capazes de dividir em dois grupos de opinião a maioria dos juristas -, o modelo de tipos psicológicos nos permitiria aceitar a coexistência de ambas as hipóteses. Ou seja: permite-nos perceber que o mundo, na verdade, não só alberga ambos os tipos de magistrados, como também revela muitos outros matizes de enorme relevância.

O estudo dos tipos, ao mesmo tempo em que oferece uma importante chave de leitura da realidade, traz ínsito uma armadilha. A armadilha não é do modelo tal como postulado; ela está vinculada exclusivamente a seu aplicador. É que, como estabelece "padrões”

${ }^{5}$ O Juiz e a Emoção: Aspectos da Lógica da Decisão Judicial, 5ª edição (no prelo), Editora Millennium, Campinas (SP), 2003, pp. 14/19. 
classificatórios, tendemos a visualizá-lo de modo estático, quando, na verdade, ele é bastante dinâmico. Os tipos definem meras tendências no modo de ser dos indivíduos. Estas tendências são de fato observáveis, e é possível reuni-las em grupos. Porém, há nuances que decorrem seja da interação dos diversos aspectos da dinâmica psíquica de cada um, seja da percepção do próprio observador. ${ }^{6}$

Publicado em 1921, não tardou para que a teoria formulada em Tipos psicológicos tivesse uso inadequado, pois parece ser "típico" do ser humano o desconforto em lidar com o imponderável, sendo fácil cair na arapuca de enxergar na tipologia uma forma de eliminá-lo de nossas relações interpessoais. A este respeito, observa uma das mais distintas biógrafas de Jung:

Ao que parece, poucas pessoas leram o livro como Jung queria. Depois que a obra passou por diversas impressões em várias línguas, ele se sentiu obrigado a abordar os "lamentáveis mal-entendidos" que transformaram o livro em “nada além de um jogo de salão infantil". Queixou-se de que até na profissão médica sua tipologia era usada para encaixar pacientes no sistema e dar-lhes os "conselhos" correspondentes. Insistiu que sua "tipologia [...] de forma alguma significa colar rótulos em pessoas à primeira vista: não é um sistema de fisiognomonia, nem antropológico, mas uma maneira crítica de lidar com a organização e a delimitação dos processos psíquicos que podem se mostrar típicos. ${ }^{7}$

Feita, portanto, esta ressalva, assevera-se que a importância do tema consiste no fato de trazer para a cena jurídica a consciência de que, embora cada ser humano possa se deixar conduzir por mecanismos inconscientes (esse passo já foi dado, graças ao trabalho de autores como os acima citados), existe a possibilidade de definir alguns padrões, mecanismos típicos, aos quais estará vinculada sua percepção de mundo (passo a ser dado no âmbito deste trabalho). Em se tratando de magistrados, isso terá relação direta com a forma

\footnotetext{
${ }^{6}$ Ainda na fase de elaboração de sua teoria, Jung havia se dado conta disso, conforme demonstra em carta escrita a um de seus colaboradores: "Quando o problema do tipo é discutido por pessoas de dois tipos opostos, a maior parte da discussão consiste de mal-entendidos e declarações contraditórias. A linguagem aqui revela a sua incrível incapacidade de fornecer as sutis nuances indispensáveis à compreensão. Cada signo verbal pode designar significado e contrassignificado sempre que tenha de cobrir pontos de vista psicológicos." Carta de Jung a Hans Schmid, de 04/09/1915, citada por Deirdre Bair, Op. cit., vol. I, p. 363.

${ }^{7}$ BAIR, Deirdre. JUNG, uma biografia (2 vols.), Trad.: Helena Londres, Editora Globo, São Paulo (SP), 2006, vol. I, pp. 372/373.
} 
como se portarão em face das pessoas que os cercam e, sobretudo, como se delineará o seu processo decisório.

Agora, cabem algumas palavras a respeito de interdisciplinaridade.

Em obra de imensa repercussão no mundo jurídico, capaz de gerar polêmica até os dias de hoje, mais de meio século passado de sua primeira edição (1934), Hans Kelsen procurou expurgar da teoria jurídica o que seria alheio ao Direito. Intitulando-a "Teoria Pura do Direito", escreve logo no primeiro capítulo de sua obra:

Quando a si própria se designa como "pura" teoria do Direito, isto significa que ela se propõe garantir um conhecimento apenas dirigido ao Direito e excluir deste conhecimento tudo quanto não pertença ao seu objeto, tudo quanto se não possa, rigorosamente, determinar como Direito. Quer isto dizer que ela pretende libertar a ciência jurídica de todos os elementos que lhe são estranhos. Esse é o seu princípio metodológico fundamental (...) De um modo inteiramente acrítico, a jurisprudência tem-se confundido com a psicologia e a sociologia, com a ética e a teoria política. Esta confusão pode porventura explicar-se pelo fato de estas ciências se referirem a objetos que indubitavelmente têm uma estreita conexão com o Direito. Quando a Teoria Pura empreende delimitar o conhecimento do Direito em face destas disciplinas, fá-lo, não por ignorar ou, muito menos, por negar essa conexão, mas porque intenta evitar um sincretismo metodológico que obscurece a essência da ciência jurídica e dilui os limites que lhe são impostos pela natureza do seu objeto. ${ }^{8}$

Desde então, a proposta de purismo metodológico apresentada por Kelsen tem servido para alimentar muitos radicalismos, e, cumpre registrar, algumas injustiças the têm sido feitas, seja por quem ostenta sua "bandeira", seja por quem a combate."

Do extrato acima colacionado, nota-se que em momento algum ele fala de um "direito" puro; o purismo é buscado na "teoria", na tentativa de se construir uma "ciência jurídica”. Kelsen não ignora e tampouco nega a conexão existente entre o Direito e as outras

\footnotetext{
${ }^{8}$ KELSEN, Hans. Teoria Pura do Direito, 6⿳a edição, Armênio Amado Editora, Coimbra, 1984, pp. 17/18.

${ }^{9}$ Neste sentido, ver: BOBBIO, Norberto. "Estrutura e Função na Teoria do Direito de Kelsen” in Da Estrutura à Função: Novos Estudos de Teoria do Direito, Editora Manole Ltda., Barueri (SP), 2007, pp. $182 / 183$.
} 
áreas de conhecimento ou metodologias de análise. Pelo contrário, reconhece-a explicitamente ("Esta confusão pode porventura explicar-se pelo fato de estas ciências se referirem a objetos que indubitavelmente têm uma estreita conexão com o Direito”).

O problema que procuramos apontar, de forma singela neste espaço, é que a proposta de Kelsen, evidentemente que desvirtuada, levou muitos a pensar ser possível separar "teoria" de "prática". A rigor, isso até é possível, mas em teoria! Um paralelo ao ora afirmado seria pretender reduzir a química, enquanto fenômeno natural, ao estudo dos elementos da tabela periódica. Conhecer as características de cada átomo tem, sem dúvida, interesse prático, mas não se consegue prescindir de outras modalidades de conhecimento - da Física, por exemplo -, no momento de analisar um fenômeno "químico".

Que cada área deva se manter preservada, atuando nos limites de sua metodologia, não há dúvida; mas que se perceba a premência da interação entre elas para melhor entender a expressão concreta de um fenômeno jurídico. Não se trata, portanto, de sustentar que a teoria dos tipos psicológicos deva ser objeto de estudo do Direito, e tampouco que dele faça parte, no sentido de compor sua identidade.

O que se sustenta é que o fenômeno jurídico, para ser bem compreendido, não pode ficar alheio à matriz de sentidos que se abre à consciência humana a partir do desenvolvimento de inúmeras outras disciplinas. Bem aceita, pelo Direito, a colaboração da Sociologia, da Ciência Política e da História, por que não aceitar, com maior amplitude do que se tem hoje, a da Psicologia? Bastante oportunas, neste ponto, as lições de Lídia Prado ${ }^{\mathbf{1 0}}$ :

Para o entendimento desse mundo, agora vazio de valores, novas abordagens procuram superar o antagonismo entre conhecimento e objeto a ser conhecido. A interdisciplinaridade é um importante instrumento dessa superação, por não separar o saber técnico (que acarreta o progresso científico da nossa era) do mundo ao qual esse conhecimento se destina.

Assim, a interdisciplinaridade é considerada como a mais recente tendência da teoria do conhecimento, decorrência obrigatória da modernidade, possibilitando que, na produção do saber, não se incida nem no radical cientificismo

${ }^{10}$ Op. cit., pp. $8 / 9$. 
formalista (objetivismo), nem no humanismo exagerado (subjetivismo). Tal saber caracteriza-se por ser obtido a partir da predisposição para um encontro entre diferentes pontos de vista (diferentes consciências), o que pode levar, criativamente, à transformação da realidade.

(...) a interdisciplinaridade enfatiza o homem enquanto ser social (que vive numa sociedade tecnologicamente desenvolvida), dotado de afetividade (que se relaciona com sua realidade interna) e com outros seres do meio em que vive. Possibilita, assim, a superação de um tipo de saber feito de especializações formais, o saber em migalhas ${ }^{11}$, o saber sem sabor ${ }^{12}$, que provoca a perda da visão da totalidade. Conforme a concepção sistêmica, até mesmo nas ciências da natureza (como nos mostram, por exemplo, as conquistas da Física moderna), inexiste distinção entre parte e todo, porque cada sistema é simultaneamente todo e parte, dependendo do ponto de referência. ${ }^{13}$

Embora tomemos como paradigma o trabalho de Jung a respeito da tipologia, existem muitos outros modelos teóricos. Veremos, aliás, que a observação de padrões humanos de conduta é tema que desperta a atenção dos homens desde tempos imemoriais, a ponto de encontrarmos uma distinção entre temperamentos junto aos gregos. No entanto, com o surgimento da Psicologia, esse estudo passou a ganhar contornos próprios, incorporando conceitos desta disciplina. Tendo em vista o pioneirismo e importância da Psicanálise, de Freud, cujas formulações constituem a gênese da psicologia do inconsciente, reputei pertinente perscrutar de que maneira a tipologia se teria conformado nesta escola.

A parte teórica, portanto, percorre as teorias tipológicas de Freud e Jung, e traz, quanto a este último, as enriquecedoras contribuições de importantes junguianos, como Marie-Louise von Franz, James Hillman e Nise da Silveira, bem como de pessoas que deram à teoria uma aplicação prática de dimensões não imaginadas por seu criador. Refiro-

\footnotetext{
${ }^{11}$ Lídia Prado informa que a expressão é de Hilton Japiassu, renomado autor e um dos pioneiros no estudo da interdisciplinaridade (dentro e fora de nosso país), e aparece em várias passagens de toda a sua obra.

${ }^{12}$ A autora também chama nossa atenção para a aproximação etimológica dos termos: "saber e sabor têm a mesma raiz. ALBERTO CAEIRO (FERNANDO PESSOA), no último verso de O guardador de rebanhos, assim liga os dois termos: "Comer um fruto é saber-lhe o sentido'."

${ }^{13}$ A respeito dessa ideia, esclarece Lídia: “A propósito, leia-se FRITJOF CAPRA, O ponto de mutação, São Paulo, Cultrix, 1986, p. 21, para quem as moléculas são todos em relação a seus átomos, mas são partes em relação às organelas que venham formar; igualmente, elas se portam em relação às células, as células em relação ao tecido, o tecido em relação aos órgãos e assim por diante".
} 
me ao trabalho de Isabel Briggs Myers e Katharine Cook Briggs, criadoras do MBTI, instrumento de aferição de tipos mais utilizado em todo o mundo.

Veremos que a principal preocupação de Jung no momento em que formulou sua tipologia era de natureza epistemológica. Não estava tão interessado em identificar padrões de conduta, embora isso decorra inevitavelmente de suas observações. $\mathrm{O}$ importante era demonstrar que diferentes subjetividades implicam diferentes pensares, e, portanto, matrizes diversas de produção teórica (científica). Em verdadeira cópula interdisciplinar, podemos trazer tais reflexões para o Direito, bastando inserir a figura do juiz onde se fala de subjetividade. A evidência do que decorre daí dispensa maiores elucubrações. Aliás, conforme nos mostra Lídia Prado, isso vem sendo percebido de longa data por alguns juristas, tendo faltado maiores iniciativas no sentido de um trabalho que apenas se pode fazer interdisciplinarmente. Escreve a referida autora:

Como Siches, o autor [Jerome Frank] entende que os juízes usam a intuição ou sentimento na escolha das premissas que embasarão a sentença. Todavia, não esquece a importância do fato de que as normas, os princípios jurídicos nelas contidos, os precedentes jurisprudenciais, os valores gerais contribuem para a formação dessas intuições. E, diante da questão da escolha entre diferentes princípios igualmente válidos, tem primacial importância a personalidade do magistrado. $^{14}$

Registre-se que tanto Siches (1903-1977) quanto Frank (1889-1957), autores de importantes obras jusfilosóficas, publicaram seus trabalhos há mais de meio século. Como pudemos verificar acima, pela citação de Posner, ainda hoje se denuncia o vácuo deixado pela ausência da Psicologia no Direito.

Tendo em vista a importância do senso de justiça para a realização do Direito, e por conta de diferentes perspectivas teóricas em torno do tema (a dos "jusnaturalistas" e dos “juspositivistas”, por exemplo ${ }^{\mathbf{1 5}}$ ), observaremos como isso se conforma à luz da tipologia,

${ }^{14}$ Op. cit., p. 19.

15 Vale lembrar que embora os termos "jusnaturalismo" e "juspositivismo" atravessem os séculos, eles apresentam tonalidades diferentes, dependendo do momento histórico e do pensador que os postula, podendo, por exemplo, o "direito natural" estar fundado na natureza das coisas (Platão e Aristóteles), em Deus, enquanto conformador da razão humana (Santo Tomás, Grócio), ou na razão propriamente dita 
e, num segundo momento, de que modo o tridimensionalismo jurídico, de Miguel Reale, pode vir a representar uma feliz síntese e ponto de acoplamento da leitura feita por cada disciplina.

Uma segunda parte do trabalho, de caráter "prático", consiste na transcrição e análise de entrevistas feitas junto a seis magistrados do Tribunal de Justiça do Estado de São Paulo, cujos tipos psicológicos são sugeridos a partir das condutas e visões de mundo por eles expressas. Nesta parte, procurei demonstrar quão enriquecedora pode ser a interface entre o Direito e a Psicologia, necessária para compreensão, dentre outras coisas, do fenômeno de produção das decisões judiciais.

Por fim, cumpre dizer que, embora a tipologia possa servir de ferramenta para maior compreensão do trabalho dos juízes, tão importante quanto isso seria o próprio magistrado valer-se da tipologia como possível via para o autoconhecimento e, a partir daí, investir no necessário movimento de ampliação da consciência, conditio sine qua non para agregar não apenas qualidade ao seu trabalho, mas sobretudo à forma como se insere no mundo.

(Leibniz, Rousseau). Mesmo a relação entre ambos muda com o tempo, havendo maior ou menor hierarquia e antagonismo. De qualquer modo, independentemente das diferenças de concepção, alguns traços distintivos são sempre encontrados, caracterizando-se o direito natural pela universalidade, imutabilidade (num mesmo período histórico) e origem (não é posto por uma instância de poder), enquanto o direito positivo é particular, mutável e promulgado por uma vontade alheia à de seu destinatário. Tércio Sampaio Ferraz Jr. Lembra-nos de que, embora tenha guardado sua importância como objeto da Filosofia do Direito, tal dicotomia enfraqueceu-se operacionalmente por conta da positivação dos direitos que são considerados fundamentais. Fontes consultadas: 1) BOBBIO, Norberto. O Positivismo Jurídico: Lições de Filosofia do Direito, Ícone Editora Ltda., São Paulo (SP), 1995; 2) HESPANHA, António Manuel. Cultura Jurídica Europeia - Síntese de um Milênio, 3를 Publicações Europa-América Lda., Portugal, 2003 (1997); 3) FERRAZ JR., Tércio Sampaio. Introdução ao Estudo do Direito (Técnica, Decisão, Dominação), 2aㅡ edição, SP, Editora Atlas, 1995. 


\section{PARTE 1}

\section{A TEORIA DOS TIPOS}

\section{INTRODUÇÃO À TEORIA DOS TIPOS}

A tipologia psicológica não tem a finalidade, em si bastante inútil, de dividir as pessoas em categorias, mas significa antes uma psicologia crítica que possibilite uma investigação e ordenação metódica dos materiais empíricos relacionados à psique. É, antes de tudo, instrumento crítico para o pesquisador em psicologia que precisa de certos pontos de vista e diretrizes para ordenar a profusão quase caótica das experiências individuais.

Carl G. Jung ${ }^{16}$

O senso de discriminação do homem certamente faz parte de seu processo civilizatório. Tal fato é refletido tanto no surgimento e aprimoramento da linguagem quanto na especialização do saber, gerando as diversas ramificações do conhecimento e o surgimento de novas "ciências". Graças a esta capacidade discriminatória, data de antigos tempos e diferentes culturas a observação de padrões de conduta entre os indivíduos.

José Jorge de Morais Zacharias, autor brasileiro junguiano, lembra, por exemplo, a introdução do calendário lunar pelo imperador Huang Ti, na China, no ano de 2637 a.C.. Nesse sentido, ensina:

"Esse calendário incluía uma antiga lenda em que um Senhor Buda (não o Sidarta Gautama), antes de despedir-se do mundo, convocou todos os animais para que viessem à sua presença. Vieram somente doze animais, e foram chegando na seguinte ordem: rato, boi, tigre, coelho, dragão, serpente, cavalo, carneiro, macaco, galo, cão e javali. Como recompensa por terem vindo, ele lhes deu o domínio sobre cada um dos doze anos de um ciclo. Assim, quem nascesse no ano do rato teria traços de personalidade próprios do animal simbólico do seu ano. Dizem os chineses que o animal do seu ano de nascimento é o animal que se esconde em seu coração. ${ }^{17}$

\footnotetext{
${ }^{16}$ Tipos ..., Anexo: “Tipologia psicológica”, p. 509, § 1057.

${ }^{17}$ Entendendo os Tipos Humanos, 2aㅡ edição, Editora Paulus, São Paulo (SP), 2006, p. 8.
} 
Dificilmente encontraríamos uma pessoa que jamais tivesse ouvido falar nos signos do Zodíaco, e ao menos de algumas das características atribuídas a cada signo. Ainda de acordo com Zacharias, "os signos do Zodíaco são classificados segundo os elementos constituintes da matéria - terra, ar, água e fogo -, havendo três signos para cada elemento. O elemento ao qual o signo de uma pessoa pertence também influencia bastante os traços de personalidade que ela irá demonstrar". ${ }^{18}$

A ideia dos quatro elementos será observada também na Grécia antiga, onde serão postulados pelo grego Hipócrates, considerado o pai da medicina. Conforme ensina Simone Clapier-Valladon, "a doutrina dos quatro humores de Hipócrates (460-370 a.C.) é uma tipologia que se vincula à divisão quaternária da cosmogonia de Empédocles e descreve quatro temperamentos", a seguir elencados:

À terra quente e úmida, Hipócrates faz corresponder o sangue, humor responsável pelo temperamento sanguíneo. O sanguíneo é de estatura média, musculoso, de rosto corado, frequentemente galhofeiro e de voz forte; é impulsivo, ativo, suporta mal as contrariedades.

Ao ar frio e seco corresponde a bílis negra, responsável pelo temperamento melancólico ou nervoso. O nervoso é um indivíduo longilíneo, pouco musculoso, no qual domina a vida interior e intelectual.

Ao fogo, quente e seco, corresponde a bílis amarela, que produz o temperamento colérico ou bilioso. Esse temperamento é o do indivíduo ativo, combativo, rápido, organizador metódico, que pode ser violento ou sectário.

À água, indicação de umidade, corresponde a linfa ou fleuma, que se reflete no temperamento do fleumático. Este é um indivíduo corpulento, com tendência à obesidade, lento, calmo, pouco emotivo, perseverante e fatalista. ${ }^{19}$

Cláudio Galeno (129-199), também médico, valer-se-á desta ideia e a ampliará, até encontrar 13 possíveis combinações de humores ${ }^{\mathbf{2 0}}$. Da classificação hipocrática, que, a

${ }^{18}$ Entendendo os Tipos Humanos, pp. 9/10.

${ }^{19}$ As Teorias da Personalidade, $1^{\mathrm{a}}$ edição, Editora Martins Fontes, São Paulo (SP), 1988, pp. 43/44.

${ }^{20}$ CLAPIER-VALLADON, Simone. As Teorias da Personalidade, 1ª edição, Editora Martins Fontes, São Paulo (SP), 1988, p. 44. 
despeito de críticas, teve o mérito de durar 1800 anos, Jung chama a atenção para o foco dado ao comportamento emocional da pessoa, o que, segundo ele, revelaria o destaque do aspecto afetivo no comportamento humano em geral. ${ }^{21}$

Ao longo do século XX, com o desenvolvimento da Psicologia, muitos outros sistemas de classificação dos tipos humanos foram propostos, tendo prevalecido, porém, até os dias de hoje, o de Carl Gustav Jung. ${ }^{22}$

Carl G. Jung (1875-1961) nasceu em Kesswil, pequena localidade da Suíça alemã. Era filho de Johann Paul Achilles Jung (1842-1896) e Emilie Preiswerk (1848-1923) ${ }^{23}$. Seu pai era pastor protestante, porém sem grande expressão em sua comunidade. No ano de 1900, após formar-se em medicina, Jung decidiu especializar-se em psiquiatria, tendo, para tanto, conseguido uma vaga num dos mais renomados centros psiquiátricos então existentes, o Hospital e Clínica Universitária Psiquiátrica Cantonal de Zurique, mais conhecido como Hospital Mental Burghölzli, onde ficaria até 1909. ${ }^{\mathbf{2 4}}$

Esta primeira década de sua vida profissional foi suficiente para lhe dar renome internacional como psiquiatra e pesquisador, tendo tido grande repercussão seus experimentos com associação de palavras, por meio dos quais consolidava o postulado da existência do inconsciente e, mais que isso, uma técnica de acesso a seus conteúdos. Não tardou para que se iniciasse intenso relacionamento com Freud (1856-1939), que logo vislumbrou no médico suíço o tão desejado herdeiro para a nascente escola da Psicanálise, por este último inaugurada.

Por conta disso, quando fundado um jornal cujo intuito era contribuir para divulgar os conceitos da Psicanálise - o Jahrbuch -, Jung foi seu editor ${ }^{25}$; e quando, em 1910, em Nuremberg, foi fundada a Internationale Psychoanalytische Vereinigung (IPV), mais tarde denominada International Psychoanalytical Association (IPA), também por influência de Freud Jung foi eleito seu primeiro presidente, e reeleito em 1911.

\footnotetext{
${ }^{21}$ Tipos ..., Anexo: “Tipos psicológicos”, pp. 470/471, §§ 951/952.

${ }^{22}$ PASQUALI, Luiz. Os Tipos Humanos, Editora Vozes, Petrópolis (RJ), 2003, pp. 16/19.

${ }^{23}$ BAIR, Deirdre. Op. cit., vol. 1, pp. 30/35.

${ }^{24}$ BAIR, Deirdre. Op. cit., vol. 1, pp. 83 e 210.

${ }^{25}$ BAIR, Deirdre, Op. cit., vol. 1, p. 283.
} 
A amizade entre os dois pesquisadores floresceu e foi cultivada em meio a uma fértil correspondência, em que debatiam aspectos teóricos, trocavam ideias sobre seus pacientes e tratavam da divulgação da nova ciência. No entanto, ao mesmo tempo em que avançavam na formulação de novos conceitos a respeito da constituição e funcionamento da psique, as diferenças entre os dois homens foram se evidenciando, até atingir seu ápice no ano de 1912. A esta altura, toda a chancela que Freud havia dado a Jung como portavoz privilegiado dos postulados da Psicanálise, transformaria agora o suíço em grave ameaça.

Escreve Bair, em excelente biografia de Jung: "Quando o ano de 1912 começou, o ‘dueto' Freud-Jung a serviço da psicanálise passou a ser um 'duelo'," ${ }^{26}$ É que nesse ano a discordância entre ambos no plano teórico ficou indisfarçável após a publicação, por Jung, de Metamorfoses e símbolos da libido, posteriormente intitulado Símbolos da transformação. Basicamente Jung pôs em cheque a tese, tão cara ao criador da Psicanálise, da primazia da sexualidade na economia libidinal. ${ }^{27}$ Passava, portanto, a representar um sério risco à divulgação do arcabouço psicanalítico, conforme concebido por Freud.

Assim, o mesmo empenho demonstrado por Freud para alçar Jung ao topo do grupo que se esforçava em gestar a nova ciência foi feito, a partir de então, no sentido contrário, de isolá-1o. ${ }^{28}$

Embora profundamente consternado com a reação de Freud, Jung manteve-se fiel a seus postulados e, afastado de um sem número de atividades vinculadas à divulgação da Psicanálise, pôde reservar mais espaço ao desenvolvimento de conceitos próprios, cujo conjunto em pouco tempo receberia o nome de Psicologia Analítica. ${ }^{29}$

Mas o que isso tem a ver com nosso trabalho? É que o profundo respeito que Jung nutria por Freud e pelo mérito de sua obra fê-lo pensar a respeito da incompatibilidade de suas percepções de mundo. Nas palavras do próprio Jung:

\footnotetext{
${ }^{26}$ BAIR, Deirdre. Op. cit., vol. 1, pp. 180, 277, 309.

${ }^{27}$ BAIR, Deirdre. Op. cit., vol. 1, pp. 276/277. A este respeito, ver também JUNG, Carl G.. Memórias, Sonhos, Reflexões, trad.: Dora Ferreira da Silva, Editora Nova Fronteira, Rio de Janeiro (RJ), 2006, pp. 202/204.

${ }^{28}$ BAIR, Deirdre. Op. cit., vol. 1, p. 287.

${ }^{29}$ BAIR, Deirdre. Op. cit., vol. 1, p. 319.
} 
Uma pergunta desempenhou um grande papel na gênese desta obra [Tipos psicológicos]: em que eu me distinguia de Freud? E de Adler? Que diferenças havia entre as nossas concepções? Refletindo sobre isso deparei com o problema dos tipos. É o tipo que precisa e limita de antemão os julgamentos do homem. O livro sobre os tipos psicológicos trata principalmente do confronto do indivíduo com o mundo, das suas relações com os homens e coisas. Nele descrevo os diferentes aspectos da consciência, as possibilidades de sua atitude em relação ao mundo (...) Meu livro sobre os tipos psicológicos conclui que todo julgamento de um homem é limitado pelo seu tipo de personalidade e que toda maneira de ver é relativa. ${ }^{\mathbf{3 0}}$

A obra de Jung a respeito dos tipos psicológicos, fruto de muitos anos de trabalho, veio a público em 1921, marcando o fim de um longo período de recolhimento e também praticamente de um jejum editorial, atribuído ao seu traumático rompimento com Freud. ${ }^{31}$

A respeito da gênese da obra, um alentado estudo da personalidade humana, escreve Jung:

Este livro é fruto de quase vinte anos de trabalho no campo da psicologia prática. Foi surgindo aos poucos no plano mental: às vezes, das inúmeras impressões e experiências que obtive na práxis psiquiátrica e no tratamento de doenças nervosas; outras vezes, do relacionamento com pessoas de todas as camadas sociais; de discussões pessoais com amigos e inimigos e, finalmente, da crítica às minhas próprias idiossincrasias psicológicas. ${ }^{32}$

Consistindo num "exame da personalidade na tentativa de explicar de que modo o inconsciente opera em pessoas diferentes" Jung como empirista ${ }^{34}$, por estar estreitamente vinculada à observação da forma de ser dos indivíduos. Como explica Bair, uma de suas mais distintas biógrafas, "o ponto de partida

${ }^{30}$ Memórias, ..., pp. 246/247.

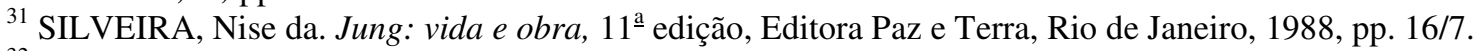

${ }^{32}$ Tipos ..., p. 17 (sem paragrafação).

${ }^{33}$ BAIR, Deirdre, Op. cit., vol. I, p. 331.

34 “A minha [filosofia] era meramente o ponto de vista empírico. Não pretendia conhecer tudo, queria apenas fazer a experiência do mundo para ver o que as coisas são", e, mais adiante: "Não tenho teoria sobre a origem da psique. Tomo os fenômenos tal como são, tento descrevê-los e classificá-los, e a minha terminologia é empírica, tal como a terminologia da botânica ou da zoologia." In McGUIRE, William e R.F.C. Hull. Entrevistas e Encontros, Editora Cultrix, São Paulo (SP), 1982, pp. 236/237. 
de Jung eram insights nascidos no contato com seus pacientes e aplicados à história, começando com o pensamento clássico, passando pela sociedade medieval e o romantismo, e terminando com o que qualificava como época contemporânea exemplificada pelo filósofo William James e as obras de Carl Spitteler, Friedrich Schiller e Goethe". ${ }^{35}$ A este rol também pode ser acrescentado o trabalho de Nietzsche, de cuja obra Jung se sentiu à vontade para extrair conclusões a respeito da personalidade do filósofo, que teria traços típicos de um intuitivo introvertido. ${ }^{36}$

Cabe esclarecer que Jung jamais apresentou sua teoria dos tipos como algo absolutamente inovador, alicerçando-a em sólida fundamentação. Singelo exemplo disso está no seguinte trecho:

A filosofia gnóstica estabeleceu três tipos que correspondem talvez a três funções psicológicas básicas: pensamento, sentimento e sensação. Os pneumatikoi poderiam estar relacionados com o pensamento, os psychikoi com o sentimento e os hylikoi com a sensação. ${ }^{37}$

No entanto, Jung inovou ao traduzir em "linguagem psicológica" o que já se sabia a respeito dos "tipos humanos" e, impossível não reconhecer, ao contribuir para o aprofundamento do tema, que municiou com os conceitos da Psicologia Analítica, tais como o de que a psique possui uma dinâmica compensatória ${ }^{38}$, importante para que se entenda, entre outras coisas, a relação entre funções principal e inferior, $e$ ainda a relevância desta relação para o chamado processo de individuação, conforme veremos oportunamente.

A nosso ver, o mais notável nesse empreendimento teórico, de base empírica, é que boa parte do objeto da observação não é o comportamento propriamente dito, mas também

${ }^{35}$ Op. cit., vol. 1, p. 331.

36 "O fato de NIETZSCHE enfatizar, por um lado, a função psicológica da intuição e, por outro, a função da sensação e do instinto, é característico de sua própria psicologia pessoal. Deve-se reconhecê-lo como intuitivo, com tendência para o lado introvertido. Em favor da primeira, fala sua arte de produção eminentemente intuitivo-artística, da qual é característica a obra $O$ Nascimento da Tragédia e ainda mais característica sua obra principal Assim falou Zaratustra. (...) Sua falta de moderação racional e concisão apontam-no como tipo intuitivo em geral. Nestas circunstâncias não surpreende que, em sua primeira obra, dê proeminência inconsciente à sua psicologia pessoal. Isto é bem próprio da atitude intuitiva que percebe o exterior através do interior, mesmo às custas da realidade.” Tipos ..., p. 147, § 225.

${ }^{37}$ Tipos ..., p. 27, $\S 10$.

38 “(...) considero a atividade do inconsciente como equilibração da unilateralidade da atitude geral, causada pela função da consciência" (in Tipos ..., p. 399, § 774). 
o perfil da elaboração intelectual (interna), que, segundo Jung, seria igualmente expressão do padrão de personalidade (tipo psicológico) de cada pensador. Ora, a repercussão disso no campo da epistemologia é evidente e pode-se dizer que a preocupação em demonstrá-lo foi central na empreitada do gênio suíço, conforme, aliás, depreende-se de suas próprias palavras:

O início de minha carreira se deu em linhas inteiramente freudianas; fui até considerado como seu melhor discípulo. Estive em ótimos termos com ele até a hora em que concluí que algumas coisas eram simbólicas. Aí Freud não concordou e identificou seu método com a teoria e a teoria com o método. Isto é impossível; não se pode jamais identificar método com ciência (...)

Não obstante, tenho plena consciência dos méritos de Freud e não tenho intenção alguma de diminuí-los. Sei, inclusive, que o que ele diz se adapta a uma grande parte das pessoas, e é possível afirmar que tais pessoas têm exatamente o tipo de psicologia que ele descreve. Adler, cujo ponto de vista era completamente diverso, também tem um grande número de seguidores, e estou convencido de que muitos têm uma psicologia adleriana. Também tenho os meus - não tão numerosos quanto os de Freud - eles são pessoas que têm presumivelmente a minha psicologia. Chego a considerar minha contribuição como minha própria confissão subjetiva. É a minha pessoa que está nisso, meu preconceito que me leva a ver os fatos de minha própria maneira. Mas espero que Freud e Adler façam o mesmo e confessem que suas ideias representam pontos de vista subjetivos. Desde que admitamos nosso preconceito estaremos realmente contribuindo para uma psicologia objetiva. ${ }^{39}$

Vemos, portanto, que a aparente impossibilidade de conciliar os pontos de vista de Freud e Adler, levou Jung a perceber com grande clareza o vínculo existente entre a produção intelectual e o universo subjetivo que a gerou, com consequências imensas para a Filosofia da Ciência, talvez ainda mal exploradas. Segundo Jung, analisado o mundo a partir da perspectiva psicológica de cada tipo, resultariam daí tantos pontos de vista teoricamente

39 Fundamentos de Psicologia Analítica (CW XVIII/1), 12 edição, Trad.: Araceli Elman, Editora Vozes, Petrópolis (RJ), “Quarta Conferência”, p. 116, §§ 274/275. 
possíveis quantos fossem os tipos, fato que torna "a crítica dos pressupostos psicológicos, quando da formação de qualquer teoria, ... uma necessidade imperiosa" ${ }^{40}$

Tal postulado abre as portas para o que Jung chamou de "psicologia crítica", que nada mais representa do que a consciência de que a Psicologia desenvolvida por Freud traz, necessariamente, as marcas de sua personalidade, de seus preconceitos, e assim por diante. Neste cenário, não há "verdades" possíveis, num sentido neutro, objetivo, absoluto. Paradoxalmente, quanto mais consciência se tiver dessa relatividade, mais objetividade será possível alcançar.

Podemos extrair daí a conclusão de que a busca de uma "verdade" não poderá jamais deixar de ser um empreendimento coletivo, cujos resultados são inapreensíveis, também, por um único indivíduo, e justamente por conta de suas idiossincrasias. Ao mesmo tempo, quanto mais tolerância houver em relação às diferenças, mais produtiva tenderá a ser a empreitada científica considerada como um todo:

(...) cada teoria sobre os processos psíquicos deve admitir que ela mesma é válida como um processo psíquico, como expressão de um tipo da psicologia humana, existente e com direito à existência. Unicamente dessas descrições típicas provêm os materiais cuja cooperação [grifo no original] torna possível uma síntese maior. ${ }^{41}$

Quando nos deparamos com a teoria junguiana dos tipos psicológicos, nela reconhecemos uma possível ferramenta de análise das influências do psiquismo do juiz em sua produção jurídica. Longe de cair num psicologismo, fato é que, parafraseando Jung, não gostaríamos de perder jamais esta nova perspectiva, que não apenas nos fornece meios para otimizar os esforços dos profissionais do Direito, mas também abre campo para a produção de um Direito mais crítico.

${ }^{40}$ A Prática da Psicoterapia (CW XVI/1), $10^{\mathrm{a}}$ edição, trad.: Maria Luiza Appy, Editora Vozes, Petrópolis (RJ), 2007, p. 109, § 236. No mesmo sentido: A Natureza da Psique (CW VIII/2), 5 edição, trad.: Pe. Dom Mateus Ramalho Rocha, OSB, Editora Vozes, Petrópolis (RJ), 2000, p. 61, § 260, onde se lê: "Uma crítica desta espécie seria de imenso valor não só para o círculo mais estreito da psicologia, como também para o círculo mais vasto das ciências em geral".

${ }^{41}$ Tipos ..., p. 458, § 930. 


\title{
CAPÍTULO 1 \\ OS TIPOS HUMANOS NA PSICANÁLISE DE FREUD
}

\section{AlgunS CONCEITOS DE TEORIA PSICANALÍTICA}

\begin{abstract}
Freud considera que o desenvolvimento mental do ser humano é determinado, antes de tudo, pela relação de seu corpo com o corpo da mãe e do pai. Em função do prazer e desprazer que experimenta no contato físico com os pais, na nutrição, na digestão dos alimentos, nas manifestações de afeição e carinho que recebe e também no desconforto e na dor que sente, o corpo da criança vai se erotizando. E essa experiência corporal não só permanece viva no inconsciente da criança, mas é a matriz das configurações mentais que terá na vida adulta, como aspectos de sua personalidade e de seu caráter.
\end{abstract}

Luiz Tenório Oliveira Lima ${ }^{42}$

Haja vista o estreito relacionamento entre Freud e Jung no início da carreira deste último, a ponto, inclusive, de Jung ser um dos grandes divulgadores da recém-nascida Psicanálise, convém lançar um olhar sobre a tipologia que chegou a ser desenvolvida por Freud.

Conforme relata Bair, "quando Jung publicou Tipos psicológicos, em 1921, Freud foi um dos primeiros a ler - e a rejeitá-lo como 'a obra de um esnobe e místico, nenhuma idéia nova [...] Não há grande dano a se esperar deste lado"", ${ }^{43} \mathrm{O}$ teor de tal comentário revela a postura defensiva do mestre em relação àquele que quiçá era considerado o mais promissor de seus "discípulos". A principal objeção levantada por Freud em relação à obra de Jung era a de que este ainda estava insistindo, como fizera desde a publicação de Símbolos da transformação, em 1912, que não poderia haver "verdade objetiva" na Psicologia, por causa das "diferenças pessoais na constituição do observador"

\footnotetext{
${ }^{42}$ LIMA, Luiz Tenório Oliveira. FREUD, Publifolha (Coleção “Folha Explica”), São Paulo (SP), 2001, pp. 54/55.

${ }^{43}$ BAIR, Deirdre, Op. cit., vol. 1, p. 371.

${ }^{44}$ BAIR, Deirdre, Op. cit., vol. 1, p. 371.
} 
A obra de Freud é monumental e grande parte dela deve-se ao apurado senso de observação de seu criador no que tange ao mundo que o cercava. Não seria razoável crer que tivesse escapado ao gênio a percepção de "padrões" de comportamento em pessoas que por tantos anos estiveram sujeitas ao crivo de sua análise. E, de fato, Freud notou a existência de padrões. No entanto, sua descrição dos mesmos revela o quanto a percepção desse autor estava naturalmente vinculada a todo o arcabouço teórico por ele já construído, de modo que ganhou ênfase um certo determinismo das fases do desenvolvimento psicossexual.

Neste sentido, Freud postulou basicamente a existência de quatro fases: oral, anal, fálica e genital, interpondo-se entre as três primeiras e esta última o chamado "período de latência”.

Conforme ensinam Fadiman e Frager, "à medida que um bebê se transforma numa criança, uma criança em adolescente e um adolescente em adulto, ocorrem mudanças marcantes no que é desejado e em como estes desejos são satisfeitos. As modificações nas formas de gratificação e as áreas físicas de gratificação são os elementos básicos na descrição de Freud das fases de desenvolvimento",45.

E que tipo de desejo poderia ser observado numa criança recém-nascida, e o que pode ser objeto desse desejo? Não é preciso nenhum estudo para saber que toda criança precisa, nos primeiros momentos de sua vida, do seio materno para se nutrir. No entanto, a grande contribuição de Freud foi perceber a implicação dessa dinâmica instintiva, de cunho biológico, na formação da personalidade dos indivíduos. Para estabelecer tal relação, Freud notou que a busca do seio materno pelo bebê atendia não apenas a um instinto de autopreservação, também estando presentes indícios da busca inconsciente de um prazer sensorial:

O chuchar [Ludeln ou Lutschen], que já aparece no lactente e pode continuar até a maturidade ou persistir por toda a vida, consiste na repetição rítmica de um contato de sucção com a boca (os lábios), do qual está excluído qualquer propósito de nutrição. Uma parte dos próprios lábios, a língua ou qualquer outro ponto da pele que esteja ao alcance — até mesmo o dedão do pé — são tomados como objeto sobre o

${ }^{45}$ FADIMAN, James e FRAGER, Robert. Teorias da Personalidade, Trad.: Camila Pedral Sampaio e Sybil Safdié, Editora Harper \& Row do Brasil Ltda., São Paulo (SP), p. 12. 
qual se exerce essa sucção. Uma pulsão preênsil surgida ao mesmo tempo pode manifestar-se através de puxadas rítmicas simultâneas do lóbulo da orelha e apoderar-se de uma parte de outra pessoa (em geral, a orelha) para o mesmo fim. O sugar com deleite alia-se a uma absorção completa da atenção e leva ao adormecimento, ou mesmo a uma reação motora numa espécie de orgasmo. Não raro, combina-se com a fricção de alguma parte sensível do corpo, como os seios ou a genitália externa. Por esse caminho, muitas crianças passam do chuchar para a masturbação. ${ }^{46}$

Freud foi o grande desbravador do inconsciente. É verdade que antes de sua formulação dos conceitos que viriam a formar a Psicanálise muitos outros pensadores apontaram para a existência dessa instância do aparelho psíquico ${ }^{47}$; no entanto, como que lhe prepararam o terreno para o grande salto dado por ele, ao sistematizar, como nenhum outro antes, a dinâmica psíquica, tendo sido fundamentais, já em fase avançada de sua elaboração teórica (segunda tópica), os conceitos de Ego, Superego e $I d$, bem como a descrição dos mecanismos de defesa do ego (recalcamento, repressão, regressão, formação reativa, sublimação, isolamento, anulação retroativa, denegação, projeção, introjeção, volta contra si e inversão do impulso). ${ }^{48}$

Nos primeiros dias de vida do ser humano, o funcionamento do aparelho psíquico estaria praticamente restrito ao inconsciente, predominando exclusivamente os chamados processos mentais primários: “(...) pode-se dizer que os processos mentais primários cons-

${ }^{46}$ FREUD, Sigmund. “A Sexualidade Infantil” in Três Ensaios sobre a Teoria da Sexualidade, Edição Standard Brasileira das Obras Psicológicas Completas de Sigmund Freud (ESB), vol. VII, Imago Editora, Rio de Janeiro (RJ), p. 169.

${ }^{47}$ Nesse sentido, Jean C. Filloux cita Nietzsche, Schopenhauer, Carl-Gustav Carus e Von Hartmann, cujos trabalhos ajudaram a criar um contexto cultural favorável à investigação das manifestações do inconsciente. Ver, do referido autor: $O$ Inconsciente, $2^{\underline{a}}$ edição, trad.: Norma Descaves, Difusão Européia do Livro (Difel), São Paulo (SP), 1966, pp. 11/18. A despeito de indícios da influência de Nietzsche e Schopenhauer em sua obra, Freud sempre afirmou ter desenvolvido seu trabalho de forma independente, não tendo em momento algum tomado os referidos filósofos como fonte de inspiração: "O alto grau em que a psicanálise coincide com a filosofia de Schopenhauer - ele não somente afirma o domínio das emoções e a suprema importância da sexualidade, mas também estava até mesmo cônscio do mecanismo da repressão - não deve ser remetida à minha familiaridade com seus ensinamentos. Li Schopenhauer muito tarde em minha vida. Nietzsche, outro filósofo cujas conjecturas e intuições amiúde concordam, da forma mais surpreendente, com os laboriosos achados da psicanálise, por muito tempo foi evitado por mim, justamente por isso mesmo; eu estava menos preocupado com a questão da prioridade do que em manter minha mente desimpedida" - in "Um Estudo Autobiográfico", ESB, vol. XX, p. 62.

${ }^{48}$ REIS, Alberto O. Advincula. "Teorias da Personalidade em Sigmund Freud", in Teorias da Personalidade em Freud, Reich e Jung, Editora Pedagógica e Universitária Ltda., São Paulo (SP), 1984, pp. 50/52. 
tituem, no bebê, a única forma de funcionamento do aparelho mental. São, portanto, anteriores à divisão da personalidade em sistemas conscientes e inconscientes". 49

Sendo puro impulso, não há na mente do bebê nenhuma instância a que se possa chamar de consciência. Pode-se dizer, portanto, que "o aparelho psíquico do bebê toma seus desejos por realidade" e, neste sentido, "ele é onipotente" ${ }^{, 50}$. A instância da consciência vai se formar justamente pelo fato de o bebê não ter todos os seus desejos satisfeitos, de modo que um novo princípio no funcionamento do aparelho mental é introduzido ao lado do princípio do prazer: o princípio de realidade, que dá início ao chamado processo secundário, assim chamado por derivar do primário, e caracterizado pela oposição entre os mencionados princípios. ${ }^{\mathbf{5 1}}$

Apesar da formação da consciência, na visão psicanalítica o núcleo ativo da personalidade permanecerá sendo sempre o inconsciente, fonte de toda energia psíquica ${ }^{\mathbf{5 2}}$, conformadora de impulsos que inicialmente serão classificados em dois grandes grupos: os de autoconservação e os sexuais (primeira tópica de Freud ${ }^{\mathbf{5 3}}$ ). Os impulsos de autoconservação são os relativos à manutenção da vida do próprio indivíduo, podendo ser exemplificados pela fome ou sede, enquanto os sexuais são os relacionados à preservação da própria espécie. Nota-se, aí, um viés bastante biológico, um olhar focado nos aspectos instintivos do ser humano. Aliás, conforme comentam Fadiman e Frager, "subjacente a todo o pensamento de Freud está o pressuposto de que o corpo é a fonte básica de toda experiência mental. Ele esperava o tempo em que todos os fenômenos mentais pudessem ser explicados com referência direta à fisiologia do cérebro. Freud sentia que seu próprio trabalho era frequentemente apenas descritivo e que seria superado por pesquisas aperfeiçoadas em

${ }^{49}$ REIS, Alberto O. Advincula, Op. cit., p. 21.

${ }^{50}$ REIS, Alberto O. Advincula, Op. cit., p. 21.

${ }^{51}$ REIS, Alberto O. Advincula, Op. cit., pp. 21/22.

${ }^{52}$ REIS, Alberto O. Advincula, Op. cit., p. 19; FADIMAN, James e FRAGER, Robert, Op. cit., p. 7.

${ }^{53}$ FREUD experimentou 83 anos de uma vida bastante produtiva. A partir de 1920, alguns dos conceitos básicos da teoria psicanalítica foram por ele reformulados, dando origem ao que se chamou de segunda tópica. Os impulsos anteriormente classificados nas categorias opostas de autopreservação e sexuais (preservação da espécie) passaram a ser agrupados numa única categoria, representativa das pulsões de Vida (sexualidade, libido, Eros), oposta, por sua vez, à da pulsão de Morte (Thanatos). (REIS, Op. cit., pp. 5/6 e 58/60.) Ainda: "Depois de muito hesitar e vacilar, decidimos presumir a existência de apenas dois instintos básicos, Eros e o instinto destrutivo. (O contraste entre os instintos de autopreservação e a preservação da espécie, assim como o contraste entre o amor do ego e o amor objetal, incidem dentro de Eros.)" in FREUD, Sigmund. Esboço de Psicanálise, ESB, vol. XXIII, p. 161. 
neurologia" ${ }^{\mathbf{5 4}}$ A corroborar tal assertiva, vale mencionar texto do próprio Freud, escrito na fase final de sua vida (1938), a respeito da "teoria dos instintos":

As forças que presumimos existir por trás das tensões causadas pelas necessidades do id são chamadas de instintos. Representam as exigências somáticas que são feitas à mente. ${ }^{55}$

Registra-se, aqui, não se desconhecer a importante ressalva feita por Renato Mezan no tocante à distinção entre instinto e pulsão e o dilema envolvendo a tradução da obra freudiana:

Ao escolher o termo "pulsão" para traduzir o conceito freudiano de Trieb, alinhamo-nos com aqueles autores, notadamente da escola lacaniana, que acentuam a originalidade desta concepção e a profunda diferença que existe entre ela e a noção de "instinto", termo escolhido por James Strachey na Standard Edition. Freud utiliza a palavra Instinkt apenas três ou quatro vezes em toda a sua obra; e para ele, o vocábulo denota um comportamento animal fixado hereditariamente e manifestado de maneira relativamente invariável em todos os indivíduos da espécie em questão. ${ }^{56}$

No entanto, tal distinção em nada interfere na observação a respeito do viés biológico de aspectos de seu pensamento.

A despeito dessa divisão entre pulsões de autoconservação e sexuais, quando levamos em conta o impulso do recém-nascido em buscar o seio da mãe como fonte de alimento, em vez de ver aí apenas a manifestação de um impulso de autoconservação, Freud tam-

${ }^{54}$ FADIMAN, James e FRAGER, Robert, Op. cit., pp. 6/7.

${ }^{55}$ FREUD, Sigmund. Esboço de Psicanálise, ESB, vol. XXIII, p. 161.

${ }^{56}$ MEZAN, Renato. Freud: a Trama dos Conceitos, 4" edição, Editora Perspectiva S/A, São Paulo (SP), 2006, pp. 154/155. Especificamente a respeito do conceito de “pulsão”, escreve FREUD: "Por 'pulsão' podemos entender, a princípio, apenas o representante psíquico de uma fonte endossomática de estimulação que flui continuamente, para diferenciá-la do 'estímulo', que é produzido por excitações isoladas vindas de fora. Pulsão, portanto, é um dos conceitos da delimitação entre o anímico e o físico. A hipótese mais simples e mais indicada sobre a natureza da pulsão seria que, em si mesma, ela não possui qualidade alguma, devendo apenas ser considerada como uma medida da exigência de trabalho feita à vida anímica. O que distingue as pulsões entre si e as dota de propriedades específicas é sua relação com suas fontes somáticas e seus alvos. A fonte da pulsão é um processo excitatório do órgão, e seu alvo imediato consiste na supressão desse estímulo orgânico", in "As Aberrações Sexuais" in Três Ensaios sobre a Teoria da Sexualidade, ESB, p. 158. 
bém observa uma manifestação de sexualidade, dando corpo à revolucionária teoria da sexualidade infantil. Neste particular, bastante esclarecedora a lição de Renato Mezan:

A produção do prazer vincula-se inicialmente ao exercício de uma função biológica fundamental, a alimentação; ela se "apóia" (sich lehnt an) nesta função, mas em seguida se torna autônoma e passa a ser procurada independentemente dela. É no momento em que o prazer sentido na sucção do seio ou da mamadeira se desliga do ato de mamar que nasce a função sexual propriamente dita: a boca, sede da primeira experiência de satisfação, constitui-se numa zona erógena, o objeto sexual se fixa no dedo ou em qualquer outra região do corpo atingível pela boca, e a área escolhida invariavelmente pertence ao próprio corpo da criança: a satisfação se torna auto-erótica depois de desvincular-se do seio. Contudo, do ponto de vista estritamente sexual, esta é a primeira forma de manifestação da pulsão, já que no estágio anterior o prazer sexual não pode ser nitidamente desvinculado do prazer determinado pela satisfação da necessidade de se alimentar. ${ }^{57}$

Vemos, portanto, que se num primeiro momento o prazer da criança decorre de um contato com um “outro", ou seja, a mãe, não tardará para que ela encontre um "substitutivo", em si mesma, visando à reprodução ou ao prolongamento desta sensação, a despeito de estar ausente o fator alimentação. Este substitutivo pode ser um dos dedos de sua mão ou qualquer outra parte de seu corpo ${ }^{\mathbf{5 8}}$ e, estando ausente o fator alimentação, e estando presente a sensação de prazer, fala-se em primeira forma de manifestação da pulsão sexual.

57 MEZAN, Renato. Freud: a Trama dos Conceitos, 4- edição, Editora Perspectiva S/A, São Paulo (SP), 2006, p. 132.

${ }^{58}$ A este respeito, comenta FREUD: "A propriedade erógena pode ligar-se de maneira mais marcante a certas partes do corpo. Existem zonas erógenas predestinadas, como mostra o exemplo do chuchar. Mas esse exemplo ensina também que qualquer outro ponto da pele ou da mucosa pode tomar a seu encargo as funções de uma zona erógena, devendo, portanto, ter certa aptidão para isso. Assim, a qualidade do estímulo, mais do que a natureza das partes do corpo, é que tem a ver com a produção da sensação prazerosa. A criança chuchadora perscruta seu corpo para sugar alguma parte dele, que depois, por hábito, torna-se a preferida; quando tropeça casualmente numa das partes predestinadas (os mamilos, a genitália), esta decerto retém a preferência. Uma capacidade de deslocamento inteiramente análoga reaparece na sintomatologia da histeria. Nessa neurose, o recalcamento afeta sobretudo as zonas genitais propriamente ditas, e estas transmitem sua excitabilidade a outras zonas erógenas, de outro modo relegadas na vida adulta, que então se comportam exatamente como genitais. Além disso, porém, tal como ocorre no chuchar, qualquer outra parte do corpo pode ser provida da excitabilidade da genitália e alçada à condição de zona erógena. As zonas erógenas e histerógenas exibem as mesmas características". (FREUD, Sigmund. "A Sexualidade Infantil” in Três Ensaios sobre a Teoria da Sexualidade, ESB, vol. VII, p. 173.) 
Verifica-se, portanto, a postulação de uma sexualidade já nas primeiras fases de vida do indivíduo. No entanto, quando se fala de sexualidade, é fundamental lembrar que no universo psicanalítico isso tem um sentido muito próprio. Conforme explica Reis, “de maneira geral, concebe-se a noção de sexualidade como sendo correlativa à noção de impulso (...) o aparelho mental é submetido a excitações (...) de procedência tanto externa quanto interna. Ao representante psíquico das excitações internas dá-se o nome de impulso" [ou pulsão]. E prossegue o mesmo autor:

Assim, na definição freudiana, impulso é um conceito energético, situado entre o somático e o psíquico, que se define por quatro características básicas: origem, especificidade, objetivo e objeto. Toda energia, ou todo impulso, possui uma origem. A origem desta energia é somática, localizada na região do corpo onde nasce a excitação. Além disto, a energia possui uma especificidade, ou seja, ela exerce uma força contínua no sentido de sua satisfação, que nada mais é do que uma diminuição da intensidade da pressão ocasionada pela excitação. O objetivo do impulso é, assim, alcançar sua satisfação através de um modo ou maneira específica e, para tanto, ele irá necessitar de um objeto. ${ }^{\mathbf{5 9}}$

Vemos, assim, que com a publicação do famoso "Três Ensaios sobre a Teoria da Sexualidade", Freud ampliou o conceito de sexualidade que, a partir de então deixaria de estar necessariamente ligado aos atos e ao prazer genitais, passando a se referir a um "conjunto de excitações e de atividades que surgem desde a infância e proporcionam um prazer que vai além da satisfação de uma necessidade fisiológica fundamental", incluindo "pulsões que não estão necessariamente ligadas à procriação". ${ }^{\mathbf{0}}$

Ao fazer uma leitura profunda da obra de Freud, Mezan nos traz o seguinte alerta:

De todos os elementos do edifício teórico da psicanálise, a teoria sexual é provavelmente aquele que mais modificações sofreu durante o desenvolvimento da obra de FREUD (...) Podemos dizer, por isso, que a história da evolução do conceito de sexualidade é idêntica à história da psicanálise. ${ }^{\mathbf{6 1}}$

\footnotetext{
${ }^{59}$ REIS, Alberto O. Advincula. Op. cit., pp. 19/20.

60 THIS, Bernard. "FREUD", in O Livro de Ouro da Psicanálise (o pensamento de Freud, Jung, Melaine Klein, Lacan, Winnicott e outros), Trad.: Alexandre Massella, Ediouro Publicações S/A, Rio de Janeiro (RJ), 2007, p. 112.

${ }^{61}$ MEZAN, Renato, Op. cit., p. 127.
} 
A despeito da evolução do conceito, corremos o risco de afirmar que os impulsos de caráter sexual e as circunstâncias de sua experimentação na infância sempre terão lugar de destaque na formação da personalidade do indivíduo adulto. Eventual falha neste desenvolvimento poderá estar na gênese de futuros transtornos, já na vida adulta. Conforme lembram Fadiman e Frager:

FREUD usa o termo fixação para descrever o que ocorre quando uma pessoa não progride normalmente de uma fase para outra, mas permanece muito envolvida numa fase particular. Uma pessoa fixada numa determinada fase preferirá satisfazer suas necessidades de forma mais simples ou infantil, ao invés dos modos mais adultos que resultariam de um desenvolvimento normal. ${ }^{62}$

Dados estes elementos conceituais básicos, passemos à análise das fases do desenvolvimento psicossexual postuladas, pela primeira vez, nos Três Ensaios sobre a Teoria da Sexualidade.

${ }^{62}$ FADIMAN, James e FRAGER, Robert, Op. cit., pp. 12/13. 


\section{A FASE ORAL}

A fase oral representa o primeiro estágio do desenvolvimento psicossexual. Praticamente o primeiro contato significativo do recém-nascido com o meio externo se dá com o seio da mãe. Inicialmente, o aparelho mental do bebê não distingue absolutamente nada além de si próprio. $\mathrm{O}$ mundo se resume a ele mesmo, até porque sua percepção ainda é muito difusa.

Atendendo à necessidade de alimentação do infante, a mãe lhe oferecerá o seio, de onde fluirá a morna seiva capaz de saciar sua fome e sede. Este contato do bebê com o seio nutridor é extremamente prazeroso, mas não apenas por conta do fator alimentação. Este fator funciona como suporte biológico do contato, ao mesmo tempo em que os lábios da criança se comportam como zona erógena ${ }^{63}$, dando origem a uma notável sensação de prazer.

Se durante o processo de amamentação a criança for confortada, aninhada, acariciada, acalentada, ela tenderá a associar o processo de prazer e redução da tensão com o processo de alimentação. Tendo havido alguma fixação nesta fase do desenvolvimento, o indivíduo poderá apresentar tendência a ser ávido apreciador do beijo (no sentido de tender à perversão), do fumo, da bebida ${ }^{64}$ ou da comida em exagero. Uma fixação nesta fase também pode explicar um comportamento excessivamente otimista e passivo, do sujeito que espera que a vida tudo lhe proveja, sem que tenha de fazer grande esforço para conquistar o que quer que seja. Portanto, "otimismo, generosidade, despreocupação, desprezo pela realidade e confiança cega no futuro" constituem traços do caráter oral. ${ }^{65}$

Existe, porém, uma categoria de indivíduos cujo comportamento revela a atividade de uma sucção insatisfatória. Parecem estar sempre pedindo algo sob a forma de solicitação ou exigência imperativa e se agarram aos outros como "sanguessugas". Neles, a impaciência é típica e seu desejo de tudo obter pode levá-los ao consumismo exagerado. Ten-

\footnotetext{
${ }^{63}$ A respeito do sentido de "zona erógena", esclarece FREUD: "Do exemplo do chuchar podemos ainda deduzir várias coisas para a caracterização do que é uma zona erógena. Trata-se de uma parte da pele ou da mucosa em que certos tipos de estimulação provocam uma sensação prazerosa de determinada qualidade" in "A Sexualidade Infantil" in Três Ensaios ..., p. 172.

${ }^{64}$ FREUD, Sigmund. “A Sexualidade Infantil” in Três Ensaios ..., p. 172.

${ }^{65}$ REIS, Alberto O. Advincula. Op. cit., p. 29.
} 
dem a apresentar certa urgência em falar e a expressar um fluxo aparentemente inesgotável de pensamentos. Na esfera intelectual, as qualidades deste tipo de caráter podem ganhar aspectos bastante positivos, uma vez que seus representantes estão sempre aptos a absorver novas ideias. ${ }^{\mathbf{6 6}}$

No entanto, existe a possibilidade de esta experiência ser vivida numa dimensão negativa, gerando no adulto sérios distúrbios alimentares. ${ }^{67}$ Fadiman e Frager destacam que "a retenção de algum interesse em prazeres orais é normal. Este interesse só pode ser encarado como patológico se for o modo dominante de gratificação, isto é, se uma pessoa for excessivamente dependente de hábitos orais para aliviar a ansiedade". ${ }^{6}$

A fase oral pode ser dividida em duas etapas, sendo a primeira delas caracterizada pela sucção do alimento (fase oral auto-erótica) e a segunda pelo ato de morder (fase oral canibálica). Traços da primeira foram retratados acima. Quanto à segunda, tem-se que a relação da criança com o objeto sexual é ambivalente, ou seja, coexistem "duas valências afetivas opostas, dirigidas ao mesmo objeto, prazer (incorporação) e destruição (mordida)", configurando o sadismo na relação afetiva. ${ }^{69}$

Reis pontua que "a derivação do sadismo oral em traços de caráter pode ser apreendido no uso agressivo da linguagem. Assim, atribui-se a tal indivíduo um caráter mordaz ou língua ferina. Neste caso, o impulso de falar significa prazer e desejo de aniquilar, destruir (...) Tem-se na figura mítica do vampiro a melhor expressão que a humanidade criou para designar tal caráter". ${ }^{70}$

\footnotetext{
${ }^{66}$ REIS, Alberto O. Advincula, Op. cit., p. 29.

${ }^{67}$ FREUD, Sigmund. "A Sexualidade Infantil" in Três Ensaios ..., p. 172.

${ }^{68}$ FADIMAN, James e FRAGER, Robert, Op. cit., p. 13.

${ }^{69}$ REIS, Alberto O. Advincula, Op. cit., pp. 29/30.

${ }^{70}$ REIS, Alberto O. Advincula, Op. cit., p. 30.
} 


\section{A FASE ANAL}

Assim como a mucosa dos lábios servirá de apoio para o desenvolvimento da sexualidade numa fase pré-genital, não tardará para que a sensibilidade do esfíncter anal entre em cena, chamando a atenção da criança e ganhando uma conotação que extrapola sua função biológica. Como registra Freud, "os distúrbios intestinais tão frequentes na infância providenciam para que não faltem a essa zona excitações intensas", e, pouco adiante:

As crianças que tiram proveito da estimulabilidade erógena da zona anal denunciam-se por reterem as fezes até que sua acumulação provoca violentas contrações musculares e, na passagem pelo ânus, pode exercer uma estimulação intensa na mucosa. Com isso, hão de produzir-se sensações de volúpia ao lado das sensações dolorosas. Um dos melhores presságios de excentricidade e nervosismo posteriores é a recusa obstinada do bebê a esvaziar o intestino ao ser posto no troninho, ou seja, quando isso é desejado pela pessoa que cuida dele, ficando essa função reservada para quando aprouver a ele próprio. Naturalmente, não é que the interesse sujar a cama; ele está apenas providenciando para que não lhe escape o dividendo de prazer que vem junto com a defecação. Mais uma vez, os educadores têm razão ao chamarem de perversas [schlimm] as crianças que "retardam" essas funções.

O conteúdo intestinal, que, enquanto corpo estimulador, comporta-se frente a uma área de mucosa sexualmente sensível como precursor de outro órgão destinado a entrar em ação depois da fase da infância, tem ainda para o lactante outros importantes sentidos. É obviamente tratado como parte de seu próprio corpo, representando o primeiro 'presente': ao desfazer-se dele, a criaturinha pode exprimir sua docilidade perante o meio que a cerca, e ao recusá-lo, sua obstinação. Do sentido de 'presente', esse conteúdo passa mais tarde ao de 'bebê', que, segundo uma das teorias sexuais infantis, é adquirido pela comida e nasce pelo intestino. ${ }^{71}$

À medida que a criança cresce, essa nova área de tensão e gratificação é trazida à sua consciência. Entre os dois e os quatro anos de idade, passará ela a contar com atenção exclusiva de seus pais, voltada para o treinamento de higiene, que implica aprender a controlar tanto as necessidades de defecação quanto de micção. Quando bem sucedida, a cri-

${ }^{71}$ FREUD, Sigmund. “A Sexualidade Infantil” in Três Ensaios ..., pp. 175/176. 
ança receberá demonstrações de agrado, sendo eventualmente elogiada; quando mal sucedida, poderá vir a ser repreendida. Portanto, perceberá que a liberação ou retenção de suas fezes tem efeito sobre os outros, sem contar o prazer auto-erótico gerado pela passagem das fezes, principalmente quando acumuladas, pelo esfíncter.

Reis destaca que a literatura psicanalítica clássica referente a este tipo de caráter é particularmente rica, havendo importantes contribuições de Sadger, Jones, Abraham e Reich, além das do próprio Freud, e que é "a partir das transformações da sexualidade anal em traços estáveis e homogêneos de comportamento que surge o caráter anal”2, expresso, basicamente, por três características, que normalmente aparecem juntas: ordem, parcimônia e obstinação. ${ }^{\mathbf{7 3}}$ Explica, também, que em fase mais avançada esse prazer, ao ser reprimido, poderá derivar, via sublimação ou formação reativa, em prazer de pintar ou modelar ou em obsessão por limpeza. ${ }^{\mathbf{7 4}}$

Neste ponto, talvez caiba um rápido esclarecimento a respeito dos conceitos de $s u$ blimação e de formação reativa, ambos elaborados por Freud, estando elencados entre os diversos mecanismos de defesa do Ego em relação aos impulsos instintivos do inconsciente.

Nas palavras de Fadiman e Frager, a sublimação é o processo pelo qual "a energia originalmente dirigida para propósitos sexuais ou agressivos é direcionada para novas finalidades, com frequência metas artísticas, intelectuais ou culturais". E ainda:

A sublimação foi denominada a "defesa bem sucedida" (Fenichel, 1945). Podemos comparar a energia original a um rio que inunda, destruindo casas e propriedades. Para evitar isso, uma barragem é construída. A destruição não pode mais ocorrer mas a pressão se desenvolve atrás do dique, ameaçando danos ainda maiores se, em qualquer ocasião, a barreira romper-se. A sublimação é a construção de canais alternativos que, por sua vez, podem ser usados para gerar energia elétrica, irrigar áreas outrora áridas, criar parques e oferecer outras oportunidades recreativas. A e-

\footnotetext{
${ }^{72}$ REIS, Alberto O. Advincula. Op. cit., p. 31.

${ }^{73}$ REIS, Alberto O. Advincula. Op. cit., p. 31. FREUD trata especificamente do chamado "caráter anal" em artigo publicado em 1908, intitulado "Caráter e Erotismo Anal”, no qual faz menção expressa a estas três características (ESB, vol. IX, pp. 159/164).

${ }^{74}$ REIS, Alberto O. Advincula. Op. cit., p. 31.
} 
nergia original do rio foi desviada com sucesso para canais socialmente aceitáveis ou culturalmente sancionados. A energia sublimada é responsável pelo que denominamos civilização. Freud alega que a enorme energia e complexidade da civilização resulta da pulsão subjacente para achar vias aceitáveis e suficientes para a energia reprimida. A civilização encoraja a transcendência das pulsões originais e, em alguns casos, os fins alternativos podem ser mais satisfatórios para o id que a satisfação dos impulsos iniciais. ${ }^{75}$

Por meio do processo de sublimação, a libido, de natureza essencialmente sexual, é "dessexualizada" ${ }^{\mathbf{7 6}}$, vindo a ser utilizada para fins socialmente aceitos.

Nota-se que, por meio da sublimação, pulsões sexuais que não poderiam encontrar vazão em determinado contexto sócio-cultural, em vez de permanecerem represadas, encontram canais alternativos de expressão: o objetivo é deslocado, porém sem que se perca a intensidade do investimento energético ${ }^{77}$. Segundo Freud, a esse mecanismo devemos todo o processo civilizatório, sendo também o mecanismo predominante na formação do caráter a que se possa chamar de "normal"78.

Muito diferente é a formação reativa. Por meio deste mecanismo, em vez de se permitir a expressão das pulsões de uma forma socialmente aceita, são as mesmas bloqueadas pelo que Freud expressivamente denominou "diques psíquicos", que a elas se opõem, representados pelas forças anímicas (moções reativas) do asco, da vergonha e da moral. ${ }^{79}$ Curiosamente, mesmo tais reações, embora presentes, podem vir a ser excluídas da consciência, passando a atuar de forma inconsciente na expressão da personalidade do indivíduo. $^{80}$

Ora, ao representar um contra-investimento feito no sentido de evitar a realização de um desejo inconsciente, a formação reativa tende a gerar posturas excessivamente enér-

${ }^{75}$ FADIMAN, James e FRAGER, Robert, Op. cit., p. 18.

${ }^{76}$ FREUD, Sigmund. $O$ Ego e o Id, ESB, vol. XIX, p. 51. No mesmo sentido, ver também o verbete "sublimação", escrito pelo próprio FREUD, em ESB, vol. XVIII, p. 272.

${ }^{77}$ FREUD, Sigmund. "Moral Sexual 'Civilizada' e Doença Nervosa Moderna", ESB, vol. IX, p. 174.

${ }_{78}^{78}$ REIS, Alberto O. Advincula. Op. cit., p. 25.

${ }^{79}$ FREUD, Sigmund. “A Sexualidade Infantil” in Três Ensaios ..., p. 168.

${ }^{80}$ FADIMAN, James e FRAGER, Robert, Op. cit., p. 21. Ao tratar do tema, REIS cita o seguinte texto de FREUD: "Em termos econômicos, a formação reativa é um contra-investimento de um elemento consciente de força igual e oposta a um investimento inconsciente. A formação reativa exclui da consciência tanto a representação sexual inaceitável como a condenação que ela suscita." (Op. cit., p. 26.) 
gicas, rígidas, acentuadamente estáticas, sendo assim um mecanismo que leva a uma organização patológica do caráter, podendo-se chegar à conclusão de que "o que dá um aspecto normal ou então patológico ao caráter é o mecanismo de transformação dominante da sexualidade pré-genital: a sublimação ou a formação reativa.",81

Enquanto a sublimação das pulsões sexuais implica condutas de elevado valor social, a formação reativa, ao produzir reações exageradas e por vezes extravagantes, tem como efeito colateral comportamentos não raro nocivos ao bom relacionamento social. Muitas vezes, a distinção entre um e outro dos referidos mecanismos assenta-se numa questão de grau. Por exemplo: sendo uma característica do caráter anal o cuidado diferenciado pela higiene, ninguém pode negar a qualidade disso em alguém que exerce profissão na qual tal cuidado constitua requisito essencial, caso dos manipuladores de alimentos. Por outro lado, a radicalização deste traço pode levar uma pessoa a evitar contato direto com seus semelhantes, em quem passa a ver possíveis fontes de "contaminação".

Conforme já vimos acima, Freud associou três características que costumam se apresentar em conjunto nas pessoas que apresentam tal caráter: seriam elas ordeiras, parcimoniosas e obstinadas, havendo uma relação mais estreita entre as duas últimas características, que constituiriam, também, "o elemento mais constante de todo o complexo". 82

A palavra ordeira é utilizada em acepção ampla: "tanto abrange a noção de esmero individual como o escrúpulo no cumprimento de pequenos deveres e a fidedignidade. $\mathrm{O}$ contrário de ordeiro seria 'descuidado' e 'desordenado'., ,83

A parcimônia inevitavelmente acaba se expressando em contextos que envolvem dinheiro. As pessoas com esse tipo de caráter provavelmente terão predileção a dividir a conta num restaurante, podendo às vezes tender para a avareza. Bons representantes desse caráter são os colecionadores de toda ordem. Nada impede, porém, que o excesso se dê em sentido inverso: que eventual fixação na fase anal seja expressa por um comportamento perdulário em relação a bens materiais ${ }^{\mathbf{8 4}}$, o que estaria associado ao prazer da criança no

\footnotetext{
${ }^{81}$ REIS, Alberto O. Advincula. Op. cit., pp. 25/26.

${ }^{82}$ FREUD, Sigmund. "Caráter e Erotismo Anal”, pp. 159.

${ }^{83}$ FREUD, Sigmund. "Caráter e Erotismo Anal”, pp. 159.

${ }^{84}$ LIMA, Luiz Tenório Oliveira. FREUD, Publifolha (Coleção “Folha Explica”), São Paulo (SP), 2001, p. 33.
} 
ato de liberação das fezes, seja num sentido auto-erótico, seja no de agradar à mãe (ou a quem lhe faça as vezes).

A fim de sugerir a conexão existente entre dinheiro e fezes, Freud lembra que desde os tempos mais arcaicos o primeiro é associado à sujeira:

Talvez a neurose aqui apenas siga um indício fornecido pela linguagem popular, que qualifica o indivíduo muito apegado ao seu dinheiro de "sujo" ou "imundo" (...) Sabemos que o ouro entregue pelo diabo a seus bem-amados converte-se em excremento após sua partida, e o diabo nada mais é do que a personificação da vida instintual inconsciente reprimida. Também conhecemos a superstição que liga a descoberta de um tesouro com a defecação, e todos estão familiarizados com a figura do "cagador de ducados" [Dukatenscheisser]. Na verdade, segundo as antigas doutrinas da Babilônia, o ouro são "as fezes do Inferno" (Mammon = ilu manman). Assim, aqui como em outras ocasiões, a neurose, acompanhando os usos da linguagem, toma as palavras no seu sentido original e significativo; parecendo utilizálas em seu sentido figurado, está na realidade simplesmente devolvendo a elas seu sentido primitivo. ${ }^{85}$

Quanto à obstinação, é característica que pode facilmente se desenvolver em direções diferentes. Em grau exagerado, expressar-se-á como teimosia e inacessibilidade; num grau mais comedido, será perseverança e escrupulosidade. Também poderá expressarse por meio de um prazer em dominar os outros, acompanhado de um receio de se deixar influenciar. Em todo caso, significará apego e retenção mental de uma ideia, independentemente de seu valor social ou cultural. ${ }^{\mathbf{8 6}}$

No pequeno, porém instigante artigo em que trata exclusivamente do caráter anal, Freud deixa claro que suas ponderações decorrem da observação da conduta de seus pacientes e não de suposições teóricas. Não obstante, evita fazer afirmações categóricas, optando por uma linguagem mais propositiva e hipotética do que propriamente dogmática. Neste contexto, afirma ele:

\footnotetext{
${ }^{85}$ FREUD, Sigmund. “Caráter e Erotismo Anal”, pp. 162/163.

${ }^{86}$ REIS, Alberto O. Advincula. Op. cit., p. 32.
} 
Se houver realmente alguma base para a relação que aqui estabelecemos entre o erotismo anal e essa tríade de traços de caráter, provavelmente não encontraremos um acentuado grau de 'caráter anal' nos indivíduos que conservaram na vida adulta o caráter erógeno da zona anal, como acontece, por exemplo, com certos homossexuais. A menos que esteja enganado, a experiência comprova amplamente essa conclusão. ${ }^{87}$

${ }^{87}$ FREUD, Sigmund. “Caráter e Erotismo Anal”, pp. 163/164. 


\section{A FASE FÁLICA}

Conforme se desenvolve, a percepção da criança a respeito de seu próprio corpo amplia-se e novas zonas erógenas vão sendo descortinadas. A partir dos quatro anos de idade, a fase de educação visando ao controle dos esfíncteres normalmente já estará superada, notando-se, a partir daí, maior atenção da criança a seus genitais, que costumam ser por ela manipulados com frequência. Até então, as pulsões sexuais davam-se de forma parcial, manifestando-se de maneiras inteiramente desvinculadas e independentes entre si. Isso se altera nessa nova fase, em que se esboça o primado da genitalidade sobre tais pulsões. No entanto, quando formulou sua teoria da sexualidade infantil (1905), Freud não postulou que isso se desse de modo completo já na infância. Naquele momento, afirmava que as fases do desenvolvimento psicossexual infantil eram duas: oral e anal, também denominadas pré-genitais, uma vez que nelas "as zonas genitais ainda não assumiram seu

papel preponderante". ${ }^{88}$ Segundo ele, o primado da genitalidade sobre as pulsões dar-se-ia apenas na puberdade, que por isso era denominada fase genital.

No entanto, embora não definida com clareza, já em 1905 uma terceira fase do desenvolvimento psicossexual, integrante ainda do período da infância, vinha se esboçando. Diz-se isso porque, já nessa época, observava Freud que, após a fase anal - caracterizada pelo auto-erotismo, ou seja, pelo não-investimento das pulsões sexuais num objeto outro, que não o próprio corpo da criança -, com frequência ou regularmente compunha o quadro da vida sexual infantil uma escolha objetal, a rigor característica do período da puberdade, "ou seja, o conjunto das aspirações sexuais orienta-se para uma única pessoa, na qual elas pretendem alcançar seus objetivos”. E prossegue:

Na infância, portanto, essa é a maior aproximação possível da forma definitiva assumida pela vida sexual depois da puberdade. A diferença desta última reside apenas em que a concentração das pulsões parciais e sua subordinação ao primado da genitália não são conseguidas na infância, ou só o são de maneira muito incompleta. Assim, o estabelecimento desse primado a serviço da reprodução é a última fase por que passa a organização sexual. ${ }^{89}$

\footnotetext{
${ }^{88}$ FREUD, Sigmund. “A Sexualidade Infantil” in Três Ensaios ..., p. 186.

${ }^{89}$ FREUD, Sigmund. “A Sexualidade Infantil” in Três Ensaios ..., p. 188.
} 
Uma das dificuldades de estudar a obra de pensadores como Freud deve-se à sua evolução ao longo do tempo, com constantes revisões de conceitos por parte do próprio autor, às vezes para retificá-los ou ampliá-los, e não raro para descartá-los. Foi assim que, em 1923, ao publicar o artigo intitulado “A Organização Genital Infantil (Uma Interpolação na Teoria da Sexualidade) ${ }^{\natural 90}$, Freud referiu-se explicitamente a uma terceira fase do desenvolvimento psicossexual, inserida entre a anal e a genital, portanto, anterior à puberdade, na qual ocorreria uma espécie de preparação da organização genital final do adulto. Com relação a esta organização final, ressalvou, nessa nova fase, uma diferença de enorme importância no desenvolvimento psicossexual de meninos e meninas, que "consiste no fato de, para ambos os sexos, entrar em consideração apenas um órgão genital, ou seja, o masculino. O que está presente, portanto, não é uma primazia dos órgãos genitais [propriamente ditos], mas uma primazia do falo". ${ }^{91}$

Tal concepção lança suas raízes no fato de a criança não se dar conta da naturalidade das diferenças anatômicas entre os gêneros masculino e feminino: tanto os meninos, quanto as meninas, atribuiriam a ausência do pênis nas meninas a um ato de castração, interpretação essa responsável por uma série de consequências marcantes na dinâmica do aparelho psíquico. É por isso que, na teoria psicanalítica, o órgão sexual masculino passa a assumir uma função simbólica na dialética intra e intersubjetiva, justificando a adoção, nesse contexto, do termo falo, e reservando-se o termo pênis para designar o referido órgão sexual na sua realidade anatômica. ${ }^{\mathbf{2}}$

É nesta fase que Freud observará um comportamento típico da criança em relação a seus genitores, comportamento esse que denominará "complexo de Édipo", nomenclatura inspirada num mito grego popularizado pela peça Édipo-Rei, de Sófocles. ${ }^{93}$

\footnotetext{
${ }^{90}$ FREUD, Sigmund. ESB, vol. XIX, pp. 153/161.

${ }^{91}$ FREUD, Sigmund. “A Organização Genital Infantil (Uma Interpolação na Teoria da Sexualidade)”, ESB, vol. XIX, p. 158.

${ }^{92}$ LAPLANCHE e PONTALIS. Vocabulário da Psicanálise, 2ª edição, Editora Martins Fontes, São Paulo (SP), 2008, p. 166.

${ }^{93}$ A narrativa do mito, que se seguirá, baseia-se na referida peça de Sófocles. No entanto, conforme esclarece Junito de Souza Brandão, o mito apresenta inúmeras variantes. Numa delas, Jocasta sequer seria mãe biológica de Édipo, mas sua madrasta. (Mitologia Grega, vol. 3, 15ª edição, Editora Vozes, Petrópolis (RJ), 2009, pp. 248/249.) De qualquer modo, o que importa, no presente contexto, são os aspectos simbólicos do mito, na versão de Sófocles, conforme explorados por Freud.
} 
Narra o mito que Laio, rei de Tebas e esposo de Jocasta, não conseguia ter filhos. Numa consulta ao oráculo de Delfos, veio a saber que sua mulher havia engravidado, e ainda que seu destino era ser morto pelo herdeiro. De fato, confirmou-se a profecia do nascimento de um menino. Diante do terrível prognóstico, o casal decidiu matá-lo. No entanto, temendo as consequências de proceder diretamente ao ato, derramando o próprio sangue, entregou o rebento a um pastor, que ficou incumbido de abandoná-lo no Monte Citéron, onde, com toda certeza, morreria por força da natureza. No entanto, o pastor não consegue cumprir tal intento, e entrega a criança a um outro pastor, de Corinto, que, por sua vez, a leva para Pôlibo e Mérope, rei e rainha desta cidade, que ansiavam por adotar um filho, uma vez que não haviam conseguido gerar prole.

Édipo cresce sem saber que é adotado. Já adulto, com base em rumores a respeito de sua adoção, questiona os pais adotivos sobre sua origem, não conseguindo levá-los a dizer a verdade - pelo contrário: juram ser seus pais biológicos. Não conseguinte conter sua inquietude, e sem que os pais saibam, Édipo dirige-se a Delfos para aí consultar Apolo, o oráculo. Este, porém, em vez de lhe responder a respeito do passado, anuncia a Édipo que ele mataria o próprio pai, vindo a desposar a mãe. Apavorado com tal perspectiva, Édipo evita voltar a Corinto. Em sua andança, defronta-se com a comitiva de Laio, que vinha em sentido contrário. Ao ser empurrado para fora do caminho, a fim de dar passagem ao rei, cuja identidade e posição ignorava, revida à agressão sofrida, ferindo-o mortalmente.

Nesta mesma época, um monstro vagava pela região de Tebas, matando a todos os que não conseguissem decifrar os enigmas propostos. Era a Esfinge. Um oráculo revelara que ela destruiria a si própria no dia em que seus enigmas fossem decifrados. Creonte, irmão de Jocasta, a rainha viúva, prometeu a mão de sua irmã, bem como o trono de Tebas, àquele que conseguisse derrotar o monstro. A façanha será alcançada por Édipo, suposto estrangeiro de Corinto, para onde evita voltar. Porém, ao desposar a Jocasta e se tornar-se o novo rei de Tebas, acabará cumprindo a tão temível profecia.

Mas o mito não se encerra aí. Édipo consuma a relação incestuosa, vindo a ter quatro filhos com Jocasta. ${ }^{94}$ Passados alguns anos, uma praga recai sobre a cidade: a esterili-

\footnotetext{
${ }^{94}$ Etéocles, Polinice, Antígona e Ismene.
} 
dade atinge os campos, as pessoas e os animais. Consultado novamente o oráculo, descobre-se que a praga apenas cessaria com a punição do assassino de Laio. Mas quem seria ele? A despeito da resistência de Jocasta em saber toda a verdade, as investigações ordenadas por Édipo terminarão por levar à identidade do assassino: ele próprio - "És o assassino que procuras", dir-lhe-á o vidente. Diante de tal cenário, revelada a ignominiosa verdade, Jocasta se enforca no quarto real e Édipo, após desatar-lhe o corpo sem vida, retira das roupas da mulher e mãe uns broches de ouro que lhes serviam de adorno, e com eles espeta os próprios olhos, cegando-se. ${ }^{95}$

Freud perceberá, nesta fase que denominará fálica, um primeiro investimento sexual objetal por parte da criança, tendo por alvo a mãe ${ }^{\mathbf{9 6}}$. Até então, conforme vimos, o investimento objetal da libido era autoreferenciado, ou seja, autoerótico (característica das fases oral e anal). $\mathrm{O}$ fato de a mudança dar-se justamente na relação entre mãe e filho, surgindo a figura do pai como "rival", é que chamará a atenção de Freud para o paralelismo existente entre essa dinâmica e a verificada no mito, que passará a ser visto como expressão singular do que ocorre no inconsciente dos indivíduos. A peça de Sófocles foi alvo de comentários de Freud numa das conferências que proferiu no ano de 1917, de onde destacamos:

Não consigo pensar que essa moralidade seja um ponto forte na peça; aliás, não tem nenhuma influência em seu efeito. Não é a ela que o expectador reage, mas ao sentido e ao conteúdo secreto da lenda. Reage como se, por autoanálise, tivesse reconhecido o complexo de Édipo em si próprio e desvendado a vontade dos deuses e do oráculo como disfarces enaltecidos de seu próprio inconsciente. É como se fosse obrigado a recordar os dois desejos - eliminar o pai e, em lugar deste, desposar a mãe - e horrorizar-se com esses mesmos desejos. E o espectador compreende as palavras do dramaturgo, como se elas fossem dirigidas a ele: "Tu estás lutando em vão contra a tua responsabilidade, e estás declarando em vão o que fizeste em oposição a essas intenções criminosas. És culpado por não teres conseguido destruí-las; elas ainda persistem em ti, inconscientemente.” E existe verdade psicológica encerrada nessa frase. Conquanto um homem tenha reprimido seus maus impulsos para dentro do inconsciente e prefira dizer a si mesmo, posteriormente, que não é res-

95 SÓfOCLES. A Trilogia Tebana, trad.: Mário da Gama Kury, Jorge Zahar Editor, Rio de Janeiro (RJ), 1990.

${ }^{96}$ Mais importante do que entender "mãe" num sentido estritamente biológico é tomar a palavra em seu sentido funcional, ou seja, como se referindo à pessoa que desempenha a função materna junto à criança. $\mathrm{O}$ mesmo raciocínio aplica-se quando nos referimos ao "pai". 
ponsável por eles, ele, não obstante, tem de reconhecer essa responsabilidade na forma de um sentimento de culpa cuja origem lhe é desconhecida. Não pode haver dúvida de que o complexo de Édipo pode ser considerado uma das mais importantes fontes do sentimento de culpa com que tão frequentemente se atormentam os neuróticos. E mais do que isso: em um estudo sobre o início da religião e da moralidade humanas, que publiquei em 1913 sob o título de Totem e Tabu [FREUD, 1912-13], apresentei a hipótese de que a humanidade como um todo pode ter adquirido seu sentimento de culpa, a origem primeira da religião e da moralidade, no começo de sua história, em conexão com o complexo de Édipo. Eu teria muita satisfação em dizer-lhes mais a esse respeito, prefiro, porém, deixá-lo de lado. Sempre que se começa com esse assunto, é difícil interromper; devemos, contudo, retornar à psicologia individual. ${ }^{97}$

Vemos, portanto, que o conceito de “complexo de Édipo" assume posição central na psicanálise e passou por diversas re-elaborações. Sua importância é de tal ordem que Freud o considerava como "complexo nuclear das neuroses"98, revestindo-se da máxima importância para estruturação definitiva da vida erótica. Afirmava ter-se comprovado, como fato característico, que o homem normal aprende a dominar o Complexo de Édipo, enquanto o neurótico permanece envolvido com ele. ${ }^{\mathbf{9 9}}$

No caso da criança do sexo masculino, como em dado momento a mãe passa a ser objeto do investimento das pulsões sexuais e, neste contexto, o pai assume o papel de "rival", sua "eliminação" implica a conquista exclusiva, pelo menino, de seu objeto de amor. No entanto, conforme já vimos acima, segundo Freud, ao dar-se conta da diferença anatômica existente entre os sexos, a criança atribui a ausência de pênis nas meninas ao fato de terem elas sido castradas. À luz dessa interpretação, o pai, que possui um pênis e é um rival mais forte do que o menino, passa a representar para ele uma séria ameaça nesse sentido. A fim de evitar a concretização da ameaça, o menino renuncia ao objeto de seu amor, a mãe, ingressando, assim, de modo abrupto, entre os cinco e seis anos de idade, no chamado período de latência, no qual se observa uma "dessexualização das relações de objeto

\footnotetext{
${ }^{97}$ FREUD, Sigmund. Conferências Introdutórias sobre Psicanálise (XXI) (Parte III - Teoria Geral das Neuroses), ESB, vol. XVI, p. 335.

${ }^{98}$ FREUD, Sigmund. Totem e Tabu, ESB, vol. XIII, p. 134.

${ }^{99}$ FREUD, Sigmund. "Psicanálise", ESB, vol. XVIII, p. 262.
} 
e dos sentimentos (e, especialmente, a predominância da ternura sobre os desejos sexuais)" ${ }^{\mathbf{1 0 0}}$, viabilizada pela intensificação do recalque.

Portanto, faz parte da superação do complexo de Édipo a identificação do menino com o pai, cuja figura será internalizada. Essa ideia de internalização da figura paterna levará Freud a situar na resolução deste conflito a formação do superego. Na lição de Oliveira Lima:

(...) a ideia de afastar o pai do caminho para ter a mãe só para si permanece e obriga o menino a devorá-lo, simbolicamente - a incorporar o pai em sua mente. Seria essa a origem do superego, aquela instância destacada do eu, que Freud define como produto da identificação do menino com a figura paterna e que, de resto, é condição indispensável para o indivíduo vir a se tornar adulto. Como não pode ser pai da própria família, ele incorpora o pai, introjeta a figura paterna e se identifica com ela em grande parte. A identificação com o pai permite ao sujeito sair da família e constituir outra. ${ }^{101}$

E quanto às meninas? Até certo ponto, com relação à menina aconteceria processo similar, porém tendo por objeto de seu amor o pai, e como rival a mãe. Todavia, em vez de ter receio de ser castrada, ela já se percebe assim; de alguma forma, já foi vítima daquilo que no menino é mera ameaça. Freud pontua que "a menina aceita a castração como um fato consumado, ao passo que o menino teme a possibilidade de sua ocorrência". ${ }^{102}$ Percebendo-se sem o pênis, ou portadora de um órgão de dimensões muito menores (clitóris), passará a sentir o que Freud denominou "inveja do pênis".

Em artigo publicado em 1925, no qual aborda especificamente algumas diferenças psíquicas decorrentes da distinção anatômica entre os sexos, Freud aponta efeitos disso sobre o modo em que se dá a resolução do complexo de Édipo:

\footnotetext{
${ }^{100}$ LAPLANCHE e PONTALIS. Op. cit., p. 263. No mesmo sentido: FREUD, Sigmund. "A Dissolução do Complexo de Édipo" (1924), ESB, vol. XIX, p. 196.

${ }^{101}$ LIMA, Luiz Tenório Oliveira. Op. cit., p. 49. Ainda no que diz respeito à relação entre a superação do complexo de Édipo e a constituição do superego, corroboramos a lição de Oliveira Lima com a seguinte citação de FREUD: "Em casos normais, ou melhor, em casos ideais, o complexo de Édipo não existe mais, nem mesmo no inconsciente; o superego se tornou seu herdeiro", in "Algumas Consequências Psíquicas da Distinção Anatômica entre os Sexos” (1925), ESB, vol. XIX, p. 285.

102 FREUD, Sigmund. “A Dissolução do Complexo de Édipo”, p. 198.
} 
Nas meninas, o complexo de Édipo é uma formação secundária. As operações do complexo de castração o precedem e preparam. A respeito da relação existente entre os complexos de Édipo e de castração, existe um contraste fundamental entre os dois sexos. Enquanto, nos meninos, o complexo de Édipo é destruído pelo complexo de castração, nas meninas ele se faz possível e é introduzido através do complexo de castração. Essa contradição se esclarece se refletirmos que o complexo de castração sempre opera no sentido implícito em seu conteúdo: ele inibe e limita a masculinidade e incentiva a feminilidade. A diferença entre o desenvolvimento sexual dos indivíduos dos sexos masculino e feminino no estádio que estivemos considerando [fase fálica] é uma consequência inteligível da distinção anatômica entre seus órgãos genitais e da situação psíquica aí envolvida; corresponde à diferença entre uma castração que foi executada e outra que simplesmente foi ameaçada. Em suas essências, portanto, nossos achados são evidentes em si mesmos e teria sido possível prevê-los. ${ }^{103}$

Curiosamente, ao vincular, de forma direta, a formação do superego à superação do complexo de Édipo, dada por meio da introjeção da figura paterna, Freud vê-se obrigado a postular mais uma diferença entre o desenvolvimento psicossexual de meninos e meninas, diferença, agora, concernente à formação do superego. Desse modo, afirma ele que esse processo de introjeção ao qual nos referimos ocorreria de forma plena em pessoas do sexo masculino, porém não do feminino. Neste ponto, Freud, de certo modo, emaranha-se em seus conceitos. Afinal, se o medo da castração, sofrido pelo menino, é fator determinante para superação do complexo de Édipo, que terá por herdeiro o superego, no caso das meninas, em que a castração já teria surtido seu efeito, estaria faltando motivo para demolição deste complexo. ${ }^{104}$

O próprio Freud se põe esta questão e, de forma hesitante, ao mesmo tempo que corajosa, responde dizendo que tal diferença geraria, nas mulheres, uma espécie de superego mais atenuado, de menor rigor (as expressões são minhas), ou, em suas palavras, não "tão inexorável, tão impessoal, tão independente de suas origens emocionais como exigimos que o seja nos homens". 105

\footnotetext{
${ }^{103}$ FREUD, Sigmund. “Algumas Consequências Psíquicas ... Distinção Anatômica ...”, p. 285.

${ }^{104}$ FREUD, Sigmund. “Algumas Consequências Psíquicas ... Distinção Anatômica ...”, p. 286.

${ }^{105}$ FREUD, Sigmund. “Algumas Consequências Psíquicas ... Distinção Anatômica ...”, p. 286.
} 
Não é finalidade deste trabalho abordar, com minúcias, todo o debate e evolução envolvendo os conceitos ligados a esta fase do desenvolvimento psicossexual. No entanto, permitimo-nos afirmar que a aparente limitação da teoria freudiana para explicar as diferenças do desenvolvimento psicossexual existentes entre os sexos, nesta fase específica, não retira a validade e importância dos conceitos de complexo de Édipo e complexo de castração enquanto fenômenos psíquicos fundamentais para estruturação da personalidade do futuro adulto. Conforme destaca Mezan, “o Édipo aparece assim como o estruturador do caráter, o que equivale a dizer que, por meio da identificação - que o origina e que se segue a ele - impõe ao ego um destino peculiar". ${ }^{106}$

Uma má resolução do complexo de Édipo pode ter consequências desastrosas na vida do futuro adulto. Conforme Carlos Estevam:

Os homens que não conseguem vencê-lo tornam-se frequentemente afeminados, acovardados e medrosos; as mulheres adquirem uma virilidade excessiva e prejudicial. Homens e mulheres tornam-se impotentes e frios, demonstrando grande timidez sexual. Experimentam sentimentos de inferioridade e o medo permanente de não serem aprovados nas coisas que fazem. Sentem-se culpados por atos que não realizaram sem que haja motivo algum para isso. Tornam-se excessivamente agressivos ou, ao contrário, sentem-se desarmados diante da vida. Frequentemente, o complexo de Édipo provoca a homossexualidade, masculina ou feminina. ${ }^{107}$

Sendo muitas as nuances do desenvolvimento psicossexual, naturalmente que os traços acima descritos nem sempre aparecem em conjunto. No entanto, até mesmo pelo variado leque das consequências atribuídas à má resolução deste complexo é que ganha ele enorme importância.

Freud não desenvolveu nenhuma descrição específica do que poderia ser considerado traço de um caráter fálico. Aliás, não se vale, em nenhum momento, de tal expressão, a despeito de a fase fálica, comparada às outras, ter sido a que mais atenção recebeu por conta de nela ter sido localizada a formação do complexo de Édipo. Poderíamos arriscar uma referência a um caráter edipiano, mas nossa intenção não é desenvolver uma tipologia a

${ }^{106}$ MEZAN, Renato, Op. cit., p. 280.

${ }^{107}$ ESTEVAM, Carlos. Freud, Vida e Obra, 2ª edição, Editora Paz e Terra, São Paulo (SP), 2002, pp. 84. 
partir dos conceitos freudianos, e sim apontar as contribuições feitas pelo pai da psicanálise neste campo. Nota-se haver mais contribuições visando à compreensão - e tratamento dos fenômenos psicopatológicos, do que propriamente à percepção de traços típicos da conduta humana, no sentido de um trabalho feito no campo da normalidade. Mais adiante, teceremos maiores considerações a respeito.

Visando a finalizar este tópico de nossa exposição, convém mencionar que Reis, em texto que trata da teoria da personalidade em Freud e que serviu de referência para nosso estudo, revela a mesma dificuldade de descrever um caráter fálico a partir da obra desse pensador. Para resolver o problema, recorre à tipologia desenvolvida por Wilhelm Rei$\mathrm{ch}^{\mathbf{1 0 8}}$. Um dos tipos postulados por Reich, em época em que ainda fazia parte da Sociedade Psicanalítica Vienense, é o do caráter fálico-narcisista. Reis servir-se-á desse trabalho para preencher o vácuo deixado por Freud neste tópico. Não vemos, porém, a pertinência de trazer, para o contexto de nosso trabalho, as elaborações reichianas sobre o caráter fálico, porque, além deste tipo de caráter, Reich descreveu outros, como o caráter masoquista, o histérico e o compulsivo (obsessivo) ${ }^{109}$, não sendo possível, a nosso ver, ter uma boa compreensão de um deles - no caso, o fálico - sem tomá-lo em perspectiva com os demais. Além disso, mesmo que as descrições de Reich sobre o caráter fálico tenham sido apresentadas, pela primeira vez, à Sociedade Psicanalítica Vienense (1926), não se podem desconsiderar as diferenças existentes entre seus construtos teóricos e os de Freud, o que não é, de forma alguma, sem efeitos quando se toma a tipologia desenvolvida por cada um.

${ }^{108}$ REIS, Alberto O. Advincula. Op c cit., p. 35. REICH desenvolve todo um trabalho voltado à caraterologia no livro ANÁLISE DO CARÁTER, traduzido para o português por Ricardo Amaral do Rego e editado pela Martins Fontes.

109 GONÇALVES, Waldir Lourenço. “Teoria da Personalidade em Wilhelm Reich”, in Teorias da Personalidade em Freud, Reich e Jung, Editora Pedagógica e Universitária Ltda., São Paulo (SP), 1984, pp. 84/93. 


\section{A FASE GENITAL}

Freud denominou de fase genital àquela que se dá na puberdade, emergindo após o longo período de latência. Lembramos que o período de latência instaura-se com o recalque das pulsões sexuais pelo advento do superego, em processo de culminação e superação, como vimos acima, do complexo de Édipo.

Conforme lembra Reis, o superego representa uma instância de internalização das interdições e trará consigo tanto um "abrandamento da exuberância da atividade sexual infantil (...) [como um] esquecimento que recobre, progressivamente, este período de efervescência erótica pré-edipiana”. E prossegue:

(...) Durante este período [de latência], os impulsos sexuais adormecem. Somente na adolescência irão despertar com fulgor. A história infantil 'A Bela Adormecida' pode ser, em parte, interpretada como personificação lendária desta história sexual do indivíduo. ${ }^{110}$

Na lição de Carlos Estevam:

Para Freud a puberdade não é o momento em que nasce o instinto sexual. Ao contrário, é justamente o momento em que o instinto sexual adquire sua forma definitiva, o momento em que ele se torna maduro e adulto. As várias partes que constituem a sexualidade infantil vão se juntando uma às outras, vão se unindo para formar um todo único. Todas as zonas erógenas que anteriormente viviam de forma independente umas das outras passam a se ligar entre si e ficam todas subordinadas ao comando da zona genital. Com a puberdade, surge o império da zona genital sobre as demais, pois é ela que passa a ser a mais importante de todas, uma vez que dela depende a função principal do instinto sexual, que é a reprodução da espécie (...) Se a evolução do indivíduo está sendo normal, os prazeres sexuais mais intensos que é capaz de experimentar situam-se agora na zona genital. ${ }^{111}$

Do mesmo modo como não se referirá a um tipo fálico, Freud também não falará de um tipo genital. Suas referências dão-se apenas à fase. Neste ponto, reputamos válido pon-

${ }^{110}$ REIS, Alberto O. Advincula. Op. cit., p. 40.

${ }^{111}$ ESTEVAM, Carlos. Op. cit., pp. 80/81. 
tuar o seguinte: a psicanálise surgiu da observação de processos psicopatológicos, particularmente de casos de histeria (uma classe de neurose), sendo clássico o de “Anna O.”, cujo acompanhamento por Freud será responsável pela elaboração, reelaboração e consolidação de conceitos fundantes da teoria psicanalítica.

Uma das grandes contribuições de Freud foi identificar no desenvolvimento psicossexual infantil uma possível etiologia das neuroses. Com o tempo, foi discriminando fases diversas desse desenvolvimento, relacionadas ao direcionamento das pulsões sexuais e à forma como encontravam satisfação. Qualquer falha nesse mecanismo tenderia a se refletir na personalidade do adulto, por vezes gerando-lhe problema; tendo estas fases transcorrido sem grandes traumas, maior seria a probabilidade de se ter um adulto normal.

Na lição de Freud, é possível "estabelecer uma fórmula para o modo como o caráter, em sua configuração final, se forma a partir dos instintos constituintes: os traços de caráter permanentes são ou prolongamentos inalterados dos instintos originais, ou sublimação desses instintos, ou formações reativas contra os mesmos." ${ }^{112}$ Ora, a própria formulação da chamada fase genital nos faz perceber ser ela praticamente o resultado de um processo. Trata-se de um redespertar, o que é corroborado pela seguinte assertiva de Freud: "Não só os desvios da vida sexual normal, como também a configuração normal desta são determinados pelas manifestações infantis da sexualidade",113, ou, ainda:

Em geral, a pulsão sexual torna-se autoerótica, e só depois de superado o período de latência é que se restabelece a relação originária. Não é sem boas razões que, para a criança, a amamentação no seio materno torna-se modelar para todos os relacionamentos amorosos. O encontro do objeto é, na verdade, um reencontro. ${ }^{114}$

Logo, pode-se afirmar que, diante de problemas experimentados na fase genital, que tem início na puberdade e se estende por toda a vida adulta, a ortodoxia freudiana nos remeterá à análise das fases pré-genitais (aí se incluindo a fálica). Afinal, parte-se da premissa de que na fase genital o que ocorre é um processo de reorganização das pulsões sexuais que em fases anteriores já experimentaram alguma forma de satisfação, sublimação

\footnotetext{
${ }^{112}$ FREUD, Sigmund. "Caráter e Erotismo Anal”, p. 164.

${ }^{113}$ FREUD, Sigmund. "As transformações da Puberdade” in Três Ensaios ..., p. 200.

${ }^{114}$ FREUD, Sigmund. "As Transformações da Puberdade" in Três Ensaios ..., p. 210.
} 
ou recalque, moldando padrões inconscientes, que por vezes funcionarão como marcas indeléveis da personalidade. Agora, sob o primado da genitalidade, com a possibilidade de um investimento efetivo, real, no objeto (o outro), até mesmo pelo fato de o desenvolvimento biológico do indivíduo caminhar no sentido de dar suporte a isso, eventual problema aí experimentado provavelmente terá suas raízes numa das fases pré-genitais.

Faz sentido, assim, falar-se, no campo da psicopatologia, tão-somente em "caráter" oral, anal ou fálico. Não haveria, nesse mesmo campo (da psicopatologia), o que se pudesse chamar de "caráter genital", motivo pelo qual talvez Freud, sobretudo preocupado em dar solução ao "patológico", não se referirá a este "tipo".

A despeito das ressalvas feitas acima ao uso da tipologia reichiana para fins de complementação dessa parte de nosso estudo, não deixa de ser interessante, no sentido de corroborar o que acabamos de afirmar sobre a falta de interesse da psicopatologia em se referir a um "caráter genital”, informar que Reich se utilizou justamente desta nomenclatura para contrapor o "normal" ao "patológico", numa dicotomia em que, de um lado, encontramos o "caráter genital", representativo do indivíduo saudável, e, do outro, o "caráter neurótico", como representativo dos estados psicopatológicos. São palavras dele:

A satisfação orgástica genital da libido e a sublimação provam ser protótipos de meios adequados; todos os tipos de satisfação pré-genital e de formações reativas provam ser inadequados (...) Em resumo, o caráter genital está de posse de uma economia da libido regulada. O termo "caráter genital" justifica-se pelo fato de, com a possível exceção de casos muito incomuns, apenas o primado genital e a potência orgástica - ela própria determinada por uma estrutura de caráter especial em contraste com todas as outras estruturas libidinais, garantirem uma economia da libido regulada [grifos no original]. ${ }^{115}$

Poderíamos encerrar aqui nosso percurso pela "tipologia" da psicanálise freudiana se Freud não tivesse publicado, em 1931, um pequeno artigo intitulado “Tipos libidinais”, no qual descreverá, de forma sucinta, três tipos psicológicos, a seguir abordados.

${ }^{115}$ REICH, Wilhelm. Análise do Caráter, 3ํㅡㄹ edição, Trad.: Ricardo Amaral do Rego, Editora Martins Fontes, São Paulo (SP), 2001, p. 171. 


\section{OS TIPOS LIBIDINAIS}

Em sua extensa obra, Freud dedicará um único artigo a tratar com exclusividade dos tipos psicológicos propriamente ditos, e isso se dará em 1931, já na fase madura de seus escritos. É verdade que em 1905, nos Três Ensaios Sobre a Teoria da Sexualidade, falaria das fases do desenvolvimento psicossexual, e também que, em 1908, publicaria artigo intitulado "Caráter e Erotismo Anal”, conforme já vimos acima. No entanto, em ambos os estudos o enfoque do autor não nos permite afirmar ter sido sua preocupação principal definir propriamente uma teoria tipológica.

Note-se que, quando Freud publicou, em 1931, o artigo intitulado "tipos libidinais”, passavam-se já dez anos da publicação de Tipos Psicológicos, de Jung, e, a despeito de saber da obra, nenhum comentário a seu respeito será feito, nessa ocasião, por Freud. A leitura do pequeno artigo revela certo desconforto de Freud em enveredar pelo campo da tipologia, uma vez que inicia seu texto com a seguinte afirmativa:

"A observação nos ensina que cada ser humano, individualmente, entende o quadro geral da humanidade conforme uma variedade quase infinita de maneiras. Se nos submetermos à multiplicidade, teremos inicialmente de escolher quais as características e os pontos de vista que tomaremos como base de nossa diferenciação" e, no parágrafo seguinte: "É de duvidar que já nos encontremos em posição de descobrir tipos que atendam a esse requisito, como decerto seremos capazes de fazer mais tarde, sobre alguma base que ainda ignoramos". ${ }^{116}$

Haveria, propriamente, um desinteresse do pai da psicanálise pelo tema, ou, em vez disso, um confessado reconhecimento da falta de recursos teóricos para incursionar de maneira profunda pelo mesmo? Com relação à sua fala, acima transcrita, também nos perguntamos se não haveria alguma crítica velada ao trabalho daquele que por muito tempo foi considerado o mais promissor de seus discípulos, que havia dez anos ousara publicar um alentado estudo a respeito do assunto. De uma forma ou de outra, num estilo marcadamente claudicante - que, aliás, parecia-lhe próprio e aparentemente muito pertinente a quem quisesse fazer ciência numa área tão pioneira e, portanto, cheia de incertezas -, Freud ter-

${ }^{116}$ FREUD, Sigmund. "Tipos Libidinais”, ESB, vol. XXI, p. 225. 
mina por sugerir uma tipologia, não sem deixar de partir do conceito de libido como elemento predominante do aparelho psíquico. É por essa razão que falará de tipos libidinais.

Interessante observar, também, como sinal do reconhecimento de Freud quanto à importância do desenvolvimento de uma tipologia, sua expressa menção ao papel decisivo desempenhado pela "constituição psíquica" do indivíduo quanto à sua forma de interação com o meio externo, no sentido de fazer escolhas visando à realização de sua felicidade, conforme faz na conclusão do livro O Mal-Estar na Civilização (1929), para, em seguida, corroborar tal entendimento com referências ao modo de ser do homem erótico, do narcisista e do homem de ação. ${ }^{117}$

Pouco tempo depois, em seu artigo sobre os tipos libidinais, no qual se dispõe a tratar especificamente do tema, Freud postulará três tipos puros: o erótico, o narcisista e o obsessivo, e três tipos mistos: o erótico-obsessivo, o erótico-narcísico e o narcísicoobsessivo $^{118}$.

Segundo Freud, o TIPO ERÓTICO seria facilmente caracterizado: "eróticos são aqueles cujo principal interesse - a parte relativamente maior de sua libido - está voltado para o amor. Amar, mas acima de tudo ser amado, é a coisa mais importante para eles. São dominados pelo temor da perda do amor e acham-se, portanto, especialmente dependentes de outros que podem retirar seu amor deles. Mesmo em sua forma pura, esse tipo é muito comum. Variantes suas ocorrem segundo se ache mesclado com outro tipo, e proporcionalmente à quantidade de agressividade nele presente. Do ponto de vista social e cultural, esse tipo representa as exigências instintuais do id, a que os outros agentes psíquicos se submeteram". ${ }^{119}$ Ainda segundo ele, este tipo dará preferência a seus relacionamentos emocionais com outras pessoas.

O TIPO OBSESSIVO distinguir-se-ia pela "predominância do superego, que se separa do ego sob grande tensão. As pessoas desse tipo são dominadas pelo temor de sua consciência, em vez do medo de perder o amor. Apresentam, por assim dizer, uma dependência

\footnotetext{
${ }^{117}$ FREUD, Sigmund. O Mal-Estar na Civilização, ESB, vol. XXI, p. 91. Na sequência de seu raciocínio, FREUD deixa claro que, ao falar de "constituição psíquica", refere-se aos tipos psicológicos.

${ }^{118}$ FREUD, Sigmund. "Tipos Libidinais”, pp. 225/228.

${ }^{119}$ FREUD, Sigmund. “Tipos Libidinais”, p. 226.
} 
interna, em vez de externa. Desenvolvem um alto grau de autoconfiança e, do ponto de vista social, são os verdadeiros e predominantemente conservadores veículos da civilização". ${ }^{120}$ Naturalmente, havendo predominância da instância do superego, há de se esperar deste tipo posturas mais conservadoras com relação à observância dos valores socialmente vigentes.

O terceiro tipo puro brevemente referido por Freud será o NARCísICO, cuja descrição, segundo ele, haveria de ser feita principalmente em termos negativos:

Não existe tensão entre o ego e o superego (na verdade, se predominasse esse tipo [narcísico], dificilmente se teria chegado à hipótese de um superego), e não há preponderância de necessidades eróticas. O principal interesse do indivíduo se dirige para a autopreservação; é independente e não se abre à intimidação. Seu ego possui uma grande quantidade de agressividade à sua disposição, a qual também se manifesta na presteza à atividade. Em sua vida erótica, o amar é preferido ao ser amado. As pessoas pertencentes a esse tipo impressionam os outros como "personalidades"; são especialmente apropriadas a atuarem como apoio para outros, a assumirem o papel de líderes e a darem um novo estímulo ao desenvolvimento cultural ou a danificarem o estado de coisas estabelecido. ${ }^{\mathbf{2 1}}$

Sabemos que foi a partir da reelaboração da teoria psicanalítica na década de 1920, no que ficou conhecido pelo nome de segunda tópica, que Freud cunhou os conceitos de ego, superego e id como conformadores das três instâncias do aparelho psíquico de cada indivíduo. Antes disso, falava-se em consciente, pré-consciente e inconsciente, conceitos que não serão propriamente abandonados, mas antes integrados à nova concepção da personalidade. ${ }^{122}$ Importante frisar que não existe uma correspondência exata entre eles. Por exemplo: o ego, instância por excelência da consciência, será formado também por aspectos inconscientes, conforme é o caso dos mecanismos de defesa. ${ }^{\mathbf{1 2 3}}$ Graças a este novo referencial teórico é que Freud poderá lançar um novo olhar para os padrões humanos de conduta e, em vez de apenas recorrer às eventuais fixações nas diversas fases do desenvolvimento psicossexual, como fizera na primeira tópica, postular, mesmo que em curtas linhas,

\footnotetext{
${ }^{120}$ FREUD, Sigmund. "Tipos Libidinais”, p. 226.

${ }^{121}$ FREUD, Sigmund. "Tipos Libidinais", p. 226.

${ }^{122}$ REIS, Alberto O. Advincula. Op. cit., p. 47.

${ }^{123}$ REIS, Alberto O. Advincula. Op. cit., p. 50.
} 
o pálido esboço de uma tipologia da "normalidade", tomando por premissa a predominância de uma das instâncias do aparelho psíquico - ego, superego ou id - na conformação da personalidade.

Pela descrição que Freud faz dos tipos puros, fica evidente que atribui a ocorrência de cada um deles ao predomínio de uma das instâncias da mente, o que, por sua vez, tem relação direta com a economia libidinal: havendo prevalência das pulsões do $i d$, ter-se-á o tipo erótico; sendo prevalente a atuação do superego, estará conformado o tipo obsessivo. Até aqui, Freud o declara expressamente, deixando implícito que, prevalecendo o ego, terse-á o tipo narcisista.

Que tais categorias dos tipos puros tenham sido deduzidas da teoria da libido é fato indicado pelo próprio Freud, seja ao afirmar que dificilmente elas escapariam da suspeita de um trabalho dedutivo, seja ao declarar que se sentia no terreno firme da experiência quando se voltava aos tipos mistos, "que podem ser observados com mais frequência do que os não mistos”. ${ }^{124}$ Isso implicava dizer, portanto, que os tipos não mistos, ou puros, decorriam de elaboração teórica.

Um ponto digno de destaque diz respeito ao caráter especulativo dessa nova postulação, num claro esforço de buscar um padrão de conduta que apontasse para a coerência de seu construto teórico. Havendo a referida divisão funcional do aparelho psíquico em três instâncias, até que ponto seria possível explicar os diferentes comportamentos humanos a partir da eventual predominância de uma delas? Arriscamo-nos, portanto, a dizer que a tipologia freudiana encontra-se na fronteira entre uma teoria que emerge da experiência (clínica) e da elaboração abstrata deduzida de conceitos elaborados com base nessa experiência, campo batizado com o nome de metapsicologia. Neste sentido, oportuna a lição de Loparic $^{\mathbf{1 2 5}}$, citado por Oswaldo Giacoia Jr.:

Mesmo não sendo, nem precisando ser verdadeiras, as especulações metapsicológicas são indispensáveis devido ao seu valor heurístico enquanto guias para a pesquisa empírica, e enquanto esquemas para organizar os resultados já obtidos. Para tan-

\footnotetext{
${ }^{124}$ FREUD, Sigmund. “Tipos Libidinais", p. 226.

${ }^{125}$ LOPARIC, Z. "Esboço do paradigma winnicottiano" in Cadernos de História e Filosofia da Ciência, série 3, vol. 11, nº 2, jul-dez 2001, p. 29.
} 
to, hipóteses e especulações metapsicológicas devem ser coerentes com a experiência clínica e, de um modo mais geral, com a experiência consciente, bem como devem sê-lo umas com as outras. ${ }^{\mathbf{1 2 6}}$

Neste ponto, arriscamo-nos a traçar uma diferença entre as tipologias de Freud e Jung: enquanto o primeiro parece partir da elaboração teórica já existente, e ver em que medida a realidade poderia ser explicada com base nela ${ }^{127}$, Jung parece ter um olhar mais isento, partindo da observação da realidade e procurando, a partir das múltiplas possibilidades por ela consteladas, daí elaborar uma teoria. Não há, portanto, na tipologia junguiana, um esforço tão visível no sentido de tentar validar um arcabouço teórico previamente dado. Talvez seja por isso que o livro Tipos Psicológicos, de Jung, pareça destacar-se, de certo modo, do conjunto de sua obra, como se tivesse personalidade própria, a despeito da evidente importância de alguns conceitos mais gerais, como, por exemplo, o do princípio compensatório da psique para sua melhor compreensão, conforme veremos no momento próprio.

Vejamos o que dirá Freud a respeito dos tipos mistos, que, segundo ele, são os mais facilmente observáveis.

No tipo ERÓTICO-OBSESSIVO (id + superego) "parece que a preponderância da vida instintual é restringida pela influência do superego. Nesse tipo, a dependência simultânea de objetos humanos contemporâneos e de resíduos dos pais, educadores e exemplos é levada a seu mais alto grau". ${ }^{128}$ Freud dirá que o tipo NARCíSICO-OBSESSIVO (ego + superego) é "o que produz, do ponto de vista cultural, a mais valiosa variação, pois soma à indepen-

\footnotetext{
${ }^{126}$ GIACOIA JR., Oswaldo. Além do princípio do prazer: um dualismo incontornável, Editora Civilização Brasileira, Rio de Janeiro (RJ), 2008, p. 23.

${ }^{127}$ Corrobora tal assertiva a seguinte frase de Freud, extraída do artigo ora comentado: "Se limitarmos nosso esforço a estabelecer tipos puramente psicológicos, a situação libidinal terá um primeiro direito a servir de base para nossa classificação". Ou seja: se se fosse admitir a elaboração de um sistema de classificação dos comportamentos humanos a partir de uma perspectiva puramente psicológica, haver-se-ia de partir da observação da dinâmica libidinal, ou, em outras palavras, seria preciso adotar como ponto de partida o edifício teórico já elaborado pela Psicanálise. No entanto, grande gênio que era, Freud sabia do risco envolvido na propositura desse ponto de partida, risco de perder contato com a realidade, conforme se deu com sua teoria da sedução, em dado momento por ele abandonada. Por esse motivo, procura ter sempre presente o seguinte alerta, expresso na sequência de seu raciocínio: "Pode-se com justiça exigir que essa classificação não seja meramente deduzida de nosso conhecimento ou nossas hipóteses sobre a libido, mas que seja facilmente confirmada pela experiência real e que contribua para o esclarecimento da massa de nossas observações e nos auxilie a apreendê-las." - FREUD, Sigmund. "Tipos Libidinais", p. 225.

${ }^{128}$ FREUD, Sigmund. “Tipos Libidinais”, p. 226.
} 
dência do mundo externo e à consideração pela exigência da consciência uma capacidade de ação vigorosa, e fortalece o ego contra o superego". ${ }^{129}$ Por fim, a respeito do tipo ERóTICO-NARCísICO (id + ego), talvez, segundo ele, o que pode ser encarado como o mais comum de todos, é também o que une opostos, "que nele podem moderar-se mutuamente. Pode-se aprender com esse tipo, quando comparado com os outros dois eróticos, que a agressividade e a atividade vão de par com uma predominância do narcisismo."130

Quando cogita da existência de um tipo misto que agregasse os três perfis puros, ou seja, do tipo ERÓTICO-OBSESSIVO-NARCÍSICO, ao mesmo tempo em que afirma ser isso um ideal, Freud reconhece sua impossibilidade prática, justamente pelo fato de que, "das três principais maneiras de utilizar a libido na economia mental, uma ou duas foram favorecidas às expensas das outras". ${ }^{131}$

Quando se pergunta a respeito da correlação entre os tipos por ele descritos e os processos patológicos, Freud conclui não ser possível, num primeiro momento, estabelecer nenhuma relação entre os tipos libidinais e a etiologia das neuroses, para, contudo, afirmar mais adiante:

Parece fácil inferir que, quando pessoas do tipo erótico caem doentes, elas desenvolverão histerias, assim como as do tipo obsessivo desenvolverão neuroses obsessivas; mas essas inferências também partilham da incerteza que acabei de acentuar. As pessoas do tipo narcísico que se expõem a uma frustração do mundo externo, embora sob outros aspectos independentes, estão particularmente dispostas à psicose, e também apresentam precondições essenciais para a criminalidade. ${ }^{\mathbf{1 3 2}}$

\footnotetext{
${ }^{129}$ FREUD, Sigmund. "Tipos Libidinais”, p. 227.

${ }^{130}$ FREUD, Sigmund. "Tipos Libidinais”, p. 227.

${ }^{131}$ FREUD, Sigmund. "Tipos Libidinais", p. 227.

${ }^{132}$ FREUD, Sigmund. "Tipos Libidinais”, p. 227.
} 


\section{CONCluSÃo}

No tocante às características atribuídas a cada tipo em sua proposta de classificação, na qual toma por base a economia da libido, a contribuição de Freud praticamente se restringe ao que vimos acima. Considerando-se, porém, a enorme importância do conjunto de seu trabalho ao estudo e compreensão dos mecanismos psíquicos, particularmente do chamado inconsciente, nenhum demérito lhe pode ser atribuído por conta disso.

Como já dito, Freud foi pioneiro em sua área. Mesmo que não tenha sido o primeiro a falar do inconsciente, faz-se justiça ao dizer que, nesse campo, ele "criou seus precursores", uma vez que "o surgimento de sua obra altera a percepção não só do futuro, mas também do passado". ${ }^{133}$ Conforme ensina Simone Clapier-Valladon, "em Freud, o inconsciente, noção filosófica muito antiga, adquire uma nova significação, a de uma realidade constituída no decorrer da história individual pelo recalcamento”. E prossegue a mesma autora:

Fortemente investido de energia pulsional, constituído em sua maior parte pelos desejos recalcados da infância, ele procura retornar à consciência por caminhos sinuosos (...) O que é novo é que, na teoria psicanalítica, o inconsciente é uma realidade recalcada. Numerosos autores, como Pascal, La Rochefoucault, Nietzsche, Festinger haviam sublinhado que os homens tendem a recusar os conhecimentos e as lembranças que os contradizem ou os questionam, mas sem dar a essa postura humana um lugar central. ${ }^{134}$

Também como já dissemos antes, a teoria freudiana passou por diversas reelaborações. Olhada a obra em seu conjunto, fala-se ao menos em duas tópicas: a primeira se estende até o início da década de 1920, momento em que sua "tipologia” estará alicerçada nas diversas fases do desenvolvimento psicossexual. Fala-se, aí, nos caracteres oral, anal e fálico. Vimos que, embora a última fase desse desenvolvimento seja a genital, Freud não se valerá da mesma para se referir a um caráter genital. Isso caberá a Reich, num momento em que ainda fazia parte da sociedade psicanalítica.

\footnotetext{
${ }^{133}$ LIMA, Luiz Tenório Oliveira. Op. cit., p. 66. Na verdade, nesse ponto Luiz Tenório refere-se a ideia postulada por Jorge Luis Borges, no ensaio "Kafka e seus precursores", em Outras Inquisições, vol. 2 das Obras Completas (Editora Globo, São Paulo, 1998).

${ }^{134}$ CLAPIER-VALLADON, Simone. Op. cit., pp. 85 e 95.
} 
No entanto, também vimos que Reich associará o caráter genital à normalidade, o que reforça a ideia de que, no âmbito da psicanálise, os demais tipos ganham importância enquanto representações de estados psicopatológicos. Isso, porém, não implica dizer que um indivíduo que apresente caráter oral, por exemplo, seja um neurótico ou alguém que exija cuidados; o que se afirma é que a descrição de tipos psicológicos, conforme feita na teoria freudiana da primeira tópica, está estreitamente ligada à observação de neuróticos, trazendo, portanto, a marca de um olhar que, sobretudo, voltou-se ao - e se nutriu do desequilíbrio. Talvez por conta disso, Freud tenha julgado necessário fazer a seguinte ressalva:

(...) devemos atribuir a cada indivíduo um erotismo oral, anal, uretral etc., e (...) a constatação dos complexos anímicos correspondentes a estes não implica nenhum julgamento sobre anormalidade ou neurose. As diferenças que separam o normal do anormal só podem residir na intensidade relativa de cada componente da pulsão sexual e no uso que lhes é dado no decorrer do desenvolvimento. ${ }^{135}$

Ressalva feita, ressalta, porém, do estudo de sua "tipologia", e não há como negálo, a clara impressão de que bebeu na fonte da psicopatologia humana.

No período da chamada segunda tópica, em que os conceitos de ego, superego e id surgirão como personagens da dinâmica psíquica, a teoria tipológica freudiana ganhará um enfoque um pouco diferente, dado à luz dessas novas instâncias. Freud referir-se-á a tipos libidinais, sendo três deles puros (de caráter mais teórico) e três mistos (mais facilmente verificáveis na prática), todos decorrentes dos diferentes graus de intensidade da libido nas diferentes instâncias do aparelho mental. Ao descrevê-los, Freud não os associará às fases do desenvolvimento psicossexual, o que não implica dizer que tal relação não exista. Mais correto seria afirmar que ele não se preocupou em aprofundar sua teoria nessa direção.

Ao analisar os tipos libidinais, temos a impressão de que Freud procurou elaborar um construto teórico que desse conta da expressão não do patológico, mas da normalidade, o que explicita de forma inequívoca, ao escrever:

${ }^{135}$ FREUD, Sigmund. “A Sexualidade Infantil” in Três Ensaios ..., p. 194 (nota “1”). 
Deve-se (...) exigir de todos esses tipos que não coincidam com quadros clínicos. Pelo contrário, devem abranger todas as variações que, de acordo com nosso juízo prático incidem dentro dos limites do normal. Em seus desenvolvimentos extremos, contudo, podem aproximar-se de quadros clínicos e dessa maneira, ajudar a unir o abismo que se supõe existir entre o normal e o patológico. ${ }^{\mathbf{1 3 6}}$

No entanto, vemos novamente que esse esforço de Freud é à evidência muito tímido face às contribuições de sua teoria visando a sanar o patológico, que indubitavelmente sempre foi o foco de suas atenções, conforme se depreende de sua própria fala:

\begin{abstract}
A hipótese das organizações pré-genitais da vida sexual repousa na análise das neuroses e é difícil apreciá-la independentemente do conhecimento destas. Podemos esperar que a continuidade dos esforços analíticos venha a fornecer-nos muito mais informações sobre a estrutura e o desenvolvimento da função sexual normal. ${ }^{137}$
\end{abstract}

Ao compararmos a tipologia freudiana às inúmeras outras que compõem o amplo arcabouço de teorias da personalidade, notamos que se destaca pela importância que confere à história do indivíduo e à gênese de sua personalidade. Na lição de Reis:

A Psicanálise estabelece que o critério afetivo, isto é, o comportamento do indivíduo face a seus objetos de amor ou objetos sexuais, é o critério central na avaliação do desenvolvimento do caráter humano. Impõe-se, assim, a necessidade de se entender o processo de desenvolvimento psicossexual como condição para se compreender a formação do caráter. ${ }^{138}$

Ou seja: a dinâmica comportamental dos indivíduos adultos estaria diretamente relacionada à forma como eles lidaram com os objetos de seu desejo desde o momento em que tiveram o primeiro contato com o mundo. Ao manterem essa mesma perspectiva, os seguidores de Freud acabarão dando maior destaque às fases do desenvolvimento psicos-

\footnotetext{
${ }^{136}$ FREUD, Sigmund. "Tipos Libidinais", p. 225.

${ }^{137}$ FREUD, Sigmund. "A Sexualidade Infantil” in Três Ensaios ..., p. 188. Embora o excerto citado faça parte de texto publicado em 1905, ou seja, ainda nos anos iniciais, uma análise mais abrangente da obra freudiana não nos leva a conclusão contrária. Reforçamos tal entendimento com a lição de CLAPIERVALLADON: "A teoria freudiana foi elaborada na perspectiva de elucidação e de terapia de personalidade patológicas, às quais os indivíduos normais são assimilados”, in Op. cit., p. 97.

${ }^{138}$ REIS, Alberto O. Advincula, Op. cit., p. 26.
} 
sexual - e seus reflexos no comportamento do indivíduo - do que propriamente à formulação dos tipos libidinais. ${ }^{139}$

Nascida no âmbito clínico, parece que a tipologia freudiana terá maior importância na análise de casos clínicos, o que não se dá na tipologia junguiana, que, conforme visto em capítulo próprio, tem em sua gênese a necessidade de dar respostas a questões decorrentes do relacionamento entre indivíduos, e isso numa situação de normalidade. É por essa razão que, ao postular seus tipos, Jung de certo modo o faz numa perspectiva acima de tudo "relacional", ou seja, demonstrando como se opõem e como se inter-relacionam as pessoas de cada tipo. Isso não se observa no trabalho de Freud, cuja descrição de tipos não aponta para a dinâmica entre eles. Exemplo: de que forma um tipo "narcisista" se relacionaria com um tipo "obsessivo"? Embora possamos especular a respeito, questões dessa natureza não são objeto da análise de Freud. Por outro lado, na tipologia junguiana a relação entre os diferentes tipos chega a ser intuitiva, até porque o enfoque relacional está na gênese da própria elaboração teórica de Jung.

Outro ponto diferencial centra-se no foco de análise de um e de outro. Na tipologia freudiana, esse foco reside na dinâmica do inconsciente. Analisa-se o predomínio do inconsciente e das experiências passadas sobre o comportamento presente. Aliás, não é por acaso que se fala em "caráter", palavra que se origina do grego kharasséin ou kharakter significando, respectivamente, gravação e marca ${ }^{\mathbf{1 4 0}}$, ao passo que na tipologia junguiana postula-se a existência de tendências naturais, inatas, independentemente da experiência do sujeito, a despeito da interferência que essa experiência possa trazer às tendências inatas. ${ }^{141}$ E é importante frisar que as referidas tendências, conforme apontadas por Jung, são identificadas pelo próprio indivíduo, ou seja, são apuradas, ao menos num primeiro plano, pela autoanálise do indivíduo a respeito de seus motivos conscientes, o que as colocaria a salvo do inevitável julgamento subjetivo do observador. ${ }^{\mathbf{1 4 2}}$

Por fim, uma vez que este trabalho se dá à luz da Psicologia Analítica, talvez seja conveniente registrar que contundente crítica foi feita por Jung a muitos dos conceitos de-

\footnotetext{
${ }^{139}$ CLAPIER-VALLADON, Simone. Op. cit., pp. 84/85 e 93.

${ }^{140}$ REIS, Alberto O. Advincula, Op. cit., p. 24.

${ }^{141}$ Tipos ..., p. $318, \S 625$.

${ }^{142}$ Tipos ..., pp. 342/343, § 607.
} 
senvolvidos por Freud e acima abordados de maneira breve. Um pequeno excerto da fala de Jung será suficiente para nos dar conta disso:

FREUD salienta a excitação e a satisfação inegáveis da criança no ato de mamar, e compara estes fenômenos aos do ato sexual. Esta semelhança leva-o a admitir que o ato de mamar tenha uma qualificação sexual. Esta hipótese seria correta se estivesse provado que a tensão de uma necessidade e a satisfação obtida com sua solução fosse um processo sexual. Mas a evidência de que o ato de mamar possui este mecanismo emocional nos prova exatamente o contrário. Podemos dizer que este mecanismo está presente tanto na função de nutrição como na função sexual. Se FREUD deduz da analogia com o mecanismo emocional a qualidade sexual do ato de mamar, então a experiência biológica justificaria também uma terminologia que qualificasse o ato sexual como função de nutrição. Estas extrapolações são injustificadas em ambos os sentidos. É evidente, pois, que o ato de mamar não pode ser qualificado como sexual (...) A obtenção do prazer não é, de forma alguma, o mesmo que sexualidade [grifo no original]. Se admitirmos, portanto, que os dois instintos coexistem de algum modo na criança de peito, estamos enganados porque projetamos uma constatação da vida do adulto para dentro da alma da criança. ${ }^{\mathbf{1 4 3}}$

É claro que Freud tinha resposta para a crítica de $\mathrm{Jung}^{\mathbf{1 4 4}}$, e, de certo modo, os debates suscitados por estes dois gigantes do pensamento continuam até o presente, enriquecidos por novas formulações e alimentados pela experiência acumulada. Será justamente a dificuldade em conciliar os dois pontos de vista, ao mesmo tempo que o reconhecimento da seriedade científica de Freud ${ }^{\mathbf{1 4 5}}$, que serviriam como mola propulsora para o desenvolvimento, por Jung, da teoria dos tipos psicológicos, resultando no que veremos a seguir.

${ }^{143}$ JUNG, Carl G.. Freud e a Psicanálise (CW IV), 4⿳亠丷a edição, Trad.: Lúcia Mathilde Endlich Orth, Editora Vozes, Petrópolis (RJ), 2007, pp. 115/117, §§ 238 e 241. A primeira edição desta obra de Jung deu-se em 1912.

${ }^{144}$ Por volta de 1916, em conferência intitulada "O Desenvolvimento da Libido e as Organizações Sexuais" (conferência XXI), FREUD parece ter dado resposta às ponderações de Jung - conferir em FREUD, Sigmund. Conferências Introdutórias sobre Psicanálise (Parte III), ESB, vol. XVI, pp. 325/342.

${ }^{145}$ JUNG, Carl G.. Fundamentos ... (CW XVIII/1), pp. 116/118, §§ 275/279. 


\title{
CAPÍTULO 2 \\ A TEORIA DOS TIPOS PSICOLÓGICOS DE CARL GUSTAV JUNG \\ 1. CONCEITOS FUNDAMENTAIS DA TEORIA DOS TIPOS PSICOLÓGICOS
}

\begin{abstract}
As quatro funções são algo como os quatro pontos cardeais, tão arbitrárias e tão indispensáveis quanto estes. Não importa que os pontos cardeais sejam deslocados alguns graus para a esquerda ou para a direita, ou que recebam outros nomes. É apenas questão de convenção e compreensão.

Mas, uma coisa devo confessar: não gostaria de perder nunca mais esta bússola em minhas viagens de descobertas. Não só devido ao fato muito natural e humano de que cada qual ama suas ideias, mas devido ao fato objetivo de que, com isso, temos um sistema de medida e orientação que torna possível o que nos faltou por muito tempo: uma psicologia crítica.
\end{abstract}

Carl G. Jung ${ }^{146}$

A teoria dos tipos psicológicos, resultado do esforço de Jung visando à compreensão das diferenças entre as pessoas, levou muitos anos para ser desenvolvida, tendo sido, conforme vimos, fundamental todo um trabalho empírico de observação. Sempre muito perspicaz em seus empreendimentos teóricos, Jung não deixou de reconhecer a complexidade de um trabalho dessa natureza, tendo em vista as nuanças existentes entre as pessoas, em parte devidas à atuação de "uma tendência especial a compensar a unilateralidade” do tipo, "gerando caracteres ou tipos secundários que apresentam uma conformação extremamente difícil de elucidar, tão difícil que seria preferível negar a existência dos tipos e acreditar nas diferenças individuais". ${ }^{147}$

Num primeiro momento de sua pesquisa, Jung postulou a existência de duas (02) atitudes dicotômicas (opostas), concernentes ao direcionamento da energia psíquica (libi-

\footnotetext{
146 “Tipos Psicológicos": conferência pronunciada no encontro de médicos de doentes mentais, Zurique, 1928 - integra, na qualidade de ANEXO, a edição brasileira da obra Tipos Psicológicos, Op. cit., pp. 497/498, $\S \S 1029 / 1030$.

${ }^{147}$ Tipos..., p. 20, § 3.
} 
do): diz-se extrovertida a pessoa cuja energia é direcionada para o mundo exterior, e introvertida a que a direciona para o mundo interior. ${ }^{\mathbf{1 4 8}}$

Num segundo momento, reconhecendo que a divisão dos indivíduos em dois grandes grupos não permitiria mais do que uma distinção bastante superficial e genérica, Jung procurou dar mais um passo no sentido de encontrar as diferenças que pudessem distinguir os indivíduos de um mesmo grupo ${ }^{149}$. Foi assim que surgiram os dois pares de funções, igualmente dicotômicos: sensação e intuição, funções perceptivas, e pensamento e sentimento, funções judicativas. Do mesmo modo como há o predomínio de uma atitude, também predomina em cada indivíduo uma função, decorrendo daí o tipo correspondente.

$\mathrm{Na}$ abreviação das atitudes e funções, usaremos as letras empregadas pelo sistema MBTI (Myers-Briggs Type Indicator), o que se justifica:

(a) pelo amplo emprego desta ferramenta de aferição de tipo, construída, conforme veremos adiante, com base na teoria junguiana;

(b) pela vasta bibliografia existente a respeito do tema, em especial nos Estados Unidos da América do Norte, na qual se segue o mesmo padrão designativo, onde "I" corresponde a introversão ("Introversion"), "E" a extroversão ("Extraversion"), "S" a sensação ("Sensing"); "N" a intuição ("iNtuition": emprega-se a letra "N" para diferenciar da abreviação utilizada para a introversão); "T" a pensamento (“Thinking") e "F" a sentimento ("Feeling").

A seguir, procuraremos explicar o que significa cada atitude e função e mencionaremos algumas características normalmente a elas associadas. Quanto a este último ponto, reputamos pertinente esclarecer que, além de Jung, contaremos com a colaboração de outros autores, muitos deles norte-americanos, que se esmeraram em desenvolver aplicações práticas decorrentes da tipologia junguiana.

\footnotetext{
${ }^{148}$ Tipos..., pp. $19 / 23$ (§§ 1/7); 319/326 (\$§ 628/641) e 354/362 (§§ 691/703).

${ }^{149}$ Tipos..., p. $22, \S 7$.
} 


\section{AS DUAS ATITUDES (INTROVERSÃO-“I" E EXTROVERSÃO-“E”)}

O que significa ser introvertido ou extrovertido e como tais atitudes são passíveis de observação na prática?

Podemos dizer que, diante de um estímulo externo, representado pelo objeto, o sujeito tende a reagir de duas formas dicotômicas: ou canalizará boa parte de sua energia para o mesmo (objeto), deixando de concentrá-la em si (sujeito), ou a canalizará para si (sujeito), atentando para as impressões - na forma de ideias e sentimentos -, suscitadas pelo objeto. Tal tendência normalmente ocorre de forma automática, inconsciente, e gera um padrão de percepção e conduta em face do mundo. No entanto, conforme frisava Jung, "todo indivíduo possui os dois mecanismos, tanto o da introversão como o da extroversão; e apenas a relativa preponderância de um ou de outro define o tipo". ${ }^{150}$

Portanto, todo ser humano traz de forma predominante uma ou outra atitude. Isso é definido em parte por constituição biológica (geneticamente), e em parte pela interação com o meio-ambiente (cultura familiar e social).

Jung menciona a predisposição biológica sobretudo na parte em que trata das atitudes, embora a ideia também se aplique às funções. Fato é que as atitudes são mais facilmente observáveis em crianças pequenas, com um ano ou um ano e meio de idade, o que nem sempre se pode dizer das funções, cujo desenvolvimento apenas é passível de observação em fase mais tardia ${ }^{151}$. A influência do meio é relativizada por se perceber que crianças de uma mesma família, ainda quando muito pequenas, já demonstram padrões bem diferentes de conduta ${ }^{\mathbf{1 5 2}}$, sendo algumas, por exemplo, mais sociáveis (tendência a extroversão) ao passo que outras mais reservadas (tendência a introversão). Segundo John L. Giannini, desde que nossa atitude natural é inata, não dependendo de uma escolha consciente, há fundamento em tomá-la como arquetípica. ${ }^{153}$

\footnotetext{
${ }^{150}$ Tipos..., p. $20, \S 4$.

${ }^{151}$ FRANZ, Marie-Louise von. A Função Inferior, 6a edição, Trad.: Ana Cândida Pellegrini Marcelo e Wilma Raspanti Pellegrini, Editora Cultrix, São Paulo (SP), 2007, pp. 13/14.

152 Tipos..., p. 318, § 625. Também a respeito da hereditariedade do tipo (atitude), ver: "Tipos Psicológicos": conferência pronunciada no Congresso Internacional sobre Educação, em 1923, e publicada em 1925 integra, na qualidade de ANEXO, a edição brasileira da obra Tipos Psicológicos, Op. cit., p. 475, § 961.

${ }^{153}$ Compass of the Soul: Archetypal Guides to a Fuller Life, Center for Applications of Psychological Type (CAPT), Gainesville, Florida, 2004, p. 117.
} 
A diferença de comportamento entre crianças extrovertidas e introvertidas foi descrita com bastante clareza por Jung em conferência por ele pronunciada em 1923, num Congresso Internacional sobre Educação, de onde reputamos pertinente trazer os seguintes excertos:

O primeiro sinal de extroversão numa criança é sua rápida adaptação ao meio ambiente e a extraordinária atenção que confere aos objetos, principalmente no que se refere à sua ação sobre eles. $\mathrm{O}$ medo dos objetos é pequeno. A criança vive neles e com eles. Aprende rapidamente, mas de modo impreciso. Parece que se desenvolve com maior rapidez do que a criança introvertida, porque é menos reflexiva e, via de regra, não tem medo. Parece que não sente especial distância entre ela mesma e os objetos, podendo, assim, brincar livremente com eles e senti-los. Gosta de levar seus empreendimentos ao extremo e, por isso, se expõe a riscos. Tudo que é desconhecido parece atraente.

Por outro lado, um dos primeiros sinais de introversão numa criança é sua natureza reflexiva e pensativa, seu pronunciado receio e, inclusive, medo dos objetos desconhecidos. Bem cedo manifesta-se também uma tendência de autoafirmação perante os objetos e tentativas de dominá-los. O desconhecido é olhado com desconfiança. Em geral, coloca forte resistência contra influências externas. A criança quer ter seu próprio caminho e, de forma alguma, aceita um caminho estranho que não consegue entender por si só. Quando faz perguntas não é por curiosidade ou sensacionalismo, mas quer nomes, significados e explicações que lhe deem segurança subjetiva em relação ao objeto. Vi uma criança introvertida que tentou os primeiros passos só depois que se familiarizou com o nome de todos os objetos em seu quarto, com os quais poderia entrar em contato. Na criança introvertida encontramos bem cedo a atitude de defesa, característica do introvertido adulto, contra o poder dos objetos, da mesma forma que podemos observar bem cedo na criança extrovertida uma notável segurança, espírito de iniciativa e alegria confiante no tratamento com os objetos.

(...)

É um fato triste mas nem por isso menos frequente que os dois tipos tenham péssimo conceito um do outro. Isso chama imediatamente a atenção de quem estuda o problema. Provém do fato de os valores psíquicos estarem localiza- 
dos em lados opostos. O introvertido vê tudo o que lhe parece valioso no sujeito; o extrovertido, ao contrário, no objeto. ${ }^{154}$

Lenore Thomson, autora norte-americana e estudiosa da tipologia junguiana, informa que pesquisas feitas a partir de imagens das áreas cerebrais ativadas, quando do uso de determinadas funções pelo indivíduo, permitiram observar que cada uma delas se vale de partes específicas do cérebro. Portanto, o uso preferencial de uma função leva ao desenvolvimento de um número maior de conexões cerebrais, tornando mais favorável seu uso posterior. $^{155}$

A mesma autora informa que estudos feitos com crianças pequenas mostraram dois diferentes padrões de conduta diante de estímulos externos. Diante de um brinquedo novo e supostamente divertido, algumas crianças mostram inicialmente algum interesse, para em seguida voltar sua atenção para outras coisas; outras crianças demonstram um interesse bastante intenso no início, mas depois, sobrecarregadas pelo estímulo, começam a chorar. Diz ela que, contrariando a ideia estereotipada que temos, as do primeiro grupo eram extrovertidas, e as do segundo introvertidas. É que o extrovertido busca maior intensidade de estímulo externo, ao passo que o introvertido tende a ficar incomodado com o mesmo quando não esteja relacionado a seus interesses. ${ }^{\mathbf{1 5 6}}$

Importante destacar que, segundo Jung, embora a atitude introvertida mantenha seu foco energético no sujeito, "não se deve identificá-la simplesmente com o eu do sujeito (...), mas ela é a estrutura psíquica do sujeito antes de qualquer desenvolvimento de um eu. O sujeito que está propriamente na base, isto é, o si-mesmo, é de longe mais abrangente do que o eu, uma vez que abarca também o inconsciente, enquanto o eu é essencialmente o ponto central da consciência". ${ }^{157}$ Portanto, não há que se tomar por "egocêntrica" a atitude introvertida.

Ainda nesse contexto, Jung associa o conceito de estrutura psíquica ao que ele chamou de inconsciente coletivo, cujas impressões nos indivíduos com atitudes introverti-

\footnotetext{
154 “Tipos Psicológicos”... 1923 (v. referência completa em nota anterior), pp. 475/476, §§ 961/962.

155 THOMSON, Lenore. Personality Type - a practical guide to understanding yourself and others through typology, Shambhala Publications, Inc., Boston, Massachussetts, 1998. p. 9/10.

156 Op. cit., p. 31.

${ }^{157}$ Tipos ..., p. 356, § 695.
} 
das se tornariam mais manifestas, justamente por terem mais força neles do que a influência do "objeto" (meio externo), como ocorre com os extrovertidos, pois "os conteúdos do inconsciente coletivo são representados na consciência como tendências e concepções manifestas". ${ }^{158}$ Isso gera certa oposição entre ambas as atitudes - de introversão e extroversão -, que pode ser fonte de julgamentos equivocados do representante de um tipo sobre o outro, conforme se depreende do seguinte excerto:

(...) assim como parece incompreensível ao introvertido que o objeto sempre deva ser decisivo, ao extrovertido continua sendo um enigma por que um ponto de vista subjetivo deva preponderar sobre a situação objetiva. Chega inevitavelmente à suposição de que o introvertido é um refinado egoísta ou um entusiasta doutrinário. ${ }^{159}$

Num dos textos em que analisa a questão das atitudes, Jung vale-se de um exemplo que ficou conhecido como "metáfora do castelo". Faz-nos imaginar dois rapazes que, ao caminhar pelo campo, deparam-se subitamente com um castelo maravilhoso. Ambos querem conhecê-lo por dentro. O extrovertido, num impulso, já vai entrando e convida seu amigo a acompanhá-lo. Este, introvertido, detém-no. Alega que talvez a entrada seja proibida e provavelmente imagina "uma série de represálias, como violências policiais, multas, cachorros brabos, etc.”. O outro, porém, em vez de ficar preso a tais elucubrações, sugere que perguntem, replicando que na certa os deixariam entrar. Para alegria de ambos, tal otimismo vem, de fato, a ser recompensado. Uma vez dentro do castelo, encontram um conjunto de poucas salas reformadas e uma coleção de velhos manuscritos. Por acaso, essa é a paixão do introvertido, que inicia uma entusiasmada conversa com o guarda de plantão e, não satisfeito com as informações de que este dispõe, sai em busca da pessoa responsável pela conservação do material. Em contrapartida, o extrovertido vai ficando cada vez mais entediado. Não há ali "nada de hospitalidade cavalheiresca, nem sombra de aventuras românticas: apenas um castelo reformado. Não precisava ter saído de casa para ver manuscritos". Os manuscritos são associados a biblioteca e esta a estudos, exames, enfim, uma situação de ameaça. Uma cortina sombria recai sobre tudo e o objeto, antes tão fascinante, ganha conotação negativa. Ele, então, passa a insistir para que saiam, contrariando a vontade do outro, que mais do que nunca quer ficar. O contraste de atitudes leva o introvertido a pensar consigo em nunca mais viajar com aquele sujeito, enquanto o extrovertido, tam-

\footnotetext{
${ }^{158}$ Tipos ..., p. $357, \S 696$.

${ }^{159}$ Tipos ..., p. $357, \S 696$.
} 
bém irritado, apenas vê falta de consideração em seu amigo: “Onde já se viu desperdiçar a linda primavera lá fora! Poderíamos estar aproveitando! E tudo por causa dessa curiosidade egoísta!",160

A partir dessa imagem, Jung se pergunta sobre o que teria acontecido. Antes de entrarem, caminhavam ambos em alegre simbiose. Graças à atuação do extrovertido, conseguiram ingressar no castelo, mas ali se quebrou o encanto: o introvertido deixou-se fascinar pelo objeto (mundo externo), enquanto o outro por seus pensamentos negativos (sujeito, mundo interno). Ou seja: houve uma inversão da dinâmica psíquica. Nas palavras de Jung:

(...) assim como no introvertido o objeto sobrepuja o sujeito, atraindo-o, sua atitude perde o caráter social. Esquece-se da presença do amigo; não o inclui mais. Submerge no objeto e não vê quanto o amigo se aborrece. E viceversa: o extrovertido perde a consideração para com o outro no momento em que sua expectativa não é satisfeita, retraindo-se em suas ideias e humores subjetivos.

Assim sendo, o acontecido pode ser formulado da seguinte maneira: por influência do objeto, apareceu uma extroversão inferior no introvertido, ao passo que uma introversão inferior substituiu a atitude social do extrovertido. Dessa forma, voltamos à frase que nos serviu de ponto de partida: o valor de um é o desvalor do outro. ${ }^{161}$

O conceito de introversão ou extroversão inferiores fica claro a partir da ideia de que o inconsciente possui, em relação à consciência, uma função compensadora. Segundo Jung, isso pode ser constatado cientificamente, por exemplo, através da análise de sonhos, nos quais se observa um "conteúdo que pode corrigir de modo essencial a atitude consciente". 162

\footnotetext{
${ }^{160}$ Psicologia do Inconsciente (CW VII/1), 17 $7^{\mathrm{a}}$ edição, trad.: Maria Luiza Appy, Editora Vozes, Petrópolis (RJ), 2007, pp. 48/49, § 81 . ${ }^{161}$ Op. cit., p. 50, $\S \S 83 / 84$.

162 “Tipos Psicológicos”... 1923, p. 479, § 969.
} 
Desse modo, um introvertido teria uma atitude extrovertida inconsciente, necessária para compensar a introversão da consciência, e vice-versa. ${ }^{163}$ Jung esclarece que o conceito de compensação foi originalmente cunhado por Adler, que o aplicava de maneira muito específica à dinâmica do sentimento de inferioridade, que haveria de ser "compensada" pela elaboração de uma superioridade fictícia. Jung, porém, toma de empréstimo a ideia e lhe dá um sentido bem mais amplo, uma vez que a transforma num princípio geral de "autorregulação do aparelho psíquico". Portanto, a atividade do inconsciente é vista "como equilibração da unilateralidade da atitude geral, causada pela função da consciência". ${ }^{\mathbf{6 4}}$

Todavia, a despeito dessa relação compensatória, a atitude inconsciente não tem a mesma qualidade que a consciente, dela se dizendo que inferior. Tal qualificativo tem significado psicológico e se refere a um menor grau de diferenciação da atitude enquanto resposta adaptativa, de forma que o indivíduo não consegue fazer atuar com tanta facilidade sua vontade sobre ela. Logo, a atitude inferior se caracteriza por certa autonomia: "é independente, ela nos acomete, fascina e enleia, a ponto de deixarmos de ser donos de nós mesmos e não nos distinguirmos mais exatamente dos outros". ${ }^{165} \mathrm{Um}$ dos sintomas da atuação da atitude inferior é a hipersensibilidade do indivíduo, pois, por habitar o inconsciente, permanece arcaica, primitiva, infantilizada.

O direcionamento da energia psíquica para o sujeito gera, nos introvertidos, uma tendência para uma relação deficiente com o objeto, relação esta que passa a ser permeada ou intermediada por sua subjetividade, e de uma subjetividade cujas raízes se projetam no inconsciente. Assim, os objetos passam a ter para ele "qualidades poderosas e aterradoras (...) Como sua relação consciente com o objeto é relativamente reprimida, ela passa pelo inconsciente onde é carregada com as qualidades deste (...) É como se o objeto possuísse, então, força mágica". 166

$\mathrm{Na}$ metáfora do castelo, vemos que o afloramento das atitudes inferiores dos rapazes gera um completo desentendimento entre eles, passando a reinar a discórdia onde an-

\footnotetext{
163 “Tipos Psicológicos”... 1923, p. 478, § 967.

${ }^{164}$ Tipos ..., pp. 398/399, §§ 773 (839)/774 (840).

${ }^{165}$ Psicologia do Inconsciente (CW VII/1), p. 50, $\$ 85$.

166 Tipos..., p. 359, § 699.
} 
tes, sob o efluxo das funções superiores, conscientes e plenamente diferenciadas, havia concórdia.

Não obstante, Jung comenta ser necessário, para o desenvolvimento da personalidade, que também as funções inferiores possam se manifestar, pois não se há de querer que as pessoas vivam permanentemente em relações simbióticas. E, mantidas as atitudes inconscientes em alto grau de indiferenciação, estará o extrovertido sujeito a perder contato com o objeto e o introvertido consigo mesmo. Extroversão e introversão são duas atitudes naturais, antagônicas entre si e que, "em sucessão harmônica, deveriam formar o ritmo da vida. Alcançar esse ritmo harmônico supõe uma suprema arte de viver". ${ }^{167}$

Encontra-se na lição de Jung a ideia de que o introvertido apresenta uma postura mais temerária em relação ao mundo externo, cujos estímulos tende a ver como ameaçadores. Por isso, sua energia psíquica é preferencialmente canalizada para si mesmo, o que redunda numa atitude mais reflexiva. Há, portanto, uma série de características que costumam estar associadas a essa dinâmica psíquica:

Os introvertidos tendem a ter uma atitude mais cautelosa e questionadora em relação ao mundo e, diante de questões essenciais, costumam deixar-se levar por considerações de caráter subjetivo; procuram preservar-se das demandas do meio caso estas não estejam de acordo com suas demandas internas; sutis e impenetráveis, normalmente taciturnos e tímidos, sentem-se mais à vontade no mundo das ideias do que no das pessoas e coisas; intensos e apaixonados, normalmente escondem cuidadosamente suas emoções ${ }^{168}$; costumam restabelecer seu equilíbrio quando sozinhos, momento em que têm oportunidade de refletir, e normalmente preferem desenvolver atividades individuais; costumam ser vistos pelas outras pessoas como calmos e "centrados" ou reservados; preferem ter menos amigos, porém investir mais na intensidade das relações; às vezes refletem demais antes de agir,

${ }^{167}$ Psicologia do Inconsciente (CW VII/1), p. 51, § 87.

168 MYERS, Isabel Briggs. Gifts Differing - Understanding Personality Type, Consulting Psychologists Press, 1980, p. 56. 
podendo perder o tempo da ação, e às vezes esquecem de checar se o mundo externo corrobora as ideias que eles possuem a seu respeito. ${ }^{\mathbf{1 6 9}}$

Em contrapartida, extraímos da fala de Jung a ideia de que o extrovertido apresenta uma postura mais destemida em relação ao mundo externo, sentindo-se atraído por seus estímulos, que são para ele fonte de prazer. Por isso, sua energia psíquica é preferencialmente canalizada para o exterior. Há, do mesmo modo, uma série de características que costumam decorrer dessa dinâmica psíquica:

Os extrovertidos tendem a ter uma atitude mais aberta em relação ao mundo e, diante de questões essenciais, costumam deixar-se levar por considerações de caráter objetivo; procuram devotar-se às demandas do meio, que para eles têm um sentido vital; transparentes e acessíveis, normalmente sociáveis, sentem-se mais à vontade no mundo das pessoas e coisas do que no das ideias; expansivos e menos apaixonados, normalmente expressam suas emoções na medida em que ocorrem; quando a extroversão se dá de maneira muito unilateral, ou seja, sem um mínimo grau de introversão, tendem a ser intelectualmente superficiais ${ }^{\mathbf{1 7 0}}$; normalmente sentem-se revigorar quando se encontram no meio de outras pessoas e, portanto, apreciam desenvolver atividades em grupo; costumam ter uma ampla rede de amigos e relacionamentos e normalmente agem de forma espontânea, sem refletir antes, de modo que muitas vezes deixam de refletir sobre o sentido de suas ações. ${ }^{\mathbf{1 7 1}}$

O senso comum associa o conceito de introversão à ideia de timidez, mas são coisas distintas. Na lição de Zacharias:

Os tímidos apresentam uma grande fragilidade perante a rejeição dos outros e, portanto, evitam expor-se, principalmente a estranhos ou ao grande público. O introvertido pode expor-se se isso for necessário. Ele não iria se expor por desconsiderar o ambiente externo e não por receio de rejeição. É possível que um extrovertido seja tímido. Embora ele fique constantemente atento aos acontecimentos do mundo a

\footnotetext{
${ }^{169}$ MARTIN, Charles R.. "Looking at Type: The Fundamentals", eighth printing, Center For Applications of Psychological Type (CAPT), Gainesville, Florida, 2007, p. 3.

${ }^{170}$ MYERS, Isabel Briggs. Op. cit., p. 56.

${ }^{171}$ MARTIN, Charles R.. Op. cit., p. 3.
} 
sua volta, ele tem vergonha de se colocar por causa da falta de autoestima ou medo da rejeição do grupo. ${ }^{172}$

De fato, já conhecemos diversos extrovertidos que declararam sua timidez para falar em público e, reversamente, introvertidos que, evidentemente não-tímidos, disseram se regozijar ao fazê-lo, ainda mais quando isso representa uma oportunidade de expor ideias nas quais acreditam. Por outro lado, bastante diferente de "falar em público" é também o chamar para si, gratuitamente, a atenção do público, o que um introvertido típico detesta fazer.

Partindo da premissa de que a conduta dos extrovertidos é baseada na situação exterior, Isabel Briggs Myers diz que, em predominando a função pensamento, eles tendem a criticar tal situação, ou analisá-la ou organizá-la; o tipo sentimento pode lutar por ela, protestar contra ou tentar atenuá-la; o tipo sensação pode se satisfazer com ela, usá-la ou simplesmente se conformar com ela, enquanto os intuitivos tenderão a tentar mudá-la. ${ }^{173}$

Ainda segundo Myers, os introvertidos, diferentemente, basear-se-ão primeiro em seu mundo interno, das ideias e conceitos mentais, de base arquetípica. Lembrando o conceito de que os arquétipos não se originam de uma experiência individual, mas podem ser por ela ativados, diz que os introvertidos se sentem à vontade quando reconhecem no mundo externo algo que já se encontra constelado internamente. Caso contrário, simplesmente podem deixar de dar importância à situação, e essa falta de contato com o sentido mais objetivo das coisas pode trazer-lhes sérios problemas. ${ }^{\mathbf{1 7 4}}$

Myers atribui aos introvertidos maior capacidade de concentração, o que nos permitimos questionar. A nosso ver, a maior facilidade do introvertido para voltar sua atenção ao mundo interno não implica necessariamente uma capacidade de concentração, mas antes capacidade de desviar sua atenção dos estímulos ("ruídos") do meio externo. Nada impede, porém, que seu mundo interior esteja mais tumultuado que o externo, evitando, propriamente, que se "concentre" no que venha a ser de seu interesse. Em contrapartida, os extro-

${ }^{172}$ Tipos - A diversidade Humana, Vetor Editora Psico-Pedagógica Ltda., São Paulo (SP), 2006, pp. 60/61.

${ }^{173}$ Gifts Differing..., p. 53.

${ }^{174}$ Gifts Differing..., pp. 53/54. 
vertidos parecem mais hábeis em lidar com vários estímulos ao mesmo tempo, como, por exemplo, ouvir música enquanto estudam. ${ }^{175}$

Em se tratando de tendências inatas, problemas podem surgir quando a criança não encontra condições favoráveis ao desenvolvimento de seu tipo. Uma criança introvertida, por exemplo, pode ser vista como problemática por pais extremamente extrovertidos, ou vice-versa, e daí ser levada a desenvolver características opostas à de seu tipo, às vezes gerando o chamado "falso tipo" ou "tipo distorcido". Segundo Jung, "quando ocorre uma falsificação do tipo, devido a influências externas, o indivíduo se torna, na maioria dos casos, neurótico e a cura só é possível restabelecendo-se a atitude que naturalmente corresponderia ao indivíduo", e ainda: "Mostrou-me a experiência que uma troca de tipo pode afetar profundamente o bem-estar fisiológico do organismo porque, na maioria das vezes, provoca forte esgotamento". ${ }^{176}$

Somos todos capazes de nos conduzir de acordo com qualquer atitude ou função. Uns têm isso mais desenvolvido e outros menos. Contudo, não deixamos de ter nossas preferências, estas normalmente associadas ao que é natural em cada um de nós. Quando agimos contra nossa natureza, voluntariamente ou não, despendemos uma quantidade maior de energia psíquica, o que explica o esgotamento mencionado por Jung.

Em seu livro, Giannini denuncia a existência de uma cultura ocidental de valorização da extroversão, muitas vezes com graves consequências para o desenvolvimento natural dos introvertidos. Um de seus pacientes, em quem as inadequadas investidas de uma mãe extrovertida deixaram marcas dolorosas, relatou o seguinte sonho:

Eu ingresso na cabine privada de um trem. Ali, vejo um menino pré-adolescente dormindo. A criança não tem boca, nariz, orelhas ou olhos. Ela vive exclusivamente dentro de si. A mãe, de maneira apelativa, exibe para mim algumas fotografias de quando era um garotinho, nas quais apresentava todos os traços faciais.

\footnotetext{
${ }^{175}$ KROEGER, Otto e THUESEN, Janet M. Type Talk: The 16 Personality Types That Determine How We Live, Love, and Work, Dell Publishing, New York, New York, 1989, p. 17.

${ }^{176}$ Tipos..., p. $318, \S \S 625 / 626$.
} 
Giannini vê na imagem desse sonho quão difícil pode ser para um introvertido desenvolver sua face externa, a persona, um papel que diga respeito às outras pessoas, especialmente quando não aceito com suas peculiaridades. ${ }^{177}$

Para finalizar, como alusão poética ao contraste do mundo que se vê a partir de cada atitude, trazemos versos de "Alberto Caeiro", um dos heterônimos de Fernando Pessoa:

Não basta abrir a janela

Para ver os campos e o rio.

Não é bastante não ser cego

Para ver as árvores e as flores.

É preciso também não ter filosofia nenhuma.

Com filosofia não há árvores: há ideias apenas.

Há só cada um de nós, como uma cave.

Há só uma janela fechada, e todo o mundo lá fora;

E um sonho do que se poderia ver se a janela se abrisse,

Que nunca é o que se vê quando se abre a janela. ${ }^{178}$

177 Op. Cit., p. 125.

${ }^{178}$ Obra e Poética em Prosa, vol. 1, por seu heterônimo Alberto Caeiro, em "Poemas Inconjuntos", Lello \& Irmão - Editores, Porto, 1986, p. 781. 


\section{AS QUATRO FUNÇÕES}

Ao elaborar sua teoria dos tipos, Jung notou a insuficiência de uma classificação binária, que dividisse os indivíduos meramente em dois grupos. Portanto, na sequência de sua investigação, postulou que "ninguém é simplesmente introvertido ou extrovertido, mas o é por conformação de certas funções". ${ }^{179}$

A ideia dos pares de funções decorreu da constatação de que todo ser humano, ao se relacionar com pessoas, ideias e coisas, o faz sempre a partir de uma base de dados ou informações sobre os quais é tomada uma decisão. Em outras palavras: ao se inserir no mundo, o indivíduo vê-se a todo momento obrigado a decidir e, para isso, precisa estar diante de alternativas que tenha previamente percebido.

Aceito isso, intui-se sem grande dificuldade que diferentes personalidades haveriam de estar relacionadas a diferentes estilos de percepção e de tomada de decisão. Às funções perceptivas, Jung designou sensação e intuição, e às judicativas designou pensamento e sentimento, que podem ser assim sucintamente apresentadas:

(...) Estes quatro tipos funcionais correspondem às quatro formas evidentes, através das quais a consciência se orienta em relação à experiência. A sensação (isto é, a percepção sensorial) nos diz que alguma coisa existe; o pensamento mostra-nos o que é esta coisa; o sentimento revela se ela é agradável ou não; e a intuição dir-nosá de onde vem e para onde vai.

O leitor deve compreender que estes quatro critérios, que definem tipos de conduta humana, são apenas quatro pontos de vista entre muitos outros, como a força de vontade, o temperamento, a imaginação, a memória, e assim por diante. Nada há de dogmático a respeito deles, mas o seu caráter fundamental recomenda-os para uma classificação. ${ }^{180}$

\footnotetext{
179 “Tipos Psicológicos”... 1923, Op. cit., p. 478, §§968.

180 "Chegando ao Inconsciente”, in O Homem e seus Símbolos, 14ํㅡㄹ edição, Editora Nova Fronteira, São Paulo (SP), 1996, p. 61.
} 
Pelo fato de se prestarem à coleta de informação, as funções perceptivas serão tidas como irracionais, e, pelo fato de se prestarem à tomada de decisão, as judicativas também serão chamadas racionais.

Num mesmo indivíduo, normalmente as funções encontram-se em diferentes graus de desenvolvimento, vindo uma delas a prevalecer sobre as demais. Jung ensina que seria ideal, para plena orientação da consciência, que todas ocorressem igualmente, mas, "na verdade, essas funções básicas estão raras vezes ou nunca igualmente diferenciadas e, portanto, disponíveis. Via de regra, uma ou outra dessas funções ocupa o primeiro plano e as outras permanecem indiferenciadas no segundo plano". ${ }^{181}$ Dizer de uma indiferenciação em segundo plano é o mesmo que delas dizer que permanecem inconscientes, mesmo que isso se dê em graus variados.

Quando se fala em inconsciente, vale o alerta de Jung:

Não se suponha que o inconsciente esteja enterrado sob muitas camadas e que só possa daí ser tirado após penosa escavação. O inconsciente, ao contrário, flui sempre para o evento psicológico e em tão grande quantidade que se torna difícil às vezes ao observador distinguir quais propriedades de caráter atribuir à personalidade consciente e quais à personalidade inconsciente. ${ }^{\mathbf{1 8 2}}$

Ao se falar na diferenciação de uma das funções, ocorre-nos perguntar por que isso se dá. Em primeiro plano, postula-se, conforme já vimos, uma predisposição biológica (“disposição interna”). Em segundo plano, surgem os fatores do meio no qual o indivíduo se insere ("circunstâncias externas"). Bem cedo a criança manifesta algumas "aptidões" em determinadas áreas e, por outro lado, dificuldades em outras. Se vincularmos isso à manifestação das funções, ao ser socialmente valorizada por aquilo que faz bem, a criança tenderá a se exercitar mais e mais nessa direção e automaticamente negligenciará outras. ${ }^{\mathbf{1 8 3}}$ Não raro, encontrará em seu caminho quem a complemente em seus pontos fracos. Aliás, tal iniciativa é bastante comum na formação de casais, numa espécie de simbiose equivalente à apontada por Jung na metáfora do castelo, acima abordada. Desse modo, a unilate-

181 “Tipos Psicológicos”... 1923, Op. cit., pp. 477, §§ 965/966.

182 Tipos ..., pp. 325/326, $\$$ 641.

${ }^{183}$ FRANZ, Marie-Louise von. Op. cit., pp. 14/15. 
ralidade do tipo vai se recrudescendo, tornando-o, muitas vezes, mais facilmente visível a quem observa o indivíduo.

Do comentário de Marie-Louise von Franz, psicóloga e uma das mais próximas colaboradoras de Jung, podemos concluir que a vida do homem em sociedade acaba criando condições favoráveis à unilateralidade, pois não podemos esquecer que o exercício das funções permite ao indivíduo adaptar-se ao meio:

(...) as pessoas que ainda vivem completamente em contato com a natureza, como os camponeses, os caçadores, os bosquímanos, a respeito dos quais Laurens van der Post escreveu, não sobreviveriam se não usassem mais ou menos todas as suas funções. Um camponês jamais poderá tornar-se tão unilateral quanto um habitante da cidade (...) se você for um solteirão e trabalhar sozinho num escritório de estatística, realmente não necessitará de quase nenhum sentimento. Isso, naturalmente, tem consequências desagradáveis, mas no mundo da natureza simplesmente você não poderia prescindir de nenhuma das funções. ${ }^{184}$

Do que se disse, fica claro que ao construir sua tipologia Jung propôs a combinação de uma atitude e uma função - as que estiverem mais diferenciadas em dado indivíduo -, do que resultará o chamado tipo psicológico. ${ }^{\mathbf{1 8 5}}$

Assim, teremos, em princípio, oito tipos possíveis, a saber:

\begin{tabular}{|c|c|c|c|c|}
\hline \multirow[b]{2}{*}{ Atitudes } & \multicolumn{3}{|l|}{ Funções } & \\
\hline & SENSAÇÃO & INTUIÇÃO & PENSAMENTO & SENTIMENTO \\
\hline INTROVERTIDA & $\begin{array}{l}\text { Sensação } \\
\text { Introvertida }\end{array}$ & $\begin{array}{l}\text { Intuição } \\
\text { Introvertida }\end{array}$ & $\begin{array}{l}\text { Pensamento } \\
\text { Introvertido }\end{array}$ & $\begin{array}{l}\text { Sentimento } \\
\text { Introvertido }\end{array}$ \\
\hline EXTROVERTIDA & $\begin{array}{l}\text { Sensação } \\
\text { Extrovertida }\end{array}$ & $\begin{array}{l}\text { Intuição } \\
\text { Extrovertida }\end{array}$ & $\begin{array}{l}\text { Pensamento } \\
\text { Extrovertido }\end{array}$ & $\begin{array}{l}\text { Sentimento } \\
\text { Extrovertido }\end{array}$ \\
\hline
\end{tabular}

Assim como proposto em relação às atitudes, também as funções, que se apresentam em pares de opostos, teriam uma dinâmica compensatória. Isso implica dizer que, a

\footnotetext{
${ }^{184}$ Op. cit., pp. 36/37.

${ }^{185}$ Tipos ..., p. 22.
} 
predominar na consciência a função sensação, aquela que se guia pelo princípio oposto, ou seja, a intuição, estaria relegada ao inconsciente, recebendo o nome de função inferior.

A dicotomia, portanto, ocorre entre funções de mesma natureza:

(a) sensação x intuição: natureza perceptiva ou irracional;

(b) pensamento x sentimento: natureza judicativa ou racional.

Jung também percebeu que o indivíduo não pode prescindir do uso de pelo menos duas funções, uma de cada natureza. Afinal, não adianta dispor de informações se não houver capacidade para decidir o que fazer com elas, ou o contrário: ter plenamente desenvolvida uma função de tomada de decisão sem que se disponha de habilidade para apreender os estímulos do meio (tanto o meio externo quanto o interno). As funções perceptivas, por exemplo, "são as nossas janelas para o mundo e, nesse sentido, fornecem os dados que pensamento e sentimento necessitam para operar". ${ }^{186}$ Portanto, existe uma relação de assessoriedade entre as funções integrantes de cada par, de modo que, em predominando uma função judicativa ou racional ( $\mathrm{T}$ - pensamento ou $\mathrm{F}$ - sentimento), o indivíduo terá necessariamente como funções auxiliares as perceptivas ( $\mathrm{N}$ - intuição e $\mathrm{S}$ - sensação), e vice-versa.

Num ciclo de cinco conferências proferidas em Londres, no ano de 1935, no que ficou conhecido por "Tavistock Lectures", Jung representou graficamente o acima dito pelo que chamou de cruz das funções:

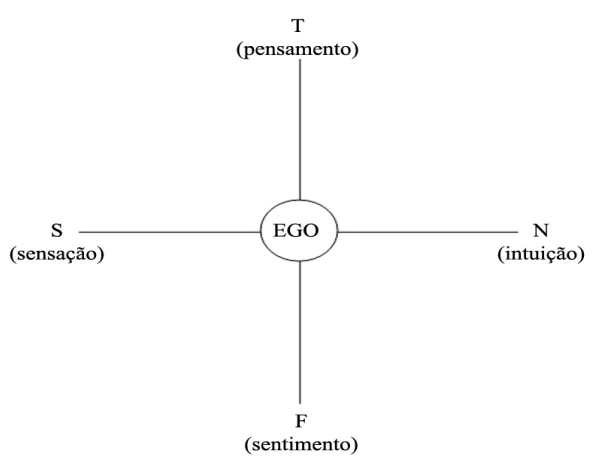

${ }^{186}$ ROBERTSON, Robin. Guia Prático de Psicologia Junguiana, trad.: Maria Silvia Mourão Netto, Editora Cultrix, São Paulo, 1992, p. 77. 
Ao centro, o ego, "dotado de certa quantidade de energia disponível, que é a força da vontade". 187

Importante esclarecer que, mesmo entre as auxiliares, normalmente há uma que predomina em relação à outra, pelas mesmas razões já explicitadas quando falamos das funções principal e inferior. Postula-se, assim, uma gradação entre as quatro. Embora sejam duas as funções auxiliares (secundária e terciária), quando na literatura tipológica se faz referência à “função auxiliar”, está-se designando a secundária.

${ }^{187}$ Fundamentos de Psicologia Analítica (CW XVIII/1), p. 13, § 28. 


\subsection{A DICOTOMIA DAS FUNÇÕES PERCEPTIVAS (SENSAÇÃO-“S" E INTUIÇÃO- "N")}

\subsubsection{SENSAÇÃO (S)}

Por meio da função sensação tomamos contato com os dados sensíveis da realidade. Vem a ser o gerenciador psíquico de tudo o que é apreendido pelos sentidos do corpo; segundo Jung, "é a função psicológica que proporciona a percepção de um estímulo físico", sendo, portanto, idêntica à percepção, relacionando-se, porém, não apenas com os estímulos externos, mas também internos. ${ }^{188}$ Como função perceptiva, parece preceder as funções do pensamento e do sentimento e, do mesmo modo que a intuição, "caracteriza fortemente a natureza da criança e do primitivo", nos quais predomina sobre as funções racionais. ${ }^{189}$

Como "função do real" - em expressão francesa que tanto agradara a Jung -, a sensação "diz que alguma coisa é, mas não exprime $o$ que é [atribuição do pensamento], nem qualquer outra particularidade da coisa em questão". ${ }^{190}$

Portanto, indivíduos em que essa função predomina apresentam postura "observadora" em relação à vida, em detrimento da imaginação, e dão grande importância aos prazeres sensoriais; muito atentos a detalhes, captam os estímulos do mundo com grande riqueza e não costumam gostar de atividades que dispensem o uso dos sentidos; tendem a dar grande valor ao conforto e até mesmo ao luxo, e neste sentido podem ser fúteis e consumistas caso as funções auxiliares (de natureza judicativa) não interfiram trazendo equilíbrio. ${ }^{191}$ Vinculam-se ao tempo presente e ao mundo real, concreto. Vivem sobretudo o "aqui" e "agora". Costumam dar importância aos fatos, a dados objetivos e, portanto, tendem a lembrar-se de minúcias. Normalmente costumam perceber as aplicações práticas de ideias ou coisas e conseguem aprender melhor quando vislumbram o lado pragmático do que lhes está sendo transmitido. Dão grande valor à experiência, mais do que a teorias. Às ve-

\footnotetext{
${ }^{188}$ Tipos ..., p. 438, § 889 (787).

${ }^{189}$ Tipos ..., p. 439, § 890 (788).

${ }^{190}$ Fundamentos de Psicologia Analítica (CW XVIII/1), p. 8, § 21.

${ }^{191}$ MYERS, Isabel Briggs. Gifts Differing..., cit., p. 63.
} 
zes ficam tão focados nos fatos do presente, ou nas experiências passadas, que acabam deixando escapar algumas oportunidades novas. ${ }^{192}$

Ainda como características desse tipo, Giannini menciona, como decorrência de seu apurado senso de observação, a importância dada às regras de etiqueta e também ao estilo. Como exemplo de seu poder criativo, cita o universo retratado nos filmes "A Festa de Babette" e "Como Água para Chocolate". 193

Quando elenca características de determinada função, Jung sempre o faz levando em consideração a atitude que se encontra mais presente. Não descreve, por exemplo, meramente o "tipo sensação", mas em vez disso fala do "sensação extrovertido". As diferenças decorrentes do predomínio de atitudes opostas são marcantes.

Além disso, muitas das afirmações que faz ao descrever os tipos retratam quadros extremos ("puros"), provavelmente colhidos de sua experiência clínica e nem sempre observáveis quando as funções e atitudes se encontrem menos unilaterais.

A respeito do tipo sensação extrovertido ${ }^{194}$, Jung afirma não haver quem possa igualar-se a ele em realismo, pois tem um senso objetivo extraordinário dos fatos. Isso se deve não apenas ao predomínio da função sensação, mas sobretudo porque ela apresenta qualidade extrovertida. É que sendo extrovertido, este tipo não apenas terá a sensibilidade sensorial da sensação, como também não projetará sobre o objeto aspectos de sua subjetividade, de seu mundo interno (característica do introvertido). Em outras palavras: está-se diante de uma sensação determinada sobretudo pelo objeto. Para ele, "nada existe além do concreto e do real; considerações sobre ou além disso são aceitas apenas enquanto fortalecem a sensação", o que às vezes se pode dar em grave violação da lógica. Quando em excesso, tal função transforma o representante deste tipo em "pessoa grosseira em busca do prazer ou num esteta refinado e sem escrúpulos".

Segundo Nise da Silveira, distinta psiquiatra e pioneira da psicologia junguiana no Brasil, quando este tipo comparece a um evento social é capaz de "descrever como esta-

\footnotetext{
${ }^{192}$ MARTIN, Charles R.. "Looking at Type...", p. 4.

193 Op. Cit., p. 132 e 136.

${ }^{194}$ Tipos ..., pp. 344/347, §§ 674/678.
} 
vam vestidas as pessoas e imediatamente reconhecerá a qualidade dos móveis, dos tapetes. Ele parece segurar os objetos entre os eixos de seus olhos como entre as hastes de uma pinça". ${ }^{195}$ Diz, ainda, que não tem afinidade com questões teóricas de caráter geral, parecendo-lhe fantasiosas as hipóteses de interpretação no campo científico. Também não costuma dar valor às manifestações da vida subjetiva, que se lhe afiguram sintomas de doença ou coisa inútil. Entre seus expoentes encontram-se engenheiros, mecânicos e comerciantes de grande sucesso profissional. No entanto, como sua intuição é de caráter inferior, podem não perceber a tempo a necessidade de se adaptar às mudanças, o que explicaria a ruína de muitos negócios. Também tem raízes em sua intuição inferior o cultivo de um misticismo arcaico, expresso por meio do gosto por histórias extravagantes de fantasmas e superstições, o que contrasta, evidentemente, com seu "realismo". 196

Sobre o tipo sensação introvertido ${ }^{197}$, Jung destaca que, por conta da atitude introvertida, "a sensação se baseia principalmente na parcela subjetiva da percepção"; isso implica dizer de uma sensação que "se refere sobretudo ao sujeito e só, em segundo plano, ao objeto". Segundo ele, em casos extremos, a supressão da influência do objeto pode chegar ao ponto de a atenção do sujeito ficar inteiramente voltada para a impressão gerada pelo mesmo, reduzindo o objeto à condição de mero estímulo; é ele coberto "com o sedimento de antiquíssima e futura ${ }^{198}$ experiência subjetiva. E, assim, a mera impressão dos sentidos se desenvolve para o fundo da riqueza intuitiva [função inferior], ao passo que a sensação extrovertida apreende o ser momentâneo e manifesto das coisas". Como a função intuição deste tipo reside inteiramente no inconsciente, sua manifestação pode dar-se na forma de percepção "de todos os aspectos dúbios, sombrios, sujos e perigosos que estão por trás da realidade".

Nise explica que, por conta da sensibilidade destes tipos às impressões causadas por um objeto, são capazes de lhe atribuir um valor racionalmente desproporcional, vindo a pagar por ele preço que outros tipos considerariam absurdo. Diz, ainda, que "nas relações amorosas vivem intensamente o aspecto sensual, sem que lhes seja necessária a presença

\footnotetext{
195 SILVEIRA, Nise da. Jung: vida e obra, 11ª edição, Editora Paz e Terra, Rio de Janeiro (RJ), 1988, pp. $59 / 60$.

196 Op. cit., pp. 60/61.

197 Tipos ..., pp. 371/375, $\S$ 718/725.

${ }^{198}$ Cabe lembrar que para a Psicanálise, assim como para a Psicologia Analítica, o inconsciente é atemporal.
} 
de verdadeiros sentimentos afetivos", também se preocupando com o próprio corpo, cujas mínimas reações são capazes de detectar. ${ }^{199}$

Reputamos muito representativo da função sensação o seguinte poema de "Alberto Caeiro" (Fernando Pessoa):

Sou um guardador de rebanhos.

O rebanho é o meus pensamentos

E os meus pensamentos são todos sensações.

Penso com os olhos e com os ouvidos

E com as mãos e os pés

E com o nariz e a boca.

Pensar uma flor é vê-la e cheirá-la

E comer um fruto é saber-lhe o sentido.

Por isso quando num dia de calor

Me sinto triste de gozá-lo tanto,

E me deito ao comprido na erva,

E fecho os olhos quentes,

Sinto todo o meu corpo deitado na realidade,

Sei a verdade e sou feliz. ${ }^{200}$

${ }^{199}$ Op. cit., p. 65.

${ }^{200}$ PESSOA, Fernando. Op. cit., vol. 1, por seu heterônimo Alberto Caeiro, em "O Guardador de Rebanhos", IX, Lello \& Irmão - Editores, Porto, 1986, p. 754. 


\subsubsection{INTUIÇÃO (N)}

Não é nada fácil explicar em termos "acadêmicos" o significado da função intuição. Por outro lado, talvez ninguém ignore seu sentido, que de certo modo equivale ao do senso comum. Vejamos como Jung se desincumbiu da tarefa:

(...) a sensação diz que alguma coisa é; o pensamento exprime $o$ que ela é; o sentimento exprime-lhe o valor. O que mais, então, poderia existir? Pode-se acreditar que a visão do mundo se complete ao saber que as coisas são, o que são e qual o valor a elas atribuído. Há, entretanto, uma outra categoria: o tempo. Tudo tem um passado e um futuro; tudo procede de um lugar, enquanto se encaminha para outro. E é impossível saber qual seja essa origem e essa destinação, a menos que se tenha o que vulgarmente é chamado "faro". Se suas atividades se relacionarem ao ramo artístico ou ao de venda de móveis antigos, você pode "ter um palpite" de que determinado objeto pertence a um grande mestre de 1720; pressentindo ser esse um bom trabalho. Ou, então, não saber que ofertas terá dentro em pouco, mas ter um palpite de que a coisa será boa. A isso se chama intuição, uma espécie de faculdade mágica, coisa próxima da adivinhação, espécie de faculdade miraculosa. ${ }^{201}$

Pouco mais adiante, Jung esclarece que em situações novas, em que não haja valores preestabelecidos ou conceitos já firmados, esta função vem a ser o único guia, consistindo numa espécie de percepção que não passa pelos sentidos, mas que se registra "ao nível do inconsciente, e é onde abandono toda tentativa de explicação dizendo-lhes: 'Não sei como isso se processa'.,202

Jung pontua que o termo vem de "intueri", significando olhar para dentro. Tanto as coisas internas quanto externas, e suas relações, podem ser objeto dessa modalidade de percepção. Sendo, como a sensação, também função perceptiva, irracional, os conteúdos da intuição 'têm caráter de 'dados’, em oposição ao caráter de 'derivado', 'produzido’ dos conteúdos do sentimento e do pensamento". Daí proviria, segundo Jung, seu caráter de

${ }^{201}$ Fundamentos de Psicologia Analítica (CW XVIII/1), pp. 9/10, § 24.

${ }^{202}$ Fundamentos..., p. 11, §§ 25/26. 
certeza e exatidão que levou tanto Spinoza quanto Bergson a considerá-la como a forma mais elevada de conhecimento. ${ }^{203}$

Em aqueles cuja função principal é a intuição, predomina uma atitude de expectativa em relação à vida. Possuem forte senso de imaginação, em detrimento da observação; dão grande importância a tudo o que os possa inspirar, remetendo a sentidos ocultos, implícitos, que captam com facilidade. De grande originalidade, são naturalmente pioneiros e inovadores em suas áreas de atuação; não costumam gostar de atividades que exijam uso atento de seus sentidos sensoriais e normalmente preferem canalizar suas energias para empreender algo em vez de aproveitar o momento presente. Em casos extremos, caso as funções auxiliares (de natureza judicativa) não interfiram trazendo equilíbrio, o intuitivo pode tornar-se muito instável, no sentido de não concluir o que começou, pois se entedia com a rotina. ${ }^{204}$ A experiência é vivida como fonte de impressões e sentidos simbólicos; as informações lhes vêm mais na forma de "insights" do que como dados que extraem da experiência; tendem a captar novas oportunidades e tendências e têm sua atenção voltada predominantemente para o tempo futuro. Manifestam interesse pelo que é abstrato e teórico e apreciam atividades que representam um desafio à criatividade. Aprendem melhor quando lhes é apresentado primeiramente um panorama geral do assunto em questão. Às vezes ficam tão focados nas novas possibilidades, no futuro, que deixam de se empenhar em concretizá-las. ${ }^{205}$

Ao confrontar o tipo sensorial com o intuitivo, Myers diz que o primeiro tende a confiar mais nos dados obtidos diretamente por ele, decorrentes de sua experiência, relegando a categoria inferior o que lhe chega por meio de palavras (relatos falados ou escritos). Para o tipo sensação, palavras são meros símbolos que precisam ser traduzidos antes de significar qualquer coisa real. Já o tipo intuitivo dispensa os dados que dependam de uma apreensão sensorial para serem conhecidos, uma vez que sua percepção tem outra natureza, estando mais fundada no inconsciente. ${ }^{\mathbf{2 0 6}}$

Myers traz ainda considerações bastante interessantes a respeito dos desempenhos acadêmicos de cada tipo. Costuma-se encontrar em posições de maior destaque aqueles

\footnotetext{
${ }^{203}$ Tipos ..., p. 430, § 865 (834).

${ }^{204}$ MYERS, Isabel Briggs. Gifts Differing..., p. 63.

${ }^{205}$ MARTIN, Charles R.. "Looking at Type...", p. 4.

${ }^{206}$ Gifts Differing..., pp. 53/54.
} 
que apresentam a função intuição seja em posição dominante, seja auxiliar. No entanto, isso não significa que sejam mais "inteligentes" que os tipos sensoriais. Cada função carrega uma modalidade específica de habilidade, na qual se distingue da outra. Quando a exigência do meio está mais de acordo com a habilidade natural de uma função, o tipo correspondente tenderá a se sair melhor do que seu oposto na resposta dada, e Myers comenta que os testes de inteligência existentes costumam se pautar pelo "tempo" de resposta. Ora, os tipos intuitivos costumam levar vantagem sobre os sensoriais quanto à rapidez de resposta, e, para eles, o conceito de inteligência está vinculado à velocidade com que se consegue apreender uma situação. Para o tipo oposto, esse conceito tem mais a ver com consistência, com o quanto a conclusão a que se chegou corresponde efetivamente aos fatos e a meticulosa averiguação dos fatores envolvidos toma mais tempo. ${ }^{207}$

A respeito do tipo intuição extrovertido ${ }^{208}$, Jung destaca o foco por ele dado ao objeto, que é captado a partir de imagens ou impressões de relações. $\mathrm{O}$ olhar do intuitivo não se dirige para a superfície física, mas para coisas que estão além dela. Por isso seu princípio é oposto ao da sensação, que se foca justamente nos detalhes que se mostram em primeiro plano para os sentidos sensoriais. Pelo fato de o estilo de uma função excluir o da outra, "para que a intuição possa funcionar, a sensação deve ser fortemente reprimida". Jung diz que se perguntarmos a um intuitivo como ele se orienta, dele ouviremos coisas que concordarão perfeitamente com sensações dos sentidos. Ora, é claro que ele possui sensações, mas a questão é que "não se orienta por elas; elas são apenas pontos de partida de sua impressão", escolhidas "por pressupostos inconscientes”. Não há função mais oportuna quando se precisa encontrar saída para uma situação bem complicada. No dia a dia, quando é grande o predomínio da intuição, o indivíduo pode vivenciar a rotina como algo sufocante, "uma prisão, uma cadeia opressora que é preciso romper". Os objetos podem ser excessivamente valorizados, mas apenas enquanto representam meios de acesso ou de realização de novas possibilidades. Uma vez que tenham desempenhado tal missão, o intuitivo pode perder todo o interesse por eles e relegá-los a acessórios incômodos. "Possibilidades emergentes são motivos cogentes dos quais a intuição não pode fugir e aos quais sacrifica todo o resto". A instabilidade deste tipo em face de situações estáveis torna evidente sua importância para a sociedade, seja do ponto de vista econômico, seja cultural. Quando está

\footnotetext{
${ }^{207}$ Gifts Differing..., pp. 58/59.

${ }^{208}$ Tipos ..., pp. 348/351, $\S$ 679/685.
} 
mais voltado para pessoas do que para coisas ${ }^{209}$, é capaz de pressentir talentos ainda não tão visíveis e investir com grande entusiasmo energia em sua realização, "mesmo que depois de amanhã os abandone". "Soubesse ele persistir numa coisa, colheria os frutos do seu trabalho, mas bem breve precisa correr atrás de nova possibilidade e abandonar o campo que plantou e que outros colherão".

Sobre o tipo intuição introvertido ${ }^{210}$, diz Jung que, por força da atitude predominante, a função se volta para os objetos interiores, que é como podem ser denominados os elementos inconscientes - em última análise, do inconsciente coletivo. Como na sensação, também a intuição introvertida tem seu fator subjetivo potencializado, a ponto de as imagens inconscientes adquirirem "a dignidade de coisas ou objetos", parecendo, para o sujeito, como que destacadas dele e existindo em si mesmas. "A grande indiferença do intuitivo extrovertido em relação aos objetos externos também ocorre no introvertido em relação aos objetos interiores". O intuitivo introvertido é capaz de ir "de imagem em imagem [interiores], correndo atrás de todas as possibilidades do seio gerador do inconsciente, sem estabelecer a conexão do fenômeno consigo mesmo". Ainda segundo Jung, como o inconsciente não é uma instância alienada do que acontece no mundo, o intuitivo introvertido pode dele extrair dados de enorme importância para a compreensão dos acontecimentos em geral. A relação deste tipo com os arquétipos, "que representam o decurso legítimo de todas as coisas experimentáveis", dá-nos base para explicar sua visão profética. Diz que, não existisse esse tipo, Israel não teria tido seus profetas. Entre os intuitivos introvertidos estão os sonhadores e visionários místicos, de um lado, e os artistas, de outro. Sendo artista, o intuitivo introvertido apresentará por meio de sua arte "coisas extraordinárias, estranhas ao mundo, reluzentes em todas as cores, ao mesmo tempo importantes e banais, belas e grotescas, sublimes e ridículas [o que pode ser atribuído ao aspecto secundário das funções judicativas]. Não sendo artista, é muitas vezes um gênio incompreendido, um estróina, uma espécie de sábio meio louco, personagem típico de romances 'psicológicos'," podendo, algumas vezes, ser "a voz que clama no deserto". Lembramos que Jung identificou em Nietzsche um representante desse tipo ${ }^{\mathbf{2 1 1}}$, como, aliás, ele próprio é visto. ${ }^{\mathbf{2 1 2}}$

\footnotetext{
${ }^{209}$ Isso ocorre quando a intuição é auxiliada por, ou auxilia a função sentimento.

${ }^{210}$ Tipos ..., pp. 375/379, §§ 726/732.

211 Tipos ..., p. $147, \S 225$.

212 SILVEIRA, Nise da. Op. cit., pp. 68/69. Diga-se, de passagem, que a extraordinária obra produzida por Jung é resultado do uso equilibrado das quatro funções. Como destaca Nise, que o conheceu pessoalmente, ele "não era um sábio de gabinete. Não desdenhava a vida real. Sabia usar as mãos: lavrava a terra, rachava lenha, cozinhava, esculpia a pedra. Introduziu a dimensão sentimento na sua obra científica,
} 
Para finalizar, ilustramos com a seguinte passagem um dos aspectos da intuição:

De que maneira a Mulher Selvagem afeta as mulheres? Tendo a Mulher Selvagem como aliada, como líder, modelo, mestra, passamos a ver, não com dois olhos, mas com a intuição, que dispõe de muitos olhos. Quando afirmamos a intuição, somos, portanto, como a noite estrelada: fitamos o mundo com milhares de olhos. ${ }^{\mathbf{2 1 3}}$

dando a importância devida à tonalidade afetiva que impregna toda experiência vivida de verdade. E seu pensamento era decerto poderoso. Mas a leitura atenta de seus livros permite discernir que sua função principal era a intuição".

${ }^{213}$ ESTÉS, Clarissa Pinkola. Mulheres que Correm com os Lobos, Trad.: Waldéa Barcellos, Editora Rocco Ltda., Rio de Janeiro (RJ), 1994, p. 26. 


\subsection{A DICOTOMIA DAS FUNÇÕES JUDICATIVAS (PENSAMENTO-“T” E SENTI- MENTO-“F”')}

\subsubsection{Pensamento (T)}

Na primeira das cinco conferências que ficaram conhecidas por "Tavistock Lectures”, Jung referiu-se à função pensamento de maneira bem-humorada. Disse ele:

Se perguntarmos a um filósofo, ele dirá que o pensamento é uma coisa extremamente complicada; portanto, nunca procure um filósofo para se informar a respeito, pois ele é, por excelência, o homem que não sabe o que é o pensamento, quando todas as outras pessoas o sabem. Quando se diz para alguém: “Olhe, pense bem!", essa pessoa sabe exatamente o que se está querendo exprimir, mas um filósofo, não. Na sua forma mais simples, o pensamento exprime o que uma coisa é. Dá nome a essa coisa e junta-lhe um conceito, pois pensar é perceber e julgar (essa faculdade é chamada "apercepção" na psicologia alemã). ${ }^{\mathbf{2 1 4}}$

O pensar pode alimentar-se de fontes subjetivas, conscientes ou inconscientes, e de dados objetivos, representados seja por fatos apreendidos pelas percepções sensíveis, seja por ideias $^{\mathbf{2 1 5}}$, como, por exemplo, as encontradas num livro ou debatidas no curso de uma conversa. Jung, porém, ressalva que não considera como "pensar" a simples justaposição de representações, a que muitos psicólogos chamam pensamento associativo. Segundo ele, "só cabe falar de pensamento quando se trata de conjugar representações através de um conceito, quando existe, pois, um ato de julgamento, quer seja ele fruto de nossa intenção quer não". 216

Segundo Myers ${ }^{217}$, os indivíduos que têm o pensamento como função principal dão mais valor aos aspectos lógicos e impessoais de um raciocínio do que aos sentimentais e pessoais, ou seja, tendem a buscar a "verdade objetiva" em determinada situação, que avaliam de maneira impessoal e aparentemente fria, sem levar em consideração preferências

\footnotetext{
${ }^{214}$ Fundamentos de Psicologia Analítica (CW XVIII/1), p. 8, § 22.

215 Tipos ..., p. 326, § 643 .

${ }^{216}$ Tipos ..., p. 434, § 874 (775).

${ }^{217}$ MYERS, Isabel Briggs. Gifts Differing..., pp. 65/68 e MARTIN, Charles R.. “Looking at Type...”, p. 5.
} 
ou juízos de valor - portanto, se forçados a escolher entre dizer a verdade e ser gentis, normalmente optam por dizer a verdade. Não se deixam conduzir pelo que os outros possam vir a pensar a seu respeito; normalmente estão mais interessados em ideias e coisas do que em relacionamentos humanos, o que lhes dá maior habilidade com processos do que com relações sociais. Costumam confrontar os argumentos das outras pessoas com base em parâmetros de "certo" e "errado" e, se for o caso, delas discordar. Normalmente objetivos e profissionais, muitas vezes carecem de cordialidade e sociabilidade, sem sequer dar-se conta disso, podendo passar a impressão de descuido ou indiferença. Costumam ser hábeis em organizar fatos e ideias numa sequência lógica, em que ficam claros o objeto e os pontos relevantes, culminando numa conclusão, sem repetição; sua análise dos fatos tende a seguir uma relação de causa e efeito. Não dão grande importância a sentimentos que não se harmonizem com o raciocínio lógico, suprimindo-os ou ignorando-os. Tomam decisões baseados em critérios objetivos e universais. Sua contribuição social funda-se na crítica a hábitos, costumes e crenças, bem como no desenvolvimento das ciências em geral.

As funções pensamento e sentimento são as únicas que ocorrem em proporções bem distintas entre os gêneros, prevalecendo a primeira entre as pessoas do sexo masculino e a última entre as do sexo feminino. Jung já havia notado tal peculiaridade ${ }^{\mathbf{2 1 8}}$, que virá a ser reafirmada por Myers ${ }^{219}$, cujas postulações têm amplo lastro estatístico. Isso nos faz incorrer no erro de associar características da função sentimento às mulheres, que, quando as apresentam, são tidas como "mais" femininas. No entanto, seria incorreto considerar "menos feminina", no sentido de problemática, uma mulher em que predomine a função pensamento, ou "menos masculino" um homem em que predomine a função sentimento.

A respeito do tipo pensamento extrovertido"220, Jung ensina que "se orienta pelo objeto e pelos dados objetivos". Em outras palavras, é o pensar voltado a realidades concretas (fatos externos) e a ideias derivadas de fora, isto é, "transmitidas pela tradição, educação e instrução". Para aferir a natureza extrovertida ou introvertida do pensamento, necessário observar a orientação do julgamento: "se provém de fora ou se tem origem subjetiva”. Um pensar introvertido até pode se ocupar com coisas concretas, mas, ao fim do processo, tende a tomar a direção do sujeito, de modo a prevalecerem os aspectos subjetivos

\footnotetext{
${ }^{218}$ Tipos ..., p. 339, § 665 .

${ }^{219}$ Gifts Differing... , p. 66.

${ }^{220}$ Tipos ..., pp. 326/337, §§642/662.
} 
sobre os conceitos gerais já existentes. O tipo pensamento extrovertido, supondo tratar-se de tipo puro (entenda-se "unilateral"), esforça-se "por colocar toda a atividade de sua vida na dependência de conclusões intelectuais que se orientam, em última análise", sempre por fatos objetivos ou ideias válidas em geral. Em outros termos, com base em dados externos, elabora fórmulas intelectuais de conduta, que impõe rigidamente não só a si mesmo como também aos circundantes. E, segundo Jung, essa rigidez pode chegar a tal ponto que "a moral do tipo pensamento extrovertido proíbe tolerar exceções". A lealdade deste tipo àquilo que entende por justo e verdadeiro pode levá-lo a inibir atividades importantes, mais ligadas ao sentimento, como as de cunho estético, "o paladar, o senso artístico, o cultivo da amizade, etc." Embora este tipo venha a levar adiante o cultivo de ideais moralizadores, paradoxalmente a radicalização de suas posturas pode produzir logo aquilo que pretende combater: "há idealistas extrovertidos tão dedicados a realizar seu ideal em benefício da humanidade que não recuam nem mesmo diante da mentira e de outros meios indignos". Jung também observa que para execução concreta de grandes projetos sociais "não basta, normalmente, o motivo da justiça e da verdade. Necessário se faz ainda o verdadeiro amor ao próximo que tem a ver muito mais com o sentimento do que com uma fórmula intelectual".

Sobre o tipo pensamento introvertido ${ }^{221}$, Jung ensina que se orienta principalmente pelo fator subjetivo, tomando por base, às vezes, um sentimento subjetivo ou uma imagem. "Os fatos externos não são a causa ou meta desse pensar, ainda que o introvertido gostasse de lhe dar essa aparência, mas este pensar começa no sujeito e reconduz ao sujeito, mesmo que ele faça larga incursão no campo da realidade concreta". Este tipo corre o sério risco de criar teorias por amor às teorias, supostamente voltado aos fatos reais, mas que na verdade não passam de imagens criadas, sem qualquer correspondência com a realidade. "Na perseguição de suas ideias ele é teimoso e ininfluenciável. Mas isso contrasta com sua sugestionabilidade por parte de influências pessoais. Quando reconhece que um objeto é aparentemente inofensivo, torna-se extremamente acessível aos elementos inferiores. Estes se apossam dele a partir do inconsciente". A rigidez e inflexibilidade de suas convicções levam os que com ele se relacionam a considerá-lo como pessoa sem consideração e autoritária. Jung reconhece a estranheza que tal concepção de pensamento possa gerar numa é-

${ }^{221}$ Tipos ..., pp. 359/365, §§ 700/708. 
poca que associa ao pensamento a ideia de plena submissão ao objeto ${ }^{222}$, desqualificando o pensar que não siga tal cartilha.

No universo do pensamento, é preciosa a lição de que ambos os "pensares" são absolutamente necessários. Segundo Jung, mesmo que sustentássemos que o pensar extrovertido seria mais adequado para assuntos de natureza objetiva e o introvertido para os de natureza subjetiva, o resultado disso não deixaria de ser desastroso por conta da unilateralidade de cada orientação, não podendo uma prescindir da influência da outra. Porque, se o pensar se submeter ao dado objetivo acabará empobrecido, reduzido a um "pensar sobre", mas não no sentido de "reflexão", e sim "de pura imitação que essencialmente nada mais exprime do que aquilo que está visível e imediatamente contido no dado objetivo". ${ }^{223}$ A unilateralidade do pensar introvertido, por sua vez, "apresenta uma tendência perigosa de forçar os fatos para dentro da forma de sua imagem ou ignorá-los totalmente para dar livre curso à sua fantasia". 224

Para encerrar o que se entende pela função pensamento, nada como algo por ela produzido, notando-se aí clareza e senso de discriminação:

A presença, pois, da justiça como uma espécie de código de ordem superior cujo desrespeito ou violação produz resistência e cuja ausência conduz à desorientação e ao sem-sentido das regras de convivência pode-nos levar a admitila como um princípio doador de sentido para o universo jurídico. Seria um princípio racional ou seria sentimento irracional, mera crença que pode ser "sentida" mas jamais demonstrada?

(...)

Razão (reason, raison, Vernunft, ratio, logos) é um substantivo cuja origem está no verbo reri, que no significado primitivo queria dizer "tomar algo por algo", portanto, ligar "coisas" entre si, donde estabelecer relações e daí calcular, pensar (pesar, sopesar etc.). (...) A ideia de razão como relacionar preside, no desenvolvimento do Ocidente, o estabelecimento de diversos princípios de correção, como os do pensamento correto (lógica), da pesquisa correta (metodologia), do correto comportamento em face de situações existenciais (prudência ou sabedo-

${ }^{222}$ Tipos ..., p. $327, \S 645$.
${ }^{223}$ Tipos ..., p. $329, \S 649$.
${ }^{224}$ Tipos ..., p. $360, \S 701$. 
ria prática), da correta justificação das avaliações (retórica). Neste sentido, aos poucos, a razão acabou por tornar-se para o homem uma espécie de núcleo de sua própria natureza (animal rationale), um valor em si que incorpora a própria dignidade humana, não constituindo um meio para obtenção de outros valores, mas o valor que dá sentido aos demais. ${ }^{225}$

${ }^{225}$ FERRAZ JR., Tercio Sampaio. Introdução ao Estudo do Direito (Técnica, Decisão, Dominação), $2^{\underline{a}}$ edição, SP, Editora Atlas, 1995, pp. 351/352. 


\subsubsection{SENTIMENTO (F)}

Talvez mais difícil do que formular o conceito de intuição tenha sido, para Jung, trazer de maneira inteligível o conceito de sentimento como função racional:

A faculdade intelectual é incapaz de formular a essência do sentimento em linguagem conceitual uma vez que o pensamento pertence a uma categoria incomensurável com o sentimento, da mesma forma que nenhuma função psicológica básica pode ser expressa exatamente por outra. A isto se deve que nenhuma definição intelectual será capaz de reproduzir o específico do sentimento, de maneira satisfatória. $^{226}$

Não bastasse isso, constatava-se - aliás, como se constata até hoje - o uso da palavra em sentido plurívoco, às vezes remetendo para as outras funções, conforme vemos na seguinte explicação:

"Sentimento" é uma palavra que pede certa explicação. Por exemplo, falamos dos sentimentos que nos inspira uma pessoa ou uma coisa. Mas também empregamos a mesma palavra para definir uma opinião; por exemplo, um comunicado da Casa Branca pode dizer: "O Presidente sente..." Além disso, a palavra também pode ser usada para exprimir uma intuição: "Senti que..."

Quando uso a palavra "sentimento" em oposição a "pensamento" refiro-me a uma apreciação, a um julgamento de valores - por exemplo, agradável ou desagradável, bom ou mau, etc.. O sentimento, de acordo com esta definição, não é uma emoção (que é involuntária). O sentir, na significação que dou à palavra (como pensar), é uma função racional (isto é, organizadora), enquanto a intuição é uma função irracional (isto é, perceptiva). Na medida em que a intuição é um "palpite", não será, logicamente, produto de um ato voluntário; é, antes, um fenômeno involuntário - que depende de diferentes circunstâncias externas ou internas - e não um ato de julgamento. A intuição é mais uma percepção sensorial que, por sua vez, também é um fenômeno irracional, já que depende essencialmente de estímulos objetivos oriundos de causas físicas e não mentais. ${ }^{227}$

${ }^{226}$ Tipos ..., pp. 441/442, § 899.

227 "Chegando ao Inconsciente", in O Homem e seus Símbolos, p. 61. 
Portanto, vemos que, para Jung, o sentimento é "também uma espécie de julgamento, mas que se distingue do julgamento intelectual, por não visar ao estabelecimento de relações conceituais, mas a uma aceitação ou rejeição subjetivas". ${ }^{228}$ Também se nota a distinção feita entre sentimento e emoção, o que, na primeira conferência das "Tavistock Lectures" ${ }^{229}$, Jung abordou do seguinte modo:

(a) normalmente a palavra "emoção" é empregada quando a reação do indivíduo é acompanhada por alguma alteração fisiológica, sendo também, para Jung, sinônimo de "afeto";

(b) não é possível haver controle voluntário das emoções, como se dá com o sentimento. Jung exemplifica: "Podemos mesmo pacificamente dar a seguinte informação a uma pessoa: 'Eu te odeio'.” Não é preciso haver emoção nessa expressão de desmerecimento. No entanto, dito isto com rancor, "então é a emoção que age";

(c) outra observação por ele feita, a nosso ver muito perspicazmente, deu-se no sentido de que as emoções são "mais contagiantes, são verdadeiras desencadeadoras de epidemia mental". E, na mesma linha de raciocínio:

A multidão que, por exemplo, esteja presa de uma condição emocional, sensibiliza a todos os que nela se encontrem, não havendo possibilidade de escapar. Mas os sentimentos dos outros, em absoluto, não nos concernem, e podemos observar que o sentimento diferenciado tem efeito calmo sobre nós, o que não se dá com a pessoa dominada por uma emoção; ela nos atinge porque o fogo continuamente dela se irradia. A chama da emoção está em seu rosto. Através de uma espécie de sincronização o sistema simpático se altera, fazendo-nos apresentar provavelmente os mesmos sinais dentro de algum tempo, o que não se dá com os sentimentos.

De outras leituras, fica claro haver estreita relação entre sentimento e emoção (ou afeto), o que tem gerado alguma confusão. Por exemplo: na mesma conferência, provocado pelo público a respeito do tema, Jung declarou ser certo "haver sentimentos cujo caráter

${ }^{228}$ Tipos ..., p. 440, $\$ 896$.

${ }^{229}$ Fundamentos ..., p. 21, § 46. 
seja emocional" 230 e, na parte de "definições" da obra Tipos psicológicos, conceituou afeto como sendo "um estado de sentimento", porém "caracterizado, de um lado, por inervações perceptíveis do corpo e, de outro, por uma perturbação peculiar do curso das ideias". 231

Vê-se claramente haver uma espécie de gradação entre sentimento e emoção/afeto, numa escala onde se mede não apenas eventuais reações fisiológicas - marca distintiva de ambos os conceitos -, mas também se se está diante de uma função racional e relativamente controlável (sentimento) ou de uma reação irracional e involuntária (emoção). Nesta mudança qualitativa é que parece residir o problema.

Giannini empreendeu notável esforço visando a equacionar a questão. Após situá-la no pensamento de Jung, afirma que este morreu sem resolvê-la, bem como também não o fizeram os psicólogos em geral, dentre os quais cita William Willeford, por ele apresentado como um dos mais astutos e profundos estudiosos do tema. Willeford teria dito que as teorias sobre "sentimento e emoção" são das mais confusas dentro da Psicologia, concluindo que "o sentimento é emocional mas não sinônimo de emoção... Há, eu presumo, uma distância, frequentemente tênue entre sentimento e emoção". ${ }^{232}$

Considerando a questão mal resolvida, Giannini volta a perguntar: de que maneira a emotividade irracional se transforma em "valor emocional" ou na "inteligência do coração"? Segundo ele, a solução pode ser encontrada em se articulando conceitos desenvolvidos pelo próprio Jung. Assim, lembra-nos da ideia de conversão ou transformação da energia tratada por Jung sob o título "Canalização da libido", onde podemos ler:

Com esta expressão penso em uma transferência das intensidades ou valores psíquicos de um conteúdo a outro, de acordo com a chamada transformação da energia que, sob a forma de calor, se converte, mediante uma máquina a vapor, em tensão do vapor e, em seguida, em energia do movimento. De maneira semelhante, a

\footnotetext{
${ }^{230}$ Fundamentos ..., p. 25, §58.

${ }^{231}$ Tipos ..., p. 387, § $751(750)$.

${ }^{232}$ Op. cit., pp. 156/157. A citação de Giannini é da obra Feeling, Imagination and the Self: Transformations of the mother-infant relationship. Evanston, IL: Northwestern University Press, p. 44.
} 
energia de certos fenômenos psíquicos se converte, por meios adequados, em outros dinamismos. ${ }^{233}$

Sugerindo que no lugar de libido ou energia podemos também entender "emoção", Giannini remete-nos à ideia, também trazida por Jung, de que "o mecanismo psicológico que transforma a energia é o símbolo, ${ }^{, 234}$, mecanismo este capaz de transformar energia potencialmente destrutiva em algo construtivo e socialmente útil. Na qualidade de arquétipo, a função sentimento traz a ela associada uma série de representações simbólicas, de natureza valorativa, aptas a converter a energia bruta da emoção em "gostar" e "desgostar" e nos mais preciosos símbolos e experiências relativos aos relacionamentos amorosos. Assim, a função sentimento é responsável por transformar a energia caótica das emoções, da mesma forma que uma usina hidroelétrica transforma quedas d'água em eletricidade. ${ }^{235}$

E Giannini prossegue. Afirma que, na medida em que a função sentimento está vinculada às experiências de relacionamento pessoal, mostra-se implicada na dinâmica de amor e ódio, última etapa de nosso processo de individuação. Dentro dessas polaridades afetivas, constela-se uma miríade de emoções por nós vivenciadas, atinentes aos relacionamentos e, portanto, à função sentimento. Seria inconcebível imaginar todo esse universo de emoções humanas sem a condução do sentimento. ${ }^{236}$

Assumindo, portanto, a premissa de que a emoção integra o trabalho de valoração que está a cargo da função sentimento, chega-se à conclusão de que a consciência não pode se desenvolver sem as emoções ${ }^{\mathbf{2 3 7}}$, conforme, aliás, o próprio Jung expressa por meio do seguinte excerto:

O conflito gera o fogo dos afetos e emoções e como todo fogo, este também tem dois aspectos, ou seja, o da convulsão e o da geração de luz. A emoção é por um lado o fogo alquímico, cujo calor traz tudo à existência e queima todo o supérfluo (omnes superfluitates comburit). Por outro lado, a emoção é aquele momento em que o aço ao golpear a pedra produz uma faísca: emoção é a fonte principal de toda

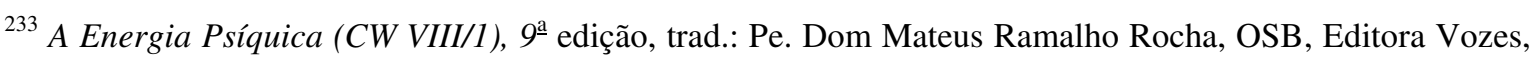
Petrópolis (RJ), 2007, p. 49 e s., § 79 e s..

${ }^{234}$ A Energia Psíquica..., p. 54, § 88.

${ }^{235}$ Op. cit., pp. $158 / 159$.

${ }^{236}$ Op. cit., pp. 160.

${ }^{237}$ Op. cit., pp. 161.
} 
tomada de consciência. Não há transformação de escuridão em luz, nem de inércia em movimento sem emoção. ${ }^{238}$

Segundo James Hillman, notável psicólogo junguiano, embora num plano mais primitivo decorra da função sentimento a experiência do "sim-não", "gostar-desgostar", "aceitar-rejeitar", não devemos cair na armadilha de reduzir o sentimento a uma dimensão meramente hedonista. Destaca que o desenvolvimento dessa função nos leva à apreciação muito mais sutil e sofisticada de valores e até sistemas de valores, organizando cada vez mais nossos julgamentos numa hierarquia racional, o que nos permite estendê-los aos planos da estética, da ética, das formas sociais ou das relações humanas. ${ }^{239}$ Ao registrar a qualidade e o valor específico das coisas, "é função do sentimento, precisamente, fazer essa exploração [da totalidade de um evento] e amplificação das nuanças e tons, que são o oposto da redução". 240

Segundo Myers ${ }^{241}$, os indivíduos em que a função principal é o sentimento dão mais valor aos aspectos afetivos e pessoais (em sentido relacional) de uma dada situação do que a aspectos lógicos e impessoais, ou seja, mais importante do que tentar estabelecer "verdades objetivas" é cuidar da harmonia entre as pessoas, cujas preferências são tidas em alta conta. Portanto, se forçados a escolher entre dizer a verdade e ser gentis, normalmente optam por ser gentis, ou, quando possível, por dizer o tanto de "verdade" que couber nos limites da gentileza. Em outras palavras, preferem a cordialidade à "verdade nua e crua", qualidade que pode passar a impressão, àqueles que forem do tipo pensamento, de que são muito indiretos ou até mesmo dissimulados. Dão importância ao que os outros possam vir a pensar a seu respeito. Normalmente estão mais interessados em relacionamentos humanos do que em ideias e coisas, o que lhes dá grande habilidade em se relacionar socialmen-

${ }^{238}$ Os Arquétipos e o Inconsciente Coletivo (CW IX/1), 5ª edição, trad.: Maria Luiza Appy e Dora Mariana R. Ferreira da Silva, Editora Vozes, Petrópolis (RJ), 2007, p. 105, § 179. A respeito da importância das emoções e também sobre sua relação com o sentimento e o afeto, conveniente registrar o posicionamento de James Hillman, um importante terapeuta junguiano: "As emoções são estados altamente significativos. Fornecem profundidade; dão e trazem sentido; desorganizam a criam ao mesmo tempo, apresentando a experiência da consciência do corpo. Em resumo, a emoção abarca o afeto, o sentimento e mais alguma coisa; o sentimento é uma atividade parcial associada principalmente com a consciência; e o afeto é quase por inteiro uma expressão fisiológica". A Função Sentimento, $6^{\mathrm{a}}$ edição, trad.: Adail Ubirajara Sobral, Editora Cultrix, São Paulo (SP), 2007, p. 125.

${ }^{239}$ A Função Sentimento, 6 $6^{\mathrm{a}}$ edição, trad.: Adail Ubirajara Sobral, Editora Cultrix, São Paulo (SP), $2007, \mathrm{p}$. 132.

${ }^{240}$ Op. cit., pp. 134/135.

${ }^{241}$ MYERS, Isabel Briggs. Gifts Differing..., p. 68 e MARTIN, Charles R.. "Looking at Type...”, p. 5. Também houve elaboração nossa com base no material fornecido por tais autores. 
te. Estão propensos a concordar com as pessoas à sua volta e a pensar como estas pensam, supondo estarem correta. Naturalmente ternos e cheios de tato, têm dificuldade em agir de forma objetiva e às vezes "profissional". Normalmente têm dificuldade para definir por onde devem iniciar uma argumentação e em qual ordem devem fazê-lo, podendo incorrer em prolixidade e repetição, abordando mais detalhes do que um tipo pensamento poderia julgar necessário. Suas decisões são tomadas com base em critérios pessoais, com seu "coração"; procuram ser compassivos. Sua contribuição social está baseada na participação efetiva em trabalhos que envolvem diretamente o bem-estar das pessoas.

Ao confrontar o tipo pensamento com o sentimento, Myers destaca ser um erro acreditar que o primeiro monopolize os processos mentais. Trata-se, na verdade, de diferentes estilos judicativos (de tomada de decisão), um sendo mais oportuno em determinadas situações, e outro em outras. ${ }^{\mathbf{2 4 2}}$ Neste ponto, porém, qualquer exemplo dado há de ser visto com ressalvas, pois se corre o risco de incorrer em simplismo reducionista. Fato é que, na prática, cada situação costuma apresentar-se com amplo leque de perspectivas, com margem à incidência das diversas funções. Algumas podem até ser tidas como mais adequadas, mas também nada impede que tal juízo advenha de um contexto sócio-cultural, ou decorra do tipo de quem está a emitir o juízo.

Hillman faz distinções pertinentes entre as funções como modos de operar e seus conteúdos. Afirma que "um pensamento pode surgir por meio da mente, mas isso não é pensar; pode-se ficar o dia inteiro dominado por maus sentimentos, mas isso não é sentir". ${ }^{243}$ Na mesma linha discriminatória, prossegue:

Podemos ter sentimentos sem termos capacidade de fazer muito com eles, sem podermos funcionar de maneira sensível. (Do mesmo modo, podemos ter intuições ou pensamentos sem funcionarmos essencialmente através da intuição ou do pensamento, isto é, podemos ter pensamentos sem termos condições de trabalhar com eles até chegar a uma conclusão.) A função sentimento pode avaliar pensamentos, objetos sensíveis e conteúdos psíquicos de qualquer espécie. Não se restringe aos sentimentos. Ela sente (aprecia e se relaciona com) mais do que sentimentos. Podemos sentir nossos pensamentos, descobrir-lhes o valor e a importância. Podemos

${ }^{242}$ Gifts Differing..., pp. $65 / 66$.
${ }^{243}$ Op. cit., p. 110. 
sentir que até as mais intensas sensações ou as maiores intuições têm pouco valor e não admitem que nos relacionemos com elas. Da mesma maneira, podemos pensar sentimentos ou sobre sentimentos - como fazemos agora nesta palestra. Os próprios sentimentos - irritação, júbilo, tédio - podem ser tratados adequada ou inadequadamente, avaliados de modo positivo e negativo, pela função sentimento. (...) Ter sentimentos e usar sentimentos marca a diferença entre os conteúdos e o processo que os organiza e exprime. ${ }^{244}$

O excerto acima nos mostra quão complexo pode se tornar o tema quando a análise das funções leva em consideração que, em sua dinâmica com o dado fenomênico, os produtos delas próprias (pensamentos, sentimentos, etc.) podem vir a integrá-lo.

Jung afirma que o sentimento, na atitude extrovertida ${ }^{245}$, "orienta-se pelo dado objetivo, isto é, o objeto é o determinante indispensável do modo de sentir. Está em concordância com valores objetivos". Isso implica dizer que pessoas deste tipo são capazes de vincular seus julgamentos a respeito do "belo" ou "bom" em função do que for socialmente aceito. Exemplifica com uma exposição de arte, na qual este tipo pode chamar de "belo" um quadro apenas porque assinado por um pintor famoso, ou ainda para não contrariar a família do responsável pela exposição ou mesmo para não criar um clima desagradável. A ele podem ser atribuídas as modas "e - o que é bem mais importante - a manutenção positiva e ampla de empreendimentos sociais, filantrópicos e culturais. Como o pensamento é reprimido ao máximo, qualquer raciocínio que contrarie o sentimento é rejeitado. Apenas consegue pensar aquilo que possa sentir.

Nise da Silveira acrescenta que quanto o tipo sentimento extrovertido se dedica à vida pública, "pode tornar-se um grande líder, fascinando pelo apelo emocional de sua personalidade mais que pela originalidade de seu pensamento", e, ainda:

Nos círculos íntimos dá os mais agradáveis amigos e amigas, pois poder-se-á dizer que foi este tipo que inventou a arte da amizade.

\footnotetext{
${ }^{244}$ Op. cit., pp. $125 / 126$.

${ }^{245}$ Tipos..., pp. 337/342, §§ 663/669.
} 
Seu calcanhar de Aquiles é o pensamento, sobretudo o raciocínio abstrato. A matemática, a reflexão filosófica, são áreas onde este tipo não se move à vontade. (...) Entenda-se que não se trata aqui de inferioridade da função pensamento num sentido quantitativo, mas de uma função que não foi afiada pelo uso, que não se diferenciou suficientemente. ${ }^{246}$

Sobre o tipo sentimento introvertido, sabemos que é determinado sobretudo pelo fator subjetivo, só se ocupando secundariamente pelo objeto. Assim, segundo Jung ${ }^{247}$, a introversão faz que apenas seja possível pressentir a profundeza do sentimento e não captála. Para estes indivíduos, vale o ditado "as águas mansas são as mais profundas". São muito discretos e se relacionam sem querer "motivar, impressionar, persuadir ou mudar o outro". Em casos extremos, podem passar a impressão de frieza e pouco caso pelos demais e podem ser arredios com estranhos. Porém, na verdade, cabe lembrar que seus sentimentos não são extensivos, porém intensivos.

Von Franz comenta que o tipo sentimento introvertido, por ter uma escala muito diferenciada de valores, constituída internamente (portanto, não dependente do que se afirma em termos sociais), costuma atuar como referencial ético para as pessoas que o cercam. Isso acontece naturalmente, apenas por suas posturas, não sendo preciso que diga ou faça nada. Por outro lado, seu pensamento extrovertido inferior frequentemente se expressa na forma de uma monomania: com um ou dois pensamentos produz "uma enorme quantidade de material", 248

Para concluir, nada como um poema de Cecília Meireles, a nos dar um retrato da "lógica" regida pelo sentimento:
Liberdade, essa palavra
que o sonho humano alimenta
que não há ninguém que explique
e ninguém que não entenda ...

Ou, na expressão de Jorge Luis Borges, em Os Justos:

\footnotetext{
${ }^{246}$ Op. cit., pp. 58/59.

${ }^{247}$ Tipos ..., pp. $365 / 369, \S \S 663 / 715$.

${ }^{248}$ Op. cit., pp. $75 / 76$.
} 
(...) Uma pessoa que acaricia um animal adormecido.

O que justifica um mal que lhe tenham feito.

O que agradece que na terra haja Mozart.

O que prefere que os outros tenham razão.

Essas pessoas, que se ignoram, estão salvando o mundo (...) 


\subsection{SOBRE AS FUNÇÕES AUXILIARES}

Visando a dar sequência à nossa exposição, concentraremos o foco de nossa análise nos efeitos decorrentes da relação entre a função principal e as auxiliares. Para tanto, optamos por transcrever, por sua clareza e profundidade, o seguinte trecho da obra de Jung:

Por razões de clareza, vamos repetir: conscientes podem ser os produtos de todas as funções; mas só falamos de conscientização de uma função quando não apenas seu exercício está à disposição da vontade, mas também seu princípio é decisivo para a orientação da consciência. Este último caso ocorre, por exemplo, quando o pensamento não é apenas um refletir posterior ou um ruminar, mas quando sua conclusão possui realidade absoluta, de modo que a conclusão lógica valha como motivo e garantia da ação prática, sem precisar de qualquer outra evidência. Esta hegemonia absoluta só cabe empiricamente a uma função e só pode caber a uma função, pois a intervenção igualmente autônoma de outra função imprimiria necessariamente outra orientação que, no mínimo em parte, haveria de contestar a primeira. Mas como é condição vital para o processo consciente de adaptação ter sempre objetivos claros e inequívocos, proíbe-se naturalmente que uma segunda função tenha a mesma categoria. Portanto a segunda função só pode ser de importância secundária, o que também se pode constatar empiricamente. Sua importância secundária consiste em não ser ela, como a função principal, única e exclusiva, absolutamente indispensável e decisiva, mas ser função auxiliar e complementar. Naturalmente, só pode ser função secundária aquela cuja natureza não está em oposição à função principal. Ao lado do pensamento, por exemplo, não pode aparecer, como função secundária, o sentimento, pois sua natureza está em demasiada oposição à natureza do pensamento. Se quiser ser verdadeiro e fiel a seu princípio, o pensamento tem que excluir rigorosamente o sentimento. Isto não afasta a possibilidade de que haja indivíduos cujo pensamento esteja no mesmo nível do sentimento, tendo ambos a mesma força motivadora consciente. Em tal caso, porém, não se trata de tipo diferenciado, mas de um pensamento e sentimento relativamente subdesenvolvidos. O mesmo grau de consciência e inconsciência das funções é característica do estado primitivo do espírito.

Mostra a experiência que a função secundária é sempre de natureza diversa, mas não oposta à função principal; assim, por exemplo, o pensamento, 
como função principal, pode facilmente unir-se à intuição como função secundária, bem como à sensação, mas nunca, como ficou dito, ao sentimento. Tanto a intuição quanto a sensação não se contrapõem ao pensamento, isto é, não precisam absolutamente ser excluídas, pois não são de essência inversamente semelhante à do pensamento, como é o caso do sentimento; este, na qualidade de função judicativa, faz verdadeira concorrência ao pensamento, enquanto aquelas são funções perceptivas que trazem ajuda benfazeja ao pensamento. Mas logo que atingissem um grau de diferenciação igual ao do pensamento, provocariam uma alteração de atitude que se oporia à tendência do pensamento. Transformariam, na verdade, uma atitude judicativa em perceptiva, oprimindo, assim, o princípio da racionalidade, indispensável ao pensar, em favor da irracionalidade da simples percepção. A função auxiliar, portanto, é possível e útil apenas na medida em que serve à função principal, sem pretender, com isso, a autonomia de seu princípio.

Para todos os tipos, encontrados na prática, vale o princípio de que, a par da função consciente principal, possuem ainda uma função auxiliar, relativamente consciente, que é diferente, em todos os aspectos, da natureza da função principal. Dessa mistura resultam figuras bem conhecidas como, por exemplo, o intelecto prático que está unido à sensação, o intelecto especulativo que é penetrado pela intuição, a intuição artística que escolhe e apresenta seus trabalhos por meio de julgamentos do sentimento, a intuição filosófica que transpõe sua visão para a esfera do compreensível, graças a um intelecto vigoroso etc.. ${ }^{249}$

Conforme já visto, ao desenvolver a teoria dos tipos psicológicos, Jung conjugou duas atitudes e quatro funções, inserindo tudo numa matriz de pares de opostos. Disso resultaram oito tipos, frutos da combinação de uma das funções - a principal - com a atitude predominante. Embora tivesse reconhecido a importância das funções auxiliares, e percebido com muita clareza a tonalidade trazida por sua atuação - o "intelecto prático que está unido à sensação”, por exemplo, representa o tipo pensamento, com função auxiliar sensação -, Jung não se empenhou em prosseguir seus estudos nessa direção.

A nosso ver, com a formulação da teoria estava cumprida a meta de equacionar para si mesmo e, por extensão, para o mundo os motivos da incompatibilidade de sua psicologia com a de Freud, e deste com a de Adler. A preocupação de Jung tinha mais uma

${ }^{249}$ Tipos ..., pp. 381/383, §§ 735/738. 
conotação filosófica do que propriamente pragmática: não tinha por principal objeto o comportamento das pessoas, mas a forma como viam o mundo e produziam ciência:

Caso fique comprovada a existência de diferenças de tipos na psique humana - e afirmo que não vejo razões para que assim não seja - o teorizador científico se defronta com um dilema desagradável: ou deixar subsistir, lado a lado, maior número de teorias contraditórias sobre o mesmo processo, ou fazer uma tentativa, de antemão fracassada, de fundar uma seita que reivindica possuir o único método certo e a única teoria verdadeira. ${ }^{250}$

A despeito disso, Pierre Ferrand, um tipologista especializado na obra de Jung e citado por Giannini, chama atenção para o fato de a teoria dos tipos representar a mais pragmática criação do psicólogo suíço, numa época em que "ser prático" ia contra os valores dos homens de ciência europeus; tal conotação era quase um insulto e Jung não estaria totalmente alheio a esse ambiente. ${ }^{251}$ Aliás, já mencionamos seu incômodo com o uso "pragmático" que, após a publicação, passou a ser em geral dado a seu trabalho.

Mas havia muito ainda por fazer no campo de investigação por ele formatado. Talvez por ser representante do grupo dos intuitivos, Jung deixou que outros, depois dele, cuidassem disso. Em 1923, com a tradução de Tipos psicológicos para o inglês, suas sementes foram lançadas nos Estados Unidos, e aí frutificaram com enorme vigor, sendo uma das consequências a elaboração do MBTI. Mas isso requer um capítulo à parte. Antes, porém, vejamos a importância desempenhada pela chamada função inferior em nosso desenvolvimento como indivíduos.

\footnotetext{
${ }^{250}$ Tipos ..., p. 457, § 928.

${ }^{251}$ Op. cit., p. 474.
} 


\subsection{A IMPORTÂNCIA DA FUNÇÃo INFERIOR NO PROCESSO DE INDIVIDUAÇÃo}

Pensar a função principal como gerenciadora de nossas habilidades mais diferenciadas faz-nos olhar com desconfiança para nossa função inferior. O tipo pensamento, por exemplo, normalmente fica muito à vontade no meio de um debate intelectual, onde pode se destacar pela clareza de seus argumentos, que sabe, como ninguém, expor de forma articulada e objetiva. Porém, quando a situação em que estiver envolvido implicar o uso diferenciado de sentimento, ver-se-á como que desnudo e poderá reagir de maneira infantil e às vezes até exagerada. Via de regra, sua função inferior não é consciente nem diferenciada e por isso não pode "sempre ser manobrada pela intenção e pela vontade". 252

Fica muito claro, portanto, que a questão não se resume a ter ou deixar de ter, de forma absoluta, habilidades relacionadas a cada função. Como elas desempenham um papel adaptativo, dificilmente conseguiríamos nos desincumbir de todas as tarefas que nos são apresentadas no curso de nossas vidas se não desenvolvêssemos minimamente cada uma delas. No entanto, por conta de uma predisposição natural, desde cedo percebemos os campos em que temos mais facilidade; somos socialmente reconhecidos e valorizados pelo que fazemos bem e muitas vezes censurados pelo que fazemos mal, de modo a nos deixar levar por uma tendência de transferir para outras pessoas as coisas para as quais nos sentimos menos aptos, porque o mundo "não tem misericórdia com a inferioridade da função inferior". ${ }^{253}$ Tudo isso contribui para reforçar a unilateralidade de nosso tipo, num ciclo vicioso.

Ao fazer a leitura dos tipos, conforme presente na obra de Schiller, Jung expressa de maneira bastante poética o desprezo que socialmente se tem em relação à função inferior:

A escravização das massas foi a ferida exposta da antiguidade, mas a escravização das funções inferiores é uma ferida sempre sangrando na psique do homem moderno. (...) Privilegiar a função mais importante reverte em vantagem para a sociedade, mas em detrimento da individualidade. ${ }^{254}$

\footnotetext{
252 JUNG, Carl G.. Fundamentos de Psicologia Analítica (CW XVIII/1), p. 15, § 35.

${ }^{253}$ FRANZ, Marie-Louise von. Op. cit., pp. 14 e 26.

${ }^{254}$ Tipos ..., p. 82, §§ 105/106.
} 
No curso do desenvolvimento de nossa personalidade, de todas as funções a que mais se ressentirá será aquela cujo princípio se opõe ao da principal. Isso não implica dizer que um tipo pensativo - para ficarmos no exemplo dado - não tenha sentimentos intensos. Segundo Jung, muito pelo contrário! Pessoas desse tipo frequentemente afirmam: "Tenho sentimentos fortes, sou muito emocionável, sou um temperamental”. E esclarece:

$\mathrm{Na}$ verdade eles se colocam sob o fluxo poderoso de suas emoções, são tomados por elas e, às vezes, vencidos. A vida particular de professores, por exemplo, constitui estudo interessantíssimo; se você quiser informações completas sobre a vida de um intelectual em sua casa, pergunte à sua esposa, e ela terá grandes estórias para contar. ${ }^{255}$

Na parte em que tratamos das atitudes, vimos, na "metáfora do castelo", que a hipersensibilidade é característica da função inferior. Vimos também como se expressa sua autonomia: à semelhança dos complexos, suas manifestações ocorrem à revelia da consciência, a ponto de se poder dizer que possuem o indivíduo, em vez de ele as possuir. ${ }^{256}$ As referidas características são sinais de sua inadaptação e primitivismo; quando precisamos dela, processa tudo de maneira muito lenta. ${ }^{257}$ Naomi L. Quenk, psicóloga especializada em tipologia junguiana, lembra que o fato de saber o que caracteriza a função inferior não representa qualquer garantia de que venhamos a ter consciência dela no momento em que nos toma, pois, "quando estamos sob a influência de algo que é inconsciente, estamos, na maior parte, inconscientes disso". 258

E por que isso ocorre? Sabemos já da postulação, na Psicologia Analítica, do princípio da dinâmica compensatória da psique, encenada pelo conjunto dos processos conscientes e inconscientes, numa espécie de autorregulação do sistema. ${ }^{259}$ Teremos melhor compreensão do fenômeno, porém, se acrescentarmos a ideia de que, na teoria junguiana, essa autorregulação não ocorre de maneira aleatória, mas encontra um sentido muito particular, que aponta para a realização do indivíduo como "totalidade".

\footnotetext{
${ }^{255}$ Fundamentos ..., p. 14, § 31 .

${ }^{256}$ JUNG, Carl G.. Psicologia do Inconsciente (CW VII/1), p. 50, § 85.

${ }^{257}$ FRANZ, Marie-Louise von. Op. cit., pp. 20/22.

${ }^{258}$ QUENK, Naomi L.. Was That Really Me?, Davies-Black Publishing, Boston, MA, 2009 (2002), p. 12.

${ }^{259}$ FREITAS, Laura Villares de; ALBERTINI, Paulo (org.). Jung e Reich: Articulando Conceitos e Práticas, Editora Guanabara Koogan S/A, Rio de Janeiro (RJ), 2009, pp. 19/20.
} 
Esta totalidade, a que Jung chamou de si-mesmo (self), deveria ser a meta de todo ser humano no curso da vida e, mesmo que ele não saiba disso, terá o próprio inconsciente funcionando de forma a encaminhá-lo rumo à sua realização, uma vez que aí está a base de todo equilíbrio psíquico. Esse caminhar em direção ao si-mesmo conforma o chamado processo de individuação. Para evitar equívocos, convém elucidar que a ideia nada tem que ver com "egoísmo" ou individualismo, referindo-se simplesmente à realização do potencial que há em cada homem, com o que pode ele se tornar "o ser único que de fato é". ${ }^{260}$

Boa parte dos pacientes atendidos por Jung era composta por indivíduos que já haviam atingido a segunda metade da vida, estando, portanto, desincumbidos da fase de amadurecimento profissional e de criação dos filhos. A necessidade que muitos comumente apresentavam era de dar um novo sentido para suas vidas. Segundo Murray Stein, conceituado psicólogo junguiano, Jung teria percebido que "o estado de espírito da pessoa de meia-idade reflete a ideia de que, ao chegar aí, o que podia ser feito está feito. E agora o quê?” E prossegue:

O significado reside alhures e a energia psíquica muda de rumo. A tarefa agora consiste em unificar o ego com o inconsciente, o qual contém a vida não vivida da pessoa e o seu potencial não-realizado. ${ }^{261}$

O mecanismo psíquico por meio do qual essa "unificação" do ego com o inconsciente ocorre é percebido sob a forma de compensação. Jung ensina, ainda, que “(...) quanto maior for o número de conteúdos [inconscientes] assimilados ao eu e quanto mais significativos forem, tanto mais o eu se aproximará do si-mesmo, mesmo que esta aproximação nunca possa chegar ao fim". ${ }^{262}$ Vemos, portanto, que "a individuação, para Jung, é um fim em si, ${ }^{, 263}$, e que em torno desse eixo se constela toda sua psicologia. ${ }^{264}$

\footnotetext{
${ }^{260}$ O Eu e o Inconsciente (CW VII/2), 6- edição, trad.: Dr ${ }^{\mathrm{a}}$ Dora Ferreira da Silva, Editora Vozes, Petrópolis (RJ), 1987, p. 50, § 267.

${ }^{261}$ STEIN, Murray. JUNG, O Mapa da Alma (uma introdução), 5ª edição, trad.: Álvaro Cabral, Editora Cultrix, São Paulo (SP), 2006, p. 157

${ }^{262}$ AION - Estudos sobre o Simbolismo do Si Mesmo (CW IX/2), $6^{\mathrm{a}}$ edição, trad.: Pe. Dom Mateus Ramalho Rocha, OSB, Editora Vozes, Petrópolis (RJ), 2000, p. 21, § 44.

${ }^{263}$ STEIN, Murray. Op. cit., p. 157

${ }^{264}$ SILVEIRA, Nise da. Op. cit., p. 101.
} 
Vista a questão sob a perspectiva tipológica, podemos dizer que até a metade da vida o indivíduo normal canaliza sua energia psíquica para as funções preferidas, de modo que suas conquistas se deverão, em grande parte, a elas. Por outro lado, aquilo que resta por realizar a esta altura da vida pode ter ficado para trás em virtude da menor diferenciação das outras funções, sobretudo a inferior. "Assim sendo, quando a função superior estiver gasta - quando começar a falhar, a perder gasolina como um carro velho -, a pessoa que conseguir voltar-se para a sua função inferior descobrirá um novo potencial de vida". ${ }^{265}$ Isso a transforma em precioso reservatório de energia, em campo rico de caminhos inexplorados, além de fonte imprescindível de criatividade. ${ }^{\mathbf{2 6 6}}$

Von Franz aponta a forma como a função inferior aparece nos contos de fada, o que também nos dá indícios de sua importância no processo de individuação:

Ao estudar casos individuais, observa-se que a função inferior tende a comportar-se como o herói tolo, o bobo divino ou o herói idiota. Ele representa a parte desprezada da personalidade, a parte ridícula e inadaptada, mas simboliza também a parte que constrói a conexão com o inconsciente, retendo, portanto, a chave secreta da totalidade inconsciente da pessoa. ${ }^{267}$

Quenk afirma que, assim como os sonhos constituíam, para Freud, "a estrada real para o inconsciente”, igual significado tem no pensamento de Jung a função inferior. De acordo com essa autora, ainda quando não interpretados, os sonhos são capazes de cumprir seu papel de ampliação da consciência - principalmente os "grandes" sonhos; o mesmo pode ocorrer com as manifestações da função inferior - principalmente as mais significativas. Afinal, não é pelo fato de ignorarmos as leis de funcionamento da psique que deixará ela de desempenhar seus papéis. No entanto, assim como o autoconhecimento pode dar-se em maior escala quando sabemos o sentido de nossos sonhos, o mesmo benefício pode advir do fato de termos consciência do caráter e das manifestações de nossa função inferior. $^{268}$

\footnotetext{
${ }^{265}$ FRANZ, Marie-Louise von. Op. cit., p. 25.

${ }^{266}$ FRANZ, Marie-Louise von. Op. cit., p. 25.

${ }^{267}$ Op. cit., pp. 19/20.

${ }^{268}$ Op. cit., pp. 10/13.
} 
Tendo grande experiência na observação tipológica, Quenk ${ }^{\mathbf{2 6 9}}$ elenca algumas características comuns a cada preferência, seja em sua manifestação adaptativa, seja em sua manifestação acirradamente unilateral:

\begin{tabular}{|c|c|c|}
\hline Preferência & Forma adaptativa & Forma unilateral \\
\hline Extroversão & $\begin{array}{l}\text { Charmoso } \\
\text { Entusiasmado } \\
\text { Sociável }\end{array}$ & $\begin{array}{l}\text { Presunçoso } \\
\text { Invasivo } \\
\text { Ruidoso }\end{array}$ \\
\hline Introversão & $\begin{array}{l}\text { Profundo } \\
\text { Discreto } \\
\text { Tranquilo }\end{array}$ & $\begin{array}{l}\text { Recluso } \\
\text { Inibido } \\
\text { Antissocial }\end{array}$ \\
\hline Sensação & $\begin{array}{l}\text { Pragmático } \\
\text { Preciso } \\
\text { Detalhista }\end{array}$ & $\begin{array}{l}\text { Tedioso } \\
\text { Confuso } \\
\text { Obsessivo }\end{array}$ \\
\hline Intuição & $\begin{array}{l}\text { Imaginativo } \\
\text { Engenhoso } \\
\text { Inspirado }\end{array}$ & $\begin{array}{l}\text { Excêntrico } \\
\text { Instável } \\
\text { Irrealista }\end{array}$ \\
\hline Pensamento & $\begin{array}{l}\text { Claro } \\
\text { Objetivo } \\
\text { Sucinto }\end{array}$ & $\begin{array}{l}\text { Crítico } \\
\text { Intolerante } \\
\text { Ríspido }\end{array}$ \\
\hline Sentimento & $\begin{array}{l}\text { Apreciativo } \\
\text { Gentil } \\
\text { Cheio de tato }\end{array}$ & $\begin{array}{l}\text { Evasivo } \\
\text { Melindroso } \\
\text { Vago }\end{array}$ \\
\hline Judicativa $^{270}$ & $\begin{array}{l}\text { Eficiente } \\
\text { Planejador } \\
\text { Responsável }\end{array}$ & $\begin{array}{l}\text { Compulsivo } \\
\text { Impaciente } \\
\text { Inflexível }\end{array}$ \\
\hline Perceptiva & $\begin{array}{l}\text { Adaptável } \\
\text { Relaxado } \\
\text { Flexível }\end{array}$ & $\begin{array}{l}\text { Procrastinador } \\
\text { Não-confiável }^{271} \\
\text { Disperso }\end{array}$ \\
\hline
\end{tabular}

Von Franz comenta que uma das dificuldades de se definir o tipo de alguém, ou mesmo o próprio, quando se alcançou a fase de saturação da função ou atitude mais diferenciadas é que a pessoa é capaz de jurar que pertence ao tipo oposto, e é sincera nisso, tamanha a importância que passa a dar às características que lhe faltaram até dado momento. $^{272}$

A mesma autora afirma não ser psicologicamente possível atribuir à função inferior o mesmo status alcançado pela superior, e isso pelo simples fato de se excluírem comple-

\footnotetext{
${ }^{269}$ Op. cit., p. 7.

${ }^{270}$ Trataremos dessa preferência, bem como da "Perceptiva", quando falarmos da contribuição de MyersBriggs.

${ }^{271}$ No sentido de realizar alguma tarefa conforme o planejado.

272 Op. cit., p. 31.
} 
tamente, uma vez que são incompatíveis. Seu desenvolvimento, porém, pode ser precedido e intermediado pelo das funções auxiliares. ${ }^{273} \mathrm{O}$ trabalho com a função inferior pode ser feito, também, de maneira simbólica, para o que Von Franz sugere o uso de uma receita alquímica:

(...) deve ser usada a receita alquímica: fazer o esforço de lidar com a quarta função, colocando-a num recipiente esférico, dando-lhe uma estrutura de fantasia. Podemos seguir, não vivendo a quarta função de uma maneira concreta, exterior ou interior, mas dando-lhe a possibilidade de expressar-se na fantasia, quer escrevendo, pintando, dançando, ou através de qualquer forma de imaginação ativa. Jung descobriu que a imaginação ativa ${ }^{274}$ era praticamente o único meio de lidar com a quarta função. ${ }^{275}$

E, como Jung fazia questão de dizer, embora a perfeição esteja longe do alcance do ser humano, podemos ao menos nos empenhar em atingir a completude. Isso exigirá que percorramos um caminho longo e muitas vezes cheio de percalços. É um caminho só nosso, no qual a tipologia pode vir a ser um do guia bastante útil, dentre outros. Mas mesmo o melhor dos guias nada pode fazer onde falta disposição e, também diríamos, coragem. E é preciso muita disposição e coragem, pois, como ensina Von Franz ${ }^{276}$, sendo a mais inconsciente das quatro funções, a inferior representa a porta pela qual os "habitantes" do inconsciente costumam passar para a consciência. Portanto, por ela veremos atravessar nossos aspectos mais sombrios, o que nos dá segurança para afirmar que o caminho para o céu passa, necessariamente, pelo inferno.

${ }^{273}$ Op. cit., p. 34.

${ }^{274} \mathrm{O}$ processo de imaginação ativa é um dos métodos empregados por Jung para investigação dos elementos originários dos processos psicológicos inconscientes. Podia-se aproveitar do fragmento de um sonho ou de uma imagem que despertasse especial interesse do paciente. A partir daí, este era convidado a iniciar uma sequência de fantasias por meio de uma concentração intencional. Na verdade, Jung não gostava de usar o termo "fantasia", alegando referir-se a coisas sem sentido, a impressões passageiras, ao passo que a "imaginação ativa" apresentava claros propósitos criadores. Tinha-se, porém, de tomar o cuidado para que não houvesse interferência da vontade consciente sobre o encadeamento de imagens; mantido este encadeamento a cargo do inconsciente, em autêntico processo ativo de imaginação, era possível acessar conteúdos que, de outra forma, apenas alcançariam a consciência por meio de sonhos. A vantagem da imaginação ativa sobre estes é que, por ser produzida em estado consciente, sua estrutura e linguagem se revelavam bem mais completos. Fontes consultadas: 1) JUNG, Carl G.. A Vida Simbólica (CW XVIII/1), $3^{\text {a }}$ edição, trad.: Araceli Elman, Editora Vozes, Petrópolis (RJ), 2007, p. 24, § 4; pp. 174/180, §§ 390/405. 2) Idem, Os Arquétipos e o Inconsciente Coletivo (CW IX/1), 5- edição, trad.: Maria Luiza Appy e Dora Mariana R. Ferreira da Silva, Editora Vozes, Petrópolis (RJ), 2007, p. 59, § 101, e 3) SAMUELS, Andrew et alii. Dicionário crítico de análise junguiana, Imago Editora Ltda., Rio de Janeiro (RJ), 1988, “imaginação ativa”, pp. 99/100.

275 Op. cit., p. 94.

${ }^{276}$ Op. cit., p. 83. 


\section{CAPÍTULO 3 \\ A CONTRIBUIÇÃO DE MYERS-BRIGGS}

\section{Histórico}

Quando, em 1923, a obra de Jung foi traduzida para o inglês, não tardou a chegar às mãos de Katharine Cook Briggs (1875-1968), que, embora não sendo psicóloga, fazia tempos vinha se esforçando para desenvolver uma tipologia humana a partir de suas observações. Mas o interesse de Briggs, que era escritora, consistia em dispor de material que servisse de base à criação de suas personagens e ela até já tinha o perfil de alguns tipos quando tomou contato com a obra de Jung, no que reconheceu o que tanto buscava. ${ }^{277}$ A esta altura, Isabel Briggs Myers (1897-1980), única filha de Katharine, já era adulta e compartilhava do interesse da mãe pelo estudo da tipologia.

Ainda muito jovem, Isabel Myers deu mostras de um talento extraordinário. Embora tenha recebido sua educação básica em casa, no período escolar sempre se destacou entre os colegas. Ávida leitora, herdou da mãe o gosto por escrever, de modo que aos quatorze anos teve um texto seu publicado em jornal. Em agosto de 1928, Myers tomou conhecimento de um concurso literário, no qual seria escolhido o melhor suspense policial. Embora o prazo final fosse o dia 31 de dezembro do mesmo ano, e tivesse duas crianças pequenas para cuidar, abraçou o desafio - vindo a vencer. Sua obra de ficção tornou-se um bestseller e serviu como estímulo a uma segunda. ${ }^{278}$ No entanto, chegou o tempo em que desempenhar o papel de mãe tornou-se prioridade, mas isso não implicou o abandono da observação tipológica para a qual fôra inspirada pela mãe e instruída pelo trabalho de Jung. ${ }^{279}$

Com o advento da Segunda Grande Guerra, mãe e filha olharam o conflito sob a perspectiva de que teria sido causado, em parte, pela falta de compreensão e intolerância com respeito às diferenças entre as pessoas, e viram quanto prejuízo isso poderia trazer à humanidade. Pouco depois, Myers soube da existência de um instrumento de aferição de

${ }^{277}$ SAUNDERS, Frances. “About Isabel Briggs Myers”, in Gifts Differing..., p. 207.

278 SAUNDERS, Frances. Op. cit., p. 207.

${ }^{279}$ KROEGER, Otto e THUESEN, Janet M. Op. cit., p. 282. 
características pessoais e vislumbrou aí um caminho para estender a contribuição de Jung a um campo prático. Assim, com auxílio da mãe, decidiu desenvolver seu próprio instrumento, que viria a ser conhecido pelo nome Myers-Briggs Type Indicator (MBTI) e cuja primeira versão apareceu em 1943. A partir daí, Myers dedicou a vida ao aprimoramento dessa ferramenta, vindo a adotar sucessivos formulários. ${ }^{280}$

Naturalmente, durante muitos anos, a acolhida junto ao meio especializado foi a mais fria possível, o que Otto Kroeger e Janet M. Thuesen, especialistas em tipologia junguiana, explicam da seguinte forma:

Em primeiro lugar, o instrumento havia sido desenvolvido por duas mulheres, o que não o tornava popular numa comunidade de psicólogos formada principalmente homens. Pior que isso era o fato de nenhuma delas ser psicóloga. Como se não bastasse, poucos psicólogos alinhavam-se com as teorias "esotéricas" de Jung. O MBTI parecia ser um instrumento cujo tempo ainda não havia chegado. ${ }^{281}$

Myers chegou a trocar correspondência com Jung a fim de lhe falar de seu trabalho. Em 1950, em carta dirigida a ela, a despeito de toda a resistência profissional que vinha experimentando, Jung a teria incentivado a prosseguir com suas pesquisas, aprimorar o instrumento e a repensar sua teoria dos tipos. ${ }^{\mathbf{2 8 2}}$

O entusiasmo de Myers parecia não esmorecer. Nem seria preciso dizer que ela estudou o que foi necessário a respeito de construção de testes e sua validação. Por meio de contatos, sempre conseguia abrir portas e encontrar um novo público ao qual submeter o material que ia aperfeiçoando. Foram milhares de pessoas. Até que, em 1956, Myers foi convidada a apresentar um seminário para a divisão de pesquisa do Educational Testing Service (ETS). A qualidade de seu trabalho não passou despercebida e, embora ainda enfrentando resistências, viu, em 1957, a referida instituição publicar o MBTI e em seguida começar a usá-lo nas escolas da região. ${ }^{283}$

\footnotetext{
${ }^{280}$ SAUNDERS, Frances. Op. cit., p. 208.

${ }^{281}$ Op. cit., p. 282.

282 GIANNINI, John L.. Op. cit., p. 7. Quanto a este ponto, Giannini cita, na verdade, trabalho de SAUNDERS, Frances. Katharine and Isabel: Mother's Light, Daughter's Journey. Palo Alto CA: Consulting Psychologist Press, 1991, p. 121.

${ }^{283}$ SAUNDERS, Frances. Op. cit., p. 209.
} 
Quase duas décadas depois, em 1975, a publicação foi assumida pela Consulting Psychologist Press (CPP), fato que trouxe ao instrumento prestígio até então desconhecido junto ao meio e contribuiu para transformá-lo no instrumento de aferição de personalidade mais utilizado na história. ${ }^{284}$

No entanto, a contribuição de Myers não se limitou a extrair do modelo junguiano de tipos psicológicos um sem número de aplicativos práticos na área educacional, corporativa e de aconselhamento psicológico. Houve também uma incursão na parte teórica, o que ficou consolidado com a publicação, em 1980, poucos meses após sua morte, da obra Gifts Differing, onde expõe o substrato teórico - e alguns resultados das pesquisas de campo do trabalho que norteou sua vida.

${ }^{284}$ SAUNDERS, Frances. Op. cit., pp. 209/210. 


\section{A DICOTOMIA DOS PARES DE FUNÇÕES QUANTO À SUA NATUREZA (TIPOS PERCEPTIVOS-“P” E JUDICATIVOS-“J”)}

Conforme vimos, Jung chegou a anunciar a importância das funções auxiliares, mas não se dedicou a seu estudo. Sua descrição pormenorizada abarcou o mínimo de oito tipos, mas, levando-se em consideração a tonalidade impressa pelas funções auxiliares, muitos outros seriam possíveis:

Disso resulta um mínimo de oito tipos perfeitamente distintos. Obviamente este número pode ser multiplicado à vontade e a qualquer tempo se dividirmos, por exemplo, cada uma das funções em três subgrupos, o que não seria impossível na prática. Poderíamos, por exemplo, dividir facilmente o intelecto em suas três formas bem conhecidas: a forma intuitiva e especulativa, a forma lógico-matemática e a forma empírica que se baseia principalmente na percepção sensorial. Decomposições semelhantes é possível fazê-las também nas outras funções básicas como, por exemplo, na intuição que possui tanto um lado intelectual quanto sentimental. Essas decomposições permitem estabelecer arbitrariamente muitos tipos, mas cada divisão ulterior torna-se cada vez mais sutil. ${ }^{285}$

Em sua ampla observação, Myers notou que a função auxiliar não apenas confere uma tonalidade à função principal, mas desempenha papel fundamental na dinâmica compensatória da atitude do indivíduo. Isso ficará mais claro adiante.

Em contato com o mundo externo, tanto o introvertido quanto o extrovertido precisam coletar dados e também decidir. Vimos que a coleta de dados é incumbência das funções perceptivas ou irracionais ( $\mathrm{P}: \mathrm{S}$ e $\mathrm{N}$ ), e que a tomada de decisão é incumbência das funções judicativas ou racionais (J: T e F). Segundo Myers, há momentos para perceber e momentos para decidir, sendo muitos os momentos em que ambas as coisas são exigidas. Portanto, também neste campo há espaço para a manifestação de preferências, e são preferências exercidas quando o indivíduo está em contato com o mundo externo, ou seja, quando extroverte. Ela exemplifica de maneira bastante singela: neste exato momento, alguns leitores ainda estão acompanhando a explicação com a mente aberta; estão, portanto, ao

${ }^{285}$ JUNG, Carl G.. "Tipos Psicológicos": ... 1923 (v. referência completa em nota anterior), pp. 481/482, § 977. 
menos no momento, usando uma função perceptiva (P). Outros, porém, já se posicionaram a respeito do que é dito, seja para concordar, seja discordar; estão usando o julgamento $(\mathrm{J}) .^{286}$

Conforme lembra Myers, antes da publicação da obra de Jung, Katharine Briggs já vinha desenvolvendo pesquisas no campo da tipologia e tinha então formulado, em trabalho que não chegou a publicar, algumas hipóteses. Embora a teoria de Jung tenha se revelado muito mais completa, a ponto de Briggs abandonar a dela, os modelos propostos foram comparados, do que resultou a conclusão de que a função auxiliar é responsável pelo processo de extroversão do tipo introvertido. ${ }^{287}$

Em Tipos Psicológicos, Jung atribui de maneira mais explícita a extroversão do introvertido à função inferior. No entanto, segundo Myers ${ }^{\mathbf{2 8 8}}$, ele não deixa de afirmar ser o papel compensatório desempenhado também pelas funções auxiliares e, para corroborar seu ponto de vista, destaca os seguintes trechos da obra do psicólogo suíço:

As funções relativamente inconscientes do sentimento, intuição e sensação que se defrontam com este pensamento [introvertido] são inferiores e têm um caráter extrovertido primitivo [g.n.]. ${ }^{289}$

Um hábito é denominado extrovertido só quando prevalece o mecanismo da extroversão. Neste caso, a função psíquica mais diferenciada está sempre em uso extrovertido, enquanto as funções menos diferenciadas estão sendo usadas introvertidamente [g.n.]. ${ }^{290}$

Para todos os tipos, encontrados na prática, vale o princípio de que, a par da função consciente principal, possuem ainda uma função auxiliar, relativamente consciente, que é diferente, em todos os aspectos, da natureza da função ao principal [g.n.]. ${ }^{291}$

\footnotetext{
${ }^{286}$ Op. cit., p. 8.

${ }^{287}$ Op. cit., p. 22.

${ }^{288}$ Op. cit., pp. 19/20.

${ }^{289}$ Tipos ..., p. 365, § 708.

${ }^{290}$ Tipos ..., p. $325, \S 640$.

${ }^{291}$ Tipos ..., p. 382, § 738.
} 
Desse modo, sentindo-se amparadas teoricamente pelos excertos acima, e, ainda, por sua própria observação, Myers-Briggs postularam que a função auxiliar do introvertido é responsável por seu relacionamento com o mundo externo (pessoas, ideias e coisas), no que desempenha, juntamente com a função inferior, o papel compensatório postulado por Jung. E se a auxiliar for de natureza perceptiva (sensação ou intuição), a extroversão, ocorrendo por meio dela, constelará um tipo perceptivo $(\mathrm{P})$; se esta função tiver natureza judicativa (pensamento ou sentimento), será constelado um tipo judicativo (J).

Quanto ao tipo extrovertido, seu relacionamento com o mundo externo está a cargo da função principal, que, conforme já sabemos, também será extrovertida. Portanto, se racional essa função (T ou F), o indivíduo será judicativo (J); se irracional ( $\mathrm{S}$ ou N), será perceptivo $(\mathrm{P})$.

É formulada, assim, uma nova dicotomia atitudinal ${ }^{292}$ (P-J), que estava implícita na tipologia junguiana, mas em momento algum explorada por $\mathrm{Jung}^{\mathbf{2 9 3}}$, contribuição de enorme importância por nos dar mais ferramentas para a compreensão dos tipos e para o estudo da psique e suas expressões. ${ }^{294}$

Myers aponta as seguintes vantagens da dicotomia elaborada em conjunto com sua mãe: (a) a natureza como cada indivíduo extroverte é mais facilmente aferível, pois diz respeito ao modo como lida com as coisas externas; (b) cada polo da dicotomia abarca um número grande de características, trazendo utilidade à classificação; (c) evita-se o uso de termos que costumam ter conotação negativa para a maioria das pessoas (conforme é o caso de irracional): em vez disso, pode-se falar em tipo perceptivo. ${ }^{295}$

\footnotetext{
${ }^{292}$ Não confundir, portanto, atitude perceptiva ou judicativa com função perceptiva ou judicativa. A atitude perceptiva ocorre quando o indivíduo extroverte por meio de uma função perceptiva.

${ }^{293}$ Gifts Differing..., p. 21.

${ }^{294}$ BAPTISTA, Sylvia Mello Silva. "Esclarecimentos sobre a 'tipologia' de Myers \& Briggs", in ALVARENGA, Maria Zelia de et alii. Mitologia Simbólica: Estrutura da Psique e Regências Míticas, Casa do Psicólogo, São Paulo (SP), 2007, p. 27. A título de curiosidade, registramos que essa obra traz um estudo de dezesseis divindades da mitologia grega, cujas personalidades representariam um dos tipos psicológicos descritos por Myers, o que nos permite inferir que não apenas os mitos expressam estruturas arquetípicas - a própria tipologia também o faz.

${ }^{295}$ Gifts Differing..., p. 22.
} 
Baseada no trabalho de Myers, Sylvia Mello Silva Baptista ${ }^{296}$, psicóloga junguiana, informa que:

Os tipos perceptivos olham a vida como algo a ser experimentado e compreendido; gostam de manter planos e opiniões o mais abertamente possível. Esperam resolver os problemas entendendo-os melhor, vendo a base deles $(\mathrm{N})$ ou vendo todos os lados da questão (S). Precisam do julgamento para dar continuidade aos propósitos e fornecer padrão de crítica e domínio às próprias ações. Os dons da percepção são: espontaneidade e aceitação da experiência do presente; mente aberta e consideração a novos fatos, ideias e propostas; compreensão do ponto de vista do outro, com apreciação da situação; tolerância; curiosidade; sempre acham algo interessante em qualquer situação; prazer pela experiência; adaptabilidade (adapta os meios disponíveis para atingir os fins).

Os tipos judicativos acreditam que a vida deveria ser orientada e decidida; gostam de ter as coisas arrumadas. Dispõem das coisas e chegam a conclusões o tempo todo. Os julgadores mais marcantes tentam estabelecer até o que o outro deve pensar; os menos marcantes pensam isso mas não externam. O ditado "uma má decisão é melhor do que nenhuma" faz sentido para o julgador. Se lhes faltar percepção, serão rígidos, diretos e incapazes de ver outro ponto de vista que não o seu (preconceito). Os dons do julgamento incluem: fazer as coisas sistematicamente como julgou ser a melhor forma (por métodos lógicos ou prazerosos e convenientes); ordem nos pertences; vida planejada; esforço sustentado com uso da força de vontade para conquistas; decisão (nem todos gostam de tomá-las); prazer em aconselhar; opinião formada sobre o que acham útil; aceitação da rotina (não para os intuitivos).

Kroeger e Thuesen explicam que na rotina diária uma das maiores fontes de tensão nos relacionamentos é a oposição entre as atitudes judicativa e perceptiva, e isso se deve ao fato de trazerem suas características - vale dizer, "diferenças" - de maneira muito visível, pois são formas de extroverter. ${ }^{297}$

Feitas estas considerações, percebemos que, ao elaborar o MBTI, Myers-Briggs reordenaram as categorias de classificação de Jung em quatro dicotomias:

\footnotetext{
${ }^{296}$ Op. cit., p. 29.

${ }^{297}$ Op. cit., p. 42.
} 
1) Extroversão (E - Extraversion) ou Introversão (I - Introversion);

2) Sensação (S - Sensing) ou Intuição (N - INtuition);

3) Pensamento (T - Thinking) ou Sentimento (F - Feeling);

4) Judicativo (J - Judging) ou Perceptivo (P - Perceiving).

Além disso, por destacar a importância da função auxiliar e incorporá-la ao seu campo de pesquisa, mãe e filha elevaram de oito para dezesseis os tipos psicológicos que chegaram a ser descritos originariamente por Jung:

1. sensação introvertida, com pensamento extrovertido (ISTTJ); ${ }^{\mathbf{2 9 8}}$

2. sensação introvertida, com sentimento extrovertido (ISFJ);

3. sensação extrovertida, com pensamento introvertido (E $\underline{S T P})$;

4. sensação extrovertida, com sentimento introvertido (E $\underline{S} F P$ );

5. intuição introvertida, com sentimento extrovertido (INFJ);

6. intuição introvertida, com pensamento extrovertido (INTJ);

7. intuição extrovertida, com sentimento introvertido (ENFP);

8. intuição extrovertida, com pensamento introvertido (ENTP);

9. pensamento introvertido, com sensação extrovertida (ISTP);

10. pensamento introvertido, com intuição extrovertida (INTP);

11. pensamento extrovertido, com sensação introvertida (ESTJ);

12. pensamento extrovertido, com intuição introvertida (ENTI);

13. sentimento introvertido, com sensação extrovertida (ISFP);

14. sentimento introvertido, com intuição extrovertida (INFP);

15. sentimento extrovertido, com sensação introvertida (ESFJ);

16. sentimento extrovertido, com intuição introvertida (ENEJ).

${ }^{298}$ Meramente por razões didáticas, optamos por sublinhar a função principal. De qualquer modo, esclarecese que a leitura da combinação das quatro letras permite inferir qual seja ela. 
Vemos que cada tipo é representado por uma sequência de quatro letras, cuja ordem segue sempre o seguinte critério, independentemente de qual seja, dentre as funções, a principal ou a auxiliar:

- 1ํㅡㄹ posição da sigla do MBTI: I ou E;

- $2^{\text {a }}$ posição da sigla do MBTI: $\mathbf{S}$ ou N;

- $3^{\text {a }}$ posição da sigla do MBTI: T ou F;

- $4^{\mathrm{a}}$ posição da sigla do MBTI: J ou P.

Assim, embora os norte-americanos que se interessaram pela tipologia junguiana tenham dado rumo diverso ao pretendido por Jung no momento em que elaborou a teoria, não se pode negar a seriedade e utilidade de seu trabalho, bem como o crescente interesse por ele. Segundo Kroeger e Thuesen, em 1972, Isabel Myers e Mary McCaulley, psicóloga clínica, fundaram, na Flórida, o Center for the Application of Psychological Type (CAPT). Tal centro decorreu, na verdade, da consolidação de um laboratório de tipologia, cujos trabalhos vinham sendo feitos desde 1969 numa universidade. Em 1975, o CAPT realizou a primeira conferência de estudiosos de tipologia. Compareceram a este evento, que se repetiria bienalmente, pouco menos de cem pessoas. Uma década depois, o número de participantes já ultrapassava oitocentos. ${ }^{299}$

Principalmente após o impulso e aplicação que recebeu nos Estados Unidos, a tipologia junguiana passou a servir de base para $^{\mathbf{3 0 0}}$ :

a) a avaliação das potencialidades profissionais de cada indivíduo, à luz da forma como se organiza seu psiquismo. É útil, portanto, no contexto de orientação vocacional;

b) definição de políticas e métodos educacionais: o reconhecimento dos tipos traz consigo a consciência de que pessoas diferentes aprendem de maneiras diferentes. É fundamental, por exemplo, saber que indivíduos extrovertidos têm seu aprendizado facilitado quando atuam em grupo, enquanto os introvertidos aprendem melhor indi- 
vidualmente; ou, ainda, que indivíduos com predominância da função sensação aprendem melhor com abordagens concretas, enquanto os intuitivos preferem uma linguagem abstrata;

c) maior eficiência na formação e gerenciamento de grupos no ambiente de trabalho: é evidente a importância de se saber as facilidades e dificuldades de cada tipo e, mais do que isso, quão precioso pode ser o resultado da interação dos diferentes tipos no ambiente de trabalho, tendo em vista sua complementaridade;

d) no tratamento psicoterapêutico: o terapeuta que conheça seja o próprio tipo, seja o de seu paciente terá melhores condições de compreender o que lhe é dito, e também de se fazer compreender, ou ainda de entender as eventuais dificuldades de comunicação entre ele e seu paciente, haja vista que terá consciência da forma como "decodificam" o mundo. ${ }^{301}$

Os psicólogos norte-americanos produziram uma gama imensa de materiais, cuja exploração mais aprofundada extrapolaria os limites deste trabalho. Para o que nos interessa, no momento, basta dizer que Jung logrou demonstrar a existência de diferenças individuais, consteladas no plano psíquico, e passíveis de organização em torno de dois pares dicotômicos (funções), um de caráter perceptivo e outro judicativo, e um par relativo ao direcionamento predominante da libido (atitudes), com reflexos nas mais importantes esferas da vida humana, inclusive a da produção do pensamento científico. Pensadores posteriores apontaram, direta ou indiretamente, a natureza arquetípica dos tipos ${ }^{\mathbf{3 0 2}}$ e se esmeraram

${ }^{301}$ Quanto ao uso da análise tipológica na cena psicoterapêutica, colhemos os seguintes dizeres de Jung: "Também descobri que o estudo dos tipos nos fornece uma orientação quanto à natureza pessoal do inconsciente, sua qualidade pessoal num determinado caso. Se examinar um extrovertido, verificará que seu inconsciente tem uma qualidade introvertida, porque todas as qualidades extrovertidas se manifestam na consciência dele, ficando as introvertidas no inconsciente; portanto, o inconsciente tem qualidades introvertidas, e o mesmo ocorre com as funções. Isso deu-me uma indicação do valor diagnóstico, ajudou-me a entender os meus pacientes. Quando passei a conhecer o tipo consciente de cada um deles, adquiri uma ideia acerca de suas respectivas atitudes inconscientes. E como um neurótico é tão influenciado pelo inconsciente quanto pelo consciente, ele é influenciado, por assim dizer, por um outro tipo". In McGUIRE, William e R.F.C. Hull. Entrevistas e Encontros, trad.: Álvaro Cabral, Editora Cultrix, São Paulo (SP), 1982, p. 305. Excerto da quarta, de uma série de quatro entrevistas concedidas por Jung, em 1957, para o Instituto Federal de Tecnologia de Zurique.

${ }^{302}$ Exemplos disso são os trabalhos de John L. Giannini e John Beebe ("Evolving the eight-function model: 8 archetypes guide how the function-attitudes are expressed in an individual psyche”), psicólogos junguianos sediados nos Estados Unidos. 
em observar com profusão de detalhes como eles se refletem na conduta dos indivíduos e em suas relações interpessoais, o que ampliou o leque de aplicações práticas da teoria.

Chegamos aqui ao ponto de fazer a travessia para o Direito, onde visitaremos a seara de trabalho dos juízes, levando em nossa bagagem as seguintes questões: em que medida a teoria dos tipos pode contribuir também para ampliar nossa compreensão da atividade judicial? Que leitura poderemos, a partir de então, fazer não do "conceito", mas do processo de "produção" da justiça? É o que veremos a seguir. 


\title{
CAPÍTULO 4 \\ CONTRIBUIÇÕES DA TIPOLOGIA JUNGUIANA AO DIREITO
}

\author{
1. RELAÇÕES DE PENSAMENTO E SENTIMENTO COM A NOÇÃO DE "JUSTIÇA"
}

\begin{abstract}
Quando Jesus de Nazaré, no julgamento perante o pretor romano, admitiu ser rei, disse ele: "Nasci e vim a este mundo para dar testemunho da verdade". Ao que Pilatos perguntou: "O que é a verdade?" Cético, o romano obviamente não esperava resposta a essa pergunta, e o Santo também não a deu. Dar testemunho da verdade não era o essencial em sua missão como rei messiânico. Ele nascera para dar testemunho da justiça, aquela justiça que Ele desejava concretizar no reino de Deus. E, por essa justiça, morreu na cruz.
\end{abstract}

Dessa forma, emerge da pergunta de Pilatos - o que é a verdade? -, através do sangue do crucificado, uma outra questão, bem mais veemente, a eterna questão da humanidade: o que é a justiça?

Nenhuma outra questão foi tão passionalmente discutida; por nenhuma outra foram derramadas tantas lágrimas amargas, tanto sangue precioso; sobre nenhuma outra, ainda, as mentes mais ilustres - de Platão a Kant - meditaram tão profundamente. E, no entanto, ela continua até hoje sem resposta. Talvez por se tratar de uma dessas questões para as quais vale o resignado saber de que o homem nunca encontrará uma resposta definitiva; deverá apenas tentar perguntar melhor.

Hans Kelsen ${ }^{303}$

Um dos mais tradicionais debates existentes na área jurídica é a que a divide entre os adeptos da doutrina do direito natural e do direito positivo. A primeira corrente parte da premissa de que acima da ordem jurídica positiva, definida pelo soberano ou, mais modernamente, pelo Estado, paira uma ordem maior, calcada na natureza das coisas, e que há de ser respeitada. Essa ordem natural, embora não escrita, seria doadora de legitimidade e validade (no direito natural, estes dois conceitos andam juntos) às normas escritas. ${ }^{\mathbf{3 0 4}} \mathrm{Vi}$ cente Ráo assim o expressa:

${ }^{303}$ KELSEN, Hans. O que é Justiça?, trad.: Luís Carlos Borges, SP, Editora Martins Fontes, 1997, p. 1.

${ }^{304}$ António Manuel Hespanha, em trabalho magistral a respeito dos momentos históricos da cultura jurídica europeia do último milênio (e não podemos esquecer que, pelo período de tempo abarcado pelo estudo, 
O direito natural, assim concebido, procura aproximar o direito próprio, positivo, de cada povo, em torno dos postulados básicos, intransponíveis, do respeito aos direitos fundamentais do homem, àqueles direitos, isto é, cujo desconhecimento afetaria a própria natureza humana; e procura, ademais, inspirar e conduzir todos os sistemas positivos de direito em direção a um ideal supremo de justiça. $^{305}$

Essa concepção dicotômica, com as devidas adaptações decorrentes das conquistas civilizatórias no campo da cultura, é quase tão antiga quanto o Ocidente, tendo sido retratada pelos gregos na peça Antígona, de Sófocles. Conforme é sabido, Antígona, desejando sepultar o corpo de Polinices, seu falecido irmão, esbarrou em interdição baixada pelo rei Creonte. Segundo o decreto real, o cadáver de Polinices não deveria ser pranteado, e, insepulto, haveria de servir de banquete às aves carniceiras. Quem viesse a violar tal lei seria punido com o apedrejamento até a morte. Antígona, porém, desafiou a ordem legal, e providenciou o necessário ritual fúnebre. Confrontada por Creonte, este indagou como se atrevera ela a desobedecer às leis. Seguiu-se a resposta:

\begin{abstract}
Mas Zeus não foi o arauto delas para mim, nem essas leis são as ditadas entre os homens pela Justiça, companheira de morada dos deuses infernais; e não me pareceu
\end{abstract}

isso é praticamente sinônimo de cultura jurídica "ocidental”), ensina que "os juristas do período clássico identificavam a justiça com a natureza e esta com Deus. Num célebre texto do Digesto (D.,1,1,1,3) em que se define o direito mais fundamental e inderrogável - o chamado 'direito natural' - explica-se que 'o direito natural é o que a natureza ensinou a todos os animais' (ius naturale est quod natura omnia animalia docuit). E um comentador medieval do texto esclarece, numa curta glosa à palavra 'natureza', que esta não é senão Deus (natura, id est Deus). Daí o êxito de um outro texto do Digesto que definia a prudência (= saber prático) do direito (que, então, desempenhava o papel de teoria política) como uma 'ciência do justo e do injusto, baseada no conhecimento das coisas divinas e humana' (divinarum atque humanarum rerum notitia, iusti atque iniusti scientia, D.,I,1,10,2). E foi por isso também que os juristas foram tidos como quase sacerdotes, também na esteira de um texto do início do Digesto. in Cultura Jurídica Europeia - Síntese de um Milênio, 3ํㅡㄹ Publicações Europa-América Lda., Portugal, 2003 (1997), p. 75.

305 O Direito e a Vida dos Direitos, 4- edição, Editora Revista dos Tribunais Ltda., São Paulo (SP), 1997, p. 77. Na lição de Norberto Bobbio, grande jusfilósofo italiano, "na história do pensamento jurídico, o absolutismo ético é representado pela teoria do direito natural, que pretende deduzir regras de conduta universalmente válidas do estudo objetivo, 'científico', da natureza humana. Com base nessa pretensão, o jusnaturalismo sempre atribuiu à teoria do direito a tarefa de distinguir o direito justo do injusto e, portanto, de prescrever qual direito deve ser, em vez de descrever o direito que é". "Estrutura e Função na Teoria do Direito de Kelsen" in Da Estrutura à Função: Novos Estudos de Teoria do Direito, Editora Manole Ltda., Barueri (SP), 2007, p. 193. 
que tuas determinações tivessem força

para impor aos mortais até a obrigação

de transgredir normas divinas, não escritas,

inevitáveis; não é de hoje, não é de ontem,

é desde os tempos mais remotos que elas vigem,

sem que ninguém possa dizer quando surgiram.

E não seria por temer homem algum,

nem o mais arrogante, que me arriscaria

a ser punida pelos deuses por violá-las.

Eu já sabia que teria de morrer

(e como não?) antes até de o proclamares,

mas, se me leva a morte prematuramente,

digo que para mim só há vantagem nisso.

Assim, cercada de infortúnios como vivo,

a morte não seria uma vantagem?

Por isso, prever o destino que me espera

é uma dor sem importância. Se tivesse

de consentir em que ao cadáver de um dos filhos

de minha mãe fosse negada a sepultura,

então eu sofreria, mas não sofro agora.

Se te pareço hoje insensata por agir

dessa maneira, é como se eu fosse acusada

de insensatez pelo maior dos insensatos. ${ }^{306}$

Nota-se, portanto, que a ideia de justiça permeia os institutos jurídicos há séculos, embora sua realização possa encontrar formas diferenciadas ao longo do tempo, em função de cada contexto histórico-social. Por isso podemos ver nela a constelação de um arquétipo, pois está presente no inconsciente coletivo da humanidade.

A manifestação clara do arquétipo da Justiça pode ser vista em sua representação nos mitos gregos. "Segundo a noção junguiana, os mitos condensam experiências humanas

${ }^{306}$ SÓFOCLES. A Trilogia Tebana, trad.: Mário da Gama Kury, Jorge Zahar Editor, Rio de Janeiro (RJ), 1990, pp. 198 e 214. 
típicas. (...) Um mito está para a humanidade em geral como um sonho está para um indivíduo". 307

Lídia Prado informa que, na mitologia greco-romana, as deusas Têmis e Diké formavam representações de uma justiça feminina. Têmis era casada com Zeus, senhor do Olimpo, e personificava a lei e a organização do universo - era a justiça no plano divino. Da união de Têmis com Zeus nasceu Diké, a quem coube o encargo de trazer o direito aos homens e mantê-lo entre eles. Para isso, tinha de enfrentar Éris (a discórdia), Bia (a violência) e Hybris (a imoderação, que transforma o direito em injustiça). ${ }^{308}$

Têmis teve também uma filha adotiva, resultado da união anterior de Zeus com Métis (mesma raiz de metron, comedimento), deusa da Prudência e da Sabedoria. Era Atená, que foi criada com Diké. Embora Atená tenha diversas outras qualidades pelas quais é conhecida - preside, por exemplo, as artes e a filosofia -, Lídia ressalta que em seus atributos também estavam implícitas a garantia da justiça. Todavia, diferentemente das deidades citadas, "exercia uma justiça preocupada com a exatidão apolínea e a razão, privilegiando o pensamento e os princípios gerais, em detrimento do sentimento, chamada função valorativa do caso particular". 309

Lídia diz que, por se preservar virgem, Atená deixou de viver os aspectos do feminino, motivo pelo qual W. Otto, estudioso da mitologia grega, a ela se referirá: "é mulher, mas é como se fosse homem". ${ }^{\mathbf{3 1 0}}$ No contexto da tipologia, isso nos remete ao que foi dito sobre o predomínio da função pensamento nos homens, consolidando a ideia de ser um traço de "masculinidade".

Ainda segundo Lídia, tais representações da Justiça vêm constelando arquetipicamente o Direito nos últimos 2500 anos, divisando-se ainda, no Brasil, a despeito de consideráveis avanços, o "predomínio de uma racionalidade avessa ao sentimento". 311 Reconhecendo a importância da conjugação de ambos os princípios - o do pensamento e do sentimento -, a referida autora aponta, como via para o equilíbrio, uma maior conexão do jul-

\footnotetext{
${ }^{307}$ PRADO, Lídia Reis de Almeida. Op. cit., pp. 122.

${ }^{308}$ Op. cit., p. $124 / 126$.

${ }^{309}$ Op. cit., p. $128 / 130$.

${ }^{310}$ Les Dieux de la Grèce, trad. C.N. Grimberg e A. Morgant, Paris, Payot, 1981, p. 50 - apud PRADO, Lídia Reis de Almeida. Op. cit., p. 131.

${ }^{311}$ Op. cit., pp. 123/131.
} 
gador com os valores vinculados ao arquétipo da anima, que na Psicologia Analítica vem a ser o arquétipo do feminino. ${ }^{312}$

Conforme lembra Tercio Sampaio Ferraz Jr., em termos figurativos, ou simbólicos, a Justiça é representada pela imagem da balança:

Desde as mais antigas tradições, a simbologia da justiça traz a balança como um de seus símbolos mais constantes. O equilíbrio dos pratos (ison) parece trazer à justiça seu sentido nuclear. A balança, porém, não apenas mostra o equilíbrio, mas é também um instrumento apto, tecnicamente, a alcançá-lo. Ou seja, faz parte do sentido nuclear da justiça o procedimento de sopesar os atos e as compensações, portanto, o processo de dar e receber (...) Por sua vez, o equilíbrio se alcança quando o fiel da balança está reto de cima a baixo (de recto, palavra que, no baixo latim, substituía o termo jus, dando origem às palavras direito, droit, diritto, right, Recht, derecho). ${ }^{313}$

No mesmo sentido, Fábio Konder Comparato:

(...) a virtude da justiça tende sempre a alcançar um certo estado de equilíbrio, longe de todo excesso. Não por outra razão a deusa Tétis foi representada, no imaginário grego, portando uma balança. A realização da justiça pressupõe, sempre, um constante sopesamento de valores. ${ }^{314}$

Por conta da proximidade da concepção de um "direito natural" com a ideia de "Justiça", poderíamos postular sua correspondência ao predomínio da função sentimento em sua formulação. Mas, no momento em que o movimento iluminista destronou Deus do centro do mundo e em seu lugar coroou a "razão", tudo o que quisesse ter valor precisava carregar seu selo. E o jusnaturalismo não escapou incólume a esse movimento: o conteúdo do Direito natural deixou de ser teocêntrico para ser racionalista, dando origem ao chamado jusracionalismo. ${ }^{315}$

\footnotetext{
${ }^{312}$ Op. cit., pp. $134 / 139$.

${ }^{313}$ FERRAZ JR., Tercio Sampaio. "Justiça como retribuição: da razão e da emoção na construção do conceito de justiça" in Estudos de Filosofia do Direito (Reflexões sobre o Poder, a Liberdade, a Justiça e o Direito), 2 edição, SP, Editora Atlas, 2003, p. 218.

314 Ética (Direito, Moral e Religião no Mundo Moderno), Editora Companhia das Letras, São Paulo (SP), 2006, p. 529.

315 KRETSCHMANN, Ângela. História Crítica do Sistema Jurídico: da Prudência Antiga à Ciência Moderna, Livraria Editora Renovar Ltda., Rio de Janeiro (RJ), 2006, p. 155.
} 
Embora esse novo direito natural ainda polarizasse com o direito positivo, que, segundo jusracionalistas, a ele teria de se submeter, pouco tinha que ver com o espírito do direito natural de raízes clássicas. Conforme Hespanha, tal contraste vale seja em relação aos juristas romanos clássicos, "que desconfiavam, por sistema, das formulações genéricas - 'non ex regula ius sumatur' [o direito não provém da regra], D.,50,17,1; ou 'in iure civili omnis definitio periculosa est' [em direito, toda a definição é perigosa], D.,50,17,202”, seja com relação à doutrina jurídica aristotélico-tomista:

Aí, imperava, pelo contrário, a ideia de que o direito é uma arte, dirigida por regras, apenas prováveis, de encontrar o justo e o injusto. Certezas, não as havia, daí decorrendo esse constante confronto das opiniões (...) É claro que este processo de cientificização do direito deparou com o ceticismo de alguns ${ }^{316}$; mas, com o advento do otimismo cartesiano, ficou bastante estabelecido no pensamento jurídico (como nas restantes disciplinas filosóficas e morais). ${ }^{317}$

No mesmo sentido, em importante estudo histórico-crítico, Ângela Kretschmann traça interessante quadro a respeito do surgimento e desenvolvimento do saber jurídico ocidental, considerando, inclusive, a distinção entre saber prático e saber teórico. Tal distinção era feita pelos pensadores gregos, sem, no entanto, que houvesse desvalorização do primeiro:

Aristóteles notou que dada a variabilidade do saber prático não seria possível a mesma exatidão que encontramos no "saber teórico", pois a ciência teórica só versa sobre realidades imutáveis e eternas. Assim, Aristóteles não equipara o saber teórico ao prático, pois a "Política" (no sentido amplo) ou Filosofia prática não poderia comparar-se com a cientificidade da ciência estrita, a episteme apodítica, pois o objeto da filosofia prática, o justo e o excelente, não é imutável e liga-se ao método dialético, que é sempre inacabado em qualquer fase de seu desenvolvimento - não equipara, mas também não os separa. Isso quer dizer ainda, que apesar de não equipar em termos de "exatidão", não deixa de equipar os dois saberes em termos de importância.

\footnotetext{
316 "Por exemplo, de Montaigne, de Bacon e de Pascal, cujas observações sarcásticas ou angustiadas sobre a contingência do direito era uma resposta altamente adequada" [nota do próprio Hespanha].

${ }^{317}$ Op. cit., pp. 227/228.
} 
O método das ciências práticas exclui o uso de demonstrações dedutivas ou por meio de silogismo científico - ao contrário, a verdade do objeto das ciências práticas só é atingido através de certas pré-condições do sujeito, como a experiência da vida ética. Na ciência política, não é possível falar de uma exatidão, como nas ciências matemáticas, exatidão que seria até contrária ao objeto em questão, de forma que o método é determinado pelo objeto e não o contrário. $\mathrm{O}$ método do saber moral é tópico-dialético, o que implica o uso da retórica, mas esta vista como ciência do discurso, da argumentação, e não como ciência da "manipulação" - enquanto o saber teorético-objetivo possui método apodítico. (...) Como entender isso? O raciocínio que precede a ação é chamado de "silogismo prático", diferindo dos silogismos teóricos universais. (...) A compreensão teórica pode vir a fornecer uma arché (princípios) a partir da qual o raciocínio prático pode tirar suas premissas fundamentais.

\section{(...)}

Se de um lado Sócrates, Platão e Aristóteles sabiam diferenciar o que era saber teórico (especulativo) da práxis, defendiam a ideia de que o saber prático deveria vir ligado ao saber teórico, pena de carecer de sentido. Ao contrário, na modernidade (e na época da "razão iluminada") veremos o surgimento do paradigma da filosofia primeira (ciências naturais e exatas, de saber imutável necessário), passando a ser ressaltado o primado da teoria sobre a práxis (...) a ideia moderna de ciência, subordinando-se às exigências da nova ciência da natureza, a seu pensamento metódico e exigência de verificação, ilegitimou cada vez mais o saber da ciência prática, que vem ligada à Prudência. ${ }^{318}$

O jusracionalismo foi contemporâneo ao surgimento do Estado moderno, responsável pelo movimento de codificação, que viria a mudar definitivamente o cenário jurídico no mundo civilizado. A mudança seria mais radical na França, tendo em vista que, segundo Hespanha, aí se sentiriam os efeitos da Revolução, por força da qual seria renegado todo o Direito anterior, ao mesmo tempo que identificado com os novos códigos aquele a ser seguido. Os códigos napoleônicos fariam a consolidação do referido movimento doutrinal, sendo vistos como uma espécie de positivação da razão. ${ }^{319}$

${ }^{318}$ KRETSCHMANN, Ângela. Op. cit., pp. 34/40.

${ }^{319}$ Op. cit., p. 267. 
Tecemos todo esse quadro apenas para que possamos perceber que a ideia de justiça sempre oscilou entre os princípios do sentimento e do pensamento, muitas vezes perdendo-se entre um e outro, mas jamais conseguindo abrir mão de ambos. Mesmo quando prepondera a razão iluminista, podemos postular que assim foi porque os homens da época viram nela um valor. Não se deram conta, porém, do desequilíbrio que isso geraria pelo fato de pensamento (razão) e sentimento (valor) regerem-se por princípios opostos. Em outros termos: não é possível basear o senso de justiça (sentimento) na razão (pensamento).

Dois séculos e meio antes de Jung, ou seja, em 1670, o filósofo francês Blaise Pascal (1623-1662), ao discorrer a respeito de razão e fé, tornou célebre a seguinte frase: "O coração tem suas razões, que a razão não conhece". ${ }^{320}$ Segundo Ch.-M. des Granges, "ao dizer que 'o coração tem razões que a razão desconhece', Pascal não está afirmando que os sentimentos e a inteligência se opõem. Está mostrando que há no homem duas maneiras de conhecer". ${ }^{321}$ Des Granges nega a "oposição" para afirmar a existência de duas maneiras de conhecer. No entanto, à luz da teoria dos tipos psicológicos, sabemos que isso é verdade em graus diferentes nos diferentes indivíduos. Naqueles em que a função pensamento predominar, a função sentimento - "razão do coração" - terá menor expressão, pois ocupará um lugar de inferioridade, e vice-versa.

Quase um século depois de Pascal, David Hume (1711-1776), filósofo inglês de grande expressão, por-se-ia a investigar em que medida razão e sentimento estariam relacionados ao juízo moral. Cremos que, no lugar de "juízo moral”, poderíamos colocar "senso de justiça", sem que com isso houvesse alteração de sentido nos termos da equação. Foi em 1751 que Hume publicou o resultado de seu trabalho, de onde, após impressionante argumentação, chegou à seguinte conclusão:

Parece evidente que os fins últimos das ações humanas não podem em nenhum caso ser explicados pela razão, mas recomendam-se inteiramente aos sentimentos e às afecções da humanidade, sem nenhuma dependência das faculdades intelectuais. (...) Assim, os distintos limites e atribuições da razão e do gosto são facilmente de-

\footnotetext{
${ }^{320}$ Pensamentos, Editora Martin Claret, São Paulo (SP), 2008, p. 41.

${ }^{321}$ GRANGES, Ch.-M. des. In introdução a Pensamentos (obra de PASCAL), $4^{\mathrm{a}}$ edição, Editora Nova Cultural, São Paulo (SP), 1988, p. XIX.
} 
terminados. A razão transmite o conhecimento sobre o que é verdadeiro ou falso; o gosto fornece o sentimento de beleza e deformidade, de virtude e vício. ${ }^{322}$

Ao comentar o pensamento de Hume, escreve Comparato:

David Hume (...) insistiu no fato de que a razão é inerte, e jamais pode prevenir ou produzir alguma ação ou afeição. A razão é pura descoberta da verdade e da falsidade, as quais consistem na aceitação ou rejeição, seja da relação real entre ideias, seja da existência real e da importância de fatos. Ora, as paixões, volições e ações, as quais constituem a matéria-prima da moral, são evidentemente insuscetíveis de uma aceitação ou rejeição intelectual. Elas jamais podem, por conseguinte, ser tidas por verdadeiras ou falsas, racionais ou irracionais, mas são, simplesmente, louváveis ou censuráveis. ${ }^{323}$

Vemos, portanto, a percepção, por autores de épocas diferentes, de um mesmo dado de realidade: o de que o homem apresenta, em sua relação com o mundo, duas naturezas diferentes de "conhecimento", que Jung expressará, em linguagem psicológica, na forma de duas funções judicativas - portanto, ambas de caráter "racional", embora de uma racionalidade sujeita a princípios opostos.

Admitindo-se, portanto, ser o sentimento a função valorativa do homem, natural seria concluir que dele decorre o senso de justiça. Por outro lado, é preciso notar que o Direito, numa sociedade complexa, parece não poder abrir mão de um ordenamento positivado, e a lei e a ordem estão mais associados à função pensamento. Talvez por isso Giannini chame nossa atenção para o fato de extensa literatura tipológica associar à função pensamento um forte senso de justiça, chegando a citar o exemplo de um paciente, tipo pensamento, cuja clareza e senso de justiça são muito apreciados pela esposa. ${ }^{324}$ Em contrapartida, a mesma literatura, sabedora que a função sentimento é a responsável pelo sopesamento de valores, no âmbito jurídico atribui ao sentimento a qualidade da "misericórdia". Isso enseja o seguinte quadro:

\footnotetext{
322 "Sobre o Sentimento Moral", Apêndice I ao livro Investigações sobre o entendimento humano e sobre os princípios da moral, Editora Unesp, São Paulo (SP), 2003, pp. 376/377.

${ }^{323}$ Ética..., p. 272.

${ }^{324}$ Op. cit., pp. 166/167.
} 


\begin{tabular}{|l|l|}
\hline Função pensamento $\rightarrow$ & Justiça \\
\hline Função sentimento $\rightarrow$ & Misericórdia \\
\hline
\end{tabular}

Não nos agrada essa ideia. Primeiro, porque existe uma carga negativa associada ao conceito de misericórdia, que está relacionado a "indulgência, graça, perdão", o que nem sempre é possível no campo jurídico. Portanto, ficaria afastada daí a incidência da função sentimento? Segundo, porque, como operadores do Direito, sabemos que a noção de justiça não se desvincula do trabalho de sopesamento de valores, justamente o que cabe à função sentimento desempenhar.

Quando nos deparamos com uma situação prática de julgamento, parece muito difícil, porém, dispensar o trabalho de qualquer das funções racionais. Porém, mais importante do que dizer que o senso de justiça está mais vinculado a uma do que a outra é, a nosso ver, compreender a diferença de seus princípios de funcionamento. Até porque, não deixa de haver um "senso de justiça" que decorre do pensamento, cujos contornos são bastante específicos. Isso pode ser ilustrado pelo seguinte exemplo:

Imaginemos um vagão de trem onde haja assentos reservados para pessoas idosas, mulheres grávidas e portadores de crianças de colo. Tais assentos estão devidamente sinalizados e, na ausência de pessoas nas condições referidas, seu uso é livre.

Em dado horário do dia, o vagão lota e não só os assentos são ocupados, como sequer há espaço para quem queira ficar de pé. Subitamente, uma mulher grávida ingressa no vagão e se dirige aos assentos reservados. Nele encontra dois jovens, um do tipo pensamento e outro do tipo sentimento. Ambos se dispõem a ceder seu lugar. No entanto, o tipo pensamento o fará deixando-se guiar pela ideia de que "assim deve ser", uma vez que há normas que o obrigam a tanto; o tipo sentimento, por sua vez, o fará mais por um senso de alteridade.

Imaginemos, porém, que os bancos especiais estejam ocupados por pessoas idosas, e que os referidos jovens se encontrem sentados ao lado, 
em bancos comuns. Vendo a grávida de pé, é possível que o tipo pensamento pondere: "Ora, os bancos especiais já estão ocupados e estou muito cansado. Trabalhei o dia todo e não estou disposto a ceder meu lugar, até porque não há nada que me obrigue a isso. Já existem bancos reservados para esse tipo de situação". Por outro lado, nada impede que ceda seu lugar graças às circunstâncias em que foi educado, por trazer consigo, internamente, a regra de que "assim deve proceder". Já o tipo sentimento, vendo a referida situação, cederá seu lugar por fazer contato com o desconforto da mulher grávida.

Caso ambos os jovens cedam seus lugares, para quem os observa ficará o registro de uma conduta exatamente igual. No entanto, embora externamente se assemelhem, sabemos que sua motivação é bastante diversa.

Em contrapartida, conquanto em nosso exemplo tenhamos tomado cada função atuando de acordo com a pureza de seu princípio, na prática é mais comum vê-las como fluxos que se lançam com maior ou menor força à consciência, às vezes engendrando um conflito interior, às vezes em aparente harmonia, sem que o indivíduo se dê conta de que, na verdade, a despeito de terem a mesma natureza (judicativa), apresentam princípios diferentes.

O próprio Hume, em brilhante lição de equilíbrio, demonstrou que, embora amparados por princípios diferentes, "razão" (pensamento) e sentimento colaboram, na verdade, quase sempre na formação dos juízos morais:

Os filósofos da Antiguidade, embora afirmem muitas vezes que a virtude nada mais é que a conformidade com a razão, parecem em geral considerar que a moral deriva sua existência do gosto e do sentimento. Porém, nosso modernos investigadores, embora também falem muito da beleza e da deformidade do vício, têm-se comumente esforçado para explicar essas distinções por meio de raciocínios metafísicos e deduções baseados nos mais abstratos princípios do entendimento. (...) Só se pode disputar sobre a verdade, não sobre o gosto; o que existe na 
natureza das coisas é a norma de nosso julgamento, mas a norma do sentimento é o que cada pessoa sente dentro de si mesma. (...) Ninguém raciocina sobre a beleza de uma outra pessoa, mas fá-lo frequentemente sobre a justiça ou injustiça de suas ações. (...) quando as verdades que [as inferências e conclusões do entendimento] ... revelam são indiferentes e não engendram desejo ou aversão, elas não podem ter influência na conduta e no comportamento. O que é honroso, o que é imparcial, o que é decente, o que é nobre, o que é generoso, toma posse do coração e anima-nos a abraçá-lo e conservá-lo. O que é inteligível, o que é evidente, o que é provável, o que é verdadeiro, obtém somente a fria aquiescência do entendimento e, satisfazendo uma curiosidade especulativa, põe um termo a nossas indagações.

(...)

Esses argumentos de cada um dos lados (e muitos mais poderiam ser fornecidos) são tão plausíveis que tendo a suspeitar que ambos podem ser sólidos e satisfatórios, e que razão e sentimento colaboram em quase todas as decisões e conclusões morais. ${ }^{325}$

A despeito da colaboração recíproca, é preciso deixar claro que, nos juízos morais dos quais o senso de justiça faz parte -, se o sentimento define o grau de rejeição ou aceitação que se deve ter diante de determinado fato, é o pensamento que confere ao ato a necessária justificação. Nada impede, porém, que o valor esteja previamente firmado na forma de regras escritas, passando-se, assim, a falsa impressão de estar o sentimento ausente da cena jurídica.

Na Grécia, Diké era originariamente simbolizada com uma balança na mão esquerda, ao que se acrescentou, posteriormente, uma espada. Conforme ensina Lídia, a primeira "representava o equilíbrio e a igualdade e a espada era o símbolo de potência e precisão".326 Também podemos fazer dessa imagem uma leitura à luz do debate acima travado, tomando a balança e a espada como representações do sentimento e do pensamento, respectivamente. Não há completude quando um atua sozinho e, paradoxalmente, pelo fato de serem regidos por princípios opostos, o excesso de um haverá de eliminar por completo o outro. Esta dificuldade é vivenciada diariamente pelos operadores do Direito, e talvez de maneira mais intensa por aqueles a quem cabe o ofício de julgar.

\footnotetext{
${ }^{325}$ Investigações sobre o entendimento humano e sobre os princípios da moral, Op. cit., pp. 226/229.

${ }^{326}$ PRADO, Lídia Reis de Almeida. Op. cit., p. 126.
} 
Cremos que as funções racionais, quando muito unilaterais, podem facilmente levar o indivíduo a trilhar o caminho que leva à emoção bruta. ${ }^{327} \mathrm{O}$ tipo pensamento, quando unilateral, no momento em que precisar "valorar" equivalerá a um homem sem bússola no deserto: como encontrar o caminho de casa, se todas as direções podem ser o norte ou o sul? Por sua vez, a unilateralidade do sentimento, quando vivenciada pelo juiz, equivalerá, em nosso exemplo, ao homem com bússola - portanto, saberá a direção a seguir -, mas não terá meios para isso.

O sentimento, quando sob forte carga emocional, abandona o necessário equilíbrio (para o qual pode contribuir o pensamento) e resvala para o excesso. Nesse sentido, preciosa a lição de Montaigne, que nos é trazida por Comparato ${ }^{328}$ :

"Nous pouvons saisir la vertu de façon qu'elle en deviendra vicieuse, si nous l'embrassons d'un desir trop aspre et violant. Ceux qui disent qu'il n'y a jamais d'excess en la vertu, d'autant que ce n'est plus vertu si l'excess y est, se jouent des parolles [...]. On peut et trop aimer la vertu, et se porter excessivement en une action juste. A ce biaiz s'accomode la voix divine: Ne soyez pas plus sages qu'il ne faut, mais soyez sobrement sages.

[Podemos nos prender à virtude de forma a torná-la viciosa, caso nos abracemos a ela com um desejo muito áspero e violento. Pode-se amar a virtude, e se portar com excesso numa ação justa. A este respeito concerne a voz divina: Não sejam mais sábios do que o necessário, mas sejam sobriamente sábios.] $]^{329}$

Kelsen, jurista de indiscutível envergadura intelectual, que vemos como um representante do tipo pensamento, propôs-se a investigar a essência do valor da justiça. Resultado desse esforço foi a publicação do livro “O que é justiça?” A proposta, em si, já nos dá indícios do uso da função pensamento, que se serve justamente para definir o sentido (“o que é”) de tudo o compõe nosso mundo. Evidentemente, a resposta não poderia advir com o uso exclusivo dessa função, quanto ao que ele jamais se enganou:

\footnotetext{
${ }^{327}$ Neste sentido, ver as considerações feitas, na parte teórica, a respeito da relação existente entre sentimento e emoção. Giannini trata do sentimento como função gerenciadora dos processos emocionais. Devemos lembrar que no tipo pensamento essa função é inferior. Isso implica dizer que, embora as emoções deste tipo possam não frequentar a superfície de sua vida cotidiana, elas existem e estão nas profundezas de sua psique, onde, distantes da consciência, podem aí irromper de forma arcaica, intensa e explosiva.

${ }^{328}$ Ética..., p. 529: trecho extraído da obra Essais, livro I, capítulo XXX.

${ }^{329}$ Tradução nossa.
} 
Se existe algo que a história do conhecimento humano nos pode ensinar é que como têm sido vãos os esforços para encontrar, por meios racionais, uma norma absolutamente válida de comportamento justo, ou seja, uma norma que exclua a possibilidade de também considerar o comportamento contrário como justo. Se podemos aprender algo da experiência espiritual do passado é o fato de que a razão humana só consegue compreender valores relativos. Isso significa que o juízo, por meio do qual algo é declarado como justo, nunca poderá ser emitido com a reivindicação de excluir a possibilidade de um juízo de valor contrário. Justiça absoluta é um ideal irracional. ${ }^{330}$

Este é o quadro do valor da justiça, quando dada sua elaboração a um tipo pensamento. Em vez de dizer "irracional", conforme de fato parece ser para um representante desse tipo, à luz da teoria junguiana podemos dizer que de uma outra racionalidade, cujo princípio é oposto ao do pensamento. É a "razão do coração", como diria Pascal.

Cumpre registrar que, em seu arrazoado, Kelsen valeu-se dos excessos cometidos por aqueles que acreditavam representar os mais elevados ideais de justiça: "Os mais altos ideais morais foram comprometidos pela intolerância daqueles que os defenderam". ${ }^{331}$ Sem desconsiderar, evidentemente, que muitos exageros possam ser cometidos por representantes do tipo sentimento, a intolerância a que Kelsen se refere tende a acontecer quando o juízo moral é submetido à lógica do pensamento, principalmente na atitude introvertida, situação em que aspira a se tornar universal e absoluto.

\footnotetext{
${ }^{330}$ Op. cit., p. 23. Kelsen conclui seu ensaio da seguinte forma: "Iniciei este ensaio com a questão: o que é justiça? Agora, ao final, estou absolutamente ciente de não tê-la respondido. A meu favor, como desculpa, está o fato de que me encontro nesse sentido em ótima companhia. Seria mais do que presunção fazer meus leitores acreditarem que eu conseguiria aquilo em que fracassaram os maiores pensadores. De fato, não sei e não posso dizer o que seja justiça, a justiça absoluta, esse belo sonho da humanidade. Devo satisfazer-me com uma justiça relativa, e só posso declarar o que significa justiça para mim: uma vez que a ciência é minha profissão e, portanto, a coisa mais importante em minha vida, trata-se daquela justiça sob cuja proteção a ciência pode prosperar e, ao lado dela, a verdade e a sinceridade. É a justiça da liberdade, da paz, da democracia, da tolerância”. Op. cit., p. 25. Note-se que a investigação termina com uma rendição - o pensamento rendeu-se à seguinte evidência: é impossível alcançar racionalmente uma definição de "justiça", ou seja, em termos que satisfaçam aos princípios do pensamento: objetividade, universalidade, etc.. Assim, fechou o ensaio recorrendo à declaração de outros valores, momento em que, a nosso ver, dá mais indícios de seu tipo, uma vez que as coisas mais importantes de sua vida são sua profissão, a ciência, a verdade, a sinceridade... - e, portanto, tudo aquilo que for necessário cultivar para seu florescimento.

${ }^{331}$ Op. cit., p. 24.
} 
Se por um lado considerarmos que no universo do pensamento não há valores absolutos - aí todos os valores são relativos -, e, por outro, que o pensamento se guia pelo que é geral e universal, podemos concluir que, no momento de valorar tenderá ele a se perder. Ou melhor, tenderá este tipo a recorrer a "princípios", o que na esfera jurídica corresponderá, em larga medida, à norma, seja ela representada pelo texto legal, seja pela tradição jurídica. Quando muito unilateral, aplicam-se os alertas feitos por Theodor W. Adorno: "O pensamento que mata o desejo, seu pai, é alcançado pela vingança da tolice" ${ }^{, 332}$, ou ainda: "Tão logo esteja apagado o último traço de emoção, só resta ao pensamento a tautologia absoluta". 333

Um dos traços mais marcantes do Direito é que se incumbe ele de criar uma ordem geral, válida para todos, e isso é viabilizado pela legislação, cujos princípios parecem seguir exclusivamente os critérios do pensamento, motivo pelo qual, num recorte simbólico, costuma-se associar a lei ao Logos, de certo modo identificando-a com o universo do ani$m u s$, arquétipo do masculino, ao qual estão ligadas as ideias de "universalidade, de impregnação espiritual, de claridade e racionalidade". ${ }^{334}$ Mas isso equivaleria a uma parte apenas de um processo que na verdade é mais amplo. Antes de surgir como texto impresso, momento em que de fato se reveste das características do Logos, a lei é precedida necessariamente por um processo de valoração. Não é qualquer conteúdo que conformará o cerne da legislação, mas aquele que foi tido como justo ou bom para determinado grupo em dado momento histórico. Isso é corroborado pela lição de Miguel Reale, um dos maiores jusfilósofos que nosso país já produziü ${ }^{335}$ :

É na ideia de valor que ROGER BONNARD vai procurar a solução dos problemas postos pela relação fato-norma, a fim de explicar as ligações entre o ordenamento jurídico e os elementos externos. (...) Um certo valor é atribuído às coisas e aos atos em razão dos resultados que produzem, dos fins aos quais são orientados. Dessa valoração resulta que tal atividade humana se apresenta como de-

\footnotetext{
${ }^{332}$ Minima Moralia, Trad.: Gabriel Cohn, Beco do Azougue Editorial Ltda., Rio de Janeiro (RJ), 2008, p. 118.

${ }^{333}$ Op. cit., p. 119.

${ }^{334}$ SAMUELS, Andrew et alii. Dicionário crítico de análise junguiana, Imago Editora Ltda., Rio de Janeiro (RJ), 1988, p. 121. Ao Logos se contraporia o conceito de Eros, por sua vez associado ao arquétipo da anima, representativo dos aspectos do feminino (Idem, pp. 120/121).

335 A rigor, Reale endossa a tese de Roger Bonnard, professor de Bordeaux, que, segundo ele, neste ponto conta com o apoio dos mais ilustres juristas contemporâneos. In Fundamentos do Direito, $3^{\mathrm{a}}$ edição, Editora Revista dos Tribunais, São Paulo (SP), 1997, pp. 284/285.
} 
vendo ou não devendo ser, de maneira hipotética ou categórica. Isto é, resulta uma norma para a ação humana. Valorar equivale, pois, a normatizar o mundo prático. A norma é, por conseguinte, posterior e consecutiva ao valor. $\mathrm{O}$ conceito de valor é logicamente anterior ao conceito de norma.

(...)

O valor, conclui ele, é uma noção primordial e a valoração se apresenta como um fato cuja realização rigorosamente se impõe, constituindo, não apenas um paradigma de apreciação e de julgamento, mas uma verdadeira base de legislação.

Os seres humanos, para viverem em sociedade, não podem depender do senso de justiça de cada indivíduo isoladamente. Se uns o trazem naturalmente de maneira mais apurada, outros não. Ademais, o Direito, enquanto sistema, cumpre um importante papel de organizar as expectativas dos indivíduos, apontando o que se pode esperar diante do surgimento de uma contingência. ${ }^{\mathbf{3 3 6}}$ Existe, portanto, a necessidade de se estabelecer, dentre outras coisas, um parâmetro "ético" coletivo, havendo até quem nele veja, diante da perda de referenciais da pós-modernidade, uma alternativa ao caos ético. ${ }^{337}$ A lei desempenha essa função, não podendo, portanto, deixar de ser vista como resultado da atuação conjunta de pensamento e sentimento.

É claro que, não sendo a sociedade homogênea, e por isso mesmo, comportando grupos diferenciados e até antagônicos de interesses, o que pode não ser justo ou bom para uns, sê-lo-á para outros. Exemplo disso é o atual Código de Defesa do Consumidor (Lei n ${ }^{\circ}$ 8.078/1990), celebrado pelos consumidores por conta das inúmeras vantagens que lhes são conferidas - como a inversão do ônus da prova em algumas hipóteses ou ainda a corresponsabilização solidária dos agentes de uma cadeia produtiva -, e provavelmente tido como um "exagero" por boa parte dos empresários que a ele têm de se submeter.

\footnotetext{
${ }^{336}$ LUHMANN, Niklas. Sociologia do Direito, vol. I, Tempo Brasileiro, trad.: Gustavo Bayer, Rio de Janeiro, 1983, pp. 55/56 e 80.

${ }^{337}$ NALINI, José Renato. “A Questão da Ética. Estamos Atravessando uma Crise?” in ZIMERMAN, David e COLTRO, Antônio Carlos Mathias (org.), Aspectos Psicológicos na Prática Jurídica, 2ª edição, Millennium Editora Ltda., Campinas (SP), 2008, p. 26.
} 


\section{A DINÂMICA DAS FUNÇÕES E O OFÍCIO DE BEM JULGAR}

O rei Salomão virou símbolo daquele juiz no qual os valores da justiça e da sabedoria estão plenamente incorporados, a ponto de a expressão "justiça salomônica" virar sinônimo de boa justiça. A história das duas mulheres que disputavam a maternidade de uma criança é célebre. Insinuando-se a dividir o infante ao meio, de modo a dar metade a cada contendora, o reio veio a saber, pela reação de ambas, qual seria a verdadeira mãe, a ela restituindo a criança. ${ }^{338}$

Se pararmos para analisar o caso, notaremos que não havia dúvida a respeito da regra a aplicar. Desde o início, Salomão estava decidido a entregar a criança para sua verdadeira mãe. Em outras palavras: a "lei" era clara. O problema, portanto, residia em saber qual das duas mulheres preenchia a condição fática, e foi neste ponto que incidiu toda a astúcia do israelita. Preenchida a lacuna fática, a aplicação da decisão foi mera consequência natural.

Aproveitaremos a ilustração para pontuar que a atividade jurisdicional enfrenta um desafio que se apresenta em dois planos, o perceptivo e o judicativo. Ora, a sistemática processual organiza-se justamente em torno desse paradigma, sendo a fase instrutória relativa à produção de provas (o que implica dizer: "fornecimento de informações" para o juiz) - anterior à fase de sentença - relativa à tomada de decisão. Na primeira, mostra-se fundamental a atuação competente dos advogados. Mas, mesmo que estes façam o seu melhor, cada juiz tem suas peculiaridades na forma de apreciar o que lhe foi dado. Um juiz do tipo sensação, por exemplo, tenderá a ter posturas mais pragmáticas em relação à condução do caso, além de atentar para todo tipo de detalhe, seja relativo ao que está nos autos, seja à conduta das partes e respectivos patronos. Já um juiz do tipo pensamento tenderá a conduzir o processo com o máximo de objetividade, não perdendo muito tempo com as repercussões "pessoais" de seu trabalho. O processo será por ele mentalmente elaborado como um grande jogo de xadrez, onde cada movimento é visto na perspectiva de seus efeitos lógicos, e com base nisso é conduzido. O leitor poderá ver com detalhes o funcionamento dessa dinâmica na parte prática de nosso trabalho. Após sua análise, não haverá como negar a influência de aspectos subjetivos na maneira como se processa a justiça.

${ }^{338}$ Reis, 3,16-28. 
A tradicional ideia de um juiz que julga interpretando a lei a partir de um procedimento lógico-dedutivo há muito está ultrapassada. ${ }^{339}$ Sobreleva-se a importância do sentimento (sentire) que, conforme bem lembra Lídia Prado, seguindo lição de Siches, está na base do termo "sentença". ${ }^{\mathbf{3 4 0}}$ No entanto, mais que isso, por meio da teoria dos tipos podemos atentar para a maneira como sentimento e pensamento, bem como outras funções, processam-se em cada magistrado e conformam diferentes estilos judicativos, vinculados a seu tipo psicológico.

Tal perspectiva não pode ser menosprezada, ainda mais no contexto atual, em que mais poder é dado aos juízes em virtude da impossibilidade de tudo abranger pela letra da lei - a complexidade da sociedade contemporânea não o permite. Recorre-se, portanto, crescentemente ao uso de princípios e aos chamados conceitos juridicamente indeterminados, cabendo ao juiz, diante do caso concreto, achar um sentido próprio a partir de uma matriz hermenêutica bastante extensa, cujo não-regramento lhe confere excessiva liberdade. ${ }^{341}$ Essa liberdade é campo fértil para expressão, de maneira consideravelmente visível, da diversidade tipológica.

Uma questão interessante é se haveria um tipo ideal para desempenhar a judicatura, dentre os dezesseis elencados por Myers-Briggs.

Na verdade, o que existe são ganhos e perdas decorrentes do uso de determinada função em detrimento de outras, e a realidade nunca se apresenta de maneira tão simples a permitir, sempre, que uma delas produza resultados de maneira mais vantajosa em relação à outra. Mas, por outro lado, insistimos em esquecer de considerar também o viés de nosso próprio tipo, no momento em que avaliamos o trabalho do juiz. Aquilo que venha a nos parecer altamente positivo, caso estejamos olhando para a situação por meio da lente do pensamento, pode ser reprovável para alguém que se valha do sentimento.

\footnotetext{
${ }^{339}$ PRADO, Lídia Reis de Almeida. Op. cit., pp. 14/22.

${ }^{340}$ Op. cit., p. 14.

${ }^{341}$ STRECK, Lenio Luiz. Hermenêutica Jurídica e $(m)$ Crise, 4 $4^{\underline{a}}$ edição, RS, Livraria do Advogado Editora, 2003, pp. 108/110.
} 
As situações com as quais um magistrado tem de se haver ao longo de sua carreira são as mais diversas. Há causas que exigem maior "tato", como as de família, enquanto outras pedem abordagens mais objetivas, como as de natureza tributária. Mas, analisadas as situações com profundidade, perceberemos que até esse tipo de consideração pode ser unilateral, incorrendo em superficialismo. Por exemplo: uma questão tributária, que tomamos como ilustração de algo mais "técnico", pressupondo não exigir tanto a atuação da função sentimento, pode trazer enormes implicações em termos sociais (coletivos), obrigando, portanto, o magistrado a ponderar a respeito; em contrapartida, a causa de família pode exigir, circunstancialmente, uma postura mais incisiva junto a uma das partes ou mesmo patronos, no que não deixa de ser muito útil o estilo da função pensamento.

Outro ponto digno de nota é que, sendo as pessoas muito diferentes entre si, nada impede que a função auxiliar de um tipo pensamento (sensação ou intuição) seja percebida como mais desenvolvida do que alguém que a traga como principal. Ilustraremos isso por meio de uma equação muito singela, porém didática. Imaginemos que o grau de desenvolvimento de uma função pudesse ser medido dentro de uma escala de 0 a 10. Partindo dessa premissa, imaginemos que "A" tem suas funções desenvolvidas em graus "9" (T - princi-

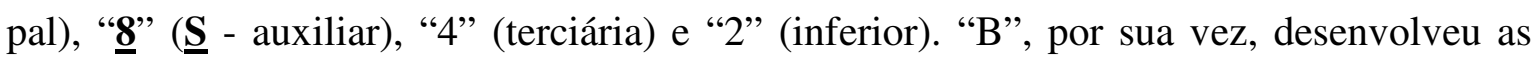

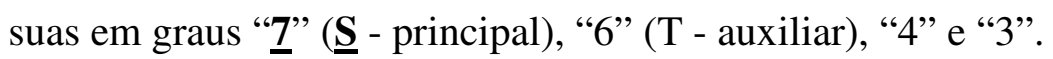

Deste modo, segundo nosso exemplo, mesmo tendo a função sensação (S) como auxiliar, em termos comparativos "A" a traria muito mais diferenciada do que "B", em que ela é função principal.

Além disso, não há nenhuma garantia de que alguém que pertença a determinado tipo traga efetivamente o rol de características - habilidades e inabilidades - associadas ao mesmo $^{\mathbf{3 4 2}}$, do mesmo modo que ninguém deve deixar de seguir uma profissão simplesmente pelo fato de seu tipo psicológico não ser nela o mais frequente. ${ }^{\mathbf{3 4 3}}$

Feitas estas breves ressalvas, fato é que, conforme demonstram as estatísticas, alguns tipos são mais frequentes em algumas profissões do que em outras, e isso pode ser

\footnotetext{
${ }^{342}$ QUENK, Naomi L.. Essentials of Myers-Briggs Type Indicator Assessment (Essentials of Psychological Assessment), John Wiley \& Sons, Inc. 2000, p. 148.

${ }^{343}$ QUENK, Naomi L.. Essentials ..., p. 72.
} 
atribuído à ideia de que os indivíduos naturalmente tendem a se sentir atraídos pelas atividades em que suas funções mais diferenciadas (o que equivale a dizer "habilidades") são justamente as mais exigidas e, portanto, valorizadas. Se tenho dificuldade com raciocínio abstrato (intuição), e facilidade para lidar com pessoas (sentimento/extroversão), é mais provável que eu queira ser um administrador de empresas, por exemplo, do que um físico nuclear.

Em seu livro, Myers divulga algumas pesquisas nessa linha. É expressiva, por exemplo, a concentração dos tipos "sensação", principalmente quando a função auxiliar é o pensamento (ST), entre os estudantes de finanças e comércio. A explicação para isso é que, em tais áreas, o que o indivíduo precisa ter é uma noção muito realista dos fatos (S), que devem ser analisados de maneira impessoal e objetiva (T). Há também claro predomínio dos extrovertidos (E). Esse conjunto de traços (EST) tem em comum a predileção por trabalhos que não exijam grande uso da capacidade de abstração. ${ }^{344}$

Outro exemplo dado abrange estudantes de "ciências". Já nesta área, prevalecem indivíduos do tipo "intuição" (N), principalmente quando a função auxiliar é o pensamento (NT). Myers explica serem aí valorizadas as capacidades de perceber possibilidades $e$ princípios relacionados à sua resolução. Há também, na amostra, clara prevalência dos introvertidos (capacidade de enxergar o desconhecido, em grau mais intenso do que o das demais pessoas). ${ }^{345}$

Pesquisas semelhantes foram desenvolvidas no Brasil, algumas delas divulgadas por Zacharias, tudo no sentido de confirmar o acima dito: cada tipo tende a buscar profissões cujas habilidades mais exigidas estejam de acordo com as funções e atitudes predominantes. $^{346}$

Não encontramos nenhuma pesquisa que trouxesse o perfil tipológico mais frequente no poder judiciário, mas Myers divulga uma que foi feita junto a estudantes de Direito. ${ }^{347}$ Em $73,4 \%$ dos indivíduos, a função pensamento $(\mathrm{T})$ apareceu seja como principal

\footnotetext{
${ }^{344}$ MYERS, Isabel Briggs. Gifts Differing ..., p. 42.

${ }^{345}$ Op. cit., p. 43.

${ }^{346}$ Tipos - A diversidade Humana, pp. 134/155.

${ }^{347}$ Op. cit., p. 49.
} 
(39,5\%), seja como auxiliar (33,9\%); 55,2\% eram extrovertidos (E) e 44,8\% introvertidos (I); 59,2\%, intuitivos (I) (auxiliar ou principal), e 40,8\%, sensoriais (S) (idem); 57,0\%, judicativos (J), e 43,0\%, perceptivos (P). A função sentimento (F) apareceu em 26,6\% da amostra, ou seja, foi a menos predominante. As combinações mais comuns foram:

- ESTJ (13,1\%) (atitude extrovertida / função principal: pensamento / função auxiliar: sensação / atitude judicativa), e

- ENTJ (12,7\%) (atitude extrovertida / função principal: pensamento / função auxiliar: intuição / atitude judicativa).

Em nossa pesquisa de campo, chegamos a entrevistar seis magistrados, dentre eles um desembargador, todos do Tribunal de Justiça de São Paulo. Desses 6, 4 eram introvertidos (I) e 2 extrovertidos (E); 5 judicativos (J) e 1 perceptivo (P); 5 pensativos (T) e 1 sentimental (F); 5 sensoriais (S) e 1 intuitivo (N). Embora a amostra seja desprezível num universo de mais de 2000 juízes e 360 desembargadores, pode nos dar uma vaga ideia do provável perfil da instituição.

Tomando-se cada preferência que predominou, configura-se o tipo ISTJ (introvertido / principal: sensação / auxiliar: pensamento / judicativo).

Tal perfil é coerente com a imagem que se tem do judiciário, cujos integrantes tendem a ser mais introspectivos do que sociáveis (I); mais voltados à solução de problemas constelados no momento presente $(\mathrm{S})$ do que a perscrutar possibilidades futuras $(\mathrm{N})$; mais objetivos e impessoais $(\mathrm{T})$ do que afetuosos $(\mathrm{F})$ e, por fim, mais afeitos a rotinas e à tomada de decisão (J) do que ao improviso e a tarefas criativas (P). Não por acaso, os entrevistados que se aproximaram mais desse perfil mostraram-se senão mais vocacionados, certamente mais à vontade com a carreira em todos os aspectos de sua personalidade.

Cremos que uma das maiores preocupações para o exercício da jurisdição deva ter por foco o senso de justiça. Pelo que foi já foi dito até então, vimos que tal senso lança raízes na função sentimento, mas precisa do pensamento para se fazer presente no mundo de maneira discriminada e bem estruturada. Isso vale para a produção de leis e também de sentenças. Contudo, sendo funções opostas, a forma mais provável de tê-las em relativo 
equilíbrio é que nenhuma delas esteja muito diferenciada; para isso, haverão de ser funções auxiliares, não importa em qual ordem (secundária ou terciária). A este respeito, ensina Jung:

Ao lado do pensamento, por exemplo, não pode aparecer, como função secundária, o sentimento, pois sua natureza está em demasiada oposição à natureza do pensamento. Se quiser ser verdadeiro e fiel a seu princípio, o pensamento tem que excluir rigorosamente o sentimento. Isto não afasta a possibilidade de que haja indivíduos cujo pensamento esteja no mesmo nível do sentimento, tendo ambos a mesma força motivadora consciente. Em tal caso, porém, não se trata de tipo diferenciado, mas de um pensamento e sentimento relativamente subdesenvolvidos. ${ }^{348}$

Em desempenhando as funções judicativas ( $\mathrm{T}$ e F) o papel de auxiliares, as perceptivas (S e N) serão principal e inferior. Parece-nos bastante razoável a ideia de um juiz com função perceptiva diferenciada, porque o magistrado está limitado a julgar o caso com base nas informações que estão nos autos, que foram previamente submetidas ao filtro representado pelas partes e seus patronos. Com o contraditório, procura-se criar o cenário adequado para a mais completa produção de provas possível. Mesmo assim, todo operador do Direito sabe que o juiz - assim como os advogados - em boa parte dos processos apenas tem acesso a uma parcela da realidade. Portanto, antes do crítico momento de produzir a sentença, talvez o maior desafio do juiz seja mesmo o de bem processar as informações pertinentes (lembremos o caso de Salomão), o que fica a cargo das funções perceptivas.

Apesar das ressalvas feitas, tendo em vista a tendência que temos de operar em bases simplistas, voltamos à lição de Jung, no sentido de afirmar a unicidade do ser humano:

É simples e óbvio o princípio fundamental das duas atitudes opostas, mas complicada e difícil de inferir é sua realidade concreta, pois todo indivíduo é exceção à regra. Por isso não é possível dar uma descrição do tipo, por mais perfeita, que se aplique a mais do que um indivíduo, ainda que, em certo sentido, milhares pudessem ser por ela bem caracterizados. A conformidade das pessoas é apenas um lado delas, o outro lado é sua peculiaridade. A psique individual não se explica por nenhuma classificação. Contudo, a compreensão dos tipos psicológicos abre um caminho para um entendimento da psicologia humana em geral. ${ }^{349}$

\footnotetext{
348 Tipos ..., p. 382, $\$ 736$.

349 “Tipos Psicológicos”: ... 1923, p. 475, § 960.
} 


\section{UMA POSSÍVEL SÍNTESE: A TEORIA TRIDIMENSIONAL DO DIREITO, DE MI- GUEL REALE}

Por meio da tipologia junguiana, temos acesso não apenas a um sistema teórico capaz de explicar parte das diferenças individuais em termos de percepção e conduta, como também nos conscientizamos de limitações que cada um traz quanto à capacidade de compreender o mundo que o cerca.

Evidentemente, e esse parece ter sido o ponto de partida de Jung, diferentes estilos perceptivos e judicativos tendem a levar a diferentes teorias, tão próprias de cada função quanto mais seu criador a elas se render. Se a obra de um jurista como Kelsen, por exemplo, for vista sob a perspectiva de seu tipo (pensamento), tem-se um ganho de compreensão, uma vez que se pode imaginar a dificuldade de tal pensador em incluir, numa teoria pura do direito, aspectos que não sejam inteiramente objetivos e universais. Na feliz síntese de Hespanha, com inserção de comentários nossos:

Kelsen considerou o direito como um especial sistema de normas, cujo fundamento não estava noutros sistemas normativos, como a religião ou a moral [= rejeição de temas de importância para a função sentimento]; mas também não estava na ordem dos fatos (por exemplo, numa política, na utilidade) [= rejeição de temas de importância para a função sensação]. Ou seja, uma norma jurídica não teria vigência por ser moral ou útil, mas porque e apenas porque é uma norma jurídica, i.e., conforme ao direito [= adoção de critérios consentâneos à função pensamento]. Ser conforme ao direito é, afinal, ser obrigatória em virtude do comando de uma norma superior. Daí que o direito constitua uma pirâmide normativa (Stufentheorie), no topo da qual se encontra a Constituição. Mas como a própria Constituição carece de um fundamento jurídico, a construção teórica de Kelsen obriga a pressupor uma "norma fundamental" (Grundnorm), que valida a Constituição, e cujo conteúdo poderia ser assim formulado - "Toda a norma jurídica legítima (i.e., estabelecida de acordo com o direito) deve ser observada". Uma norma destas é autorreferencial, ou seja, aplica-se a si mesma; e, com isto, legitima-se a si própria e a todas as outras. ${ }^{\mathbf{3 5 0}}$

Como se vê do excerto acima, Kelsen fundou a validade de todo o sistema de normas - de qualquer sistema, independentemente do contexto histórico-social em que se insi-

${ }^{350}$ Op. cit., p. 310. 
ra ele - numa norma abstrata, pressuposta, a que chamou de "norma fundamental". Para ele, "o problema da Justiça, enquanto problema valorativo, situa-se fora de uma teoria do Direito que se limita à análise do Direito positivo como sendo a realidade jurídica". ${ }^{351}$ Não que negasse a importância da Justiça; apenas afirmava que, não sendo possível definir seu conceito em termos racionais, seu uso se faria sempre a serviço de alguma ideologia, não podendo ser objeto de uma ciência. Portanto, se o Direito quisesse ocupar um espaço como ramo científico, haveria de definir seu objeto de maneira isenta. Assim surgiu a teoria pu$r a$, que pode ser considerado o primeiro esforço de proposição do Direito enquanto sistema de normas, postas pelo Estado e válidas em determinado território, numa estrutura hierárquica. $^{352}$

Evidentemente, oposições sobrevieram aos montes e nos mais variados tons. ${ }^{353}$ Mas o que importa no âmbito deste estudo é a percepção daqueles que, em vez de ver na teoria pura a formulação de um equívoco, não deixaram de lhe atribuir todo o valor que possui, reconhecendo, porém, ao mesmo tempo, que deu conta de apenas uma parte da realidade do fenômeno jurídico. Dentre estes se insere Miguel Reale. ${ }^{354}$

O jusfilósofo brasileiro afirma que, ainda no seu tempo de juventude, intuiu aquilo que daria lugar à Teoria Tridimensional do Direito. Chamou-lhe a atenção o fato de os grandes jusfilósofos italianos dividirem a Filosofia do Direito, para fins pedagógicos, em três partes: uma destinada ao estudo do fenômeno jurídico dado como fato social (abordagem fenomenológica, que Reale viria a associar à Sociologia Jurídica); a segunda, pondo a tônica na ideia do Direito ou Justiça (abordagem valorativa, posteriormente associada à Filosofia do Direito) e, a terceira, ocupando-se com o Direito enquanto sistema de normas (onde se insere Kelsen - ramo que Reale atribuiria à Ciência do Direito). Cada uma dessas

${ }^{351}$ KELSEN, Hans. Teoria Pura do Direito, p. 14.

${ }^{352}$ BOBBIO, Norberto. Op. cit., pp. 193/195.

${ }_{353}^{35}$ KELSEN, Hans. Op. cit., pp. 7/11 (prefácio à primeira edição, de 1934).

${ }^{354}$ Por exemplo, escreve ele: "Falar de Hans Kelsen é falar sem dúvida alguma do maior jurisconsulto ou do maior jurisfilósofo do nosso século. A personalidade de Kelsen é tão significativa que eu costumo dizer que a sua contribuição filosófico-jurídica funciona como uma espécie de Meridiano de Greenwich para determinar a posição dos nossos pensadores. É-se isto ou aquilo conforme se está mais perto ou mais longe de Kelsen. Com isto, estou demonstrando a alta admiração e o inestimável apreço que tenho pela obra de Hans Kelsen, que tive a fortuna de conhecer pessoalmente e de admirar não apenas como homem, mas como autor sempre vigilante em seu próprio pensamento". Nova Fase do Direito Moderno, Editora Saraiva, São Paulo (SP), 1990, pp. 195/196. O fato de Reale ver em Kelsen um referencial que permite situar os demais pensadores do Direito conforme a distância que mantêm do pensamento do autor da Teoria pura não deixa de ser mais um indício da unilateralidade desta doutrina, ao mesmo tempo que de sua excelência enquanto obra do pensamento. 
abordagens pareceu-lhe dar conta de uma parte do Direito enquanto experiência. Afinal, embora o Direito seja norma, é também, mas não só. No insubstituível relato de Reale:

Se se perguntasse a Kelsen o que é Direito, ele responderia: Direito é norma jurídica e não é nada mais do que norma. Muito bem, preferi dizer: não, a norma jurídica é a indicação de um caminho, porém, para percorrer um caminho, devo partir de determinado ponto e ser guiado por certa direção: o ponto de partida é o fato, rumo a determinado valor. (...) Direito não é só norma, como quer Kelsen, Direito não é só fato como rezam os marxistas ou os economistas do Direito, porque Direito não é economia. Direito não é produção econômica, mas envolve a produção econômica e nela interfere; o Direito não é principalmente valor, como pensam os adeptos do Direito Natural tomista, por exemplo, porque o Direito ao mesmo tempo é norma, é fato e é valor. E, pela primeira vez, na introdução do livro Teoria do Direito e do Estado, disse aquilo que generosamente um dos maiores discípulos de Kelsen, Josef Kunz, qualificou de "fórmula realeana": "o Direito é uma integração normativa de fatos segundo valores". ${ }^{355}$

E Reale foi além: postulou que os três elementos (fato, valor e norma) não apenas se correlacionam, mas também se dialetizam, havendo "uma dinamicidade integrante e convergente" entre eles, e que pode tomar cada qual como ponto de partida, gerando-se, assim, três ordens de dialética:

$$
\begin{aligned}
& \text { fato } \rightarrow \text { valor } \rightarrow \text { norma (dialética correspondente à Ciência do Direito) } \\
& \text { norma } \rightarrow \text { valor } \rightarrow \text { fato (dialética correspondente à Sociologia do Direito) } \\
& \text { norma } \rightarrow \text { fato } \rightarrow \text { valor (dialética correspondente à Filosofia do Direito) }
\end{aligned}
$$

Desse modo, Reale apresentou-nos um Direito como realidade tridimensional, que pode ser captada a partir de três perspectivas inseparáveis, sob pena de se ignorar uma de suas facetas. Há, segundo o memorável filósofo, apenas uma "variação no ângulo ou prisma de pesquisa. A diferença é, pois, de ordem metodológica, segundo o alvo que se tenha em vista atingir", ${ }^{356}$

\footnotetext{
355 "Preliminares ao Estudo da Teoria Tridimensional do Direito", suplemento ao livro Teoria Tridimensional do Direito (situação atual), $5^{\mathrm{a}}$ edição, Editora Saraiva, São Paulo (SP), 1994, pp. 118/119. Esta parte suplementar ao referido livro corresponde à reconstrução de "aula" ministrada por Miguel Reale, em 25/03/1992, por ocasião de homenagem a ele feita (à época, com 81 anos de idade), na Faculdade de Direito da Universidade do Estado do Rio de Janeiro.

${ }^{356}$ Op. cit., pp. 119/121.
} 
Essa dialética da tridimensionalidade está presente não apenas no momento da produção da norma escrita, mas também quando de sua interpretação, o que permite a adequação de seu sentido às exigências do caso concreto. Muito interessante, ainda, a associação feita por Reale (sinal, novamente, de sua intuição) entre o fenômeno da tridimensionalidade do Direito e as atividades artísticas:

Notem que o tridimensionalismo não serve só para o Direito, mas para qualquer atividade cultural. Assim é que o artista, inspirado ante certa realidade factual, projeta a sua preferência valorativa, impressionista ou expressionista, por exemplo, e esta se concretiza numa forma expressa por uma pintura ou uma escultura. O que é uma obra de arte senão a expressão formal de uma vivência axiológica do fato vivido pelo artista? Ora, o que é forma para o artista é norma para o jurista. A norma é a forma que o jurista usa para expressar o que deve ou não deve ser feito para a realização de um valor ou impedir a ocorrência de um desvalor. ${ }^{357}$

A Teoria Tridimensional do Direito expressa, a nosso ver, como seria a produção jurídica dada sob a perspectiva do uso equilibrado e dinâmico das funções propostas por Jung: o fato há de ser apreendido pelas funções perceptivas (sensação ou intuição); o valor há de ser apreciado e expresso por meio do sentimento e a norma, seja como texto legal a ser interpretado, seja como resultado dessa interpretação, exigiria a atuação do pensamento, mas tudo isso em processo dialético, de inter-relação.

O não poder abrir mão do princípio ordenador do pensamento, ao mesmo tempo que a Justiça - essencialmente ligada ao sentimento - constitui seu princípio norteador irrenunciável, é fato que obriga o operador do Direito a um diálogo permanente entre funções opostas. Isso nos leva a afirmar que, se por um lado a teoria dos tipos é capaz de trazer importantes contribuições para a compreensão de como a ciência do Direito pode caminhar para uma completude, por outro revela que a produção de uma sentença justa tem por berço um eterno paradoxo. O bom juiz vivencia-o diariamente, sentindo-se não raras vezes como se estivesse pairando sobre um abismo que gera, ao mesmo tempo, fascínio e perplexidade.

${ }^{357}$ Op. cit., pp. 124/125. 
PARTE 2

UMA POSSÍVEL APLICAÇÃO DA TEORIA DOS TIPOS

\title{
ANÁLISE DO PERFIL TIPOLÓGICO DE SEIS MAGISTRADOS DO TRIBUNAL DE JUSTIÇA DO ESTADO DE SÃO PAULO
}

\begin{abstract}
O juiz é um intelectual que trabalha com o sentimento, e suas sentenças têm raízes nele. Por isso expressam-se nos mesmos cognatos de sensação, sensitivo, sensorial e sentido - a sentença é o que o juiz sente, e, ao assim se proclamar, espera-se que ele tenha a justiça como a matriz de suas percepções.
\end{abstract}

César Asfor Rocha ${ }^{358}$

\section{INTRODUÇÃ̃o}

Elaborado o arcabouço teórico, é evidente que nosso trabalho ficaria incompleto se não demonstrássemos sua implicação prática no universo judicial. Uma maneira de fazer isso é buscar demonstrar a influência do tipo psicológico do magistrado:

(a) em sua visão de mundo (efeito epistemológico);

(b) sobre a forma como ele preside o feito e interage com os demais atores do processo (advogados, partes e tribunais superiores);

(c) no caminho que percorre para chegar à sentença.

Com essa finalidade, procedemos à coleta de material para análise, consistente principalmente no conteúdo de entrevistas concedidas com base em questionário padrão, por nós elaborado.

${ }^{358}$ ROCHA, Cesar Asfor. Cartas a um jovem juiz: cada processo hospeda uma vida, Campus/Elsevier Editora Ltda., Rio de Janeiro (RJ), 2009, p. 148. 
Essa parte empírica revelou, depois de executada, toda sua relevância, na medida em que serviu para debelar algumas ideias pré-concebidas, como, por exemplo, a de que os EXTROVERTIDOS (E) tendessem a buscar mais o contato com as partes do que os INTROVERTIDOS (I), o que deveria resultar numa maior designação de audiências por aqueles. Essa ideia, como veremos, não resistiu aos fatos. Outra hipótese que não sobreviveu ao trabalho de campo foi a de que um juiz do tipo PERCEPTIVO (P) tenderia a acumular mais processos pendentes de julgamento do que seus colegas JUDICATIVOS (J). Assim, percebemos que o leque de possibilidades da conduta humana ultrapassa infinitamente nossa capacidade de especular a seu respeito.

Embora o principal material de análise tenha sido o teor das entrevistas, contamos também com a observação da conduta de alguns dos magistrados em audiência. Além disso, três dos entrevistados, atendendo a pedido nosso, ainda separaram amostras de decisões por eles proferidas.

Por razões evidentes, envidamos esforços visando a proteger a identidade dos envolvidos, o que nos obrigou a efetuar pequenos recortes no material, cuidando, porém, para não descaracterizar aspectos da personalidade de seus autores.

Penso ser importante frisar que nosso trabalho não se presta a tecer quaisquer juízos de valor sobre as pessoas dos magistrados e convidamos o leitor a fazer o mesmo. Estamos interessados exclusivamente em apontar o quanto o exercício da jurisdição acaba se pautando também por aspectos metajurídicos, de natureza psicológica, incidentes no curso da atuação de cada julgador - e tão alheios à sua vontade quanto mais inconsciente ele estiver deles.

Ressaltamos que, preocupados em aumentar a consistência das hipóteses construídas a partir da análise dos discursos, procuramos confrontá-las com o resultado da aplicação de um questionário próprio, de aferição de tipos ${ }^{\mathbf{3 5 9}}$. Não obstante, mesmo os resultados

\footnotetext{
${ }^{359}$ O questionário de que nos valemos foi desenvolvido a partir do apresentado por David Kersey no livro Please Understand Me II: Temperament, Character, Intelligence, com adaptação da $\operatorname{Prof}^{\underline{a}} \operatorname{Dr}^{\mathbf{a}}$ Anna Mathilde Pacheco e Chaves. O resultado do trabalho da Prof ${ }^{\mathrm{a}}$ Anna Mathilde foi submetido a análise crítica, gerando a substituição de algumas questões por outras, desenvolvidas pelo Prof. Dr. José Jorge de Morais Zacharias na versão "II" de seu "Questionário de Avaliação do Tipo Psicológico" (QUATI), bem como por nós, que também nos valemos do auxílio de trabalho desenvolvido por Renee Baron, publicado sob o título What Type Am I? Ao final da aplicação do questionário, procurou-se submeter seu resultado à apreciação dos analisandos, cujo consentimento serviu como critério complementar de sua validação.
} 
obtidos por questionários dessa natureza não são absolutos ${ }^{\mathbf{3 6 0}}$, devendo ser considerados, no caso de nosso trabalho, em consonância com o restante do material colhido.

As análises não foram apresentadas em ordem inteiramente aleatória. Isso implica dizer que se supõe um ganho de compreensão caso sejam lidas na sequência em que aparecem, porque algumas se basearão nas anteriores, em tentativa de contrastar tipos opostos e assim facilitar a apreensão dos conceitos e tornar mais visível a influência do tipo psicológico do magistrado na atuação jurisdicional.

Para finalizar, cumpre mencionar que as entrevistas foram concedidas em clima de informalidade, como convinha a um trabalho dessa natureza. A fim de manter a autenticidade do material produzido e permitir uma correta aferição do tipo, foram preservadas, na transcrição das falas, as expressões mais coloquiais que, embora pouco compatíveis a um magistrado no exercício de sua função, são inerentes a seu universo subjetivo enquanto integrante do gênero humano, e é nessa qualidade que aqui nos interessamos por ele.

\section{Quadro de preferências:}

\begin{tabular}{|c|c|}
\hline Preferência por & Características básicas decorrentes da preferência \\
\hline $\begin{array}{l}\text { IE } \\
\text { I (introversão) ou } \\
\text { E (extroversão) }\end{array}$ & $\begin{array}{l}\text { I: energia voltada para o mundo interno, ou } \\
\text { E: energia voltada para o mundo externo. }\end{array}$ \\
\hline $\begin{array}{l}\text { SN } \\
\text { S (sensação) ou } \\
\text { N (intuição) }\end{array}$ & $\begin{array}{l}\text { S: foco em fatos e na realidade presente, com forte senso prático, ou } \\
\mathrm{N} \text { : foco em visões e possibilidades, com forte senso de oportunidade. }\end{array}$ \\
\hline $\begin{array}{l}\text { TF } \\
\text { T (pensamento) } \\
\text { ou } \\
\text { F (sentimento) }\end{array}$ & $\begin{array}{l}\text { T: toma decisões de forma objetiva e impessoal, calcada sobretudo em princípios lógicos e } \\
\text { universais, ou } \\
\text { F: toma decisões baseada principalmente em valores pessoais e subjetivos. }\end{array}$ \\
\hline $\begin{array}{l}\text { JP } \\
\text { J (judicativa) ou } \\
\mathbf{P} \text { (perceptiva) }\end{array}$ & $\begin{array}{l}\text { J: prefere situações definidas e tem facilidade para decidir, o que pode fazer de maneira } \\
\text { precipitada, ou } \\
\text { P: prefere situações abertas e flexíveis, o que pode se traduzir em certa dificuldade para } \\
\text { tomar decisões. }\end{array}$ \\
\hline
\end{tabular}

${ }^{360}$ A esse respeito, julgamos pertinente a crítica trazida por ANDREW SAMUELS na obra Jung e os PósJunguianos, Imago Editora Ltda., Rio de Janeiro (RJ), 1989, pp. 108/110. 


\title{
2. ENTREVISTA COM "ISABELLA"
}

\begin{abstract}
É o "diga", o famoso "diga, diga, diga, diga"... Isso é revoltante [em tom contundente]. Às vezes o processo chega às minhas mãos - como sou auxiliar, mudo muito de uma vara para outra, portanto, pego muitos processos em curso -, fico espantada com a sucessão de "diga, diga, diga, diga..." e me pergunto porque ainda o magistrado não decidiu! É mais fácil decidir!
\end{abstract}

Isabella é uma jovem juíza. Quando, próxima de finalizar o curso secundário, precisou escolher a faculdade que seguiria, oscilou entre Direito e Medicina. Como parte de sua preparação para o exame vestibular, passou a acompanhar com certa regularidade as notícias veiculadas nos jornais, fato que alimentou revolta em seu espírito, principalmente por conta dos desmandos em nossa política. Assim, associou ao estudo do Direito o caminho onde encontraria esclarecimentos a respeito do "certo" e do "errado" na sociedade. Segundo ela, a lei seria um referencial para isso.

No ensino médio, gostava de todas as matérias que tinham bons professores à frente. No entanto, ao nominá-las, enunciou a Matemática em primeiro lugar, cuja professora "era muito boa, muito brava". Relatou dificuldade com Física, que "até hoje" acha difícil.

Uma vez na faculdade, motivada pela busca da independência financeira, logo cedo começou a estagiar em escritório de advocacia. Brigava com seu chefe sempre que se sentia obrigada a desrespeitar alguns princípios. Quando ainda criança, sua mãe profetizou que ela teria problemas com eventuais "chefes", pois dificilmente se submetia ao que não concordasse. Percebendo que se sentiria mais útil à sociedade se seguisse a carreira de magistrada, prestou concurso e foi admitida no judiciário estadual paulista.

Isabella tem grande apreço pelo trabalho que faz, a ponto de uma jornada no fórum ser capaz de mudar para melhor seu humor. Não obstante, quando perguntei que visão tinha do judiciário, fez questão de ser bem sincera: "Hoje?... Depois de alguns anos, tenho uma visão triste, porque tem muita coisa errada, como em qualquer lugar. Só que, para mim, no judiciário não poderia ter". Neste ponto, Isabela referia-se a interferências indevi- 
das de pessoa(s) da cúpula da instituição, em trabalho de natureza correcional que ela procurou empreender junto a uma vara, da qual, ao fim, chegou a ser afastada.

Demonstrou forte consciência da importância de pacificar as partes, em vez de simplesmente decidir a lide. Empenha-se nisso, mas admite certa dificuldade nessa área. Declara que, a despeito de seus esforços, as partes costumam sair conflitadas internamente, "não saem satisfeitas". Indagada como se sente em relação a isso, respondeu: "Paciência. Fiz minha parte. Decido com base no Direito". Embora tenha passagem pelo Juizado Especial Cível, informa jamais ter decidido um feito com base na equidade ${ }^{\mathbf{3 6 1}}$ e admitiu não ficar confortável com essa via. Quase chegou a isso num caso específico, mas as partes acabaram fazendo acordo.

No curso de uma audiência, procura orientar as partes. Admite haver dias em que está menos paciente, mas mesmo assim tenta desempenhar desse modo sua função jurisdicional. No contato mais direto com os litigantes, dá sinais de como está vendo a situação posta em juízo e também de como pretende decidir. Caso não façam acordo, decide. $\mathrm{Na}$ audiência, observa bem a conduta dos presentes. Afirma que as partes sempre acabam desabafando e dando sinais de sua boa ou má-fé, sendo tudo isso levado em consideração no momento de decidir.

A fim de exemplificar sua postura ao julgar, Isabella citou um caso em que um dos envolvidos apresentou, em audiência, petição muito mal feita. Juntou extratos bancários sem grifar as informações relevantes, obrigando-a a ficar procurando no meio dos documentos. Essa situação deixou-a agitada e irritada, motivo pelo qual evitou sentenciar o processo, pois reconheceu que tal estado emocional a tornaria mais severa, interferindo em sua decisão. Admitiu que quanto mais "sem educação é o advogado, mais rígida se torna”, procurando prestar atenção a isso.

E se uma das partes estiver de boa-fé, porém assistida por um mal advogado, enquanto a outra, de má-fé, tem a seu lado um profissional habilidoso, como se porta? Res-

\footnotetext{
${ }^{361}$ Esclareça-se que a Lei no ${ }^{\text {9 }}$.099/1995, que dispõe sobre os Juizados Especiais, autoriza expressamente o juiz a decidir com base na equidade (arts. $5^{\circ}, 6^{\circ}$ e 25 ), princípio de aplicação restrita no ordenamento jurídico brasileiro, haja vista que o magistrado apenas pode recorrer a ele nas hipóteses em que houver expressa previsão legal (Lei no 5.869/1973 - Código de Processo Civil, Art. 127. O juiz só decidirá por equidade nos casos previstos em lei). Ver "equidade" no "glossário jurídico".
} 
pondeu pender para o lado do mais fraco, passando a ser mais rigorosa com aquele que esteja agindo de má-fé. Ou seja, procura compensar:

Uma vez recebi um processo em que eu tinha certeza que a finalidade era burlar direito de terceiros. O advogado do autor era bom, mas para mim era evidente que havia má-fé. Levei horas para sentenciar. Estudei muito a fim de encontrar uma saída para julgar a ação improcedente. A parte tecnicamente mais fraca acabou ganhando o processo. É possível "sentir" o processo; ele também vem com uma carga emocional, ao menos para mim.

Ao longo de sua carreira, Isabella sempre foi muito criteriosa na designação de audiências conciliatórias. Afirma ser necessário levar em consideração uma série de fatores que interferem no andamento dos trabalhos: pessoal em cartório, impressora, computador, advogados querendo despachar, sobrecarga da pauta, que se projeta por um ano, etc.. Há uma série de coisas a considerar. É preciso pôr numa balança o que vale mais a pena. Desse modo, sempre procurou concentrar o esforço de conciliação nas audiências instrutórias. No entanto, declara como exceção a essa regra as causas de família, nas quais reconhece a necessidade de sempre fazer audiência de conciliação.

A despeito do andamento processual, também marca audiência conciliatória a fim de atender a pedido de advogado de uma das partes, pois "é função do juiz tentar conciliar". Sempre tenta isso, em todos os processos.

O tempo despendido no esforço conciliatório é muito variável, vindo a depender "da abertura das partes para isso". Costuma ouvir das partes, no meio do acordo, "que a juíza é quem decide", ao que responde que "se deve buscar o que for mais justo, mais equitativo", dando sua opinião a respeito, opinião esta "que sempre é bastante considerada. Sempre".

Perguntada a respeito de como se sente em audiência de conciliação, respondeu: "A mesma. Não faço a menor diferença com audiência instrutória".

Perguntada sobre se sempre costuma ouvir a parte contrária após a réplica, independentemente da juntada de documentos, Isabella respondeu: 
É o "diga", o famoso "diga, diga, diga, diga"... Isso é revoltante [em tom contundente]. Às vezes o processo chega às minhas mãos - como sou auxiliar, mudo muito de uma vara para outra, portanto, pego muitos processos em curso -, fico espantada com a sucessão de "diga, diga, diga, diga..." e me pergunto porque ainda o magistrado não decidiu! É mais fácil decidir! Acaba mais um processo, resolve-se mais um problema, o cartório terá um processo a menos! Fica nessa sucessão de “diga, diga, diga, diga...” Às vezes o processo é realmente complicado e carece de esclarecimento. Porém, nesse caso, dou um despacho especificando o que precisa ser esclarecido, e pronto.

Esclareceu que costuma seguir o seguinte procedimento:

Muito simples. Petição, contestação, réplica. Depois, segue um despacho assim: "Querem as partes produzir provas? Especifiquem, em cinco dias, justificando". Depois disso, o processo vem para mim. Analiso-o, vejo se é possível julgar no estado ou saneio-o. Em todos os processos faço isso. Todos. Exceto os de crime, ou de falência, que são diferentes. Mas nos demais, faço isso. A meu ver, é simples.

Indagada a respeito do que mais costuma chamar sua atenção quando recebe uma petição inicial (exemplifico da seguinte maneira: organização? Apresentação? Tese do advogado? Pedido? Raciocínio? Valor(es) posto(s) em juízo? Situação sócio-econômica da parte?), relata perceber muita falta de objetividade na maneira como os advogados peticionam, com iniciais mais extensas do que precisariam ser. Num primeiro contato com o pleito, vê "se a parte está enrolando ou se está dizendo o que aconteceu". E prossegue:

Em regra, enrola-se muito. Não se vai direto ao ponto. Lá para a décima lauda é que se diz o que aconteceu. Isso me chama a atenção sempre: a falta de objetividade. Outra coisa: às vezes vejo uma petição colorida, com várias palavras coloridas. É raro, mas me chama a atenção. Este sujeito pensa que está num carnaval... A formatação vem toda torta, usa letras garrafais para o que acha absurdo, põe vários pontos de exclamação (...) A cada mês, recebo 1.000 novos processos. Não é possível perder tempo com enrolação. Estou sendo bem sincera. 
Numa audiência, nossa magistrada procura observar atentamente a postura e o jeito de falar dos presentes. Quando às vezes alguém se exalta, intervém, dizendo: "caaalma..." [em tom autoritário] “... o que aconteceu?”, com o que confere oportunidade para que a pessoa conte sua história. A partir disso, costuma sugerir alguma solução, sempre analisando a reação dos envolvidos.

Lembrou de uma situação em que a advogada de umas das partes, referindo-se à pouca idade da entrevistada, disse: "Desculpe chamá-la de você, mas é que você é tão novinha", ao que respondeu preferir ser tratada por "senhora", do mesmo jeito que a trataria. “Afinal, não somos amigas, sou uma magistrada!" A fim de não deixar o clima tenso, quando isso acontece procura amenizar dizendo parecer nova por conta dos cremes modernos para a pele, etc.. No entanto, faz questão de manter a formalidade, até para que a outra parte não ache que ela tem laços de amizade com aquela que toma certa liberdade:

Até por isso. Essa formalidade existe na Justiça e tem um sentido, que é a imparcialidade. Claro que há outros sentidos, mas para mim o principal é o da imparcialidade, manter uma distância das partes.

Ao perceber que a parte ou a testemunha estão mentindo, fica muito brava. No caso da testemunha, adverte-a que "tem obrigação de dizer a verdade, que não pode omitir nada senão vai presa e será processada por falso testemunho”. Lembra de já ter mandado prender duas testemunhas, após incidente de acareação ${ }^{\mathbf{3 6 2}}$ :

Cheguei a prender duas pessoas, em audiência, por falso testemunho. Em acareação, numa cidade muito pequena. Era praxe as pessoas mentirem em audiência. A escrevente de sala, que morava na cidade, comentava isso, que todos mentiam perante o juiz. Então, após acareação, prendi dois meninos que mentiram numa tentativa de defender o amigo. Após minha ordem de prisão, o advogado pediu para conversar com eles, gerando sua retratação. Nesse caso, não acontece nada, nem B.O. nem nada. Apenas faço constar do termo. Essa regra tem exceção. Por exemplo, num processo do júri, em que percebo que a testemunha mente porque sente

\footnotetext{
${ }^{362}$ Incidente previsto no Código de Processo Civil (CPC), Art. 418: "O juiz pode ordenar, de ofício ou a requerimento da parte: (...) II - a acareação de duas ou mais testemunhas ou de algumas delas com a parte, quando, sobre fato determinado, que possa influir na decisão da causa, divergirem as suas declarações".
} 
medo de represálias: mora na favela, onde prevalece outra realidade. Já aconteceu de o promotor pressionar a testemunha ao perceber que ela mentia, e eu ter de interferir, a fim de que amenizasse a pressão. Portanto, há casos e casos. Hoje, após anos de carreira, para mim é muito claro que cada caso é um caso. Não adianta. Antes, eu não tinha essa noção. Creio que isso se deva à experiência profissional.

Isabella atuou em todas as áreas: família, cível, criminal, eleitoral. Dentre estas, gostou menos da de família, à qual atribui um desgaste emocional muito grande:

Por incrível que pareça, a audiência na área de família às vezes é mais carregada do que a de um júri por homicídio triplamente qualificado, ao menos para mim. Envolve muita emoção. Não entendo muito, por exemplo, a mãe usar o filho como escudo contra o ex-marido, e coisas do gênero, pegar um filho e não devolver, não pagar pensão, etc.. Isso, para mim, foge da moral mínima, do mínimo ético universal que as pessoas têm de ter. Por isso, é muito complicado trabalhar nessa área. $\mathrm{O}$ que mais gosto é trabalhar com criminal. É que sou muito prática. Não gosto de enrolação. Dou despachos curtos. Gosto de resolver o problema da parte. Não faço questão de mostrar erudição jurídica, que li tantos livros para resolver aquele caso; gostaria de ter tempo para fazer isso, mas não é possível. Na área criminal, quando o juiz manda prender alguém, a pessoa aparece presa na semana seguinte. Vê-se o resultado de sua atuação. Quando trabalhei numa câmara criminal, atuando no tribunal, julgando casos que dificilmente iriam para uma instância superior, notei uma postura diferente: era mais boazinha. Mas ao atuar numa vara criminal [primeira instância], não sou nada boazinha. Pelo contrário. Sou bem rigorosa. Quando atuei por um ano e meio numa determinada região da capital, a criminalidade caiu $50 \%$, porque eu deixava todos os bandidos presos - homicidas, estupradores. Quem me relatou isso foi o delegado e também uma amiga promotora. Infelizmente, não dispomos de instrumentos outros além do cárcere para lidar com a criminalidade. $\mathrm{O}$ problema é social, mas o Estado não lida bem com isso. O que pode um magistrado fazer diante de alguém que põe uma arma de fogo na cabeça de outra pessoa, tranca toda uma família num quarto, em clima de terror? O jeito é pôr o sujeito na prisão, pois é o que funciona. Vejo as coisas funcionarem na área criminal; no cível, não. A parte fica dez anos executando uma sentença, sem chegar a nenhum resultado.

Revelou que para o julgamento das causas cíveis baseia-se mais na doutrina e, para as causas criminais, vale-se sobretudo da jurisprudência. 
Indagada sobre se costuma receber advogados para despachar, respondeu que sim, pois gostaria de ser recebida pelo magistrado caso estivesse advogando. Apenas no meio de uma audiência, ou quando está atrasada para iniciar alguma é que evita fazê-lo. No entanto, não tem uma boa visão geral dos advogados, pois percebe a predominância do "uso temerário de atos processuais... mais má-fé do que boa-fé. É isso. Infelizmente”. Continua, esclarecendo seu ponto de vista:

Embargos de declaração, por exemplo: toda sentença tem embargos de declaração ${ }^{363}$. Hoje despachei três processos de embargos de declaração e em todos a parte queria reforma da sentença. Não é caso de embargos. Portanto, tenho aplicado multa sempre que noto o uso dos embargos com intuito protelatório, pois é caso de litigância de má-fé. Multo na hora. Sentencio de cinco a sete processos por dia. Já pensou se todos gerarem embargos de declaração?! Não farei mais nada além de julgar embargos! E os outros processos? O advogado é o responsável por isso. Associo tudo ao advogado, pois a parte é leiga. É preciso fazer essa separação. Às vezes o problema é o advogado, não a parte. Já aconteceu de o advogado começar a gritar em audiência, brigando com o outro advogado; é preciso não fazer a parte pagar por isso, porque às vezes ela nem sabia que o advogado teria tal conduta. Como tem mais coisas ruins do que boas, isso prejudica a imagem de toda a classe. Ontem, uma advogada que já tinha certa idade, uma senhora, educada, bonita, em dado momento começou a se exaltar durante a audiência. Queria falar antes da vez dela e interrompia a todo momento a fala da parte. Pedi-lhe calma por duas vezes. Na terceira vez, gritou:

- Eu não vou falar?! Quero prestar meu depoimento pessoal. A senhora não vai gravar?

Respondi:

- A senhora não quer se sentar aqui e presidir a audiência? Quem preside a audiência sou eu. Agora, quem está falando é a autora. Quando eu decidir que chegou sua vez, a senhora poderá falar e isso será gravado. Se a senhora não quiser falar, tudo bem, será aplicada a pena de confissão. Mas não estou entendendo porque a senhora está agindo dessa forma.

${ }^{363}$ Ver "embargos de declaração" no "glossário jurídico". 
Fico nervosa, porque há casos estressantes, difíceis. Não é necessário tratar o juiz dessa forma. Talvez porque eu seja nova, não sei, ou porque ela estava muito irritada... Enfim: é negativa a imagem que tenho da advocacia.

No que diz respeito à digitalização de processos, revelou-se entusiasta da ideia, pelo fato de passar "a ser tudo mais rápido". No entanto, fez uma ressalva sobre a falta de estrutura material para dar suporte ao projeto. Lembrou que na justiça do trabalho talvez já esteja funcionando dessa forma, com limite de páginas para petições iniciais, sendo tudo enviado eletronicamente. "Funciona".

Para finalizar a entrevista, li para Isabella o seguinte texto, extraído do livro O Juiz e a Emoção, de Lídia Reis de Almeida Prado: "Karl Llewellyn acredita que, geralmente, a mente do juiz primeiro antecipa a decisão que considera justa (dentro da ordem jurídico-positiva) e depois procura a norma que pode servir de fundamento a essa solução, a-

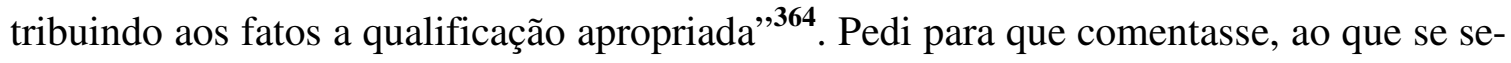
guiu:

Essa é uma parte marcante do livro. Acho que é assim mesmo. Isso acontece. Ao olhar o processo, não deixo de ter uma posição imediata a respeito. Primeiro vem o bom-senso. A gente vai buscar na lei onde o bom-senso encontra fundamento. Mas posso mudar de opinião; posso perceber um documento pequeno, que passou despercebido num primeiro momento, e que muda minha visão da causa. Já mudei de opinião várias vezes, até por achar na legislação regras até então por mim desconhecidas. Já aconteceu de eu mudar de opinião durante a própria fundamentação.

${ }^{364}$ Op. cit., pp. 13/14. 


\subsection{ANÁLISE DO PERFIL TIPOLÓGICO DE "ISABELLA"}

No caso de Isabella, algumas características típicas ressaltam, enquanto outras parecem ficar menos evidenciadas, conforme veremos.

Uma característica que nos parece evidente na personalidade de Isabella é a facilidade para a tomada de decisões. Ela não demonstra ter necessidade de buscar um leque muito grande de informações (atribuição das funções PERCEPTIVAS - P) para então decidir um caso (atribuição das funções JUDICATIVAS - J). Isso fica relativamente claro quando mostra certo conforto em decidir uma causa na hipótese de as partes não terem logrado chegar a um acordo. Mais do que isso: quando Isabella afirma que, no curso dos esforços conciliatórios, costuma dar sua opinião a respeito do caso, indica já ter uma decisão tomada internamente, não sofrendo em, com isso, eventualmente influenciar o rumo da transação.

Outro sinal de que Isabella deve pertencer ao tipo JUDICATIVO é a forma contundente como se refere à sucessão de despachos proferidos por colegas seus visando a trazer ao processo um maior número de dados:

É o "diga”, o famoso "diga, diga, diga, diga"... Isso é revoltante [em tom contundente]. Às vezes o processo chega às minhas mãos - como sou auxiliar, mudo muito de uma vara para outra, portanto, pego muitos processos em curso -, fico espantada com a sucessão de "diga, diga, diga, diga..." e me pergunto porque ainda o magistrado não decidiu! É mais fácil decidir!

Portanto, pode-se afirmar que, no exercício de sua profissão, Isabella não demonstra ter dificuldade para tomar decisões.

Assim, confrontados os dois extremos - o de quem decide a partir de alguns dados da realidade, correndo o risco de precipitar-se (característica do tipo JUDICATIVO - J), e o de quem procura exaurir a exploração dos dados antes de tomar decisões, correndo o risco de eventualmente fazê-lo com certo atraso (característica do tipo PERCEPTIVO - P) -, há razões plausíveis para inserirmos Isabella no primeiro grupo. Isso implica dizer que 
ela extroverte por meio de uma função racional, embora ainda não saibamos qual das duas possíveis: PENSAMENTO (T) ou SENTIMENTO (F).

Antes de tentarmos responder a isso, reputamos conveniente voltar o foco de nossa análise para suas funções perceptivas, ou irracionais: predominaria em Isabella a função SENSAÇÃO (S) ou a INTUIÇÃO (N)?

O conteúdo da entrevista põe em relevo sobretudo um senso prático não apenas na conduta de Isabella, como também em sua forma de ver o mundo. No momento de decidir, por exemplo, sobre se designa ou não audiência conciliatória para determinado caso, parece ser guiada pela praticidade, pois afirma levar em consideração uma série de fatores, como pessoal em cartório, sobrecarga de pauta, etc., pondo tudo numa balança a fim de avaliar o que vale mais a pena em termos de resultado.

Nossa entrevistada apenas adota como "regra" a designação de audiências conciliatórias em todas as causas de família, o que também parece decorrer de um senso prático, pois é sabido que nessa área o processo alcança melhor resultado quando se concede às partes envolvidas maior espaço para o extravasamento de seus conteúdos emocionais. Também chama a atenção a percepção que Isabella tem das petições iniciais, censurando a falta de alinhamento de parágrafos, o uso de palavras coloridas (“... este sujeito pensa que está num carnaval") e de letras garrafais. Ou seja: tem-se a impressão de que o foco de sua percepção volta-se mais para o concreto, com aferição de "detalhes" a partir dos sentidos (característica da SENSAÇÃO) do que para o abstrato, com aferição da realidade de maneira mais difusa e inconsciente (característica da INTUIÇÃO).

Outro momento em que a função SENSAÇÃO se faz presente está no motivo pelo qual Isabella justificou seu gosto pela área criminal: vê nela resultado concreto de sua atuação profissional, diferentemente da área cível, em que a parte vencedora muitas vezes se vê obrigada a executar a sentença por dez anos, "sem chegar a nenhum resultado".

O mesmo entusiasmo de cunho "funcionalista" é observável em sua posição favorável à digitalização dos processos, a partir do que tudo poderá fluir de maneira mais rápida (pode-se entender mais "prática"). Até mesmo na ressalva que faz a essa tendência, o 
foco de sua atenção recai sobre a eventual falta de suporte material para o pleno êxito do projeto, ou seja, está mais atenta aos aspectos de execução da ideia (característica do tipo SENSAÇÃO) do que para a excelência da ideia em si mesma (característica do tipo INTUIÇÃO).

Evidentemente, o mundo exige a presença de ambas as funções: não basta ter ideias inovadoras, porém inexequíveis (o que decorreria de um tipo INTUITIVO puro), mas é preciso ter ideias inovadoras. Ao mesmo tempo, é necessário contar com quem tenha habilidade para executá-las de forma consistente, levando a tarefa até o fim.

A predileção de Isabella pelo concreto parece fazer-se visível também na forma como sentencia o processo, pois prefere ter mais produtividade - resolver um número maior de casos ("o problema da parte") - a desenvolver teses: "Não faço questão de mostrar erudição jurídica, que li tantos livros para resolver aquele caso; gostaria de ter tempo para fazer isso, mas não é possível”.

Por outro lado, sentimos dificuldade para encontrar, em sua fala, indícios da função INTUIÇÃO, levando até mesmo à hipótese de que seria sua função inferior, quando não a terciária. Nessa mesma direção, observamos que quando Isabella fala das disciplinas com que se deparou no curso secundário, aponta maior dificuldade (aliás, "até hoje”) em Física, reforçando a hipótese de que suas maiores habilidades não se concentram no manejo de ideias abstratas, campo de predileção dos INTUITIVOS.

Diante do quadro acima, sentimo-nos relativamente confortáveis para afirmar que a fala de Isabella aponta para o predomínio da função SENSAÇÃO sobre sua oposta, a INTUIÇÃO.

Voltado, agora, o foco de nossa análise para as funções judicativas ou racionais, vejamos o que predominaria em Isabella: a função PENSAMENTO ou o SENTIMENTO?

Um aspecto aparentemente claro em sua personalidade é a habilidade para desenvolver raciocínios lógicos. Não por acaso, ela nos fala de uma facilidade em Matemática, cuja professora considerava "muito boa, muito brava". Além da facilidade com tal discipli- 
na, também nos chama a atenção a forma como o elogio é feito: não era boa por ser "boazinha"; era boa por conseguir manter a disciplina dos alunos ("brava”). Portanto, Isabella demonstra valer-se de critérios de avaliação de caráter mais "objetivo" (característica do PENSAMENTO) do que "subjetivo" (característica do SENTIMENTO).

ANNA MATHILDE PACHECO E CHAVES, ao escrever sobre a influência dos tipos na dinâmica do ensino-aprendizado, afirma que um aluno do tipo SENTIMENTO (EXTROVERTIDO) "prefere um professor menos intelectual e mais afetivo do que o contrário". ${ }^{365}$ O discurso de Isabella, portanto, a respeito de sua relação com seus professores não parece trazer a marca do tipo SENTIMENTO.

Quando Isabella afirma ter optado pela carreira jurídica por conta de uma busca pela definição do "certo" e do "errado", nota-se estar sua busca pelo ético imantada pelo caráter lógico-racional, decorrente do estudo, o que também podemos tomar como sinal da função PENSAMENTO, uma vez que busca parâmetros éticos de natureza objetiva. Nesse ponto da fala de Isabella notamos também um traço de INTROVERSÃO. Isso está sutilmente presente na forma como justifica a opção pelo estudo do Direito: diante de sua indignação com os escândalos políticos, sentiu necessidade de "estudar" a lei, ou seja, de buscar um sentido moral mais profundo de avaliação do mundo (meio externo) que a cerca, caracterizado pela hostilidade. Isso é característica típica do INTROVERTIDO.

Importante lembrar que o fato de apresentar traços de INTROVERSÃO não significa que essa atitude seja predominante na personalidade de Isabella. Apenas estamos apontando as características de cada elemento da tipologia, sem ainda chegar à conclusão sobre se nossa entrevistada é INTROVERTIDA ou EXTROVERTIDA, o que será possível após uma análise mais abrangente.

Outro sinal da predominância da função PENSAMENTO pode ser extraído da maneira como Isabella revelou conduzir as audiências. Ela não hesita em expressar sua autoridade sempre que necessário - e a experiência demonstra que muitas vezes o é. No entanto, depois de pôr as coisas em ordem, procura "amenizar" o clima gerado pela exposição

365 “Aplicações Educacionais", capítulo do livro Tipos: a diversidade humana, de ZACHARIAS, José Jorge de Morais, Op. cit., p. 99. 
do poder de que foi munida pelo Estado. Isso aponta para as funções PENSAMENTO e SENTIMENTO, mas a primeira preponderando sobre a última. Seriam funções secundária e terciária, respectivamente? A hipótese já está formulada. Avancemos.

Quando confrontada com a mentira de uma testemunha, Isabella é capaz de promover uma acareação e relata já ter dado ordem de prisão a dois rapazes, e isso logo no início de sua carreira. São posturas vinculadas à execução de princípios, o que, no caso dela, parece apontar para a ação da função PENSAMENTO, cujo primeiro sinal, na verdade, surgiu quando se falou da designação de audiências conciliatórias: há toda uma ponderação lógica e de cunho prático a respeito das circunstâncias envolvidas. No entanto, já mais experiente, Isabella aprendeu a ponderar a respeito da necessidade de amenizar a aplicação literal da lei, conforme é o caso da tolerância dispensada à testemunha que mente não para favorecer uma das partes do processo, mas para proteger sua própria integridade física (“... percebo que a testemunha mente porque sente medo de represálias: mora na favela, onde prevalece outra realidade"). Isso reforça a hipótese de as funções PENSAMENTO e SENTIMENTO estarem atuando juntas, embora uma delas - a primeira - pareça predominar.

Num outro momento de sua fala, Isabella dá sinais de uma função SENTIMENTO menos desenvolvida, uma vez que chegou a afirmar que “(...) a audiência na área de família às vezes é mais carregada do que a de um júri por homicídio triplamente qualificado, ao menos para mim. Envolve muita emoção". Em seguida, quando procura explicar as razões de tamanho desgaste emocional por ela vivenciado na área de família, vale-se da função PENSAMENTO, cujo assento está nos princípios:

Não entendo muito, por exemplo, a mãe usar o filho como escudo contra o exmarido, e coisas do gênero, pegar um filho e não devolver, não pagar pensão, etc.. Isso, para mim, foge da moral mínima, do mínimo ético universal que as pessoas têm de ter. Por isso, é muito complicado trabalhar nessa área.

Podemos atribuir outro ponto para a hipótese de que a função PENSAMENTO predomina no psiquismo de Isabella quando nos deparamos com a aplicação de multa pelo uso 
indevido do recurso de embargos declaratórios "366: "Multo na hora". Mais uma vez, vê-se tal postura aliada a um senso prático, característico da função SENSAÇÃO: "Sentencio de cinco a sete processos por dia. Já pensou se todos gerarem embargos de declaração?! Não farei mais nada além de julgar embargos! E os outros processos?”

Colhidos estes elementos, já nos sentimos aptos a sugerir a preponderância da função PENSAMENTO sobre sua oposta, o SENTIMENTO.

Falta definir duas coisas: não apenas a atitude predominante no psiquismo de Isabella - se INTROVERTIDA ou EXTROVERTIDA -, mas também qual das duas funções apuradas é a principal: PENSAMENTO ou SENSAÇÃO?

Precisamos lembrar que a função principal tem sempre a natureza da atitude predominante, e, ainda, que se atribui à função auxiliar atitude oposta à da função principal ${ }^{367}$. Em outras palavras: se Isabella for de atitude INTROVERTIDA, sua função principal será vivida de maneira INTROVERTIDA e, como contrapeso, EXTROVERTERÁ por meio da função auxiliar; se Isabella for de atitude EXTROVERTIDA, também será EXTROVERTIDA a maneira como usará sua função principal, e INTROVERTIDA será sua função auxiliar.

Por conta do que ficou dito acima, ao sugerirmos que Isabella pertenceria ao tipo JUDICATIVO, ou seja, que extroverte por meio de uma função racional/judicativa (T ou F - no caso dela, T), é possível afirmar o seguinte:

(a) se Isabella for INTROVERTIDA, sua função principal será a irracional, no caso SENSAÇÃO, pois já sabemos que ela extroverte por meio de uma função racional, no caso, PENSAMENTO, que então será auxiliar;

(b) se Isabella for EXTROVERTIDA, sua função principal será a racional, no caso, PENSAMENTO, e irracional a função auxiliar, no caso, SENSAÇÃO.

\footnotetext{
${ }^{366}$ A lei processual civil (CPC, art. 538, par. único) prevê aplicação de multa na hipótese de uso indevido dos embargos declaratórios, mas, na prática, é muito raro vê-la aplicada.

${ }^{367}$ MYERS, Isabel Briggs. Gifts Differing ... , p. 20.
} 
Em alguns casos parece mais fácil definir qual atitude ou função predominam no psiquismo de uma pessoa, mas em outros isso é tarefa bastante árdua. Quanto mais unilateral estiver a atitude ou a função, mais visível será. No entanto, e felizmente, nem sempre as pessoas vivenciam de maneira uniforme suas preferências. Um magistrado com forte senso de dever pode fazer um grande esforço para "extroverter" e desempenhar suas funções como se fôra um "EXTROVERTIDO", caso entenda ser isso importante para alcançar melhores resultados, sem que, no íntimo, seja na verdade um INTROVERTIDO. No caso de Isabella, julgamos colher de sua fala mais indícios de INTROVERSÃO do que de EXTROVERSÃO.

Como no INTROVERTIDO o direcionamento da energia psíquica tem por alvo o próprio sujeito, a relação que este passa a ter com o objeto (meio externo) costuma ser visivelmente permeada por um senso de subjetividade. Mas nem sempre isso é muito evidente, podendo ser observado, com a sutileza que é peculiar a esse tipo de análise, no trecho em que Isabella, quando perguntada a respeito da visão que tinha do judiciário enquanto instituição, diz ser ela "triste, pelo fato de ter muita coisa errada, como em qualquer lugar. Só que, para mim, no judiciário não poderia ter". Ou seja, parte de uma idealização (olhar interno) e, ao constatar a não-correspondência da realidade a ela, experimenta uma sensação de tristeza. Assim como na apreciação do "mundo político", também aqui o meio externo traz um quê de "ameaçador".

Outro aspecto mais típico da atitude INTROVERTIDA diz respeito à vinculação rígida às próprias ideias e princípios, a ponto de a mãe ter profetizado que ela teria dificuldade para se submeter a algum superior hierárquico, o que de fato Isabella percebeu quando estagiou em escritório de advocacia e teve de se defrontar com situações que feriam "seus princípios". A imagem que um EXTROVERTIDO costuma fazer de um INTROVERTIDO é muitas vezes a de um indivíduo egocêntrico, fechado numa visão pessoal e inflexível do mundo, impossível de ser desafiada pela realidade ${ }^{\mathbf{3 6 8}}$.

Talvez também se possa vislumbrar em Isabella uma forma INTROVERTIDA de ser na maneira como se refere à classe dos advogados, que tende a ser mais negativa do

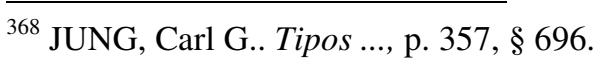


que positiva, mais ameaçadora e pessimista do que redentora e otimista, como seria mais típico da atitude EXTROVERTIDA ${ }^{369}$.

Partindo de um outro ângulo de análise, que leva em consideração as funções, lembramos já termos sugerido as que prevalecem em Isabella: SENSAÇÃO e PENSAMENTO. Apenas não sabemos qual toma a frente da outra. Uma dica, porém, pode ser buscada se nos perguntarmos a respeito da função inferior, porque, definida esta, teremos a superior. No caso de Isabella, concorrem ao cargo de função inferior as funções INTUIÇÃO (pois é a que se opõe à SENSAÇÃO) e SENTIMENTO (é o que se opõe ao PENSAMENTO).

Ora, pelo discurso acima analisado, parece-nos mais presente a função SENTIMENTO do que a INTUIÇÃO. Se esta última ocupar a posição de função inferior, que é o que nos parece acertado, a SENSAÇÃO (que a ela se opõe) será a função principal e, até por raciocínio lógico, PENSAMENTO a auxiliar.

Mas sabemos, também, que a função principal de Isabella há de ser expressa por meio da atitude predominante, ou seja, sendo SENSAÇÃO a função principal, Isabella será SENSAÇÃO INTROVERTIDA.

Conforme vimos acima, a função pela qual Isabella parece extroverter é do tipo JUDICATIVO ou racional (PENSAMENTO - T ou SENTIMENTO - F, no caso dela, T); logo, Isabella não pode extroverter por meio da função SENSAÇÃO, que é irracional. Não extrovertendo por meio da função SENSAÇÃO, e sendo INTROVERTIDA sua atitude predominante, resta-nos deduzir logicamente ser a SENSAÇÃO sua função principal, predominando, portanto, sobre o PENSAMENTO.

Isabella concordou em responder ao questionário de aferição de tipo, o que confirmou as sugestões feitas acima. Ao final, confrontada com as características gerais atribuídas ao tipo apontado, assentiu com elas.

\footnotetext{
${ }^{369}$ Isso não significa, em absoluto, que todo introvertido seja pessimista e todo extrovertido otimista. É evidente que há introvertidos otimistas e extrovertidos pessimistas, até porque todos devemos ter - como, de fato, temos, até por imposição de sobrevivência -, ao mesmo tempo aspectos de introversão e extro-
} 


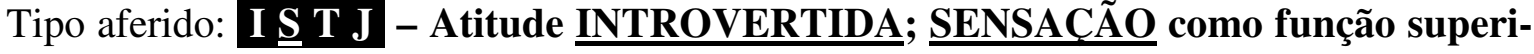 or e PENSAMENTO como função auxiliar.}

Identificado o tipo mais provável de Isabella, vejamos como se expressa a função SENSAÇÃO (afeita a detalhes) quando iluminada pelo PENSAMENTO (hábil em construir raciocínios lógicos):

Vistos em saneador.

Partes legítimas e bem representadas, presentes as condições da ação e pressupostos processuais.

Fixo os pontos controvertidos: (i) cumprimento exato do contrato de previdência privada celebrado entre as partes; (ii) alteração unilateral do contrato; (iii) regras diferenciadas para a concessão de um mesmo benefício, em desigualdade entre integrantes do mesmo grupo.

Defiro a produção de prova pericial contábil requerida pelo autor. Nomeio o perito contábil Intime-o para estimar seus honorários, devendo iniciar os trabalhos após o depósito. As partes deverão apresentar quesitos e indicar assistente técnico, se for o caso, em 10 dias. Laudo em 30 dias.

Os assistentes técnicos oferecerão seus pareceres no prazo comum de 10 dias após a apresentação do laudo, independentemente de intimação (art. 433, parágrafo único do CPC).

A parte autora deverá arcar com as verbas honorárias, não verificando, in casu, a hipótese de inversão do ônus da prova, devendo prevalecer a regra do artigo 333 do CPC. Concedo o prazo de 10 dias para o depósito, após o arbitramento.

Quesitos do juízo:

1. Se houve cumprimento exato do contrato celebrado entre as partes.

2. Se houve alteração unilateral do contrato.

3. Se há regras diferenciadas para integrantes do mesmo grupo.

versão. O que se pontuam são características mais conformes a cada tipo tomado idealmente, construído o ideal a partir de dados estatísticos. 
Produzida a prova pericial, digam as partes sobre o laudo em 10 dias.

Não vislumbro ser necessária a colheita de prova testemunhal, a priori, por isso deixo de designar data para audiência.

Determino à requerida junte aos autos cópia do(s) contrato(s) celebrado(s) entre as partes, em 5 dias.

Intime-se.

\section{MATERIAL COLHIDO NO CURSO DAS AUDIÊNCIAS}

Tive oportunidade de acompanhar a atuação de Isabella ao longo de seis audiências, ao fim das quais apenas um processo teve continuidade; os outros cinco foram extintos da seguinte forma: 1 (um) por desistência do autor, 1 (um) por sentença homologatória de acordo e 3 (três) por sentença de mérito.

Assim que as partes ingressavam na sala, Isabella logo perguntava se havia acordo: “tem proposta?” Em não havendo, voltava sua atenção para pontos específicos do processo, como, por exemplo, a ausência de prova da entrega de mercadoria e coisas do gênero. Em dado momento, diante do inconformismo da autora com as alegações do réu, nossa magistrada disse àquela, em tom gentil: "Mas a senhora não produziu prova disso [dos fatos alegados]. Precisa provar o que alega..."

Após encerramento dos debates, pedia às partes para que aguardassem fora da sala pela prolação da sentença. Uma vez sozinha, passava à decisão, digitada diretamente por ela num computador. Como muitos juízes se valem da presença do escrevente e ditam para ele o teor da sentença, questionei-a a respeito. Ela alegou que desse modo seu "raciocínio é mais rápido". Não pude deixar de ver nesse conjunto de medidas um sinal de INTROVERSÃO.

Duas audiências foram acompanhadas por um estudante de Direito. Em dado momento, e a pedido dele, o escrevente veio perguntar se Isabella permitiria a inclusão de seu nome no termo de audiência, para fins de comprovação de presença. A resposta foi: "Não... Já pensou se todos os estagiários me pedirem isso?!..." Podemos ver nessa conduta um 
senso de praticidade (SENSAÇÃO), amparado por uma racionalidade mais objetiva (PENSAMENTO).

Num outro processo, nossa magistrada conseguiu levar as partes a um acordo pelo fato de apresentar ao autor, que era o ponto de resistência, uma perspectiva concreta daquilo que poderia ser obtido caso prosseguisse com a ação. "Olha, eu aceitaria", comentou ela, em tom bastante gentil. Como a oferta feita pela empresa ré era até melhor do que a média dos valores fixados pelo tribunal, o acordo acabou sendo realizado.

Isabella prima por uma intensa apuração da realidade, que vem na forma de "detalhes", sendo capaz de fazer rápidas buscas pela "internet" a fim de se certificar de alguma informação que possa auxiliá-la na avaliação do caso. Essa preocupação com a verdade fática às vezes cria situações incomuns. Foi o que ocorreu num caso que me relatou. $\mathrm{O}$ autor da ação adquirira um aparelho de telefonia móvel e alegava defeito do produto, com base no que pretendia ser indenizado. Tratava-se de um senhor de idade. Após olhar para ele, percebendo seu perfil e forma de agir, Isabella perguntou:

- O aparelho está com defeito ou o senhor é que não sabe usar?!...

Notando a surpresa e o constrangimento do autor, prosseguiu:

- O senhor tem aí o manual?

O homem apresentou a ela o manual do aparelho que, por acaso, estava com ele. Isabella, então, procurou a parte relativa à função cujo defeito se alegava e logrou fazer dois testes, no que confirmou o engano em que incorria o demandante. No entanto, para surpresa de todos os presentes, apesar das evidências ele insistia na existência do defeito, alegando não ter notado o resultado do teste. Diante disso, Isabella advertiu-o:

- Quer dizer que todo mundo notou que o aparelho funcionou, menos o senhor?! Se quiser prosseguir com a ação, vou julgar. Mas acho melhor o senhor não fazer isso...

Era caso certo de litigância de má-fé, finalizado com a desistência do autor. O advogado da empresa ré ficou encantado. Disse-lhe nunca ter presenciado nada parecido e parabenizoua pela iniciativa. No entanto, Isabella respondeu que nada mais fez do que recorrer à inspeção judicial, meio de prova previsto legalmente ${ }^{370}$.

\footnotetext{
${ }^{370}$ De fato, dispõe o art. 440 do Código de Processo Civil: "O juiz, de ofício ou a requerimento da parte, pode, em qualquer fase do processo, inspecionar pessoas ou coisas, a fim de se esclarecer sobre fato, que interesse à decisão da causa".
} 


\title{
3. ENTREVISTA COM "EUSTÁQUIO"
}

\author{
Algumas pessoas me dizem, em audiência: \\ - Puxa, doutor, isso não é justo! \\ - Tem razão. Não é justo. Mas na sua situação é o melhor \\ caminho. E sempre falo: Não se esqueça de que Deus es- \\ creve certo por linhas tortas.
}

A vida de Eustáquio desembocou na magistratura em parte por acaso. Antes de finalizar o curso de Direito, constituiu família e precisou aumentar sua renda de modo a garantir aos filhos a mesma qualidade de educação que ele recebera de seus pais. Foi um período de grandes dificuldades, tanto do ponto de vista financeiro quanto pessoal. Por um lado, uma nova família crescia sob sua responsabilidade direta; por outro, ele vivenciava dolorosas perdas com a partida quase simultânea de seus avôs, aos quais era muito vinculado afetivamente. Tal combinação parece ter gerado uma carga mais pesada do que ele pôde à época suportar. Com suas palavras:

Mal saí do cemitério, meus problemas conjugais começaram: eu tinha de estudar e ver o que ia acontecer de minha vida familiar. A estas perdas sucederam-se outras. Foi uma fase terrível. Acabei me separando de minha mulher. Eu estava desempregado e acabei ficando sem alternativa: era passar ou passar. Prestei vários concursos: magistratura, ministério público, procuradoria do município, delegado de polícia. O primeiro em que passei foi o da magistratura. Curiosamente, depois que passei, sentia-me incapaz de prestar qualquer outro concurso, pois não conseguia me lembrar de mais nada do que havia estudado. Veja: não foi nenhuma vocação decorrente de um referencial na família. Foram necessidades imperativas, com objetivos muito claros. De repente, encontrei uma vocação acadêmica.

Indagado a respeito da visão que possui do judiciário, Eustáquio diz ser "a pior possível”. No centro de sua crítica, coloca o excessivo “culto à forma:

Nosso paradigma de atuação profissional é lamentável (...) as pessoas são muito "parnasianas": cultuam a forma; têm a veleidade de acreditar que por meio da lei poderemos construir um país de anjos. Ao pensarem que quem manda é a lei, alfor- 
riam-se de qualquer responsabilidade por suas atuações (...) Não se rompem paradigmas.

No caso, refere-se ao paradigma do juiz como funcionário público, a ele atribuindose a função de aplicar a lei a partir de um procedimento lógico-formal, sem criatividade, sem atentar para as peculiares exigências de determinado caso concreto. Na visão de Eustáquio, o juiz não é propriamente um funcionário público, mas "uma parcela do Poder do Estado e, justamente por isso, tem uma imensa responsabilidade e dever (...) acho que as pessoas estão muito preocupadas com a questão do próprio prazer, da própria satisfação, e veem no tribunal de justiça um 'patrão'. Mas as pessoas do tribunal devem ser vistas como parceiras; afinal, estamos todos no mesmo barco".

Eustáquio considera fundamental para solução do litígio o contato do juiz com as partes. Afirma ser a audiência o "ato mais importante que o juiz pode realizar. É nesse momento que ele tem condições de 'quebrar a forma' e olhar para as pessoas”. Como exemplo, lembrou de um processo de execução cuja sentença havia sido proferida por um colega seu que, em sua opinião, havia sido excessivamente rigoroso com as partes sucumbentes. Eustáquio atuou apenas na fase de execução (cumprimento do julgado) e alimentara um forte sentimento de indignação em relação aos devedores por conta da enorme quantidade de expedientes processuais por eles utilizados a fim de frustrar a satisfação do crédito. Todavia, o contato com as partes na audiência conciliatória serviu para mudar sua opinião:

O credor era arrogante, tinha um aspecto sujo e passava uma péssima impressão; do outro lado, o casal de devedores: o marido, com jeito de malandro, mas daqueles que sempre se deixam enganar, enquanto a mulher expressava um ódio terrível em relação ao credor. Ela entrou envergonhada. Enquanto a audiência se desenvolvia, e o credor mentia, a raiva da mulher se acirrava. Acabei intervindo a fim de acalmá-la. Naquele momento, mudei radicalmente a ideia que tinha a respeito daquele casal, que até então eu considerava ordinário por haver usado de todos os artifícios possíveis para emperrar o andamento da execução: descobri que eram inocentes. A dinâmica da audiência revelou isso. 
Outro exemplo interessante diz respeito a uma audiência de investigação de paternidade, o que, segundo Eustáquio, "parece ter virado moda. Desculpe a expressão, mas parece haver uma 'síndrome do chifre' no país que é um negócio impressionante". Ao prosseguir falando, demonstra que seu incômodo maior decorre do fato de os adultos acabarem envolvendo os filhos em suas tramas, gerando sofrimento para os pequenos. Isso é evidenciado pelo uso de um palavreado bastante agressivo:

E o que os animais me fazem, desculpe a expressão: eles lixam os próprios cornos com a autoestima das crianças. Ora, ninguém tem o direito de fazer isso. Eu bato firme. Não permito que essas coisas ocorram. Levo as partes a um acordo.

Leva as partes a um acordo?... Mas como isso se poderia dar? Eustáquio sequer aguardou a pergunta, já foi logo esclarecendo:

Numa audiência, perguntei ao autor:

- Por que o senhor quer fazer o exame [de DNA]?

- Mas não é o meu direito? - respondeu ele, em tom arrogante.

- Não. É seu direito em termos. Porque o judiciário não é aventura. Não se "mata curiosidade" aqui. Preciso saber o que está se passando.

- Tenho recebido muitos telefonemas anônimos, dizendo que eu não sou o pai.

- Bom... e quem é esse anônimo?

- Eu não sei, senão não seria anônimo! - respondeu ele, em tom exaltado.

- E por que você escuta?... Existe gente ruim no mundo. Por que você tem de partir do princípio de que o "anônimo" é que está falando a verdade, em vez de sua mulher?

Então, ele começou a tecer uma série de justificativas. No meio delas, ele disse:

- E depois... minha filha também quer saber a verdade, porque ela atendeu a uma destas ligações e passou a ter dúvida.

Quando ouvi isso, presumi que a tal filha tivesse uns dezesseis, dezessete anos, no mínimo, que seria o necessário para que ela pudesse avaliar a situação. Perguntei:

- E qual é a idade de sua filha?

- Ela tem oito anos - respondeu ele.

- Oito?!

Nesse momento, foi como se eu "tivesse tido uma luz". Falei para ele: 
- Meu senhor, então vamos fazer o seguinte: em primeiro lugar, o senhor está desistindo desta ação agora, e ainda vai colocar no papel: "Eu não tenho dúvida de que minha filha é minha filha”. Segundo: se eu souber que o senhor está ainda pedindo para os seus amigos ligarem para sua casa, juro que acabo com sua raça!

Ele ficou cabisbaixo e não teve como responder a isso. Há coisas que não são ditas no processo e que apenas podem ser vividas, extraídas na dinâmica que se instala nas audiências. A pessoa emite uma mensagem por meio de enunciados dotados de significado mas também existe uma linguagem corporal, à qual precisamos estar bastante atentos. Este senhor a que me refiro acabou confirmando minha intuição pelo estado de choque em que ele ficou e a baixada de olhos que ele deu.

Não consegui conter meu espanto diante do grau de certeza de Eustáquio quanto à correção de sua "leitura corporal". E se isso não correspondesse à realidade?! Portanto, decidi questioná-lo sobre o interesse do autor da ação investigatória de contratar advogado e se dar ao trabalho de ingressar em juízo se, na realidade, não tivesse dúvidas a respeito da paternidade. Eustáquio continuou enfático:

Tinha uma nova bruaca, uma nova mulher no pedaço e ele não queria pagar alimentos para a antiga. O caminho é começar a questionar a filiação. Isto é bastante comum. Em razão das novas relações familiares, as pessoas abandonam as anteriores. Não estão nem aí; não têm a menor consideração. Mas para perceber isso é preciso estar atento para o que as partes sentem. Quanto mais ficamos presos à forma, mais nos tornamos escravos do outro; quanto mais se traz as partes à audiência, mais condição há de sentir o que está acontecendo. Outro dia me desgastei com um advogado em audiência - ambos não estávamos num bom dia -, para depois perceber que estávamos sustentando a mesma coisa! Somos amigos até hoje.

Por considerar a audiência conciliatória como "o ato mais importante que o juiz pode realizar", Eustáquio simplesmente a designa em todos os processos por ele conduzidos. Uma vez instalada, muito peculiar é sua forma de nela proceder:

Nessa audiência dou marretada para tudo que é lado. Para que servem as marretadas? Servem para adequar o rumo do processo. Hoje em dia é muito comum o advogado, em ações de alimentos, argumentar com a obrigatoriedade de ambos os cônjuges. É verdade. No entanto, há casos em que o valor pago é muito baixo. Já 
peguei processo em que a parte pagava doze reais de pensão, doze reais! Em virtude disso, estabeleci um piso aqui: meio salário mínimo. Menos do que isso, não tem conversa, vai ter de pagar. Quando dizem estar desempregados, pergunto:

- Você faz o que da meia-noite às seis?

- Durmo.

Daí, respondo:

- Dormia... Agora, arrume outro emprego.

Não pude conter minhas risadas, gerando da parte dele o seguinte comentário: "Ora, senão fica muito fácil!"

Perguntei quanto tempo costumam durar as audiências conciliatórias. Respondeu não haver um tempo certo, embora se possa definir um padrão de comportamento, sendo possível, a partir dele, "saber que as coisas vão se desenvolver dentro de uma lógica". No dia de nossa entrevista, Eustáquio havia designado onze audiências, dez delas conciliatórias e uma de justificação de posse. O intervalo previsto entre elas era de vinte minutos. Ao observar a pauta, julgando insuficiente o tempo reservado para cada caso, a primeira ideia que me veio à mente foi a de que haveria atrasos sucessivos e cumulativos, pois é o que costumo vivenciar em minha prática profissional. Todavia, no curso daquela tarde, finalizada a última audiência, dei-me conta do tamanho de meu equívoco: a média de duração de cada audiência havia sido de doze minutos, com acordos realizados em sete processos! Segundo Eustáquio, é claro que há processos nos quais as audiências acabam tomando mais tempo, podendo durar até "algumas horas". No entanto, não é o que prevalece.

Cheguei a marcar audiências com intervalos de dez minutos entre uma e outra; passei para quinze e atualmente elas são marcadas com intervalos de vinte minutos. Esse é um bom tempo. Muitas vezes o acordo acontece antes da audiência. Muitas vezes, a parte não pode mesmo pagar alimentos. Então, costumamos [o plural se deve à participação do representante do ministério público nesse raciocínio, conforme pude aferir ao acompanhar algumas audiências] conceder um prazo, por exemplo, de seis meses, no qual ela terá de pôr a vida em ordem, passando a pagar alimentos a partir daí. 
De fato, as audiências têm sido por excelência o momento de resolução do processo, mesmo que para trazer o acordo à luz Eustáquio tenha de se valer de um fórceps. Num dado momento de sua carreira contabilizou nada menos que trinta audiências por dia. Nesse período, os intervalos entre elas eram de dez minutos. Como isso era possível? - perguntei.

É uma questão de objetivo, de meta (...) Aquilo era uma loucura! Você não pode imaginar a confusão. Teve uma vez que marquei quarenta audiências. Pensei na possibilidade de metade dos intimados não aparecer. Acabei fazendo trinta e seis, e foram trinta e seis acordos!

Explica que quando assumiu a vara encontrou quase seis mil processos em andamento, número que considera muito próximo ao do "ponto de inflexão", a partir do qual fica muito difícil ao magistrado manter algum controle. Portanto, tratou de reduzi-lo. Evidentemente, um tal ritmo alucinante de trabalho apenas é possível com uma equipe de funcionários sintônica, e Eustáquio dispõe disso.

Enquanto uma audiência tem curso, numa sala contígua uma outra é instalada. Após algumas "marteladas" iniciais, dadas com a finalidade de colocar as partes nos trilhos de um possível - no caso de Eustáquio, mais adequado seria dizer "provável” - acordo, o magistrado retira-se para a sala ao lado, onde desfere os primeiros golpes de "ordenação das coisas".

Eustáquio relata que na área de família costuma alcançar acordo em cerca de $95 \%$ dos casos, experiência que reforça, para ele, o princípio da imprescindibilidade da audiência conciliatória. Mesmo que o acordo não se realize numa primeira tentativa, aumentam as chances de seu êxito na audiência seguinte (instrutória).

No entanto, é preciso que se diga que tamanha eficácia também se deve à aplicação de uma técnica muito particular. Logo cedo, Eustáquio percebeu que os obstáculos a um acordo quase nunca estão expressos nos autos e tampouco são confessáveis diante da parte contrária. Portanto, a fim de identificar e, a partir daí, poder combater os empecilhos à finalização de mais um processo, conduz uma das partes para outra sala, a fim de ter com ela 
uma conversa reservada, única forma de "saber exatamente o que está acontecendo". Segundo ele, "é uma questão de lógica: o tamanho da briga não é compatível com o motivo documentado. Por conta dessa distância muito grande, preciso saber o que está no meio. Às vezes as pessoas não colocam [no papel] por vergonha, por temor... Às vezes o problema está no orgulho, na inveja... O juiz, então, pode fazer um trabalho de tranquilização, mostrando que o litígio não tem sentido, que não se pode ficar preso a bobagens”.

Diante de tal iniciativa, como se porta o advogado da parte? Ele a acompanha nessa conversa reservada? - perguntei. Neste ponto, Eustáquio revela o tamanho de sua ousadia, pois a presença ou não do advogado na referida conversa também passa por seu crivo utilitarista, sendo permitida na medida em que possa ajudar, e vedada caso perceba que possa atrapalhar. Evidentemente, muitos advogados protestam, conforme ele próprio relata:

- Nunca vi isso!

- Doutor - respondo -, estou trabalhando.

- Mas é o meu cliente! - replica, com ar de indignação, o advogado.

- Sim, eu sei. É o seu cliente. Mas o senhor fala por ele, não no lugar dele. O senhor é só um porta-voz e o juiz quer ter um contato direto com a parte. E esse contato vai se dar em separado. Depois, se for o caso, se o senhor merecer, eu conto [risos]. Então, pare com isso, que não está funcionando!...

Talvez por conta de minha reação corporal, seguiu-se o comentário:

Estou muito próximo do autoritário. Exerço autoridade com firmeza, sei disso, pois tenho autocrítica, e muitas vezes passo feito um trator em cima do pessoal, mas... tenho aquela ideia: estou resolvendo problemas. O juiz é a referência e a audiência não é um espaço para exercício de "democracia", no qual os envolvidos tenham de ser consultados a respeito do que acham ou do que gostam. Não! Há uma objetividade a respeito do que deve ser cumprido.

Eustáquio relata um caso de separação em que o marido não queria pagar alimentos para a mulher. Ele concordava com tudo, mas nem pensar em pagar alimentos. Ela, na verdade, não dependia financeiramente dele, embora afirmasse isso. "Nessas horas, a verdade 
para as mulheres é um atentado ao pudor" [risos]. Na audiência conciliatória, Eustáquio convidou o separando para uma conversa reservada, o que se deu na presença do respectivo advogado:

- Escuta, rapaz, você pague os alimentos e não me encha mais a paciência.

- Não, mas...

- Você quer pagar por três anos, quatro anos?... É o que vai acontecer se o acordo não sair. Pague por mais seis meses. Afinal, ela já concordou [a mulher queria, no início, pensão por um ano, mas aceitou fechar por seis meses]... Será mais inteligente de sua parte. Podemos conversar com ela, para ver se concorda em receber por mais quatro meses. Mas se ela não concordar, você pagará por mais seis. Está claro? Tentarei baixar, mas, se eu não conseguir, o senhor já sabe qual é o horizonte de decisão, e não atrapalhe minha vida. Eu o estou defendendo. Se você não faz um acordo, o processo vai se arrastar, terá audiência instrutória, recurso, tribunal, e, enquanto isso, o senhor continuará pagando. Levará uns quatro anos. É isso o que o senhor quer? Garanto-lhe ser muito mais econômico pagar por mais seis meses.

- Doutor, o senhor tem razão! Obrigado.

E assim, segundo Eustáquio, encerrou-se o assunto. O homem topou fechar pelos seis meses, resolvendo-se mais um processo pela via conciliatória.

Há casos em que Eustáquio revela um lado bastante sensível. É o que se vê no seguinte relato:

Certa vez, ao apreciar um caso, percebi que os dois indivíduos que litigavam conheciam-se desde crianças, tendo então sido muito amigos. Durante a audiência, perguntei como era o bairro deles há trinta anos.

- Por que o senhor quer saber, doutor? - respondeu um deles, com ar de incômodo em relação à pergunta.

- É que minha mãe trabalhava com tecelagem, na época, e costumava me levar com ela a esse bairro. Mas eu era muito pequeno e não consigo me lembrar muito bem como era...

Então, ambos começaram a me contar. Lembravam dos passarinhos que caçavam juntos, das vezes em que nadaram juntos no rio, dos jogos de futebol, das namoradas, da escola, etc.. Fui dando corda para a conversa. Pois, ao final disso, quando 
voltamos ao processo, a briga deles consistiu em o credor não querer mais receber a dívida que cobrava e o devedor fazer questão de pagar à vista [risos]. Saíram abraçados da audiência. $\mathrm{O}$ advogado de um deles quis saber como eu havia conseguido isso. "Basta acreditar no ser humano", respondi.

É com base em resultados desse tipo que Eustáquio insiste não apenas na essencialidade da audiência conciliatória ("ato mais importante que existe"), como também numa abordagem mais direta e eventualmente reservada com a parte, quando cabível - e muitas vezes entende sê-lo.

Não é por ser o fórum um lugar de conflito que precisamos achar que ele precisa ser perpetuado no fórum. Minha função é resolver o problema das partes. É isso o que faço. E se o juiz investir no acordo, ele consegue chegar a ele. E parto de alguns princípios, nos quais acabo apostando. O primeiro deles é: "as pessoas são honestas, ainda que estejam no fórum”, porque, na verdade, o que querem é uma vida tranquila, e não brigar. Geralmente, as brigas decorrem de mal-entendidos.

Agora, vou dizer umas coisas meio complicadas, que parecem salvíficas, mas não são: o juiz é um bicho diferente. O juiz serve o próximo, vinte e quatro horas por dia. Isso significa que ele não tem espaço para si mesmo, e ele tem de saber disso se quiser ser um bom juiz. Se ele achar a rotina muito difícil, muito complicada e que atrapalha sua vida pessoal, não dá para entrar, para trabalhar. O juiz tem de ter uma conduta exemplar. Eu não sou paradigma de juiz.

Por quê?! - perguntei. Após breve pausa:

Porque sou muito aberto, recebo as pessoas, converso com todo mundo, não ligo para pompa, não costumo usar o paletó durante a audiência - ele fica pendurado em minha cadeira; deixo todo mundo à vontade em audiência, fala-se bobagem. Outro dia fiz a audiência de uma moça que bateu o carro. Chamei-a de "barbeira" até dizer chega. Eu queria que ela reconhecesse ter feito "uma senhora barbeiragem e parasse com bobagem". Ainda brincava com ela: "Mas você não é loira! Se fosse loira ainda lhe daria ganho de causa. Mas não sendo, é imperdoável!" [risos] 
A preocupação de Eustáquio quanto à celeridade do feito às vezes parece beirar a obsessão. Ao menos, inspira-nos tal raciocínio o procedimento por ele adotado quando não logra chegar a um acordo e o prazo para defesa se inicia a contar da audiência (procedimento previsto, por exemplo, pela lei de alimentos). Malograda a tentativa conciliatória, Eustáquio determina ao advogado do réu que protocole a contestação consigo, a fim de evitar qualquer atraso na tramitação da peça processual. Esclareceu que, feito o protocolo em outra comarca, podem passar dois meses antes de a contestação chegar ao cartório, sem contar o risco de extravio. Afirma que muitos advogados até se valem disso, a fim de ganhar tempo. Assim, criou um procedimento mais seguro: protocolo na mão dele. Isso permite à parte contrária ter absoluta previsibilidade quanto ao momento em que terá de produzir sua réplica (na hipótese de haver juntada de documentos com a contestação, o que costuma acontecer), cujo termo inicial já fica definido na própria audiência. Portanto, mesmo que a audiência conciliatória não termine em acordo, resta mantida, para ele, sua imprescindibilidade, uma vez que serve para "criar paradigmas de compromisso, que devem ser respeitados pelas partes". Por outro lado, as linhas mestras de um eventual acordo já estariam traçadas, com o que se reduz o grau de tensão.

Ora, definida, na audiência conciliatória, até mesmo a data para produção de réplica, nada impede que também já seja designada a data da audiência instrutória, o que, segundo Eustáquio, traz a vantagem de desde então se intimar pessoalmente as partes a comparecerem à mesma. Mesmo que não seja intenção dos advogados ouvi-las, saem as mesmas intimadas pelo juízo, e há razões bastante lógicas para isso:

Não espero o advogado pedir a intimação das partes para a audiência instrutória. Já faço isso, a fim de garantir sua presença e, com isso, aumentar as chances de um eventual acordo. Caso contrário, estariam elas dispensadas de comparecer. Um colega meu seguiu o trâmite normal, ocorreu reconvenção ${ }^{371}$, com enorme acirramento do litígio e polarização dos advogados, que se armaram com todos os argumentos possíveis.

Eustáquio chama minha atenção para o fato de não existir réplica nem tréplica no processo [quer dizer: na lei processual], sendo fases criadas pela praxe jurídica:

${ }^{371}$ Ver "reconvenção" no "glossário jurídico". 
Apenas existe réplica se a parte juntar documentos e levantar questões preliminares. Juntar novos documentos na réplica contraria o próprio código de processo. Os artigos 396 e $397^{372}$ apenas autorizam a juntada de documentos novos em hipóteses restritas. Se a parte fizer isso, deixo, mas não intimo a outra parte, pois normalmente não costuma ser coisa importante. Logo, não dou importância a isso ${ }^{373}$.

Indagado sobre se costuma proferir despacho saneador, Eustáquio respondeu que isso depende das características do processo:

No saneador completo o juiz precisa abordar uma série de questões, muitas delas preliminares, e fazer isso é abrir a porta para o agravo, e o agravo tranca o processo. Então, costumo fingir que não vi [risos]. Designo audiência e deixo todas as questões para decidir na audiência de instrução. O que fiz? Na verdade, mudei o perfil do processo e procuro concentrar os atos, procurando fazer que o processo chegue o quanto antes ao momento de decisão. Afinal, não são as partes que conduzem o processo, não é o promotor; quem conduz o processo é o juiz. Isso não é prepotência nem arrogância. É o princípio da autoridade, que tem de ser respeitado. Aquele que acha que todos os papéis são iguais que vá para a mediação, a arbitragem... O lugar não é aqui. Daí a ideia de usar o "saneador simples": não sendo o caso de julgamento antecipado, designo audiência de instrução, debates e julgamento para tal data, a não ser que haja alguma questão incidente muito séria.

Em sua fala, lembrou o caso de uma advogada que elegeu de maneira evidentemente equivocada o pólo passivo da ação, tornando inviável o processamento do feito. Em vez

${ }^{372}$ Do Código de Processo Civil:

Art. 396. Compete à parte instruir a petição inicial (artigo 283), ou a resposta (artigo 297), com os documentos destinados a provar-lhe as alegações.

Art. 397. É lícito às partes, em qualquer tempo, juntar aos autos documentos novos, quando destinados a fazer prova de fatos ocorridos depois dos articulados, ou para contrapô-los aos que foram produzidos nos autos.

Nota-se que, a rigor, Eustáquio tem razão: o art. 396 prevê a juntada de documentos em dois momentos: pelo autor, com a petição inicial, e pelo réu, com a resposta (contestação). Por sua vez, o art. 397 reforça o referido entendimento, pois faz menção expressa a documentos "novos": ou seja, apenas estes podem ser juntados a qualquer tempo; não sendo "novos" os documentos, a ocasião para sua juntada é a primeira oportunidade havida para isso, vale dizer, na propositura da ação (pelo autor) e na defesa (pelo réu).

${ }^{373}$ Neste ponto, Eustáquio deixa implícito que não segue a regra firmada pelo art. 398 do CPC:

Art. 398. Sempre que uma das partes requerer a juntada de documento aos autos, o juiz ouvirá, a seu respeito, a outra, no prazo de 5 (cinco) dias. 
de indeferir a inicial, determinou sua emenda. $\mathrm{O}$ indeferimento da inicial apenas é feito quando percebe "não haver a menor condição de aproveitamento".

Indagado sobre se já enfrentou alguma questão à qual o Direito não dava uma resposta muito clara, respondeu:

Não sou um juiz formalista... Quando vejo que a coisa está saindo dos trilhos, vou pelos atalhos. No entanto, via de regra, quando chega no tribunal... costuma haver reforma, por causa do paradigma normativista. Esse paradigma aceita, para supressão de lacunas, no máximo a analogia. A interpretação extensiva esbarra no preconceito, que vem desde o Código Napoleônico, de que o juiz não legisla...

A fim de ilustrar, relatou o caso de um sujeito que, com atividades por ele empreendidas em seu comércio, encontrou uma forma de desvalorizar os imóveis vizinhos. "Ora, isso é uma grande desonestidade". Veio o dia em que um dos vizinhos ajuizou ação para coibir as condutas indevidas. A respeito, ponderou nosso entrevistado:

Minha sentença foi muito dura, mas acabou sendo reformada em alguns pontos pelo tribunal; não deveria ter sido reformada e não seria, se o tribunal tivesse essa visão. Outro exemplo: a lei de proteção dos mananciais. Surgiu uma tese cretina no sentido de que a mata ciliar já destruída não precisa ser recomposta. Isso é um absurdo, uma vez que o espírito da lei é a preservação do meio-ambiente. O que foi destruído precisa ser reconstituído. Um colega meu, que é um excelente juiz e, pior, meu amigo, deu uma sentença acolhendo aquela tese! Não me conformei! Dizia ele: "Mas a lei..." Ora, neste caso, "dane-se a lei!" Na verdade, tratava-se de uma determinada interpretação da lei; cabia interpretação diversa. É lógico que o tribunal reformou a decisão dele.

Ainda ao se referir à atuação do tribunal, Eustáquio destacou que, quando este reforma a decisão de um juiz não está, na verdade, se posicionando contra a pessoa do magistrado que a produziu:

Não é algo "pessoal”. O que existe é um raciocínio institucional consolidado no tempo e que leva os julgadores a agirem por inércia. No entanto, quando se age por inércia, deixa-se de refletir. É preciso encontrar um meio termo entre a forma e a 
possibilidade de aplicar a forma. Muitas vezes o conteúdo extravasa a forma e quando isso acontece é preciso encontrar uma solução diferente. A norma não é ponto de chegada: é ponto de partida.

Revelou ter colegas (juízes) que levam a reforma de suas decisões pelo lado pessoal. "Digo a eles que não podem ser juízes, pois a coisa não é por aí. Existe uma hierarquia natural, que se estabelece na magistratura por antiguidade".

Acrescentou dizendo ser natural que os juízes vejam nos tribunais superiores um referencial importante para o desenvolvimento de seu trabalho, para seu aprimoramento. No entanto, mesmo o tribunal não estaria alheio ao movimento generalizado de decadência cultural e intelectual observada em nossa época, circunstância em que, segundo ele, "cada um escreve o que quer". Relatou um caso em que teve uma decisão interlocutória atacada por agravo de instrumento. Nas informações do agravo, expressou sua opinião dizendo "que seria excelente se o tribunal não acolhesse a tese do agravante, sendo interesse do réu tão-somente procrastinar o feito". Resultado: sua decisão não apenas foi reformada, como também percebeu que o desembargador em questão "reforma agora todas as minhas sentenças, todas, todas e mais algumas [risos]. Mas o erro é dele, não é meu. Então, temos enfrentado, ultimamente, esse tipo de problema: a subida, para o tribunal, de gente despreparada".

O curioso é que, apesar dessa polarização de entendimentos, no curso do processo acima referido a decisão proferida pelo tribunal acabou restando prejudicada pelo julgamento do feito, efetuado logo em seguida por Eustáquio. Com isso, nosso magistrado reputou perdido o objeto do recurso. Ao analisar o caso, dei sinais de dúvida a esse respeito, ao que ele emendou: "Caso os interessados entendessem de modo contrário, que buscassem as vias próprias. Não houve nenhum recurso da decisão [sentença]”.

A respeito da importância da jurisprudência e da doutrina no desenvolvimento de seu trabalho, Eustáquio respondeu que "quando se quer fundamentar uma posição nova, a doutrina é indispensável; quando se quer consolidar uma posição nova, a jurisprudência é importantíssima, porque ela mostra que aberturas já foram feitas no paradigma lógicoformal. Então, depende muito da situação. O ideal é articular, na sentença, dogmática (dou- 
trina) e norma positivada". No entanto, dependendo do caso concreto, parece não ter problema algum em assumir posicionamento divergente com o adotado pelos tribunais superiores. Admitindo ser o ordenamento jurídico muito aberto, declara que "o juiz pode decidir do jeito que quiser que encontrará de algum modo amparo no ordenamento". Dito isto, exemplificou citando o procedimento da "execução de alimentos":

- O STJ ${ }^{374}$ inventou que cabia prisão na hipótese de inadimplemento das três últimas. Bobagem, mas, enfim, foi o que se decidiu. Nunca segui, pois é uma tremenda besteira.

- Nunca seguiu?! - exclamei, surpreso.

- Não. Mas está aí a importância de se fazer a audiência e conversar com os envolvidos. Quando o casal se separa, na esperança de ter o marido de volta, a mulher deixa de cobrar alimentos. É isso o que acontece. Portanto, os iluminados que inventaram essa jurisprudência não entendem de ser humano, de vida. Foi o que citei no início: "acreditam que serão capazes de criar uma sociedade de anjos por meio da norma". A parte tem de pagar tudo, e não tem conversa, senão vai para a prisão. Nesse caso, o pagamento acontece em dois segundos.

Não me conformando com esse entendimento, ponderei:

- Caso a mulher não tenha cobrado ao longo de dois anos, gerando acúmulo do valor, que se tornou expressivo. Você entende que o devedor tem de pagar tudo, sob pena de prisão?...

- Os alimentos não são pagos para a mulher, mas para o filho. O juiz está atuando no interesse do menor, não da mulher. Os alimentos têm de ser pagos. Depois a jurisprudência evoluiu. Eles viram que tinha escrito besteira - porque o juiz com orientação lógico-formal fica com a cabeça pequena: os advogados esperavam acumular três pensões e ajuizavam uma ação nova. Seguiu-se a segunda jurisprudência: "pode cobrar também as vincendas"; depois, veio a terceira jurisprudência: "esse entendimento não vale para o devedor contumaz”. Mas o que é isso?! Isso é uma jurisprudência que quebra o principal, o princípio do Direito de que a norma em geral é abstrata. Está se reinventando a roda. Cheguei a decretar a prisão de um devedor que iria se casar no final de semana. A advogada tentou se valer disso, mas determinei o depósito do valor. Como não houve depósito, decretei a prisão e ele não casou. Quando ele foi solto, a advogada voltou com bobagem. Alertei-a para o

374 "STJ" é a abreviação de Superior Tribunal de Justiça, instância máxima do poder judiciário nacional para decidir o assunto referido por Eustáquio. 
risco de nova prisão; até coloquei no despacho que "se tem dinheiro para casar, tem dinheiro para pagar os alimentos". É uma questão de prioridade.

- Ah, ele tem direito de ser feliz - disse ela.

- O escambau! O dever dele é de criar os filhos. Se der para ter outra mulher, sorte dele; se não der, azar, não casa!

Ao receber uma petição inicial, diante de um universo de elementos que demandam por sua atenção (exemplifiquei com: "organização", "apresentação", "tese do advogado", "pedido", "raciocínio", "valor(es) posto(s) em juízo" e "situação sócio-econômica da parte"), declarou:

Os juízes mais experientes leem apenas os fatos, e de vez em quando o pedido. É o que basta para saber o que está acontecendo. Salvo em se tratando de uma ação muito nova, muito diferente. Não sendo, já se tem os parâmetros legais.

Numa audiência, costuma observar "tudo":

Olho tudo: a forma como se anda, a postura do advogado, como se senta, como se fala, a entonação, os olhares, se olha para o juiz, ou para baixo, ou para cima; como reage à pergunta feita por mim (se olha para o lado, ou para baixo, etc.). Se a parte olhar para baixo e depois para cima, está mentindo.

Eustáquio aprendeu algumas técnicas de leitura corporal há bastante tempo, com um amigo psicólogo, e afirma ter tido no campo familiar um terreno muito fértil para aprimorar esse tipo de percepção. Quando identifica que a parte está mentindo, costuma "dar bronca", mas "sem ataques histéricos". Em se tratando de testemunha mentirosa, apenas em casos extremos adota medidas mais drásticas. Normalmente, limita-se a chamar sua atenção:

- Escuta, não quero sacanear contigo, bancar o mais esperto, mas você vinha seguindo esta linha de raciocínio e a partir daqui você mudou. Onde está a verdade? A testemunha se atrapalha... Então, registro todas as incongruências no termo - que é ditado por mim, mas na primeira pessoa - a fim de avaliar, mais tarde, se o depoimento é importante ou não. Porque acho equivocado prender testemunha em audiência, salvo em casos teratológicos. 
Ao perceber a existência de descompasso técnico entre os advogados das partes, costuma supri-lo naturalmente a fim de garantir a efetividade do Direito como "instrumento de justiça".

De todas as áreas do Direito em que atuou, apenas não tem prazer naquela em que tem de lidar com questões envolvendo crianças e adolescentes, apontando maior sensibilidade a isso depois de sua própria experiência de paternidade:

É muito complicado, pois não se tem instituições, não tem gente interessada, só políticos e autoridades falando bobagem para se capitalizar politicamente em cima dessa situação. Sem contar que é angustiante ver uma criança morrendo e não ter o que fazer: é uma tragédia! É uma questão muito mais social do que jurídica.

Quando perguntei se costuma receber advogados para despachar, sua primeira expressão foi: "Lógico!" Afirma manter seu gabinete permanentemente aberto aos advogados:

Primeiro, porque despacho logo e ele não fica me atrapalhando a vida; segundo, porque quando ele entra em minha sala e fica sentado, esperando ser atendido, pode ver que estou trabalhando. Então, é importante ele ver que não estou "enrolando". O juiz que trabalha de portas fechadas pede para ser questionado, no mínimo. O outro poderá pensar: "Por que ele está de porta fechada, o que tem a esconder?"

A respeito da advocacia, Eustáquio revelou-se contrário à tese que apresenta o advogado como figura essencial: "O indivíduo tem de ter plenitude de sua cidadania e exercer sua autodefesa". Ou seja: as pessoas deveriam ter a faculdade de optar pela contratação, ou não, desse profissional. No entanto, sendo ele necessário, é fundamental que seja bem preparado. Refuta a alegação de que a parte leiga não dispõe de conhecimento técnico, uma vez que tal deficiência pode facilmente ser suprida pelo juiz. Afinal, ele "já faz isso hoje em dia", de modo que as coisas acabam mesmo é ficando "nas costas do juiz". Há bons advogados; no entanto, a maioria deixa a desejar: "escreve muita bobagem, carrega nas tintas..." 
Ao ser confrontado com o movimento de digitalização dos processos, Eustáquio manifestou insatisfação:

Não gosto, porque eu não confio na máquina. $\mathrm{O}$ mundo cibernético me lembra muito o "Big Brother", ou o "Admirável Mundo Novo". Tornamo-nos escravos da máquina, que passa a pensar por nós.

Surpreso com o teor de sua resposta, voltei à pergunta:

- Mas a digitalização vai contra isso em que sentido?... Porque consiste na transformação de papel em arquivo digital... Ou você está enxergando outra coisa que não estou entendendo?...

- Na hora em que você põe tudo no computador, as decisões também são feitas pelo computador. Você facilita a forma e a tendência é de desaparecerem as audiências de tentativa de conciliação. A tendência é de eliminar a audiência. Tanto é que já tem vários juízes que já fazem isso.

- Bom, acho que é mais uma questão de estilo. Porque se sua maneira de proceder é fazer audiências, não é por conta da digitalização que terá de deixar de fazer isso.

- É que você cria um modus operandi que acaba se impondo com o tempo. Quando você põe tudo no computador perde-se a dimensão física do problema. Pegar um processo dessa altura [gesticula com as mãos], você vê fisicamente o tamanho da encrenca, e sabe o grau de atenção que deverá ter para aquilo. Se estiver tudo digitalizado, isso será expresso em "megabites", e daí?... Não existe impacto, a confrontação...

A fim de finalizar a entrevista, li para Eustáquio o seguinte trecho do livro $O$ Juiz e a Emoção, de Lídia Reis de Almeida Prado, pedindo-lhe para que o comentasse: "Karl Llewellyn acredita que, geralmente, a mente do juiz primeiro antecipa a decisão que considera justa (dentro da ordem jurídico-positiva) e depois procura a norma que pode servir de fundamento a essa solução, atribuindo aos fatos a qualificação apropriada”,375. O que segue vêm a ser as elucubrações de Eustáquio a respeito:

Sim e não. Porque sim e não? Quando falei pra você das 30 audiências, para isso funcionar preciso partir de um corpo de conceitos e preconceitos que me permitem

${ }^{375}$ Op. cit., pp. 13/14. 
articular aquela situação e aquelas relações levando sempre em consideração um norte de solução. Mas, por outro lado, pensar desse jeito é alimentar o máximo da prepotência e arrogância do juiz. Porque acreditar absolutamente nesse princípio é ser solipsista, isto é, isolar-se da realidade e tornar-se um deus, onisciente, onipresente e onipotente. Esse é o risco de raciocinar desse jeito. Portanto, é preciso ter continuamente um canal aberto a novos momentos que o processo oferece. Houve um caso de assassinato motivado por um copo de cerveja. O promotor, do alto de nossa capacidade técnica e autoridade, anunciou:

- Vamos fazer o júri deste animal em um mês!

Porém, o menino, no interrogatório, convenceu-me de sua inocência:

- Doutor, sou inocente, apenas me defendi...

- Mas Zezinho, está claro!... - respondi-lhe, fazendo alusão à evidência das provas.

- Doutor, eu não fiz isso de propósito. Ele tentou me bater o tempo todo.

E eu acreditei nele... Perguntei:

- Mas por que você estava com a faca?

- Não, era minha faca de descascar laranja. Esqueci e fui com ela para o baile.

Ora, é normal, no interior, os indivíduos terem aquela faquinha cortada ao meio, usada para descascar laranja. E o que chamava a atenção era o fato de Zezinho ser um franguinho pequenininho, enquanto o João era um baita de um crioulo de dois metros de altura, um armário! E a prova demonstrou que Zezinho agiu em legítima defesa. João foi bater em Zezinho e levantou-o pelo colarinho. Zezinho avisou-o:

- Me solta, senão vou te acertar!

- Quero ver!

Pronto. Foi um só golpe, que o pegou bem na aorta. Analisando o caso, reconheci a excludente de antijuridicidade e da legítima defesa. Houve recurso do promotor, que achou a sentença absolvitória um absurdo. O caso subiu para o tribunal, onde o procurador de justiça ${ }^{376}$ pediu a manutenção da mesma, mas o tribunal reformou-a, mandando o caso para júri. Isso é só para você ver... No júri, Zezinho acabou absolvido, lógico. Não é possível condenar alguém com essa oscilação de opiniões.

Mas é verdade que se parte desse princípio [o exposto por Llewellyn], porque, se não for assim, não é possível coordenar; se o juiz sempre estiver "em ponto morto" e for receber tudo aquilo que se diz como uma verdade nova, cairá na situação do Kant... Por que existe ciência? Porque existe algum ponto de partida do qual tenho um começo, senão... Daí é que Kant concebe a ideia dos juízos sintéticos a priori,

${ }^{376}$ Nome dado ao representante do Ministério Público, quando atuante em segundo grau de jurisdição; em primeiro grau, é chamado "promotor de justiça". 
um repositório de conhecimento que nos permite articular o mundo. Mas, se o indivíduo se deixa engessar por conta desse repositório de conhecimento, ele se tornará prepotente e arrogante. Mas, se usar essa estrutura mantendo-a suficientemente flexibilizada... Como é que Welzel fala?... A tolerância torna a diferença possível, e a diferença faz a tolerância necessária. Isso é importante. Mas, ao mesmo tempo, não se pode ser tolerante ao extremo, a ponto de aceitar qualquer novidade, qualquer situação, como se tudo fosse válido, porque haverá perda de referenciais e consequente dissolução do indivíduo. É preciso ter uma espinha dorsal sólida, consistente, que permita ao indivíduo trabalhar diversas situações, dando-lhes o peso que merecem. Se o juiz tiver uma perspectiva lógico-formal no plano da justiça comutativa, estará frito, não lhe sendo possível articular, porque a coisa se torna muito linear. Porém, se ele trabalhar na perspectiva de justiça distributiva, que é proporcional, estará no espaço, e não achatado numa igualdade chã. Algumas pessoas me dizem, em audiência:

- Puxa, doutor, isso não é justo!

- Tem razão. Não é justo. Mas na sua situação é o melhor caminho. E sempre falo: Não se esqueça de que Deus escreve certo por linhas tortas." 


\subsection{ANÁLISE DO PERFIL TIPOLÓGICO DE "EUSTÁQUIO”}

As características que mais se evidenciam em Eustáquio parecem ser as relacionadas à sua função principal, que, de tão discriminada, permite-nos postulá-la logo no início de nossa análise como sendo o PENSAMENTO. A função principal de Eustáquio também se acentua tendo em vista seu grande contraste com a função inferior - SENTIMENTO -, que se revela pouco desenvolvida.

Uma das características mais marcantes de quem traz o PENSAMENTO como função principal é a utilização de parâmetros objetivos para lidar com ideias e pessoas; para o PENSAMENTO, o que faz uma ideia ser boa ou ruim é seu grau de verdade ou falsidade; o que faz uma conduta ser aceitável ou reprovável é sua correspondência a princípios, e não sua conveniência ou adequação a dada circunstância. Essa forma de ser, quando levada a um extremo, pode parecer bastante rígida, particularmente quando apreciada por pessoas pertencentes ao tipo oposto. Não por acaso, o entrevistador, apesar do esforço consciente visando a não exteriorizar eventuais juízos de valor sobre o conteúdo do que lhe revelava o entrevistado, não pôde evitar alguns sinais visíveis de que achava muito "duras" ou exageradas as atitudes de Eustáquio em algumas situações. Foi o caso, por exemplo, da "leitura corporal", por ele feita, por ocasião de uma audiência de investigação de paternidade, na qual levou o autor da ação, sob séria admoestação, a desistir do processo:

\footnotetext{
- Meu senhor, então vamos fazer o seguinte: em primeiro lugar, o senhor está desistindo desta ação agora, e ainda vai colocar no papel: "Eu não tenho dúvida de que minha filha é minha filha”. Segundo: se eu souber que o senhor está ainda pedindo para os seus amigos ligarem para sua casa, juro que acabo com sua raça!
}

Em regra, todo processo traz às partes nele envolvidas certo incômodo. Aquele que promove a ação tem de se dar ao trabalho de contratar advogado, expor sua intimidade para este profissional, despender recursos financeiros, enfrentar o desgaste emocional de ter pessoas conhecidas sendo arroladas como "rés" na ação e assim por diante, além de correr o risco da sucumbência, que traz não apenas efeitos financeiros mas, em alguns casos, sobretudo morais, pois ninguém gosta de "perder" a ação. 
No entanto, Eustáquio, no caso acima relatado, teve "certeza" de que o pai da criança não tinha sérias razões para interpor a ação investigatória, certeza esta calcada numa "leitura corporal" feita no curso da audiência, e, segundo ele, corroborada pela reação do autor ao comando judicial: "Ele ficou cabisbaixo e não teve como responder a isso".

Continuamos pondo em cheque tal "leitura", conforme feita por Eustáquio. Afinal, a autoridade exercida naturalmente por Eustáquio, decorrente de sua personalidade, acaba sendo fortemente reforçada pela posição que ele ocupa na qualidade de julgador. Todo aquele que julga exerce poder sobre seus semelhantes, e está legitimado para isso. Se a essa autoridade, de natureza institucional, vem a somar-se uma outra, de cunho pessoal, como acontece no caso de nosso entrevistado, cria-se uma situação que exige por parte do sujeito algum esforço de autocontrole, sob pena de se forjarem excessos. Fica, ao jurisdicionado, a impressão de ter sido atropelado por um "rolo compressor", não havendo reação possível uma vez que não se concede qualquer espaço para uma reação...

Essa é uma outra hipótese interpretativa que arriscamos dar para a cena descrita pelo magistrado. Em outras palavras: o fato de ter o autor da ação ficado cabisbaixo e sem resposta à censura feita pelo juiz pode ser a reação de quem se sentiu subjugado, e não necessariamente um consentimento ao quadro fático que Eustáquio supunha descortinar.

Portanto, também chama nossa atenção o grau de certeza de Eustáquio, que traz a densidade de uma rocha e se mostra inabalável. Em dado momento, ele reconhece estar muito próximo do autoritário, chegando ao ponto de passar "feito um trator em cima do pessoal”, o que parece justificado por uma boa causa: resolver problemas. Uma maneira tão "autorreferenciada" de processar os dados da realidade é sinal claro de um PENSAMENTO INTROVERTIDO, a respeito do qual escreve JUNG:

"O pensar [introvertido] pode entreter-se com dados concretos ou abstratos mas, na hora decisiva, orienta-se por dados subjetivos. Não reconduz, a partir da experiência concreta, para a coisa objetiva, mas para o conteúdo subjetivo. Os fatos externos não são a causa ou meta desse pensar, ainda que o introvertido gostasse de lhe dar esta aparência, mas este pensar começa no sujeito e reconduz ao sujeito, mes- 
mo que faça larga incursão no campo da realidade concreta”,377, ou, ainda: “(...) o pensamento introvertido apresenta uma tendência perigosa de forçar os fatos para dentro da forma de sua imagem ou ignorá-los totalmente para dar livre curso à sua fantasia". 378

Outro momento de reação incontida do entrevistador diante da "dureza" de posicionamento do entrevistado deu-se com a descrição, por Eustáquio, do diálogo que costuma manter com os réus, em ações de alimentos, nas quais estes últimos costumam alegar falta de possibilidade financeira de arcar com a obrigação:

- Você faz o que da meia-noite às seis?

- Durmo.

Daí, respondo:

- Dormia... Agora, arrume outro emprego.

O que é rematado pelo seguinte comentário, feito por ele: "Ora, senão fica muito fácil!" Ou seja: não importa o que o réu venha a fazer, tem ele de arcar com a obrigação alimentar e ponto final. Isso é tratado na forma de um princípio inegociável, válido para todos (critério da universalidade/impessoalidade) e em quaisquer circunstâncias (critério da objetividade). Esta é a forma de processar informações típica do PENSAMENTO, cujo fortalecimento na ATITUDE INTROVERTIDA gera, segundo JUNG, convicções cada vez mais rígidas e inflexíveis. ${ }^{379}$

No curso da entrevista, fica claro que a rigidez da conduta de Eustáquio é fonte de atritos junto aos próprios jurisdicionados, conforme dá conta o seguinte excerto da entrevista, que diz respeito ao procedimento de convocar uma das partes para uma conversa reservada, sem a presença de seu respectivo patrono:

- Nunca vi isso! [Protesto do advogado.]

- Doutor - respondo -, estou trabalhando.

- Mas é o meu cliente! - replica, com ar de indignação, o advogado.

${ }^{377}$ Tipos ..., p. $360, \S 700$.
${ }^{378}$ Tipos ..., p. $360, \S 701$.
${ }^{379}$ Tipos ..., p. $364, \S 707$. 
- Sim, eu sei. É o seu cliente. Mas o senhor fala por ele, não no lugar dele. O senhor é só um porta-voz e o juiz quer ter um contato direto com a parte. E esse contato vai se dar em separado. Depois, se for o caso, se o senhor merecer, eu conto [risos]. Então, pare com isso, que não está funcionando!...

Ao proceder desse modo, Eustáquio deixa-se guiar pela crença de que está resolvendo problemas, e resolver problemas, no caso de um magistrado, pode ser visto sob a perspectiva da redução do número de processos em andamento - melhor ainda se tal redução for expressiva e feita pela via da "conciliação". Ninguém pode acusar Eustáquio de não trilhar esse caminho.

Todavia, conforme observamos, e como é típico do PENSAMENTO, a solução do problema vale mais do que o bem-estar das pessoas que trazem o problema. ${ }^{\mathbf{3 8 0}}$ Exemplo disso é a condução de uma das partes para uma sala reservada: se tal conduta por si só já configura um ato de ousadia por parte do magistrado, parece beirar a temeridade quando é vedada ao advogado da parte a possibilidade de acompanhá-la. Eustáquio demonstra não se importar com isso. Se, para ele, o juiz desempenha um papel fundamental como solucionador dos litígios, cumpre destacar serem estes tomados num sentido objetivo, sem o que não seria possível, por exemplo, designar audiências com intervalo de dez minutos entre cada uma e ser bem sucedido nessa empreitada. Isso apenas é possível com a adoção de princípios muito claros, válidos em todas as situações; apenas é possível a partir da ideia de que “o juiz é a referência e a audiência não é um espaço para exercício de 'democracia', no qual os envolvidos tenham de ser consultados a respeito do que acham ou do que gostam. Não! Há uma objetividade a respeito do que deve ser cumprido".

Vale notar que a iniciativa de levar a parte para um ambiente reservado dá-se sob a intenção de "saber exatamente o que está acontecendo", a despeito do desconforto pessoal que isso possa gerar seja para a parte, seja para os advogados.

\footnotetext{
380 Às vezes, a conduta de Eustáquio pode nos levar a pensar o contrário disso, conforme se dá quando relata como procedeu diante dos amigos de infância que litigavam. No entanto, mesmo neste caso, é possível dizer que Eustáquio adotou a estratégia que lhe pareceu mais adequada para solucionar o litígio, ou seja, a tônica de sua ação continuou tendo por foco a "solução do problema". Se, para isso, a estratégia mais "lógica" se mostrasse trazer à tona os sentimentos de amizade dos litigantes, tanto melhor.
} 
Outro indício do predomínio da função PENSAMENTO é o uso de expressões chulas ou, quando não, confessadamente duras, conforme se verifica nas seguintes passagens, em algumas com licenças requeridas pelo próprio entrevistado:

- Desculpe a expressão, mas parece haver uma "síndrome do chifre" no país que é um negócio impressionante.

- E o que os animais me fazem, desculpe a expressão: eles lixam os próprios cornos com a autoestima das crianças. Ora, ninguém tem o direito de fazer isso. Eu bato firme. Não permito que essas coisas ocorram. Levo as partes a um acordo.

- Nessa audiência [conciliatória] dou marretada para tudo que é lado. Para que servem as marretadas? Servem para adequar o rumo do processo.

- Surgiu uma tese cretina no sentido de que a mata ciliar já destruída não precisa ser recomposta. Isso é um absurdo (...)

- O escambau! O dever dele é de criar os filhos. Se der para ter outra mulher, sorte dele; se não der, azar, não casa!

E muitos outros exemplos como os acima podem ser colhidos de sua fala. Embora já tenhamos feito essa ressalva, julgamos conveniente reforçá-la: para conceder a presente entrevista, Eustáquio despiu-se da persona de magistrado e, de modo bastante descontraído, teceu considerações a respeito de sua profissão. Era justamente isso o que se esperava do entrevistado, não se devendo tecer juízos de valor sobre a inadequação de seu discurso à função jurisdicional, uma vez que esta não estava sendo exercida naquele momento. Aliás, até ao se permitir total descontração, sem se preocupar com eventual juízo que o entrevistador pudesse fazer em relação à sua pessoa, Eustáquio dá mostras do predomínio da função PENSAMENTO. Um representante do tipo oposto (SENTIMENTO) tenderia a se preocupar mais com a imagem projetada socialmente, uma vez que é sensível a isso também em relação aos outros.

Eustáquio põe claramente sua função PENSAMENTO a serviço das partes litigantes e, com isso, por meio de cálculos "lógicos" impecáveis leva-as a perceber a "irraciona- 
lidade" que seria dar continuidade ao litígio. Nosso magistrado tem facilidade para perceber quando o processo traz espaço para aplicação dessa lógica redentora:

(...) é uma questão de lógica: o tamanho da briga não é compatível com o motivo documentado. Por conta dessa distância muito grande, preciso saber o que está no meio. Às vezes as pessoas não colocam [no papel] por vergonha, por temor... Às vezes o problema está no orgulho, na inveja... O juiz, então, pode fazer um trabalho de tranquilização, mostrando que o litígio não tem sentido [ou, em outras palavras, "lógica"], que não se pode ficar preso a bobagens.

Um exemplo disso está no relato da conversa que teve reservadamente com uma das partes - no caso, o marido -, em processo de separação:

- Escuta, rapaz, você pague os alimentos e não me encha mais a paciência.

- Não, mas...

- Você quer pagar por três anos, quatro anos?... É o que vai acontecer se o acordo não sair. Pague por mais seis meses. (...) Será mais inteligente de sua parte. Podemos conversar com ela, para ver se concorda em receber por mais quatro meses. Mas se ela não concordar, você pagará por mais seis. Está claro? Tentarei baixar, mas, se eu não conseguir, o senhor já sabe qual é o horizonte de decisão, e não atrapalhe minha vida. Eu o estou defendendo. Se você não faz um acordo, o processo vai se arrastar, terá audiência instrutória, recurso, tribunal, e, enquanto isso, o senhor continuará pagando. Levará uns quatro anos. É isso o que o senhor quer? Garanto-lhe ser muito mais econômico pagar por mais seis meses.

- Doutor, o senhor tem razão! Obrigado.

Quando fala de sua relação com o Tribunal, também desponta com clareza o predomínio de uma perspectiva do tipo PENSAMENTO, podendo-se destacar os seguintes pontos da visão que Eustáquio tem do universo profissional no qual está inserido:

(a) a falta de preparo intelectual de muitos magistrados, tendo em vista não estarem os tribunais alheios ao "movimento generalizado de decadência cultural e intelectual observada em nossa época, circunstância em que cada um escreve o que quer"; 
(b) a falta de coerência nos julgamentos, do que foi exemplo a sucessiva alteração da jurisprudência no que concerne à execução de alimentos: "O STJ inventou que cabia prisão na hipótese de inadimplemento das três últimas. Bobagem, mas, enfim, foi o que se decidiu. Nunca segui, pois é uma tremenda besteira. Depois a jurisprudência evoluiu. Eles viram que tinha escrito besteira - porque o juiz com orientação lógico-formal fica com a cabeça pequena: os advogados esperavam acumular três pensões e ajuizavam uma ação nova. Seguiu-se a segunda jurisprudência: 'pode cobrar também as vincendas'; depois, veio a terceira jurisprudência: 'esse entendimento não vale para o devedor contumaz'. Mas o que é isso?! Isso é uma jurisprudência que quebra o principal, o princípio do direito de que a norma em geral é abstrata. Está se reinventando a roda";

(c) não levar pelo lado pessoal eventual reforma de seus julgados, o que nem sempre observa em alguns colegas seus de magistratura: "Digo a eles que não podem ser juízes, pois a coisa não é por aí. Existe uma hierarquia natural, que se estabelece na magistratura por antiguidade".

Todo este quadro parece apontar, de maneira harmoniosa não apenas para o PENSAMENTO, mas também para a atitude INTROVERTIDA, falando-se, portanto, no tipo PENSAMENTO INTROVERTIDO, a respeito do qual julgamos conveniente trazer ainda a seguinte lição de Jung:

[O representante desse tipo] Só consegue aceitar com dificuldade que algo, que para ele é claro, não o seja para todos os outros (...) Ou é calado ou avança sobre as pessoas que não o entendem; reúne exemplos para provar a enorme burrice humana. $^{381}$

Se buscássemos nos signos linguísticos os indicativos do tipo psicológico, provavelmente os encontraríamos. No caso de Eustáquio, importa observar que a palavra "lógico" ou "lógica", talvez típica da função PENSAMENTO, mostrou-se muito presente no curso de sua fala.

${ }^{381}$ Tipos..., p. 364, $§ 706$. 
$\mathrm{Na}$ análise feita até aqui, não apenas sugerimos qual seria a função principal de Eustáquio (PENSAMENTO), como também opinamos sobre a provável atitude nele predominante: INTROVERSÃO. Vejamos que outros aspectos de sua personalidade corroborariam este ponto de vista.

Já vimos, como sinais de presença da INTROVERSÃO em Eustáquio, a força determinante de sua subjetividade na apreensão dos dados externos. Ele confia muito na impressão que lhe causam os estímulos do meio, de modo que a realidade funciona menos como elemento conformador de sua maneira de pensar do que como corroborador desse pensar. Nas palavras de Jung:

A consciência introvertida vê as condições externas mas escolhe as determinantes subjetivas como decisivas (...) Enquanto o tipo extrovertido se apoia principalmente naquilo que provém do objeto, o introvertido se baseia em geral no que a impressão externa constela no sujeito. ${ }^{382}$

A partir dessas premissas, podemos identificar nos seguintes trechos da fala de Eustáquio indícios de sua INTROVERSÃO:

- "Outro dia me desgastei com um advogado em audiência - ambos não estávamos num bom dia -, para depois perceber que estávamos sustentando a mesma coisa! Somos amigos até hoje.”: por serem mais abertos ao objeto, os EXTROVERTIDOS tendem a percebê-lo de forma mais isenta, no sentido de não projetar sobre ele, no mesmo grau que os INTROVERTIDOS, aspectos de sua própria subjetividade. Os INTROVERTIDOS, por sua vez, por agirem de forma contrária, tendem a perceber o meio externo a partir do filtro - neles mais espesso do que nos EXTROVERTIDOS - de ideias preconcebidas e, por isso, costumam se envolver mais em mal-entendidos como o retratado por Eustáquio.

- “E parto de alguns princípios, nos quais acabo apostando. O primeiro deles é: 'as pessoas são honestas, ainda que estejam no fórum', porque, na

${ }^{382}$ Tipos ..., p. 354, § 692. 
verdade, o que querem é uma vida tranquila, e não brigar. Geralmente, as brigas decorrem de mal-entendidos.": neste ponto, Eustáquio aponta para um de seus filtros de percepção, constituído de forma apriorística.

- "Na verdade, mudei o perfil do processo e procuro concentrar os atos, procurando fazer que o processo chegue o quanto antes ao momento de decisão. Afinal, não são as partes que conduzem o processo, não é o promotor; quem conduz o processo é o juiz. Isso não é prepotência nem arrogância. É o princípio da autoridade, que tem de ser respeitado. Aquele que acha que todos os papéis são iguais que vá para a mediação, a arbitragem... O lugar não é aqui.": chama a atenção a rigidez das ideias expressas nessa fala, que passa justamente a impressão de "prepotência e arrogância", normalmente transmitida pelas pessoas cujas posturas estão fortemente enraizadas em verdades subjetivas, pouco permeáveis à ação do meio externo, o que caracteriza a INTROVERSÃO que, conforme já vimos acima, no caso de Eustáquio é visivelmente marcada pela função PENSAMENTO.

- "Portanto, os iluminados que inventaram essa jurisprudência não entendem de ser humano, de vida. Foi o que citei no início: 'acreditam que serão capazes de criar uma sociedade de anjos por meio da norma'. A parte tem de pagar tudo, e não tem conversa, senão vai para a prisão. Nesse caso, o pagamento acontece em dois segundos.": novamente um indício de rigidez, com prevalecimento de verdades e princípios firmados por ele, em detrimento da pressão do meio externo. Isso também está presente na opinião expressa por Eustáquio quanto à dispensabilidade do advogado, que parte da crença (novamente a expressão de um universo subjetivo) de ser suficiente a atuação do magistrado na produção da justiça, como se a verdade expressa pelo juiz, ao fim do processo, pudesse prescindir de uma avaliação crítica externa, conforme cabe ao advogado fazer e, na verdade, não apenas em defesa dos interesses de seu cliente, mas também à luz da correta aplicação do ordenamento jurídico ao caso concreto. Em outras palavras: há, na atuação do bom advogado, não apenas a representação dos interesses de "um cliente", mas também, em muitos casos, o exercício do papel de "guardião das 
instituições e valores sociais". Afinal, não fossem falíveis os juízes, não haveria necessidade de instâncias recursais, e não seriam tão frequentemente reformadas as decisões proferidas nas instâncias inferiores.

Diante de tudo o que foi dito, sentimo-nos relativamente confortáveis para ver em Eustáquio um representante do tipo PENSAMENTO INTROVERTIDO. Resta-nos aferir qual seria sua função auxiliar ( $\mathrm{S}$ ou $\mathrm{N}$ ), bem como se estamos diante de um tipo PERCEPTIVO (P) ou JUDICATIVO (J).

Ora, conforme já vimos na parte teórica de nosso trabalho, às vezes a definição de algumas características pode revelar, por raciocínio lógico, as demais. Isso ocorre, por exemplo, na relação existente entre função principal e inferior, por definição sempre opostas. $\mathrm{Na}$ análise sobre a qual nos debruçamos no momento, uma vez identificada a atitude predominante (I) e também a função principal (T) de Eustáquio, podemos facilmente daí deduzir o seguinte raciocínio:

(a) a função principal é utilizada em conformidade com a atitude predominante;

(b) assumida a hipótese de que a função principal de Eustáquio seja o PENSAMENTO;

(c) e assumida a hipótese de que sua $\underline{\text { atitude }}$ predominante seja a INTROVERSÃO;

(d) haveremos de assumir também a hipótese de que Eustáquio usa sua função PENSAMENTO de modo INTROVERTIDO;

(e) por força da dinâmica compensatória da psique, se a função principal de Eustáquio for introvertida, sua função auxiliar será normalmente usada de forma extrovertida ${ }^{383}$;

(f) por sua vez, sendo o PENSAMENTO - função principal de Eustáquio - de natureza racional (ou seja, de cunho é judicativo - J), a função auxiliar de Eustáquio ( $\mathrm{S}$ ou $\mathrm{N}$ ) terá, necessariamente, natureza irracional, ou seja, será de cunho perceptivo - P;

(g) sendo de cunho perceptivo a função auxiliar de Eustáquio, e sendo extrovertida a orientação da mesma, deduz-se facilmente estarmos diante de um tipo PERCEP-

${ }^{383}$ MYERS, Isabel Briggs. Gifts Differing ..., p. 20. No mesmo sentido: JUNG, Carl G.. Tipos ..., p. 325, § 640. 
TIVO (P), pois assim é aquele que extroverte por meio de uma função irracional/perceptiva (S ou N).

Quando iniciamos nosso estudo da teoria dos tipos, chegamos a imaginar que um juiz do tipo "P" teria sérios problemas para exercer a magistratura, sendo provavelmente o autor da sequência dos despachos que constituem o pesadelo de muitos advogados: os famosos "diga, diga, diga, diga..." mencionados por Isabella, não se chegando nunca a uma decisão, uma vez que o foco da energia do tipo "P" está preferencialmente voltado para a coleta de informações; ao decidir, o indivíduo do tipo "P" tende a experimentar alguma angústia.

Portanto, não foi sem certa surpresa que percebemos que um magistrado do tipo "P”, conforme é o caso de Eustáquio, pode vir a se destacar justamente pela objetividade com que consegue conduzir um processo a seu termo final. Como isso se dá? Convidaremos o leitor a manter essa pergunta em suspenso enquanto buscamos, no discurso de Eustáquio, a confirmação dessa característica, revelada acima por raciocínio dedutivo.

Logo no início de sua fala, Eustáquio nos dá indícios de que extroverte por meio de uma função perceptiva:

Prestei vários concursos: magistratura, ministério público, procuradoria do município, delegado de polícia. O primeiro em que passei foi o da magistratura.

Ou seja: ingressar na magistratura não foi, para ele, a realização de uma meta previamente bem definida. A meta, na verdade, era ingressar em alguma carreira jurídica, qualquer que fosse ela, a fim de sanar um problema financeiro.

As pessoas do tipo "J" tenderiam a eleger previamente uma das possíveis carreiras e estudar de modo focado para o respectivo concurso, podendo, não obstante, a título de experimentação, até se sujeitarem a outros, mas tendo em mente o que fôra previamente eleito. 
As pessoas do tipo "P”, porém, são mais flexíveis, mais abertas aos imprevistos e por isso mesmo mais adaptáveis a eles. E ainda parece haver um segundo indício de tais características no mesmo parágrafo da referida fala de Eustáquio: "De repente, encontrei uma vocação acadêmica”. Ora, Eustáquio não planejara ser professor, como seria típico de um "J": isso simplesmente aconteceu em sua vida, modo de ser típico de um "P".

Otto Kroeger e Janet M. Thuesen ilustram da seguinte forma a fala de um representante do tipo "P": "Quando um grupo do qual faço parte está tentando tomar uma decisão, gostaria de poder sair da sala e voltar depois de ultrapassada essa fase." ${ }^{\mathbf{3 8 4}}$ Em outras palavras: ter de decidir e planejar é algo que, para essas pessoas, normalmente exige o dispêndio de muita energia, de modo que, se puderem, procuram evitá-lo.

Outra característica desse tipo, claramente presente em Eustáquio, é sua confessada aversão à "forma". Justamente por fazer parte de um universo - o jurídico - e, dentro dele, de uma profissão - a magistratura - nos quais a forma vem a ser um dos pilares estruturantes $^{\mathbf{3 8 5}}$, isso parece ser um importante fator de desgaste para Eustáquio, visto que, sob sua perspectiva, o judiciário está repleto de "parnasianos”386.

Por não ser muito afeito a "regras" (situações fechadas e não propiciadoras do improviso), o magistrado do tipo "P" tende a se insurgir contra situações configuradoras de hierarquia. Embora em determinado ponto do discurso de Eustáquio ele revele conformismo com eventuais reformas de seus julgados pelo tribunal, em outros pontos prevalece um senso crítico com relação a isso, principalmente quando seus "improvisos" encontram aí um opositor implacável:

Não sou um juiz formalista... Quando vejo que a coisa está saindo dos trilhos, vou pelos atalhos. No entanto, via de regra, quando chega no tribunal... costuma haver reforma, por causa do paradigma normativista.

\footnotetext{
${ }^{384}$ KROEGER, Otto e THUESEN, Janet M. Op. cit., p. 43. O trecho citado é tradução livre do seguinte excerto: "When a group I'm in is trying to make a decision, I wish I could just leave the room and come back when it's over."

${ }^{385}$ Neste sentido, basta lembrar que o desrespeito ao procedimento processual previsto em lei pode dar ensejo à anulação do processo, sendo esta uma garantia não só de ordem constitucional, como também está inserida no título dos direitos e garantias fundamentais (CF/1988, art. 5º, inciso LIV).

${ }^{386}$ Como pudemos observar no início de nossa entrevista, Eustáquio emprega tal expressão no sentido de exagerado apego à forma.
} 
Em sua autopercepção, Eustáquio chega a declarar que não se vê como paradigma de juiz. De certo modo - à luz do estereótipo que se faz dos profissionais do Direito, mormente quando integrantes da magistratura -, ele tem razão, pois a conduta de seus pares é justamente oposta à descrita por ele:

(...) sou muito aberto, recebo as pessoas, converso com todo mundo, não ligo para pompa, não costumo usar o paletó durante a audiência - ele fica pendurado em minha cadeira; deixo todo mundo à vontade em audiência, fala-se bobagem.

Os juízes mais conservadores podem até ficar arrepiados diante desse perfil, mas nos sentimos muito à vontade para afirmar que não é o formalismo o que torna um juiz melhor ou pior no desempenho de suas funções.

Admitindo já ter convencido nosso leitor do quão plausível seria incluir Eustáquio no grupo dos PERCEPTIVOS $(P)$, voltemos à pergunta que ficou em suspenso: se assim é, como Eustáquio consegue ser tão eficaz na solução dos litígios, uma vez que a facilidade em tomar decisões é normalmente atribuição dos tipos JUDICATIVOS (J)?... A resposta reside numa quase imperceptível sutileza: é que "não decidir" não pode ser tomado como sinônimo de "não resolver".

E o segredo de nosso magistrado perceptivo está justamente aí: ele não extingue os processos dados sob sua jurisdição por meio de decisões propriamente ditas; ele os extingue, ou seja, resolve-os investindo a maior parte de sua energia no sentido de levar os envolvidos a um acordo ("Eu bato firme. Não permito que essas coisas ocorram. Levo as partes a um acordo"). Talvez isso ajude a explicar a quase obsessão de Eustáquio pelas audiências conciliatórias, que vê como:

(a) um meio alternativo à formalidade do rito processual: "Quanto mais ficamos presos à forma, mais nos tornamos escravos do outro; quanto mais se traz as partes à audiência, mais condição há de sentir o que está acontecendo"; 
(b) meio mais adequado de ter acesso não só a um maior número de informações, como também a informações de melhor qualidade, que de outro modo estariam fora do alcance do magistrado: "Há coisas que não são ditas no processo e que apenas podem ser vividas, extraídas na dinâmica que se instala nas audiências. A pessoa emite uma mensagem por meio de enunciados dotados de significado mas também existe uma linguagem corporal, à qual precisamos estar bastante atentos”.

$\mathrm{E}$, curiosamente, não satisfeito em deixar a coleta de informações inteiramente à mercê da dinâmica processual ortodoxa e, dentro dessa ortodoxia, à mercê da colaboração dos advogados, Eustáquio saiu-se com uma solução criativa (uma maior criatividade, aliás, também é típica dos perceptivos): sempre que sente necessidade, e costuma sentir, convoca uma das partes para a tal conversa reservada, onde procura saber exatamente o que está acontecendo.

Essa tática, aliada à da designação de audiência em todos os processos por ele presididos, leva a uma equação cujo resultado operacional é impressionante:

Teve uma vez que marquei quarenta audiências. Pensei na possibilidade de metade dos intimados não aparecer. Acabei fazendo trinta e seis, e foram trinta e seis acor$\operatorname{dos} !$

Nota-se, portanto, na forma de ser de Eustáquio também um forte pragmatismo: sua função PENSAMENTO está mais voltada para as situações concretas consteladas num tempo presente (característica atribuída à função SENSAÇÃO) do que para ideias abstratas, cujo vértice esteja apontando para o futuro (característica atribuída à função INTUIÇÃO). Temos aí, portanto, os primeiros indícios de sua função auxiliar, e há muitos outros.

A energia de Eustáquio é tão voltada para o resultado concreto que, malograda a tentativa de acordo - o que ocorre na minoria dos casos -, ele chega ao ponto de solicitar sejam as petições protocoladas com ele, para com isso evitar maiores delongas e também viabilizar o agendamento preciso da data em que o advogado da parte contrária poderá retirar os autos, sem necessidade de intimação posterior para isso. 
Por ocasião da audiência conciliatória, as partes e respectivos advogados já saem todos intimados dos atos seguintes, havendo, inclusive, a celebração do que Eustáquio designou "paradigmas de compromisso".

Seu senso de praticidade também o impede de se lançar no debate de questões abstratas que possam atrapalhar o curso célere do processo. Isso explica um despacho saneador simples ("não sendo o caso de julgamento antecipado, designo audiência de instrução, debates e julgamento para tal data"), no qual se mostram presentes:

(a) o predomínio de uma posição pessoal (atitude introvertida - I);

(b) uma indiferença em relação à expectativa da parte quanto à solução de preliminares - “(...) costumo fingir que não vi” (função pensamento -T);

(c) a não-tomada de decisão (função perceptiva - P), e

(d) o predomínio de um senso prático, pois, ao decidir preliminares, o juiz abre a porta para o agravo, e “o agravo tranca o processo” (função sensação - S).

O predomínio da SENSAÇÃO sobre a função oposta é sugerido também pelo foco de Eustáquio para o detalhe. Numa audiência, ele procura observar absolutamente tudo:

Olho tudo: a forma como se anda, a postura do advogado, como se senta, como se fala, a entonação, os olhares, se olha para o juiz, ou para baixo, ou para cima; como reage à pergunta feita por mim (se olha para o lado, ou para baixo, etc.). Se a parte olhar para baixo e depois para cima, está mentindo.

Esta não seria a forma de proceder típica de um INTUITIVO.

Eustáquio concordou em responder ao questionário de aferição de tipo, o que confirmou o resultado acima.

Tipo aferido: I S T P - Atitude INTROVERTIDA; PENSAMENTO como função superior e SENSACÃO como função auxiliar. 


\section{MATERIAL COLHIDO NO CURSO DAS AUDIÊNCIAS}

O material a seguir nos fornecerá maiores elementos representativos da personalidade de Eustáquio, permitindo-nos ilustrar mais amplamente as hipóteses aventadas sobre seu tipo psicológico.

Audiência conciliatória em ação de alimentos. O réu possuía três filhos menores, cada um com uma mulher diferente, tendo de pagar alimentos para todos. No processo movido pela terceira mulher, este sob apreciação de Eustáquio, foram fixados alimentos na proporção de $20 \%$ dos rendimentos líquidos do pai da criança, respeitado, porém, o patamar mínimo de meio salário. Em dado momento, a mãe da criança reclamou da insuficiência desses valores:

- Um bebê gasta mais do que isso... - lamuriou-se ela.

Imediatamente, Eustáquio respondeu:

- Mas nas circunstâncias em que a concepção se deu, a senhora não poderia esperar algo muito diferente disso, concorda?

- Concordo - respondeu ela, premida pela evidência do raciocínio do magistrado.

No curso da audiência, Eustáquio não deixou de distribuir um "puxão de orelha" para o réu:

- O senhor sabe o que deveria fazer e não fez. Não saia da linha de novo!

Houve, no mesmo dia, outra audiência versando sobre alimentos, movida pela filha contra o pai. Na verdade, a filha já era moça crescida, contando cerca de dezoito anos. O pai morava em Estado distante e não tinha nenhum convívio com ela, tentando, a todo custo, reduzir o valor da pensão. Em dado momento, a fim de ilustrar a falta de consideração do pai com relação a ela, a moça relatou ter ele dito preferir vê-la debaixo de um caminhão.

Esta audiência foi instalada na sala contígua, de modo que outra ocorria em paralelo.

Na entrevista que me concedeu, Eustáquio deixou clara sua propensão a defender os filhos que pleiteiam alimentos de seus pais. Nessa audiência, isso foi demonstrado, uma 
vez que não escondeu sua irritação com a resistência do réu em auxiliar a filha na proporção esperada por ela. Nosso magistrado simplesmente parecia não ter ouvidos às justificativas que o pai em vão tentava dar:

- Se está difícil, fica um pouco mais: pague por mais três anos - disse-lhe Eustáquio.

$\mathrm{O}$ acordo saiu praticamente a fórceps.

Enquanto se redigia o termo, Eustáquio fez a moça sentar-se próxima dele, momento em que filosofou a respeito de sua situação:

- Você é órfã de pai vivo. Não é dessa maneira que você deve procurar chamar a atenção... receber dinheiro de quem quer vê-la debaixo de um caminhão... Melhor manter distância. Seja firme, seja forte, seja independente, é melhor do que receber um dinheiro amaldiçoado.

Ao mesmo tempo em que Eustáquio tentava diminuir a expectativa da moça em relação ao recebimento de proventos do desalmado pai, este assistia a tudo em meio a lágrimas. Até que ponto eram sinceras, apenas ele poderá dizer - para si mesmo.

Outro caso que vale a pena relatar diz respeito a uma separação litigiosa. O casal possuía um único filho, de onze anos. Ao ser ameaçada pelo marido, a mulher abandonou o lar, deixando para pegar o filho depois, no que, porém, não teve êxito, pois o pai do menino era muito apegado a ele. Aliás, pude entender que parte dos conflitos vividos pelo casal decorriam de divergências na educação do menino.

Ao perceber que o marido não desejava a separação e que a mulher era irredutível a esse respeito, Eustáquio convocou-a a uma conversa reservada, onde se deu o seguinte diálogo:

- Me conta: o que está acontecendo?

Nesse espaço reservado, a mulher ficou mais à vontade para chorar e não tardou a revelar que seu marido era usuário de drogas. Não obstante, seria um ótimo pai. Diante de tal revelação, Eustáquio passou a demonstrar grande preocupação com a criança:

- A senhora acha correto ter deixado seu filho para trás?

- Ele me ameaçou - respondeu a mulher, ainda chorosa.

No entanto, Eustáquio continuou repreendendo-a: 
- Então, o que a senhora está ensinando ao seu filho é que basta ameaçar para conseguir o que se quer?... Veja bem, eu jogo muito limpo com as pessoas, não escondo nada: a senhora fez bobagem!

O sobressalto do magistrado tinha por justificativa a falta de prova para o fato de o pai do menor usar drogas, o que traria dificuldade para passar, de imediato, a guarda do menino para a mãe. No entanto, quando retornou com a mulher para a sala de audiências, encontrou a conversa com o promotor em estado bastante adiantado: o separando confessara ser usuário de cocaína. O alívio de Eustáquio foi visível, valendo, inclusive, elogios ao homem pela coragem de assumir publicamente sua condição de dependência química. Com isso, Eustáquio teve como passar a guarda do menino para a mãe, fazendo constar o seguinte no termo:

Dada a palavra ao requerido, por ele foi dito: MM. Juiz, eu não concordo com a forma pela qual o meu filho é alimentado, mas admito ser usuário de cocaína.

Para compensar, as visitas poderiam dar-se de forma livre e os alimentos apenas seriam devidos passados doze meses da data da audiência, período conferido ao separando para que se sujeitasse a tratamento visando a se livrar da dependência química.

Para finalizar, trazemos a observação feita por Kroeger e Thuesen a respeito de representantes do tipo ISTP: "Eles preferem trabalhar 'no limite', mesmo que isso lhes traga algum risco, se este for o meio necessário para terminar o trabalho.”,387

${ }^{387}$ Op. cit., p. 231 . O trecho citado é tradução livre do seguinte excerto: “They thrive on and prefer "working on the edge', even putting themselves at risk, if that's what it takes to get the job done." 


\title{
4. ENTREVISTA COM "JUDITH”
}

\begin{abstract}
Essa não é minha função. Minha função é decidir. Cada um tem o dever de conhecer a lei. É claro que um maior conhecimento técnico por parte do advogado poderá ajudar a parte. Digamos que uma parte tenha um advogado não tão preparado, que, ao usar determinado argumento, deixe de mencionar um artigo de lei no qual se poderia basear. Nesse caso, eu posso recorrer ao artigo de lei. Mas, se o advogado não consegue impugnar os fatos, a consequência está na lei: os fatos não impugnados serão considerados verdadeiros. Não é função do juiz tentar compensar essa falta de técnica.
\end{abstract}

Para Judith, a escolha da carreira jurídica não se deu por nenhuma razão importante. Quando precisou optar por algum curso universitário, dividiu-se entre o Direito e a Psicologia. O primeiro acabou prevalecendo por trazer "mais opções de escolha no futuro". Maior clareza a esse respeito talvez estivesse vinculada ao fato de ela ter um advogado em sua família.

Ao longo do curso de Direito, teve vontade de ser promotora, o que expressou da seguinte maneira:
Porque sempre tive o ideal da justiça. Nunca me vi como advogada, pois jamais quis defender alguma coisa em que eu não acreditasse. Quanto à magistratura, a- chava a instituição do poder judiciário pouco democrática, muito fechada. Em comparação, achava a instituição do ministério público mais aberta, mais democrá- tica, onde haveria um tratamento igualitário entre seus membros. A partir do tercei- ro ou quarto anos da faculdade, pus isso em mente. No segundo e terceiro anos, fiz estágio em escritório. Depois disso, comecei a prestar uma série de concursos para estagiar junto ao ministério público federal, estadual ou a procuradoria do estado.

Judith estagiou por uns seis meses na procuradoria estadual, onde lidava com processos envolvendo interesses da fazenda. Depois disso, passou para o ministério público estadual, onde o foco de sua atuação voltou-se para a área criminal, da qual afirmou gostar. Quando chegou ao fim do curso universitário, não pôde mais dar continuidade a esse estágio. O próximo passo que deu foi prestar concurso para o ministério público estadual. $\mathrm{Na}$ 
primeira tentativa, não conseguiu passar da segunda fase. $\mathrm{Na}$ época em que soube desse resultado, foi aberto um concurso para ingresso na magistratura:

Embora continuasse querendo o ministério público, (...) pensei que prestar esse outro concurso me ajudaria a manter meu ritmo de estudo. Passei em todas as fases, até chegar na oral. Nessa última fase, a avaliação dura uns quatro dias. Temos de fazer testes psicológicos, passamos por entrevista com psicólogos e assistentes sociais. Também há atividades em grupo. Na entrevista, tive de falar, por duas tardes, porque eu queria ser juíza. A partir daí, acabei me convencendo de que o que eu queria mesmo era ser juíza [risos]. Mas não fui aprovada na fase oral. Fiquei sabendo, pela banca, que se por um lado demonstrei muito bem porque queria ser juíza, por outro passei certa insegurança por nunca ter trabalhado.

Como nunca trabalhou, se fez estágios ao longo dos últimos anos de faculdade? É que Judith não os havia considerado como "trabalho"... No entanto, nos concursos seguintes adotou outro enfoque a respeito de sua autoavaliação, de modo que, quando lhe perguntavam se havia trabalhado, passou a responder que sim, fazendo menção aos estágios.

Depois de ter sido rejeitada para a magistratura, voltou a disputar uma vaga no ministério público. Curiosamente, passou em todas as fases até que, na última, "eu não sabia mais justificar porque queria ser promotora. Dei-me conta de que não queria mesmo ser promotora: queria ser juíza”.

Mas, nesse ponto, houve também uma manobra do destino: esse concurso foi anulado por fraude. Conta ela que o suspeito pelo vazamento da prova era justamente um dos integrantes da banca, por acaso membro do ministério público. Portanto, ao mesmo tempo em que Judith dava-se conta de sua vocação para o judiciário, deixava de lado a idealização que fazia em relação à outra instituição.

Malgrado esse esclarecimento, ela continuou participando do concurso de ingresso para o ministério público, ao mesmo tempo em que participava de outro para a magistratura. Foi vencendo todas as etapas de ambos os processos seletivos, até que sua aprovação neste último fê-la desistir daquele. No entanto, esclarece: 
Mesmo aprovada na magistratura, se sentisse que era o ministério público o que eu queria não deixaria de continuar, até porque estava definindo o que faria profissionalmente por toda minha vida. Hoje me sinto muito feliz com a carreira que escolhi.

Após alguns anos de experiência acumulada na qualidade de juíza, indaguei a respeito da visão que tem do poder judiciário enquanto instituição, ao que ela respondeu:

Acho que, embora seja uma instituição destinada a produzir justiça, existe nela muita injustiça. Se as coisas caminhassem de forma mais regular dentro do poder judiciário, não haveria necessidade de uma instituição como o CNJ (Conselho Nacional de Justiça). Mas, da forma como as coisas são, acho bom que exista esse órgão. Claro, desde que este órgão também atue de forma democrática, justa e regular.

Você poderia dar um exemplo do que lhe passou essa impressão de instituição onde ocorrem injustiças?

Um exemplo de algo que ocorreu comigo. Certa vez, onde eu trabalhava, uma outra juíza queria passar para mim processos que eram atribuição dela. Quando levei o caso à corregedoria, ouvi o seguinte: Você não sabe que na magistratura é assim: quem trabalha mais, fica com mais? Então, acho que existe, às vezes, certo protecionismo para algumas pessoas, não decorrente necessariamente de relações pessoais, mas até mesmo de padrões institucionais. Há, por exemplo, um certo machismo. Embora muitas mulheres estejam ingressando nos quadros, os cargos mais importantes ainda são ocupados por homens.

Quando perguntei a respeito da visão que tinha do processo judicial, antes de começar a responder Judith definiu a seguinte moldura: "Diante dessa pergunta, penso no processo enquanto procedimento e não enquanto disciplina”.

Em seguida, manifestou seu incômodo com a morosidade do sistema, que atribui a dificuldades de ordem material, como número de funcionários, insuficiente treinamento dos mesmos, ausência de equipamentos adequados. Por outro lado, mostra-se favorável a um procedimento que permita às partes plena oportunidade de manifestação de suas ra- 
zões, de modo que a justiça de uma decisão acaba dependendo de um procedimento que "não pode ser tão célere".

Segundo Judith, a solução do litígio nem sempre depende de um contato com as partes. Isso varia de acordo com a natureza da matéria posta sub judice. Em envolvendo questões pessoais, esse contato se mostra necessário. Esse quadro é comum na área de família, onde os problemas debatidos no processo não refletem as questões pessoais envolvidas. Portanto, aí o contato direto passa a ser essencial, sendo a audiência "a oportunidade que a parte tem de se manifestar, de expor seus sentimentos. Isso acaba resolvendo o processo, que pode ter uma solução melhor do que a sentença”. Porém, Judith declara haver casos em que a audiência se mostra dispensável:

Numa briga entre duas empresas, por uma questão contratual, dificilmente o contato pessoal vai trazer algum resultado efetivo, até porque quem vem à audiência é um preposto e não quem está ligado emocionalmente àquilo. Se o contato for feito com quem estiver ligado emocionalmente à questão, a audiência até pode gerar algum resultado.

Com base nisso, Judith adota critérios claros para designar audiência conciliatória: nas causas de família, sempre; nas cíveis, baseia-se em consulta às partes - se ambas manifestarem interesse, a audiência é designada; se uma delas quiser e a outra não, a audiência deixa de ter lugar. Explica a magistrada: "Afinal, a parte não tem obrigação de vir à audiência. Portanto, não adianta eu designá-la se uma das partes não tiver interesse, pois acabará não vindo".

O tempo de duração desse tipo de audiência é muito relativo. Na área de família costumam durar mais, porque há necessidade de se dar espaço para que as questões de base venham à tona:

O que está gerando o conflito pode não ser objeto do processo; às vezes a questão é outra. Portanto, é possível solucionar outras questões se a parte tiver espaço para se expressar. 
Por outro lado, há audiências em que as partes já vêm com o acordo delineado. Também é rápida a audiência em que a proposta de acordo apresentada por uma parte revela-se exageradamente distante da expressa pela outra, mostrando a absoluta inviabilidade do mesmo.

Indagada sobre como se sentia em audiências conciliatórias, Judith respondeu gostar de fazê-las, seguindo-se, porém, uma ressalva: "É difícil falar sobre um sentimento, é mais difícil do que falar sobre coisas objetivas". Também destacou que procura ouvir ambas as partes do processo, a fim de delas extrair o máximo de informações.

O despacho saneador é proferido nos casos que não comportam julgamento antecipado. Judith considera-o essencial para a condução da instrução: "Costumo fazer relatório e fixo os pontos controvertidos. Se for o caso de perícia, já fixo os quesitos do juízo, porque acho que isso vai direcionar a perícia".

Perguntada se já teve de julgar algum processo para o qual o ordenamento jurídico não dava uma resposta muito clara, Judith disse não se lembrar dessa situação, embora acredite que já possa ter ocorrido. Porém, normalmente "há uma norma a aplicar ou algum princípio e, claro, aquilo que você entende como sendo o justo para aquela questão. Às vezes, quando a questão não esteja tão objetivamente no ordenamento jurídico, sempre dá pra encaixar em algum ponto do ordenamento, em algum princípio, em alguma regra constitucional; sempre dá para fundamentar em alguma coisa. Se a questão não estiver de maneira tão objetiva na lei, dá para complementar, tanto de um lado como de outro. Fica um pouco de acordo com o sentimento do juiz".

Doutrina e jurisprudência são muito importantes no desenvolvimento de seu trabalho. Mas não se prende a elas: apenas as toma como pontos de partida para firmar seu posicionamento em determinado caso, mesmo quando majoritárias. Afirma que, como algumas matérias são muito repetidas, é normal o juiz, com o tempo, acabar formando uma posição a respeito delas. 
Judith mantém o hábito de ler todos os acórdãos que vêm para sua vara, independentemente de serem relativos a decisões proferidas por ela ou por algum colega seu. Vê nisso uma forma de se "atualizar um pouco".

Ao receber uma petição inicial, a atenção de Judith é atraída sobretudo pelos "fatos envolvidos naquela demanda",388 . Em segundo lugar, pelo "pedido e o valor da causa". Na sequência de sua fala, comentou:

Com relação a valores envolvidos [num sentido axiológico], muitas vezes não é possível fazer esse juízo apenas com base na petição inicial. Às vezes, claro, isso é inerente, mas às vezes é difícil saber se aquela situação alegada ocorreu ou não. É preciso aguardar a contestação. O valor da causa é um dos principais motivos de emenda da petição inicial ${ }^{389}$. Talvez por isso me chame mais a atenção. É um dos motivos de maior erro, de boa ou má-fé. Muitas vezes a parte atribui à inicial valores muito menores do que os devidos. Por isso, sempre olho.

Falando em valor da causa, sabemos que em ações envolvendo danos morais a parte costuma pedir ao juiz para que arbitre o valor da indenização. Não obstante, pode a parte estimar, na petição inicial, o valor que quer. Como você se porta em relação a isso: determina-lhe que defina o quanto quer e isso passa a ser o valor da causa? Judith responde:

Eu não peço para a parte definir a fim de ajustar o valor da causa, embora fosse o tecnicamente mais correto. Essa situação não se enquadra nos pedidos de valor incerto ou indeterminado. Mas não costumo mandar emendar por conta disso, pois entendo que causaria um prejuízo ao processo. Além disso, o entendimento majoritário no tribunal é no sentido de que pode haver estimativa. Se eu mandar emendar e a parte não o fizer, terei de extinguir o feito. Portanto, embora tecnicamente ache

\footnotetext{
${ }^{388}$ Ao lhe pôr esta questão, exemplifiquei da seguinte maneira: "organização? Apresentação? Tese do advogado? Pedido? Raciocínio? Valor(es) posto(s) em juízo? Situação sócio-econômica da parte?"

${ }^{389}$ A lei obriga o autor de uma ação judicial, quando de sua propositura, a atribuir "valor à causa". Com base nesse valor, são calculadas, dentre outras coisas, as custas processuais, cujo recolhimento deve ser feito no início, em favor do Estado. Além da apuração das custas, outro efeito decorrente do valor da causa é a definição do foro competente para julgar o processo. Há advogados que, ignorando as regras incidentes nessa questão, dão à causa um valor diminuto, visando ao recolhimento a menor de custas. Em regra, o "valor da causa" deve manter consonância com a expressão econômica da pretensão apresentada em juízo (pedido).
} 
que o valor da causa deva manter relação com a expectativa da parte, acabo aceitando, nesses casos, o valor dado à causa pela parte, sem mandar emendar.

A respeito de eventual mentira em audiência, Judith diz ser mais comum verificá-la em testemunhas do que nas partes. Como se porta diante disso? Esclarece não haver consequência legal para a mentira da parte ${ }^{390}$. No depoimento pessoal ${ }^{391}$, a consequência legal adviria nos casos de omissão ou confissão. E complementa:

É difícil. Se surgir alguma contradição com o que consta dos autos, peço à parte para que explique. O que posso imaginar ser "mentira" pode vir a ser esclarecido. Eu acho o depoimento pessoal uma prova praticamente inútil. Em poucos casos, em que há questões pessoais envolvidas, pode ser válida; em outros, como em causas cíveis, acho difícil extrair daí alguma utilidade. Mas não indefiro a oitiva, até porque está na lei. Não haveria fundamento para indeferi-la. Às vezes, os próprios advogados desistem dela ou deixam de recolher as custas necessárias para a intimação [da parte], que fica prejudicada.

Em se tratando de mentira de testemunha, Judith diz costumar adverti-la a respeito das consequências legais ${ }^{392}$. Essa circunstância pode ser aferida por conta de contradição em relação ao que a própria testemunha disse, ou em relação ao discurso de outra testemunha. A advertência pode ser feita mais de uma vez, como oportunidade de retratação. Posteriormente, a análise do caso pode ensejar instauração de inquérito, o que já aconteceu. Judith diz que isso é mais comum na área criminal do que na cível, principalmente em relação ao que foi dito pela testemunha em fases anteriores.

É sabido que muitas vezes existe um descompasso técnico entre os advogados das partes. Indagada sobre se costuma de alguma forma "compensar" isso, a resposta de Judith foi direta e objetiva:

\footnotetext{
${ }^{390} \mathrm{Na}$ verdade, no processo civil há sim: o art. 17, inciso II, do CPC prevê ser hipótese de litigância de má-fé, punível com multa. Porém, na prática, é muito raro verificar sua aplicação. A mentira da parte não é sancionada no processo penal.

${ }^{391}$ Depoimento pessoal é o nome dado ao depoimento da parte.

${ }^{392}$ A lei prevê que a mentira da testemunha configura crime e ainda que deve o juiz, no início de sua inquirição, tomar dela o compromisso de que apenas dirá a verdade, advertindo-a da existência de sanção criminal caso faça afirmação falsa, cale ou oculte a verdade (CPC, art. 415).
} 
Essa não é minha função. Minha função é decidir. Cada um tem o dever de conhecer a lei. É claro que um maior conhecimento técnico por parte do advogado poderá ajudar a parte. Digamos que uma parte tenha um advogado não tão preparado, que, ao usar determinado argumento, deixe de mencionar um artigo de lei no qual se poderia basear. Nesse caso, eu posso recorrer ao artigo de lei. Mas, se o advogado não consegue impugnar os fatos, a consequência está na lei: os fatos não impugnados serão considerados verdadeiros. Não é função do juiz tentar compensar essa falta de técnica.

Ao ouvir tal resposta, imaginei o caso de um réu que, tendo razão, sequer saiba o que fôra alegado por seu advogado em defesa, e tenha sido tal defesa muito mal elaborada. Portanto, voltei à pergunta: digamos que o advogado da parte não tenha sido muito competente na contestação e que, pela reação desta, em audiência instrutória, você perceba isso. A resposta de Judith revelou a existência de um posicionamento muito claro sobre o tema, corroborando, com outras palavras, o já dito acima por ela:

Posso tentar contemplar isso em audiência conciliatória. O Direito é técnico e algumas técnicas têm de ser utilizadas. Essa é uma delas: se o fato não estiver impugnado na contestação, ele é presumido verdadeiro. Proferido o despacho saneador, e fixados os pontos controvertidos, não se pode voltar atrás e abrir espaço para novos argumentos, fazendo o processo voltar a uma fase anterior. Senão o processo não teria fim, e a morosidade, que é a principal reclamação que se dirige ao Poder Judiciário, aumentaria mais ainda. Portanto, acho que algumas regras técnicas têm sempre de ser respeitadas. Como o Direito é muito amplo, às vezes é até possível dar um jeito, mas é muito difícil. Cada caso é um caso.

Salvo a juntada de documento novo, Judith não costuma ouvir a parte contrária após a réplica. Aliás, em se tratando de matéria exclusivamente jurídica, e daquelas que se repetem no judiciário (exemplifica com causas versando sobre "contratos bancários"), já passa para a sentença, sem nem mesmo consultar as partes sobre eventual interesse em tentar conciliar. Diante de minha exclamação com tal postura, que me pareceu um pouco "precipitada", esclareceu: 
Essa audiência [a conciliatória] não é obrigatória, e isso por conta de um novo dispositivo que foi acrescentado ao art. 331 do $\mathrm{CPC}^{393}$. Portanto, não existe a possibilidade de anulação [da sentença, por alegada "violação de rito processual"]. Quando acho que pode haver qualquer dúvida a respeito de valores, peço para a parte informar se tem interesse na conciliação e para especificar provas que pretende produzir. Caso haja interesse, então marco essa audiência, ainda que eu, pessoalmente, não acredite na realização de acordo. Mas é critério das partes, que têm esse direito. Mas se uma das partes não quiser essa audiência, não a designo. Afinal, não está obrigada a comparecer e acho inútil prolongar a pauta, fazer a parte vir - já vi advogado reclamar, em audiência que havia sido designada por colega meu: "Mas para que foi designada se a parte contrária nem veio?" Havendo interesse em produzir prova, analiso o pedido.

Judith não gostou de atuar na área criminal, que considera "muito repetitiva". Além disso, mencionou o fato de muitas questões serem resolvidas na polícia, "de um jeito ou de outro..." Trabalhar no júri até que não foi ruim, mas a incomodava a demora do procedimento e a falta de compreensão de muitos jurados a respeito do que se passava no processo. Portanto, é uma área em que não gostaria de voltar a trabalhar. Tem preferência pelas áreas cível e de família. O cível atrai-a pela oportunidade que aí tem de estudar e o direito de família por perceber que pode "ajudar a resolver o problema das pessoas mais do que em outras áreas. Gosto de fazer as audiências de conciliação, por mais que durem duas ou três horas, traz uma satisfação pessoal ver os problemas resolvidos".

Nossa entrevistada não se incomoda em receber advogados para despachar, o que afirmou fazer sempre. Ao responder a essa pergunta, restringiu-se a dizer: "Sempre, sem problema algum". No curso da entrevista, voltei à questão, perguntando "por quê":

${ }^{393}$ Art. 331. Se não ocorrer qualquer das hipóteses previstas nas seções precedentes, e versar a causa sobre direitos que admitam transação, o juiz designará audiência preliminar, a realizar-se no prazo de 30 (trinta) dias, para a qual serão as partes intimadas a comparecer, podendo fazer-se representar por procurador ou preposto, com poderes para transigir. (Redação dada ao caput pela Lei ${ }^{\circ} 10.444$, de 07.05.2002, DOU 08.05.2002, com efeitos a partir de 3 (três) meses após a data de publicação) (...)

$\S 3^{\circ}$ Se o direito em litígio não admitir transação, ou se as circunstâncias da causa evidenciarem ser improvável sua obtenção, o juiz poderá, desde logo, sanear o processo e ordenar a produção da prova, nos termos do $\$ \mathbf{2}^{\mathbf{0}}$. (NR) (Parágrafo acrescentado pela Lei ${ }^{\circ}$ 10.444, de 07.05.2002, DOU 08.05.2002, com efeitos a partir de 3 (três) meses após a data de publicação) (Grifamos.) 
Primeiro, porque não vejo nenhum motivo contrário; depois, essa é minha função. Se o advogado precisa falar comigo, estou aqui, à disposição durante o horário de expediente.

Aproveitei para perscrutar a opinião de Judith a respeito da classe dos advogados:

Não tenho uma visão fixa ou rígida. Acho que, como em todo lugar em que há seres humanos, há advogados bons tecnicamente e com bom caráter, bem como advogados mal preparados e com caráter não tão bom, que agem de má-fé... Acho que existe de tudo. Não tenho uma visão estereotipada. É o que acontece em qualquer outro lugar.

Quando confrontada com o movimento visando à digitalização dos processos, Judith começa com uma referência à sua dificuldade pessoal no que diz respeito a lidar com os procedimentos de informática, que exigem um conhecimento que ela ainda não domina. No entanto, é bastante taxativa ao dizer que terá de enfrentar tal dificuldade, de modo que isso não virá a ser impedimento à adoção do que for necessário à modernização das tarefas. Num segundo momento, faz referência à falta de suporte material:

(...) não existe estrutura suficiente. Não adianta tentar implantar a digitalização se não existe respaldo material, aparelhos, para isso. Sei de varas que já funcionam com o sistema digital e que ele chega a não funcionar em determinado período do dia; é muito mais demorado despachar em sistema digital do que no tradicional. A assinatura digital exige a instalação de programas específicos no computador e às vezes surgem dificuldades pela falta de instalação dos mesmos, obrigando o juiz a ir atrás do funcionário de informática e depender dessa assistência. Isso gera estresse. Outro ponto importante: os advogados serão obrigados a trazer tudo digitalizado? Se não, qual deverá ser a estrutura do tribunal para lidar com a necessidade de digitalizar aquilo que for trazido pelos advogados?... À parte esse tipo de dificuldade, acho que será bom.

Reputando interessante procurar saber até que ponto a entrevistada tem consciência de aspectos de sua personalidade que lhe trazem sejam dificuldades, sejam facilidades no dia a dia, fiz essa pergunta a Judith. Sua resposta foi bastante objetiva: "Na parte da facili- 
dade: sinto ter a liderança necessária para conduzir uma audiência”. Forcei maiores considerações: pode explicar melhor?

O juiz é o presidente da audiência. Em determinados momentos, a audiência fica tumultuada e cabe ao juiz restabelecer a ordem. Por exemplo: certa vez, num júri, o réu começou a gritar e a ameaçar o promotor, que estava falando. Precisei recolocar o réu em seu devido lugar. Disse-lhe para que se calasse, no que fui atendida. O juiz precisa saber desempenhar seu papel de presidente da audiência.

O ponto seguinte concernia a dificuldades, momento em que Judith pareceu fazer um esforço maior de autoinvestigação, cujo movimento foi sendo expresso enquanto ocorria, até alcançar um fluxo espontâneo:

Talvez ao longo da carreira eu tenha... É uma profissão que envolve relacionamento humano de variadas formas, com advogados, partes... Então, é importante repensar a questão dos relacionamentos... Sempre tem um problema. No começo, um pouco mais. Às vezes um certo envolvimento a mais... Uma questão de família, por exemplo. Às vezes me sinto mais envolvida do que deveria, por exemplo, com uma das partes. Talvez não devesse trazer o problema para mim e nem me colocar, durante uma audiência, às vezes, mais de um lado do que de outro. Claro, às vezes quando envolve menores isso fica mais difícil. No começo de minha carreira, enfrentei certa dificuldade numa comarca em que os advogados como que competiam com os juízes; às vezes até faltavam com a educação, numa espécie de disputa. Por exemplo: certa vez eu estava presidindo uma audiência e um advogado que aguardava na sala começou a falar ao celular, atrapalhando os trabalhos. Recusava-se a parar com isso alegando ser a sala do juiz um lugar público. Já passei por essas situações... No começo, era mais combativa, até por achar que não se trata de uma questão pessoal, mas do próprio Judiciário; hoje acho que sou menos combativa em relação a esse tipo de coisa, pois acho que o desgaste não vale tanto a pena. Quando os advogados vinham despachar, costumava ouvir todos os argumentos e muitas vezes contra-argumentava. Hoje não: despacho pela conclusão e depois decido. Aprendi a ficar mais contida.

Judith revelou que, quando suas decisões são reformadas pelo tribunal, não costuma sofrer com isso. Normalmente, encara os problemas enfrentados sob uma óptica técnica, 
havendo posicionamentos majoritários e minoritários. No entanto, no curso de sua carreira, recorda um caso específico em que a atuação reformadora do tribunal causou-lhe tristeza. Era o caso de uma criança que não recebia os devidos cuidados de sua mãe biológica. Quando foi retirada desta, estava "cheia de fezes e com doenças de pele". Como não havia abrigo oficial para acolhê-la, acabou sendo encaminhada para uma família substituta. Os anos se passaram e os vínculos afetivos foram sendo naturalmente construídos. No entanto, em dado momento a mãe biológica reivindicou a guarda do menor. Baseada em estudos sociais e psicológicos, que unanimemente demonstravam a vinculação positiva da criança à nova família, Judith rejeitou o pedido feito pela mãe natural. O tribunal, porém, expressou entendimento diverso:

Quando isso aconteceu, eu nem estava mais à frente daquela vara. Vim a saber da reforma por comentário de um colega. Ele havia ficado triste com a reforma e comentou comigo. Causou dor ao meu coração pensar que aquela criança, que estava bem cuidada e adaptada à nova família, perderia abruptamente essa condição.

Você diz ser uma questão técnica o fato de o tribunal reformar suas decisões. Mas não pode acontecer de o tribunal reformar e você sentir que isso não foi correto?

\begin{abstract}
Sim, muitas vezes! Já aconteceu de o tribunal reformar decisões minhas e mesmo assim, em outros processos, eu manter meu posicionamento. No entanto, o contrário também é possível: às vezes mudo meu entendimento, passando a adotar o entendimento expresso pelo tribunal no âmbito de determinado recurso. Mantenhome sempre aberta a eventuais mudanças, a adotar novas posições.
\end{abstract}

Li para Judith o seguinte trecho do livro O Juiz e a Emoção, de Lídia Reis de Almeida Prado, pedindo-lhe para que o comentasse: "Karl Llewellyn acredita que, geralmente, a mente do juiz primeiro antecipa a decisão que considera justa (dentro da ordem jurídico-positiva) e depois procura a norma que pode servir de fundamento a essa solução, atri-

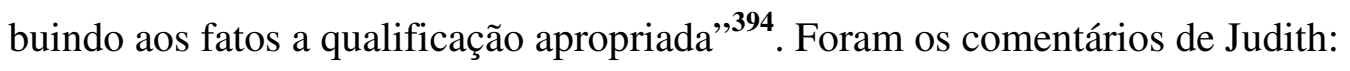

Em regra, acho que é isso o que acontece, mas não em 100\% dos casos. Às vezes, minha antecipação do mais justo não encontra respaldo na norma. Às vezes, a regra

${ }^{394}$ Op. cit., pp. $13 / 14$. 
é contrária e, quando a lei se mostra objetiva em relação ao assunto em questão, mudo meu entendimento. No entanto, em geral, creio que a coisa acaba acontecendo dessa forma.

Igualmente sucinta foi sua resposta quando indagada a respeito de haver diferença entre sua personalidade enquanto juíza e a que apresenta socialmente:

Acho que essencialmente não. Talvez fosse até melhor que houvesse diferenças. Gostaria de ser mais maleável fora da magistratura. Talvez eu siga muito as regras... 


\subsection{ANÁLISE DO PERFIL TIPOLÓGICO DE “JUDITH”}

A objetividade é provavelmente a característica que mais chama a atenção no discurso de Judith a respeito de sua forma de ser, sugerindo, em termos de dinâmica psíquica, o predomínio da função PENSAMENTO. A designação ou não de audiências conciliatórias, por exemplo, segue critérios lógicos, regras aplicáveis de maneira universal aos casos que se lhe apresentam: nas causas de família, sempre; nas cíveis, a depender do resultado de consulta feita às partes - se ambas manifestarem interesse, a audiência é designada; se uma delas quiser e a outra não, a audiência deixa de ter lugar.

Como explica Judith, sendo a audiência de caráter conciliatório, a parte não tem obrigação de comparecer. Se o juiz a designa independentemente de saber da intenção dos litigantes, corre o risco de ocupar inutilmente sua pauta. Afinal, a ausência de um deles não traz ao faltante nenhum prejuízo processual e torna inviável o acordo, além de gerar incômodo ao que se dispôs a comparecer. Nesse sentido, Judith lembra:

Já vi advogado reclamar, em audiência que havia sido designada por colega meu:

"Mas para que foi designada se a parte contrária nem veio?"

Portanto, notamos aí um considerável contraste em relação à conduta de Eustáquio, cujo perfil já analisamos. Diferentemente de Judith, vimos que aquele magistrado tem por regra designar audiências conciliatórias em todos os processos, não importando sejam eles da área de família ou da cível em geral. Eustáquio não consulta as partes a respeito. Também vimos que o referido magistrado traz características que apontam para o predomínio da função PENSAMENTO. Ora, se esta também é a hipótese que começamos a traçar para a personalidade de Judith, como explicar a diferença de postura entre eles?

Aproveitamos a questão para reiterar oportuna ressalva teórica: conforme vimos em capítulo próprio, pessoas com a mesma tipologia podem apresentar comportamentos consideravelmente diferentes, mesmo que as quatro letras identificadoras de seu tipo sejam as mesmas. No entanto, em regra, condutas diferentes apontam para tipos diferentes, e será o caso de Judith e Eustáquio. Na verdade, eles apresentam tipos opostos: não na função principal, que suspeitamos seja a mesma para ambos, mas na atitude. 
Enquanto em Eustáquio apontamos as características de um PENSAMENTO INTROVERTIDO, em Judith parece predominar o PENSAMENTO EXTROVERTIDO. Apesar da suposta proximidade entre pessoas com a mesma função principal, Von Franz destaca que mais difícil do que compreender alguém do tipo contrário é compreender alguém com o mesmo tipo funcional, porém com a atitude oposta: um fica sem saber "como as coisas funcionam na cabeça do outro, não consegue penetrar nela". 395

Ao tecer comentários a respeito do tipo PENSAMENTO INTROVERTIDO, Jung não deixou de contrastá-lo com seu congênere EXTROVERTIDO, para o qual, segundo ele, "a representação dos fatos é de verdade indiscutível, pois o fator subjetivo está excluído e os fatos se provam por si mesmos (...)"396 [grifamos].

Ainda na lição de Jung, é como se o PENSAMENTO EXTROVERTIDO dissesse: Est, ergo est (é, portanto é), enquanto o PENSAMENTO INTROVERTIDO diz: Cogito, ergo cogito (penso, portanto penso). Este último [introvertido] "levado ao extremo chega à evidência de seu próprio ser subjetivo, ao passo que o pensamento extrovertido chega à evidência de sua plena identidade com o fato objetivo", a ponto de negar-se a si mesmo ao se conformar plenamente ao objeto. ${ }^{397}$

Portanto, é verdade que ambos os tipos PENSAMENTO - Judith e Eustáquio - têm como função principal aquela que se caracteriza pela objetividade e pela facilidade em desenvolver raciocínios lógicos. No entanto, enquanto no caso de Eustáquio essa função é carregada de matizes de sua própria subjetividade, ou seja, para ele a realidade funciona menos como elemento conformador de sua maneira de pensar do que como corroborador desse pensar, para Judith o pensar se coloca em plena sintonia com o dado externo e a ele se submete.

Com base nisso, podemos sugerir que um magistrado com o perfil de Judith tende a ser mais legalista - ou seja, a buscar o sentido "objetivo" da norma jurídica, no qual acredita - do que seus colegas introvertidos, que tenderiam a suspeitar da inexistência de um

\footnotetext{
${ }^{395}$ A Função Inferior, Op. cit., p. 80.

${ }^{396}$ Tipos ..., p. $361, \S 702$.

${ }^{397}$ Tipos ..., p. 361, § 702.
} 
sentido objetivo da norma, uma vez que todo sentido normativo haveria de ser projetado por eles. Para o tipo PENSAMENTO EXTROVERTIDO, havendo suficiente clareza na norma, de modo a dar conta da demanda apresentada ao magistrado, basta aplicá-la. O contraste entre estes dois tipos ainda foi objeto do seguinte comentário de Jung:

Ambos os modos de pensar sentem o outro como usurpação, surgindo então o efeito sombra que um projeta sobre o outro. O pensar subjetivamente orientado parece mera arbitrariedade e o pensar extrovertido, incomensurável chatice e banalidade. Por isso os dois pontos de vista se digladiam sem tréguas. ${ }^{398}$

Mesmo que Judith tenha respondido afirmativamente à colocação de Karl Llewellyn, no sentido de que geralmente o juiz antecipa a decisão que considera justa, procurando em seguida sua fundamentação na ordem jurídico-positiva, podemos notar uma diferença clara entre as atitudes introvertida e extrovertida da função PENSAMENTO.

O PENSAMENTO INTROVERTIDO tende a levar em consideração o que reputa justo e, em seguida, busca a norma para fundamentar seu posicionamento, dando a ela a elasticidade que for necessária para isso - afinal, não se pode criar, por meio da lei, “um país de anjos" [do discurso de Eustáquio]; já o PENSAMENTO EXTROVERTIDO tende a ser mais submisso ao sentido "objetivo" que a norma venha a ter, até porque, diferentemente do introvertido, costuma dar mais peso a este sentido, a acreditar em sua existência:

Às vezes, minha antecipação do mais justo não encontra respaldo na norma. Às vezes, a regra é contrária e, quando a lei se mostra objetiva em relação ao assunto em questão, mudo meu entendimento.

No entanto, no caso de Eustáquio, a quem elegemos como representante do tipo PENSAMENTO INTROVERTIDO, tendo ele um entendimento a respeito de como deve ser julgado determinado caso, esse entendimento tende a ser, então, “o" sentido da norma:

Um colega meu, que é um excelente juiz e, pior, meu amigo, deu uma sentença acolhendo aquela tese! Não me conformei! Dizia ele: "Mas a lei...” Ora, neste caso,

${ }^{398}$ Tipos ..., p. 329, § 648. 
"dane-se a lei!" Na verdade, tratava-se de uma determinada interpretação da lei; cabia interpretação diversa. [Do discurso de Eustáquio.]

Embora nos antecipemos em relação a outro aspecto da tipologia de Judith, o contexto torna conveniente que façamos referência ao fato de que, por definição, todo PENSAMENTO EXTROVERTIDO venha a constelar também um tipo JUDICATIVO (J). Sim, porque o PENSAMENTO é uma função racional, e, sendo extrovertida, Judith lidaria com o mundo externo a partir de sua função principal que, no caso dela, postulamos seja o PENSAMENTO. Uma demonstração detalhada de como se processa a relação entre atitude preferida (I ou E), função principal e os tipos “ $P$ ” e “ $J$ ” pode ser vista na análise do perfil tipológico de Eustáquio, para onde remetemos o leitor interessado.

E por que isso é importante neste ponto de nossa análise? Porque justamente os tipos JUDICATIVOS tendem a ser mais afeitos a regras, sentindo-se incomodados quando as violam, o que não se verifica nos tipos PERCEPTIVOS, que têm preferência pelo inusitado e pelo improviso. De certo modo, isso está presente no comentário de Judith a respeito do pensamento de Llewellyn.

Retornemos, porém, à análise de sua função principal. Que outros indícios podemos apontar do predomínio da função PENSAMENTO?

Já vimos que não raras vezes a função principal nos é indicada pela inferior, que em alguns casos é mais visível. Judith nos dá uma preciosa dica a respeito, quando, indagada sobre como se sentia em audiências conciliatórias, rematou sua resposta com a seguinte assertiva: "É difícil falar sobre um sentimento, é mais difícil do que falar sobre coisas objetivas".

Por outro lado, ao falar de aspectos de sua personalidade que favorecem seu trabalho, Judith fez menção à "liderança" que sabe exercer no curso de uma audiência, e que está baseada na autoridade de seu cargo:

O juiz é o presidente da audiência. Em determinados momentos, a audiência fica tumultuada e cabe ao juiz restabelecer a ordem. Por exemplo: certa vez, num júri, o 
réu começou a gritar e a ameaçar o promotor, que estava falando. Precisei recolocar o réu em seu devido lugar. Disse-lhe para que se calasse, no que fui atendida.

No caso de Judith, encontramos dificuldade em analisar sua função principal separada da atitude. Por isso já nos referimos, logo no início de nossa análise, à qualidade $E X$ TROVERTIDA de seu pensamento. Considerado esse aspecto de sua personalidade, nosso trabalho ficará facilitado se lembrarmos que tal combinação constela necessariamente um tipo "J".

Portanto, podemos dizer que no discurso de nossa magistrada as características de um tipo “ $\boldsymbol{E} \_\boldsymbol{T} \boldsymbol{J}$ ” ficam relativamente visíveis, por exemplo, na forma como lida com eventual descompasso técnico entre os advogados das partes. Judith simplesmente afirma não ser sua função empreender alguma compensação. Aliás, tem bastante clareza a respeito de sua função: "Essa não é minha função. Minha função é decidir".

Para um PENSAMENTO EXTROVERTIDO, seria preciso que o esforço de compensação do descompasso mencionado tivesse algum assento na lei, porque, para o representante desse tipo, o que é, é; e o que não é, não é. Não cabe a ele atuar sobre a realidade a partir da projeção de aspectos de sua subjetividade (característica do INTROVERTIDO). Cabe à parte, isso sim, contratar o advogado e arcar com as consequências de uma má contratação, consequências estas, aliás, previstas em lei - por cujo cumprimento um "J" PENSATIVO tende a primar:

(...) se o advogado não consegue impugnar os fatos, a consequência está na lei: os fatos não impugnados serão considerados verdadeiros. Não é função do juiz tentar compensar essa falta de técnica.

Neste ponto da entrevista, a única ressalva aparentemente feita por Judith quanto à eventual atuação compensatória do magistrado diz respeito à falta de menção, pelo advogado, de determinado "artigo de lei no qual se poderia basear". Nesse caso, Judith admite suprir a omissão. Ora, mas aí estaria ela amparada em "lei", tendo em vista a existência dos ancestrais brocardos jurídicos "da mihi factum dabo tibi jus" [dá-me os fatos que te darei o direito] e "juria novit curia” [o juiz conhece a lei]. 
Segundo a tradição jurídica, comete realmente falta grave o advogado que não fornece ao juiz os fatos necessários a fazer prevalecer sua tese, sendo, porém, contornável no sistema jurídico-processual eventual impropriedade na indicação da norma jurídica incidente, até porque a última palavra a respeito da norma incidente é mesmo reservada ao julgador, não estando ele sequer adstrito às que forem apontadas pelas partes. $\mathrm{O}$ mesmo não ocorre com os fatos, havendo princípio jurídico que obriga o magistrado, no julgamento da causa, a ater-se aos fatos trazidos aos autos (quod non est in actis non est in mundo).

Contamos com a licença de nosso leitor para uma irresistível digressão. A respeito da disparidade técnica entre os patronos das partes, e suas consequências face ao juiz, lembra-nos um ensinamento de Piero Calamandrei, advogado que, com base em sua larga experiência forense, diz o seguinte:

Com muita frequência, os juízes, pela tendência que todo homem sente a proteger os fracos contra os fortes, são levados, sem perceber, a favorecer a parte mais mal defendida: às vezes, um defensor inexperiente, se encontrar um juiz de coração generoso, poderá ser de grande valia para seu cliente. ${ }^{399}$

Talvez a lição do admirável autor italiano não tenha a mesma força junto aos juízes do tipo PENSAMENTO EXTROVERTIDO, para os quais, em nome de um princípio maior, "algumas regras técnicas têm de sempre ser respeitadas", mesmo que, por vezes, isso possa trazer alguma injustiça para a parte. Claro que, sob o ponto de vista deste magistrado, nenhuma injustiça haverá: não se trata, portanto, de ser indiferente a ela, mas, antes, de percebê-la sob uma perspectiva própria de seu tipo.

Normalmente, "dar um jeito" à margem da técnica não compõe a rotina do representante desse tipo: isso, para ele, costuma ser muito penoso, "muito difícill". Jung ensina que "a moral do tipo pensamento extrovertido proíbe tolerar exceções. Seu ideal tem que ser realizado, custe o que custar, pois, a seu ver, é a mais pura formulação da realidade objetiva e, portanto, tem que ser verdade aceita em geral, indispensável à

${ }^{399}$ Eles, os Juízes, Vistos por um Advogado, trad.: Eduardo Brandão, SP, Editora Martins Fontes, 1997, p. 7. 
salvação da humanidade. E isto não por amor ao próximo, mas do supremo ponto de vista da justiça e da verdade". 400

Para o tipo PENSAMENTO, o sentido do justo tende a estar muito próximo dos conceitos de "certo" e "errado" firmados abstratamente, e seu juízo sobre os fatos trazidos à sua apreciação será feito a partir da adequação dos mesmos com algumas regras traçadas idealmente. Portanto, não raro a conclusão a respeito da justeza de uma conduta depende do resultado da confrontação de princípios, que, ao ser feita, deixa como rastro um traçado silogístico, um edifício retórico cujos blocos são amalgamados pela coerência.

Todavia, embora toda decisão judicial precise ser fundamentada, sob pena de nulidade $^{\mathbf{4 0 1}}$, qualquer profissional do direito "sabe" que nem sempre uma boa fundamentação conduz a uma decisão justa, bem como nem toda fundamentação deficiente conduz a uma decisão injusta. Com base em sua experiência, tal constatação levou Calamandrei a tecer as seguintes ponderações:

Mais que nos virtuosismos cerebrais da dialética, os bons juízes confiam em sua sensibilidade moral (...) Todos os advogados sabem que os decisórios justos são muito mais frequentes do que fundamentações irrepreensíveis, de modo que, muitas vezes, depois de uma reforma por vício de fundamentação, o redator do acórdão não pode fazer outra coisa, em sã consciência, senão reproduzir, com maior habilidade, o dispositivo da decisão reformada. Isso acontece porque, às vezes, o juiz de dotes morais superiores aos dotes intelectuais sente, por intuição, de que lado está a razão, mas não consegue encontrar os expedientes dialéticos para demonstrá-lo. ${ }^{402}$ (Grifamos).

Nosso jurista não dispunha das ferramentas teóricas de que ora nos valemos e, por isso, não expressa sua percepção em linguagem psicológica. Por isso emprega a expressão "sente, por intuição", quando, na verdade, postulamos que sentir e intuir sejam coisas bastante diversas. Não obstante, seu comentário não deixa de nos ser bastante útil, mormente se corremos o risco de transpô-lo para nosso universo semântico. Da observação

\footnotetext{
${ }^{400}$ Tipos ..., p. 331, $§ 652$.

${ }^{401}$ Diga-se de passagem que, no ordenamento jurídico brasileiro, tal princípio tem assento constitucional (CF/1988, art. 93, IX).

${ }^{402}$ Op. cit., p. 181.
} 
feita por CALAMANDREI, vemos que já percebia ele a oposição existente entre SENTIMENTO e PENSAMENTO, e o maior desenvolvimento, no juiz tipo SENTIMENTO, do senso de justiça ${ }^{403}$. Ao mesmo tempo, também é nítida a percepção de que um SENTIMENTO mais desenvolvido costuma trazer um PENSAMENTO em posição inferior, donde a maior dificuldade de "encontrar os expedientes dialéticos" para fundamentar o julgado...

Isso não implica dizer que um juiz do tipo PENSAMENTO não seja um bom juiz, pois seria o mesmo que partir da falsa premissa de que alguém do tipo PENSAMENTO não sente, ou de que alguém do tipo SENTIMENTO não pensa. Ou, ainda, deslocar todo o mérito de uma boa judicatura para a capacidade de identificar onde está o justo, como se também não fosse vital para o exercício e longevidade dos valores democráticos a elaboração de uma fundamentação coerentemente amparada pelo ordenamento jurídico positivo.

Um bom juiz é resultado desse equilíbrio delicado, e este apenas é possível quando cada um conhece seus pontos fortes, que eventualmente precisem ser "contidos", e os fracos, que demandam atenção especial no sentido de seu desenvolvimento. No curso de nossa entrevista, Judith revelou, em certos pontos de sua fala, que tem posto em marcha esse mecanismo compensatório. Está na hora de devolver à nossa magistrada o foco de nossa atenção.

A qualidade EXTROVERTIDA do PENSAMENTO de Judith também pode ser vislumbrada na forma como respondeu à pergunta "Costuma receber advogados para despachar?" Limitou-se a dizer: "Sempre, sem problema algum". O que nos chama a atenção é a ausência de qualquer reflexão a respeito, tomando-se esse último termo no sentido de elaboração "do sujeito" sobre o fato objetivo, o que seria próprio de um INTROVERTIDO. E vale notar que, mesmo quando "provocamos" alguma reflexão ["Por quê??”], o pensamento de Judith continuou conformado por aspectos dotados de uma qualidade mais $o b$ jetiva que subjetiva:

\footnotetext{
${ }^{403}$ Isso fica mais claro ainda no seguinte trecho da obra de CALAMANDREI: "O risco das causas costuma estar neste antagonismo: entre o juiz lógico e o juiz sensível (...) entre o juiz que para não cometer uma injustiça está disposto a se rebelar contra a tirania da jurisprudência e o juiz que, para salvar a jurisprudência, está disposto a deixar esmagar nas inexoráveis engrenagens da sua lógica um homem vivo". $O p$. cit., p. 185.
} 
Primeiro, porque não vejo nenhum motivo contrário; depois, essa é minha função. Se o advogado precisa falar comigo, estou aqui, à disposição durante o horário de expediente.

A mesma objetividade pode ser vista na avaliação que faz da classe dos advogados: "Acho que existe de tudo. Não tenho uma visão estereotipada". Em termos objetivos, quem pode não he dar razão? De fato, como em qualquer profissão, há na advocacia bons e maus profissionais, tanto do ponto de vista técnico quanto moral. Tomamos isso como indício de PENSAMENTO EXTROVERTIDO: EXTROVERTIDO, porque prepondera o objeto em relação ao sujeito, e PENSAMENTO porque avaliado o objeto de maneira ontológica - o que é - em vez de axiológica - que valor tem para mim. Apenas para fins de contraste, cumpre lembrar o quanto sua opinião difere da expressa pelos magistrados INTROVERTIDOS a respeito do mesmo tema:

Enfim: é negativa a imagem que tenho da advocacia. [Do discurso de Isabella.]

A respeito da advocacia, Eustáquio revelou-se contrário à tese que apresenta o advogado como figura essencial: "O indivíduo tem de ter plenitude de sua cidadania e exercer sua autodefesa" (...) as coisas acabam mesmo é ficando "nas costas do juiz". Há bons advogados; no entanto, a maioria deixa a desejar: "escreve muita bobagem, carrega nas tintas...” [Do discurso de Eustáquio.]

Outra forma muito curiosa de expressão da atitude EXTROVERTIDA é a necessidade que muitos EXTROVERTIDOS têm de externalizar seu pensamento como maneira de melhor processá-lo e apreendê-lo. É muito comum, portanto, vermos um EXTROVERTIDO “pensar alto", ou seja, verbalizar o pensamento enquanto seu processo de construção se dá. ${ }^{\mathbf{4 0 4}}$ Como o fluxo de sua energia psíquica (libido) está voltado para o mundo externo, se visualizarmos esse fluxo como um curso de águas, é como se o pensamento do EXTROVERTIDO se deixasse arrastar por ele e, passasse, em parte, a se processar "externamente". No caso de Judith, parece ter sido esse o movimento que se deu na fase de definição de sua vocação profissional:

${ }^{404}$ KROEGER, Otto e THUESEN, Janet M. Op. cit., p. 35. / QUENK, Naomi L. Essentials ..., p. 8. 
$\mathrm{Na}$ entrevista, tive de falar, por duas tardes, porque eu queria ser juíza. A partir daí, acabei me convencendo de que o que eu queria mesmo era ser juíza [risos]". Foi "falando" que Judith tomou contato com seu "eu interno", e tanto falou ("por duas tardes") que esse contato pôde se fazer de maneira intensa e, como pudemos deduzir de sua fala, irreversível: "eu não sabia mais justificar porque queria ser promotora. Dei-me conta de que não queria mesmo ser promotora: queria ser juíza.

Num momento de nossa curta entrevista, quando solicitei a Judith que falasse de algum aspecto de sua personalidade que, segundo ela, lhe traria dificuldades no exercício da profissão, configurou-se um exemplo típico desse "PENSAR EXTROVERTIDO":

Talvez ao longo da carreira eu tenha... É uma profissão que envolve relacionamento humano de variadas formas, com advogados, partes... Então, é importante repensar a questão dos relacionamentos... Sempre tem um problema. No começo, um pouco mais. Às vezes um certo envolvimento a mais... Uma questão de família, por exemplo.

A característica da extroversão também nos é sugerida pela maneira como Judith interagia com os advogados que vinham despachar com ela: "costumava ouvir todos os argumentos e muitas vezes contra-argumentava. Hoje não: despacho pela conclusão e depois decido. Aprendi a ficar mais contida." Por que aprendeu a ficar mais contida? Na parte mais reservada de nossa conversa, Judith comentou comigo que, diante de uma contra-argumentação, alguns advogados tentavam convencê-la de suas razões, o que podia tornar o contato estressante. Assim, aprendeu a controlar seu impulso mais natural, que é o de falar, de interagir com o outro, dando-nos um exemplo de como um EXTROVERTIDO pode perceber que, sob dadas circunstâncias, uma atitude INTROVERTIDA vem a ser mais adequada, passando, não sem algum esforço, a adotá-la.

Igual esforço pode ser visto no sentido de evitar atrito com as pessoas (em nossa entrevista, citou como exemplo a conduta grosseira ou competitiva de advogados), o que Judith identifica como uma "menor combatividade". Com o passar do tempo - leia-se: conforme caminha para a maturidade -, ela chegou à conclusão de que em alguns casos "o desgaste não vale tanto a pena". Isso é indício de maior integração de sua função inferior (SENTIMENTO). 
Conforme já dito acima, apesar de podermos deduzir que Judith se relaciona com o mundo externo por meio de um perfil JUDICATIVO $(J)$, será que conseguiríamos encontrar em seu discurso alguns indícios disso?

Quando nossa entrevistada se refere à escolha de sua carreira profissional, notamos uma tendência em definir isso com alguma brevidade e de modo bastante focado. Já no quarto ano do curso de graduação, tinha posto em mente que faria carreira no Ministério Público. É verdade que veio a mudar de ideia depois, em circunstâncias já exploradas acima. Afirma ter participado do concurso para a magistratura apenas para "manter seu ritmo de estudo", e não porque tivesse dúvidas a respeito da carreira a seguir. Portanto, tal alternância não pode ser vista como sinal de "falta de foco" para tomar decisão (característica mais típico de um "P”), até porque, uma vez definida a nova meta - ingressar nos quadros da magistratura -, Judith perseguiu-a com denodo: "Dei-me conta de que não queria mesmo ser promotora: queria ser juíza". Isso contrasta com a conduta de Eustáquio, um suposto representante do tipo "P", de cujo discurso colhemos a seguinte assertiva:

Prestei vários concursos: magistratura, ministério público, procuradoria do município, delegado de polícia. O primeiro em que passei foi o da magistratura.

Outro aspecto típico de um "J", presente na conduta de Judith, diz respeito à brevidade da instrução processual. Conforme já dito acima, salvo a juntada de documento novo, Judith não costuma ouvir a parte contrária após a réplica. Aliás, em se tratando de matéria exclusivamente jurídica, e daquelas que se repetem no judiciário (exemplifica com causas versando sobre "contratos bancários"), já passa para a sentença, sem nem mesmo consultar as partes sobre eventual interesse em tentar conciliar.

Eustáquio também afirmou não costumar conferir muito espaço para a manifestação das partes, porém sua "coleta de informações" é particularmente intensa e até mesmo peculiar nas audiências conciliatórias, por ele designadas, sem exceção, "em todos os processos”. Judith não: além de não conferir às partes mais espaço para manifestação do que o previsto em lei, ela não perde a oportunidade de julgar antecipadamente a lide. Em outras 
palavras: sua energia psíquica parece percorrer com notável facilidade e rapidez o caminho que leva à decisão.

Ao fim de nossa entrevista, Judith expressou o desejo de ser diferente em sua vida pessoal, na qual gostaria de ter mais maleabilidade e de seguir menos as regras do que na magistratura. Além de ser indicação do tipo "J", também é sinal de uma personalidade que começa a ansiar pelo seu oposto, terreno fértil para, quem sabe, o início do longo processo de individuação.

Resta, por fim, lançar o foco de nossa análise em busca de indícios da função auxiliar de Judith.

Sabemos que haveria de ser uma das funções irracionais: S (sensação) ou N (intuição), mas qual delas? Qualquer que seja, atuaria a reboque da função principal (PENSAMENTO), que lhe daria uma capacidade de perceber as coisas objetivamente. Auxiliado o PENSAMENTO pela SENSAÇÃO, o foco da atenção se voltaria para os dados concretos da realidade, no tempo presente, sendo o mundo percebido tal como ele é; auxiliado o PENSAMENTO pela INTUIÇÃO, a atenção se voltaria para as possibilidades e sentidos simbólicos constelados no presente, mas com foco no tempo futuro, sendo o mundo percebido tal como um vir a ser.

Talvez o que mais chame a atenção para pessoas do tipo SENSAÇÃO seja seu senso de praticidade, e nos parece que isto está bastante presente em Judith. O despacho saneador, por exemplo, apenas é por ela proferido nos casos que não comportam julgamento antecipado. Havendo possibilidade de julgar antecipadamente, não há, a seu ver, razões para sanear o feito. No entanto, sendo o caso de saneá-lo, ela costuma fazer relatório $e$ fixar os pontos controvertidos e, se for o caso de perícia, já fixa os quesitos do juízo, porque acha que isso vai direcionar a perícia.

Por outro lado, quando recebe a petição inicial, o que primeiramente chama a atenção de Judith são os fatos envolvidos na demanda. A atração pelos fatos seria tendência também da função PENSAMENTO que, em combinação com a preferência característica da função auxiliar, será reforçada. 
Diante deste quadro, arriscamo-nos a dizer que, na qualidade de auxiliar, prevalece em Judith a função SENSAÇÃO.

Judith concordou em responder a um questionário de aferição de tipo, o que confirmou o acima sugerido.

\section{Tipo aferido: E S T J - Atitude EXTROVERTIDA; PENSAMENTO como função superior e SENSACÃO como função auxiliar.}

\section{MATERIAL COLHIDO NO CURSO DAS AUDIÊNCIAS}

Tive oportunidade de assistir apenas a uma audiência de Judith que, na verdade, tem relativamente poucas em pauta. Tratava-se de audiência de instrução e julgamento, estando prevista a oitiva de duas testemunhas, estas arroladas pela empresa ré.

As testemunhas ausentaram-se por falta de intimação e a ré acabou por desistir delas. Tampouco houve depoimento pessoal das partes. Não obstante, visando a prestigiar a presença dos envolvidos, Judith indagou a respeito do interesse em apresentar "alegações finais", o que foi feito por ambos os polos.

Enquanto as alegações finais eram digitadas pelo escrevente de sala, Judith aproveitava para dar andamento a outros feitos. Finalizadas as manifestações, voltou o foco de sua atenção para os presentes, mas simplesmente para encerrar a audiência.

Depois disso, brindou-me com os seguintes comentários: ela já tinha um posicionamento formado a respeito do caso, devendo a ação ser julgada improcedente com base no laudo pericial. Disse que normalmente deixa para definir o cabimento da prova oral após a perícia, porque esta poderá apontar a inutilidade daquela prova ou, pelo contrário, revelar sua pertinência. No caso em questão, a perícia havia sido "conclusiva", tornando desnecessária qualquer outra prova. Portanto, ela teria indeferido o pedido de prova testemunhal, já sentenciando de imediato o caso. No entanto, o despacho deferindo a oitiva das testemunhas havia sido proferido por outra juíza, durante sua ausência na vara. 
Judith também comentou que se as alegações finais fossem gerar atraso na tramitação do feito, tê-las-ia indeferido, porque, na verdade, apenas cabem após produção de prova oral, o que, no caso, não se deu (PENSAMENTO + SENSAÇÃO).

É impressionante a clareza logística de Judith a respeito da tramitação processual, sobre a qual ela fala como se estivesse diante de um tabuleiro de xadrez, passando a impressão de dominar perfeitamente a técnica (PENSAMENTO). Também curiosa sua conduta aparentemente "fria" em relação às partes (sinal de força da função PENSAMENTO), e sua capacidade de se concentrar em outras coisas (analisar outros feitos), apesar da existência de fontes de "ruído", o que é característica típica dos EXTROVERTIDOS. 


\title{
5. ENTREVISTA COM "MIRTES"
}

\begin{abstract}
Eu sou superfeliz como juíza, mas eu me realizo... dez vezes mais enquanto mãe de família. Eu tenho tudo da vida: chá e café. Eu quero tudo. Às vezes eu vou a um restaurante, e falo: "Quero chá e café". Da vida eu quero tudo. Se der para realizar tudo, eu acho maravilhoso.
\end{abstract}

Conheci Mirtes por acaso. Naquele dia, eu tinha agendado almoço com Carla, uma amiga comum, também juíza. No meio do percurso, Mirtes fez contato com ela e apareceram ambas no restaurante.

Ao falar de meu trabalho a respeito de tipos psicológicos, comentei precisar encontrar um juiz com determinado perfil, momento em que Carla sugeriu que talvez fosse o de Mirtes. O fato de esta última mostrar-se aberta a me receber foi indício animador de que talvez Carla tivesse razão. Felizmente, as apurações feitas posteriormente vieram a confirmar seu palpite.

Mirtes afirma que optou pela carreira jurídica por ter gostado sempre das matérias humanísticas, bem como de escrever e falar [risos]. Daí para a magistratura foi um passo curto. Ser juíza representou a realização de "um sonho de faculdade, que foi sendo construído ao longo do curso". Mas foi um sonho amadurecido, porque Mirtes afirma ter estudado "como seria o dia a dia das outras profissões: advogados, promotores" e acreditou que "seria muito feliz se ficasse numa posição em que pudesse analisar os dois lados da questão e ser imparcial".

Portanto, a opção pela magistratura foi na verdade resultado das várias atividades jurídicas que desempenhou. Uma delas, em que Mirtes atuou depois de formada, até envolve processo seletivo bastante disputado. Mas nossa entrevistada decidiu abandoná-la por não se sentir realizada profissionalmente. Digno de nota o comentário que fez para assinalar o que a marcou nessa transição: 
Eu gostava muito, tinha muitos amigos lá dentro. Trabalhávamos muito em conjunto, o que, aliás, gerou um choque para mim quando vim para a magistratura, onde trabalho tão sozinha. No entanto, ainda não estava realizada profissionalmente.

Mirtes atribuiu sua falta de realização profissional em outra carreira à falta de liberdade para aplicar a lei da maneira que entendia correta. Além disso, considerava o trabalho muito burocrático e "não gostava de lidar só com números, com execução".

Já como juíza, sente-se "superfeliz, super-realizada". A única ressalva que faz é lamentar a falta de oportunidade de ficar mais tempo no interior, "porque você fica mais próximo dos jurisdicionados, você entende a cidade, o que você faz tem um resultado visível maior do que numa metrópole como São Paulo".

Indagada a respeito de sua visão do judiciário, Mirtes respondeu:

Ah, é um poder organizado... Tem a sua... carreira... demarcada... Às vezes fico triste porque a gente começa no interior e as promoções acabam levando a gente pra capital e... você começa sozinho numa comarca, sendo bem jovem, e depois você... vai para uma segunda entrância, onde tem de dividir a vara com outra pessoa... e depois vem para a capital ou para uma cidade maior. Eu gostaria, por exemplo, de poder voltar um dia para uma cidade de (...) mil habitantes, como era a cidade onde comecei, e fazer um trabalho de mais anos, aí ficar 5, 10 ou 15 anos nessa cidade pequena, numa comunidade pequena, para ver o resultado do trabalho. Então, acho que a instituição poderia nos dar uma oportunidade, na carreira, de poder ficar numa cidade menor para quem tivesse vocação para trabalhar numa cidade menor.

Sabemos que, caso o juiz queira permanecer em determinada comarca, ele até pode, mas isso implica não progredir na carreira. Se pudesse progredir em sua carreira e, ao mesmo tempo, permanecer numa cidade pequena, Mirtes "o faria com gosto".

Isso não significa que ela esteja infeliz no momento presente, porque, embora em cidade maior, Mirtes afirma que ainda consegue conhecer os jurisdicionados por atuar numa vara específica, onde é menor o número de advogados com quem acaba trabalhan- 
do. Portanto, deixa clara a importância que tem, para ela, a oportunidade seja de conhecer os jurisdicionados, sejam os advogados que os representam: “(...) era muito bom, porque pude conhecer os advogados com quem trabalhava".

Para Mirtes, o processo judicial "é um instrumento para obtenção do remédio jurídico, da pacificação social”, nem sempre eficiente, porém necessário.

A respeito da audiência, considera-a muito importante por permitir proximidade com as pessoas, oportunidade "em que você olha nos olhos do réu, nos olhos das testemunhas" e em que pode "sentir a matéria e o que está sendo tratado. É imprescindível", motivo pelo qual sempre designou as audiências conciliatórias, "sempre".

E quanto tempo costumam durar? - perguntei.

De forma espontânea, Mirtes responde: “Ah, o quanto precisar para as partes se apaziguarem" [risos]. Em tais audiências, afirma sentir-se super bem, adorando realizá-las [risos].

Em sua vara, a margem de sucesso das audiências conciliatórias é por ela estimada em 95\%, sendo designadas até quando o rito processual não as prevê de forma específica em determinado caso, momento em que faz uso de um artigo do código de processo civil, que o permite como faculdade do juízo ${ }^{405}$.

Quando o caso é "muito carregado, tem muita briga", reserva um dia especial para a audiência. Assim, nossa entrevistada desconfia marcar mais audiências conciliatórias que seus colegas de trabalho:

Acabo marcando mais audiências conciliatórias que todos os juízes (...), porque marco até... eu uso muito o artigo que fala da possibilidade e para marcar... mesmo em execução de alimentos, mesmo em pedido de prisão, antes de expedir o mandado de prisão por dívida alimentar. Tento marcar antes uma audiência de concilia-

\footnotetext{
${ }^{405}$ Mirtes não conseguiu se recordar do artigo, que é o 125 , IV, do CPC, onde se lê: Art. 125. O juiz dirigirá o processo conforme as disposições deste Código, competindo-lhe: (...)

IV - tentar, a qualquer tempo, conciliar as partes. (Incluído pela Lei $\mathrm{n}^{\circ}$ 8.952, de 13.12.1994)
} 
ção. Em minha pauta acho que tenho muito mais audiências de conciliação que meus colegas.

Isso leva a um quadro de cinco ou seis audiências por dia, cujos intervalos variam de acordo com o caso, de modo a não gerar atrasos e impedir que as partes fiquem esperando além do que haviam programado: “(...) quase não tem atraso aqui. Quando tem, peço desculpas, mas é muito raro ter atraso em audiência”.

O esforço bem sucedido de Mirtes em solucionar os casos por meio da conciliação torna raro o procedimento de instrução processual e, consequentemente, a prolação de despachos saneadores, que calcula em "uns três por semana, se muito. Acho que nem chega a isso".

Porém, mesmo quando necessária a instrução, Mirtes não costuma estendê-la, sendo rara a oitiva da parte em "tréplica": "Só se precisar, mas se não, não. Senão marco uma audiência pra conversar com todo mundo. Acho mais fácil. É muito mais fácil, eu acho”.

Um ponto marcante de nossa entrevista surgiu quando lhe perguntei se já enfrentou situações em que o Direito não dava uma resposta muito clara às questões postas em juízo. Aqui, Mirtes se diferenciou claramente de todos os demais magistrados que entrevistei. Espontaneamente, e com muita naturalidade, disse:

Todos os dias. Eu sempre falo. Porque na vara de família, se o juiz aplica a sentença, ele estará sendo menos justo do que se tentar uma conciliação. Porque é fácil para o juiz, na vara de família, fazer uma partilha de bens: $50 \%$ para cada um em caso de casamento. No entanto, a pessoa tem toda uma vida com a outra. Construíram juntos. Às vezes a pessoa gosta mais de uma casa, ou de um carro ou mesmo terreno, sabe-se lá por que motivo ou em que momento ela escolheu. Não se está tratando só de dinheiro, mas de uma vida em comum, de uma esperança, de amor. Então, quando o juiz fala " $50 \%$ para cada um" porque as partes não chegaram a um acordo, nem sempre está aplicando justiça. Às vezes, numa conciliação, em que cada um cede, "este para você e este para mim"... Ainda mais... Eu acho, em direito de família, muito mais justo... chega muito mais perto da satisfação das pessoas do que simplesmente fixar uma percentagem. Nessa hora você... no fundo a concilia- 
ção é uma chance de as pessoas transigirem a respeito do que elas construíram durante uma vida. O que querem mais?... Quando o juiz fixa 50\% para cada um, aplica a lei, mas nem sempre a justiça.

De qualquer modo, se, uma vez feita a audiência conciliatória, as partes não lograrem chegar a um acordo, Mirtes instrui o feito "a fim de ver a quem cabe o Direito" e resolve por meio da sentença. Nesse ponto, admite ser a decisão judicial justa, dada à luz de uma previsão legal, lembrando que ainda assim podem as partes decidir extinguir o condomínio como melhor lhes convier, "porque em família sempre cabe acordo, sempre”.

Quando lhe perguntei que importância tinham jurisprudência e doutrina em seu trabalho, Mirtes respondeu:

Os dois têm, têm... No direito de família, acho que a jurisprudência é mais... é muito usada, porque é muito dinâmico. As relações familiares estão mudando. O peso que você faz... é... para uma separação hoje em dia é diferente do peso que tinha há 20 ou 30 anos, ou 40 anos. A gente acaba aplicando mais a jurisprudência, eu acho.

É verdade que, em alguns casos, a jurisprudência se mostra bastante inovadora com relação ao cenário jurídico de determinada época, mas normalmente as inovações são primeiramente antecipadas pela doutrina. Foi pensando assim que lhe fiz a seguinte pergunta: Quando você diz que aplica a jurisprudência porque as coisas estão mudando, você dá a entender que, na sua maneira de ver, a jurisprudência estaria um passo à frente da doutrina. Em alguns casos, não acontece o contrário? Mirtes respondeu:

Em algumas questões, sim! Em algumas questões sim, mas... [toca o celular, que ela atende.] No meu caso, também tem doutrina porque... a escola do Rio Grande do Sul... a Maria Berenice Dias... também tem doutrina muito avançada em termos de família, eu acho também. Então, os dois estão bem estruturados na minha área. Então, estou bem feliz, tanto em doutrina quanto em jurisprudência.

Como Mirtes reagiria diante de temas polêmicos, como, por exemplo, a questão da união homoafetiva, em que ainda se encontra uma jurisprudência claudicante? "Não tem problema. Eu prefiro estar feliz com minha consciência do que com a mídia”. 
Como sua resposta limitou-se a isso, perguntei se já havia acontecido alguma vez. Ela respondeu que sim, diante do que solicitei que desse um exemplo:

Por exemplo, a retificação de registro... é... de registro civil... de pessoa com pedido de mudança de sexo, sem fazer nenhuma restrição na cédula... Dei provimento, apesar de já ter uma jurisprudência assim... pequena. Que é crescente, mas ainda pequena.

Mesmo que tenha de ir contra o posicionamento de representante do ministério público, Mirtes diz fazer prevalecer o que considera justo. Para ilustrar, citou o caso de um aborto, por ela autorizado, a despeito de oposição do promotor, que "tinha uma formação cristã muito forte e discordava da medida". Mirtes explica:

(...) em casos de doença do feto, com impossibilidade de nascimento viável, de uma vida... tinha impossibilidade de nascimento... de uma vida digna... poderia até haver nascimento com vida, durante alguns dias, mas nada além disso. Existe quem sustente haver direito à vida, mesmo em tais circunstâncias. Eu achava que não haveria direito a uma vida digna [frisou "digna”], justa, e é assim... você autoriza... não dá nem tempo: é tudo tão rápido, que não dá nem tempo de recurso, de nada, porque autorizou, autorizado está, e tem de fazer correndo por causa do risco de vida da mãe.

Ao receber uma petição inicial, Mirtes diz que a objetividade é o que mais chama sua atenção, complementando:

A narração do problema e a objetividade do pedido, eu acho. A gente só pode ajudar, só pode direcionar se a pessoa conseguir colocar que prestação jurisdicional ela quer, o que ela precisa.

Quando procurei investigar um pouco mais de que forma Mirtes percebia a falta de objetividade nas petições, ela exemplificou com os casos de separação litigiosa, em que um dos cônjuges atribui ao outro a culpa pela separação. Disse ser isso desnecessário, uma vez que dificulta a conciliação e não altera em nada o resultado do processo. Disse que tanto a 
jurisprudência quanto a doutrina "já aboliram essa coisa de culpa. (...) Basta dizer que não quer mais continuar, basta um lado não querer, e pronto".

Havendo discussão a respeito da guarda das crianças, Mirtes informa estar superada a preferência da mãe:

A tônica toda, hoje, é com quem a criança estará melhor, independentemente de mãe ou pai. Todo o balizamento do direito de família é este. E pai e mãe concorrem igualmente, o avô... Antigamente, o pai só trabalhava e a mãe só ficava em casa ou só educava. Hoje em dia vale com quem a criança vai estar melhor. E ponto. Não importa... E nem... até a adolescência a gente nem ouve a criança. Porque a criança é muito fácil de ser manipulada... a criança oscila... ela não quer... E é muito peso você passar para a criança uma decisão que você está preparado para dar, com embasamento técnico, com a ajuda de psicólogos, de assistentes sociais. Você é que está investido daquele poder. Aí vai virar para a criança e perguntar para ela com quem quer ficar? É desumano até passar a função do juiz para a criança. É muito peso. Então, eu nunca ouvi [a criança]. Nem adolescente. Nem nunca tive que ouvir. Mas evito ao máximo. Menor de 12 anos, jamais! Só se fosse em caso extremo, mas eu nunca tive que ouvir.

Mirtes revela estar em sintonia com o que há de mais avançado na área do Direito de Família. Costuma deferir, por exemplo, a "guarda compartilhada", tomando apenas o cuidado de verificar as condições dos envolvidos:

(...) para isso dar certo, as pessoas têm que se dar muito bem, têm que estar num estado já mais avançado de convivência. Não é possível dá-la no período póstraumático de separação ou em que está aquela guerra, com todo mundo competindo, quando ainda há a dor do abandono ou da traição. Mas, eu costumo, aqui tem muitos casos de guarda compartilhada que dão certo.

Neste quesito, não vê impedimento na idade da criança que, segundo ela, pode até ser bem pequena (com 3 ou 4 anos de idade): "Defiro até pernoite ou visita de criança bem pequenininha, que não esteja na fase de amamentação". É que parte do pressuposto de que as crianças são o que há de mais importante na vida das pessoas, não importando se trate da mãe ou do pai. Por outro lado, pondera que, se "algum dia um deles faltar, o outro terá 
de dar conta, não é mesmo? Então, quanto mais... quanto... Numa separação, quanto mais a criança tiver contato, ainda pequena, com o genitor que não vai ficar com a guarda, melhor. E isso para todo mundo. Para a mãe... para todo mundo".

Numa audiência, o que mais chama a atenção de nossa magistrada?

A boa atuação dos advogados e a urbanidade que um advogado tem pelo outro, sem ver no advogado da parte adversa o seu inimigo. Então... esse bom... quando a gente tem bons advogados, um na frente do outro, litigando sobre interesses antagônicos, porém abertos a um diálogo, ou eles conseguem respeitar tanto seu cliente quanto a parte contrária, não importa qual dificuldade tenha o litígio, a coisa corre muito bem.

Caso os advogados não demonstrem muita urbanidade, Mirtes trata de corrigir a situação:

(...) costumo lembrá-los disso. E não permito nunca [com ênfase] que a parte destrate o outro advogado. Acho até que... em família, tem que ter um pouquinho mais... aberto (...) você pede com delicadeza para parar e tudo o mais, mas não dá para admitir que o advogado da outra parte seja destratado. Isso é inadmissível. Porque ele não é inimigo. Ele está assessorando, aí paro, explico. Não pode. E o advogado também pegar as dores e xingar a outra parte, ou ser indelicado com a outra parte, aí falo: "Doutor, não faça, é injusto... é outro patamar... o Senhor pode conversar tecnicamente com o outro advogado, litigar... colocar os pontos... mas não pode... essa ofensa, assim... é muito". Tenho experiência de balizar júri, de ficar ali, com os ânimos acirrados, então aqui vejo que é um jurizinho de cada vez, é uma disputinha... Geralmente... Aí eu falo assim para as partes... para os advogados: "Eles [as partes] têm motivo para estarem magoados, não os advogados. É a parte técnica. A gente veio aqui para resolver a parte técnica".

Curiosamente, o mesmo grau de delicadeza que Mirtes tem no trato com as pessoas ela tem de rigor diante da mentira de uma testemunha. Supõe ter sido a juíza do júri que "mais mandou instaurar processos por falso testemunho". Primeiro adverte a testemunha, dando-lhe chance para se retratar. Se a testemunha insiste no que suspeita ser inverdade, manda instaurar inquérito policial, sem qualquer problema. Isso não significa que descon- 
sidere a situação da testemunha que mente por temer represálias do acusado. É que, segundo Mirtes, geralmente a testemunha mente visando a criar um álibi que o favoreça [ao acusado], a despeito de contradizer prova dos autos - as testemunhas que mentem, portanto, costumam ser as de defesa, não as de acusação.

(...) não tenho problema em processar alguém por falso testemunho. Não me sinto incomodada com isso. Não me sinto desrespeitada quando isso ocorre. Acho que a justiça está sendo... mas não enquanto pessoa, a pessoa da juíza, ai, que despre$z o ! \ldots$ que esteja querendo tripudiar minha pessoa... Não me sinto assim. É uma... é uma... vai contra a Justiça. É um crime contra a Administração da Justiça e ponto.

E se a mentira for da parte? Bem, segundo Mirtes, no processo criminal isso não representa problema, pois aí é permitido à parte mentir. No de família, o que ocorre é que a parte narra os fatos sob sua perspectiva, não se tratando, portanto, de faltar com a verdade. Lembra, outrossim, que "nunca é o melhor de uma pessoa que está numa vara de família. Porque se ela estivesse em seu estado normal, se a gente for pensar bem... você trazer para o Estado, para um julgador, alguém decidir alguma coisa sobre a sua família... é... é... duro. É porque a coisa não está em seu estado normal. Não é verdade?"

Mirtes afirma que toda vez que se encontra no cartório de família, pensa que "cada processinho desses começou de uma jura de amor". Afinal, "não importa o que tenha rolado. Até arrolamento. Porque no fundo alguém casou com alguém, teve filho... todos os meus começaram com uma história de amor. Em todos bateu um coraçãozinho. Em todos”.

Ela tem se dado muito bem na área de família. No exercício da profissão, o único problema consiste na falta de suporte humano: faltam funcionários em cartório, o que gera grande atraso nos andamentos processuais. Assim, os processos não ficam parados aguardando sentença, mas a juntada de petições ou o cumprimento de decisões há muito proferidas pelo magistrado. Vejamos como Mirtes expressa isso:

(...) o tribunal está ruim com coisa de funcionários. Se perguntar: quer mais um juiz ou três funcionários? Três funcionários! Até 1 pra 1 a gente está trocando. Se deixar, eu me troco por um funcionário também [rindo]. Porque a gente não precisa de... Porque tem muito serviço? Tem. O atraso aqui, nosso, é de juntada... todo dia, 
em fim de tarde, eu faço juntada, meu colega já faz juntada, a gente faz serviço de cartorário todos os dias.

No curso de sua fala, Mirtes acabou tecendo algumas considerações a respeito de seu colega de trabalho e, ao fazê-lo, expressou um estilo muito particular:

Tem muito número, mas... e colega... é maravilhoso, meu colega, superqueridinho. Eu o adoro. Tive muita sorte. Ele tem muito mais experiência que eu. Ele vem no fim do dia me ajudar. Ah, nas coisas em que eu tenho dúvida, eu coloco um bilhetinho... Fulano... eu coloco um coraçãozinho, pra ele vir me ajudar [risos]. Mas foi uma coisa de amor à primeira vista. Porque eu... eu estava bem colocada... eu podia ir para uma vara melhor posicionada ou eu poderia vir para cá. Eu com... no (...), eu fui como se não fosse juíza do cartório, às seis da tarde, e fui super bem recebida. Me atenderam super bem. Aqui, como tem segredo de justiça, não adiantava eu... eu não me identifiquei como juíza lá [em cartório cível], pedi uns processos, me ajudaram... Eu vim aqui e me apresentei. Mas eu adorei meu colega, e também eu acho que gosto mais da matéria de família, que tem muita coisa de fato, a gente faz muita audiência, tem contato com as partes... Porque no fundo, quando você está no crime, é isso mesmo, é fato, não é? Você trabalha muito com fato, com a instrução... Acho que eu tenho mais perfil de juíza de fato do que, por exemplo, a Siclana, que gosta muito de cível... você trabalha muito com lei... né... com teses...

Em percebendo um descompasso técnico entre os advogados das partes, Mirtes procura supri-lo, e muitas vezes age de maneira bastante ativa para isso, sem, porém, comprometer sua imparcialidade:

Eu procuro suprir. Eu procuro. E às vezes eu até chamo a defensoria, mesmo que... Mas aqui a gente tem o ministério público, né, que ajuda a... ajuda muito. Agora, no júri, quando tem uma diferença técnica muito grande e o réu está indefeso, eu... não é que nem eu dou o réu por indefeso... a lei... eu chamo o advogado, e falo: "Doutor, eu estou achando que há um descompasso..." delicadamente, peço assim... é... eu procuro conversar com o advogado. Eu não o deixo constrangido. Eu falo: "Doutor, olha... o Senhor está bem?..." E mesmo que eu vá... dissolver... por causa disso... eu converso com o advogado para ele pedir a renúncia, dizer que não está bem... Pra não constranger, porque acho que isso, na carreira do advogado, é uma 
coisa assim... Não deixa o réu ser prejudicado, mas também não... não... não procuro... Ou então até esclareço pro advogado: "Olhe, doutor, eu acho que... talvez esteja tendo uma falha... não gostaria de fazer isso...” Já aconteceu uma vez.

Felizmente, situações extremas são raras, mas importante frisar a atenção e o modo de atuação de nossa magistrada no tocante a esse problema, que analisaremos detidamente abaixo.

Indagada a respeito das áreas de atuação de sua preferência, ela disse "adorar" o júri, por causa da "imediatidade da decisão. Eu gosto de instruir... Aquela plenária em que você instrui, em que você já vê o resultado, em que você já dá a pena e em que tudo é imediato, é rápido. A prestação jurisdicional é imediata. Você volta com o sentimento de dever cumprido". No júri, Mirtes não sente que está julgando pessoas, mas fatos. É o fato cometido que entra em questão, e não a pessoa que o cometeu, embora a pena recaia sobre ela.

A área em que menos gostou de atuar foi a tributária, que em seu discurso até soou com certo desdém. Achou-a "só... só... técnica".

Mirtes sempre recebe os advogados que a procuram para despachar. Inclusive fez isso durante nossa entrevista:

Recebo sempre. Eu sou a rainha [risos]. A minha pauta é o dia inteiro. Acho que resolve. Eu gosto muito. Eu peço pra vir de (...) [refere-se a um dia da semana], que não tem audiência, mas pode vir no dia que for, que eu recebo todos. Eu acho que resolve.

Ela afirma ter "uma visão ótima da advocacia, eu acho que... é um serviço superbacana, eu me dou super bem... é... acho que uma das minhas melhores amigas é advogada, então eu vejo a dificuldade que ela tem, é cliente que liga, pressão... eu vejo... a gente até modifica a visão que a gente tem, porque é duro ser... porque você tem pressão do cliente o dia inteiro, não é?” E prossegue:

Porque ele [o advogado] tem várias causas, e eu tenho vários processos. Mas para o cliente é aquele processo. E às vezes ele põe no advogado a solução do problema. 
E, sabe, aí vira psicólogo, vira tudo, né, coitado do advogado. Eu acho muito importante o papel de um bom advogado. Eu acho importantíssimo. E, às vezes, falo: "Doutor, segure o seu cliente... dê umas dicas assim, até por uma questão emocional, para não deixar ficar tão nervoso, e tudo o mais". Recebo o dia inteiro. Eu falo com o advogado: "Doutor, pelo amor de Deus, não deixe a parte entrar na minha sala para não ficar influenciada, não é? Não posso ter contato com a parte, mas com o Senhor o dia inteiro". Não é? O dia inteiro... Eu tenho segredo de justiça, mas, mesmo com segredo de justiça, às vezes tem um intervalinho e aí a gente deixa, digo para entrar nesse intervalinho e falo com o advogado. E no júri, então, não tem o que falar, porque a gente recebe o dia inteiro advogado, porque é um processo, ali, às vezes ele está de pé. Ele vem e diz: "Dra., eu não estou preparado, eu preciso de mais dias, fui intimado, e o réu está solto", aí pede mais dias, pede pra adiar... e, realmente, prefiro, porque, precisa estudar mais? A gente fala: "Tudo bem”. Tem prejuízo? Não tem. O réu está solto? Está solto. Então...

Portanto, para ela, o advogado é figura absolutamente imprescindível no sistema de administração da justiça, "imprescindível pra tudo", motivo pelo qual se posiciona contra o projeto de lei que dispensa a atuação do causídico em alguns processos de separação ou divórcio. Segundo ela, sem o advogado as partes deixam de ter o necessário "respaldo... técnico, jurídico. No fundo, é ele que segura a pessoa. É muito fácil ser juíza! Eu falar: 'eu decido' é bonito. Mas eu tenho oficial de justiça e toda uma máquina... Mas o advogado é que esclarece as pessoas sobre os direitos".

Lembrando o posicionamento favorável de Eustáquio a respeito da autotutela dos cidadãos, insisti um pouco mais nessa questão da imprescindibilidade do advogado, perguntando a ela sobre o que achava da autotutela na área cível, como ocorre nos juizados especiais, por exemplo. Mirtes respondeu:

Eu ainda acho que com advogado é outra coisa. É muito melhor, é muito mais dinâmico, eu acho que o advogado... realmente dá um amplo acesso à Justiça. Eu acho.

Embora eu seja advogado, confesso que o otimismo de Mirtes em relação à classe me exasperava. Tentei mais uma vez perscrutar algum ponto de vista um pouco mais sombrio, até no sentido de tentar montar um quadro um pouco mais "equilibrado". Perguntei- 
lhe sobre a questão da má-fé dos advogados, fazendo referência a opiniões expressas por colegas dela, em outras entrevistas. Você não tem essa percepção? A resposta dela foi:

Aqui na família, não. No crime, eu acho que eles têm que fazer tudo... eu acho que o advogado tem que rasgar a camisa, tem que suar a camisa, tem que jurar a inocência de qualquer réu, porque quem tem que ver o outro lado é o juiz. Acho que o advogado bom é aquele que realmente está ali, batalhando, são os que dão trabalho, porque se eu tivesse um réu na família, iria querer um advogado assim, bom, batalhador... Tanto que eu tenho amigas que são defensoras públicas e com quem eu não gosto nem de trabalhar. Eu falo: “Ai, meu Deus!" E fora o "minha querida”, eu admiro o trabalho... Eu admiro muito o trabalho. Mas eu sei que vai agravar de tudo, vai dar um trabalhão, vai brigar comigo, por causa de algum indeferimento. Mas eu falo: "Veste a camisa." Eu admiro.

Então você não associa a imagem do advogado àquela ideia de malandragem?... "Não. Eu não tenho isso associado, de jeito nenhum".

Não teve jeito. Ou melhor: o jeito foi desistir e partir para outra pergunta, a fim de não tornar minha insistência desagradável.

A respeito da digitalização dos processos, Mirtes relata que tal procedimento já está relativamente avançado em sua vara, a ponto de ela não assinar mais nada, senão digitalmente. Embora se sinta um pouco refém do sistema, por causa da dependência, por exemplo, da "internet", percebe tratar-se de um movimento sem volta: "Acho que é a evolução, mesmo. A gente está numa era digital... Não tem muito como fugir”.

À parte a inevitabilidade do advento dos novos procedimentos, Mirtes admite que não conseguiu se emancipar completamente do papel, cujo uso, por ela, faz-se necessário em circunstâncias específicas: "Quando preciso raciocinar, pensar, uma sentença mais complicada... eu ainda preciso do papel. Eu ainda preciso".

Quando convidada a falar de aspectos de sua personalidade que, segundo ela, seriam fonte tanto de dificuldades quanto de facilidades, ela começou pelas primeiras: "Talvez o ser muito expansiva... eu acho". 
Buscando maiores esclarecimentos, perguntei por que isso the geraria problema. Após pensar por um instante, ela voltou a falar:

Porque às vezes está aquele conflito entre... o casal... e assim, as pessoas entram na justiça... colocam na mão do juiz... a separação, uma coisa íntima... colocam. Você está tentando conciliar... você fala alguma coisa até no sentido de conciliar e as pessoas, às vezes as partes viram e falam: "Não se meta na minha vida!" Mas eu não pedi pra vir aqui... eu não pedi pra ninguém... Então, ju... eu acho... você quer ser expansiva, você quer apaziguar... é... é difícil... Às vezes, por essa qualidade, por ser expansiva, e eu falo alto, às vezes as pessoas ficam até... parece que eu estou brigando... estou no meio da briga do casal, e eu não quero brigar, nada, só quero a pacificação social. Então, acho que isso: eu falo alto e acho que com o tempo a gente... eu sempre falo alto, e acho que minha voz é bem... acho que você vai ver, quando você gravar, é bem... segura, talvez. Talvez passe um autoritarismo... então, acho que isso às vezes atrapalha.

Em seguida, na mesma linha reflexiva, teceu algumas ponderações a respeito do quanto o estereótipo que as pessoas têm do juiz pode interferir na relação que ela busca estabelecer com as partes:

É que a própria imagem do juiz, que talvez já está num patamar mais alto... você já está... as pessoas já entram melindradas... Então, eu acho que ainda que... e a imagem que o público tem do juiz... Ele já faz... já... já vem estereotipado: o juiz vai mandar, o juiz é bravo, o juiz é isso, o juiz é aquilo. Aí, não importa quantos sorrisos você faça. Como sua voz é muito assim as pessoas já param e já... já se intimidam e não é exatamente o... às vezes o que a gente quer passar, mas a gente tem que conviver com isso. A imagem... que a gente, que as pessoas, que o público tem de você é diferente.

No quesito facilidade, Mirtes diz que "ser mãe... ter muitos filhos... Eu acho que isso ajuda". Eu quis saber em que sentido ela afirmava isso, provocando a seguinte resposta: 
Ajuda porque você já sabe como é criança... Até quando você vai ter que decidir uma guarda, você sabe que não adianta... Eu não uso muito chamar a criança aqui pra ouvir... Porque a parte é que fala: "Ai, papai é bom, mamãe é ruim”. Você sabe que no fundo está sendo manip... porque é fácil manipular criança, é muito fácil! Ou jogar um filho contra o outro... basta uma coisinha assim no dia, não é? Criança é muito imediata. Às vezes dá um beijinho, dois beijinhos e noutro dia... Então é... o fato de... de... Outra característica pessoal: eu já estou no meu (...) [Mirtes casouse mais de uma vez] casamento... então é... Você tem uma experiência, eu acho, de vida, que você traz pra cá. Você é mais paciente, eu acho.

Nossa entrevistada mostrou-se bastante à vontade com as eventuais reformas de suas decisões por parte do tribunal, fato que atribui "ao segundo grau de jurisdição. Nada pessoal. É o direito da parte de ter revista a decisão e, graças a Deus, há alguém que reveja minha decisão! [risos] Eu não tenho nenhum problema”.

Afirma que, do mesmo modo que ela julga conforme sua consciência, os desembargadores haverão de julgar conforme a consciência deles. A reforma, portanto, decorre de mera "questão hierárquica. O tribunal manda... cumpra-se. E olha que eu mando prender um monte e todo mundo manda soltar. Sou a rainha das informações em mandado de segurança, de habeas corpus, não tenho problema nenhum, nenhum”.

Confrontada com a citação de Karl Llewellyn ${ }^{\mathbf{4 0 6}}$, Mirtes fez os seguintes comentários:

Eu acho que é verdade. Eu concordo com ele. Eu também acho isso. Ele faz... a gente faz a análise, vê quem é que está com a razão... claro, a gente tem um feixe axiológico formado pela vida inteira e depois que você já se convenceu de quem está certo aí você procura a norma pra justificar... você pega sua justificativa e procura a norma.

\footnotetext{
406 "Karl Llewellyn acredita que, geralmente, a mente do juiz primeiro antecipa a decisão que considera justa (dentro da ordem jurídico-positiva) e depois procura a norma que pode servir de fundamento a essa solução, atribuindo aos fatos a qualificação apropriada". Citação extraída do livro O Juiz e a Emoção ..., pp. 13/14, de Lídia Reis de Almeida Prado.
} 
Perguntei a ela se já teria acontecido de, em sua "busca pela norma", mudar de opinião. A resposta veio rápida: "Não".

A fim de gerar maior reflexão, mantive-a neste ponto: não?... Ela reiterou: "Acho que nunca". Com outras palavras, insisti: sempre aquele sentimento que você teve se confirmou? Então, Mirtes explicou que forma seu sentimento em relação ao caso depois da análise de todos os fatos, ou seja, já na fase final do processo, no momento em que a sentença está para ser proferida:

Aí você vai procurar, conforme o artigo não sei o que... Você já está com aquela... a decisão... Mesmo porque, se a gente for ver... a norma há de ser interpretada, não é? Então, no fundo, você faz a interpretação da norma no momento em que você está fazendo a decisão.

Para concluir nossa entrevista, perguntei a Mirtes se ela notava haver alguma diferença entre sua personalidade enquanto magistrada e a que apresentava fora do ambiente de trabalho.

Para minha surpresa, o conteúdo que veio a seguir representou cerca de um quarto de toda a entrevista, transmitindo-me uma impressão exata do quanto os afazeres não profissionais de nossa magistrada ocupam espaço em sua vida. Aliás, ela o expressou muito bem ao dizer:

Eu sou uma dona-de-casa, Antoin. Eu faço bico de juíza, entendeu, eu tenho muitos filhos (...) a gente faz vários papéis, né?

Nesse momento, Mirtes passou a falar de seus filhos. Descreveu um pouco da personalidade de cada um e reproduziu diversos diálogos havidos com eles, num retrato luminoso e com molduras em dourado cintilante. Era a imagem típica de uma mãe orgulhosa de sua prole, sentimento arrematado pela frase "Filho é nossa obra de arte!", repetida diversas vezes.

(...) Então, então são muitos papéis, eu acho, que a gente exerce. Hoje é meu... hoje eu faço (...) anos de casamento. Hoje é meu aniversário de casamento (...)... então 
eu acho assim, é... é tão... a gente faz tantos papéis, eu acho, na vida, que... não dá pra resumir, aqui, só como juíza. Eu falo: é uma parte, é o que me maltrata entre o almoço e o jantar, é uma parte do dia. Mas eu tenho, assim, um... E meu marido não é da área (...) então eu acabo sendo mais colorida, eu acho... Não tenho medo das cores... Eu acho que... por causa disso, também. Então, você acaba tendo mais a cabeça aberta pro mundo. Minha casa é mais colorida... é... eu sou mais colorida, não é, eu gosto das coisas coloridas, eu sou mais expansiva e eu acho que, no fundo, dá pra sentir que eu sou uma pessoa muito feliz até no contato (...) Quase metade do restaurante [refere-se ao restaurante em que fizemos nosso primeiro contato] eu conhecia (...)... eu tenho até padrinho de casamento daquele restaurante (...) Mas eu acho assim, que por mais que queira... e... é... é... a gente não é igual em todos os lugares, apesar de eu ser muito expansiva (...)... E, claro, eu sou mais alegre, eu acho, do que os outros juízes... né? Eu acho... eu não tenho esse problema com autoridade porque eu tenho tanta coisa pra fazer, Antoin, sabe?... Tanta coisa! Todo mundo sabe que eu... no fundo, eu que cozinho em casa, eu que faço almoço, janta, não tenho nem empregada. Mal tenho faxineira durante a semana... Então, sou eu que tomo conta de tudo.

Mirtes relatou uma rotina extremamente dinâmica e heterogênea. Sua vida fora do fórum é igualmente repleta de tarefas, nas quais desempenha de forma ampla e plena os papéis de mãe e de esposa. Encontra espaço para cozinhar para os filhos, arrumar a casa, participar de atividades escolares e da vida social do esposo, em consideração ao qual afirma evitar os tailleurs cinza:

Se eu aparecer lá [refere-se ao ambiente social do marido] de tailleur cinza acho que... o pessoal me... [risos] eu sou apedrejada. Vão falar: "O homem casou com uma ET!"

Não conseguindo conter meu espanto com a quantidade de tarefas por ela desempenhadas, perguntei-lhe como conseguia dar conta de tudo. Muito candidamente, respondeu: "Ué, por quê! Porque eu trabalho aqui da uma até as sete, oito..." Complementarmente, confessou dormir pouquíssimo, o que, segundo ela, seria característica de sua família.

Como a descrição da personalidade de Mirtes fora de seu ambiente de trabalho não me pareceu contrastar com a personalidade de Mirtes-juiza, fiz-lhe a seguinte pergunta: 
Mas em que medida a personalidade de Mirtes como juíza difere da personalidade dela fora desse papel?... O que eu estou vendo é uma personalidade relativamente uniforme. Onde é que a Mirtes... Neste ponto, fui interrompido por ela que, num volume mais alto de voz, procurou explicar algo que, para ela, eu parecia não ter entendido:

Porque fora daqui eu não estou nem de vestido: estou de chinela Havaiana ou de tênis, jogando basquete ou futebol com a criançada. Eu vou segurar pênalti na escola...

Bem, portanto aqui você procura ser mais formal, embora pessoalmente não seja... "Sim, muito mais do que eu sou normalmente. Eu sou de brincar de pega-pega na rua... com a criançada. [Risos.] Eu vou pra escola brincar de... de... de esconde-esconde dentro da escola".

Seguiu-se uma longa descrição de sua dinâmica familiar que, visando à preservação da intimidade da entrevistada, deixo de reproduzir neste espaço. No entanto, posso dizer que Mirtes refere-se literalmente aos filhos como a um sonho que se realiza. Embora ela se realize profissionalmente no papel de juíza, afirma realizar-se "dez vezes mais no papel de mãe de família", que acaba prevalecendo em sua vida:

Eu sou superfeliz. Assim, então... o papel, assim, de mãe de família é mais... prevalece mais até do que o de juíza. Não sei se porque tenho muitos filhos... (...) Então, prevalece... E acho que me realizo... to... eu sou superfeliz como juíza, mas eu me realizo... dez vezes mais enquanto mãe de família (...) Eu tenho tudo da vida: chá e café. Eu quero tudo. Às vezes eu vou a um restaurante, e falo: "Quero chá e café". Da vida eu quero tudo. Se der para realizar tudo, Antoin, eu acho maravilhoso. 


\subsection{ANÁLISE DO PERFIL TIPOLÓGICO DE “MIRTES”}

Uma possível diferença de personalidade entre Mirtes e Judith foi indicada logo no início de nosso contato. Por cautela, antes de me dirigir ao local da entrevista, enviei por celular uma mensagem para a entrevistanda, solicitando confirmação do encontro. Cada uma respondeu a seu modo:

JUDITH: "Confirmado" (objetiva)

MIRTES: "Claro. Bjs" (calorosa)

É preciso dizer que, até então, meu único contato com Mirtes havia se dado num restaurante.

Quando cheguei ao local da entrevista, Mirtes conduziu-me a uma sala reservada, contígua a seu gabinete, onde podíamos ficar mais à vontade. Não obstante, manteve a porta aberta, de modo a poder acompanhar o acesso de pessoas e atender eventuais advogados que a procurassem para despachar. Também o aparelho celular permaneceu ligado, tendo havido pelo menos três ligações no curso de nossa entrevista, todas atendidas por ela com bastante bom humor. Ou seja: manteve-se "disponível para o mundo".

Embora elegante, Mirtes usava cores um pouco destoantes do estereótipo que se tem dos juízes, cuja persona é associada à sisudez e à circunspeção. Como notamos em seu discurso, Mirtes não se vê portando tailleurs cinzentos.

A sala reservada, onde me atendeu, trazia a divisória forrada com um tecido colorido. Na pequena mesa de centro, biscoitos feitos artesanalmente por uma amiga - Mirtes fez questão de compartilhá-los comigo, momento em que não deixou de tecer elogios aos dotes culinários de quem os havia feito. Almofadas cor-de-rosa eliminavam qualquer dúvida, se é que ainda pudesse haver alguma, de que ali reinava uma personalidade "tipicamente feminina”. Na verdade, bem mais que isso: uma personalidade cujo calor humano irradiava como um sol, não deixando incólume qualquer pessoa que se situasse dentro de seu campo de ação. 
A título de exemplo, cito que durante nossa entrevista fomos interrompidos por uma escrevente que solicitava a atenção de Mirtes, mas em assunto a ser tratado após minha saída. Em particular, Mirtes pediu para que eu não me incomodasse com aquilo, que não havia nenhuma pressa, pois não se tratava de assunto sério. Explicou ter ensinado uma das escreventes a pintar o olho e que isso gerou todo um movimento de ensinoaprendizagem entre as demais, cujo resultado queriam exibir a ela.

Diante de sinais tão evidentes e reiterados de EXTROVERSÃO, bem como da presença marcante de características da função SENTIMENTO, assumiremos como premissa inicial estarmos diante de um tipo SENTIMENTO EXTROVERTIDO.

Como já tivemos oportunidade de dizer na parte teórica de nosso trabalho, o fato de as funções PENSAMENTO e SENTIMENTO serem as únicas que ocorrem de maneira diversa entre os gêneros, estamos acostumados a associar as características da primeira a "masculinidade" e as da última a "feminilidade". Assim, quando afirmamos a feminilidade de Mirtes com base no predomínio da função SENTIMENTO, como fizemos acima, quisemos na verdade explorar um estereótipo.

A força da EXTROVERSÃO de Mirtes pode ser notada em diversos traços de sua personalidade, dentre os quais destacamos:

- sua marcante expansividade, a ponto de, às vezes, até lhe trazer certa dificuldade:

Porque às vezes está aquele conflito entre... o casal... e assim, as pessoas entram na Justiça... colocam na mão do juiz... a separação, uma coisa íntima... colocam. Você está tentando conciliar... você fala alguma coisa até no sentido de conciliar e as pessoas, às vezes as partes viram e falam: "Não se meta na minha vida!"

\section{- A preferência em trabalhar em grupo:}

Eu gostava muito, tinha muitos amigos lá dentro. Trabalhávamos muito em conjunto, o que, aliás, gerou um choque para mim quando vim para a magistratura, onde trabalho tão sozinha. 
- o predomínio de uma visão mais otimista da vida:

Eu tenho tudo da vida: chá e café. Eu quero tudo. Às vezes eu vou a um restaurante, e falo: "Quero chá e café". Da vida eu quero tudo. Se der para realizar tudo, Antoin, eu acho maravilhoso.

- uma forma mais espontânea do que reservada em lidar com os estímulos do meio:

Recebo sempre. Eu sou a rainha [risos]. A minha pauta é o dia inteiro. Acho que resolve. Eu gosto muito. Eu peço pra vir de (...) [refere-se a um dia da semana], que não tem audiência, mas pode vir no dia que for, que eu recebo todos.

- a característica do "pensar alto", ou, em outras palavras, "para fora", conforme se demonstra, graficamente, por meio das reticências que acompanham a maior parte de seu discurso, citando-se, a título de exemplo:

Mas eu não pedi pra vir aqui... eu não pedi pra ninguém... Então, ju... eu acho... você quer ser expansiva, você quer apaziguar... é... é difícil... Às vezes (...)

Por outro lado, é interessante destacar que não se observam grandes traços de INTROVERSÃO seja no que Mirtes relata, seja no comportamento que tive oportunidade de observar.

Também importa dizer que, mais relevante do que analisar um ou outro traço característico de determinada atitude ou função é a análise do conjunto, haja vista que um EXTROVERTIDO pode - aliás, é até bem saudável que o faça - apresentar traços muito claros de INTROVERSÃO, e vice-versa. Portanto, a análise do conjunto de traços é que nos dará indícios das tendências/preferências que guiam determinado indivíduo, conformando assim sua personalidade.

Também digno de nota o fato de nossa entrevistada ver em sua expansividade uma eventual fonte de dificuldades no exercício da profissão. Em tese, a força de uma personalidade está basicamente assentada na atitude e na função predominantes. No entanto, incor- 
reríamos em equívoco primário se, a partir disso, fôssemos levados à conclusão de que a expansividade, característica básica de um EXTROVERTIDO, aquilo em que ele é forte, trar-lhe-á sempre mais benefícios do que prejuízos. É que isso depende, necessariamente, do que o meio está exigindo do indivíduo em determinado momento, pois são as circunstâncias externas que indicarão se alguma atitude ou função são mais adequadas do que outras naquele momento específico. Haverá situações em que a atitude mais adequada seja a de contenção, em vez de expansão, podendo esta última parecer invasiva, conforme Mirtes experienciou numa audiência conciliatória em que foi convidada a "não se meter" na vida do casal.

Portanto, bastante ilustrativo o exemplo dado por ela, revelando o quanto aspectos mais desenvolvidos de nossa personalidade podem parecer inadequados em certas circunstâncias, o que vem a ser providencial para o desenvolvimento da atitude ou das funções até então menos prestigiadas por nós.

Até aqui, concentramo-nos no predomínio da atitude EXTROVERTIDA de nossa entrevistada. Mas, como ensina Jung, "ninguém é simplesmente introvertido ou extrovertido, mas o é por conformação de certas funções". ${ }^{407}$ No caso de Mirtes, a função que parece predominar é o SENTIMENTO, havendo vários indícios nesse sentido.

Antes de prosseguirmos analisando os dados da entrevista, talvez convenha lembrar ser o SENTIMENTO uma função racional, portanto, de tomada de decisão. Sua diferença em relação ao PENSAMENTO (também função racional) é que, enquanto este se caracteriza por uma apreciação "impessoal" dos dados da realidade, não se importando tanto se com isso surgem decisões "duras", desde que coerentes e afinadas com princípios universais, válidos para todos, a função SENTIMENTO tende a produzir decisões mais circunstanciadas, que levam em consideração as peculiaridades do caso sob análise, tomado sempre à luz de um feixe axiológico.

O estilo de decidir da função SENTIMENTO traz inevitavelmente a marca da pessoalidade, mas não no sentido de que seja "parcial" e sim no da enunciação de um juízo valorativo, que é o "que nos diz, por exemplo, se uma coisa é aceitável, se ela nos agrada

407 “Tipos Psicológicos”: ... 1923, p. 478, § 968. 
ou não". 408 Isso está presente desde o início da fala de Mirtes, quando vincula "sua felicidade" a uma profissão que lhe permitisse "analisar os dois lados da questão e ser imparcial”, o que não era possível na carreira que antecedeu à de magistrada, onde tinha de se empenhar pelo prevalecimento de uma interpretação da lei com a qual nem sempre concordava.

No entanto, o que nos importa, no curso da presente análise, é lembrar a maior proximidade da função SENTIMENTO com o senso de justiça, o que também é captado pela experiência forense de Calamandrei:

Não digo, como ouvi repetir, que a inteligência excessiva seja prejudicial ao juiz; digo que o juiz ótimo é aquele em que prevalece, sobre a cauta cerebralidade, a pronta intuição humana. O senso de justiça, pelo qual, sabidos os fatos, logo se sente quem está com a razão, é uma virtude inata, que nada tem a ver com a técnica do direito - como na música, em que a maior inteligência não consegue suprir a falta de ouvido. ${ }^{409}$

Conforme já vimos na análise do perfil de Judith, onde o autor italiano se refere a intuição, podemos aqui tomar o termo no sentido de sentimento, porque na teoria junguiana não é a INTUIÇÃO que nos informa a respeito de quem tem razão, uma vez que é função de "coleta de dados", o que implica dizer "não-valorativa".

O que isso tudo tem que ver com nossa magistrada? É que verificamos, em sua maneira de ponderar a respeito da aplicação da lei ao caso concreto, ou seja, de "fazer justiça", a preponderância de juízos valorativos sobre os juízos lógico-dedutivos. Ou seja: Mirtes parece bem distante, em sua atuação profissional, do juiz "boca-da-lei", que vê na sentença uma “conclusão”, o mero resultado de uma operação silogística em que os fatos desempenhariam o papel de premissa maior e a lei o de premissa menor.

Não por outro motivo, quando lhe perguntei sobre se já havia enfrentado situações em que o Direito não dava uma resposta muito clara às questões postas em juízo, respon-

\footnotetext{
408 JUNG, Carl G.. Fundamentos de Psicologia Analítica (CW XVIII/1), p. 8.

${ }^{409}$ Eles, os Juízes ..., p. 181.
} 
deu: "Todos os dias", e concluiu seu raciocínio dizendo que, numa partilha decidida judicialmente, "o juiz aplica a lei, mas nem sempre a justiça".

Outro exemplo em que nos parece preponderar a "lógica" do SENTIMENTO pode ser visto no trecho em que Mirtes justifica o acolhimento de pedido de aborto, em caso de doença de feto, comprometedora de condições de uma "vida digna" para o futuro ser:

(...) em casos de doença do feto, com impossibilidade de nascimento viável, de uma vida... tinha impossibilidade de nascimento... de uma vida digna... poderia até haver nascimento com vida, durante alguns dias, mas nada além disso. Existe quem sustente haver direito à vida, mesmo em tais circunstâncias. Eu achava que não haveria direito a uma vida digna [frisou “digna”], justa, e é assim... você autoriza... (...) e tem de fazer correndo por causa do risco de vida da mãe.

Prevalecendo a função PENSAMENTO, o pedido também poderia ser deferido, mas provavelmente a justificativa tenderia a ter outra roupagem, a ser mais calcada em alguma norma ou princípio jurídico e que provavelmente lhe serviriam de ponto de parti$d a$. Isso não implica dizer, porém, que um magistrado em que prepondere a função PENSAMENTO não se deixe guiar, num ou noutro caso, pela função oposta, ainda mais quando a situação exija, de maneira contundente, seu uso.

Lembramos um caso que teve enorme repercussão no meio jurídico e em relação ao qual podemos dizer que faltou ao magistrado se valer da função SENTIMENTO quando ela se fazia imprescindível. Tratava-se de ação com pedido de antecipação de tutela, visando a obrigar o Estado a fornecer medicamentos novos para tratamento de AIDS. Vejamos as ponderações do magistrado, que devem ser lidas em contraste com a forma como Mirtes tende a atuar diante de casos que também envolvam a vida humana:

Poder Judiciário

X Vara da Fazenda Pública

Comarca de São Paulo

Proc. n. X

Indefiro a antecipação de tutela. 
Embora os autores aleguem ser portadores de AIDS e objetivem medicação nova que minore as sequelas da moléstia, o pedido deve ser indeferido, pois não há fundamento legal que ampare a pretensão de realizar às expensas do Estado o exame de genotipagem e a aquisição de medicamentos que, segundo os autores, não estão sendo fornecidos pelo SUS.

A Lei 9.313/96 assegura aos portadores de HIV e doentes de AIDS toda a medicação necessária a seu tratamento. Mas estabelece que os gestores do SUS deverão adquirir apenas os medicamentos que o Ministério da Saúde indicar para cada estado evolutivo da infecção ou da doença. Não há possibilidade de fornecimento de medicamentos que não tenham sido indicados pela autoridade federal.

Por outro lado, não há fundado receio de dano irreparável ou de difícil reparação. Todos somos mortais. Mais dia, menos dia, não sabemos quando, estaremos partindo, alguns, por seu mérito, para ver a face de Deus. Isto não pode ser tido por dano.

Daí o indeferimento da antecipação de tutela.

Cite-se a Fazenda do Estado.

Defiro gratuidade judiciária em favor dos autores.

Intimem-se.

São Paulo, (...) 2001.

Fulano de Tal

Juiz de Direito

Mas, a nosso ver, o ponto mais marcante da fala de Mirtes, no sentido de indicar a maneira como a função SENTIMENTO se expressa no exercício da jurisdição surge em seu comentário à citação de Llewellyn, tendo ela concordado incondicionalmente com este autor. Ou seja: Mirtes afirma primeiro tomar uma decisão a respeito de como julgar determinado caso e buscar, depois, no ordenamento jurídico o fundamento que lhe dê sustentação: 
Eu acho que é verdade. Eu concordo com ele. Eu também acho isso. Ele faz... a gente faz a análise, vê quem é que está com a razão... claro, a gente tem um feixe axiológico formado pela vida inteira e depois que você já se convenceu de quem está certo aí você procura a norma pra justificar... você pega sua justificativa e procura a norma.

Nota-se a referência expressa de Mirtes ao feixe axiológico, o que pode ser tomado como sinal do quão presente estaria a função SENTIMENTO em sua consciência, constelada como função principal.

Achamos tão importante não deixar margem a dúvidas neste seu processo de tomada de decisão que insistimos em saber se ela alguma vez havia alterado seu ponto de vista depois de visitar o universo normativo. Mirtes foi muito clara: "Não (...) Acho que nunca".

Isso pode ser indício de um PENSAMENTO que se sujeita à função oposta (SENTIMENTO), de maneira que, quando é chamado - e será no momento da elaboração do discurso jurídico -, terá por missão construir o caminho lógico que conduza à conclusão previamente definida pelo SENTIMENTO. Mirtes nos lembra que "a norma há de ser interpretada, não é? Então, no fundo, você faz a interpretação da norma no momento em que você está fazendo a decisão".

A respeito dessa dinâmica, aliás típica de um SENTIMENTO EXTROVERTIDO, escreve Jung:

Só é possível sentir "corretamente" quando nada perturba o sentimento. E nada perturba tanto o sentimento como o pensamento. É óbvio, pois, que neste tipo o pensamento é reprimido ao máximo. (...) O que não consegue sentir, também não consegue pensar conscientemente. "Não consigo pensar o que não sinto", disse-me certa paciente, em tom indignado. Consegue pensar muito bem enquanto o sentimento o permitir; e toda conclusão, por mais lógica, que possa levar a um resultado perturbador do sentimento é rejeitada de antemão. Simplesmente não será pensada. ${ }^{410}$

${ }^{410}$ Tipos ..., p. 340, § 665 . 
Por sua vez, na descrição que faz dos tipos psicológicos, Von Franz escreve o seguinte a respeito do SENTIMENTO EXTROVERTIDO:

São pessoas bem ajustadas, muito razoáveis, que se envolvem amavelmente com o mundo, conseguem, de alguma forma, levar todos a lhes darem o que elas querem. Elas suavizam o ambiente tão maravilhosamente que a vida transcorre com muita facilidade. Esse tipo é muito frequentemente encontrado entre mulheres que de maneira geral têm uma vida familiar muito feliz, entre muitos amigos. ${ }^{411}$

Por ter sua energia voltada para o mundo externo (EXTROVERSÃO) e gostar de lidar com pessoas (SENTIMENTO), esse tipo de personalidade emana uma calorosidade peculiar e tende a semear permanentemente a harmonia no ambiente à sua volta. Vejamos como Mirtes se relaciona com as pessoas e o modo como percebe o mundo:

\section{- Relacionamento com o colega de trabalho:}

(...) ... e colega... é maravilhoso, meu colega, superqueridinho. Eu o adoro. Tive muita sorte. Ele tem muito mais experiência que eu. Ele vem no fim do dia me ajudar. Ah, nas coisas em que eu tenho dúvida, eu coloco um bilhetinho... Fulano... eu coloco um coraçãozinho, pra ele vir me ajudar [risos]. Mas foi uma coisa de amor à primeira vista.

\section{- Visão das partes em litígio:}

Mirtes afirma que toda vez que se encontra no cartório de família, pensa que "cada processinho desses começou de uma jura de amor (...) não importa o que tenha rolado. Até arrolamento. Porque no fundo alguém casou com alguém, teve filho... todos os meus começaram com uma história de amor. Em todos bateu um coraçãozinho. Em todos".

\section{- Relacionamento com os filhos:}

Nesse momento, Mirtes passou a falar de seus filhos. Descreveu um pouco da personalidade de cada um e reproduziu diversos diálogos havidos com eles, num retrato luminoso e com molduras em dourado cintilante. Era a imagem típica de uma

${ }^{411}$ A Função Inferior, Op. cit., p. 69. 
mãe orgulhosa de sua prole, sentimento arrematado pela frase "Filho é nossa obra de arte!", repetida diversas vezes.

O mesmo filtro afetivo pode ser visto no modo como Mirtes se refere aos advogados, na medida em que parece minimizar os aspectos sombrios desses profissionais. Todavia, não deixa de ser relevante o fato de o entrevistador pertencer à classe. Contrastemos essa informação com o fato de que normalmente os EXTROVERTIDOS, por terem sua energia psíquica mais voltada para o objeto que para o sujeito, tenderem a ter uma percepção mais "realista" das coisas e, portanto, a alimentar menos preconceitos (no sentido de ideias pré-concebidas).

Portanto, é provável que a falta de referência de Mirtes aos aspectos negativos dos advogados deva-se menos a uma falta de percepção e mais a um estilo de expressão de ideias que se preocupa prioritariamente em não comprometer a harmonia do meio. Assim atua a função SENTIMENTO. Em sua modalidade EXTROVERTIDA, ela pode notar muito bem a parede cinzenta, mas trata logo de pintá-la de rosa ou, não sendo isso possível, de estender sobre ela algum tecido colorido. Para alguém que opera segundo tal função, mais importante do que fazer prevalecer a verdade numa fala, é garantir que as pessoas se sintam bem; tem menos relevância dizer o que realmente se pensa a respeito de determinado assunto. Não por acaso, Jung afirma que sem esse tipo seria "inconcebível uma convivência social, bela e harmônica". 412

Uma vez instalada a audiência, quando Mirtes trabalha para que os advogados se tratem bem, ela provavelmente não está preocupada em fazer valer sua autoridade como juíza, ou ainda em fazer respeitar a norma que obriga as partes e seus patronos a se comportarem com urbanidade: sua preocupação deve ser de fato com o bem-estar das pessoas. Porque, se assim não fosse, poderia advertir duramente o advogado desrespeitoso, mas o que prevalece é a delicadeza (o que não a impede, porém, de ao mesmo tempo ser firme):

Você pede com delicadeza para parar e tudo o mais, mas não dá para admitir que o advogado da outra parte seja destratado. Isso é inadmissível. Porque ele não é inimigo. Ele está assessorando, aí paro, explico. Não pode. E o advogado também pe-

${ }^{412}$ Tipos ..., p. 338, § 664. 
gar as dores e xingar a outra parte, ou ser indelicado com a outra parte, aí falo: "Doutor, não faça, é injusto... é outro patamar... o Senhor pode conversar tecnicamente com o outro advogado, litigar... colocar os pontos... mas não pode... essa ofensa, assim... é muito".

A mesma gentileza se observa na maneira com que Mirtes tenta contornar o descompasso técnico existente entre os advogados das partes (há, aí, gentileza não apenas com o patrono, mas sobretudo um cuidado para com a parte que viria a ser prejudicada pela deficiente atuação de seu advogado):

(...) eu chamo o advogado, e falo: "Doutor, eu estou achando que há um descompasso..." delicadamente, peço assim... é... eu procuro conversar com o advogado. Eu não o deixo constrangido. Eu falo: "Doutor, olha... o Senhor está bem?..." E mesmo que eu vá... dissolver... por causa disso... eu converso com o advogado para ele pedir a renúncia, dizer que não está bem... Pra não constranger, porque acho que isso, na carreira do advogado, é uma coisa assim... Não deixa o réu ser prejudicado, mas também não... não... não procuro... (...)

A predileção de Mirtes em lidar com pessoas parece ser a mola propulsora da designação de audiências, ato em que se sente super bem e que adora realizar, designando "sempre" as de natureza conciliatória, segundo ela em quantidade bem maior que seus colegas, não se deixando tolher pelo rito processual: as audiências conciliatórias são designadas “mesmo em execução de alimentos, mesmo em pedido de prisão, antes de expedir o mandado de prisão por dívida alimentar", para o que ela se vale de um artigo genérico do Código de Processo Civil. Mas a audiência instrutória não perde lugar, também sendo sempre designada a fim de permitir não tanto a coleta de informações, mas principalmente seu contato com as partes:

Mesmo quando necessária a instrução, Mirtes não costuma estendê-la, sendo rara a oitiva da parte em "tréplica": "Só se precisar, mas se não, não. Senão marco uma audiência pra conversar com todo mundo. Acho mais fácil. É muito mais fácil, eu acho". 
Alguém poderia lembrar que Eustáquio, o juiz que tomamos como exemplo de um tipo PENSAMENTO INTROVERTIDO, também designava audiências em todos os processos. É verdade. No entanto, sua motivação era outra: Eustáquio vale-se das audiências como forma de resolver o processo, tendo desenvolvido uma dinâmica muito peculiar para alcançar um alto grau de produtividade nesse sentido; Mirtes, porém, embora também busque a solução do processo, parece colocar o bem-estar das pessoas envolvidas num plano superior. Sinal disso foi a resposta que deu quando lhe perguntei quanto tempo costumam durar tais audiências: "Ah, o quanto precisar para as partes se apaziguarem” [risos] (grifei). Afinal, ela poderia ter dito: Quanto tempo precisar para se chegar a um acordo. Os profissionais do Direito sabem que um acordo pode ser obtido sem que as partes necessariamente se apazigúem; também sabem que, uma vez apaziguadas as partes, o acordo é praticamente consequência natural.

Por gostar de pessoas, o que é característico de quem atua sob comando da função SENTIMENTO, Mirtes tenderá a sentir tanto mais prazer em seu trabalho quanto mais ele lhe permitir estreitar seus relacionamentos. Em sua fala, expressa de modo muito claro a satisfação que teve em atuar em cidade de interior, porque aí podia "ficar mais próxima dos jurisdicionados", também não escondendo a importância que tem, para ela, o conhecer os advogados com quem trabalha.

Também é típico do SENTIMENTO EXTROVERTIDO um esforço de adequação àquilo que é valorizado no meio social em que se insere, ao qual não procura fugir ${ }^{\mathbf{4 1 3}}$. No caso de Mirtes, ela provavelmente não porta tailleurs cinza pela importância que têm os outros "papéis" em sua vida, aos quais não deixa de se ajustar e, pelo visto, muito bem. Enquanto juíza, ninguém dirá a ela que está vestida de modo “inadequado" apenas por causa do uso de cores mais alegres; mas, enquanto esposa, a dissonância do tailleur cinza seria imediatamente denunciada: "Se eu aparecer lá de tailleur cinza acho que... o pessoal me... [risos] eu sou apedrejada. Vão falar: 'O homem casou com uma ET!'”

Já vimos que outro modo de apurar a função principal de um indivíduo é atentando para sua função inferior, uma vez que ambas necessariamente se opõem. Haveria, no discurso de Mirtes, sinais de um PENSAMENTO INFERIOR? Cremos que sim. Ela manifes-

${ }^{413}$ JUNG. Carl G.. Tipos ..., p. 339, § 665 . 
tou, por exemplo, preferência por áreas mais concretas, preterindo aquelas que exijam maior manejo de conceitos teóricos, como ocorre em boa parte do Direito Civil:

Acho que eu tenho mais perfil de juíza de fato do que, por exemplo, a Siclana, que gosta muito de cível... [onde] você trabalha muito com lei... né... com teses...

Nossa magistrada também desgostou de trabalhar com áreas em que outras características mais condizentes com o PENSAMENTO, como a objetividade e o raciocínio lógico, costumam ser as mais exigidas, como se dá no Direito Tributário - segundo ela, "só... só... técnica". Também se queixou do período de sua vida em que teve de "lidar só com números, com execução".

Observemos, outrossim, como Mirtes começou a falar do Judiciário enquanto instituição, e o rumo que tomou seu discurso:

\footnotetext{
Ah, é um poder organizado... Tem a sua... carreira... demarcada... Às vezes fico triste porque a gente começa no interior e as promoções acabam levando a gente pra capital e... (...)
}

Ou seja: chegou a ensaiar uma análise mais conceitual, abstrata ("poder organizado... carreira..."), mas logo seu pensamento deu espaço para uma abordagem mais subjetiva, pessoal, quase sem qualquer carga de pensamento propriamente dito. Neste ponto, bem ilustrativo o comentário de Von Franz:

Num tipo sentimental é assim que os pensamentos operam: são pensamentospássaro que pousam em sua mente e voam para longe. Antes de ele poder dizer: "O que eu estou pensando?", o pensamento já se foi. ${ }^{414}$

\section{E ainda:}

O tipo sentimental extrovertido não gosta de pensar, porque essa é a sua função inferior e do que ele menos gosta é do pensamento introvertido - pensar sobre princípios filosóficos, abstrações ou questões básicas da vida. Essas questões mais pro-

${ }^{414}$ Op. cit., p. 71. 
fundas são cuidadosamente evitadas e eles consideram que pensar sobre tais problemas é entregar-se à melancolia. ${ }^{415}$

Essa relativa fragilidade no uso do PENSAMENTO pode ser vista, no caso de Mirtes, quando a convidamos a raciocinar com mais profundidade a respeito do papel da doutrina e da jurisprudência como fatores de inovação jurídica [Quando você diz que aplica a jurisprudência porque as coisas estão mudando, você dá a entender que, na sua maneira de ver, a jurisprudência estaria um passo à frente da doutrina. Em alguns casos, não acontece o contrário?] Mirtes atrapalhou-se um pouco, novamente substituindo seu pensar pelo sentir:

Em algumas questões, sim! Em algumas questões sim, mas... [toca o celular, que ela atende.] No meu caso, também tem doutrina porque... a escola do Rio Grande do Sul... a Maria Berenice Dias... também tem doutrina muito avançada em termos de família, eu acho também. Então, os dois estão bem estruturados na minha área. Então, estou bem feliz, tanto em doutrina quanto em jurisprudência.

Coisa semelhante ocorreu quando a fiz observar que não havia propriamente uma diferença de personalidade entre Mirtes-juíza e Mirtes-mãe-esposa-etc. Em vez de raciocinar a respeito, sua reação foi emocional - houve elevação do seu tom de voz -, seguida de uma repetição, embora com outras palavras, de conteúdos que já haviam sido expostos. Alguns estudiosos de tipologia costumam apontar o fenômeno da repetição de ideias como algo típico do SENTIMENTO ${ }^{\mathbf{4 1 6}}$. Ao repeti-las no discurso, os indivíduos desse tipo estariam na verdade tentando estruturar seu raciocínio. Aceitemos ou não esse postulado, fato é que pode ser observado no discurso de nossa entrevistada.

Cumpre lembrar que a suposta fraqueza do PENSAMENTO, verificada neste tipo, deve-se na verdade ao maior espaço por ele dado ao SENTIMENTO. Jung ensina que “(...) neste tipo o pensamento é reprimido ao máximo. Não se diz com isso que esta espécie de mulher não pense de maneira alguma; ao contrário, talvez pense muito e de forma esperta,

${ }^{415}$ Op. cit., p. 70.
${ }^{416}$ MYERS, Isabel Briggs. Op. cit., p. 68. 
mas seu pensar nunca é sui generis (original) e, sim, um acessório epimeteico de seu sentimento". 417

Por outro lado, conforme alerta Myers, isso também não implica dizer que o tipo PENSAMENTO tenha a hegemonia dos processos mentais; não tem nem mesmo a hegemonia do PENSAMENTO. Segundo a pesquisadora americana, os testes de inteligência convencionais costumam ter pessoas do tipo SENTIMENTO alcançando as pontuações mais elevadas, quando, por exemplo, esta função se conjuga com a INTUIÇÃO (Myers diz isso referindo-se aos tipos INFP e INFJ). ${ }^{418}$

Ainda com base em tal autora, também podemos afirmar que, quando alcançada determinada solução por meio do SENTIMENTO, este tipo pode ter mais habilidade do que o PENSAMENTO para construir a respectiva fundamentação ${ }^{\mathbf{4 1 9}}$. Tem-se observado também que, quando dois tipos PENSAMENTO debatem, cada um tende a proclamar, a seu turno: "Isto é verdade", a despeito de às vezes se manterem em posições antagônicas, enquanto o tipo SENTIMENTO contenta-se em dizer: "Isto é o que tem valor para mim", ${ }^{20}$ e quem poderá questioná-lo a esse respeito?

Ora, ao aceitarmos seja Mirtes uma representante do tipo SENTIMENTO EXTROVERTIDO, isso implicará que também seja JUDICATIVA (J), pois estará extrovertendo por meio de uma função racional (SENTIMENTO). Que indícios, porém, poderíamos apontar em sua fala que nos levariam a isso?

Em primeiro lugar, cumpre lembrar que os tipos JUDICATIVOS (J) primam pela fixação de metas a cumprir e costumam persegui-las com afinco, até chegar a bom termo. Para eles, nada como a "sensação de dever cumprido". Preferem situações fechadas e tendem a ter facilidade para decidir, o que, no exercício da magistratura, deve levar a procedimentos instrutórios mais breves.

\footnotetext{
${ }^{417}$ Tipos ..., p. $340, \S 665$.

${ }^{418}$ Op. cit., p. 66.

${ }^{419}$ Op. cit., p. 67.

${ }^{420}$ Op. cit., p. 67.
} 
Embora prefira conduzir as partes a um acordo, no que é motivada por seu senso de justiça, Mirtes não pareceu ter problemas quando se vê diante da necessidade de sentenciar, até porque a qualquer momento as partes envolvidas podem alterar o resultado do processo por meio de um acordo, "porque em família sempre cabe acordo, sempre".

Depois, num outro momento, quando procurou justificar sua predileção pelo júri, destacou a imediatidade do procedimento e o prazer que sente por terminar o trabalho "com o sentimento de dever cumprido".

Outro momento que sugere a prevalência do tipo "J" é sua postura complacente em relação à superioridade hierárquica do tribunal. Quando tratamos de Eustáquio, vimos que os tipos PERCEPTIVOS $(\mathrm{P})$ tendem a ter mais dificuldade para lidar com autoridade.

Por fim, vimos o quanto a rotina de Mirtes é carregada: cuida de várias crianças, cujo estudo acompanha, cuida da casa, é companheira do marido e parece cumprir rigorosamente a rotina do fórum, que, diante de todo o restante, ainda considera "um bico". Bastante impressionado com isso tudo, quando lhe perguntei como dava conta de tanta coisa, respondeu: "Ué, eu trabalho aqui da uma até as sete, oito..." Isso me permite fantasiar que dificilmente Mirtes conseguiria se desincumbir de todos os seus afazeres se não estabelecesse metas muito claras e seguisse uma rotina a fim de cumpri-las.

Resta investigar qual seria a mais provável função auxiliar de nossa magistrada. As alternativas são SENSAÇÃO e INTUIÇÃO.

Ora, chamou-nos a atenção a importância dada por Mirtes a poder "ver o resultado do trabalho". Para os tipos INTUITIVIOS, normalmente o prazer está mais em "projetar" do que propriamente em "executar" o trabalho. Não parece ser o caso de Mirtes que, além disso, trata com bastante pragmatismo o resultado a ser buscado, o que fica claro pelo valor por ela dado ao "pedido" deduzido pela parte em sua inicial: “A gente só pode ajudar, só pode direcionar se a pessoa conseguir colocar que prestação jurisdicional ela quer, o que ela precisa". 
Outro detalhe que aponta para a atuação da função SENSAÇÃO é o modo pelo qual Mirtes escolheu a vara para a qual seria promovida: simplesmente foi conhecê-la, ou seja, recorreu à experiência (algo próprio da função SENSAÇÃO) em vez de se apoiar em sua imaginação (algo próprio da função INTUIÇÃO). Na mesma linha de concretude, temos a seguinte confissão, feita por ela mesma: “Acho que eu tenho mais perfil de juíza de fato”, o que, aliás, serviu de base para explicar sua predileção pelo júri: "Porque no fundo, quando você está no crime, é isso mesmo, é fato, não é? Você trabalha muito com fato, com a instrução..."

Há, por fim, no comportamento de Mirtes algo típico do indivíduo SENSAÇÃO, que é gostar dos prazeres sensoriais que a vida pode proporcionar, buscando desfrutar intensamente dos mesmos ${ }^{\mathbf{4 2 1}}$ : “Às vezes eu vou a um restaurante, e falo: 'Quero chá e café'. Da vida eu quero tudo".

Diante deste quadro, arriscamo-nos a dizer que, na qualidade de auxiliar, prevalece em Mirtes a função SENSAÇÃO.

Nossa entrevistada concordou em responder a um questionário de aferição de tipo, o que confirmou o acima sugerido.

Tipo aferido: E S E J - Atitude EXTROVERTIDA; SENTIMENTO como função superior e SENSACÃO como função auxiliar.

${ }^{421}$ MYERS, Isabel Briggs. Op. cit., p. 63. 


\title{
6. ENTREVISTA COM "EVANDRO”
}

\begin{abstract}
A área que eu gosto mesmo é a área cível e família. Porque o que me dá prazer mesmo, Dr. Antoin, e é prazer de verdade, é realização como pessoa humana, é resolver os problemas das pessoas. Quando eu não consigo, eu sofro. Quando eu consigo, a minha alma se alegra e... e... é um refrigério para mim. (...) Esse dia, para mim, é um gozo, é um gozo, é um gozo! Porque eu fui instrumento daquele ato, um pequeno instrumento. (...) Agora, no crime... o que é que se vai resolver? Absolutamente nada. Absolutamente nada.
\end{abstract}

Conheci Evandro no exercício de minha profissão. Homem cordial, sabe deixar os jurisdicionados à vontade, sem, porém, abdicar de seu papel de juiz. Chamou minha atenção pela forma como conduziu uma audiência conciliatória, designada em processo que já durava quatorze anos. Sim, quatorze anos! A perenização devia-se à litigiosidade existente entre as partes. Naquele dia, assim que ingressamos em sua sala - partes e respectivos advogados -, Evandro foi logo anunciando: "O dia de hoje foi reservado exclusivamente para vocês. Temos todo o tempo que for necessário". Ou seja: sabendo da dificuldade de relacionamento entre os interessados, cuidou de tudo o que estava a seu alcance para tornar o cenário propício a um acordo.

A audiência foi exaustiva. Durou sete horas, inclusive estendendo-se além do horário normal de funcionamento do fórum. Ao longo desse tempo, o magistrado deu plena liberdade às partes, cuidando apenas para fazer intervenções pontuais, sempre no sentido de evitar o acirramento de ânimos ou mesmo de acolher algum desabafo, cujos efeitos eventualmente nocivos à meta do acordo ele tratava de neutralizar. Ao final, aconteceu o que no início parecia impossível: os pontos de litígio foram todos equacionados por meio de uma transação ${ }^{\mathbf{4 2 2}}$.

Pensando bem, o que são sete horas de audiência diante de quatorze anos de duração do processo? Quanto tempo mais aquela lide teria tomado das vidas de todos os envolvidos, magistrado inclusive? Não obstante, quantos juízes teriam tido disposição para tanto

${ }^{422}$ Ver "transação" no "glossário jurídico". 
e, mesmo que tivessem disposição, quantos estariam suficientemente preparados? Evandro não só tinha disposição, como também se revelava preparado.

Esta breve, porém intensa vivência com Evandro despertou meu interesse em estudar sua personalidade. Após consultá-lo a respeito, naquela mesma audiência, sobreveio uma resposta gentil: "É claro! Quando o senhor quiser, Dr. Antoin. Basta me ligar. Anote meu telefone direto".

Liguei para ele muitos meses depois, mas foi como se o compromisso tivesse sido assumido no dia anterior: "É claro que me lembro! Como haveria de esquecer?", disse-me ele. Agendamos dia e horário, em seu gabinete, no fórum. Ainda nesse contato telefônico, Evandro frisou achar importante termos não apenas horário para começar, mas também para terminar, pois assim cuidaríamos de ser devidamente objetivos, fazendo o encontro render e evitando divagações desnecessárias.

No dia marcado, apresentei-me pontualmente em seu gabinete. Evandro conduziume a uma sala reservada, onde, sobre uma mesa de centro, havia água mineral para ambos, em copos acompanhados de guardanapo. Nesse clima de acolhida, demos início à entrevista.

Comecei querendo saber o que o teria levado a optar pela carreira jurídica. Evandro revelou-me, então, sua origem modesta. Seus pais não tinham muita instrução formal e, em sua juventude, ele chegou a trabalhar como operário a fim de custear os estudos. Nessa época, quando contava dezessete anos, uma curiosa experiência marcou seu espírito:

Eu trabalhava numa fábrica, eu era operário, e eu encontrei, atirado num canto qualquer, num lixinho, um livreto. Eu descobri que aquilo era excerto, era parte de um código qualquer e fiquei encantado com aquilo, descobrindo que, por exemplo, a pesca poderia ser objeto de regras... e aquilo me encantou... E faltava muito pouco tempo, eu tinha dezessete, dezoito ou dezenove anos e já era um momento de ir para o terceiro grau de instrução. Nessa época eu também estudava contabilidade, de nível técnico e... enfim... eu não tinha, também, digamos assim, uma deficiência minha, por conta do ensino... público, eu não aspirava ingressar numa carreira científica das áreas exatas, química ou matemática, enfim. Agora eu sempre tive uma 
facilidade muito grande... porquanto eu sempre fui autodidata - lia gibis, lia rótulos, lia bula de remédios -, então, era como se tivesse um vínculo entre a ciência do direito e a língua portuguesa, e as leituras... enfim, as ciências assim chamadas de ciências humanas. Então, eu fui atraído para o Direito por conta disso. É a impressão que eu tenho.

Bastante curioso, também, foi o que levou Evandro a optar pelo judiciário:

Aí tem uma explicação, tem uma explicação. Quando eu, ainda muito garoto, doze ou treze anos, na minha casa, uma casa muito singela, enfim, só pegava um canal de televisão, que era o antigo, que nós chamávamos de "Canal 2", que era a Televisão Cultura. A Televisão Cultura abria e fechava sua programação com o Hino Nacional. Aquilo me extasiava [com ênfase]! Assim, ela ia mostrando as coisas bonitas do nosso país... Então, naquele momento, Dr. Antoin, um sonho foi assim nascendo dentro do meu coração. Eu dizia assim para mim: "um dia eu hei de servir o meu país", e eu, na sucinta compreensão das coisas, eu entendia que servir o país reclamava compor a estrutura do Estado. Hoje não: para mim, pode servir na advocacia, na medicina, em qualquer atividade você pode servir ao país. Mas naquele momento, servir o país era ser autoridade pública. Então, as coisas foram se, digamos assim, se encaixando. Veja bem, eu ingressei na carreira do Direito, eu entrei, eu era advogado, inclusive amava a advocacia. Mas era como se aquele sonho de garoto estivesse dentro de mim. Tanto é verdade, Dr. Antoin, que na advocacia, quando eu ia despachar com um juiz, aquilo para mim era... tinha uma aura [destacou "aura"]. O meu respeito pela figura do juiz era, naturalmente, muito maior do que a pessoa dele. Para mim não importava a pessoa dele, mas aquela função que ele exercia, para mim era uma coisa, assim, mágica, tamanho era o meu respeito por ele. Então, eu ia despachar, advogado, e via ali encarnado o poder judiciário, a autoridade estatal de estar a serviço do seu país, então aquilo, eu dizia para mim, é... é...: "Eu posso...", ou "Eu devo..." Aquilo me chamava. Exatamente o que se chama de "vocação", foi o chamado que eu recebi, Dr. Antoin. E eu vou dizer uma coisa: é uma coisa indomável, indomável... Tanto é verdade que, quando eu deixei a advocacia para integrar a magistratura, eu me vi desempregado [frisou "desempregado"]. Eu pedi demissão num escritório importante (...). Então, foi o maior risco, talvez, da minha vida. Nessa época, a minha mulher, eu já era casado, estava à espera (...) [de um filho]. Então eu corri - e me orgulha dizer isso - eu corri 99\% 
de chances de, vamos dizer assim, ter um filho, sem condições de prover as suas necessidades.

Evandro tinha plena consciência dos riscos que corria e que as chances de passar num concurso como o da magistratura eram mínimas. Na verdade, ele desvinculou-se do escritório de advocacia no qual trabalhava apenas quando chegou à fase da "escola de magistratura", segunda etapa do processo seletivo, cuja duração seria de noventa dias. Portanto, já havia passado na primeira fase do concurso. Foi nesse momento que comunicou o fato a seu superior hierárquico. Todavia, embora fosse um excelente profissional, não the foi permitida uma "licença" do trabalho, tendo ele de fazer uma opção. Caso superada a segunda fase do concurso, haveria ainda uma terceira. Não obstante, Evandro foi atrás de sua vocação de maneira focada e determinada, mesmo que para isso tivesse de enfrentar uma situação de desemprego. Evandro ainda lembra o alerta dado por seu antigo chefe:

"Evandro, é um risco muito grande que você está correndo. Você está seguro do que você está fazendo?" E eu disse a ele: "É isso que eu quero, Jorge". E ele disse assim: "Então, eu lamento muito. Passe no DP" [Departamento de Pessoal]. É... Então, eu quero dizer, assim... o meu chamado fez com que eu me expusesse a um risco gigantesco. No fim, por uma série de razões, que eu atribuo até a forças... é... não conhecidas, eu fui aprovado. Esse é, digamos assim, um fragmento da minha história.

Quando indaguei a respeito da visão que tinha do judiciário, Evandro respondeu:

Hã... como posso dizer?... É... Eu tenho, assim, algumas críticas... não propriamente ao judiciário, mas é algo que eu... culminei por enxergar, que é algo maior, que é o sistema judicial. Se nós... afirmarmos "o judiciário", é como se nós pudéssemos excluir outras instituições importantes que compõem o sistema, como, por exemplo: o ministério público, a advocacia, a defensoria, a procuradoria, o poder legislativo, então, o sistema é muito grande. E hoje, conhecendo um pouco mais, eu tenho, assim, algumas... - e que não são poucas - críticas... Isso, veja bem, por conta da ineficiência... patente do sistema.

No restante de sua fala, Evandro esclareceu o que entende por ineficiência do sistema: segundo ele, o Estado não cumpriu sua promessa constitucional de, como contrapar- 
tida ao monopólio da jurisdição, "oferecer a solução de conflitos intersubjetivos das pessoas". Nesse sentido, diz assistir diariamente a um quadro de "incompetência tamanha [frisou], (...) uma das razões inclusive, de... por que não dizer, devo ser franco, de uma certa frustração".

Quanto ao processo, Evandro o vê como "um instrumento... imperfeito [frisou "imperfeito"]... de... apuração da verdade... e de solução de um conflito". E continua:

Ele é imperfeito na medida em que... o... o processo, em primeiro lugar, por conta da necessidade de procuradores - dos advogados -, e por conta, naturalmente, da impossibilidade, como eu vejo, impossibilidade de o processo retratar a verdade verdadeira das coisas. $\mathrm{O}$ processo retrata, apenas, a meu ver, fragmentos, e muito miúdos [frisou "muito miúdos"] da realidade. Primeiro, porque as partes não levam os fatos em sua inteireza, levam apenas a parcela, a faceta dos fatos que lhes interessa. Eu vejo, então, a dificuldade que o juiz tem em reunir os fragmentos. Eu, outro dia brinquei: reunir os cacos que as partes lhe oferecem. Para oferecer, é... para... como se ele pudesse recompor um vaso quebrado. Ou seja, jamais! [frisou "jamais"] ... talvez, ... uma utopia dizer que se reconstitui a verdade dos fatos num processo judicial. Por mais esforço que o juiz faça e, por exemplo, por mais esforço também das partes. Que, na verdade, das partes não, porque são os seus advogados, e os advogados, eles também não têm como extrair tudo o que está dentro... dos seus constituintes. Então, é um trabalho cheio de imperfeições. A parte revelará apenas um pouco do fato para o seu patrono, porque, aquele ponto que ela sabe que não interessa ela vai ocultar. Sem dizer que, quando nós... vivenciamos um fato, ... passado um tempo, nós o reproduzimos de uma maneira, e passado mais um pouco de tempo nós o reproduzimos de outra maneira, por conta de toda, digamos assim, todo o complexo de emoções daquela pessoa. Se ela estiver bem num momento ela interpreta de uma maneira; se ela não tiver dormido bem, interpretará de outra... Num momento da vida, ela enxerga a vida de uma forma, noutro momento, de outra forma. Então, a reprodução de um fato no processo é de uma imperfeição extraordinária! E é com esse material, digamos assim, que lida o juiz. E também tem ele as suas dificuldades, tudo de ordem psicológica. Talvez eu seja por isso encantado com esse trabalho, porque, em realidade, o nosso trabalho, eu posso dizer, é pura psicologia. Pura psicologia. 
Diante de um instrumento com tamanhas imperfeições, conforme é o processo na perspectiva de Evandro, a pergunta seguinte apontou para um ato que certamente, para ele, teria enorme relevância. Quando indaguei que opinião tinha sobre a audiência, nosso entrevistado inspirou profundamente, fazendo-me rir, ao que se seguiram extensas considerações:

Isso merece uma pausa. [Pausa.] Eu li há, não mais que 15 ou 20 dias, um trabalho que eu reputo extraordinário, feito por uma ilustre advogada fluminense, a respeito da importância da oralidade no processo. Esse artigo, ... por ela escrito, dizia assim: que ela entrevistou diversos magistrados, da justiça comum fluminense, e eles disseram, em variadas ocasiões, que a importância é menor porque a prova oral é cheia também de imperfeições e etc., etc., etc.. Não sei. E qual é a minha opinião? Veja bem, na audiência... há mais de um tipo de audiência: a audiência da colheita de prova oral [chamada audiência instrutória], como há a audiência para se buscar a composição das partes [chamada audiência conciliatória]. No que diz respeito à colheita de prova oral, eu estou de acordo com o que disseram meus colegas fluminenses. Ou seja: no Brasil, talvez por conta de uma cultura de não-delação, mas que está entranhada na aura nacional, o juiz... é como se partisse de um pressuposto, qual seja, o de que a testemunha está faltando com a verdade. Por isso, ... não costumo, digamos, valorizar demais a prova testemunhal. Acontece, sim, outros tipos de audiência, as da autocomposição. A audiência da autocomposição tem sido por mim, ... valorizada a todo instante. Por quê? Porque ela não se presta tãosomente para a busca da autocomposição. A busca da autocomposição é um dos objetivos [frisou "um dos objetivos"]. Por quê? Porque se não se alcançada a autocomposição, o juiz teve oportunidade de perceber o perfil de cada uma das partes litigantes e dos seus patronos [frisou "patronos"]. Porque o processo, com a frieza das suas letrinhas impressas, é completamente diverso da manifestação, ao vivo e em cores, das partes envolvidas. Porque ali elas se soltam. Por isso que, quanto mais tempo possa dar o juiz, quanto mais liberdade, quanto mais abertura ele possa dar, maiores são as probabilidades de o juiz aferir, sentir as pessoas, os seus jurisdicionados. Por isso ela é de uma importância muito grande [frisou "muito"]. Elas, partes, muitas vezes, elas convencem os juízes, de um modo melhor até mesmo, com o meu máximo respeito, que os seus próprios patronos... porque elas, angustiadas, elas revelam a sua angústia abertamente. E outra: muitas vezes não é com as palavras: é com seus olhos, é com seus músculos, é com seu... corpo. Eu li, ... recentemente, que na comunicação as palavras são responsáveis apenas por 7\% 
da comunicação. O outro percentual está no tom da fala... está na expressão corporal: na minha perna, no meu pé, no meu semblante, no braço, o ângulo do meu braço... tem uma significância - o ângulo! E tudo isso aí... - eu não sou bobo nem nada, ... eu já li o livro do Pierre Weil ${ }^{423}$-, tudo isso aí eu estou lendo na audiência. E muita vez, a pessoa, que está ali, não tem a mínima desconfiança que eu a esteja avaliando. Então, para resumir: a importância da audiência é, a meu ver, extraordinária [frisou "extraordinária"]. Eu só tenho julgado processos no estado, sem ouvir as pessoas envolvidas, quando a matéria envolvida ... vamos dizer assim, o dispensa por completo, por exemplo, a anulação de um tributo. Mas, se é conflito entre duas pessoas naturais, é sempre importante ouvi-las, senti-las, em audiência.

A riqueza de detalhes da análise empreendida por Evandro nas audiências, aduzida acima, fez-me reputar pertinente mantê-la na íntegra.

A fim de designar audiências conciliatórias, sabemos que goza o juiz de ampla liberdade e amparo legal, do que nosso entrevistado não deixa, evidentemente, de fazer uso. Aliás, oportuno dizer que ele "jamais, jamais, jamais!" consulta as partes sobre se têm ou não interesse em conciliar. Este tipo de despacho, relativamente comum no meio judicial, desperta a crítica do comedido Evandro, que o vê como "uma tentativa de escapar de um dever ético do juiz, que é, inclusive, mostrar às pessoas quem é ele". Dever ético do juiz de mostrar quem ele é?! Sim, foi isso mesmo o que ele disse, pois acredita, segundo suas palavras:

(...) que o juiz deva mostrar para as pessoas: "Eu sou o julgador", e não se esconder, burocraticamente. É o que se vê hoje. Desculpe a crítica. Mas, agentes de Estado não querem personalizar a sua atuação. Então, quanto menos conhecido, melhor! Ele pode escrever a maior bobagem do planeta, porque é apenas um carimbo que está num papel e a pessoa não vai reconhecê-lo jamais, na feira, na igreja, em lugar algum! Ele está escondidinho. Convenientemente escondido. Então, eu tenho cá para mim, que é um dever da autoridade judiciária dizer: "Boa tarde. Eu sou responsável pelo seu processo".

${ }^{423}$ PIERRE WEIL, psicólogo francês radicado no Brasil, foi autor de livro muito conhecido, intitulado "O Corpo Fala" (coautoria de ROLAND TOMPAKOW), que já superou a 50ª edição. 
Perguntei se tamanho zelo não sobrecarregaria a pauta. Mas, por incrível que pareça, Evandro responde que nada que uma boa administração não resolva. À época da entrevista, contabilizava apenas "43 audiências para o futuro", numa pauta que se projetava apenas por 42 dias. Na verdade, no cenário que encontramos desde há muito no judiciário paulista, pode-se dizer que Evandro demonstra uma eficiência extraordinária. E faz questão de dizer:

Eu marco audiências em processos de inventário, eu marco audiências em processos de execução, eu já marquei audiências em processos de execução fiscal... para poder ter contato com as pessoas.

Perguntei quanto tempo costumam durar, em média, suas audiências. Evandro respondeu:

Ah... Primeiro, o seguinte: como as pessoas são feitas todas de emoção, elas precisam de um tempo para... sentar... ler o ambiente em que elas estão, para baixar a adrenalina, para sentir se o juiz é isso ou é aquilo, é bravo ou não é bravo; sentir a disposição do outro, precisa de um tempo. Então, eu não consigo fazer uma audiência com menos de meia hora. Audiência, para mim, é um mínimo de meia hora. Menos do que isso eu reputo como sendo um ato de faz-de-conta. Agora, eu tenho, assim, eu tenho marcado aud... eu, antes de marcá-las, naturalmente que eu examino o processo para entender, ... tanto quanto possível, a dimensão do conflito. E sempre ... eu penso assim: o conflito, em realidade - interessante isso, porque me parece que, nem todo processualista se põe a estudar esses aspectos do processo - o processo, a lide, em realidade, é apenas, apenas a ponta do iceberg do conflito. $\mathrm{O}$ conflito, muita vez, não tem nada que ver com a lide do ponto de vista... judicial. O conflito é alguma coisa mais profunda do que a simples ... relação de crédito e débito, ou, então, de separação. Tem razões outras! São de natureza ... metajurídica. Então, quando leio o processo, eu procuro intuir qual será efetivamente o problema [frisou "efetivamente"]. Antes do momento da audiência, se preparar para que eu, digamos assim, investigue [frisou "investigue"]... como se eu fosse um médico, ter que achar onde é que está... (...) Dr. Antoin... numa audiência, aqui, eu descobri que num negócio de uma máquina, um engenheiro comprou uma máquina, etc., mas o conflito mesmo [frisou "mesmo"], a origem dele foi uma palavra usada por alguém de uma das empresas. Que, a palavra mal empregada, sugeriu que o vende- 
dor fosse um pilantra! E depois de mais de meia hora é que saiu isso. E eu deixo as pessoas falarem, falarem, falarem, e aí o dono da empresa disse:

- Eu tenho mais de 60 anos e nunca, ninguém, jamais me chamou de pilantra!

Aí eu identifiquei qual era a razão do problema. E aí, nós trabalhamos para dizer o seguinte:

- É... será que não foi... um... digamos assim, um... um lapso? Então, se ela pedisse desculpas, porque realmente, o senhor... - Aí vem o peso do juiz: - O juiz sabe que o senhor é um homem idôneo!

E aí, veja, o espírito dele que começa a... O juiz falou que sabe que ele é uma pessoa idônea, e a outra parte:

- Não, realmente, a tal pessoa que pode ter falado isso poderia estar passando por uma dificuldade pessoal...

E aí, veja bem, aí nós abrimos o caminho para resolver o processo. Mas o problema não era o processo; o problema era uma expressão. Isso, por exemplo, nas relações familiares... o problema não é a casa, quem fica com a casa, não é nada disso! São coisas que estão lá no âmago da pessoa [frisou "âmago"]. Então, ... para não perder o foco: a audiência tem que ter no mínimo meia hora. Mas, muita vez, reclama o dobro disso, ou o triplo disso... e... eu quero dizer ao senhor que nós já fizemos audiência, aqui, com oito horas de duração. Envolvendo muitas pessoas, enfim, ... já cheguei fazer com oito horas de duração.

Conforme já relatei no início, eu mesmo tive oportunidade de vivenciar uma audiência dessas. Evandro explica que, quando assumiu a vara, percebeu que alguns conflitos "eram muito grandes, muito longevos". Por isso, confere um tratamento especial a estes, reservando a audiência para o início da tarde e deixando a pauta livre para que possa durar “o tempo que for necessário”. Qual será a eficácia desse método de trabalho? A resposta é inequívoca: "Aqui, a não-resolução de conflitos por meio da autocomposição é a exceção [frisou "exceção"]. A regra é a autocomposição".

Além de este estilo trazer enorme satisfação pessoal a Evandro, em termos estatísticos ele informa haver uma redução de 0,5 a $0,8 \%$ ao mês dos processos pendentes, ou seja, liquidam-se mais processos do que os que entram:

O percentual é pequeno, mas com significado muito grande, naturalmente. Acho, inclusive, que esse bom resultado tenha ligação direta com esse modo de dirigir a 
unidade e de dirigir o processo, ou seja, muitos processos que eu dirijo até a audiência de tentativa de conciliação e, nesse instante, é decidido o processo pelas próprias pessoas envolvidas, e é um que baixa na minha planilha, do meu acervo.

Embora nem todos os advogados compartilhem dessa visão, Evandro comenta que tem crescido o número daqueles profissionais que compreendem sua postura:

E me parece que é um movimento, que está ocorrendo no país, e quem sabe até mesmo no mundo, um movimento ... contrário à chamada "cultura da sentença". Nas palavras de Kazuo Watanabe, é preciso romper com a chamada cultura da sentença, para nós implantarmos a cultura da pacificação. Veja bem, nesses (...) anos eu vi inúmeros advogados, vamos dizer assim, até mesmo a dificultar o acordo. Mas eu tenho observado que cai o número desse tipo de advogado. A culpa é dele? Eu digo: "Não. A culpa é de uma formação. Ele muita vez foi formado para o litígio". Agora, na medida em que as escolas e a própria advocacia vai se renovan$d o$, parece que a tendência é que o número seja muito grande de pessoas favoráveis à autocomposição.

Indagado a respeito do despacho saneador, Evandro respondeu:

Veja bem, ... [pausa] Vamos por partes. Toda vez que... toda vez que vencida... muito bem, eu trabalho da seguinte maneira: vencida a fase ... postulatória do processo $^{424}$, vencida a parte postulatória, eu me entrego a um exame mais acurado dele. Por quê? Para preparar a audiência de autocomposição. Veja bem: a minha experiência revela que se houver... se houver ... dúvida quanto à legitimidade das partes $^{425}$, a probabilidade de autocomposição é muito pequena. Por exemplo: se A promove uma ação contra $\mathrm{B}$ e $\mathrm{C}$, e entre esse $\mathrm{B}$ e $\mathrm{C}$ há... um atribui ao outro a responsabilidade, digamos assim, pelo evento danoso, não importa... enquanto o juiz não resolver isso, é muito pequena a probabilidade de autocomposição. Então, antes de marcar, eu resolvo essa questão, não, naturalmente, a questão de fundo. A questão de quem é que poderá responder ou não pelo... pela pretensão daquele pedido. Não é? Então... Do que é que eu ia falar mesmo, Dr. Antoin? [Do despacho saneador...] Ah, do despacho saneador. Então, veja bem, se tiver ... disputa, dúvida, relativamente às condições da ação, enfim, eu resolvo para poder aumentar,

${ }^{424}$ Ver "fase postulatória" no "glossário jurídico".

${ }^{425}$ Ver "legitimidade das partes" no "glossário jurídico". 
digamos assim, as probabilidades de autocomposição. Agora, se não houver, se não houver, eu já vou direto para a audiência, sem qualquer pronunciamento. Porque eu tenho também ... uma outra experiência. Qual seja? Qual seja? ... Quanto menos decisão houver no processo, maiores as probabilidades de um sucesso. $\mathrm{Ou}$ seja, eu só decido, então, se a questão for de legitimidade... Porque, inclusive, se eu afasto $\mathrm{C}$, é só o B que eu tenho para trabalhar com A, e não os três.

Aproveitei para expressar a Evandro o seguinte raciocínio, que me ocorreu naquele momento: ao tomar o menor número possível de decisões antes da audiência conciliatória, o magistrado não sinaliza para as partes seu entendimento a respeito da causa. Em outras palavras: não alimenta em nenhuma delas eventual "certeza" quanto ao resultado da lide, o que aumenta as chances de uma solução amigável. Diante dessa colocação, ele exclamou:

Exatamente! Exatamente! E acho assim: o juiz, ele só deve se pronunciar, se pronunciar quando efetivamente já não tem mais condição, não tem mais probabilidade de compor as pessoas, as partes.

Infelizmente, nem todos os processos podem ser resolvidos por meio da composição, circunstância que obriga o juiz a decidir, a julgar. Portanto, perguntei-lhe se alguma vez ele se viu em situação em que o Direito não dava a devida resposta para o caso:

Eu não me lembro... de ter enfrentado jamais a situação de não ter encontrado no ordenamento. Por quê? Porque eu entendo que o ordenamento oferece condições de solução para tudo. Como assim? É que o ordenamento congrega também princípios... como... regras de sobredireito. Então, eu me valho deles, princípios positivados, e que permitem, digamos assim, uma possibilidade das mais variadas. Se eu não tiver, Dr. Antoin, uma regra positiva, infraconstitucional - e infraconstitucional válida, naturalmente, em vista da Constituição da República -, eu tenho ali [na Constituição Federal] princípios que regem os fundamentos da República Federativa do Brasil, tem princípios da dignidade da pessoa humana e outros... Então, eu encontro maneira de resolver... Inclusive, não sinto desconforto nenhum.

Quanto à relevância de jurisprudência e doutrina em seu trabalho, Evandro relativizou-a. Reconheceu-as como "faróis". São para ele, sem dúvida, de grande importância, mas não são tudo. Acima delas deve sempre estar "o raciocínio" do juiz, cujo pensamento não se pode deixar "embotar". 
Quando recebe uma petição inicial, qual serão os aspectos que mais chamam a atenção de nosso magistrado (exemplifiquei com: "organização", "apresentação", "tese do advogado", "pedido", "raciocínio", "valor(es) posto(s) em juízo" e "situação sócioeconômica da parte")?

Ah, exatamente todos esses pontos são por mim examinados. Ah... veja bem. A apresentação, tamanho da fonte, ... o espaçamento, a limpeza, a linguagem [frisou "linguagem"] - importantíssima: se é prolixa, se não é prolixa, se é afetada, se não é afetada, se é... antiga ou se é contemporânea... se muito longa (prolixa, já falei), ... Enfim, esses aspectos, digamos assim, plásticos... são muito importantes. Por quê? Porque eu acredito que, em primeiro lugar: quem sabe que tem razão, quem sabe, ou seja, quem está seguro da sua tese... está seguro da sua tese, é conciso e não precisa ser prolixo. Não precisa também ser afetado, pode ser sereno. Então, tudo isso entra, digamos assim, num, num computador que nós temos dentro do nosso cérebro, para nós, digamos assim, começa ali o nosso convencimento. É nesse instante, é na leitura da petição inicial. Eu digo aos meus prezados alunos: "Meus amigos, jamais [frisou "jamais"] escrevam uma petição inicial como eu tenho lá, em juízo, com 38 laudas. Porque isso é uma mensagem subliminar, quem escreveu 38 laudas é porque não está seguro da sua tese! Quem tem segurança, faria esse, essa ação... em 10 laudas, quando muito [frisou "quando muito"]. Trinta e oito jamais!" Outra coisa: "Não atirem dezenas de jurisprudências na sua petição inicial. É outro sinal de insegurança! Basta para o juiz dizer o fato, dizer qual é o fundamento do seu pedido e dizer qual é a sua pretensão. Não precisa mais nada, nada, nada além disso". Ou seja: você botou além, esse excesso vai prejudicá-lo. Então, devo lhe dizer: a petição inicial reclama um cuidado muito grande.

Dando-me por satisfeito com essa resposta, parti para a próxima pergunta, que dizia respeito aos aspectos percebidos, em primeiro lugar, numa audiência. Exemplifiquei com: postura das partes? Dos advogados? Das testemunhas?

Evandro disse ter seu interesse despertado pela "serenidade das pessoas". Entende que a pessoa serena passa a mensagem de que acredita estar amparada pelo Direito, crê estar do lado certo. Em contrapartida, a "pessoa nervosa, ansiosa [frisou "ansiosa"] emite mensagem exatamente contrária”. Isso, para ele, é “muitíssimo importante”. Exemplifica: 
Por exemplo, a pessoa que ... antes que o juiz lhe conceda a palavra já dispara a falar; a pessoa que ataca com palavras ácidas a outra parte, que ataca o advogado, ou o advogado que também faz isso... às vezes acontece, eles estão todos contando para o juiz que eles estão, ou que pelo menos se sentem numa posição ... desconfortável, e isso é importante para o juiz.

Qual é a reação de Evandro diante de uma testemunha mendaz?

Hã... [Pausa.] Eu não externo. Em primeiro lugar, eu não externo essa minha sensação. Eu não externo. Esse fato vai... vai, vai compor meu julgamento. Mesmo... mesmo que não venha escrito na sentença. (...) O juiz não escreve tudo o que pensa. Duvido que algum juiz ponha em seus autos todo o seu pensamento. O que o juiz ... externa, digamos assim... é uma apresentação mínima dos fundamentos do seu julgamento. Não é o todo.

Caso a testemunha caia em contradição, Evandro procura "dar-lhe corda". Mesmo havendo uma mentira "escancarada", não chama a atenção da testemunha. "Não! Eu escrevo isso na sentença. Caso seja escancarada, porque pode não ser escancarado". Na verdade, afirma que estudos feitos sobre o assunto fortaleceram sua cautela neste campo:

Dr. Antoin, eu... sou um pouco cuidadoso, depois de alguns estudinhos a respeito da, da... da verdade, da mentira... Eu... eu não acredito que toda gente, digamos assim, é... saiba que está mentindo. Até porque, "verdade" ou "mentira" são conceitos não matemáticos! Eu acredito... que... os fatos da vida não são suscetíveis de apreensão pelos sentidos humanos. Isso é um engano [frisou "engano"]. Basta que nós abramos aquele livrinho, Discurso sobre o Método, de Descartes, que diz assim: que não há nada mais falho do que os sentidos. Muito bem! Então, eu sempre acredito que aquela pessoa que está falando algo para mim, ela pode estar acreditando que aquela seja a verdade ${ }^{426}$. Portanto, dizer que ela está mentindo me parece alguma coisa prematura, precipitada. Cada pessoa ... só pode... - e quando pode -, enxergar uma parcela diminuta, pequeníssima da realidade. Ela não tem condi-

${ }^{426}$ Em seu livro Law \& the modern mind, Jerome Frank traz alguns relatos sobre a relatividade do depoimento testemunhal. Num deles, refere-se a experiência feita por um professor de Direito Criminal junto a seus alunos. Houve uma séria briga em sala de aula, inclusive com o saque de arma de fogo. O professor conseguiu intervir e evitar o pior. Aproveitando-se do fato - que, na verdade, sem que os alunos soubessem fôra encenado por atores -, o professor solicitou a alguns dos presentes que descrevessem, por escrito, o que havia ocorrido. A mesma solicitação foi feita a outros alunos um dia depois e ainda após uma semana. Ao fim desse intervalo, procedeu-se ao cruzamento dos fatos narrados. Os "erros", classificados nas categorias de "omissão", "acréscimo" e "alteração" foram inúmeros, com frases e atos atribuídos a quem sequer abriu a boca ou mesmo esboçou a referida ação. Op. cit., pp. 116/117. 
ções de apreender um fato em sua inteireza. Então, eu não posso presumir que ela esteja mentindo.

Nosso entrevistado demonstrou entusiasmo quando the perguntei se procurava compensar eventuais descompassos técnicos entre os advogados das partes, ainda mais percebendo estar a vantagem do lado de alguém que age de má fé:

A sua pergunta é extraordinária! Extraordinária. E... eu quero acreditar, inclusive, que Calamandrei fala, salvo engano, sobre isso. Hã... existe uma tendência, não sabemos qual é a explicação... mas o juiz tende naturalmente a se colocar do lado da parte mais fraca, especialmente ... se ela estiver, digamos assim, com assistência menos qualificada do que a outra. É uma tendência, assim, muita vez ... indomável de ... equilibrar os pratinhos da balança. ... Inclusive porque, veja bem, eu penso que isso não seja... não seja ... tampouco irregular. Porque... é necessário, aliás, necessaríssimo".

Na sequência de seu raciocínio, ainda ponderou que no processo civil toma-se como premissa que as partes litigantes têm advogado e, ainda, que têm suporte econômico, o que "não confere com a realidade. Não confere com a realidade. Se um consumidor litigar contra uma importante empresa de... refrigerante, naturalmente a empresa de refrigerante terá maior capacidade e melhores armas que esse consumidor. Então, é necessário que ... o juiz, por meio de mecanismos já previstos na ordem normativa, possa colocá-los em igualdade de condições... processuais. Isso é importante”.

Evandro raramente concede oportunidade para "tréplica":

É no máximo a réplica. Agora, é muito interessante a pergunta pelo seguinte: porque muita vez, muita vez, nem a réplica eu concedo. E por quê? ... Para a nossa tristeza, ocorre, alguma vez, de as partes empregarem, em seus arrazoados e em suas petições, expressões muito ácidas. Se eu perceber - por isso é importante a leitura do processo, sempre, em todas as suas partes - se eu perceber que a contestação, resposta, enfim... traz acusações muito graves, eu... como num diálogo, se eu der a palavra, vai vir outro ataque! Então eu já, imediatamente, eu chamo as pessoas. Eu não permito o ataque. 
Nosso entrevistado investe uma quantidade enorme de energia visando a evitar o atrito entre as partes do processo, e esse investimento acaba inspirando procedimentos sui generis, como o relatado a seguir:

Em alguns processos, em alguns processos... antes de mandar citar o réu, eu o convoco para audiência. Ou seja, note que eu tenho precipitado, sempre que posso quando não há previsão de trazer as pessoas, eu trago as pessoas: na execução, no inventário, e no processo que prevê para o "momento três ou quatro", muita vez eu puxo paro o "momento dois", ou o "momento um"... não dá para o "zero", porque sem a demanda eu não posso fazer nada. Ou seja, a partir do momento em que vem uma petição inicial, de acordo com, digamos assim, a natureza do problema ali... narrado, eu chamo a outra [parte] sem citar. Por que, Dr. Antoin? Certa feita uma... um funcionário, logo que eu cheguei aqui, não compreendia o meu método, pois achava assim as coisas mais loucas... "Mas escute, não existe isso!...” Aí eu paro e explico. Veja bem, veja bem: uma pessoa procura um advogado... está nervosa... Procura um advogado... muita vez, pode até ser um advogado sereno, tranquilo, que não escreve aquilo, não põe no papel aquela acidez, ele suaviza. E me parece, inclusive, que seja bom que o advogado faça isso, suavize... em vez de botar tudo, as palavras... Mas pode acontecer que o advogado, supondo que sendo assim ... fiel às palavras do seu cliente, ponha na petição. Aí ele vai mostrar para o cliente, que vai dizer assim: "É isso mesmo!" Só que, muita vez, a leitura desta petição inicial vai dificultar imensamente a resolução do conflito entre essas pessoas. Então, eu mando convocar sem cópia da petição inicial.

Diante da revelação que Evandro fazia, não pude deixar de conter meu espanto: Nossa... É que foge completamente ao procedimento tradicional o juiz enviar o oficial de justiça para simplesmente convocar a parte para uma audiência, sem que ela tenha acesso ao que está sendo dito a seu respeito... Mas Evandro continua: "Nossa... Porque, ... justamente!"

Perguntei: Mas e quanto ao prazo? Vai começar após a audiência?

Lógico! Não tem processo ainda. Uma vez uma pessoa disse:

- Mas isso aí não viola o direito do contraditório, o direito disso, daq... o direito do devido processo legal? 
E eu digo:

- Filho, filho... - É que a gente tem, Dr. Antoin, que enxergar o processo de uma maneira um pouco mais ampla do que é ensinado na faculdade e como é tocado nas unidades judiciárias por aí. É uma coisa muito mais complexa, tem muito mais emoção, a palavra que usa, o momento, o que pede ou o que não pede... O oficial de justiça vai até a casa, a pessoa tem vergonha porque os vizinhos veem... Então, tudo isso aí é como se fosse ignorado pelo código de processo civil. Então vai, eu digo assim - e foi uma oficiala de justiça que veio, inclusive, falar comigo:

- Filha, diga para a pessoa que é apenas uma audiência que o juiz pediu... - e ela também [a oficiala de justiça] é muito importante nesse trabalho de suavizar - ... que compareça no dia tal lá, que ele quer conversar.

E é só isso! [Frisou "só isso".] Daí, eu desperto o diálogo da seguinte maneira [já na audiência]:

- Senhor João, olha, o senhor sabe que... a Dona Maria, ela está dizendo aqui que... - eu suavizo! - ... que não há mais condição de que os senhores possam... é... manter o casamento, viu senhor João? O senhor é um homem bom, e tudo, mas... está muito difícil, senhor João!

Veja só: com isso, a probabilidade de o senhor João aceitar, por exemplo, que o juiz diga:

- Senhor João, eu preciso que o senhor me... me diga... que dia o senhor pode sair da casa, senhor João?

Dr. Antoin, é com muita alegria que eu quero revelar isso para o senhor: foram variados casos... casos em que eu recebi pedidos, medidas liminares de separação de corpos... Quando não tem jeito, e eu vejo que a mulher está correndo um risco muito grande... porque o marido anda armado, porque ontem ele chegou... o risco é muito grande... eu não posso assumir, eu, o juiz, esse risco! Mas, se for alguma coisa, por exemplo: "Ele me bate nos últimos cinco anos..." Em vez de dar uma liminar, que é uma coisa muito ... ácida, grave, e que pode expô-la a um risco outro, de ele voltar no dia seguinte!... eu simplesmente mando chamá-lo, e ajusto com esta pessoa, ajusto a data que ele sairá da casa. Faço isso em audiência. Ou seja, resumindo: reputo de uma importância muito grande, que o juiz, primeiro, ouça seu jurisdicionado, e se ele puder precipitar o momento, tanto melhor.

Dentre todas as áreas em que atuou, Evandro desgostou da criminal. Nesse campo, lembra citação de um colega seu, Luiz Flávio Gomes, que teria dito que "o juiz criminal é 
o distribuidor da dor..." E Evandro repete a frase: "O distribuidor da dor." Seguiu, daí, um longo e melancólico arrazoado sobre a atuação do juiz criminal:

Veja bem, condenar as pessoas... tem um peso muito grande, tem um peso... eu diria assim, cósmico, vamos chamar assim. A ponto de eu dizer, eu creio nisso, capaz de vergar uma pessoa [aqui, ele se refere à pessoa "do magistrado"]. É muito pesado... (...) O peso psíquico é capaz de fazer um homem triste, vergar o seu corpo. Porque, veja bem, ah... é verdade, concordo, que a condenação muita vez é absolutamente necessária. "Condenar" vem de com damno, ou seja, aquilo que corresponde ao dano. Alguém ... cometeu... - cometeu é o verbo certo? - deu causa, deu causa a um dano, ele atrai a condenação, que é a resposta ao dano. Então, um homem dá causa a um dano de natureza social, o crime, vem o Estado, por meio do juiz e responde àquilo. Mas, em realidade, ele causou uma dor e o juiz vem e lhe causa outra dor. É uma dor lícita? Pode ser. É uma dor justa? Pode ser. Mas é uma dor. E ser o aplicador da dor - um ano, dois anos, dez anos... - isso começa a pesar muito, inclusive porque, quando se começa a examinar o sistema penal, n... o sistema penal dá margem a interpretações e valorações as mais diversas do magistrado: será que eu estou sendo justo? Isso aí é uma... uma dúvida que me parece não ter resposta! Não tem resposta! Então, muita vez me perguntei: "Não estou eu sendo simples instrumento da opressão do Estado?" "Eu estou sendo usado pelo Estado para oprimir”. Porque o sistema penal, ele tem destinatários específicos. Só não vê quem não quer! Determinadas camadas da sociedade são, digamos assim, predestinadas à condenação penal e outras jamais [frisou "jamais"] se sentarão à frente do magistrado. Porque o sistema está montado de maneira a evitar que isso ocorra. Há diversas maneiras, vistas e revistas, de fazer com que os grandes criminosos jamais se vejam nas barras dos tribunais. Esse é um peso muito grande que carrega o juiz criminal. A menos que ele, vamos dizer assim ... se anestesie, mas eu nunca desejei ingressar na magistratura para ser um juiz anestesiado, sabe?

A mesma intensidade emocional empregada por Evandro para explicar o porquê não se compraz com a área criminal pode ser observada no discurso que emprega para descrever sua satisfação em atuar nas áreas cível e de família:

A área que eu gosto mesmo é a área cível e família. Porque o que me dá prazer mesmo, Dr. Antoin, e é prazer de verdade, é realização como pessoa humana, é re- 
solver os problemas das pessoas. Quando eu não consigo, eu sofro. Quando eu consigo, a minha alma se alegra e... e... é um refrigério para mim. Um acordo judicial ... no campo da família... um filho ou uma filha, outro dia, que eu vi, a filha que entrou aqui não falava com o pai há um bocado de tempo... a comunicação estava truncada... E depois o pai chora em audiência, estende a mão... e ela também chora e saem abraçados... Esse dia, para mim, é um gozo, é um gozo, é um gozo! Porque eu fui instrumento daquele ato, um pequeno instrumento. Então, veja bem, eu tive oportunidade de, no exercício da minha profissão, não que eu tenha resolvido o conflito mas, a partir daquele instante, as probabilidades de o conflito se resolver aumentam. Não havia probabilidade nenhuma, estava trancado. Agora, no crime... o que é que se vai resolver? Absolutamente nada. Absolutamente nada.

Diante de tudo o que foi dito acima, já é de se esperar que esse magistrado receba advogados para despachar:

Recebo sempre (...) eu já fui advogado, Dr. Antoin, e... e... e eu sempre via como uma ofensa [frisou "ofensa"] o juiz não querer me receber. Então, quando eu... foi uma experiência muito importante ser advogado - quando eu vim para a magistratura, eu já tinha aprendido como não ser, como não ser um juiz inacessível. Então, a... a acessibilidade ... é muito importante. É claro que precisa também de um... digamos assim, ... saber direitinho, não pode ser uma coisa, assim, escancarada, mas é importante.

Evandro ainda não tem a vivência do processo digital. No entanto, vê esse movimento como algo "irrefreável". Quanto a seus efeitos, diz ser "um pouco cético", uma vez que não poderão ser afastados os "males que não estão somente na forma do processo. Então, eu espero que eu esteja enganado, naturalmente, mas só o fato de transformar o que é papel em arquivo eletrônico, mas com as deficiências todas que eu posso ver hoje, me parece que não vai mudar muita coisa".

Ao olhar o relógio, notei o risco iminente de extrapolar o tempo pré-determinado pelo entrevistado e isso me fez comentar que já estávamos chegando ao fim da entrevista, ao que ele respondeu, em tom sincero: "Não tem pressa". 
Passei à leitura do pensamento de Llewellyn - "Karl Llewellyn acredita que, geralmente, a mente do juiz primeiro antecipa a decisão que considera justa (dentro da ordem jurídico-positiva) e depois procura a norma que pode servir de fundamento a essa solução, atribuindo aos fatos a qualificação apropriada"427 -, que lhe pedi para comentar. Segue o comentário de Evandro:

Eu concordo plenamente [com ênfase], e digo mais: ele deve ter se inspirado em palavrinhas de Piero Calamandrei, que diz exatamente isso: que o juiz primeiro encontra o telhado, e depois constrói as paredes.

Finalizei nossa entrevista perguntando se ele diria haver alguma diferença de personalidade quando no exercício da função e fora do ambiente de trabalho:

Não. Eu vejo assim, Dr. Antoin: a minha... a minha... Eu não gosto da palavra "função", eu não gosto da palavra "função". Ah... a minha missão, o meu sacerdócio, digamos assim, ... é de tal modo absorvente... que... ele baliza todos os meus comportamentos da minha vida. Eu... eu me vejo juiz nos mais mínimos atos, nos mais mínimos atos... Naturalmente que, no dia a dia, na vida cotidiana, ... eu posso me liberar da formalidade, da roupa, da gravata e tudo, mas o núcleo, o... esse, esse eu não troco com a roupa. Não, não. O juiz em todo o momento, o núcleo, os valores, isso... são muito densos, assim, para... para que eles sejam relativizados de acordo com o... o espaço e o tempo.

${ }^{427}$ Op. cit., pp. 13/14. 


\subsection{ANÁLISE DO PERFIL TIPOLÓGICO DE "EVANDRO”}

Julgo pertinente revelar que Evandro foi o segundo juiz que entrevistei. Naquele momento, eu ainda não tinha amadurecido a ideia de que pessoas pertencentes a um mesmo tipo psicológico pudessem apresentar grandes diferenças entre si. Confesso que me dar conta disso, a partir de meu contato com Evandro, foi uma experiência impactante. Contarei como ocorreu.

Finalizada a entrevista, seguiu-se conversa mais informal. Revelei a Evandro meu encantamento com seu perfil e que, enquanto ele falava, fui tentando imaginar quais seriam a atitude e as funções predominantes em sua dinâmica psíquica. Todavia, ao verificar o resultado do questionário que ele acabava de preencher, notei ter errado feio, pois imaginara estar diante de um tipo EXTROVERTIDO, INTUITIVO e SENTIMENTAL, quando, na verdade, e para minha surpresa, o questionário apurou o contrário disso. Foi então que ele fez a defesa do resultado apurado, validando-o.

Disse ser mesmo um INTROVERTIDO, embora adorasse falar em público. Aproveito para lembrar ao leitor que já tratamos, na parte teórica deste trabalho, de alguns preconceitos existentes em relação às atitudes, sendo um erro crer que os introvertidos detestam falar em público. Não gostam é de fazer isso no intuito de ser o "centro das atenções", mas podem apreciar muito a oportunidade de expor suas ideias, desde que percebam haver importância naquilo que pretendem expressar.

Com relação aos demais traços, disse-lhe ter imaginado ser ele INTUITIVO por causa de algumas inovações quanto a procedimentos adotados. Os tipos SENSORIAIS tendem a ser mais "conservadores", o que decorre de seu apreço pela experiência. Foi então que ele relatou ser mesmo bastante conservador. Como exemplo, citou o hábito de comprar seu sapato, há anos, na mesma loja, escolhendo sempre o mesmo modelo.

Não obstante, passei-lhe a impressão de que havia grandes contrastes entre o tipo aferido e a conduta observada no curso de seu trabalho. Os traços de gentileza, por exemplo, para mim tão evidentes, são típicos do SENTIMENTO. Na verdade, eu ainda carregava a impressão gerada por despachos como o seguinte, por ele proferidos: 
Fls. (...) - Processo $\mathrm{n}^{\mathrm{o}}(\ldots)$ - Vistos. Examinados os nove volumes deste processo, não identifiquei disposição estatal - verdadeira - em aproximar as partes e estimular o diálogo, pelo que me sinto no dever de fazê-lo. Antes, pois, de conhecer dos $r$. argumentos das partes, permito-me realçar da invariável conveniência da autocomposição, fenômeno de melhores resultados práticos do que comandos estatais heterocompositivos - como sabem os todos experientes Advogados oficiantes nos autos. A elevação - presumível - das partes litigantes aliada à extraordinária demora na solução dos problemas - isto que por certo não lhes convém -, inspiram-me a confiança de que possamos encontrar o ponto de equilíbrio de seus respeitáveis interesses. Outrossim, visando a intermediar-lhes o diálogo, ficam todos CONVIDADOS - por este ato, independentemente de quaisquer outras formalidades - a comparecerem à minha presença no próximo dia (...) às (...) horas. Aí, no exercício de seu dever ético de pacificação social, o juízo procurará a solução autocompositiva da demanda, subtraindo, tanto quanto possível, eventuais obstáculos existentes no caminho da concórdia. Observo que, pela natureza da audiência por mim ora designada, dedicarei a ela todo o tempo necessário para o melhor diálogo entre todos, de modo que muito me honraria que ninguém se ausentasse. Aos e. Advogados, conhecedores mais do que ninguém das controvérsias existentes entre as partes, SOLICITO, ademais, a especial consideração de, em lhes sendo possível, darem início - desde logo - às desejáveis negociações entre todos. Intimem-se.

Evandro, então, não se conteve e acabou segredando que ele próprio muitas vezes não se compreendia. Curiosamente, pouco depois encontrei em Jung o seguinte comentário a respeito de seu tipo: "Este tipo dificilmente está aberto à compreensão objetiva e também, na maioria dos casos, não se compreende a si próprio". ${ }^{428}$

Alguns leitores já devem ter percebido que estou falando do tipo SENSAÇÃO INTROVERTIDA. Compartilho com o leitor essa experiência para mostrar o quanto pode ser difícil apurar o tipo psicológico de alguém. Essa dificuldade não existe apenas de uma pessoa em relação à outra, mas também em relação a si mesma, porque, na verdade, temos em nós a potencialidade de agir conforme qualquer tipo, e às vezes o fazemos - em desconformidade com nossas preferências mais íntimas -, visando a atender a exigências do meio.

${ }^{428}$ Tipos ..., p. $357, \S 696$. 
Após apuração do tipo de Evandro através do questionário, conseguimos identificar, em seu discurso, elementos corroboradores daquele resultado.

Partindo do discurso produzido em nossa entrevista, talvez possamos afirmar que o ponto mais evidente da personalidade de nosso entrevistado seja a INTROVERSÃO. Mas com base no que dizemos isso?

A começar, note que Evandro costuma convocar audiências conciliatórias em todos os processos sob sua batuta, bastando que as partes sejam pessoas naturais. Essa característica fez que, no início de nosso estudo, o tomássemos como EXTROVERTIDO.

Sendo esta a quinta análise de nosso acervo, partimos da premissa de que o leitor já se tenha dado conta de que a atitude do juiz (I ou E), por si só, não parece implicar maior ou menor tendência à designação de audiências. O que mudará de um para outro tipo é a forma de conduzir a audiência. Constata-se, por exemplo, que um INTROVERTIDO tende a interagir menos, enquanto um EXTROVERTIDO tende a interagir mais com os participantes. Isso se verifica no caso de Evandro. Sendo INTROVERTIDO, dificilmente receberá de uma das partes do processo a advertência que coube à radiante Mirtes: "Não se meta na minha vida!" Conforme pudemos observar em longa audiência por ele presidida, suas interferências eram sempre muito pontuais, não se vendo este magistrado precisando fazer nenhum esforço para conter a fala.

Por outro lado, também já sabemos que um determinado tipo pode apresentar traços de outro, sendo necessário verificar o conjunto de traços característicos predominantes. Neste sentido, cabe buscar os variados sinais de INTROVERSÃO em Evandro, e que podem ser identificados nos seguintes aspectos:

- ser, confessadamente, um autodidata, o que denota tendência a um aprendizado que se faz de maneira reservada, em vez de em grupo: “(...) eu sempre fui autodidata - lia gibis, lia rótulos, lia bula de remédios". 
- a valorização, por ele, do sujeito, em detrimento do objeto, ou, em outras palavras, dos aspectos subjetivos implicados não apenas na prestação jurisdicional, como também na percepção dos dados da realidade:

(a) quanto à prestação jurisdicional, diz ele "que o juiz deva mostrar para as pessoas: 'Eu sou o julgador', e não se esconder, burocraticamente. (...) agentes de Estado não querem personalizar a sua atuação. (...) Ele [o juiz] está escondidinho. Convenientemente escondido. Então, eu tenho cá para mim, que é um dever da autoridade judiciária dizer: 'Boa tarde. Eu sou responsável pelo seu processo'."

(b) Quanto à percepção dos dados da realidade, para Evandro parece não haver objetividade possível. Ele próprio põe isso em destaque quando cita Descartes: "Eu acredito... que... os fatos da vida não são suscetíveis de apreensão pelos sentidos humanos. Isso é um engano [frisou "engano"]. Basta que nós abramos aquele livrinho, Discurso sobre o Método, de Descartes, que diz assim: que não há nada mais falho do que os sentidos. (...) Cada pessoa ... só pode... - e quando pode -, enxergar uma parcela diminuta, pequeníssima da realidade. Ela não tem condições de apreender um fato em sua inteireza".

- a preponderância dos pontos de vista subjetivos sobre os dados da realidade. Este ponto está diretamente relacionado ao anterior, mas com ele não se confunde. Com base nele, diz-se que o INTROVERTIDO costuma apresentar uma "maneira determinada e bem generalizante de exprimir-se, que exclui de antemão qualquer outro parecer", podendo-se ter a impressão, principalmente à luz de uma perspectiva extrovertida, de que se está diante de "um refinado egoísta ou entusiasta doutrinário". 429

- a apreensão subjetiva dos dados da realidade leva o INTROVERTIDO a conferir-lhes todo um significado simbólico, resultado justamente da projeção de

${ }^{429}$ JUNG, Carl G.. Tipos ..., p. 373, § 721. 
sua subjetividade sobre eles ${ }^{\mathbf{4 3 0}}$. Isso está presente em vários momentos da fala de Evandro, valendo mencionar o "peso cósmico" por ele atribuído ao ato de condenar uma pessoa em juízo criminal, ou ainda a troca intencional do substantivo "função" por "missão" ou "sacerdócio", para referir-se à sua atividade profissional.

Aceitamos, portanto, com relativa tranquilidade a hipótese de estarmos diante de um INTROVERTIDO.

Outro traço de personalidade que chama facilmente nossa atenção diz respeito ao modo como Evandro extroverte, havendo indícios de ser ele do tipo JUDICATIVO (J). Sinal disso foi sua iniciativa de definir conosco, previamente, a duração da entrevista, o que nos pareceu decorrer menos de uma necessidade objetiva e mais de uma preferên$\mathrm{cia}^{431}$. Além disso, quando comparecemos a seu gabinete, Evandro já nos aguardava, tendo inclusive preparado o ambiente em que se daria o encontro. Isso pode revelar preferência pelo planejamento (característica dos JUDICATIVOS), em lugar do improviso (característica dos PERCEPTIVOS). A conduta observada em Eustáquio, por exemplo, juiz que supusemos PERCEPTIVO, foi o contrário disso: precisamos aguardar sua chegada, ou seja, atrasou-se um pouco e decidimos juntos, no momento mesmo, onde seria concedida a entrevista.

O estilo JUDICATIVO também pode ser visto na descrição que Evandro faz de seu processo de ingresso na magistratura. Ele sabia exatamente o que queria, e apostou todas as suas fichas nisso, correndo o risco de ficar desempregado numa fase delicada da vida, a ponto de seu superior hierárquico alertá-lo:

"Evandro, é um risco muito grande que você está correndo. Você está seguro do que você está fazendo?" E eu disse a ele: "É isso que eu quero, Jorge".

\footnotetext{
${ }^{430}$ VON FRANZ, Marie-Louise. Op. cit., p. 38.

${ }^{431}$ Nesse sentido, destaco de nossa entrevista: "Ao olhar o relógio, notei o risco iminente de extrapolar o tempo pré-determinado pelo entrevistado e isso me fez comentar que já estávamos chegando ao fim da entrevista, ao que ele respondeu em tom sincero: 'Não tem pressa'."
} 
Outro aspecto que pode ser tido como sinal do tipo JUDICATIVO é a dificuldade declarada por Evandro de se despir do "núcleo" de juiz:

(...) Naturalmente que, no dia a dia, na vida cotidiana, ... eu posso me liberar da formalidade, da roupa, da gravata e tudo, mas o núcleo, o... esse, esse eu não troco com a roupa. Não, não. O juiz em todo o momento, o núcleo, os valores, isso... são muito densos, assim, para... para que eles sejam relativizados de acordo com o... o espaço e o tempo.

É claro que este último ponto pode ser explorado a partir de perspectivas muito mais complexas, que fogem seja dos limites deste trabalho, seja da alçada deste pesquisador. Mas não deixa de ser pertinente a proximidade entre o perfil JUDICATIVO e a "persona do juiz”, particularmente no que tange à aceitação, elaboração e ao cumprimento de regras.

O seguinte trecho da fala de Evandro merece um comentário à parte, pela dúvida que possa suscitar em nosso leitor. Quando ele diz - "E acho assim: o juiz, ele só deve se pronunciar (...) quando efetivamente já não tem mais condição, não tem mais probabilidade de compor as pessoas, as partes" -, parece aproximar-se da postura que vimos em Eustáquio. No entanto, enxergamos grandes diferenças entre ambos os estilos, até mesmo a ponto de sugerir tratar-se de "opostos" no ponto ora tratado (J ou P).

Se ambos prestigiam a resolução do processo por meio da conciliação, como que "evitando", com isso, ter de "decidir", parece-nos que Evandro o faz acima de tudo visando à efetiva pacificação das partes, o que apenas é possível dando a elas espaço suficiente (mínimo de 30 minutos, em casos menos complexos, ou até 8 horas, nos mais complicados) para que tragam à luz, naturalmente, as verdadeiras razões do conflito. Se o acordo não se produzir, ele decide, e isso não parece lhe causar grande angústia.

Já no caso de Eustáquio, parece haver um certo "inconformismo" por parte do magistrado em não alcançar o acordo. Dizemos isso por conta da imensa quantidade de energia que ele investe nesse sentido, inclusive expondo-se exageradamente, de modo que o acordo deixa de ser sinônimo de "pacificação" dos litigantes para ser, antes, uma forma de resolução do processo sem tomada de decisão por parte do juiz. 
A hipótese de estarmos diante de um INTROVERTIDO JUDICATIVO configura o seguinte cenário: sendo Evandro JUDICATIVO, isso equivale a dizer que ele extroverte por meio de uma função racional (T ou F), e, ainda, que sua função principal é do tipo irracional (S ou N). Tal perspectiva, que coloca PENSAMENTO e SENTIMENTO no eixo das funções auxiliares, parece-nos bastante coerente com a impressão que ele nos passa, uma vez que as características de ambas estas funções apresentam considerável visibilidade em sua personalidade, afastando a ideia de que uma delas seja sua função principal e a outra a inferior. Falando em função principal, qual seria, a nosso ver, a de Evandro?

Se partirmos da premissa de que um INTUITIVO está propenso a enxergar tendências de uma situação (seu tempo, portanto, é o futuro), em detrimento dos detalhes, enquanto o tipo SENSORIAL observa os detalhes (seu tempo é o presente), aos quais dá enorme importância, estaremos inclinados a dizer que Evandro pertence mesmo é ao segundo tipo. Nesse aspecto, aliás, impressiona o grau de percepção sensorial que ele põe em campo na condução de um processo:

A audiência da autocomposição tem sido por mim, ... valorizada a todo instante. Por quê? Porque ela não se presta tão-somente para a busca da autocomposição. A busca da autocomposição é um dos objetivos [frisou "um dos objetivos"]. Por quê? Porque se não se alcançada a autocomposição, o juiz teve oportunidade de perceber o perfil de cada uma das partes litigantes e dos seus patronos [frisou "patronos"]. Porque o processo, com a frieza das suas letrinhas impressas, é completamente diverso da manifestação, ao vivo e em cores, das partes envolvidas. Porque ali elas se soltam. Por isso que, quanto mais tempo possa dar o juiz, quanto mais $l i$ berdade, quanto mais abertura ele possa dar, maiores são as probabilidades de o juiz aferir, sentir as pessoas, os seus jurisdicionados. Por isso ela é de uma importância muito grande [frisou "muito"]. Elas, partes, muitas vezes, elas convencem os juízes, de um modo melhor até mesmo, com o meu máximo respeito, que os seus próprios patronos... porque elas, angustiadas, elas revelam a sua angústia abertamente. E outra: muitas vezes não é com as palavras: é com seus olhos, é com seus músculos, é com seu... corpo. Eu li, ... recentemente, que na comunicação as palavras são responsáveis apenas por $7 \%$ da comunicação. O outro percentual está no tom da fala... está na expressão corporal: na minha perna, no meu pé, no meu semblante, no braço, o ângulo do meu braço... tem uma significância - o ângulo! E tu- 
do isso aí... - eu não sou bobo nem nada, ... eu já li o livro do PIERRE WEIL -, tudo isso aí eu estou lendo na audiência. E muita vez, a pessoa, que está ali, não tem a mínima desconfiança que eu a esteja avaliando. Então, para resumir: a importância da audiência é, a meu ver, extraordinária [frisou "extraordinária”] (...) se é conflito entre duas pessoas naturais, é sempre importante ouvi-las, senti-las, em audiência.

Ou seja: havendo conflito entre duas ou mais pessoas naturais ${ }^{\mathbf{4 3 2}}$, Evandro sequer as consulta a respeito do interesse em conciliar, até porque, conforme revela, a audiência conciliatória não será designada apenas para buscar a autocomposição. Servirá para trazer as partes - bem como seus patronos - à presença do magistrado que, além de já ter lido as letrinhas impressas dos autos, terá oportunidade de vê-los, ouvi-los e, provavelmente, até cheirá-los se necessário for, em autêntico trabalho de investigação, no qual cada "detalhe" tem importância na formação do mosaico de informações de que sente necessidade nosso juiz para firmar seu convencimento. Essa habilidade em perceber detalhes, que, além de parecer natural, vem sendo aprimorada ao longo do tempo (“... não sou bobo nem nada, ... eu já li o livro do Pierre Weil”), é sinal considerável do predomínio, em sua psique, da função SENSAÇÃO.

\section{A respeito do tipo SENSAÇÃO INTROVERTIDO, escreve Von Franz:}

Nunca esquecerei o depoimento dado pela $\mathrm{Sr}^{\mathrm{a}}{ }^{\mathrm{a}} \mathrm{Jung}$. Somente após tê-la ouvido é que senti haver entendido o tipo perceptivo introvertido. Fazendo a descrição de si mesma, ela disse que o tipo perceptivo introvertido era como uma chapa fotográfica, altamente sensível. Esse tipo, quando alguém entra numa sala, percebe o modo como a pessoa entra, o cabelo, a expressão do rosto, as roupas e a maneira de caminhar. Tudo isso dá uma impressão muito precisa do tipo perceptivo introvertido; cada detalhe é absorvido. A impressão vem do objeto para o sujeito; é como se uma pedra caísse em águas profundas - a impressão cai mais fundo, mais fundo, e afunda. Por fora, esse tipo mostra-se totalmente estúpido. Ele apenas senta e olha, e não se sabe o que está acontecendo dentro dele. Fica parecido com um pedaço de madeira, sem nenhuma reação - a não ser que reaja através de uma das funções auxili-

${ }^{432}$ A expressão "pessoa natural” opõe-se a "pessoa jurídica”. 
ares: pensamento ou sentimento. Porém, interiormente, a impressão está sendo absorvida. ${ }^{433}$

É evidente que o exercício da percepção sensorial com tanta acuidade exige que a audiência dure um tempo mínimo, necessário não apenas para que o juiz perceba as partes e seus advogados, mas também para que estes se revelem com mais autenticidade, livres da adrenalina inicial. Para Evandro, esse tempo mínimo é de meia hora; menos que isso reputa "um ato de faz-de-conta". Essa quase obsessão de Evandro em ter contato com as partes induziu-nos a pensar ser ele um EXTROVERTIDO, quando, na verdade, análise mais cuidadosa revelou tratar-se de efeito da função SENSAÇÃO, de tentativa de "reunir os fragmentos, ... os cacos que as partes lhe oferecem", às vezes sem ter "a mínima desconfiança” disso.

Na designação das audiências conciliatórias, parece predominar, portanto, um aspecto "prático", típico da função SENSAÇÃO, dela podendo-se dizer, ainda, que guiada, no caso de Evandro, mais pelo PENSAMENTO que pelo SENTIMENTO. Sim, porque nosso magistrado parte de algumas premissas:

(a) o conflito narrado nos autos não passa de uma "ponta de iceberg";

(b) as verdadeiras razões do conflito subjazem não reveladas;

(c) é possível descobrir as verdadeiras razões caso se investigue;

(d) a investigação pode ser feita por meio de um contato direto com as partes, ou seja, da audiência conciliatória.

Parece haver, portanto, na designação dessas audiências acima de tudo o cumprimento de um ritual necessário à boa solução do caso, cuja “chave” parece ser dada pela “informação" faltante, a ponto de suscitar uma postura investigativa por parte do magistrado. Embora a função SENTIMENTO se faça perceber, não arriscaríamos dizer que prevalece sobre o PENSAMENTO, por conta do considerável grau de objetividade que acreditamos estar sempre presente na ação de Evandro:

${ }^{433}$ Op. cit., pp. $46 / 47$. 
(...) se tiver ... disputa, dúvida, relativamente às condições da ação, enfim, eu resolvo para poder aumentar, digamos assim, as probabilidades de autocomposição. (...) Ou seja, eu só decido, então, se a questão for de legitimidade... Porque, inclusive, se eu afasto C, é só o B que eu tenho para trabalhar com A, e não os três.

Interessante notar, por outro lado, o quanto Evandro procura valer-se das quatro funções, personificando o que seria a atuação ideal não só de um magistrado, mas de todo ser humano em suas relações com o mundo e as pessoas.

Revela, por exemplo, que tenta intuir as verdadeiras razões do conflito (“... quando leio o processo, eu procuro intuir qual será efetivamente o problema [frisou "efetivamente"]"). A INTUIÇÃO é uma luz cuja fonte está no inconsciente; segundo Jung, é "um tipo de percepção que não passa exatamente pelos sentidos" ${ }^{\mathbf{4 3 4}}$. No entanto, a despeito de também recorrer a ela, a grande força de Evandro parece estar na função oposta, que funciona como um farol bem maior, cujo facho luminoso se projeta para fora, no mundo concreto, e vasculha em cada beco tudo o que está apto a ser apreendido pelos sentidos. É uma busca ampla e irrestrita pelo "detalhe não-revelado", cuja descoberta, ou não, selará a sorte do processo.

Da mesma forma, Evandro procura valer-se do SENTIMENTO (“... maiores são as probabilidades de o juiz aferir, sentir as pessoas, os seus jurisdicionados"), embora notemos que essa função auxiliar, assim como o PENSAMENTO, pareça caminhar a reboque da principal.

Assumimos, portanto, a hipótese de que a SENSAÇÃO lidera o grupo, uma vez que se dá prioridade à coleta de dados - tomados em detalhes mínimos -, feita de maneira bastante objetiva (PENSAMENTO), não se deixando de avaliar a postura das partes e de seus advogados (SENTIMENTO).

A mesma atenção ao detalhe pode ser vista na análise que Evandro faz da petição inicial. É acuradíssima e, como bom INTROVERTIDO que é, cada detalhe percebido por nosso magistrado estará repleto de significados:

${ }^{434}$ Fundamentos de Psicologia Analítica (CW XVIII/1), "Primeira Conferência", p. 11, § 26. 
Ah, exatamente todos esses pontos são por mim examinados. Ah... veja bem. A $a$ presentação, tamanho da fonte, ... o espaçamento, a limpeza, a linguagem [frisou "linguagem"] - importantíssima: se é prolixa, se não é prolixa, se é afetada, se não é afetada, se é... antiga ou se é contemporânea... (...) Então, devo lhe dizer: a petição inicial reclama um cuidado muito grande.

A predominância do mundo interno (subjetivo) sobre o externo (objetivo), tão clara em seu discurso, demonstra a natureza INTROVERTIDA da função SENSAÇÃO. Em determinado momento, isso parece beirar o radicalismo, conforme se constata no posicionamento expresso a respeito do fenômeno da "mentira":

(...) "verdade" ou "mentira" são conceitos não matemáticos! Eu acredito... que... os fatos da vida não são suscetíveis de apreensão pelos sentidos humanos. Isso é um engano [frisou "engano"].

Além do quadro montado por Evandro, um olhar de natureza objetiva, próprio de um EXTROVERTIDO, revelaria outro cenário, no qual algumas pessoas teriam, sim, maior consciência de que mentem, com maior chance de se achar que o fazem deliberadamente para tentar sobrepor seus interesses aos da parte adversa. A respeito do eventual radicalismo da SENSAÇÃO INTROVERTIDA, Jung comenta:

\begin{abstract}
Nos casos normais, o objeto jamais é desvalorizado conscientemente, mas é privado de sua atração ao ser imediatamente substituído por uma reação subjetiva que já não se refere à realidade do objeto. Isto naturalmente opera como desvalorização do objeto. A um tipo desses podemos facilmente perguntar: por que afinal existimos, o que justifica a existência dos objetos, já que tudo de essencial acontece sem o objeto? Essa pergunta pode ser válida nos casos extremos, não nos casos normais, pois o estímulo é indispensável à sensação, apenas produz algo diferente do que a situação externa faria supor. ${ }^{435}$
\end{abstract}

Há, portanto, uma tendência natural da SENSAÇÃO INTROVERTIDA de, inconscientemente, desvalorizar o objeto. $\mathrm{O}$ problema surge quando isso alcança um grau em que

${ }^{435}$ Tipos ..., p. 373, § 721. 
a existência do mesmo chega a ser negada. Tal extremo não vem, porém, a ser protagonizado por nosso magistrado, que admite "dar corda" à testemunha cujo depoimento lhe pareça inconsistente, levando tudo em consideração no momento de proferir sentença, mesmo que não o declare, a não ser que seja algo "escancarado".

Na ausência de evidências, o que ele não se permite é presumir "que ela esteja mentindo". Portanto, evita expor-se desnecessariamente - e também à testemunha, o que, além de temerário, geraria desgaste inútil, sem qualquer acréscimo à equação formada pelos interesses que compõem o processo. A nosso ver, isso revela o grande equilíbrio alcançado por Evandro no desenvolvimento de sua personalidade.

Em outro excerto da entrevista, cremos vislumbrar o modo SENSAÇÃO INTROVERTIDA de atuar, com participação das funções auxiliares. Fazemos referência ao procedimento sui generis adotado por Evandro, que, "em alguns casos", ao receber a petição inicial, determina a intimação das partes a comparecer em juízo, evitando, contudo, a entrega da contrafée (36 $^{\mathbf{3 6}}$ ao réu. Faz isso em nome da preservação das pessoas envolvidas, uma vez que as petições iniciais costumam trazer expressões bastante "ácidas". Isso apontaria para a função SENTIMENTO. No entanto, mais uma vez preferimos vê-la constelada numa consciência cuja preocupação maior está em não prejudicar o cenário adequado ao esforço conciliatório ${ }^{437}$ (pragmatismo próprio da função SENSAÇÃO, em que há grande valorização do resultado), mesmo porque o procedimento adotado por ele pode gerar algum desconforto para o réu e seu patrono. Afinal, toda essa originalidade desafia a letra do código de processo civil (podemos ver nisso traços do estilo PERCEPTIVO, ao mesmo tempo em que de INTROVERSÃO, em virtude da subjetividade), o que tende a gerar insegurança nos integrantes do polo passivo, como o medo da "perda de prazo" para oferecimento de defesa e coisas do gênero.

Tal iniciativa dificilmente seria sustentada por nosso magistrado não fosse a consistência e clareza de seu arrazoado, no sentido de justificar-lhe a validade (vê-se aí a força da função PENSAMENTO, embora também a serviço dos valores constelados pela função SENSAÇÃO). Evandro, portanto, faz valer o princípio “dos males, o menor”.

\footnotetext{
${ }^{436}$ Ver "contrafé" no "glossário jurídico".

${ }^{437}$ Diz ele: "Só que, muita vez, a leitura desta petição inicial vai dificultar imensamente a resolução do conflito entre essas pessoas. Então, eu mando convocar sem cópia da petição inicial."
} 
A mesma preocupação com os ataques de uma parte a outra, atentando contra a meta maior da jurisdição, que é "pacificá-las" de para tréplica:

É no máximo a réplica. Agora, é muito interessante a pergunta pelo seguinte: porque muita vez, muita vez, nem a réplica eu concedo. E por quê? ... Para a nossa tristeza, ocorre, alguma vez, de as partes empregarem, em seus arrazoados e em suas petições, expressões muito ácidas. Se eu perceber - por isso é importante a leitura do processo, sempre, em todas as suas partes - se eu perceber que a contestação, resposta, enfim... traz acusações muito graves, eu... como num diálogo, se eu der a palavra, vai vir outro ataque! Então eu já, imediatamente, eu chamo as pessoas. Eu não permito o ataque.

Portanto, fica muito claro o posicionamento de Evandro enquanto magistrado: sua função, ou melhor, missão não consiste tanto em julgar o processo, dizendo quem tem razão. Aliás, não parece estar tão preocupado com isso. Julgar, em seu caso, parece ser o resultado de um esforço que não deu certo; é uma espécie de atestado de falha do "sistema judicial" quanto ao desígnio maior da pacificação. Isso fica patente quando fala de sua predileção pelas áreas em que tal atuação é possível e, em contrapartida, pelo desprazer que sente em face da jurisdição criminal, onde "nada se resolve":

Um acordo judicial ... no campo da família... um filho ou uma filha, outro dia, que eu vi, a filha que entrou aqui não falava com o pai há um bocado de tempo... a comunicação estava truncada... E depois o pai chora em audiência, estende a mão... e ela também chora e saem abraçados... Esse dia, para mim, é um gozo, é um gozo, é um gozo! Porque eu fui instrumento daquele ato, um pequeno instrumento. Então, veja bem, eu tive oportunidade de, no exercício da minha profissão, não que eu tenha resolvido o conflito mas, a partir daquele instante, as probabilidades de o con-

\footnotetext{
${ }^{438}$ Lê-se no despacho por ele proferido (v. acima): "Aí, no exercício de seu dever ético de pacificação social, o juízo procurará a solução autocompositiva da demanda, subtraindo, tanto quanto possível, eventuais obstáculos existentes no caminho da concórdia". A viva consciência de Evandro quanto a esse mister ético, de pacificação social, é corroborada pelo que ele declarou em entrevista: “(...) o Estado não cumpriu sua promessa constitucional de, como contrapartida ao monopólio da jurisdição, 'oferecer a solução de conflitos intersubjetivos das pessoas'. Nesse sentido, diz assistir diariamente a um quadro de 'incompetência tamanha [frisou], (...) uma das razões inclusive, de... por que não dizer, devo ser franco, de uma certa frustração'."
} 
flito se resolver aumentam. Não havia probabilidade nenhuma, estava trancado. Agora, no crime... o que é que se vai resolver? Absolutamente nada. Absolutamente nada.

De fato, numa área em que a "pacificação social” dá lugar à retribuição da dor pela dor, não parece haver muito espaço para exercício de um sacerdócio: o espaço para "pacificar" cede aí seu lugar ao dever de "punir". O sofrimento de Evandro diante disso mostra, mais uma vez, o efeito da atitude INTROVERTIDA em sua maneira de ver o mundo.

Dando desfecho à argumentação relativa ao predomínio da função SENSAÇÃO, temos o depoimento de nosso próprio entrevistado, que vê sua "realização como pessoa humana" no ato de "resolver os problemas das pessoas".

Quanto à posição ocupada pelas funções auxiliares, já adiantamos a opinião de que, em nosso entender, prevaleceria o PENSAMENTO sobre o SENTIMENTO. Quando diz "Eu não permito o ataque" -, a postura de Evandro assemelha-se à de Mirtes. A proximidade chega a ser "literal". No entanto, não deixa de haver uma sutil diferença na qualidade da preocupação de ambos em preservar as partes, notando-se um aspecto mais pessoal na fala daquela magistrada, que traz em tons mais fortes as cores típicas da função SENTIMENTO:

E não permito nunca [com ênfase] que a parte destrate o outro advogado. (...) não dá para admitir que o advogado da outra parte seja destratado. Isso é inadmissível. Porque ele não é inimigo. Ele está assessorando, aí paro, explico. Não pode. E o advogado também pegar as dores e xingar a outra parte, ou ser indelicado com a outra parte, aí falo: "Doutor, não faça, é injusto... é outro patamar... o senhor pode conversar tecnicamente com o outro advogado, litigar... colocar os pontos... mas não pode... essa ofensa, assim... é muito”. (...) Aí eu falo assim para as partes... para os advogados: "Eles [as partes] têm motivo para estarem magoados, não os advogados. É a parte técnica. A gente veio aqui para resolver a parte técnica”.

Em Evandro, que não deixa de ser pessoa bastante amável, as características do PENSAMENTO parecem refletir mais o "brilho do sol", ou seja, ocupam mais o espaço externo da psique, representado pela consciência, do que os aspectos do "coração". A gen- 
tileza que se depreende, por exemplo, do despacho acima citado não deixa de ser sincera, mas, ao mesmo tempo, parece ter passado pelo crivo do raciocínio. A afetuosidade da função PENSAMENTO vem revestida de "bons modos", numa roupagem de "pessoa educada", cordial; já a afetuosidade da função SENTIMENTO (EXTROVERTIDO) emana puro "calor humano", ou seja, é quente. A título de metáfora, se compararmos o fluxo de afetividade ao elemento água, poderíamos dizer que num tipo em que predomina a função PENSAMENTO, ele flui dentro dos limites e contornos de um cano, enquanto num tipo mais SENTIMENTAL, principalmente quando EXTROVERTIDO, equipara-se ao jorro de uma cachoeira.

Do mesmo modo, demonstra a força do PENSAMENTO de Evandro a articulação lógico-sistemática de seu discurso, que percorre com facilidade conceitos abstratos, alguns deles imantados de pura Filosofia. Nos seguintes trechos, ficam evidenciadas também a clareza e a capacidade discriminatória de seu raciocínio:

- Eu tenho, assim, algumas críticas... não propriamente ao judiciário, mas é algo que eu... culminei por enxergar, que é algo maior, que é o sistema judicial. Se nós... afirmarmos "o judiciário", é como se nós pudéssemos excluir outras instituições importantes que compõem o sistema, como, por exemplo: o ministério público, a advocacia, a defensoria, a procuradoria, o poder legislativo, então, o sistema é muito grande.

- Veja bem, na audiência... há mais de um tipo de audiência: a audiência da colheita de prova oral [chamada audiência instrutória], como há a audiência para se buscar a composição das partes [chamada audiência conciliatória]. No que diz respeito à colheita de prova oral, eu estou de acordo com o que disseram meus colegas fluminenses (...) o juiz... é como se partisse de um pressuposto, qual seja, o de que a testemunha está faltando com a verdade. Por isso, ... não costumo, digamos, valorizar demais a prova testemunhal.

No entanto, as qualidades que ressaltamos estão presentes em todo seu discurso, que é de uma coerência irretocável, valendo destacar, outrossim, a parte em que Evandro explica a necessidade de resolver, antes da audiência conciliatória, questões que a experiência revelou serem prejudiciais a eventual acordo, como a da legitimidade das partes. 
Também nos parece típica da função PENSAMENTO a facilidade de encontrar respostas no ordenamento jurídico às questões levadas a juízo, e de fazê-lo sem grande desconforto:

Eu não me lembro... de ter enfrentado jamais a situação de não ter encontrado no ordenamento. Por quê? Porque eu entendo que o ordenamento oferece condições de solução para tudo.

Outro momento em que as funções auxiliares parecem atuar sobre um mesmo ponto, mas cada uma a seu tempo, é o da apreciação de situação em que uma das partes encontra-se mal representada no processo. Evandro respondeu experimentar uma tendência “... indomável de ... equilibrar os pratinhos da balança. ... Inclusive porque, veja bem, eu penso que isso não seja... não seja ... tampouco irregular. Porque... é necessário, aliás, 'necessaríssimo'.”

Quando fala em tendência “indomável”, podemos pensar na atuação da função SENTIMENTO, que, por ser terciária, está mais inconsciente. Em seguida, porém, ele traz fundamentos objetivos para seu entendimento, num esforço que parece ficar a cargo do PENSAMENTO, o que se diz por conta da clareza própria de quem se nutre da luz da consciência. Ao final, não deixa de mencionar que o ordenamento jurídico mesmo prevê mecanismos de equiparação (“... o juiz, por meio de mecanismos já previstos na ordem normativa ..."), e que esta tem, na verdade, caráter processual.

O senso de alteridade, característico também da função SENTIMENTO, está na base de sua receptividade aos advogados:

Recebo sempre (...) eu já fui advogado, Dr. Antoin, e... e... e eu sempre via como uma ofensa [frisou "ofensa"] o juiz não querer me receber.

Limites, porém, se mostram necessários - "É claro que precisa também de um... digamos assim, ... saber direitinho, não pode ser uma coisa, assim, escancarada, mas é importante" -, revelando o "tempero" que sempre fica cargo do PENSAMENTO.

Por fim, quando indagado a respeito da relevância de jurisprudência e doutrina em seu trabalho, Evandro relativizou-a. Reconheceu a ambas como "faróis". Importantes, sem 
dúvida, mas que não são tudo. Disse que acima delas deve sempre estar o raciocínio do juiz, cujo pensamento não se pode deixar "embotar". Tomamos mais este ponto como sinal da presença diferenciada da função PENSAMENTO em sua personalidade.

Poderíamos fazer uma análise exaustiva dos inúmeros outros indícios que nos levam a postular o PENSAMENTO como função auxiliar de Evandro. No entanto, ficaremos restritos à suposta suficiência do acima exposto.

Conforme já dito antes, ao responder ao questionário de aferição de tipo, Evandro nos auxiliou a perceber os aspectos acima destacados.

\section{Tipo aferido: I $\underline{\mathbf{S}}$ T J - Atitude INTROVERTIDA; $\underline{\text { SENSACÃ̃ }}$ como função superi- or e PENSAMENTO como função auxiliar.}

Segundo Kroeger e Thuesen, o tipo ISTJ talvez seja o que mais se deixe conduzir pelo senso de responsabilidade dentre os 16 tipos postulados. Em nome daquilo que "deve ser feito", é capaz de assumir características típicas de um EXTROVERTIDO, a ponto de se fazer passar por um, ou mesmo de adotar uma conduta mais gentil do que seria típico de alguém em que o PENSAMENTO se sobrepõe ao SENTIMENTO. ${ }^{439}$ Quando escreve a respeito dos indivíduos que operam segundo esse tipo, Myers destaca que alguns deles às vezes desenvolvem de forma marcante a terceira função (SENTIMENTO), para uso nos relacionamentos humanos, principalmente com seus amigos mais íntimos. ${ }^{440}$ Evandro parece tê-lo feito em relação aos jurisdicionados.

${ }^{439}$ KROEGER, Otto e THUESEN, Janet M. Op. cit., p. 215.

${ }^{440}$ Gifts Differing ..., p. 104. 


\title{
7. ENTREVISTA COM "ÉMERSON"
}

\begin{abstract}
- A cada decisão, (...) se eu posso falar de ética, eu falo. (...) não tenho interesse de fazer curso de processo e não sei o $q u e$, mas... Ética, Filosofia, estou continuamente lendo. Para absorver, e ver se eu compreendo esse momento. Eu sou parte dele mas, às vezes, eu me sinto muito excluído... que eu sou do passado...

- Ou do futuro!

- Ou do futuro...
\end{abstract}

Émerson é desembargador do Tribunal de Justiça do Estado de São Paulo. Juiz de carreira, contabiliza já mais tempo dentro do que fora do judiciário. Faltando pouco para aposentar-se, podemos dizer que é daqueles raros magistrados que deixarão atrás de si muito mais do que sentenças e acórdãos. Portador de uma mente brilhante, nosso entrevistado impressiona pela isenção de seu juízo crítico, do qual não poupa nem a si mesmo.

As respostas que Émerson deu às perguntas que lhe apresentei foram ao mesmo tempo bastante extensas e ricas, permitindo um bom acesso não apenas a traços de sua personalidade como também a seu pensamento. A fim de não perdermos esse conteúdo, reputei conveniente manter sua fala quase na íntegra.

Ainda adolescente, nosso entrevistado pensara em ser médico. Afirmou que, à épo$\mathrm{ca}^{441}$, percebia que a carreira jurídica "já era uma carreira um pouco desgastada: havia excesso de advogados, a advocacia não era uma... uma profissão muito bem vista, né?". E prossegue:

Havia sempre, assim, uma... uma espécie de desconfiança quanto à lisura, quanto à ética, quanto ao bom proceder do advogado, que parecia alguém que prevaleceria da desgraça alheia para ou prolongar a lide, ou obter vantagens, ou impedir acordos, etc. e tal. Eu já tinha intuitivamente essa... esse conceito. Eu queria ser médico. Mas eu, eu tinha uma dificuldade muito grande com... com sangue, com coisas assim. Em aulas de medicina le-

${ }^{441}$ Década de 1960. 
gal, depois, eu vim a comprovar... Ficava muito impressionado, eu era muito sensível com questão de sangue.

Se, por um lado, a aversão à ideia de ter de lidar com sangue manteve-o afastado da Medicina, por outro o gosto por disciplinas como História, Português e Literatura impulsionava-o a optar por alguma profissão humanística. Foi incentivado a fazer Direito, sob o argumento de que não precisaria ser como os outros. Diziam-lhe:

“Todo lugar tem gente com sinal positivo e sinal pos... negativo". Aí, eu fui fazer Direito e... de certa forma, eu me apaixonei pelo Direito. (...) no meu tempo era $\mathrm{Ci}$ ências Jurídicas e Sociais. Eu gostei mais da "Sociais" do que da "Jurídicas”. (...) Gostei de História do Direito, de Direito Romano, de tudo o que era assim... as origens, a... eu ficava muito embevecido, né? $\mathrm{E}$, ao mesmo tempo, eu verifiquei que o treino da linguagem, o treino do uso da palavra me permitiria... viajar, né, expondo meu pensamento, escrevendo mais, lendo mais. Eu fiquei muito contente. Eu quase que enveredei para a política... na minha cidade (...) ... porque eu trabalhava com um prefeito que era meu amigo. Logo no final do curso (...) ele queria que eu fosse sucessor dele, etc.. Mas eu comecei a ver que a política é uma coisa muito incerta, que você tem que ficar agradando e... e fazendo conchavos, e traindo a sua convicção, e não sendo franco... Aí eu falei: "Não dá." Aí eu fui fazer concurso... quase que por acaso, no final da gestão, para o ministério público. Fiz... quase não fiz! Um amigo que... nós estávamos numa inauguração de fim de... administração, e ele falou:

- É hoje o seu concurso. Você não vai fazer? Você está aqui ainda, né?

Eram onze horas da manhã e o concurso era a uma hora. Eu falei:

- Não, eu acho que não vou... Nem me preparei, nem estudei nem nada...

- Não, você vai, você vai, você vai, eu vou com você!

Olha que coisa... providencial. Eu vim, fiz, caiu alguma coisa que eu... pude desenvolver. Naquele tempo não havia limite de espaço para você escrever. Então, eu praticamente fiz dissertações de tudo. Até acho que eu contribuí para reduzir o... conteúdo [refere-se à adoção de limite de espaço para respostas em concursos posteriores]. (...) Fiquei todas as horas e minutos para entregar a prova. Coloquei tudo o que eu achava. E passei no... escrito. E daí, passei no escrito e fui para o oral, entrei no oral e... me apaixonei pela, pelo ministério público. Fiquei muito contente. Fui (...) anos promotor, fui muito feliz... Mas daí eu cheguei numa comarca em que 
eu vi que o promotor sozinho ele... ele, ele dificilmente consegue fazer justiça se ele encontra um juiz ruim, né? E... meu juiz era doente, era... tanto que veio, depois de tirar vários promotores da carreira, porque ninguém aguentava ele, ele foi colocado em disponibilidade, mas eu, por, por... uma decepção, assim, dentro do ministério público, porque eu queria fazer um movimento para tirar esse juiz da magistratura, fui impedido pelo Procurador Geral, que... ele era um moço influente, o juiz... afilhado do Procurador Geral... esse tipo de coisa. Pois eu, muito irascível pela altura, assim, dentro do possível, muito apaixonado, muito idealista... falei: "Eu vou sair!" E fui fazer concurso para a magistratura... mais por... birra. E depois... eu fui passando. E... em lugar de o ministério público me segurar... quando você... no meu tempo, pelo menos, quando você... tenta sair do ministério público, você é considerado uma... ofensa grave. Então, as pessoas começaram a me evitar, e começaram me hostilizar, sabe? Mesmo porque eu tinha ido substituir um promotor que já havia saído do ministério público para entrar na magistratura e o Procurador Geral me falava:

- Você não se aproxime muito do Doutor Fulano de Tal, ele é um "transfole", que trocou a instituição por um prato de lentilhas.

E eu acabei ficando... muito amigo dele, quase irmão, amigo de infância. (...) Nós ficamos muito ligados. Bom, fui prestar concurso... eles me hostilizando... Porque eu... eu acreditei que, quando eu fosse prestar concurso, o ministério público todo viesse falar assim:

- Não, Doutor, não saia... o promotor... que ele é um apaixonado, você vestiu a camisa, não é?...

Mas foi ao contrário. Eles foram me hostilizando, me hostilizando... e eu fui passando nas fases. E quando eu cheguei à magistratura, eu fui muito bem recebido. $A$ banca, não é?... era uma banca... de cavalheiros, de desembargadores educadíssimos! (...) Passei... podia ter passado até melhor, passei em (...) lugar [colocação extraordinária], porque não... não estava apaixonado: eu estava muito triste, estava muito... angustiado. Quando eu tomei posse... no dia da posse... não havia escola da magistratura, havia só, depois da posse solene... os convidados iam embora... um juiz, assessor da corregedoria geral fazia uma preleção de... o que nos esperaria. E era um juiz, assim, extremamente competente, mas muito técnico, muito... muito erudito, muito pernóstico, e ele começou a falar da responsabilidade do juiz... e eu comecei... a ter um arrependimento muito grande, assim: "O que é que eu estou fazendo aqui?!" Saindo de uma instituição, que naquela altura, né, eu entrei no ministério público em (...) [há mais de 20 anos]... Nós estávamos procurando um cami- 
nho para nos tornarmos uma instituição respeitada, consolidada, né? Porque era um absurdo lógico o ministério público: tinha que ser "advogado sem paixão"; tinha que ser "juiz apaixonado". (...) E... eu comecei a ficar irritado, irritado... no meio da palestra eu saí. E fui ao gabinete do presidente, falar com os juízes auxiliares, que eu queria tornar sem efeito a minha posse. Aliás, não sei se isso é indício de insegurança... ou de temeridade... ou de inconsequência... E aí o juiz auxiliar... ficou assustadíssimo e falou:

- Só um minutinho, um minutinho só - e entrou para falar como o presidente, e o presidente me chamou.

E... eu já estava com vergonha a essa altura, né? E eu falei:

- Não, eu não quero falar com o presidente.

Aí ele me mandou sentar, serviu café. E falou:

- Mas doutor, a magistratura tem tanta esperança no senhor... Por que o senhor vai...

- Ah, eu prefiro continuar a ser um promotor... razoável, mais convencido, do que um juiz sem vocação...

Eu vim mais por... como um gesto, assim, un beau geste, achando que eles não iriam me segurar, mas me seguraram:

- Não, mas o senhor fique, a magistratura recebeu o senhor de braços abertos... Olha... fique, tente, dê essa chance para o senhor. Nunca houve caso de juiz saindo para ser promotor. Se o senhor não gostar da magistratura, o senhor vai e eles vão receber o senhor com todas as honras e... vai ser um caso excepcional. Mas o senhor tem que se dar essa chance! Se o senhor prestou concurso era porque o senhor queria... e tal e tal... E... o senhor tem mais um tempinho?

Eu falei:

- Ah... claro! - Sabe, envergonhado por fazer o presidente do tribunal... Tomar tempo com um sujeito que tinha tomado posse fazia alguns minutos... Aí ele me põe um outro juiz... que é muito famoso... (...) e falou:

- Carlos, segura esse moço aí! Ele não está querendo ficar...

Aí o Carlos começou a me mostrar, a percorrer tod... Aí, o tribunal inteiro já sabia (...) que eu queria sair. Aí foi aquela coisa toda. Eu entrava naquela sala, e aquelas senhoras velhinhas:

- Estou rezando pelo senhor! Eu vou ser sua madrinha... Fica Doutor!

E eu comecei a fazer uma promessa para mim mesmo, e falei: "Eu vou ficar... que vergonha, né! Desculpe o mico (se falava isso à época)... mas eu não vou voltar aqui durante dois anos" - o tempo da vitaliciedade... - de vergonha. E eu fui, e fi- 
quei, e estou aqui até hoje. Então... não que... Se eu tivesse... se eu olhasse, assim, em termos de carreira, se eu tivesse ficado no ministério público, minha carreira teria sido mais... mais espetacular, assim, pela... pela liberdade, pela desenvoltura que o ministério público tem. Meus colegas... [citou o nome de inúmeros colegas, cujas carreiras se projetaram inclusive para fora da instituição]... e eu me inclinaria, com certeza, para essa atividade... mais humana. Acho que a magistratura, pelo menos quando eu entrei, ela era muito... ela blindava você. Você tem que ficar muito... recolhido... e... e isso... me... me inibiu, em algumas coisas. E... mas nunca fiquei muito preocupado com isso pela segurança de... Eu sabia... fiz dois concursos... dois concursos relativamente árduos e... sabia que se eu tivesse que fazer outro eu faria, sem receio. Então, eu nunca permaneci atado ao que se espera... daquele "juiz paulista". Há uma frase: "Juiz paulista não dá entrevista”, não fala... ele só fala nos autos. E isso ainda hoje é repetido! Então, o juiz que... que se comunica, ou que está receptivo, ele tem uma... uma resistência, tipo... muito "polifacetada" ou "polifacética"... sei lá. Primeiro, argumenta-se com a lei... que a lei orgânica da magistratura proíbe o juiz de falar... Depois, é a vulnerabilidade, o juiz fica vulnerável, porque, se ele fala, ele fica preso à... à opinião emitida... não, é? Terceiro, ele se expõe a ser contestado e "não é interessante que uma expressão da soberania estatal venha ser contestada”... Então, são visões... para chegar num campo, assim, bem trivial: "o juiz quer aparecer, é exibido, quer fazer carreira solo, se considera melhor que os outros...” Então tem, e há muitas, muitos argumentos para fazer com que o juiz seja... um ser... naturalmente comedido, discreto, reservado... como se isso... o liberasse de ter os conflitos pessoais, que ele tem, em cada processo. Ele não é um autômato, um robô.

Quando indagado a respeito de sua visão do poder judiciário, Émerson iniciou tecendo um amplo quadro panorâmico:

Olha, o judiciário como instituição, ele... ele não se conhece. E é muito difícil você fazer um diagnóstico numa... num... num Estado como o brasileiro... que é uma... um campo para uma pesquisa antropológica muito interessante, porque convivem, num mesmo espaço físico, ilhas pré-históricas, pré-medievais, medievais, modernas, pós-modernas... Então, você tem... essa heterogeneidade da sociedade... produziu um modelo de judiciário que também é muito sofisticado, muito heterogêneo para quem propala na doutrina que o judiciário é uno, não é? O judiciário, poder nacional... são duas justiças comuns: estadual e federal. Três justiças especiais: mi- 
litar, laboral e... e a eleitoral. São 27 tribunais estaduais muito autônomos; tribunais superiores, 5 tribunais regionais federais, 23 tribunais regionais do trabalho, 27 tribunais regionais eleitorais... Então, é... é um conjunto muito... disforme, não é?, um arquipélago muito... e ele não sabe exatamente o que ele é... Talvez, com o Conselho Nacional da Justiça, ele se encaminhe a... uma... possível homogeneização principiológica, ou de... estrutural ou alguma coisa assim que ele venha a sinalizar.

Mas seu discurso não se encerrou aí. Na mesma toada, prosseguiu, agora numa perspectiva mais pessoal, ao mesmo tempo em que crítica:

Mas essa... essa resistência que existe ao $\mathrm{CNJ}^{442}$ mostra que... não há consenso... $\mathrm{Na}$ verdade, é um... eu, eu vejo... com... certa tristeza o desaparecimento de algumas balizas morais que o tribunal... que o judiciário teve. Você teve... quando eu entrava na magistratura, você tinha 36 desembargadores no tribunal de justiça, dos quais se dizia que um era corrupto, não é? Mas havia 35 varões... acima de qualquer suspeita... que bastava você olhar... que você... eles transmitiam uma idéia de respeito, de serenidade, de equilíbrio, de ponderação... de bom-senso, de sabedoria! E eles gozavam, eles fruíam desse respeito que... a minha geração devotava. Eu... eu tinha um verdadeiro pavor de percorrer o $5^{\circ}$ andar, o $6^{\circ}$ andar do palácio, porque eu não queria... me encontrar com os desembargadores. São coisas, assim... lógico, hoje desapareceu. Todo mundo é "você", todo mundo é... são 360 desembargadores. Mas há menos compostura, há menos... uma... uma conversão axiológica muito grande... e... eu diria que se nós fizéssemos uma média geral, e se nós perguntássemos ao juiz brasileiro o que é o judiciário, ele diria: "É a empresa em que eu trabalho". Qual é a finalidade do judiciário? "É me pagar bem, e me assegurar todas as vantagens". E... não vejo, assim, perspectiva de você alterar isso rapidamente, porque... nós fazemos um concurso público que replica e intensifica essa tendência à arrogância, à prepotência, porque... você afere a capacidade de memorização... a partir de 11 mil candidatos, como esse agora, e você recruta 100, 90, $70 \ldots$ e eles têm todo o direito de se considerarem muito especiais, muito predestinados, muito... e... depois de algum tempo... você ingressa numa estrutura onde o

${ }^{442} \mathrm{CNJ}$ é sigla representativa do Conselho Nacional de Justiça, órgão criado pela Emenda Constitucional no ${ }^{-}$ 45, de 08/12/2004, para integrar a estrutura do poder judiciário. É composto por quinze (15) membros, escolhidos na forma prevista no art. 103-B, da Constituição Federal, dentre os quais um ministro do Supremo Tribunal Federal, que o presidirá. Presenciou-se grande resistência a sua criação, que foi feita na perspectiva política de se erigir como agente controlador e fiscalizador do poder judiciário, com competência para tomar medidas disciplinares em face de magistrados e baixar atos regulamentares, de nível nacional. 
que existe é o juiz e o resto não interessa, numa estrutura onde o funcionário é uma pecinha descartável... ele começa a crescer... na autoestima... ele começa a... achar que o mundo nasceu para servi-lo e que se a sociedade não gostar do tipo de justiça que ela tem, ela que procure se ajustar à justiça e não... Não sei... Você vê que isso é... é um pouco de pessimismo também... mas de tanto a verificar... a resistência a você ter... reações... voltadas para o aperfeiçoamento da prestação jurisdicional. Se você pergunta para um juiz... um clássico, um juiz tradicional, um juiz conservador o que falta no judiciário? Ele diz:

- Falta funcionário, falta dinheiro, falta me pagar melhor, falta isso...

E é uma cultura do repasse... - essa expressão é do Ministro Sepúlveda Pertence:

- O executivo não me dá recurso financeiro, o legislativo me fornece uma lei imperfeita... então eu sou uma vítima. Não tenho culpa de estar nessa situação de disfunção. A disfunção não é minha, a disfunção é da... é do contexto, e eu sou impotente para mudar isso.

Essa é a visão. (...) Acho que... a despeito de todas as vicissitudes e de todas as carências e deficiências... um juiz pode melhorar... ele pode fazer uma justiça mais adequada, ele pode ser um fator de renovação, pode motivar... os responsáveis. Mas eu não diria que haja... uma má-fé... uma... um comprometimento... ontológico, de: "Não, eu quero ficar na mediocridade, no mal." Não. Se você conversa individualmente, todos são sensíveis a esse... diálogo. Agora, você não consegue fazer com que isso seja... uma... uma política interna. Você só consegue reunir juízes para falar de vantagens, para fazer desagravo para algum colega que foi pretensamente ofendido, não é? E... só para isso! Se você começa a falar em melhorar, há uma resistência, assim, um pouco por comodismo, um pouco por descrédito, não é? E... por egoísmo, por não querer... Começar a mudar dá trabalho!

A respeito de sua visão do processo judicial, Émerson respondeu:

O processo... eu acho que... que... aconteceu com o processo alguma coisa que aconteceu com o ministério público, mal comparando. Ele não tinha autonomia científica, não é?, era direito adjetivo que... o pessoal que estudava processo ficava muito irritado com essa expressão: “Direito adjetivo, o que é isso?” Ele lutou tanto para conseguir autonomia científica, produziu-se uma tonelagem tão enorme de... de processo, de ciência processual, que ele passou a ser mais importante do que direito substancial. E hoje, a maior parte das... das lides são resolvidas processualmente. É mais fácil você esmiuçar uma... uma "exceção", uma "ilegitimidade de 
parte", uma "carência", não é?... uma "questão prejudicial”, qualquer coisa que impeça você de chegar ao cerne. Porque o cerne... para alguém que conservou um pouco de sensibilidade, ele angustia, ele traz um pouco de desconforto, porque... o juiz está trabalhando numa UTI social. Se as pessoas cumprissem com suas obrigações, honrassem a sua palavra... houvesse uma observância espontânea do direito, você não precisaria de justiça. Quando alguém ou algo chega à justiça, é porque houve uma falência de caráter, aí, e, se alguém ainda guardou alguma sensibilidade, ele vai absorver um pouco daquilo e vai ficando cada vez mais desalentado. Então, uma das fugas do juiz é resolver processualmente. Ele tem aquela justificativa pronta: "Eu não sou tutor de maiores e capazes. Se ele escolheu um mal advogado o problema é dele. Eu cumpri com a minha obrigação. Estou com a consciência tranquila... o processo é... a forma é obrigatória. Nós temos que... que trabalhar de acordo com as regras do jogo, e eu não quero saber do seu problema. Você leva o seu problema embrulhadinho, pasteurizado, e não me traga mais aqui”. Então, por isso esse apego, esse apego à preclusão, à prescrição, à decadência, não é?... a resistência à fungibilidade de forma... e todas essas $\operatorname{coisas}^{443}$.

Na sequência, perguntei que importância nosso entrevistado dava à audiência e ao contato por ela proporcionado com as partes.

Ele [contato com as partes] é extremamente importante, mas... o juiz... ele não é, ainda, treinado a conferir relevância a este aspecto que ele considera menor diante da sublime missão da dicção do direito. E isso é uma questão cultural, é uma... uma... é uma cultura que é impingida ao juiz, continua a sê-lo, embora atenuada, porque nas primeiras preleções dos juízes novos, era expressa a recomendação de que não se perdesse muito tempo com a conciliação, porque daria a impressão, principalmente para os juízes jovens, de que eles estavam fugindo ao trabalho de sentenciar... tentando obter uma conciliação forçada e que poria a justiça sob suspeita. Então, os desembargadores diziam:

- Você... não perca tempo, você... faça formalmente a proposta conciliatória, depois, você... procure sentenciar, porque é a hora de você mostrar seu nome, de fazer... construir a sua imagem institucional... O tribunal só vai conhecer o juiz pela

${ }^{443}$ Émerson faz menção a institutos jurídicos que podem se sobrepor ao mérito de uma causa, impedindo que o juiz chegue a apreciá-lo. Prescrição e decadência, por exemplo, são conceitos vinculados ao tempo, e não ao mérito. Um credor tem um tempo definido para exigir judicialmente seu crédito. Passado esse tempo, embora continue credor, não poderá mais se valer do poder judiciário para perseguir seu direito, que, despido de força jurídica, fica restrito a uma dimensão meramente moral. 
sua sentença, pelo apuro, pelo cuidado com que ele redigir, não pelas conciliações que ele fez.

Então, esta... isso leva o juiz... e levou, tem levado... a não perder tempo com essa... com a realização da justiça. Ele não tem preocupação com o justo, ele tem realização... ele tem... uma... uma preocupação com a produtividade, com a produtividade técnica que... também repercuta na avaliação que a hierarquia fará dele. Depois a teoria reforça isso: quando se verifica que o código, tentando corrigir formas procrastinatórias, determina que o juiz fixe os pontos controvertidos, isso é para inibir a possibilidade de uma discussão... que venha a... fugir daquilo que o juiz entendeu que é o ponto nevrálgico. E, de certa forma, a técnica da audiência é feita toda... em atenção a isso. É como corolário dessa cultura, porque... você faz com que a parte responda só àquilo que você quer e você... indefere, por impertinência, qualquer pergunta que queira ir mais além. Então, a objetividade, a concisão, a pressa, a necessidade de produtividade, a fixação do ponto controvertido, a falta de aval... a falta de critério para avaliar a conciliação... faz com que a audiência seja alguma coisa que os juízes acham algo que... amola ele.

Mas e a sua postura? - perguntei.

É claro que eu também já fui um juiz assim! Fui um juiz assim, jovem. Porque... uma das coisas que... eu falava, depois que entrei na magistratura: "Pelo menos eu fiquei mais distante do povo", porque o juiz atende... o promotor atende o povo. E eu... não era que eu achava ruim atender - eu gosto de conversar -, mas era a minha impotência de resolver coisas que não estavam... e isso continua sendo, num país como o nosso... o que vem ao judiciário é... é uma percentagem pequena que é tema jurídico: é problema social, é problema sociológico, é problema econômico, é problema de, de... psicológico, é problema de saúde, é problema de carência, é problema de prest... de outras prestações do Estado. Então, o Direito, ele tem... não tem muito a... a responder aos pleitos que vêm do povo, assim, na linguagem do povo, sem a decodificação técnica... Então, dá um desalento muito grande em você ficar atendendo e não ter soluções. A cada caso, você precisaria parar, telefonar para alguém ou fazer um ofício. Eu fiz muito isso... Agora, hoje, eu acho que nós estamos... nós refizemos, nós reconceitualizamos a... o valor da conciliação. Como a conciliação se obtém em audiência, é óbvio que... hoje nós temos uma outra óptica. Então, eu mesmo, quando falo com juízes jovens, eu falo: "Não hesite em estender, pelo tempo que for necessário, para... obter uma conciliação”. Eu falo da ética, das 
alternativas à solução do conflito, que é muito superior à... à decisão judicial, não é?, que é uma resposta heterônoma, onde as partes são totalmente excluídas e é o Estado que vem ali e se substitui, e diz o que ele fala e às vezes desagrada a todos os interessados. Quando, se você... encaminha uma negociação, você consegue substituir o contraditório por uma espécie de empatia, cada um tentando se colocar no lugar do outro, e ainda que transija e perca alguma coisa, você legitima a solução a que chegou porque você participou, você entendeu, não é? Quando a decisão, o que não é raro, que ela não seja compreensível pelo próprio destinatário dela ele precisa, outra vez, do decodificador, para traduzir o que aconteceu.

Então, se eu entendi bem, enquanto o senhor ainda era juiz, o senhor, de certo modo, seguia alguns parâmetros que eram sinalizados pelo tribunal?

No início sim. Isso porque você tem, hoje menos, mas... naquele tempo, mesmo porque... o respeito era muito maior, ou... a gente levava mais em consideração os sistemas... Hoje a juventude está um pouco... um pouco mais descomprometida com essas... com respeito aos mais velhos, com a hierarquia... Porque hoje... eu vejo o descompromisso do jovem com relação a... eles não estão muito preocupados com a corregedoria... com nada. Eu era muito temeroso, respeitava...

Diante dessa resposta, acabei ficando confuso a respeito da frequência com que Émerson designava audiências conciliatórias no período em que atuava em primeiro grau de jurisdição, de modo que insisti: - Mas de qualquer forma, em processo de família, por exemplo, até pela natureza do processo o senhor, como magistrado, devia intimar as partes para uma tentativa de conciliação, não?

Sim, eu sempre fiz... eu sempre fiz... Eu acredito que devo ter sido desde o início um juiz atípico, assim, porque... eu... começava a enxergar que cada processo é uma, é uma... partícula de areia no oceano, mas, para aquela parte eu faço a diferença. Então... se eu reduzir em 0,000001 a injustiça do mundo, pode ser imperceptível, mas houve menos injustiça. Então, nunca me recusei a fazer o melhor possível. (...) Então, quand... nas primeiras audiências eu sempre quis ser muito rápido, até porque eu não posso ver processo ali me esperando... me incomoda muito, então, eu sou rápido. E aí eu comecei decidir a... as ações criminais logo após o debate. O pessoal debatia e eu sentenciava, não é? E aí, o que acontece? Você tem o 
réu, sentado ali, e você tem que condená-lo. Então, eu... eu enfrentei, nos primeiros dias, essa coisa. Eu acho que é constrangedor... (...) Depois você começa a pensar: "Ou eu acredito, ou não acredito no que eu faço. Ou eu acho que estou tentando fazer o melhor possível, ou, se eu tenho dúvidas, eu... eu... ou, se não acredito no sistema, eu não posso fazer isso". Então, eu comecei usar a técnica de fazer sentenças muito... objetivas, claras... pouco... usando muito pouco de linguagem que não fosse acessível ao... ao interessado, no caso, o réu, e quase sempre o réu é um pobre, né? E... eu comecei a fazer isso olhando... encarando o réu. Então, quando eu terminava, eu dizia: "O senhor entendeu? Entendeu o que aconteceu? O senhor viu que o senhor não deixou alternativa ao juiz, senão de fazer isso?" Eu nunca tive um réu que me contestou. Eles sempre... mesmo aqueles que estavam irritados, revoltados, no fim eles abaixavam a cabeça e se eles ficavam encarando eu os encarava também. Então, várias vezes você tem que adjetivar... quando fica um pouco irritado, quando... a vítima é menor... ou drogado... Então, me deu um ... [ininteligível] muito grande, posso vir a ser assassinado... pode haver revanchismo, etc., mas... ele viu que eu fiz... com a maior isenção... eu fiz o que... o que era preciso fazer! Não é vingança... nem nada. E na questão cível, eu sempre, também... houve um caso... que eu lembro, eu sempre fui muito rápido. Quando o pessoal tinha pressa, rezava para cair na minha vara, porque eu não perdia tempo. E continuo assim. (...) Não há possibilidade de você ficar... prolongando a angústia das pessoas, certo? Tem que... ter um tempo previsto para fazer isso. Então, um caso de... despejo... numa indústria... uma grande indústria foi desativada e começou a... a despejar os ex-empregados que moravam na vilinha industrial. E veio o oficial de justiça -e caíram... não sei porque não houve prevenção, talvez porque fossem mais de 500 casas, e houve um acordo de que elas... as ações de despejo seriam distribuídas igualmente entre as quatro varas da comarca, para não ter uma com quinhentos processos, e... e as minhas saíam bem rápido, os meus despejos. Aí, chega o oficial e fala:

- Doutor, o senhor não vai acreditar: quem mora na casa é uma velhinha de 97 anos, que mora com a empregada, que tem 103 anos... Elas não têm família, elas não tem para onde ir... Elas... elas vivem de fazer boneca de pano... e é isso o que as sustenta e as mantêm lá. - Isso na década de 1980. Não havia o Lula dando pensão, bolsa família para todo mundo. Então, eu falei:

- O que eu faço?... Eu vou marcar uma conciliação.

Marquei uma conciliação para dali a um mês e pouquinho. Aí o advogado da empresa veio e falou: 
- Mas doutor, todos os outros saíram! - E eu falei:

- Mas eu não tenho coragem de mandar despejar essas... velhinhas. - Aí eles vieram e, na conciliação...

- Tem acordo, Doutor? [Pergunta feito pelo juiz ao advogado da empresa autora.]

- Não tem.

E a velhinha também não tinha advogado... Aí eu nomeei advogado, e o advogado pediu... acho que até por minha recomendação, ele pediu prazo... Eu devolvi o prazo... e foi fazendo... e eles... agravaram, não é? Veio o tribunal... E eu informei o que estava acontecendo... Eu sei que eu demorei... fiz lá um uso... ilegal, vamos dizer assim, abusivo, arbitrário... Mas... eu... esperei as duas morrerem. Porque não era muito... podia ter morrido antes, mas... a ordem natural das coisas...

\section{E demorou quanto tempo, mais ou menos? - perguntei.}

Ficou ainda, um ano, ou um ano e meio... não sei. (...) Então, eu sempre procurei tentar fazer justiça. Não guardo nenhuma... eu posso ter errado muito, e... com certeza... mas eu não tenho nenhuma... nenhum peso na consciência, de dizer: "Eu fiz o mal", ou "Fiz injustiça..." Isso me dá uma segurança muito grande.

Doutor, e as audiências conciliatórias, quando aconteciam, o senhor lembra quanto tempo costumavam durar, em média?

É muito... muito... não tem média, porque depende muito do caso, depende dos advogados e depende da... da pré-disposição das partes, uma coisa é se for de famíli... Eu via, ainda jovem, a força moral que o juiz tem em relação a casais que estão se separando e que já discutiram... e que já avaliaram, e que já vieram predispostos... e, quando eles estão diante do juiz, se o juiz tem um pouco de tirocínio, de sensibilidade, de humanismo para conversar... o que foi o casamento, o que foi a promessa... de viver e... e auxiliar um ao outro, até que a vida... até que a morte os separe, e... o que vai repercutir em relação aos filhos... E o testemunho que você dá de uma falência, em que você se comprometeu a uma coisa que não conseguiu fazer... $E$ incrível o... o número de pessoas que pedem mais tempo para pensar. Então, se você... destinar, nos juízes de família, com um talento, com uma paciência... é dom... para esse desempenho... eles fariam uma justiça de muito maior qualidade, certo?, do que aquela coisa... rotineira... e quase automática, não é? 
Indaguei se ele costumava prolatar o "despacho saneador", ao que sobreveio a seguinte resposta:

Sim, eu... eu, quando juiz de vara, eu... não entrava numa audiência... posso ter entrado quando vim substituir, quando me ligavam às 11 horas da manhã, eu estava em (...) [cita uma comarca do interior do Estado, próxima à capital], e tinha de fazer audiência a uma hora na Lapa, na Casa Verde, no Foro Central... ou em Santo Amaro... porque o juiz está sujeito a isso. E quando você chega, a mesa está cheia assim. Mas, quando eu... titular de vara, eu chamava... e tinha uns hábitos, assim, um deles era chamar, todos os dias, os dez processos mais antigos... em andamento. "Por que está parado?" Então, chegava à vara... você tem obrigação de fazer uma correição imediata. Aí, eu... eu pedia: "Olha, a partir de amanhã, você me traz os dez processos mais antigos, daí os outros dez, e os outros dez... Então, eu ia revisando tudo e verificando porque estava parado. E... as... os processos de audiência eram trazidos pelo menos na véspera, para que eu os examinasse. Aí eu já fazia um... roteiro, como se eu fosse sentenciar. Começava ali, da petição inicial... anotava a página, contestação, testemunhas - onde elas estavam -, etc. e tal. E tudo para... para poder... me inteirar das coisas. Porque é muito triste você chegar numa audiência e o juiz não ter a menor noção. Então, quando eu fazia o saneador, já era uma... uma antecipação. Muitas vezes eu fiz o saneador... no meu tempo, computador não havia, quando fui juiz de primeiro grau, mas eu tenho muita facilidade de datilografar. Então eu já fazia a sentença. Já deixava a sentença guardada. E, a part... só... acrescentava alguma coisa que fosse mudar. Porque... muito raro que a... aquilo que vem depois das... das duas peças - no cível: petição inicial e contestação -, é muito raro que... que a coisa tome outro rumo, né? Porque... o juiz... ele lê a petição inicial e fala: "Ah, o autor tem razão, tem toda razão". Aí vem a contestação, e ele fala assim: “Não, não... Quem está errado é o outro". E aí você vai... adotar... as suas premissas e você faz o que você quer. Você pode não perceber, mas você vai... você já constrói a sua linha lógica de raciocínio. E... é muito raro... Como hoje, eu acho que as minhas sustentações orais, elas... é muito raro [frisou “muito raro], eu nunca... eu não tenho tido, nos últimos anos, alguma sustentação que tenha mudado o meu... meu ponto de vista. Se era uma coisa tão importante... ela já deveria ter constado dos autos. Então, assim, aquelas... tentativas de chamar a atenção para alguns detalhes... Eu até... quando o advogado é meu conhecido, eu falo: 
- Olha, pode... não precisa sustentar, que estou acolhendo a sua tese. - Mas, mesmo assim, eles falam:

- Não, a parte veio, e eu fui contratado para fazer a sustentação oral... - e tomam o tempo da gente. É uma tristeza nesse sentido.

Neste momento, minha consciência de advogado fez-me exclamar:

- Mas doutor, tem o voto dos demais, não é?!

- Não, não é assim. - respondeu ele, passando a explicar que as câmaras de julgamento do tribunal costumam congregar magistrados que têm afinidade, "pássaros de igual plumagem”, sendo muito difícil ter no grupo "um elemento estranho". Isso é raro e, em ocorrendo, a tendência é de que, com o tempo, venha a ser "expelido":

É... é aquela coisa: você gosta de trabalhar com quem você conhece, com quem tem amizade, tem familiaridade e afinidade. Então, eu faço o voto, eu mando... para o revisor, que... já sabe... as nossas teses são... (...) são repetitivas. E o terceiro também acompanha. Nós já sabemos qual é o ponto dele. Hoje, nem mais... se pede vista por delicadeza, porque são tantas as sustentações, que o terceiro já fala assim: “Não, eu também já vi...” Então a sustentação passou a ser... não vejo que possa haver uma... pois disso o próprio Supremo $[\mathrm{STF}]$ está reclamando... que o advogado recém-formado chega lá... fazendo uma sustentação assim meio... tatibitate...

Felizmente, minha experiência como advogado junto aos tribunais não me permitiu registrar o quadro descrito por Émerson. No entanto, no escritório em que trabalho procuramos respeitar a regra de apenas fazer sustentações orais em casos cuja complexidade e valores envolvidos realmente o exijam, e não simplesmente para atender a uma expectativa do cliente. Há sentenças que levam o advogado a sentir que o juiz realmente errou, justificando um combate mais intenso junto à instância superior na busca de uma reversão do julgado.

Portanto, não pude deixar de relativizar a assertiva de Émerson, mencionando um caso em que atuamos recentemente e no qual, por conta da distribuição de memoriais, o relator retirou-o de pauta, para melhor apreciação. Diga-se de passagem que nossa apelação acabou por ser inteiramente provida - tudo levando a crer que, não fossem os memoriais, não o seria. Ao me ouvir, Émerson disse: 
- Sim, pode acontecer... mas é muito raro.

- Porque o advogado procura distribuir memoriais e sustentar, para evitar que... imaginando que muitos casos são julgados numa inércia, o dele caia numa vala comum.

- Claro. É verdade.

O telefone tocou e Émerson atendeu. Assim que terminou, perguntamos se alguma vez enfrentou situação em que o Direito não dava resposta muito clara à questão posta em juízo. Ele disse:

Olha, eu... eu vou ser obrigado a ser, assim... teórico. O ordenamento... ele é completo. O que... o que eu acho que as pessoas não perceberam... ou algumas pessoas não perceberam, na nossa área... é que, a partir de 1988, houve uma revolução. Não é? A... a Constituição, ela abandonou o modelo de lei que se submete ao princípio de antinomia, que tem regras para fazer desaparecer a lei que se antinomiza com a outra... na especialidade... cronologia, etc. e tal. E... substituiu por princípio. Então, o princípio é uma coisa fluida, é algo com que eu possa brincar como massinha de criança... Então, eu não... não há a menor possibilidade de eu dizer que o Direito não... não dá resposta. O que a gente não pode é confundir o Direito com a lei. A lei, sim, é cada vez mais ambígua, cada vez mais... um produto defeituoso, produzido a toque de caixa, uma resposta tópica, por esse novo feudalismo que se chama parlamento. Porque não tem interesse de... bem comum. Tem setores que se digladiam e... por compromisso, conseguem aprovar um texto muito... imperfeito. O juiz vai completar isso aí, com a principiologia... É por isso que eu insisto na tese de que se deve recrutar melhor o juiz, porque ele... ele pode fazer o que ele quer... ele faz o que ele quer. Aparentemente, como técnico... mas, ele pode... a decisão já... já feita, e ele vai dar... a... a linguagem... a roupagem jurídica.

A pergunta seguinte dizia respeito à importância de "doutrina" e "jurisprudência" no trabalho de Émerson. Nesse momento, teve grande destaque um estilo talhado ao longo de décadas no exercício da profissão:

Olha, eu... consulto muito... continuo a ler... doutrinadores, principalmente os jovens... quando necessário eu vou às fontes, às origens. Sem falar, eu acho... da clareza de José Frederico Marques, o... Maximiliano, toda hora eu uso... Mesmo o Pontes... eu... conforme você... precisa. Agora, mais em final de carreira, como eu 
estou - falta pouco tempo para eu sair -, eu já não me... não me preocupo muito com a... com a... doutrina. Eu, eu... lógico que, se necessário, eu vou, mas... eu tenho... um esquema de... resolver as questões que já... ficou como uma estrutura mental minha... eu vejo... o que é que é o relevante e... tenho tido decisões cada vez mais concisas, sintéticas, tentando atingir o ponto... para até procurar atender o comando que foi solicitado, ou constituído com muita... com muita insistência. E tem intensificado a... a... o reclamo de uma justiça mais rápida. [Fomos interrompidos por uma escrevente.] Então, o que me... o que me... me tem servido é, assim, uma certa, um certo acervo que já está... é difícil eu ter de mudar aquilo que eu já construí, não é? (...) eu tenho (...) anos de atividade diuturna nisso. Então, talvez... a... pode ser pretensão, pode ser prática, pode ser... cansaço, mas... as coisas já... já... eu não tenho... novidades. Então... é lógico que eu vejo... eu fico contente quando... (...) o STJ acolheu alguma orientação que eu considere protetiva, efetivamente tutelar, abrangente, com uma concepção de direito transgeracional, de cuidar do futuro, das próximas gerações... E eu coloco, quando vem, em abono. Mas eu acho que é bom você saber... e, você sabe, eu não vou fazer... iludir ninguém, há juízes que, que não... que declinaram de pensar: eles procuram jurisprudência e... eles perfilham a jurisprudência dominante, sem questionar, sem... Eu, até agora, não perdi o hábito de... de provocar, entendeu? Então, até... e sabendo que é uma conduta insana, mas... procuro defender teses, assim, consentâneas com a minha orientação, mesmo sabendo que a orientação dominante... Às vezes eu até me curvo para não suscitar embargos... infringentes, mas eu ressalvo, ao dizer: " $A$ minha posição já foi exposta inúmeras vezes e tal, mas... não convencido, mas vencido, para (...) evitar procrastinação, mesmo porque depois os embargam viram... viravam o caso e eu iria virar vencido... Ainda assim, não... ela me serve... quando é... de acordo com o que eu penso. Não é? Quando não é, eu tento... dizer que... talvez a melhor orientação fosse outra, com respeito e tal. Mas não sou daqueles que declinam de pensar. Eu tenho muito colega que não... que não... não quer saber: "Ah, o Supremo já decidiu assim, o STJ assim...", e não questionam. Eu acho muito perigoso. Por isso, quando falavam da súmula vinculante, eu sempre disse: “Não se preocupem, pois nós já somos tão... servis à súmula... que não é vinculante, que a vinculante não vai mudar nada! Ao contrário, vai liberar... e o juiz vai falar: 'Agora, não tenho nem que ter remorso por não pensar'."

No que diz respeito ao que mais lhe chama a atenção quando recebe os autos, Émerson diz que seu incômodo, na verdade, dá-se com “o volume, a extensão das peças", o 
que nem sempre tem vinculação com a complexidade do caso, uma vez que "questões até singelas são expostas em longas petições, em muitas laudas”. Afirma ainda, nesse sentido, que quando o advogado é seu conhecido, diz-lhe: "Se você teve que escrever tanto é porque você não tem razão!” E prosseguiu, na linha de "percepção dos autos":

Bom, em tese, quando... quando a causa é importante, há uma... uma sofisticação bastante grande: o papel é muito bom, o raciocínio é muito bom, o português é muito bom, o visual é muito... atraente, a documentação, etc.... Quando... o que dá... o que deprime é erro de português... de advogado menos qualificado... coisas assim. E ainda existe. $\mathrm{O}$ que, de certa maneira... na minha área, uma coisa que a gente fica um pouco desalentado é a reiteração das teses vencidas. São coisas, assim, completamente pacificadas e... há uma insistência... na mesma tecla... Não me dá trabalho, porque... o voto está pronto, e tal, mas você tem que manusear e falar, toda vez a mesma coisa. Dá, dá... às vezes vontade de você... falar que é litigância de má-fé, mas você entende que às vezes o cliente é que está perturbando, e tal. Outra coisa que... que me causa, assim, um pouco de espanto, mas eu sei que é o sistema que obriga, são os embargos de declaração. São cabíveis em relação a pontos omissos, obscuros e contraditórios. Todos os acórdãos têm embargos, mas a gente sabe que é da... do pré-questionamento.

Procurei explorar também o estilo perceptivo de Émerson no contexto das audiências:

Sabe, isso chega a ser uma coisa tão... automática ... Em... em regra, o... a parte, ela... ela ainda tem uma postura... temerosa... de receio... é uma coisa tensional. Às vezes, ela está ali se defrontando com o ex adverso... Há alguma coisa pouco esclarecida, onde o ambiente nunca é um ambiente... É um ambiente tenso, não é? Mas... eu sempre também... procurei... deixar... o pessoal à vontade... a justiça existe para resolver problemas, etc. e tal. Agora, é que às vezes você tem antipatia, não é? Isso é normal. Às vezes o advogado é mal encarado, não cumprimenta, não é?, ou aquele que interrompe a audiência pedindo um despacho, ou que vem e começa a falar com a parte... Eu... às vezes eu acho que... a boa educação, ela também começou a desaparecer um pouco, não é?... [O entrevistado atende a novo telefonema, o que tomamos como sinal de que, pelo volume de coisas que tem a resolver 
numa jornada, simplesmente não pode se dar ao luxo de ficar inteiramente "indisponível".]

Indagado sobre que postura costuma adotar diante da mentira da parte, respondeu:

Olha... o juiz sempre se sente um pouco, assim, ludibriado. Ele sabe, a imagem é muito velha, que ele está... que ele vê a pontinha do iceberg e que por baixo deve ter uma coisa imensa e que se procura esconder. Agora, você não... você tem... você é treinado a não perder a sua... a sua placidez. Você tem que ser alguém... ali... um profissional propenso a ouvir os maiores absurdos e sem demonstrar emoção. Agora, é evidente que você... depois, você... na sentença, você... toma um rumo que... para um bom decifrador, ele vai detectar que você não entrou. Às vezes até... pode ter sido injusto, mas aquela intuição, aquela sensação, ela vai influenciar, evidentemente.

E, a respeito da mentira da testemunha - que, diferentemente da mentira da parte, é tipificada como crime por nosso ordenamento jurídico:

A mentira da testemunha, a gente... eu já tive... quando eu fazia audiência... continuo fazendo audiência! Porque eu tenho audiência do órgão especial, daqueles que são... réus... qualificados, com prerrogativa em virtude da função... Em relação à testemunha, várias vezes eu já... interrompi um depoimento para falar: "O senhor se lembrou... que eu disse no início... que mentir em juízo é crime? Está bem ciente disso", e tal? Mas, não tenho a esperança de que com isso eu iniba, não é?, se alguém foi treinado, mesmo, para... Quase sempre a testemunha... já tem um parti pris, já tomou partido, então... é difícil você conseguir uma neutralidade. Ninguém é neutro! Não há neutralidade num processo. Todos, e cada um no seu papel, na sua. O que é interessante, eu não sei se vocês observam isso, são as testemunhas que... com o intuito de ajudar, prejudicam! Mentem... de uma forma tão descarada, que descaracterizam o.. a estrutura, o arcabouço, a estratégia de defesa do... de quem elas querem ajudar. Você fica até irritado. Oh, pensa que eu sou imbecil.

O senhor nunca tomou a iniciativa de mandar instaurar um inquérito, para apurar? 
Tenho... tenho... mas muito pouco... Eu nem lembro, assim... nunca foi uma coisa... Eu sempre achei a audiência, na verdade, uma espécie de teatro... do absurdo. É muito raro... a não ser num caso muito... que o testemunho vá mudar a situação fática. Num acidente em que você, de repente, pode... se convencer ou trazer insegurança... traz mais, assim, incerteza, quando você ouve uma testemunha presencial. Agora, a gente sabe que o testemunho é uma coisa extremamente falível, não é? Eu mesmo... me autoavalio falando. Eu tenho uma visão das coisas, então, depende da minha capacidade de observação, da minha capacidade de memorização, da minha utilização das expressões, do tempo... daquilo que me afeta mais. Então, a Psicologia do testemunho... eu sempre tento, e os promotores, estudá-la... Têm uns colombianos muitos interessantes, Gustavo Humberto Rodríguez, que tem um livro sobre o testemunho, e... eu até usava isso aí para mostrar que a prova testemunhal é... é uma coisa muito frágil para ensejar a certeza de que você precisa para chegar a uma decisão que você acha... imune a... [atende o telefone].

Qual é sua postura caso perceba um descompasso técnico entre os advogados das partes?

A minha tendência é suprir, sabe, é compensar. Mas é uma tendência, assim, quixotesca. Salvo se esse incompetente for também... deixar um sintoma de maucaratismo, entendeu? Mas se você ver que é uma pessoa só despreparada, e a parte... desassistida... se ela não tiver... uma... sensibilidade do julgador para tentar compensar... ela vai ser prejudicada por um fator que não guarda pertinência com justiça, não é? Então, eu... eu... a minha tendência é tentar suprir. Então, aí, muito antes de ser uma coisa rotineira... mandar fazer prova... sabe?... de ofício, reinquirir, fazer uma série... requisitar documentos, eu sempre fiz isso com a menor semcerimônia, dizendo que mesmo no processo civil o que interessa é a busca possível da utopia da verdade real. A verdade real... quem é que sabe?

No que diz respeito à réplica, Émerson mostrou tendência a deixar as partes se manifestarem sempre que houvesse juntada de algum documento ou que fosse feita alguma alegação importante, “dando oportunidade para o pessoal falar o que quisesse". Nesse sen- 
tido, afirmou: "um dos despachos que mais proferi foi era aquele do 398"444. Enquanto juiz, após a réplica, uma vez já formada sua convicção, não procrastinava mais o feito.

Dentre as diversas áreas jurídicas, Émerson gostou mais quando teve de trabalhar com Direito Ambiental e desgostou do Direito do Trabalho. O que o agrada no primeiro é nele reconhecer a possibilidade de "exercer um papel docente, assim, pedagógico", tendo sido o meio-ambiente alçado, pela Constituição Federal, ao nível de um "bem da vida, de uso comum do povo, usufruível... até pelas futuras gerações”. Segundo ele, esse ramo do Direito "trouxe a possibilidade de (...) ... desequilibrar essa neutralidade, que nunca existe, porque ele está, também, defendendo o direito de quem não tem voz, que é o porvir, cuja existência está vinculada aos cuidados que nós tivermos hoje com relação à natureza. Então, dá uma... uma sensação de que você está sendo realmente útil, e que a sua decisão sai daquele caderninho, que depois é destinado ao arquivo, e pode gerar efeito para o futuro".

Quanto ao Direito do Trabalho, para ele não há aí propriamente uma "justiça... que busca o equilíbrio." Trata-se, antes, de "uma técnica de repartição de rendas através do Estado", em que há um "maniqueísmo" que lhe parece "irreal”, porque "o empregado sempre tem razão, por mais malandro que seja. Ele é instrumento fácil na mão de advogados inescrupulosos... Então, aquela... aquela praxe de pedir cem mil reais e depois fazer um acordo de cinco mil, me dava nojo, sabe?"

Apesar das dificuldades de agenda, Émerson procura uma forma de se manter acessível aos advogados que pretendem despachar com ele, apenas cuidando para que esse tipo de iniciativa não interrompa seu "trabalho intelectual de fazer e de proferir voto". Portanto, ao ser procurado, informa ao advogado os dias e horários em que estará disponível no tribunal, dispondo-se a agendar com o pretendente até uma hora antes da sessão de julgamento.

Indagado a respeito de sua visão da advocacia, reiterou a opinião, já existente em sua juventude, de que haveria "excesso de advogados". E, ainda:

444 ... art. 398, do Código de Processo Civil, onde se lê: "Sempre que uma das partes requerer a juntada de documento aos autos, o juiz ouvirá, a seu respeito, a outra, no prazo de 5 (cinco) dias". 
Eu acho que a faculdade de Direito, ela... continuou com uma visão extremamente anacrônica da... da sociedade. Ela tem uma formação eminentemente adversarial. O aluno no primeiro ano de bacharelado já quer impetrar a segurança, quer fazer separação de corpos, quer fazer ação de despejo, quer... iniciar em juízo. Os tribunais, em lugar de... (os tribunais!) As escolas, em vez de treinarem o aluno para as novas realidades, onde eles podiam fazer... muita conciliação, muita negociação... Já consta no estatuto da ordem que ele deve evitar lides temerárias, mas, na verdade, ele... ele quer entrar em juízo. Então, acho que o excesso de bacharéis faz com que a sociedade inteira fique mais conflitiva. Porque dá a impressão de que o advogado não sabe fazer outra coisa senão litigar, senão demandar. Então, salvo honrosas exceções... e há muita sofisticação: revestir lides que são e... poderiam ser mais singelas... de uma... de um arsenal de... de preliminares, de aflições, de coisas... só para tumultuar. Eu gostaria que a advocacia fosse convertida em uma profissão da pacificação... e não a profissão do litígio.

Ao terminar de ouvir seu ponto de vista, comentei:

- De certo modo, é uma visão pessimista... - ao que ele respondeu:

- É.

No que tange ao movimento de digitalização dos processos, Émerson mostrou-se favorável, mencionando um aspecto não lembrado pelos demais magistrados que entrevistei: o da preservação do meio-ambiente pela enorme economia de papel, pois "cada papel a mais representa sacrifício de árvores, etc. e tal”.

Ao participar de recente seminário sobre "Poder Judiciário e Sociedade", tive oportunidade de ouvir do Ministro César Asfor Rocha, então presidente do Superior Tribunal de Justiça, que o Tribunal de Justiça do Estado de São Paulo estaria entre os três únicos do país a não adotar, ainda, o sistema de digitalização dos processos que são remetidos àquela instância, em Brasília. Aproveitei para investigar a opinião de Émerson a respeito dos possíveis motivos de tal atraso. Sua resposta foi franca:

Conservadorismo. Resistência a uma... a uma orientação que vem do Conselho Nacional de Justiça, que é considerado um órgão estranho, e que fere o federalismo. 
Indagado a respeito dos aspectos de sua personalidade que, segundo ele, trariam facilidade e dificuldade à sua atuação como magistrado, respondeu:

A facilidade... não sei se seria humildade ou compreensão... assim, uma... uma $a$ ceitação de que o mundo... tem características que não são aquelas que eu consideraria, mas... Porque a criatura é falível, é limitada... é... é premida por circunstâncias... age... de uma forma... que não se pode... prever. Ou seja, não é bom você esperar... ter expectativas de comportamento em relação às pessoas... querendo que elas sejam... primícias, não é?, sejam figuras místicas, druídicas, sei lá, demiúrgicas... São pessoas falíveis, feitas de uma matéria... de um material muito miserável, não é? A condição humana é... deveria trazer para todos humildade, se reconhecer como seres finitos, que têm uma duração ínfima, não é?, algumas décadas e tudo acabou... E que não caberia, nessa trajetória, pretensão, arrogância... sentimento de superioridade... Então, isso, de uma certa forma... eu acho que me ajuda a... a tentar dar as respostas que a justiça humana pode dar. [Pausa.] Paradoxalmente, eu diria que o que prejudica é que no fundo eu teria a vontade de que as pessoas fossem diferentes. Então, me... ainda me iludo com a traição, com a... com a falta de transparência... com a pessoa ser uma na sua frente e outra atrás, não é? Então, quando... você tende a conviver no mesmo espaço, e se relacionar com as mesmas pessoas... E eu trabalho com a presunção de boa fé, sempre achando que as pessoas são confiáveis... teriam como primeiro gesto a bondade, a generosidade, a partilha... E aí, quando eu fico sabendo (...): “Olha, sabe o que falaram de você?”... eu ainda fico triste. Então, isso ainda é uma coisa que... que me... Mas falo assim: "Eu já podia saber disso. Eu tenho consciência", mas, no fundo... eu gostaria que aquela esperança fosse concretizável.

Émerson informou não trazer nenhum registro de uma decisão sua que tenha sido reformada de modo a feri-lo. Diz ter sempre tido "muita noção de que... o direito é visto... de diferentes formas, de diferentes maneiras", e de que um juiz é sempre o resultado de um conjunto complexo de fatores: "a sua história pessoal, a sua erudição, a sua ideologia, a sua religião, as suas idiossincrasias, os seus... as suas antipatias”. De qualquer modo, ao longo da carreira teve a felicidade de receber mais elogios do que críticas a respeito de sua atuação como julgador. 
Hoje, na qualidade de desembargador, nosso entrevistado exerce predominantemente o papel de manter ou reformar as decisões proferidas por seus colegas de primeira instância. Perguntei-lhe se o faz com algum cuidado, ao que ele respondeu:

Eu tento. Uma coisa que eu procuro sempre fazer é citar o nome do juiz no acórdão. Eu começo meu acórdão dizendo: “A sentença do juiz Fulano de Tal”... para dar uma... um reconhecimento de que eu li e que eu sei que é ele que está sentenciando. Agora... quando eu vou... quando eu vou reformar, (...) eu tenho a impressão de que eu já tenha sido duro, algumas vezes, quando é uma... rejeição da inicial por inépcia, por uma questiúncula, assim: "Emende a inicial em dez dias!" E aí, no "emende", ele extingue, não é? Então, eu começo dar uma lição de ética, não é? (...) Se ele [refere-se ao advogado que ingressou com a ação] fez a petição inicial já com algum defeito, não é porque você diz: "Emende em 10 dias" que ele vai saber o que ele errou, não é? Então, ... algumas... e quando eu vejo uma questão que demandaria uma porção de considerações, que ele julga antecipadamente, porque quer ficar livre do processo... e você não tem condição absoluta disso! E ele não leva em consideração, aí, por mais que você tente ser delicado, você fala: "Realmente, não atentou o juiz que deveria... é muito louvável a... antecipação... o julgamento antecipado, é sempre viável, claro, mas... aqui...” Agora, eu nunca... nunca fui rude, assim, sabe?

Passei à leitura do pensamento de LLEWELLYN ${ }^{445}$, que lhe pedi para comentar. Segue o comentário de Émerson:

É isso mesmo. Concordo. (...) muito antes de haver esse tipo de pesquisa que você está fazendo - nós nunca fomos muito pródigos nisso, não é? (...) - mas, eu sempre... falei: "O juiz faz o que ele quer, faz o que ele quer!" Ele já sabe, exatamente... às vezes, muito antes de encerrar, ele já julgou, já prejulgou. E isso é o que acontece com todo mundo, com as pessoas que estão aí! A toda hora. Eu estou falando e você está me julgando, se eu estou falando bobagem, se eu falo desse jeito se eu falo do outro... O juiz... ele faz esse julgamento... ele tem de assinar e tem de justificar. Aí, ele vai buscar a justificativa que coincida com o seu julgamento. En-

445 "Karl Llewellyn acredita que, geralmente, a mente do juiz primeiro antecipa a decisão que considera justa (dentro da ordem jurídico-positiva) e depois procura a norma que pode servir de fundamento a essa solução, atribuindo aos fatos a qualificação apropriada". Citação extraída do livro O Juiz e a Emoção ..., pp. 13/14, de Lídia Reis de Almeida Prado. 
tão, quando... no início de carreira - eu sou testemunha e referência concreta disso -, eu julgava... como eu precisava justificar, eu ia procurar a jurisprudência que me servisse. Então, a minha mulher estava grávida, eu falava para ela, que não tinha muito o que fazer... Então, eu falava:

- Se você não tiver o que fazer, vai procurando nas Revistas dos Tribunais... - Aí, ela dizia:

- Achei jurisprudência, mas tudo contrário.

- Bom, mas se não tiver do meu jeito, eu...

Eu era muito duro... no crime. Eu queria coisas que levassem à condenação.

- Não tem. Tem só absolvição.

Mas é assim mesmo. E meu comportamento continua sendo esse.

Quando Émerson, ou melhor, sua mulher não achava precedentes que pudessem corroborar seu julgamento a respeito do caso, ele, em vez de alterar seu convencimento, escrevia: "Embora... tal e tal, a maior parte tal e tal, nesse caso é diferente, porque nesse caso...", e procurava, "nos argumentos que tinham sido usados para absolver, contraargumentar para condenar".

Haveria diferença entre a personalidade de nosso entrevistado enquanto no exercício da profissão e fora dela? Confrontado com tal pergunta, ele respondeu:

Olha, uma coisa de que eu sou acusado na minha família é de ser juiz 24 horas por dia, 7 dias por semana, 30 dias por mês, 365 por ano. Sempre fui, assim, muito... criticado... por ser assim. Uma das coisas que eu ouvia muito era: "Olha, aqui você não é corregedor, hein! Aqui você não é corregedor”. Há uma tendência de você se deformar, vamos dizer assim, você se deforma. Eu sou do tempo em que eu falava para os meus filhos:

- Olha, cuidado com o que vocês fazem, porque você é filho de juiz...

E eles falavam:

- Mas pai, eu não tenho nada com isso.

Eu falava:

- Não, você tem sim!

Então eu acho muito difícil... Eu nunca consegui, assim, falar, em uma hora, como uma porção de gente, que vem para São Paulo: “Oh, que bom! São Paulo...” Sai da Praça da Sé, tira a gravata e ninguém sabe quem você é. Eu não... não consigo! 
Talvez seja um defeito, não é?... Uma das coisas que me levaram a me preparar para a aposentadoria, porque... a maior parte dos juízes... (...) se acostumam com esse ambiente e depois não tem mais o ambiente. E, quando você sai, você leva um susto, pois a vida não é essa coisa de traz cafezinho, traz água... Excelência... Então, eu tenho bem noção disso, mas... Às vezes é uma coisa maior do que eu mesmo... Por exemplo, eu nunca consegui relaxar... sabendo que eu tinha processo me esperando. A primeira vez em que eu fui para a Europa, depois de casado, em (...), eu briguei o tempo inteiro com a minha mulher, porque eu não tinha visto nem o roteiro. Aí, no avião mesmo, quando eu fui ver o roteiro, eu comecei a criticar e ela começou a chorar, e disse: "Eu cuidei de tudo sozinha, fiz tudo. Você agora vem dar palpite? Você nem me ouviu, você não teve tempo de conversar". Então, não acho que eu seja exemplo, e... uma das coisas, assim, que hoje eu lamento, é... às vezes eu começo a pensar... eu passei quase quarenta anos da minha vida fazendo uma coisa que era descartável, porque a sociedade vai ter de encontrar outras formas de resolver seus problemas, porque nós não estamos resolvendo. Então, quem pode, foge da justiça, e nós... nós nos tornamos como que uma instância simbólica, para dizer que existe a democracia... então os tribunais estão abertos, estão funcionando... Algumas demandas chegam... não são resolvidas... mas, a sociedade diz: “Tem acesso à justiça. Não tem saída, mas tem acesso...”. E nem sempre a resposta que a justiça dá é a resposta que a sociedade gostaria. Então, isso me dá... Agora, eu sacrifiquei a minha vida pessoal em torno de uma causa que talvez não fosse uma causa tão nobre quanto... quanto eu sonhei, e que ao longo do tempo ela veio perdendo substância, veio perdendo conteúdo, veio perdendo ética, veio se contaminando... E uma sociedade que pensa mais em resultados práticos, factíveis, em hedonismo, em materialismo, etc., e muito menos em... justiça (...) Às vezes eu tenho esse tipo de... de reflexão. Mas... continuo fazendo minha liçãozinha de casa... A cada decisão, eu tenho sempre uma... se eu posso falar de ética, eu falo. Estudo o mínimo... não estou me aprofundando... não tenho interesse de fazer curso de processo e não sei o que, mas... Ética, Filosofia, estou continuamente lendo. Para absorver, e ver se eu compreendo esse momento. Eu sou parte dele mas, às vezes, eu me sinto muito excluído... que eu sou do passado...

- Ou do futuro! [risos.]

- Ou do futuro... 


\subsection{ANÁLISE DO PERFIL TIPOLÓGICO DE “ÉMERSON”}

Iniciamos nossa análise fazendo uma confissão ao leitor: a escolha de Émerson não foi aleatória. Após entrevistar cinco magistrados em que a SENSAÇÃO era função principal ou auxiliar, alimentamos o desejo de fechar o ciclo da pesquisa de campo com algum INTUITIVO. Temos a impressão de que tal perfil não seja muito comum no poder judiciário, que lida com dados do passado a fim de solucionar um problema do presente, postura que nos parece mais consentânea com aqueles que operam sob o estilo da função SENSAÇÃO. Desconfiamos, portanto, que um INTUITIVO no judiciário haveria de se sentir um tanto "deslocado" e, ainda, mesmo que pudesse trazer grandes benefícios para a instituição, talvez a recíproca não fosse verdadeira.

Émerson parece ter todos os traços que apontam para o predomínio da função INTUIÇÃO, e, ao mesmo tempo, revela certo "deslocamento". Até que ponto uma coisa está relacionada à outra, reputamos prematuro afirmá-lo de forma taxativa, principalmente pela inexpressividade estatística de nossa amostra. Mas fica desde já firmada a hipótese.

Como é típico do INTUITIVO, as análises de Émerson parecem de fato partir $d o$ geral para o particular. Observa-se com clareza, por exemplo, que, quando indagado a respeito da visão que tinha do poder judiciário, Émerson iniciou sua fala com uma análise "panorâmica", ao mesmo tempo que bastante "objetiva", já sinalizando também a forte presença da função PENSAMENTO. Teceu amplo quadro de como o órgão está estruturado nacionalmente: "São duas justiças comuns: estadual e federal. Três justiças especiais: militar, laboral e... (...)" etc., e apontou quão difícil é enxergar aí alguma identidade:

O judiciário como instituição, ele... ele não se conhece. E é muito difícil você fazer um diagnóstico (...) num Estado como o brasileiro... que é (...) um campo para uma pesquisa antropológica muito interessante, porque convivem, num mesmo espaço físico, ilhas pré-históricas, pré-medievais, medievais, modernas, pós-modernas... Então, você tem... essa heterogeneidade da sociedade... produziu um modelo de judiciário que também é muito sofisticado, muito heterogêneo para quem propala na doutrina que o judiciário é uno, não é? 
Parece que a atenção de nosso entrevistado tende mesmo a considerar o todo, de modo que o judiciário é inserido em contexto bastante amplo, do qual se torna muito complicado fazer um "recorte". A homogeneização possível fica a cargo do CNJ e, mesmo assim, em termos principiológicos e abstratos, não concretos.

Num segundo momento de sua fala, Émerson abandona o plano de uma análise mais abstrata e, no concreto, envereda por uma avaliação bastante ácida do que se pode chamar de burocratização da figura do juiz. Segundo ele, tomado pela "média geral", o juiz brasileiro teria o seguinte perfil:

(a) vê o judiciário como a empresa em que trabalha, cuja finalidade é a de lhe "pagar bem e assegurar todas as vantagens";

(b) em virtude do rigor do processo seletivo e do culto social ao cargo que ocupa, tende a desenvolver um sentimento de superioridade em relação às pessoas que o cercam, resultado, diríamos nós, de uma identificação com a persona;

(c) atribuiria a disfunção do sistema a fatores estranhos à sua atuação ("cultura do repasse");

(d) embora, tomado individualmente, possa ter muitas qualidades positivas, quando em grupo apresenta grande resistência a mudanças, "um pouco por comodismo, um pouco por descrédito".

Ainda ao falar do judiciário enquanto instituição, Émerson revela certo ressentimento pelo que podemos chamar de processo de "dessacralização", mas isso a partir de um público interno, não externo, ou seja, teria havido uma perda de respeito de seus próprios membros em relação ao significado simbólico que a função haveria de suscitar. Segundo ele, embora antigamente também houvesse falibilidade ("um corrupto no tribunal"), fato é que "havia 35 varões... acima de qualquer suspeita... que (...) transmitiam uma idéia de respeito, de serenidade, de equilíbrio, de ponderação... de bom-senso, de sabedoria! E eles gozavam, eles fruíam desse respeito". Hoje, porém, "todo mundo é você" e "há menos 
compostura", tendo havido "uma conversão axiológica muito grande". Numa perspectiva mais filosófica, podemos afirmar que o que Émerson denuncia é o esvaziamento do simbólico.

Também bastante próprio o modo como nosso magistrado tratou da questão do "processo judicial". Neste ponto, cabe o seguinte esclarecimento: sabemos que grande parte das palavras são plurissemânticas e, ainda, que a pluralidade de sentidos não está apenas no léxico, também se constelando na própria dinâmica da comunicação oral, como, por exemplo, no tom em que a palavra é empregada, ou no gesto corporal de que se faz acompanhar. A expressão "processo judicial” pode remeter a diversos universos de sentido, cabendo essa escolha ao entrevistado. Supomos que essa escolha também seria capaz de fornecer indícios da função predominante em cada indivíduo, podendo ser mais ou menos objetiva (PENSAMENTO x SENTIMENTO); mais ou menos subjetiva (INTROVERTIDO x EXTROVERTIDO); mais abstrata (INTUITIVO) ou mais instrumental (SENSAÇÃO).

Judith, magistrada que tomamos como representante do tipo PENSAMENTO EXTROVERTIDO, quando confrontada com a pergunta ("que visão tem do processo judici$a l$ ?”), fez questão de definir o contorno semântico da expressão:

Diante dessa pergunta, penso no processo enquanto procedimento e não enquanto disciplina.

Além de se dar conta da pluralidade de sentidos, algo que podemos tomar como indício do tipo aferido (PENSAMENTO EXTROVERTIDO), ela optou por aquele que apontava para aspectos mais práticos ("procedimento"), em vez de teóricos (“disciplina”), o que se mostrou bastante coerente com o predomínio da SENSAÇÃO como função auxiliar.

Mirtes, tomada como representante do tipo SENTIMENTO EXTROVERTIDO, resumiu sua visão à seguinte frase:

É um instrumento para obtenção do remédio jurídico, da pacificação social. 
Onde vemos aí os sinais da função SENTIMENTO? Justamente no recurso a um "clichê jurídico", de modo que ela não precisou pensar para responder. Por outro lado, não sabemos se Mirtes teve consciência da diversidade de sentido da expressão "processo judicial". No entanto, caso tenha tido, fato é que sua resposta enveredou pelo significado mais concreto ("instrumento"), o que também mostra coerência com sua função auxiliar (SENSAÇÃO).

Já Evandro, em quem julgamos ver um representante do tipo SENSAÇÃO INTROVERTIDA, também destacou o aspecto prático do "processo", ao qual associou, de imediato, a ideia de "instrumento imperfeito de apuração da verdade e de solução de um conflito".

Émerson seguiu caminho diverso. Analisou a questão a partir de uma perspectiva conceitual (mesmo que daí extraia efeitos práticos), do embate jurídico existente entre:

(a) os que veem o processo como mera ferramenta procedimental destinada à realização de um direito material, não podendo este sucumbir ao formalismo (daí a dicotomia "direito substantivo" x "direito adjetivo") - visão que tende a atenuar eventuais irregularidades formais cometidas pelos advogados das partes, e

(b) os que o veem o processo como conjunto de atos "com valor intrínseco próprio", cuja não-observância é capaz de obstar, em nome de princípios como o da "segurança jurídica" e do "contraditório", a perseguição do direito material. ${ }^{446}$

Há outro ponto digno de nota nessa parte da fala de Émerson: novamente vê-se um tom contundente em relação a seus colegas de profissão, cuja "disfuncionalidade" parece levá-lo às raias da ira. Mas não é apenas a contundência do discurso que desperta nossa atenção - sinal da função PENSAMENTO; percebemos a mensagem subliminar de um

${ }^{446}$ BEDAQUE, José Roberto dos Santos. Efetividade do processo e técnica processual, Malheiros Editores Ltda., São Paulo (SP), 2006, pp. 418/419. 
isolamento, como se Émerson se sentisse um pássaro de diferente plumagem - sem que haja qualquer juízo de valor nisso -, o que, de certo modo, ele revela de maneira expressa nas seguintes falas:

- O que é que eu estou fazendo aqui?! [Reação tida por ocasião de sua cerimônia de posse como magistrado, enquanto ouvia o discurso de um colega, à época assessor da corregedoria geral, tratando do que os esperaria.]

- Acho que a magistratura, pelo menos quando eu entrei, ela era muito... ela blindava você. Você tem que ficar muito... recolhido... e... e isso... me... me inibiu, em algumas coisas.

- eu nunca permaneci atado ao que se espera...

- Ah, eu prefiro continuar a ser um promotor... razoável, mais convencido, do que um juiz sem vocação...

- Eu acredito que devo ter sido desde o início um juiz atípico, assim, porque... eu... começava a enxergar que cada processo é uma, é uma... partícula de areia no oceano, mas, para aquela parte eu faço a diferença.

- Agora, eu sacrifiquei a minha vida pessoal em torno de uma causa que talvez não fosse uma causa tão nobre quanto... quanto eu sonhei, e que ao longo do tempo ela veio perdendo substância, veio perdendo conteúdo, veio perdendo ética, veio se contaminando... E uma sociedade que pensa mais em resultados práticos, factíveis, em hedonismo, em materialismo, etc. [valores estes mais sedutores aos que se deixam guiar pela função SENSAÇÃO], e muito menos em... justiça (...) Às vezes eu tenho esse tipo de... de reflexão.

- A cada decisão (...) se eu posso falar de ética, eu falo. Estudo o mínimo... não estou me aprofundando... não tenho interesse de fazer curso de processo e não sei o $q u e$, mas... Ética, Filosofia, estou continuamente lendo. Para absorver, e ver se eu compreendo esse momento. Eu sou parte dele mas, às vezes, eu me sinto muito excluído... que eu sou do passado... 
Esse sentimento de "exclusão", repetido de diferentes formas por Émerson, reforçou a ideia que temos (a rigor, ainda um pré-conceito) no sentido de um INTUITIVO não se sentir muito "em casa" no judiciário. Porém, preconceitos à parte, veremos que muitos outros indícios há da INTUIÇÃO como função principal.

A "visão panorâmica" também é enunciada quando lhe perguntamos a respeito daquilo que mais the chama a atenção quando recebe os autos de um processo. Nesse momento, afirmou que seu incômodo, na verdade, dá-se com “o volume, a extensão das peças", o que, segundo ele, nem sempre tem vinculação com a complexidade do caso, uma vez que “questões até singelas são expostas em longas petições, em muitas laudas”.

Alguém poderia notar que, no caso dos demais magistrados entrevistados, que atuam em primeiro grau de jurisdição, em vez de pôr o foco de nossa pergunta "nos autos do processo", pusemo-lo na "petição inicial". Seria uma observação pertinente. No entanto, nosso entrevistado voltou a dar sinais de sua maneira típica de apreender os estímulos do meio quando indagado a respeito do que percebia, em primeiro lugar, nas "audiências". Como sabemos, respondeu:

Sabe, isso chega a ser uma coisa tão... automática ... (...) É um ambiente tenso, não é?

Ora, ele não deixa dúvidas a respeito de uma percepção mais "difusa", cujo sentido é divisado pela expressão "ambiente tenso". Segundo Von Franz, "para funcionar, a intuição precisa olhar as coisas de longe ou de modo vago, a fim de captar certo pressentimento vindo do inconsciente, semicerrar os olhos e não olhar os fatos muito de perto. Se se olhar com muita precisão para as coisas, o foco serão os fatos e o pressentimento não surgirá”. ${ }^{447}$

Também podemos vislumbrar a expressão da INTUIÇÃO quando ele diz considerar a audiência "uma espécie de teatro do absurdo". Tal ponto de vista apenas pode advir de quem não leva em consideração a realidade "aparente", mas o que está oculto, não declarado. Todo operador do Direito sabe que tanto as partes quanto as testemunhas costumam, na

${ }^{447}$ Op. cit., p. 51. 
verdade, ser "preparadas" para ir à audiência, onde se trava um verdadeiro jogo cênico. Um INTUITIVO “sabe" disso, capta-o automaticamente.

Outro ponto bastante interessante diz respeito ao comentário feito por Émerson quando trouxemos à tona o tema da digitalização dos processos. Em vez de ficar adstrito aos aspectos práticos, visíveis e imediatos dessa tendência - e eventuais dificuldades para sua implementação, como o fizeram os tipos mais sensoriais -, sua mente deixou-se guiar pelas consequências reflexas, como a da preservação do meio-ambiente pela enorme economia de papel.

Assim como percebeu, há décadas, a saturação do mercado de trabalho pelo excesso de advogados, para Émerson está muito clara a falência do velho paradigma do judiciário como fórum privilegiado de resolução de conflitos:

(...) a sociedade vai ter de encontrar outras formas de resolver seus problemas, porque nós não estamos resolvendo. Então, quem pode, foge da justiça, e nós... nós nos tornamos como que uma instância simbólica, para dizer que existe a democracia.

No entanto, o simbolismo, aqui, vem no pior dos sentidos: o de um templo sem espírito, com rituais conduzidos por sacerdotes sem fé, pregadores de uma religião sem Deus. É mera "casca", contorno externo de um grande vazio; restos de um sonho que, ao longo do tempo, foi perdendo substância, perdendo conteúdo, perdendo ética e veio se contaminando...

Na visão de um INTUITIVO, uma sociedade que pensa mais em "resultados práticos, factíveis, em hedonismo, em materialismo" - princípios típicos de quem se guia pela SENSAÇÃO -, é uma sociedade onde não há espaço para justiça.

É claro que, para quem está propenso a enxergar tendências e, de certo modo, antecipar o futuro, há muito as Faculdades de Direito parecerão compactuar com "uma visão extremamente anacrônica da sociedade", sendo necessário, sempre que possível, "exercer um papel docente, assim, pedagógico”, ou ainda aproveitar cada oportunidade que se abre 
para uma lição de ética. Afinal, o que está faltando no mundo não é estudar mais processo; o que falta é Ética, e compreender como vivenciá-la hodiernamente.

Não por acaso, a área do Direito que mais trouxe prazer a Émerson foi a Ambiental, quando teve oportunidade de nela judicar, pois, no fundo, é aquela em que a atuação do judiciário mais pode se projetar para o futuro; é onde cabe ao magistrado defender "o direito de quem não tem voz, que é o porvir, cuja existência está vinculada aos cuidados que nós tivermos hoje com relação à natureza". Mesmo que não esteja tão "em casa", neste ponto é como se fosse dado ao INTUITIVO ter "seu quarto" e decorá-lo a seu gosto (frisese que a Constituição Federal alçou o meio-ambiente ao nível de um bem da vida), de onde lhe advém a sensação de estar sendo realmente útil.

Esse idealismo de Émerson pode servir de base para explicar sua aversão ao Direito do Trabalho, que é por ele visto por seu aspecto mais materialista, onde reina um pragmatismo sem limites éticos:

(...) o empregado sempre tem razão, por mais malandro que seja. Ele é instrumento fácil na mão de advogados inescrupulosos... Então, aquela... aquela praxe de pedir cem mil reais e depois fazer um acordo de cinco mil, me dava nojo, sabe?

Quando o INTUITIVO (N) tem a reboque a função PENSAMENTO (T), ou mesmo o contrário, é conhecida sua predileção pela elaboração teórica em sua área de atividade. Em seu livro, Isabel B. Myers divulga, por exemplo, pesquisa feita entre alunos da área científica, constatando que $57,30 \%$ eram orientados pelas referidas funções (NT). ${ }^{\mathbf{4 4 8}}$ Tal perfil tenderia mesmo a sentir enfado diante da mera reiteração de teses:

(...) na minha área, uma coisa que a gente fica um pouco desalentado é a reiteração das teses vencidas. São coisas, assim, completamente pacificadas e... há uma insistência... na mesma tecla...

Fossem vistas as coisas meramente do ponto de vista prático, bastaria reiterar, da mesma forma, o voto dado, que "já está pronto", mas esse tipo de rotina costuma gerar

${ }^{448}$ Gifts Differing..., p. 43. 
muito desgaste para quem, como o INTUITIVO, gosta de se deparar sempre com novos desafios.

Vale lembrar, por fim, as áreas que mais despertaram o interesse acadêmico de Émerson: hoje, revela seu amor pela Filosofia e pela Ética; nos anos de bacharelado, pelas disciplinas mais afeitas com as Ciências Sociais que Jurídicas e, nestas últimas, as de caráter mais teórico:

Gostei de História do Direito, de Direito Romano, de tudo o que era assim... as origens, a... eu ficava muito embevecido, né? E, ao mesmo tempo, eu verifiquei que o treino da linguagem, o treino do uso da palavra me permitiria... viajar, né, expondo meu pensamento, escrevendo mais, lendo mais.

Portanto, parece haver indícios suficientes a corroborar a sugestão acima feita de estarmos diante de um INTUITIVO. Por outro lado, também estão visíveis, a nosso ver, os sinais de um PENSAMENTO bastante desenvolvido. O que predominaria?

Não nos parecesse clara a preponderância da função INTUIÇÃO, como já afirmado antes, poderíamos descartar a hipótese de predomínio da função PENSAMENTO com base na seguinte observação: se assim fosse, Émerson teria o SENTIMENTO como função inferior, e não nos parece que seja esse o caso, até devido ao intenso interesse que demonstra, desde muito jovem, pela ética. Desse modo, pelo fato de supormos haver um relativo desenvolvimento de funções que são naturalmente opostas, conforme é o caso de PENSAMENTO e SENTIMENTO - com predomínio da primeira -, postulamos serem estas funções auxiliares (secundária e terciária) de Émerson.

Já que não fizemos segredo sobre o palpite que tínhamos a respeito de qual seria a função auxiliar de nosso magistrado, vejamos que indícios mais temos disso.

Quando ele afirma ter descartado a carreira de advogado por conta do excesso de profissionais e também pelo fato de não ser "uma profissão muito bem vista", ficamos em dúvida sobre o que prevalece nesse julgamento moral: "princípios" (PENSAMENTO) ou "valores" (SENTIMENTO)? 
Em outro momento, surge dúvida semelhante. É quando, por exemplo, Émerson fala de seu flerte com a carreira política e das razões que o afastaram dela:

Mas eu comecei a ver que a política é uma coisa muito incerta, que você tem que ficar agradando e... e fazendo conchavos, e traindo a sua convicção, e não sendo franco... Aí eu falei: "Não dá."

Nota-se aí um tom introvertido (“convicção" e um quê de "antigregarismo”), mas, por ora, o foco de nossa atenção reforçará a ideia do predomínio da função PENSAMENTO, a quem repudiam as ideias de "ficar agradando" e de "não ser franco": "Não dá".

Outro episódio por ele relatado dificilmente seria protagonizado por um tipo SENTIMENTAL: em plena cerimônia de posse, levantar-se no meio do discurso do juiz assessor da corregedoria, a fim de tornar sem efeito o ato. É claro que Émerson ficou constrangido com isso, mas prevaleceu um impulso mais "perturbador do meio".

Até o presente, nosso magistrado parece ter preservado a ideia de que mais vale lutar por uma boa causa do que manter o consenso e a harmonia no entorno. Isso não implica, de forma alguma, ser "grosseiro", e sim, embora com gentileza e tato, não deixar de dizer o que precisa ser dito. Émerson conhece como ninguém os aspectos sombrios de sua profissão, e faz questão de sobre eles lançar, de maneira inclemente, um forte facho de luz:

E... não vejo, assim, perspectiva de você alterar isso rapidamente, porque... nós fazemos um concurso público que replica e intensifica essa tendência à arrogância, à prepotência.

E a crítica não para aí:

Você só consegue reunir juízes para falar de vantagens, para fazer desagravo para algum colega que foi pretensamente ofendido, não é? E... só para isso! Se você começa a falar em melhorar, há uma resistência, assim, um pouco por comodismo, um pouco por descrédito, não é? E... por egoísmo, por não querer... Começar a mudar dá trabalho! 
Émerson deixa claro, também, que não abre mão de um pensar crítico e provocativo, mesmo que às vezes pareça insano defender teses contrárias à orientação dominante ("não sou daqueles que declinam de pensar"). Tal postura ainda serve como ponto de crítica à acomodação de muitos colegas, para quem, segundo ele, a súmula vinculante chega a ganhar uma conotação redentora:

Não se preocupem, pois nós já somos tão... servis à súmula... que não é vinculante, que a vinculante não vai mudar nada! Ao contrário, vai liberar... e o juiz vai falar: “Agora, não tenho nem que ter remorso por não pensar".

Cremos ver no episódio das velhinhas cujo despejo deixou de ser decretado a atuação preponderante da função SENTIMENTO. Mesmo assim, a análise que nosso entrevistado faz é guiada pelo PENSAMENTO, que traz um aspecto mais "extrovertido", em que o objeto é a norma jurídica, sem o que provavelmente não diria ter feito uso "ilegal, vamos dizer assim, abusivo, arbitrário" de sua posição profissional. Um tipo SENTIMENTAL, mesmo agindo da mesma forma, tenderia a dar outra roupagem a essa conduta, ou mesmo a própria função PENSAMENTO, se imantada do subjetivismo típico da atitude introvertida.

Quando diz que sempre procurou tentar fazer justiça, nosso entrevistado dá a entender que acredita na existência de princípios que se sobrepõem ao ordenamento positivado, o que, aliás, fica explícito quando assevera a consagração de uma nova ordem jurídica após a Constituição Federal de 1988, a partir da qual fica repelida qualquer possibilidade de haver lacunas no sistema.

No curso de sua fala, Émerson forneceu também consideráveis indícios de ser um tipo JUDICATIVO. Como sabemos, pessoas deste tipo, ao extroverterem por meio de uma função racional (PENSAMENTO - T ou SENTIMENTO - F, no caso dele, T), preferem situações mais definidas/fechadas; bem como planejar a improvisar; decidir a protelar, e só relaxam após o cumprimento do dever. Nosso magistrado nos dá várias indicações disso, sendo excertos de sua fala: 
- Nas primeiras audiências eu sempre quis ser muito rápido, até porque eu não posso ver processo ali me esperando... me incomoda muito, então, eu sou rápido. E aí eu comecei decidir a... as ações criminais logo após o debate.

- Quando o pessoal tinha pressa, rezava para cair na minha vara, porque eu não perdia tempo. E continuo assim.

- Mas, quando eu... titular de vara, eu chamava... e tinha uns hábitos, assim, um deles era chamar, todos os dias, os dez processos mais antigos... em andamento. "Por que está parado?”

- Por exemplo, eu nunca consegui relaxar... sabendo que eu tinha processo me esperando.

- Porque... o juiz... ele lê a petição inicial e fala: "Ah, o autor tem razão, tem toda razão". Aí vem a contestação, e ele fala assim: "Não, não... Quem está errado é o outro".

- Aí eu já fazia um... roteiro, como se eu fosse sentenciar. Começava ali, da petição inicial... anotava a página, contestação, testemunhas - onde elas estavam -, etc. e tal. E tudo para... para poder... me inteirar das coisas. Porque é muito triste você chegar numa audiência e o juiz não ter a menor noção.

- Então, quando eu fazia o saneador, já era uma... uma antecipação. Muitas vezes eu fiz o saneador... (...) Então eu já fazia a sentença. Já deixava a sentença guardada. [Traço que também pode ser visto como característico da função INTUIÇÃO.]

- “O juiz faz o que ele quer, faz o que ele quer!” Ele já sabe, exatamente... às vezes, muito antes de encerrar, ele já julgou, já prejulgou.

- Olha, pode... não precisa sustentar, que estou acolhendo a sua tese.

- A primeira vez em que eu fui para a Europa, depois de casado, em (...), eu briguei o tempo inteiro com a minha mulher, porque eu não tinha visto nem o roteiro. Aí, no avião mesmo, quando eu fui ver o roteiro, eu comecei a criticar e ela começou a 
chorar. [Neste ponto, além da característica de um tipo JUDICATIVO, que tem necessidade de ver o roteiro, sobressalta também a função PENSAMENTO.]

Se aceitarmos o predomínio de traços JUDICATIVOS em sua personalidade, estaremos assumindo, também, que Émerson extroverte por meio da função PENSAMENTO. Ora, cumpre lembrar que, ao mesmo tempo, sugerimos ser essa sua função auxiliar, e INTUIÇÃO a principal, o que implica dizer da prevalência da atitude INTROVERTIDA.

$\mathrm{Na}$ verdade, há bastante equilíbrio entre ambas as atitudes (extroversão e introversão), de modo que Émerson está distante de uma situação de unilateralidade, com predomínio, porém, da INTROVERSÃO. Isso se vislumbra por meio de seu tom mais pessimista que otimista e pela riqueza de seu mundo interior, expresso pelas reflexões profundas decorrentes da ruminação dos estímulos externos. Julgamos já ter tecido muitas considerações a este respeito nas análises anteriores, podendo ser maçante sua repetição. Não correremos esse risco.

A respeito do INTUITIVO INTROVERTIDO e seu eventual interesse pelas questões morais - tão presente em Émerson -, escreve Jung:

Ainda que não seja do feitio do tipo introvertido intuitivo fazer da percepção um problema moral, pois para isso é necessário certo fortalecimento das funções judicativas [fenômeno facilmente observável no caso de nosso entrevistado], basta uma diferenciação relativamente pequena do julgamento para transferir a contemplação do puramente estético para o moral. (...) O problema moral surge quando o intuitivo se coloca em relacionamento com sua visão, quando não mais se contenta com a simples contemplação e sua valorização e configuração estéticas, mas chega a perguntar: o que significa isso para mim e para o mundo? O que resulta disso para mim e para o mundo em termos de dever ou tarefa? ${ }^{449}$

Émerson concordou em responder ao questionário de aferição de tipo, o que confirmou o resultado acima.

${ }^{449}$ Tipos..., p. $378, \S 731$. 
Tipo aferido: I N T J - Atitude INTROVERTIDA; INTUICÃO como função superior e PENSAMENTO como função auxiliar.

MYERS traz comentário de VAN DE HOOP a respeito dos representantes desse tipo (INTJ):

Embora eles possam ter apenas um vago pressentimento a respeito do caminho que querem trilhar, e a respeito do sentido de suas vidas, não obstante irão rejeitar com grande veemência qualquer coisa que não se coadune com isso. ${ }^{450}$

Essa conduta ficou bastante clara na trajetória de Émerson, o que se pode depreender dos seguintes excertos de sua fala:

\section{- Quando decidiu sair do ministério público:}

(...) mas eu, por, por... uma decepção, assim, dentro do ministério público, porque eu queria fazer um movimento para tirar esse juiz da magistratura, fui impedido pelo Procurador Geral, que... ele era um moço influente, o juiz... afilhado do Procurador Geral... esse tipo de coisa. Pois eu, muito irascível pela altura, assim, dentro do possível, muito apaixonado, muito idealista... falei: "Eu vou sair!"

\section{- Quando quase tornou sem efeito sua posse como magistrado:}

E... eu comecei a ficar irritado, irritado... no meio da palestra eu saí. E fui ao gabinete do presidente, falar com os juízes auxiliares, que eu queria tornar sem efeito a minha posse. Aliás, não sei se isso é indício de insegurança... ou de temeridade... ou de inconsequência...

${ }^{450}$ Op. cit., pp. 110/111. O trecho citado é tradução livre do seguinte excerto: “Although they may have only a vague feeling about the way they want to go, and of the meaning of their life, they will nevertheless reject with great stubbornness anything that does not fit in with this." (VAN DER HOOP, J.H.. Conscious orientation, Harcourt Brace, New York, 1939, p. 48.) 


\title{
CONCLUSÃO
}

\begin{abstract}
Impressionante é, por exemplo, a diversidade de indivíduos humanos e a profusão caótica de casos particulares cujas circunstâncias especiais de vida e cujo caráter singular produzem quadros clínicos que - se é que existe ainda disposição para tanto - só podem ser enquadrados num diagnóstico clínico fazendo certa violência.
\end{abstract}

Carl G. Jung ${ }^{451}$

(...) a trajetória de cada pessoa é singular por causa do acervo histórico familiar, educacional e emocional do temperamento que cada um porta com maior ou menor galhardia, mas há uma coisa que é inerente a todos os juízes dignos desse honroso nome: a virtude da temperança, da inadmissão de excessos, da rejeição das demasias. Tudo que é demasiado é por isso mesmo nefasto (...)

Cesar Asfor Rocha ${ }^{452}$

Se pararmos para lançar um olhar panorâmico sobre as diversas linhas classificatórias, sob as quais se busca agrupar os seres humanos com características comuns, notaremos algo curioso: dependendo do enfoque que se dê, indivíduos reunidos num determinado grupo, à luz de determinada classificação, poderão fazer parte grupos distintos quando tomamos classificação diversa. Ou seja, dificilmente se verifica uma sobreposição dos variados sistemas classificatórios, o que apenas aponta para uma inegável realidade: cada ser humano é único, sendo a personalidade expressão de um dinamismo psíquico complexo e inabarcável em sua totalidade.

Assim, a teoria dos tipos psicológicos, por mais sofisticada que possa ser, por mais profundo que penetre nas sutilezas da psique humana, não há de passar de porta de entrada para o estudo da personalidade; não é porto de chegada. A capacidade que possamos ter de prever, em alguma medida, o movimento das marés está longe de significar o conhecimento pleno do oceano, cujo mistério será permanente desafio à nossa inteligência, à qual se

\footnotetext{
451 “Tipos Psicológicos”: texto publicado em 1936, integra, na qualidade de ANEXO, a edição brasileira da obra Tipos Psicológicos, Op. cit., p. 504, § 1039.

${ }^{452}$ Cartas a um jovem juiz..., pp. 149/150.
} 
põe uma limitação insuperável, que é o fato de a psique ser ao mesmo tempo sujeito e objeto de estudo, portanto, para sempre objeto impregnado de subjetividade. ${ }^{453}$

Portanto, não bastasse a complexidade que lhe é própria enquanto "objeto" de estudo, tem-se lucidez quanto ao fato de que esse objeto não se mantém indiferente às luzes que sobre ele se lançam na tentativa de perscrutá-lo. Talvez mais do que em qualquer outra disciplina, na Psicologia sujeito e objeto se confundem. Tal circunstância traz limitações e implicações muito específicas, impedindo o investigador que delas tenha ciência - e como não tê-la? - de se vincular a categorias fechadas e estáticas. A psique é essencialmente dinâmica. O homem é e sempre será produtor e produto de cultura, a par de outros fatores. Qualquer teoria que deixe de espelhar essa realidade, mesmo que minimamente, há de ser vista com desconfiança. Não nos parece ser o caso da teoria dos tipos psicológicos de Jung, que abre espaço para o dinamismo a que nos referimos.

Contudo, a validade de aplicação da teoria está proporcionalmente ligada à consciência de suas limitações. Indivíduos pertencentes a um mesmo tipo psicológico, por exemplo, podem ser muito diferentes, mesmo que a igualdade do tipo aponte para uma série de semelhanças. Em primeiro lugar, há inúmeros fatores que atuam sobre a personalidade do indivíduo, como complexos, grau de educação, aspectos culturais, grau de inteligência ou sensibilidade, etc., e que não se devem a seu tipo. Segundo, não se pode deixar de considerar que, dentre as próprias variáveis tipológicas, diferenças podem surgir por conta do grau de desenvolvimento das funções auxiliares, ou mesmo da integração da função inferior de um e de outro. A unilateralidade de atitudes e funções, portanto, pode ser maior ou menor, o que redunda, dentro de um mesmo tipo, em tonalidades bastante distintas.

A singela análise do perfil de nossos entrevistados fornece-nos uma referência concreta do que é dito acima. "Isabella" e "Evandro", por exemplo, embora portem traços de personalidade que os colocam dentro do mesmo "nicho tipológico" (ISTJ), não são sequer pessoas semelhantes. Ilustração desse fato é o contraste de posicionamentos a respeito das áreas criminal e de família. Outro contraste pode ser visto no comentário feito à ideia de

\footnotetext{
${ }^{453}$ Jung tinha plena clareza a esse respeito: “(...) no caso da psicologia, ocorre uma situação peculiar: em sua formação conceitual, o processo psíquico não é apenas objeto mas também sujeito", in Tipos ..., p. 454, $\S 924$.
} 
Llewellyn ${ }^{454}$, que, em "Isabella", pareceu ter um enfoque mais parecido com o dado por um tipo pensamento (ver posicionamentos de "Eustáquio" e "Judith", outros dois entrevistados), enquanto em "Evandro" notamos maior proximidade com o tipo sentimento (ver posicionamento de "Mirtes"), o que pode ser sinal de que este último, cuja função auxiliar é o pensamento, esteja em fase mais avançada do processo de individuação, pois sua função terciária (sentimento) já aparece mais integrada à consciência, ou, em outros termos, nela encontra mais acolhida. Assim, podemos concluir que o fato de "Evandro" e "Isabella" terem apresentado o mesmo tipo psicológico indica tão-somente que são pessoas operando de acordo com os mesmos princípios, mas o modo como as funções interagem entre si, seu próprio grau de desenvolvimento, etc., tudo isso dá origem a marcantes diferenças.

Dizê-lo parece tornar inútil esta ferramenta teórica. No entanto, entre dois extremos, preferimos gerar a ideia de que, "de tão relativa, tal ferramenta para nada serve", do que a de que "abarca todas as variáveis possíveis da personalidade de um ser humano”. De nossa parte, não temos dúvida de que se trata de ferramenta útil, porém será tão mais útil quanto mais consciência tivermos de suas limitações.

As possibilidades do ser são muito mais extensas e complexas do que se possa apreender por meio de uma teoria, qualquer que seja ela - a de Jung, frise-se, jamais teve tal pretensão. E ele sempre fez questão de não deixar dúvidas a respeito, como se pode verificar de muitas de suas falas, conforme se pôde ver ao longo deste trabalho. ${ }^{\mathbf{4 5 5}}$

A teoria dos tipos tão-somente revela tendências. A diferença entre os tipos determina o como cada um tende a se comunicar, mas não o que é comunicado. Portanto, sentenças com o mesmo conteúdo decisório podem advir de juízes com tipologias diferentes, e sentenças com diferentes conteúdos decisórios podem advir de juízes com o mesmo tipo.

\footnotetext{
${ }^{454}$ Conforme vimos no curso das entrevistas, foi lido para cada entrevistado o seguinte trecho do livro O Juiz e a Emoção, de Lídia R. A. Prado, pedindo-se para que comentasse: "Karl Llewellyn acredita que, geralmente, a mente do juiz primeiro antecipa a decisão que considera justa (dentro da ordem jurídicopositiva) e depois procura a norma que pode servir de fundamento a essa solução, atribuindo aos fatos a qualificação apropriada".

${ }^{455}$ Não obstante, outro exemplo disso é o seguinte excerto: “(...) [Sobre os tipos:] trata-se apenas de uma espécie de esqueleto a que temos de adicionar a carne. Poderíamos dizer que é algo como uma região mapeada por pontos de triangulação, o que não significa que essa região consista em pontos de triangulação; isso se faz apenas para que tenhamos uma ideia das distâncias". In McGUIRE, William e R.F.C. Hull. Entrevistas e Encontros, Op. cit., p. 279. Excerto da segunda, de uma série de quatro entrevistas concedidas por Jung, em 1957, para o Instituto Federal de Tecnologia de Zurique.
} 
Por outro lado, não deixa de ser útil saber que, embora nem todo físico tenha inteligência suficiente para ser um "Einstein", não se pode produzir o que este cientista produziu sem o uso da função intuição.

Em nossa pesquisa de campo, procuramos verificar a manifestação fenomênica de cada tipo no universo forense, enquanto expressão da psique do juiz. Ressalva óbvia concerne ao tamanho de nossa amostra, o que nos limita a observações de caráter qualitativo, o que não nos impede de sugerir novos rumos de investigação. Com base nos dados colhidos empiricamente, podemos asseverar:

(a) não parece haver relação entre as atitudes de extroversão e introversão e a frequência com que os magistrados designam audiências. As diferenças deverão ser observadas na forma como esse ato processual será conduzido e em como o magistrado interagirá com as partes e advogados. Neste ponto, como a audiência é necessariamente um ato de interação entre pessoas, mesmo o juiz introvertido terá de atuar sua extroversão, tornando difícil notar que atitude predomina pela simples análise da conduta externada. Aliás, é bem possível que um tipo "pensamento extrovertido" pareça, em audiência, mais introvertido do que um "sensação introvertido", por exemplo, no qual a função sentimento, não sendo inferior, poderá permitir a expressão de maior afetuosidade, fato normalmente tomado como sinal de "extroversão". O próprio Jung chegou a identificar, numa fase de seus estudos, o tipo pensamento com o introvertido e o tipo sentimento com o extrovertido. $^{456}$

(b) Ao analisar o perfil de "Judith", que tomamos como representante do tipo pensamento extrovertido, chegamos a levantar a hipótese de que este tipo teria maior propensão a adotar, na aplicação do Direito, posturas "positivistas”. Uma ampliação da amostragem poderia reforçar a hipótese, ou afastá-la.

(c) Outro dado interessante surgiu com a refutação da ideia de que o tipo sentimento pudesse ser a expressão mais autêntica da "misericórdia". Como partimos dessa premissa, foi com grande surpresa que nos deparamos com o seguinte dado, ex-

${ }^{456}$ Tipos ..., p. 23, $\$ 7$ (essa abordagem foi expressa no anexo "A questão dos tipos psicológicos" - conferência feita no Congresso Psicanalítico de Munique, em SET/1913 - pp. 461/469, §§ 931/950). 
traído de nossa entrevista com "Mirtes", por nós tomada como representante do tipo sentimento extrovertido:

Supõe ter sido a juíza do júri que "mais mandou instaurar processos por falso testemunho". Primeiro adverte a testemunha, dando-lhe chance para se retratar. Se a testemunha insiste no que suspeita ser inverdade, manda instaurar inquérito policial, sem qualquer problema: “(...) não tenho problema em processar alguém por falso testemunho. Não me sinto incomodada com isso. (...) vai contra a Justiça. É um crime contra a Administração da Justiça e ponto."

Seria interessante verificar, estatisticamente, se tal rigor de fato é expressão do tipo. De qualquer modo, arriscamos, a respeito, a seguinte explicação: é típico da atitude extrovertida a valorização do objeto (fatos, ideias e coisas externas), em detrimento de aspectos do sujeito (internos). Conjugada a atitude extrovertida com a função sentimento, isso pode implicar a busca de critérios objetivos de valor. Onde poderia encontrá-los o juiz, senão na lei (lato senso)? Outra linha de raciocínio consistiria em tomar tal rigidez como expressão da função inferior, que traria aspectos de um pensamento introvertido. Nesse sentido, vale a lição de Nise da Silveira, que, referindo-se ao sentimento extrovertido, escreve: "Essa pessoa tão transbordante de calor humano surpreende muitas vezes seus íntimos quando formula julgamentos críticos extremamente duros e frios, com o caráter de sanções definitivas". 457

(d) No que tange ao mesmo tipo - sentimento extrovertido -, também reputamos de interesse verificar se a postura que "Mirtes" declarou ter na área criminal - no sentido de aí julgar fatos, não pessoas - seria expressão "normal" do tipo, ou uma reação compensatória inconsciente, o que "Evandro" denominou "anestesia".

(e) Conforme vimos na análise do perfil de "Mirtes", às vezes o que num determinado contexto pode ser "força", em outro se transfigura em "fraqueza". Por exemplo: a força do extrovertido é extroverter, e todas as qualidades associadas à extroversão. No entanto, em situações que exigem mais contenção, a tendência para extroverter, se incontida, pode gerar problemas e levar o indivíduo a condutas

${ }^{457}$ Op. cit., p. 59. 
que muitas vezes parecerão invasivas. Isso acentua o caráter adaptativo das preferências, cuja valoração não pode ser feita numa perspectiva abstrata, mas sempre considerando concretamente as exigências do meio.

(f) O trabalho de campo fortaleceu a hipótese de que, pelo fato de o judiciário ser um fórum de solução de litígios, uma postura pragmática, típica da função sensação, tende a prevalecer sobre uma postura mais teórica, associada aos intuitivos. Do mesmo modo, parece ser atividade mais atraente para pessoas que preferem ter atitudes mais definidas em relação à vida, com predileção pela tomada de decisão. Isso nos leva ao perfil "SJ", que, de fato, pareceu predominar em nossa pequena amostra.

(g) Mereceria estudo aprofundado a repercussão da atitude perceptiva $(\mathrm{P})^{\mathbf{4 5 8}}$ na judicatura, atitude esta que, em tese, estaria por trás da sequência de despachos " $d i$ ga, diga, diga, diga...", causadora de tão contundente repúdio por parte de "Isabella". Deparamo-nos com um único representante deste tipo (“Eustáquio”), que, de fato, parece ter encontrado formas pouco ortodoxas de solucionar os litígios. Mas ninguém se engane em pensar que este tipo "não serve" para o ofício. Como já foi dito antes, o problema sempre reside na excessiva unilateralidade do tipo. Porque, não havendo excesso, um tipo perceptivo pode perfeitamente desincumbir-se da tarefa de julgar, muitas vezes enriquecendo-a com sua abundante criatividade. Por outro lado, havendo unilateralidade da atitude judicativa (J), o problema se inverte: em vez de demorar para decidir, o magistrado precipita-se em fazê-lo, matando a dialética do contraditório ${ }^{\mathbf{4 5 9}}$ em seu nascedouro e dando margem à anulação de sua sentença. Em nossa vida profissional já vivenciamos isso

${ }^{458}$ É preciso não confundir atitude perceptiva ou judicativa com função perceptiva ou judicativa. Conforme vimos na parte teórica, quando tratamos da contribuição de Myers-Briggs à tipologia de Jung, estas pesquisadoras preocuparam-se em verificar de que maneira o tipo introvertido lidava com o mundo exterior (extrovertia). Constataram, então, a importância, para isso, da função auxiliar, percebendo que a natureza perceptiva ou judicativa da função responsável pela "extroversão" dava origem a outro grupo bem distinto de padrões de comportamento. Quando se extroverte por meio de uma função perceptiva (Ssensação ou N-intuição), fala-se em atitude perceptiva, indicada pela letra "P"; quando se extroverte por meio de uma função judicativa (T-pensamento ou F-sentimento), fala-se em atitude judicativa, indicada pela letra "J". Evidentemente, enquanto o introvertido extroverte por meio de sua função auxiliar, o extrovertido o faz por meio da principal, dando origem, também, às atitudes propostas por Myers-Briggs. As letras "P" e "J" formam a quarta dicotomia das preferências empregadas pelo MBTI e ocupam a quarta posição de suas sequências de letras indicativas do tipo psicológico. Exemplo: ISTJ; ISTP; ESTJ; etc..

${ }^{459}$ Ver "contraditório" no "glossário jurídico". 
inúmeras vezes. Segundo Jung, a capacidade de dispor unilateralmente de uma função, de maneira voluntária, era sinal de alta cultura. Em contrapartida, quanto mais involuntária a unilateralidade, mais claro sinal será de barbarismo; e, ainda, quanto mais compulsiva a unilateralidade, mais "demoníaca" tenderá a se tornar a conduta do indivíduo por conta da dinâmica compensatória levada a efeito pela psique. $^{460}$

Ainda sobre este ponto, oportuna a lição de Jerome Frank, trazida por Lídia Prado:

É evidente que a uniformidade e a certeza do Direito se debilitam na medida em que as personalidades de todos os juízes não são idênticas, a na medida em que os juízes não têm iguais hábitos mentais e emocionais. Jerome Frank não esconde que essa circunstância seja desagradável, mas assinala que a uniformidade levaria a consequências muito piores, pois implicaria escolher para a judicatura pessoas pouco talentosas, de mente rígida, estereotipada, predispostas a ignorar os matizes individuais de cada caso. ${ }^{461}$

Para terminar, breve comentário deve ser feito sobre a teoria tridimensional do Direito, de Miguel Reale.

É comum observar que, quando estamos com uma teoria em mente, tendemos a enxergar o mundo como que "através dela", que se convola em espécie de filtro perceptivo, organizador dos processos da consciência. Desse modo, quando tivemos contato com a teoria dos tipos, este passou a ser um de nossos filtros e, por meio dele, identificamos na postulação de Reale considerável paralelismo, guardada, é claro, a peculiar linguagem e o ferramental próprio de cada disciplina. Identificamos na teoria tridimensional a formulação jurídica do modelo de funcionamento equilibrado das funções perceptivas e cognitivas. Pois vale lembrar que, ao propor a tomada do fenômeno jurídico em três dimensões - fato (a cargo das funções sensação e intuição), valor (a cargo do sentimento) e norma (a cargo do pensamento) -, a teoria realeana exige o uso concomitante das quatro funções.

Todavia, para não ficarmos apenas nessa constatação, podemos dizer que, com base na cópula interdisciplinar de que resultou este trabalho, se foi um feito e tanto a formulação

\footnotetext{
${ }^{460}$ Tipos ..., p. 203, $\S 376$ e 377.

${ }^{461}$ Op. cit., p. 18.
} 
da teoria tridimensional de Reale, o postulado de Jung nos ajuda a compreender porque feito maior seria sua operacionalização no cotidiano dos profissionais do Direito. É que, sem consciência das limitações epistemológicas impostas pelo tipo, teremos dificuldade para entender porque, para alguns, o modelo realeano parecerá mera abstração, continuando o tipo sensação, por exemplo, quando em acentuada unilateralidade, a dar maior peso aos fatos, em detrimento dos outros aspectos da realidade, e assim por diante.

Esperando ter preenchido em algum grau uma lacuna existente, ficaremos felizes se, algum dia, diante da pergunta sobre o ponto de vista de Llewellyn, alguém contiver seu impulso pessoal e, em vez de meramente projetar sua própria subjetividade no mundo, responder: "Depende. Depende do tipo psicológico em questão" -, em postura que grande contribuição trará para uma maior completude da ciência jurídica.

Falar de um juiz "ideal” é o mesmo que fantasiar a respeito de um "ser humano ideal". Não tem utilidade nenhuma, ou melhor, é esforço temerário, pois nos afasta da realidade. Se, no entanto, nossa mente insistir em seguir esse rumo, que tomemos por ideal a atitude de reconhecer o que há de precioso em cada pessoa, fazendo com que cada uma, com sua individualidade instransponível, seja permanente desafio a qualquer teoria, no lugar de transformá-la em mais um instrumento de subjugação.

Neste ponto, embora deslocados de seu contexto, não deixam de ser ilustrativos os seguintes versos, com os quais encerramos este trabalho:

Nem sempre sou igual no que digo e escrevo.

Mudo, mas não mudo muito.

A cor das flores não é a mesma ao sol

De que quando uma nuvem passa

Ou quando entra a noite

E as flores são cor da sombra.

Mas quem olha bem vê que são as mesmas flores.

$(\ldots) .{ }^{462}$

462 “Alberto Caeiro", in PESSOA, Fernando. Op. cit., p. 765. 


\section{GLOSSÁRIO}

Todo trabalho interdisciplinar tende a gerar dificuldades decorrentes do uso de termos específicos de cada uma das disciplinas nele articuladas. No nosso caso, Direito e Psicologia. Isso nos obriga a disponibilizar, para o leitor, um pequeno glossário. Ao buscar explicar o sentido de alguns termos ou expressões, mantivemos em mente a ideia de que os signos jurídicos teriam por destinatário o público não versado em Direito, valendo, mutatis mutandis, o mesmo raciocínio para os conceitos da Psicologia. Por isso, evitamos ao máximo, o uso de expressões técnicas, que, embora trouxessem ganho quanto à precisão, exigiram, por sua vez, também o devido esclarecimento, num ciclo interminável. Portanto, procuramos nos desincumbir dessa tarefa de maneira singela, empregando uma linguagem sucinta e tanto quanto possível simples.

O emprego de aspas indica que o termo em questão, utilizado para conceituar um outro, faz parte dos que integram o presente glossário. 


\section{JURÍDICO}

Audiência: ato processual no qual o juiz convoca as partes e respectivos advogados à sua presença. Divide-se em duas espécies: (a) conciliatória (ou de conciliação ou de autocomposição): tem por finalidade empreender esforços visando à solução amigável do litígio, o que ocorre quando as partes chegam a um acordo. Neste tipo de audiência o juiz meramente orienta os envolvidos, atuando como conciliador. Em havendo acordo, é o mesmo homologado pelo juiz. O ato homologatório também é sentença, mas não tem conteúdo decisório, pois não houve julgamento propriamente dito. Não havendo acordo, e verificada a necessidade de produzir prova oral (oitiva de testemunhas, por exemplo), caberá ao juiz designar uma segunda audiência, esta de instrução e julgamento; (b) instrutória ou de instrução e julgamento: é a audiência destinada à produção da prova oral. Tomam-se os depoimentos pessoais das partes (autor e réu) e das testemunhas. Com esta audiência termina o trabalho de produzir provas. A partir daí, resta ao juiz julgar, decidindo quem tem razão.

Citação: ato pelo qual se dá ciência, ao réu, de que foi ajuizada uma ação contra ele. Este ato se concretiza com a entrega, ao réu, de cópia integral da "petição inicial" ("contrafé"), o que pode ser feito tanto pelo correio quanto por oficial de justiça.

Contestação: nome dado ao ato e também à peça processual (texto escrito) de defesa, apresentada pelo réu após tomar ciência do processo. A contestação porta os argumentos do réu, por meio dos quais se opõe ao que é pedido pelo autor. Como normalmente é acompanhada de documentos, após seu oferecimento o juiz costuma intimar o autor a se manifestar sobre eles, ato que recebe o nome de "réplica".

Contraditório: princípio jurídico de natureza processual, tem por finalidade garantir às partes do processo, que ocupam posições antagônicas, iguais oportunidades para expor seus argumentos e produzir as provas dos fatos alegados. 
Contrafé: nome dado à cópia da "petição inicial", entregue ao réu em ato que recebe o nome de "citação", de modo que possa tomar ciência do que foi alegado contra ele pelo autor da ação.

Demanda (judicial): sinônimo de ação judicial.

Depoimento pessoal: o nome dado ao depoimento daquele que é parte - autor ou réu - num processo judicial. Difere do depoimento das testemunhas, que se chama depoimento testemunhal.

Desembargador: título dado ao magistrado quando, progredindo em sua carreira, passa a ocupar uma vaga no tribunal de justiça do Estado ao qual está vinculado. Na qualidade de desembargador, normalmente o magistrado apenas julga processos em fase de recurso. Em outros termos, funciona como uma segunda instância de julgamento, apreciando pedido da parte recorrente, no sentido de reformar decisão tomada, em primeira instância, por outro magistrado (juiz).

Despacho saneador: assim que o autor ajuíza ação judicial em face do réu, é este citado (v. “citação”) para contestar (v. "contestação"). O confronto dos argumentos e fatos apresentados pelas partes litigantes normalmente produz um quadro de dúvidas e contradições. São os chamados pontos controvertidos. Neste momento, o juiz deve decidir algumas questões processuais que eventualmente surjam, como, por exemplo, a alegação de "ilegitimidade de parte”, bem como fixar (declarar) os pontos controvertidos. Sem isso, o processo seguiria com irregularidades. Produz-se, assim, um despacho, que consiste em manifestação do juiz, dirigida às partes, dizendo-lhes quais são os pontos controvertidos, decidindo questões processuais e ordenando que definam as provas que pretendem produzir. Considera-se, com isso, $s a$ neado o processo.

Direito natural: nome dado ao direito que não é produzido pelo Estado ou por qualquer autoridade mundana. Sua natureza é pressuposta. Os defensores de sua prevalência sobre o "direito positivo", que nele haveria de se fundar, são denominados jusnaturalistas. 
Direito positivo: é o direito produzido pela autoridade política e expresso por meio de normas escritas (leis). Seus defensores normalmente rejeitam a existência de outro direito e são denominados juspositivistas.

Embargos de declaração: é uma modalidade de recurso. Cabe na hipótese de a decisão judicial apresentar contradição, obscuridade ou omissão. O vício alegado pela parte deve ser analisado pelo próprio magistrado que produziu a decisão, a quem cabe supri-lo, caso se convença da pertinência da alegação. No entanto, muitos advogados usam esse recurso visando a benefícios indiretos, e não por acreditarem que a decisão apresente algum dos vícios referidos. Um benefício indireto, por exemplo, é ganhar mais tempo para preparar outro tipo de recurso, de maior complexidade, porque os embargos declaratórios têm como efeito interromper o curso do prazo para o mesmo. A lei prevê aplicação de multa para o uso indevido desses embargos, mas, na prática, é muito raro vê-la aplicada.

Equidade: é o nome dado ao julgamento particularizado de um caso, para o qual não se encontra resposta específica no ordenamento jurídico. É o ideal de justiça aplicado ao caso particular. No sistema jurídico brasileiro, constitui princípio de aplicação restrita, pois o magistrado apenas pode recorrer a ele nas hipóteses em que houver expressa previsão legal (Lei nº 5.869/1973 - Código de Processo Civil, Art. 127. O juiz só decidirá por equidade nos casos previstos em lei).

Fase instrutória: v. "instrução processual”.

Fase postulatória (do processo): o processo, na verdade, procedimento, apresenta três fases: postulatória, instrutória (v. "instrução processual") e decisória. A postulatória é a primeira delas. É a fase em que se inicia o processo, assim chamada porque aí as partes apresentam seus pedidos (postulam).

Ilegitimidade de parte: ver "legitimidade de parte". 
Instrução processual: instruir um processo é o mesmo que produzir as provas cabíveis. Encerrar a fase de instrução processual significa superar o momento em que podem as provas ser produzidas. Embora o esforço de produção de provas seja coordenado pelo juiz, que é o presidente do processo, as provas devem ser produzidas por iniciativa das partes, pois é destas o interesse de convencer o juiz da tese sustentada por cada uma.

Jusnaturalista: v. "direito natural".

Juspositivista: v. "direito positivo".

Lei: no curso deste trabalho, o termo é empregado em sentido amplo, representando toda e qualquer "norma" escrita produzida pelo poder político, em qualquer das três esferas de organização (legislativa, executiva e judiciária).

Legitimidade das partes: parte legítima é a autorizada, pela "lei", (a) a pedir judicialmente algo, sendo, portanto, autora de uma ação judicial (legitimidade ativa), e, (b) aquela perante a qual esse algo pode ser pedido, sendo, portanto, ré (legitimidade passiva). Exemplo: se o carro de "A" colide com o de "B”, causando-lhe prejuízo, a ação indenizatória deve ser proposta por "B", que tem legitimidade para ser autor, contra "A", que tem legitimidade para ser réu na ação proposta por "B"; não pode ser proposta por "C" (ilegitimidade ativa), ou mesmo contra "D" (ilegitimidade passiva).

Norma: o termo pode ser usado tanto como sinônimo de "lei", quanto no de sentido decorrente da interpretação da lei. Nesta segunda forma, não se fala em norma sem ao mesmo tempo se falar em interpretação de texto legal, do qual a norma seria o resultado e o juiz seu único intérprete autêntico.

Petição inicial: o termo "petição" diz respeito, em sentido amplo, a "pedido". Todas as manifestações das partes, num processo, são dirigidas ao juiz da causa, e corporificadas por meio de petições. A inicial, conforme o nome diz, vem a ser a primeira petição. Por meio dela dá-se início ao processo. Deve preencher uma série de requi- 
sitos legais, cuja ausência pode gerar sua rejeição (indeferimento) por parte do juiz, com a consequente extinção do processo.

Positivismo jurídico: em termos gerais, é doutrina que restringe o objeto da ciência do direito às suas manifestações normativas, conforme produzidas pelo Estado. Adquire, portanto, um perfil estruturalista (como o direito é feito), em oposição ao funcionalista (para que serve).

Reconvenção: em regra, cabe ao autor apresentar um pedido ao juiz, e ao réu, em defesa, alegar ser o pedido incabível. Ou seja, o autor pede e o réu se defende. O réu nada pede. No entanto, em situações específicas, a lei permite ao réu, no momento em que apresenta sua defesa, também apresentar pedido, ato ao qual se dá o nome de reconvenção. Em outros termos: é a ação movida pelo réu contra o autor, no âmbito da própria ação ajuizada por este último contra o primeiro.

Réplica: manifestação produzida pelo autor da "demanda", após a “contestação".

Teoria tridimensional do Direito (de Miguel Reale): teoria que propõe a análise do fenômeno jurídico em três dimensões: a fática, a axiológica e a normativa. Elas se interrelacionam dialeticamente.

Transação: ato por meio do qual as partes do processo chegam a um acordo, fazendo-se concessões recíprocas. 


\section{PSICOLÓGICO}

Anima: para Jung, "arquétipo" do feminino, atuante na "psique" masculina.

Animus: para Jung, "arquétipo" do masculino, atuante na "psique" feminina.

Arquétipo: é a parte herdada da "psique", gerando predisposições humanas típicas para agir, pensar, sentir (...) é um fenômeno que transcende a consciência, não se tratando (...) de representação herdada, mas de um modo herdado de representação psíquica. ${ }^{463}$ Equivale, para a "Psicologia Analítica", ao gene para a genética. Forma a base para o "inconsciente coletivo".

Atitude: consiste no direcionamento da energia psíquica - se predominantemente para o mundo exterior, origina o tipo extrovertido; se para o interior, dá origem ao introvertido. Em virtude da "função autorreguladora" ou "compensatória" da "psique", a atitude predominante, que é um fenômeno da consciência, constela sua oposta no inconsciente.

Complexo: são imagens e ideias inconscientes, porém de tal forma carregadas emocionalmente que conseguem exercer um campo de atração sobre outros elementos do psiquismo do indivíduo, definindo sua percepção de mundo e de si mesmo. Dado seu caráter autônomo (no sentido de possuir o indivíduo, em vez de ele os possuir), Jung os via como psiques parciais.

Complexo de Édipo: conceito elaborado por Freud, seu nome é tomado de empréstimo do mito grego, que era visto pelo fundador da "Psicanálise" como seu equivalente simbólico. Este "complexo" é tema central da teoria psicanalítica, segundo a qual se manifesta em período específico do desenvolvimento psicossexual (dos três aos cinco anos de idade), exprimindo-se diferentemente no menino e na menina. Sua dinâmica envolve a criança (sujeito do complexo) e as pessoas que desempenham junto a ela os papéis de "pai" e "mãe".

${ }^{463}$ PRADO, Lídia Reis de Almeida. Op. cit., p. 31. 
Função: modalidade de operação psíquica que se mostra estável em relação a seu princípio de funcionamento, mesmo diante de circunstâncias diversas.

Função autorreguladora ou compensatória (da "psique"): diz respeito à natureza da dinâmica existente entre consciente e "inconsciente", que funciona no sentido de estabelecer um equilíbrio psíquico diante de algum desenvolvimento unilateral.

Imaginação ativa: um dos métodos empregados por Jung para investigação dos elementos originários dos processos psicológicos inconscientes. A partir do fragmento de um sonho ou de uma imagem de especial interesse para o paciente, este era convidado a iniciar uma sequência de imagens, cujo encadeamento ficava a cargo do "inconsciente”. Por essa razão, Jung acreditava que assim podia acessar os conteúdos deste.

Inconsciente: o termo pode ser usado tanto como substantivo (o inconsciente) quanto como adjetivo (conteúdos inconscientes). Diz respeito aos aspectos não conscientes de nossa "psique". A "Psicanálise" freudiana o vê basicamente como algo que se forma em torno de conteúdos reprimidos. Na "Psicologia Analítica", o inconsciente, conforme descrito por Freud, representaria, com algumas alterações, apenas o chamado inconsciente pessoal, pois essa escola postula também a existência de uma dimensão coletiva do inconsciente, o chamado inconsciente coletivo, conformado pelos "arquétipos".

Individuação: termo trazido para a Psicologia por Jung, está ligado à ideia de que os processos psíquicos não são aleatórios, mas se constelam na forma de um processo finalístico, tendo por norte o que ele chamou de si-mesmo, ou self, para onde deve seguir cada indivíduo a fim de poder vivenciar a expressão de sua totalidade.

MBTI: abreviação de Myers-Briggs Type Indicator, instrumento de aferição de tipo psicológico desenvolvido por Isabel Briggs Myers e Katharine Cook Briggs, estudiosas da tipologia junguiana. Este instrumento é baseado nas dicotomias tipológicas postuladas por Jung (um par de "atitudes" e dois pares de "funções"), acrescido da dicotomia desenvolvida pelas pesquisadoras mencionadas (atitude judicativa ou per- 
ceptiva). São aferidos dezesseis tipos, cada um representado por uma série de quatro letras.

Psicanálise: nome dado ao conjunto de conceitos elaborados por Sigmund Freud. Não é apenas um corpo de conhecimento teórico, mas também uma técnica terapêutica.

Psicologia Analítica: nome dado ao conjunto de conceitos elaborados por Carl G. Jung. Não é apenas um corpo de conhecimento teórico, mas também uma técnica terapêutica.

Psique: totalidade dos fenômenos mentais, tanto conscientes quanto "inconscientes".

Tipo psicológico: é o resultado do desenvolvimento unilateral de algumas "atitudes" ou "funções". Mais modernamente, é definido pela combinação da atitude predominante com um par de funções, uma de natureza judicativa (responsável pela tomada de decisões) e outra de natureza perceptiva (responsável por captar informações). Todo tipo é dinâmico e constela, ao mesmo tempo, padrões de funcionamento do consciente e do "inconsciente", que funcionam de maneira compensatória (v. "função autorreguladora ou compensatória”). 


\section{BIBLIOGRAFIA}

\section{GERAL E INTERDISCIPLINAR}

ADORNO, Theodor W.. Minima Moralia, Trad.: Gabriel Cohn, Beco do Azougue Editorial Ltda., Rio de Janeiro (RJ), 2008.

BRANDÃO, Junito de Souza. Mitologia Grega, vol. 3, 15ª edição, Editora Vozes, Petrópolis (RJ), 2009.

COMPARATO, Fábio Konder. Ética (Direito, Moral e Religião no Mundo Moderno), Editora Companhia das Letras, São Paulo (SP), 2006.

FOUCAULT, Michel. A Ordem do Discurso, 15- edição, trad.: Laura Fraga de Almeida Sampaio, Edições Loyola, São Paulo, 2007.

HUME, David. Investigações sobre o entendimento humano e sobre os princípios da moral, Editora Unesp, São Paulo (SP), 2003.

PESSOA, Fernando. Obra e Poética em Prosa, vol. 1, Lello \& Irmão - Editores, Porto, 1986.

PRADO, Lídia Reis de Almeida Prado. O Juiz e a Emoção: Aspectos da Lógica da Decisão Judicial, 2ª edição, Editora Millennium, Campinas (SP), 2003.

SÓFOCLES. A Trilogia Tebana, trad.: Mário da Gama Kury, Jorge Zahar Editor, Rio de Janeiro (RJ), 1990.

ZIMERMAN, David e COLTRO, Antônio Carlos Mathias (org.). Aspectos Psicológicos na Prática Jurídica, 2ª edição, Millennium Editora Ltda., Campinas (SP), 2008. 


\section{DIREITO}

BEDAQUE, José Roberto dos Santos. Efetividade do processo e técnica processual, Malheiros Editores Ltda., São Paulo (SP), 2006.

BOBBIO, Norberto. O Positivismo Jurídico: Lições de Filosofia do Direito, Ícone Editora Ltda., São Paulo (SP), 1995.

. "Estrutura e Função na Teoria do Direito de Kelsen" in Da Estrutura à Fun-

ção: Novos Estudos de Teoria do Direito, Editora Manole Ltda., Barueri (SP), 2007, pp. $181 / 210$.

CALAMANDREI, Piero. Eles, os Juízes, Vistos por um Advogado, trad.: Eduardo Brandão, SP, Editora Martins Fontes, 1997.

CAMPILONGO, Celso F. Política, Sistema Jurídico e Decisão Judicial, Editora Max Limonad, São Paulo, 2002.

CAPPELlETTI, Mauro. Juízes Legisladores?, trad.: Carlos Alberto de Oliveira, Sérgio Fabris Editor, Porto Alegre (RS), 1993.

FERRAZ Jr., Tércio Sampaio. Introdução ao Estudo do Direito (Técnica, Decisão, Dominação), 2ª edição, SP, Editora Atlas, 1995.

Estudos de Filosofia do Direito (Reflexões sobre o Poder, a Liberdade, a Justiça e o Direito), 2ª edição, SP, Editora Atlas, 2003.

FRANK, Jerome. Law and the modern mind, New York, Transaction Publishers, New Brunswick, N.J., 2009 (1948).

GRAU, Eros Roberto. Ensaio e Discurso sobre a Interpretação/Aplicação do Direito, SP, Malheiros Editores, 2002.

O Direito Posto e o Direito Pressuposto, 5ª edição, Malheiros Editores,

São Paulo (SP), 2003.

HESPANHA, António Manuel. Cultura Jurídica Europeia - Síntese de um Milênio, $3^{\text {a }}$

Publicações Europa-América Lda., Portugal, 2003 (1997).

KELSEN, Hans. O que é Justiça?, trad.: Luís Carlos Borges, SP, Editora Martins Fontes, 1997.

Teoria Pura do Direito, 6믈 edição, trad.: João Baptista Machado, Coimbra, Armênio Amado-Editora, 1984.

KRETSCHMANN, Ângela. História Crítica do Sistema Jurídico: da Prudência Antiga à Ciência Moderna, Livraria Editora Renovar Ltda., Rio de Janeiro (RJ), 2006. 
LUHMANN, Niklas. Sociologia do Direito, vol. I, Tempo Brasileiro, trad.: Gustavo Bayer, Rio de Janeiro, 1983.

MAXIMILIANO, Carlos. Hermenêutica e Aplicação do Direito, $10^{\mathrm{a}}$ edição, RJ, Editora Forense, 1988.

NALINI, José Renato. Recrutamento e Preparo de Juízes, Editora Revista dos Tribunais, São Paulo (SP), 1982.

. A formação da vontade judicial: fatores legais, sociais e psicológicos in Lex: Jurisprudência do Supremo Tribunal Federal, vol. 19, $n^{\circ}$ 219, pp. 5 a 11, mar 1997.

POSNER, Richard A.. How Judges Think, Harvard University Press, Cambridge, Massachussetts, 2008.

RÁO, Vicente. O Direito e a Vida dos Direitos, 4- edição, Editora Revista dos Tribunais Ltda., São Paulo (SP), 1997.

REALE, Miguel. Fundamentos do Direito, $3^{\underline{a}}$ edição, Editora Revista dos Tribunais, São Paulo (SP), 1997.

Teoria Tridimensional do Direito (situação atual), $5^{\mathrm{a}}$ edição, Editora Saraiva, São Paulo (SP), 1994.

Nova Fase do Direito Moderno, Editora Saraiva, São Paulo (SP), 1990.

STRECK, Lenio Luiz. Hermenêutica Jurídica e(m) Crise, 4⿳亠丷a edição, RS, Livraria do Advogado Editora, 2003. 


\section{PSICOLOGIA}

ALVARENGA, Maria Zelia de et alii. Mitologia Simbólica: Estrutura da Psique e Regências Míticas, Casa do Psicólogo, São Paulo (SP), 2007.

BAIR, Deirdre. JUNG, uma biografia (2 vols.), Trad.: Helena Londres, Editora Globo, São Paulo (SP), 2006.

BARON, Renee. What Type Am I?: The Myers-Brigg Type Indication Made Easy, Penguin Books, 1998.

CORLETT, Eleanor S. e MILLNER, Nancy B.. Navigating Midlife - Using Typology as a Guide, Davies-Black Publishing, Mountain View, California, 1993.

ESTÉS, Clarissa Pinkola. Mulheres que Correm com os Lobos, Trad.: Waldéa Barcellos, Editora Rocco Ltda., Rio de Janeiro (RJ), 1994.

ESTEVAM, Carlos. Freud - vida e obra, $2^{\text {a }}$ edição, Editora Paz e Terra, São Paulo (SP), 2002.

FILLOUX, Jean C.. O Inconsciente, $2^{\underline{a}}$ edição, trad.: Norma Descaves, Difusão Européia do Livro (Difel), São Paulo (SP), 1966.

FRANZ, Marie-Louise von. A Função Inferior, $6^{\mathrm{a}}$ edição, trad.: Ana Cândida Pellegrini Marcelo e Wilma Raspanti Pellegrini, Editora Cultrix, São Paulo (SP), 2007.

FREITAS, Laura Villares de; ALBERTINI, Paulo (org.). Jung e Reich: Articulando Conceitos e Práticas, Editora Guanabara Koogan S/A, Rio de Janeiro (RJ), 2009.

FREUD, Sigmund. "Alguns Comentários sobre o Conceito de Inconsciente na Psicanálise" (1912) in Escritos sobre a Psicologia do Inconsciente, vol. 1, Imago Editora, Rio de Janeiro (RJ), 2004, pp. 79/93.

Três Ensaios sobre a Teoria da Sexualidade (1905), Edição Standard Brasileira das Obras Psicológicas Completas de Sigmund Freud (ESB), vol. VII, Imago Editora, Rio de Janeiro (RJ).

. "Caráter e Erotismo Anal” (1908), ESB, vol. IX.

. “Moral Sexual 'Civilizada' e Doença Nervosa Moderna” (1908), ESB,

vol. IX.

Totem e Tabu (1913-1914), ESB, vol. XIII.

“O Desenvolvimento da Libido e as Organizações Sexuais" (1916-1917)

(conferência XXI), in Conferências Introdutórias sobre Psicanálise (Parte III), ESB, vol. XVI. 
Conferências Introdutórias sobre Psicanálise (XXI) (Parte III - Teoria Geral das Neuroses), ESB, vol. XVI.

. "Psicanálise" (1925-1926), ESB, vol. XVIII.

Verbete "sublimação" (1925-1926), escrito pelo próprio FREUD, em ESB, vol. XVIII.

. O Ego e o Id (1923), ESB, vol. XIX.

. "Algumas Consequências Psíquicas da Distinção Anatômica entre os Sexos" (1925), ESB, vol. XIX.

. “A Organização Genital Infantil (Uma Interpolação na Teoria da Sexualidade)" (1923), ESB, vol. XIX.

. "A Dissolução do Complexo de Édipo" (1924), ESB, vol. XIX.

. “Um Estudo Autobiográfico" (1924), ESB, vol. XX.

. "Tipos Libidinais" (1931), ESB, vol. XXI.

. O Mal-Estar na Civilização (1929), ESB, vol. XXI.

. Esboço de Psicanálise (1938), ESB, vol. XXIII.

GIACOIA JR., Oswaldo. Além do princípio do prazer: um dualismo incontornável, Editora Civilização Brasileira, Rio de Janeiro (RJ), 2008.

GIANNINI, John L.. Compass of the Soul: Archetypal Guides to a Fuller Life, Center for Applications of Psychological Type (CAPT), Gainesville, Florida, 2004.

HILLMAN, James. A Função Sentimento, $6^{\mathrm{a}}$ edição, trad.: Adail Ubirajara Sobral, Editora Cultrix, São Paulo (SP), 2007.

JUNG, Carl Gustav. O Homem e seus Símbolos, 14를 edição, SP, Editora Nova Fronteira, 1996.

. Memórias, Sonhos, Reflexões, trad.: Dora Ferreira da Silva, Editora Nova Fronteira, Rio de Janeiro (RJ), 2006.

Estudos Experimentais (CW II), trad.: Edgar Orth, Editora Vozes, Petrópolis (RJ), 1997.

Freud e a Psicanálise (CW IV), 4ª edição, Trad.: Lúcia Mathilde Endlich Orth, Editora Vozes, Petrópolis (RJ), 2007.

. Tipos Psicológicos (CW VI), trad.: Lúcia Mathilde Endlich Orth, Editora Vozes, Petrópolis (RJ), 1991.

Psicologia do Inconsciente (CW VII/1), 17 $7^{\mathrm{a}}$ edição, trad.: Maria Luiza Appy, Editora Vozes, Petrópolis (RJ), 2007. 
O Eu e o Inconsciente (CW VII/2), $6^{\mathrm{a}}$ edição, trad.: Dr ${ }^{\mathrm{a}}$ Dora Ferreira da Silva, Editora Vozes, Petrópolis (RJ), 1987.

. A Energia Psíquica (CW VIII/1), 9ª edição, trad.: Pe. Dom Mateus Ramalho Rocha, OSB, Editora Vozes, Petrópolis (RJ), 2007.

A Natureza da Psique (CW VIII/2), 5ª edição, trad.: Pe. Dom Mateus Ramalho Rocha, OSB, Editora Vozes, Petrópolis (RJ), 2000.

Os Arquétipos e o Inconsciente Coletivo (CW IX/1), 5- edição, trad.: Maria

Luiza Appy e Dora Mariana R. Ferreira da Silva, Editora Vozes, Petrópolis (RJ), 2007. AION - Estudos sobre o Simbolismo do Si Mesmo (CW IX/2), 6 $6^{\mathrm{a}}$ edição, trad.: Pe. Dom Mateus Ramalho Rocha, OSB, Editora Vozes, Petrópolis (RJ), 2000.

A Prática da Psicoterapia (CW XVI/1), 10 edição, trad.: Maria Luiza Appy, Editora Vozes, Petrópolis (RJ), 2007.

Fundamentos de Psicologia Analítica (CW XVIII/1), 12 edição, trad.: Araceli Elman, Editora Vozes, Petrópolis (RJ), 2004.

A Vida Simbólica (CW XVIII/1), 3- edição, trad.: Araceli Elman, Editora Vozes, Petrópolis (RJ), 2007.

KROEGER, Otto e THUESEN, Janet M. Type Talk: The 16 Personality Types That Determine How We Live, Love, and Work.

LAPLANCHE e PONTALIS. Vocabulário da Psicanálise, 2ª edição, Editora Martins Fontes, São Paulo (SP), 2008.

MARTIN, Charles R.. "Looking at Type: The Fundamentals", eighth printing, Center For Applications of Psychological Type (CAPT), Gainesville, Florida, 2007.

McGUIRE, William e R.F.C. Hull. Entrevistas e Encontros, trad.: Álvaro Cabral, Editora Cultrix, São Paulo (SP), 1982.

MEZAN, Renato. Freud: A Trama dos Conceitos, $4^{\mathrm{a}}$ edição, Editora Perspectiva, São Paulo (SP), 1982.

MYERS, Isabel Briggs. Gifts Differing - Understanding Personality Type, Consulting Psychologists Press, 1980.

MYERS, Isabel Briggs et alli. MBTI MANUAL - A Guide to the Development and Use of the Myers-Briggs Type Indicator, $3^{\text {rd }}$ edition, Mountain View, California, 2003.

PASQUALI, Luiz. Os Tipos Humanos, Editora Vozes, Petrópolis (RJ), 2003.

PIERI, Paolo Francesco. Dicionário Junguiano, trad.: Ivo Storniolo, Editora Paulus, São Paulo (SP)/Editora Vozes, Petrópolis (RJ), 2002. 
POSNER, Richard A.. How Judges Think, Harvard University Press, Cambridge, Massachussetts, 2008.

QUENK, Naomi L.. Essentials of Myers-Briggs Type Indicator Assessment (Essentials of Psychological Assessment), John Wiley \& Sons, Inc. 2000. . In the Grip - understanding type stress, and the inferior function, $2^{\text {nd }}$ edition, CPP, Inc., Mountain View, California, 2000. Was That Really Me?, Davies-Black Publishing, Boston, MA, 2009 (2002).

REICH, Wilhelm. Análise do Caráter, $3^{\underline{a}}$ edição, Trad.: Ricardo Amaral do Rego, Editora Martins Fontes, São Paulo (SP), 2001.

REIS, Alberto O. Advincula et alii. Teorias da Personalidade em Freud, Reich e Jung, Editora Pedagógica e Universitária Ltda., São Paulo (SP), 1984.

ROBERTSON, Robin. Guia Prático de Psicologia Junguiana, trad.: Maria Silvia Mourão Netto, Editora Cultrix, São Paulo, 1992.

SAMUELS, Andrew. Jung e os Pós-Junguianos, Imago Editora Ltda., Rio de Janeiro (RJ), 1989.

SAMUELS, Andrew et alii. Dicionário crítico de análise junguiana, Imago Editora Ltda., Rio de Janeiro (RJ), 1988.

SILVEIRA, Nise da. Jung: vida e obra, 11 $1^{\mathrm{a}}$ edição, Editora Paz e Terra, Rio de Janeiro (RJ), 1988.

STEIN, Murray. JUNG, O Mapa da Alma (uma introdução), $5^{\mathrm{a}}$ edição, trad.: Álvaro Cabral, Editora Cultrix, São Paulo (SP), 2006.

THIS, Bernard. “FREUD”, in O Livro de Ouro da Psicanálise (o pensamento de Freud, Jung, Melaine Klein, Lacan, Winnicott e outros), Trad.: Alexandre Massella, Ediouro Publicações S/A, Rio de Janeiro (RJ), 2007.

THOMSON, Lenore. Personality Type - a practical guide to understanding yourself and others through typology, Shambhala Publications, Inc., Boston, Massachussetts, 1998.

ZACHARIAS, José Jorge de Morais. Tipos - A diversidade Humana, Vetor Editora PsicoPedagógica Ltda., São Paulo (SP), 2006. Entendendo os Tipos Humanos, $2^{\mathrm{a}}$ edição, Editora Paulus, São Paulo (SP), 2006. 